\title{
O programa
}

\section{Minha Casa \\ Minha Vida}

habitação e produção do espaço urbano em diferentes escalas e perspectivas

Organização Doralice Sátyro Maia

Glaucio José Marafon 

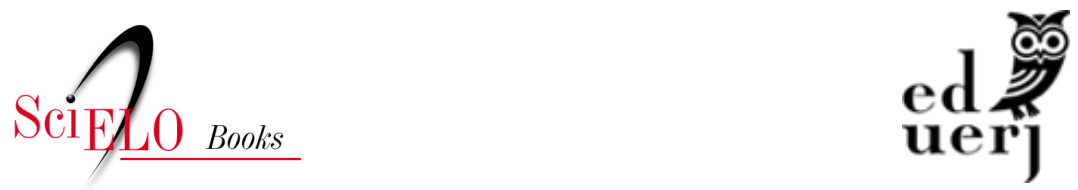

O programa Minha Casa Minha Vida: habitação e produção do espaço urbano em diferentes escalas e perspectivas

\author{
Doralice Sátyro Maia \\ Glaucio José Marafon \\ (orgs.)
}

\title{
SciELO Books / SciELO Livros / SciELO Libros
}

MAIA, D. S., and MARAFON, G. J., eds. O programa Minha Casa Minha Vida: habitação e produção do espaço urbano em diferentes escalas e perspectivas [online]. Rio de Janeiro: EDUERJ, 2020,312 p. ISBN: 978-65-00-03029-7. https://doi.org/10.7476/9786500030297.

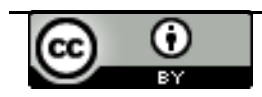

All the contents of this work, except where otherwise noted, is licensed under a Creative Commons Attribution 4.0 International license.

Todo o conteúdo deste trabalho, exceto quando houver ressalva, é publicado sob a licença Creative Commons Atribição 4.0.

Todo el contenido de esta obra, excepto donde se indique lo contrario, está bajo licencia de la licencia Creative Commons Reconocimento 4.0. 


\section{O Programa Minha Casa Minha Vida:}

habitação e produção do espaço urbano em diferentes escalas e perspectivas 


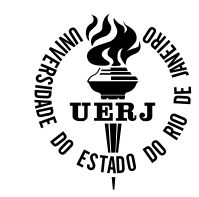

UNIVERSIDADE DO ESTADO DO RIO DE JANEIRO

Reitor

Ricardo Lodi Ribeiro

Vice-reitor

Mario Sergio Alves Carneiro

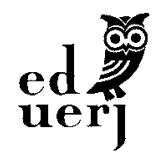

EDITORA DA UNIVERSIDADE DO

ESTADO DO RIO DE JANEIRO

\section{Conselho Editorial}

Glaucio José Marafon (presidente)

Henriqueta do Coutto Prado Valladares

Hilda Maria Montes Ribeiro de Souza

Italo Moriconi Junior

José Ricardo Ferreira Cunha

Katia Regina Cervantes Dias

Lucia Maria Bastos Pereira das Neves

Luciano Rodrigues Ornelas de Lima

Maria Cristina Cardoso Ribas

Tania Maria Tavares Bessone da Cruz Ferreira

Anibal Francisco Alves Bragança (EdUFF) 


\title{
O Programa Minha Casa Minha Vida: habitação e produção do espaço urbano em diferentes escalas e perspectivas
}

\author{
Organização \\ Doralice Sátyro Maia \\ Glaucio José Marafon
}

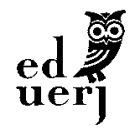

Rio de Janeiro

2020 
Copyright @ $\odot 2020$, dos autores.

Todos os direitos desta edição reservados à Editora da Universidade do Estado do Rio de Janeiro. É proibida a duplicação ou reprodução deste volume, ou de parte do mesmo, em quaisquer meios, sem autorização expressa da editora.

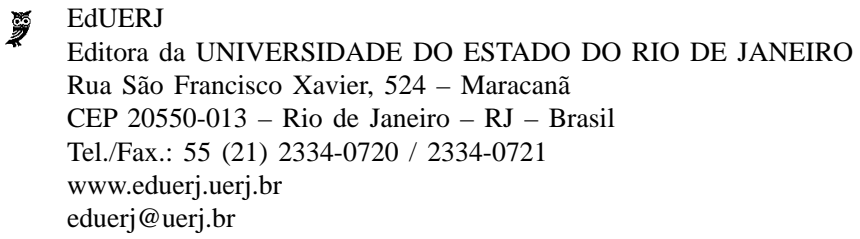

\section{Editor Executivo \\ Coordenadora Administrativa \\ Coordenadora Editorial \\ Assistente Editorial \\ Coordenador de Produção \\ Assistente de Produção \\ Supervisor de Revisão \\ Revisão}

Revisão Técnica

Capa

Projeto Gráfico e Diagramação
João Feres Júnior

Elisete Cantuária

Silvia Nóbrega de Almeida

Thiago Braz

Mauro Siqueira

Érika Neuschwang

Elmar Aquino

Thiago Braz

João Martorelli

Márcia Cabral

Aline Santos Costa

Mauro Siqueira

Emilio Biscardi

CATALOGAÇÃO NA FONTE

UERJ/REDE SIRIUS/NPROTEC

P964 O Programa Minha Casa Minha Vida: habitação e produção do espaço urbano em diferentes escalas e perspectivas [recurso eletrônico] / Organização Glaucio José Marafon, Doralice Sátyro Maia. - 1. ed. - Rio de Janeiro : EdUERJ, 2020.

1 recurso online (312 p. ; 16x23 cm); il. : ePub.

ISBN 978-65-00-03029-7

1. Planejamento urbano. 2. Habitação popular. 3. Programa Minha Casa Minha Vida (Brasil). I. Marafon, Gláucio José, 1962-. II. Maia, Doralice Sátyro.

CDU 332.812:711

Bibliotecária: Thais Ferreira Vieira CRB-7/5302 


\section{Sumário}

Apresentação - O Programa Minha Casa Minha Vida: habitaçáo e produçáo do espaço urbano em diferentes escalas e perspectivas 7

Doralice Sátyro Maia e Glaucio José Marafon

Teorias de localizaçáo: do espaço absoluto e relativo ao espaço relacional

Flaviane Ramos dos Santos e Maria Encarnação B. Sposito.

Metrópole em movimento: reflexóes sobre a produçáo do espaço na Regiáo Metropolitana do Recife a partir da localização dos empreendimentos do PMCMV .53

Luciana de Carvalho Gomes

O Programa Minha Casa Minha Vida contribui para a construçáo do direito social à moradia? A experiência no Estado do Rio de Janeiro .75 Angela Moulin Simóes Penalva Santos e Pedro Henrique Ramos Prado Vasques

Espacializaçáo do Programa Minha Casa Minha Vida no estado e na capital do Rio de Janeiro

Gustavo Bezerra de Brito, José Silvan Borborema Araújo e Glaucio José Marafon

A inserção urbana de empreendimentos do Programa Minha Casa Minha Vida em João Pessoa, Campina Grande e Patos, na Paraíba 141

Livia Miranda, Demóstenes Moraes e Juliana Peixoto de Araújo

Periferização da produçáo imobiliária no século XXI: a produçáo do

Programa Minha Casa Minha Vida em João Pessoa - PB

Eliane Campos dos Santos e Paula Dieb Martins 
PMCMV e produção imobiliária nas cidades de Patos e

Cajazeiras/PB

Luciana Medeiros de Araújo

A produção imobiliária do PMCMV no bairro de Santa Cruz -

Rio De Janeiro/RJ: análises e contextos no período de 2005 e 2010

Vania Regina Jorge da Silva e Miguel Angelo Ribeiro

A produção do espaço urbano e o Programa Minha Casa Minha Vida em Russas - Ceará

Jéssica Liana de Sousa

Uma crítica ao processo de autossegregação através da análise de três condomínios Minha Casa Minha Vida 269

Fábio Gustavo Pontes Martin e Marcelo Werner da Silva

A apropriaçáo dos espaços de lazer no conjunto habitacional Major

Veneziano (I, II, III E IV) em Campina Grande, PB.

Sâmara Iris de Lima Santos

Sobre os autores 307 


\section{Apresentação - O Programa Minha Casa Minha Vida: habitação e produção do espaço urbano em diferentes escalas e perspectivas}

Doralice Sátyro Maia Glaucio José Marafon

A escrita de um texto em conjunto requer, antes de tudo, uma decisão dos autores de como se dará a sua estrutura e o que compete a cada um registrar. Optamos por iniciar esta coletânea com algumas anotaçóes sobre a pesquisa que a originou, como também sobre o tema que se faz presente nos capítulos da obra, além de uma rápida apresentação sobre eles.

\section{Notas de Pesquisa}

Este livro é resultado da pesquisa "Grandes infraestruturas urbanas, ensino superior e desenvolvimento regional: reconfigurando as relaçóes entre as cidades médias, as cidades pequenas e o campo", realizada com recursos da Coordenação de Aperfeiçoamento de Pessoal do Ensino Superior (Capes) e do Ministério da Integração entre 2013 e 2018. A pesquisa foi desenvolvida em três instituiçôes: Universidade Estadual Paulista - UNESP (campus Presidente Prudente-SP), Universidade do Estado do Rio de Janeiro - UERJ (campus Maracanã-RJ) e Universidade Federal da Paraíba - UFPB (campus João Pessoa-PB). Trata-se, pois de um trabalho realizado por três equipes de pesquisadores e professores dos cursos de Geografia e dos Programas de Pós-Graduação em Geografia das respectivas instituiçôes.

A pesquisa teve seis objetivos amplos: 
1. Fortalecer as relaçóes entre equipes de pesquisa que são associadas à Rede de Pesquisadores sobre Cidades Médias, ampliando suas frentes de trabalho científico e contribuindo para a formação de recursos humanos em nível de pós-graduação;

2. Aprofundar as relaçóes acadêmicas entre os programas de pósgraduação integrados a esta proposta, de modo que, de um lado, o mais consolidado contribua para o fortalecimento dos outros dois e, de outro, a interação entre os três favoreça a troca de ideias e de formas de se organizar a pós-graduação e se fazer pesquisa;

3. Realizar estudo nas cidades de Campina Grande e Patos, na Paraíba; Caruaru, em Pernambuco; Campos, no norte fluminense; Marília e Presidente Prudente, no oeste paulista - o que se desdobra em dois objetivos específicos:

a. 3.1. conhecer melhor a realidade dessas cidades, suas relaçóes com o campo e as regióes que comandam;

b. 3.2. oferecer elementos para algum nível de generalização em pesquisas semelhantes por meio de desenvolvimento de metodologia de investigação científica.

4. Ampliar o conhecimento científico sobre o tema, contribuindo para o desenvolvimento regional nos territórios estudados e para a diminuição de disparidades regionais no país por meio de estudos comparativos, que náo têm como télos a ideia de que as regióes devem ser homogêneas; mas sim que deve haver, por parte das políticas públicas, compromisso com a equidade de condiçôes para toda a sociedade, o que implica em dotação territorial dos meios necessários para tal;

5. Analisar as repercussóes do Programa Minha Casa Minha Vida nas cidades de Campina Grande e Patos, na Paraíba; Caruaru, em Pernambuco; Campos, no norte fluminense; Marília e Presidente Prudente, no Estado de São Paulo, no que se refere à produção/ expansão/consumo da cidade, à dinâmica econômica e regional e às novas relaçóes entre a cidade e o campo;

6. Investigar as implicaçóes socioespaciais resultantes da implantação de novos cursos e de novos campi em algumas cidades localizadas no interior do Estado da Paraíba, particularmente em Campina Grande e nos municípios da área de sua influência; em Caruaru, 
no estado de Pernambuco; em Campos, no norte fluminense; e em Marília e Presidente Prudente, procurando avaliar como estas instituiçóes atendem moradores do campo e de cidades pequenas.

Observe-se que os dois primeiros objetivos procuraram atender aos propósitos maiores da Capes - fomentar a "expansão e consolidação da pós-graduaçáo Stricto Sensu (mestrado e doutorado) em todos os estados da Federação." Dentre os resultados, destacam-se o fortalecimento das relaçóes entre as equipes e seus respectivos programas de pós-graduaçáo por meio de missóes docência, participação de docentes em bancas examinadoras, formação de graduandos, mestrandos e doutorandos, inclusive com a realização de doutorado-sanduíche em instituição estrangeira, além das apresentaçóes de trabalhos em eventos científicos nacionais e internacionais e das publicaçóes em anais de eventos, periódicos e livros.

No que se refere aos objetivos 3, 4, 5 e 6, o foco é a concretização da pesquisa em dois principais eixos de investigação: as repercussóes do Programa Minha Casa Minha Vida nas cidades eleitas pelas três equipes e as implicaçóes socioespaciais derivadas da política de implantação de novos cursos e de novos campi de ensino superior. A concretizaçáo desses objetivos resultou em algumas publicaçóes já realizadas e serão apresentadas de forma mais ampliada nos dois livros organizados pelos coordenadores da pesquisa. O primeiro volume, aqui apresentado, dedica-se ao Programa Minha Casa Minha Vida, já o segundo tratará das repercussóes da política de ampliação do ensino superior e da relação entre cidade e campo.

Muito embora esta publicação tenha como propósito principal apresentar e divulgar os resultados da pesquisa, decidiu-se ampliar a discussão convidando alguns autores que trabalharam com a temática em outras realidades ou que a estudaram com outros recursos, mas que se somam aos estudos realizados por nós.

Desta forma, o leitor não vai encontrar somente textos que trazem análises e resultados de pesquisas concretizadas com recursos do Edital Pró-Integração Capes/MIntegração, mas também estudos feitos no âmbito de outros programas de pós-graduação e que aqui se somam. No mesmo sentido, apesar de se ter as cidades médias como principal recorte espacial, entende-se

1 Disponível em https://www.capes.gov.br/historia-e-missao. Acesso em 18 out. 2019. 
que o debate a respeito do Programa Minha Casa Minha Vida e da política de ampliação do ensino superior náo deve se restringir às realidades urbanas classificadas como médias ou pequenas, pois tais políticas se deram fortemente também nas realidades metropolitanas. Assim sendo, além dos estudos concretizados nas cidades indicadas no projeto inicial - Campina Grande e Patos na Paraíba, Caruaru em Pernambuco, e Campos dos Goytacazes no Rio de Janeiro -, amplia-se o leque de cidades estudadas, algumas pelo grupo de pesquisadores - a exemplo de Resende, no Rio de Janeiro -, e outras que se somaram uma vez que os autores sáo pesquisadores que integram os grupos de pesquisa liderados pelos coordenadores do projeto. Assim, este volume reúne textos que tratam do Programa Minha Casa Minha Vida em realidades metropolitanas como Recife e Rio de Janeiro, em capitais como João Pessoa, ou em cidades pequenas localizadas em outras unidades federativas, como Russas, no Ceará. Acrescenta-se que os autores dos capítulos desta obra são pesquisadores que mantêm diálogos e são parceiros dos coordenadores da pesquisa em outros projetos e outras atividades. Além disso, a decisão por se ampliar o conjunto de autores e de realidades analisadas deu-se com o propósito de consolidar novas parcerias de pesquisa e de redes de intercâmbio entre os grupos de pesquisa e também entre os programas de pós-graduaçáo.

Explicita-se ainda que, embora o projeto tenha indicado uma matriz metodológica para a pesquisa, as equipes e os autores tiveram liberdade de eleger os aportes teórico-metodológicos. Tal decisão possibilitou a diversidade das leituras e das reflexóes sobre as realidades estudadas. Os organizadores entendem que, apesar de exigir o rigor acadêmico-científico, o fazer do conhecimento científico também clama pela diversidade teórica e pela liberdade de escolha e de ideias. Desta forma, destaca-se que os autores dos capítulos são responsáveis pelas suas posturas teórico-metodológicas e pelas suas conclusóes. Contudo, isso não significa que os organizadores se eximem da responsabilidade do que se publica, pois os textos apresentados foram lidos e aprovados pelo que se considera uma postura acadêmico-científica. Evidentemente há textos que revelam maior aprofundamento teórico, outros trazem mais resultados da pesquisa empírica, uns são mais descritivos, outros mais analíticos, enfim, um "retrato" da diversidade acadêmica dos que se debruçaram e que continuam a mergulhar nesse grande universo do que se constituiu as cidades produzidas pela política nacional de habitação do Programa Minha Casa Minha Vida. 
Vale registrar que escrevemos a apresentação de um livro sobre uma política pública tão importante no momento que se anuncia o seu término sem uma substituição; ou seja, finalizamos a obra sem termos clareza do que será desenvolvido enquanto política dirigida à habitação, tampouco à habitação de interesse social.

\section{O Programa Minha Casa Minha Vida (PMCMV)}

Em quase todos os capítulos, o leitor vai encontrar algumas notas a respeito do PMCMV. Contudo, faremos aqui uma síntese do programa no seu transcurso. Ainda que muitos autores já tenham escrito a respeito, cabe aqui apresentá-lo, afinal é sobre ele que trata este volume. ${ }^{2}$

O Programa Minha Casa Minha Vida foi criado pelo Governo Federal por meio da lei $n^{\circ} 11.977 / 2009$ e constitui-se em uma política voltada para a habitação. No decurso de 2009 a 2019 o programa apresenta três versóes, denominadas de fases. Desde a sua concepção inicial, destinava-se a diferentes faixas de renda, tendo como o máximo dez salários mínimos. ${ }^{3}$ Portanto, apresentava na sua concepção três faixas de financiamento, e a participação do Estado variava conforme as faixas de renda das famílias. A fase 1 é implementada de 2009 a 2011; a fase 2, de 2011 a 2014 e a fase 3, de 2016 a 2019. Na primeira fase, as faixas de renda foram estabelecidas de acordo com o número de salários mínimos e, a partir da segunda fase, os valores foram fixados. $\mathrm{Na}$ fase 2 , as faixas da população se apresentaram da seguinte forma:

- Faixa 1 - famílias com renda de até $\mathrm{R} \$ 1.600$ reais;

- Faixa 2 - famílias com renda de até $\mathrm{R} \$ 3.275$ reais;

- Faixa 3 - famílias com renda entre $\mathrm{R} \$ 3.275$ até $\mathrm{R} \$ 5$ mil reais.

Em 2016, na fase 3 do programa, houve um pequeno ajuste nos valores, acrescentando mais uma faixa de renda, denominada de Faixa 1,5. Nessa fase, as faixas estabelecidas foram:

2 Dentre as várias obras, trabalhos de conclusão de doutorado, mestrado e graduação, além de artigos em periódicos, cita-se o livro organizado por Adauto Cardoso (2013).

3 Alterado em 2015 pela lei $\mathrm{n}^{\circ} 13.173$. 
- Faixa 1 - famílias com renda de até $\mathrm{R} \$ 1.800$ reais;

- Faixa 1,5 - famílias com renda de até R $\$ 2.600$ reais;

- Faixa 2 - famílias com renda de até $\mathrm{R} \$ 4.000$ reais;

- Faixa 3 - famílias com renda de até R $\$ 7.000$ reais.

Deve-se considerar o propósito do PMCMV, definido na lei 11.977 de 2009:

Art. 1ํㅡ O Programa Minha Casa, Minha Vida - PMCMV tem por finalidade criar mecanismos de incentivo à produção e aquisição de novas unidades habitacionais ou requalificação de imóveis urbanos e produção ou reforma de habitações rurais, para famílias com renda mensal de até $\mathrm{R}$ \$ 4.650,00 (quatro mil, seiscentos e cinquenta reais) e compreende os seguintes subprogramas:

I - o Programa Nacional de Habitaçấo Urbana (PNHU)

II - o Programa Nacional de Habitação Rural (PNHR)

Para a implementação do referido programa, a lei determina que se observe a disponibilidade orçamentária e financeira e, dentre as participaçóes, estabelece a do "Fundo de Arrendamento Residencial (FAR), mediante integralização de cotas e transferirá recursos ao Fundo de Desenvolvimento Social (FDS)". ${ }^{4}$

Em conformidade com o perfil socioeconômico, definidas pelas faixas de renda, o PMCMV apresenta duas matrizes de financiamento para a habitação: um voltado para o que é chamado de Habitação de Interesse Social, e o outro destinado à Habitação de Mercado. Shimbo (2012) denomina de dois subsistemas: o primeiro corresponde à faixa 1, que na primeira versão do programa correspondia às famílias com renda até três salários mínimos, na fase 2 às famílias com renda até $\mathrm{R} \$ 1.600,00$ (mil e seiscentos reais) e na fase 3 às famílias com renda até $\mathrm{R} \$ 1.800,00$ (mil e oitocentos reais). Observe-se que no decurso de 2009 a 2019 houve uma variação nos valores do salário mínimo, tendo-se uma significativa alteração especialmente entre os anos de 2009 a 2016 (Tabela 1):

${ }^{4}$ Lei 11.977 de 2009. 
Tabela 1 - Valores do Salário Mínimo Brasileiro e Percentual de aumento por ano

\begin{tabular}{c|c|c|c}
\hline \multirow{2}{*}{ Ano } & Vigência & Valor (R\$) & $\begin{array}{c}\text { Percentual de } \\
\text { aumento }\end{array}$ \\
\hline 2009 & $01 / 01 / 2009$ & 465,00 & 12,05 \\
\hline 2010 & $01 / 01 / 2010$ & 510,00 & 9,68 \\
\hline 2011 & $01 / 03 / 2011$ & 545,00 & 5,88 \\
\hline 2012 & $01 / 01 / 2012$ & 622,00 & 14,13 \\
\hline 2013 & $01 / 01 / 2013$ & 678,00 & 9,00 \\
\hline 2014 & $01 / 01 / 2014$ & 724,00 & 6,78 \\
\hline 2015 & $01 / 01 / 2015$ & 788,00 & 8,84 \\
\hline 2016 & $01 / 01 / 2016$ & 880,00 & 11,68 \\
\hline 2017 & $01 / 01 / 2017$ & 937,00 & 6,48 \\
\hline 2018 & $01 / 01 / 2018$ & 954,00 & 1,81 \\
\hline 2019 & $01 / 01 / 2019$ & 998,00 & 4,61 \\
\hline
\end{tabular}

Fonte: https:/www.contabeis.com.br/tabelas/salario-minimo/ [Acesso em 18 out. 2019].

A tabela mostra os percentuais de aumento do salário mínimo por ano, o que explica a alteração na definição das faixas de renda do PMCMV da fase 1 para a fase 2. Pois, se inicialmente definia-se como Faixa 1 as famílias até 3 salários mínimos, em 2009 tal montante correspondia à renda máxima de $\mathrm{R} \$ 1.395,00$ (mil e trezentos e noventa e cinco reais), já em 2011, o valor era de $\mathrm{R} \$ 1.635,00$ (mil seiscentos e trinta e cinco reais). Assim, o texto da fase 2 , ao alterar a redação, define os valores por faixa correspondente ao salário mínimo do ano de 2011. Por conseguinte, ao se diminuir o ajuste do salário mínimo, reduz-se a renda máxima das famílias inseridas em cada faixa. Dessa forma, em 2016, a faixa 1 , ao ter como valor máximo de renda $\mathrm{R} \$ 1.800,00$ (mil e oitocentos reais), refere-se às famílias com renda até 2 salários mínimos e em 2019 a 1,8 salários mínimos.

Ao se analisar as modificaçóes feitas nas leis do PMCMV, outro ponto que merece destaque é a referência à regularização fundiária que, desde a sua primeira concepção (Lei no 11.977/2009) até 2017, apresentava um capítulo destinado à Regularização Fundiária de Assentamentos Urbanos. Este capítulo é revogado pela Lei $\mathrm{n}^{\circ} 13.465$ de 2017. A partir de então, uma das principais diretrizes do PMCMV, que estava direcionada à população de 
menor renda, portanto, à demanda habitacional de interesse social, é completamente eliminada.

A segunda matriz do programa, aquela destinada à habitação de mercado, tinha como propósito estimular a economia brasileira, considerando a crise econômica mundial eclodida nos Estados Unidos em 2008. Vários são os autores que discutiram essa questáo e ressaltaram muitas vezes o "desvio" de prioridades de um programa que deveria ser destinado a dirimir o problema habitacional brasileiro. A autora Lúcia Shimbo (2012) refere-se ao "Pacote Habitacional Minha Casa, Minha Vida" e explica:

Esse pacote formalizou o 'espírito' já corrente, desde meados dos anos 1990, de incentivo à provisão privada de habitação, por meio de medidas regulatórias e do aumento de recursos destinados ao financiamento habitacional empreendidas recentemente. Portanto, se levarmos em consideração esse contexto recente, o MCMV não pode ser encarado à revelia de uma política nacional de habitação. (Shimbo, 2012, p. 54).

A autora complementa: "o pacote foi apresentado como uma das principais açôes do governo em reação à crise econômica internacional e também como uma política social de grande escala”. (p. 54). Dessa forma, o programa ao mesmo tempo que atendia à falta de moradia, direciona-se para os interesses capitalistas, inclusive ao capital financeiro.

Dentre os autores que discutiram os problemas da política habitacional elaborada desde a concepçáo do PMCMV, estando voltada especialmente para o mercado imobiliário cita-se Rolnik e Nakano (2009), Cardoso e Aragáo (2011), Shimbo (2011) e Campos (2011). Torna-se evidente, que apesar do propósito em atender a uma demanda social, o "Programa não só foi criado para como também pelo setor imobiliário". (Lucena e Maia, 2016, p. 2, grifos das autoras). Além disso, há que se ressaltar as repercussóes no mercado imobiliário que incide diretamente na demanda habitacional, ou seja,

[...] o volume de recursos mobilizados, ao garantir um mercado consumidor sólido e seguro, ampliou a demanda por terra, elevando os preços imobiliários, provocando posteriormente o aumento do teto dos financiamentos, como foi anunciado em 2012 pelo Conselho Curador do FGTS, além de outras tantas consequências. (Lucena e Maia, 2016, p. 3). 
Muito embora os capítulos que compóem esta obra mostrem dados e discutam de forma mais aprofundada as repercussóes do referido programa na produção do espaço urbano, vale trazer alguns dados. Tem-se que, no período de 2009 a 2016, de acordo com os dados fornecidos pelo então Ministério das Cidades, foram contratadas um total de 4,2 milhôes de moradias. O montante é por demais representativo, revelando a produção de cidades para além do que se tinha de tecido urbano consolidado.

Para além das alteraçóes feitas na concepçáo do programa desde a sua primeira elaboraçáo, há que se registrar as mudanças que se referem ao projeto arquitetônico das habitaçôes que, após algumas iniciativas, inclusive a de financiamento de projetos de pesquisas voltados especificamente para analisarem o PMCMV, foram estabelecidas exigências como a inclusão da acessibilidade, do padrão construtivo e de materiais, dos equipamentos públicos (escolas, creches, unidades de saúde), da pavimentação do acesso aos conjuntos habitacionais e ainda do acréscimo de equipamentos, entre eles o sistema de aquecimento solar de água. Há, portanto, muito a ser analisado e discutido para se ter reflexões mais complexas a respeito das repercussóes do PMCMV na produçáo do espaço urbano.

Os textos que compóem os capítulos aqui apresentados traduzem algumas repercussóes do Programa Minha Casa Minha Vida na produção, expansão e consumo das cidades eleitas para a pesquisa - e em outras já assinaladas. Tais registros foram realizados utilizando-se diferentes recursos metodológicos e o nível de aprofundamento variou entre as equipes, entre os autores e seus respectivos trabalhos.

\section{Uma síntese da composiçáo do livro}

O livro encontra-se organizado em onze capítulos. No primeiro, de Flaviane Ramos Santos e Maria Encarnaçáo Sposito, "Teorias de localizaçáo: do espaço absoluto e relativo ao espaço relacional", é feita uma breve contextualização histórica das principais formulaçôes teóricas e dos modelos de localizaçáo das atividades urbanas. No segundo capítulo, de Luciana de Carvalho Gomes, "Metrópole em movimento: Reflexões sobre a produção do espaço na Região Metropolitana do Recife a partir da localização dos empreendimentos do PMCMV", se evidencia como a localizaçáo dos empreendimentos do PMCMV na RMR estão subordinados primeiramente aos 
interesses da produção empresarial da moradia que à real demanda do déficit habitacional ou a capacidade de oferta de infraestrutura dos municípios. Alimentam, assim, uma lógica segregacionista, na qual o agente privado determina onde vivem ricos e pobres. As localizaçóes periféricas (definidas pela produção empresarial) das moradias acabam por transformar, em primeiro plano, o espaço urbano municipal (formal ou informalmente) diante das necessidades de produção, reprodução e consumo dos moradores.

O terceiro artigo, de autoria de Angela Moulin Simóes Penalva Santos e Pedro Henrique Ramos Prado Vasques, "O Programa Minha Casa Minha Vida contribui para a construção do direito social à moradia? A experiência no Estado do Rio de Janeiro", analisa como a experiência do MCMV no Estado do Rio de Janeiro ilustra a limitaçáo do caráter social do programa, que tem sido mais identificado com políticas econômicas anticíclicas. Em particular, a maior concentração de unidades e valores contratados na capital fluminense e municípios da regiáo metropolitana de empreendimentos da faixa 1 no período inicial do programa, quando ocorreram as remoçóes para implementação das obras públicas de preparação da Cidade do Rio de Janeiro para receber megaeventos esportivos, particularmente as Olimpíadas de 2016.

O quarto artigo, de Gustavo Bezerra de Brito, José Borborema de Araújo e Glaucio José Marafon, "Espacialização do programa "Minha Casa, Minha Vida" no estado e na capital do Rio de Janeiro", buscou verificar por meio da análise dos dados quantitativos e cartográficos do ERJ e da capital, Rio de Janeiro, um possível aumento da segregação socioespacial no estado em função da renda, além da concentração de unidades habitacionais nas faixas intermediárias com maior poder aquisitivo - notadamente as faixas 2 e 3 . O quinto artigo, assinado por Lívia Miranda, Demóstenes Moraes e Juliana Peixoto de Araújo, "A inserção urbana de empreendimentos do Programa Minha Casa, Minha Vida em João Pessoa, Campina Grande e Patos, na Paraíba”, buscou desenvolver análises sobre a inserção urbana e a qualidade arquitetônica e urbanística dos empreendimentos produzidos pelo PMCMV em alguns municípios paraibanos: João Pessoa, Campina Grande e Patos.

No sexto artigo, de Eliane Campos dos Santos e Paula Dieb Martins, "Periferização da produção imobiliária no século XXI: a produção do Programa Minha Casa Minha Vida em João Pessoa - PB”, é feita uma análise acerca da estruturação do espaço intraurbano de João Pessoa para fundamentar a análise mais específica da produção habitacional vinculada ao PMCMV na 
cidade entre 2009 e 2018. O sétimo artigo, de Luciana Medeiros de Araújo, "PMCMV e produção imobiliária nas cidades de Patos e Cajazeiras /PB", apresenta resultados da pesquisa sobre a produção imobiliária e a expansão urbana das cidades de Patos e de Cajazeiras, ambas situadas na mesorregião do Sertão Paraibano, às margens da BR-230. Essas cidades compóem as Regiōes Intermediárias de Articulação Urbana, cujas áreas de influência territorial extrapolam os limites definidos por suas microrregióes geográficas e os limites estaduais.

O oitavo artigo, de Vania Regina Jorge da Silva e Miguel Angelo Ribeiro, "A produção imobiliária do PMCMV no bairro de Santa Cruz - Rio de Janeiro/RJ: Análises e contextos no período de 2005 e 2010", versa sobre a produção imobiliária do Programa Minha Casa Minha Vida (PMCMV) no bairro de Santa Cruz, localizado na Zona Oeste da urbe carioca e preocupa-se em observar as mudanças espaciais no referido bairro, relacionadas a uma gama de investimentos. O nono artigo, de Jéssica Liana de Souza e Doralice Sátyro Maia, “A produção do espaço urbano e o Programa Minha Casa Minha Vida em Russas - Ceará”, teve por objeto espacial a cidade de Russas, localizada no baixo Jaguaribe, Ceará, no Nordeste brasileiro. Este núcleo urbano possui 76.884 habitantes (IBGE, 2018), podendo, portanto, ser considerada uma pequena cidade. $\mathrm{Na}$ análise, buscou-se considerar a dinâmica socioespacial de um núcleo urbano no interior do território do Nordeste brasileiro com as suas particularidades e singularidades, sem ignorar o contexto global.

O décimo artigo, de autoria de Fábio Gustavo Pontes Martin e Marcelo Werner da Silva, "Uma crítica ao processo de autossegregação através da análise de três condomínios Minha Casa Minha Vida”, visou aprofundar o debate a respeito do processo de segregação urbana com uma visão crítica do conceito de autossegregação por meio da análise de três condomínios situados na cidade de Campos dos Goytacazes, produzidos no âmbito do maior programa habitacional do país, o Minha Casa Minha Vida (PMCMV), em sua modalidade empresarial. O décimo-primeiro - e último - artigo, de Sâmara Iris de Lima Santos, "A apropriação dos espaços de lazer no conjunto habitacional Major Veneziano (I, II, III, IV) em Campina grande, PB", efetua uma análise dos resultados da política habitacional do PMCMV em Campina Grande, optando-se por analisar o conjunto Major Veneziano, pois foi o primeiro conjunto entregue na cidade em 2011, destinado à faixa 1 do 
programa, ou seja, às famílias com renda até 3 salários mínimos conforme regia o documento do programa na época.

O livro representa o esforço coletivo de um grupo de pesquisadores associados a UNESP/PP, UFPB e UERJ, que através de missôes de trabalhos e reflexôes permitiu aprofundar a investigação sobre o Programa Minha Casa, Minha Vida.

Agradecemos a todos que contribuíram para materializar este trabalho e convidamos para uma leitura sobre esse importante programa de construção de habitação popular no Brasil.

\section{Referências}

CAMPOS, Paola Rogedo. "O preço da terra urbana e a moradia de baixo custo". In: MENDONÇA, Jupira Gomes de e COSTA, Heloisa Soares de Moura (orgs.). Estado $e$ Capital imobiliário: convergências atuais na produçâo do espaço urbano brasileiro. Belo Horizonte: C/Arte, 2011.

CARDOSO, Adauto Lúcio. (org.). O Programa Minha Casa Minha Vida e seus efeitos territoriais. Rio de Janeiro: Letra Capital, 2013.

LUCENA, Wilma Guedes de. "Habitação e Expansão Urbana: Análise do Programa Minha Casa Minha Vida nas Cidades de Campina Grande, PB e Caruaru, PE". Anais Encontro Nacional de Geógrafos. São Luís: Associação dos Geógrafos Brasileiros, 2017.

ROLNIK, Raquel e NAKANO, Kazuo. "As armadilhas do pacote habitacional". Le Monde Diplomatique Brasil. Ano 2, n. 20, março de 2009. Disponível em: http://www.diplomatique.org.br/artigo.php?id=461

SHIMBO, Lucia Zanin. Habitação Social de Mercado: A confluência entre Estado, empresas construtoras e capital financeiro. Belo Horizonte: C/Arte, 2012. 


\section{Teorias de localização: do espaço absoluto e relativo ao espaço relacional}

Flaviane Ramos dos Santos

Maria Encarnação B. Sposito

\section{Introdução}

O desenvolvimento de pesquisa relativa ao tema "Grandes infraestruturas urbanas, ensino superior e desenvolvimento regional: reconfigurando as relaçôes entre as cidades médias, as cidades pequenas e o campo" estimulou o grupo que o propôs ${ }^{1}$ a refletir sobre os fatores que orientam a localização espacial. No caso desse projeto em particular, foram destacadas as escolhas locacionais relativas ao Programa Minha Casa Minha Vida (MCMV) e à instalação de instituições de ensino superior, com o objetivo de mostrar as relaçóes entre essas escolhas e as realizadas por grandes agentes econômicos, que levam à implantação de grandes áreas comerciais e de serviços nas cidades estudadas.

Estávamos, então, diante de tripla intenção: a) reconhecer quais são as escolhas feitas pelo poder público (MCMV e universidades públicas); b) as realizadas pela iniciativa privada (especialmente hipermercados, shopping centers e outras grandes superfícies comerciais, além das instituiçóes de ensino superior privadas); c) relacionar duas lógicas que são baseadas em interes-

1 Como já explicitado na apresentação desse livro, trata-se de proposta ao Edital Pró-Integração $\mathrm{n}^{\circ}$ 55/2013, aberto pela Coordenadoria de Aperfeiçoamento do Pessoal do Ensino Superior (CAPES). Este texto, entretanto, além do interesse de contribuir para o projeto, resulta de apoio dado pela Fundação de Amparo à Pesquisa do Estado de São Paulo, para desenvolvimento da tese doutoral de Flaviane Ramos dos Santos (Processo 2017/17632-0), intitulada "Da localização estratégica às estratégias locacionais: A dimensão espacial do crédito e da fidelização nos magazines e nas escolhas dos citadinos em Presidente Prudente (SP) e Londrina (PR)". 
ses diversos (públicos e privados), mas que se inter-relacionam, visto que os agentes políticos e econômicos envolvidos com elas têm articulaçóes ou são as mesmas pessoas, em algumas situaçóes.

Era preciso partir, então, da literatura existente sobre o tema, com destaque para as reflexóes e proposiçóes atinentes aos modelos locacionais. Esse desafio foi enfrentado levando-se em consideraçáo que as ciências são construçóes humanas sujeitas às determinaçóes da época e da sociedade que as produz (Moraes e Costa, 1987). Neste capítulo, apresentamos uma breve contextualizaçáo histórica das principais formulaçóes teóricas e modelos de localização, ressaltando seus princípios e pressupostos, além das diferenças de abordagem de cada um dos autores. Em seguida, questionamos a capacidade e a validade dos modelos locacionais na análise da realidade da distribuiçáo espacial das empresas no período contemporâneo e avaliamos os motivos que levaram à superação (ou não) desses fatores e quais as transformaçóes no espaço geográfico e na sociedade, relacionadas ao progresso técnico, científico e informacional (Santos, 1996) que contribuíram para que isso ocorresse.

No decorrer do capítulo, algumas vezes indicaremos, de um lado, como essas proposiçóes adequam-se ou náo à compreensão do período atual e, de outro, como foram formuladas muito mais para apoiar as lógicas das empresas, ponderar em que medida ajudam a analisar ou criticar as opçóes feitas pelo poder público.

Dado o caráter geral do texto, não voltado diretamente à análise do material empírico da pesquisa apoiada pela CAPES, esperamos que o leitor faça as mediaçóes necessárias à articulação entre essas reflexóes e os dados da realidade que aparecem nos outros capítulos, bem como com outras pesquisas que vêm sendo realizadas.

Entender a localização das atividades no espaço urbano tem levado pesquisadores, há várias décadas, a se interessar pelo estudo dos modelos locacionais e a realizar discussão sobre sua relevância para a compreensão e a análise da problemática da localização das atividades econômicas, sendo esse interesse fundamental para entendimento do processo pelo qual os investimentos são direcionados no espaço geográfico e quais os fatores condicionantes dessa decisão.

Tendo em vista as limitaçóes que apresentam, estes modelos devem ser analisados a partir de uma perspectiva crítica, sendo que algumas se dirigem às suposiçóes feitas na sua construção, tais como o postulado da 
racionalidade dos agentes econômicos e o princípio da maximização de lucros. Outras referem-se aos fatores locacionais considerados pelos modelos que, basicamente, são os custos de transporte, de mão de obra e dos insumos. Outros ainda são direcionados à suposição do espaço como sendo homogêneo e, por último, a não consideração das estruturas de mercado não concorrenciais.

Durante certo tempo, os modelos, enquanto representação idealizada do mundo real, tornaram-se um instrumento bastante utilizado na análise da organização espacial, permitindo melhor compreensão da realidade. Sua construção avançou por dois caminhos distintos. O primeiro é aquele em que o problema começava com postulados muito simples e uma maior complexidade era introduzida gradualmente, aproximando o modelo cada vez mais da realidade, enquanto o segundo consistia em resumir a realidade mediante uma série de generalizaçóes, muitas vezes simplificadoras.

Haggett (1976) questiona os motivos que levaram à utilização dos modelos nas teorias de localização, tendo em vista que, no caso de alguns, eles são mais fáceis de refutar do que de confirmar. Assim, o autor destaca, primeiro, que a construçáo de modelos foi inevitável porque não existe uma linha divisória entre fatos e crenças. Segundo, que a construção de modelos é econômica, porque permite transmitir uma informação generalizada de forma muito simplificada. E, por último, a construção de modelos era estimulante, porque suas generalizaçóes colocam em destaque alguns elementos que necessitam de aperfeiçoamentos e, com isso, conduzem a posteriores modificaçóes. Em síntese, o papel dos modelos consiste em sintetizar o que já ocorreu e em orientar açôes que incidirão sobre a realidade.

Em que medida esses modelos, ainda que criticados e, parcialmente, refutados têm ainda orientado empresas e o poder público no momento das decisóes concernentes à localização de investimentos relativos a empreendimentos econômicos ou a políticas públicas? Essa questáo, mesmo que não respondida de modo cabal, pode orientar o leitor a nos acompanhar nas ideias que passamos a apresentar. 


\section{Teorias de Localização: De Von Thunen à Walter Isard}

A preocupação com a questáo locacional começou a ser pensada de modo sistemático somente com a emergência e o desenvolvimento do modo capitalista de produção (Corrêa, 1986), entre a segunda metade do século XVI e início do século XVII, na Inglaterra. Com a Revolução Industrial no final do século XVIII, o capitalismo alcançou um estágio mais avançado, tendo em vista que, a partir desse momento, o capital acumulado no comércio podia ser reproduzido e ampliado por meio do investimento na produçáo (compra de matéria-prima, ferramentas, máquinas e força de trabalho) e na apropriação de parte da riqueza produzida pelo trabalhador e não remunerada a ele - a mais valia (Dobb, 1980). A busca pela acumulação cada vez maior de capital promoveu transformaçóes significativas, até então nunca vistas como, por exemplo, mudanças no papel e estruturação do espaço interno das cidades e a ampliação da divisão social e territorial do trabalho.

A lógica capitalista, caracterizada pela minimizaçáo de custos e maximização de lucros, suscitou aumento da escala de produção. Com isso, nessa nova fase, a localização das atividades econômicas e da população passou a ter importância fundamental para os interesses da classe dominante, porque diante dos volumosos investimentos de capital acumulado no comércio em atividades de produçáo, circulaçáo e distribuição, o aumento dos lucros poderia ser resultado de ganhos diferenciais relacionados às vantagens locacionais (proximidade com as fontes de energia, matéria-prima, infraestrutura, meios de transporte, reservas de força de trabalho, mercado consumidor etc.) (Corrêa, 1986). Em outras palavras, a localização começou a ter enorme significado quando passou a representar um dos elementos que influenciava os custos de produção e os lucros e, portanto, a capacidade de sucesso do empreendimento no capitalismo concorrencial.

Os primeiros a teorizarem sistematicamente sobre a localização das atividades econômicas foram Johann Heinrich Von Thünen (1826), Alfred Weber (1909), Walter Christaller (1933), August Losch (1939) e Walter Isard (1956). Embora analisem atividades diferentes - isto é, agricultura, indústria e comércio -, todos eles consideram os custos dos transportes como fator fundamental na análise locacional, tendo como princípio básico a racionalidade baseada no comportamento otimizador do agente econômico por meio da minimização dos custos e/ou maximização dos lucros (Richardson, 1975). 
De maneira sintética, a seguir, apresentaremos as formulações e modelos teóricos elaborados por cada um dos autores supracitados, começando pelo economista e proprietário de terras no norte da Alemanha, Johann Heinrich Von Thünen, que publicou sua obra "O estado isolado em relação com a agricultura e a economia" (Der isolierte staat in beziehung auf landwirtschaft und nationalökonomie) em dois volumes: o primeiro, em 1826, e o segundo, em 1863 (Corrêa, 1986), na qual ele se preocupa com a influência da cidade sobre a formaçáo dos preços dos produtos agrícolas e a influência da distância da cidade sobre a renda dos agricultores (Azzoni, 1982). Por muitos autores, ele é considerado como o pioneiro da teoria de localizaçáo.

$\mathrm{Na}$ época em que suas proposiçóes foram elaboradas, estavam ocorrendo mudanças na organização espacial da agricultura em determinadas áreas da Europa, com a passagem de uma agricultura camponesa, de subsistência e venda de excedentes, para uma agricultura de mercado, na qual se reafirmava a propriedade privada e o trabalho assalariado (Corrêa, 1986). Deste modo, Von Thünen procurou descrever o que seria o uso mais racional da terra e como deveria ser a organização espacial da agricultura no âmbito da economia capitalista.

Segundo Camagni (2005), para elaboração de suas ideias, Von Thünen imaginou um estado isolado onde os fatores físicos não variavam, todas as terras seriam igualmente planas e férteis, haveria somente um meio de transporte primitivo terrestre e em linha reta e uma grande cidade no centro, acessível por todos os lados e cujos habitantes consumissem todos os produtos agrícolas. Calculando os custos de transporte e os custos de exploraçáo, Von Thünen estabeleceu a disposição dos cultivos na forma de anéis/círculos concêntricos em torno da cidade, visto que a diferenciaçáo no uso agrícola da terra se dá em virtude dos custos crescentes de transporte de cada produto cultivado, à medida que a distância do mercado consumidor aumenta (Figura 1).

A renda territorial, excedente disponível depois de ter remunerado todos os fatores de exploração, deve ser maximizada. Contudo, seu nível depende do tipo de produçấo, da quantidade produzida e da distância do mercado. Assim, em uma planície uniforme e de igual fertilidade, com uma só cidade no centro, a renda se dá em função da natureza da produção e do distanciamento do mercado (Bailly, 1978, p. 30). 
Figura 1 - Anéis de Thünen

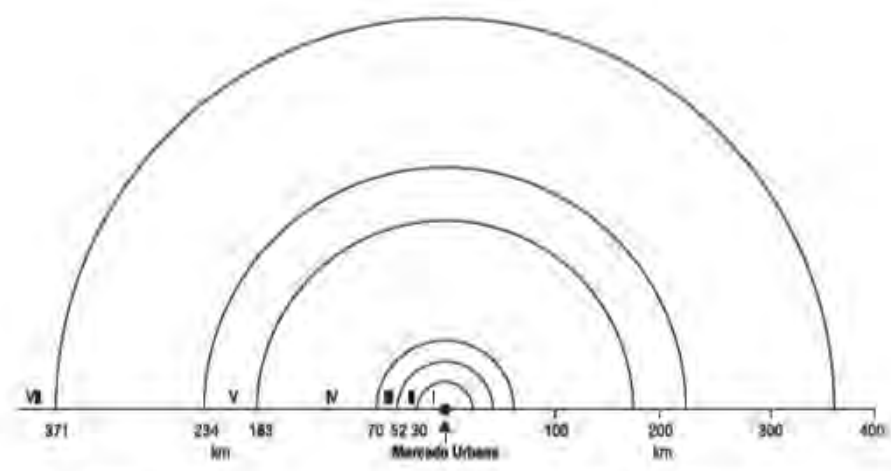

I Horticultura intensiva

II Silvicultura

V Sistema de três campos

III Sistema rotativo de cereais e raizes

IV Sistema rotativo de cultura e pastagem

VI Criação de gado

VII Floresta virgem

Fonte: Braga (2008)

$\mathrm{Na}$ sua concepção, os produtos pesados, volumosos e os perecíveis seriam encontrados próximos à cidade e os de fácil transporte, mais distantes. Assim, o primeiro anel, mais interno, estava voltado para produtos que não suportavam um transporte demorado, como verduras, flores e leite; no segundo anel temos a silvicultura; no terceiro havia o cultivo de diversos cereais (milho, trigo, centeio etc.) e tubérculos; o quarto, muito largo, era utilizado para agricultura e pastagem por rotação de culturas; no quinto, surge o sistema de três campos com o alqueive; no sexto, igualmente muito largo, temos criação extensiva; e fora destas zonas estava a floresta virgem (Braga, 2008).

Em síntese, a preocupação central de Von Thünen era determinar a composição de culturas que maximizasse a renda da terra, levando em consideração a distância do centro consumidor e o tipo de cultivo. Ao fornecer instrumentos para compreensão da estrutura espacial da agricultura e suas associaçóes com a cidade, o modelo de Von Thünen inspirou diversos outros trabalhos, notadamente em Economia Urbana, além de se constituir no marco inicial das discussóes espaciais no âmbito econômico, dando subsídios para outras perspectivas espaciais. Contudo, por se tratar de uma teoria que aborda a localização de atividades agrícolas, sendo muito influenciada por fatores climáticos e fenômenos da natureza, essa abordagem é bastante restritiva quando comparada com os outros modelos de localização (Azzoni, 1982). 
Assim, embora se trate de formulação importante na história da construção do pensamento sobre fatores de localização, ela, independentemente de seu valor como teoria, pouco oferece de elementos para se analisar as escolhas locacionais no espaço urbano. Entretanto, no que se refere aos capítulos contidos nesse livro, em que as relaçóes entre a cidade e o campo são importantes, o leitor poderá encontrar aportes que serão valiosos nessa perspectiva.

O segundo autor a se preocupar com a localização de atividades econômicas foi o sociólogo e economista alemáo Alfred Weber, que em 1909 publicou o livro "Teoria da Localização das Indústrias" (Über den Standort der Industrie), no qual analisa as atividades industriais e a influência dos custos de transportes, da máo de obra e das forças aglomerativas tendo como princípio básico a minimizaçáo do custo de transporte através da localização ótima da indústria, que ocorre quando há um equilíbrio entre a localização das matérias primas, do centro consumidor e da mão de obra (Azzoni, 1982).

Em sua formulação teórica, Weber adota os seguintes pressupostos e suposiçóes gerais: a localização das matérias-primas, a posição e o tamanho dos centros de consumo são dados e conhecidos; a mão de obra pode ser encontrada em oferta ilimitada a uma taxa de salário determinada em várias localizaçóes dadas e fixas; as condiçôes físicas e técnicas da superfície são homogêneas e; os custos de transporte variam em funçáo do peso e da distância do mercado (Braga, 2008). Além disso, implicitamente em toda a sua obra estáo os pressupostos da concorrência perfeita (ideia de que cada produtor detém um mercado ilimitado, sem possibilidade de obter vantagens monopolísticas de sua escolha locacional) e dos coeficientes fixos de produçáo (Azzoni, 1982).

Para determinar a localização ótima da indústria, Weber analisou separadamente a influência dos custos de transportes, da máo de obra e dos fatores aglomerativos. No primeiro caso, ele considerou um cenário em que existem duas matérias-primas necessárias e localizadas em dois pontos distintos e um centro consumidor, situado em um terceiro ponto. Esses três pontos formam o que denominou de triângulo locacional (Figura 2), no qual a interseçáo das circunferências dentro do triângulo locacional determina o ponto de custo mínimo de transporte (Coutinho, 2009).

Nos outros dois casos, utilizou como instrumento de análise as curvas isodapanas (iso - igual, dapanas - custos ou despesas), que permitem visualizar o padrão de variação espacial dos custos (Figura 3). A ideia era que a atividade produtiva fosse atraída na direção da localidade em que o custo de mão 
de obra fosse mais barato e favorável ao produtor, desde que essa localidade se situasse dentro da isodapana crítica (aquela na qual o custo de transporte se equilibra com a economia de gastos com máo de obra). Caso contrário, a indústria permaneceria localizada no ponto que oferece custo mínimo de transporte (Coutinho, 2009).

Figura 2 - Triângulo Locacional

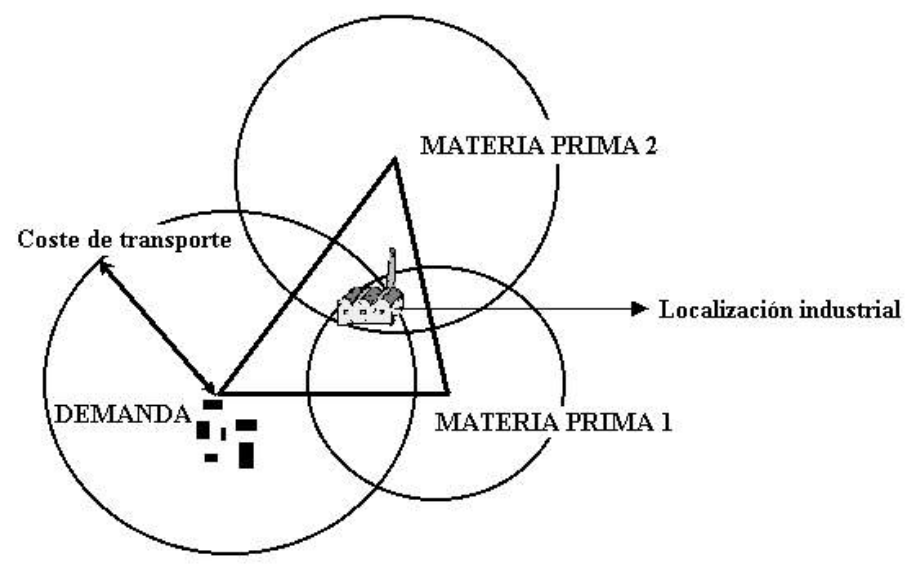

Fonte: Braga (2008)

Figura 3 - Curvas Isodapanas

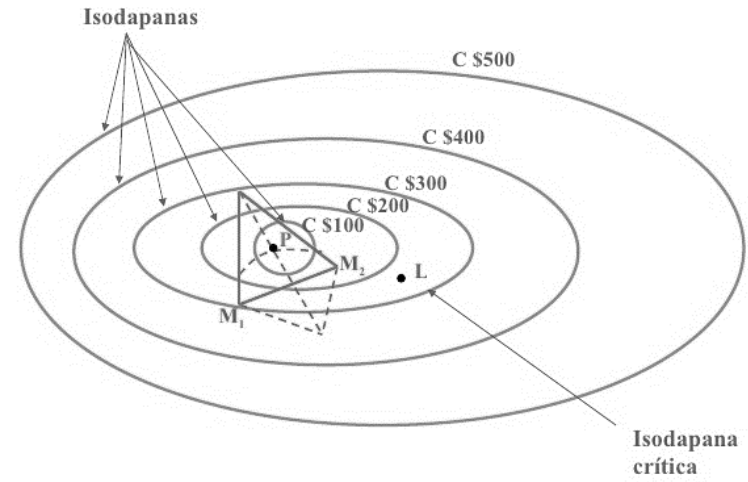

Fonte: Braga (2008) 
A partir do exposto, é possível observar que esse modelo reflete características essenciais dos processos de industrialização e urbanização do século XIX, no qual o custo de transporte constitui o principal fator de influência na escolha da localização das atividades econômicas, além da mão de obra e os fatores aglomerativos que, isolados ou em conjunto, podem compensar o fator preço de transporte no processo de minimizaçáo de custo para determinar a localização ótima da indústria (Camagni, 2005). No que se refere à pesquisa que gera esse livro, o enfoque recaiu, no espaço urbano, na atividade do setor comercial e de serviços, mas é possível considerar que aspectos associados ao peso dos transportes têm seu impacto sobre esse setor, uma vez que, no tocante ao comércio, a distância entre os centros de produçáo e armazenamento de produtos industriais, sobretudo, é elemento importante para a decisão das empresas no que se refere à presença delas em cidades médias e pequenas, onde o tamanho do mercado consumidor tem que ser ponderado vis-à-vis aos custos de instalação comercial e aos custos adicionais do transporte de bens.

Em que sejam pesados esses pontos, como possibilidades de se aproveitar elementos da formulação de Weber, uma das principais críticas a essa abordagem consiste nos seus pressupostos teóricos limitados e pouco adequados a situaçóes reais, o que dificulta sua comprovação empírica, além da náo-abordagem do lado da demanda, que é considerada como dada e independente da localização da indústria, não havendo, portanto, uma análise dela (Coutinho, 2009). Além disso, de acordo com Camagni (2005, p. 34),

O modelo weberiano responde a um enfoque de equilíbrio parcial, no qual não existe interação nos comportamentos empresariais e é um modelo estático, no qual se tem em conta sobretudo a eficiência produtiva, mas deixa-se de lado, ao menos no nível mais formalizado, os processos evolutivos, tanto no nível microeconômico (inovaçóes) quanto macroeconômico (dinâmica das condiçôes de distribuição de renda e relaçóes entre benefícios de aglomeração, rendas e salários).

Esse modelo recebeu várias críticas e aperfeiçoamentos posteriores. Em síntese, tanto para Weber quanto para Von Thünen, a localização ótima era aquela que proporcionasse menor custo em transportes - da matéria-prima para as indústrias e dos produtos para o consumidor. Contudo, uma dife- 
rença básica entre os dois autores é que enquanto Von Thünen procura responder quais atividades deverão se localizar em determinado local, Weber procura mostrar onde se localiza uma determinada atividade industrial.

A mais importante contribuição no estudo da localização de atividades econômicas foi do geógrafo alemão Walter Christaller que, em 1933, publicou a obra "Os Lugares Centrais no Sul da Alemanha" ("Die zentralen Orte in Süddeutschland”), na qual formulou uma teoria com o objetivo principal de não apenas explicar a organização espacial dos núcleos de povoamento e das suas áreas de influência, mas identificar as leis gerais que determinavam os padróes de povoamento que observava à sua volta e, deste modo, classificou as localidades de acordo com as suas funçóes e analisou as relaçóes entre elas e suas áreas de influência (Bradford e Kent, 1987).

Não podemos nos contentar com o esclarecimento das relaçóes com que se pode explicar o tamanho, o número e a distribuiçáo dos lugares centrais em casos concretos individuais. Estamos em busca de leis que trazem ordem a distribuição aparentemente arbitrária, ao número aparentemente acidental, e aos tamanhos aparentemente só condicionados individualmente dos lugares. (Christaller, 1966, p. 106) ${ }^{2}$

Christaller preocupou-se mais com a posição relativa, que seria a posição ocupada por uma localidade em relação a outras localidades, sendo expressa em tempo, percurso, custo de transporte etc., do que com a posição absoluta dos "lugares" centrais (Fajardo, 2010). Assim, sua teoria ficou conhecida como Teoria das Lugares Centrais (ou Teoria das Localidades Centrais), ${ }^{3}$ que aborda localização, tamanho, natureza e distribuição espacial do comércio e serviços e, durante muito tempo, se constituiu como a base teórica de uma grande parte da Geografia Urbana (Berry, 1971), influenciando notadamente vários autores. Contudo, na época de publicação, a obra não teve muita repercussão; só com o passar das décadas, sobretudo após sua

2 Sempre referindo-se à tradução de Eufrásio (1981).

3 Na tradução realizada por Eufrásio (1981), a expressão utilizada é "lugares centrais". Contudo, no Brasil, tanto a expressão "lugares centrais" quanto a expressáo "localidades centrais" pode ser encontrada nas publicaçóes que discorrem sobre a teoria elaborada por Christaller. Tendo em vista que o conceito de lugar compreende vivência, pertencimento e identidade, optamos por utilizar "localidades centrais", embora nas situaçóes em que o autor citado use "lugar", respeitamos a expressáo escolhida por ele e colocamos "aspas". 
tradução para o inglês, em 1966 (com o título "Central Places in Southern Germany"), é que veio finalmente a ser reconhecida por suas contribuiçóes.

Segundo a teoria, as localidades apresentam determinadas funçóes centrais que atraem os consumidores do entorno dependendo do custo de deslocamento. Essas localidades foram hierarquizadas entre si em função de dois mecanismos básicos: o alcance espacial máximo e o alcance espacial mínimo. No primeiro, tem-se um raio a partir da localidade central até onde os consumidores estáo dispostos a se deslocar para obter determinados bens e serviços. No segundo caso, tem-se a área mínima para que determinada função central possa se instalar lucrativamente (Braga, 2008). Tais mecanismos poderiam ser considerados para a análise das escolhas locacionais relativas aos usos de solo que foram estudados na pesquisa da qual esse livro resultou. Quando pensamos na localização das universidades, por exemplo, sem dúvida não se pode apenas avaliar a escala da cidade, porque grande parte de seus alunos são oriundos das cidades menores em seu raio de polarização, sendo que uma parcela deles se desloca diariamente para acompanhar seus cursos de formação na localidade central onde está a unidade universitária a que se vinculam. Num país como o Brasil, os mecanismos de alcance espacial máximo e alcance espacial mínimo têm que ser matizados pela incompletude ou ineficácia de nosso sistema de circulação interurbana, seja em decorrência das infraestruturas (sobretudo rodoviárias) e dos meios de transporte (principalmente os coletivos).

Esses pontos têm relação direta com outros aspectos da mesma formulação. Christaller baseou sua teoria em um conjunto de pressupostos, sendo que cada um deles foi expresso implícita ou explicitamente. Segundo Bradford e Kent (1987), o primeiro deles é a concepção da existência de uma planície uniforme na qual a população está igualmente distribuída e há igual facilidade de transporte em todas as direçóes, sendo os custos proporcionais à distância. Além disso, presume-se que todos os consumidores têm o mesmo rendimento, demanda igual pelos bens e serviços e que eles sempre se deslocam à localidade central mais próxima que forneça o bem ou serviço que procuram; ou seja, pressupóe-se a racionalidade por parte do consumidor em minimizar a distância que deve percorrer para satisfazer suas necessidades. Ao aplicar uma concepção como essa à realidade brasileira, defronta-se com a amplitude de nossas desigualdades socioespaciais. De todo modo, independente de maior ou menor grau de desigualdade, é bom lembrar que, 
conforme Hagget (1983), o modelo é representação idealizada e nos exemplos utilizados para ilustrar suas proposiçôes teóricas, Christaller faz algumas simplificaçôes da realidade bastante questionáveis, inclusive para o período em que foi elaborado. A partir do enunciado a seguir, por exemplo, podemos identificar algumas dessas simplificações:

Suponhamos uma regiáo de aproximadamente $80 \mathrm{~km}^{2}$ que tenha quatro mil habitantes uniformemente distribuídos por toda a região, exceto num pequeno lugar em que a população tende a se aglomerar. Suponhamos que um médico, a fim de oferecer seu serviço central nessa região, se estabeleça no centro da regiáo. A demanda de serviços médico é basicamente a mesma por toda a população, isto é, cada habitante tem aproximadamente o mesmo número de doenças ou distúrbios. Ademais, suponhamos que todas as pessoas dessa regiāo tenham rendas iguais que permitam destinar 6 marcos [moeda oficial da Alemanha até 2002, antes da adesão ao euro] por pessoa por ano para despesas médicas, após as outras necessidades prementes, tais como alimentação, vestuário e habitação, terem sido satisfeitas (Christaller, 1966, p. 47, grifos nossos).

De acordo com Bradford e Kent (1987), a racionalidade econômica também é esperada por parte do fornecedor/produtor na medida em que se pressupóe que ele tem como único objetivo maximizar seu lucro, localizando-se de maneira a obter o maior mercado consumidor possível. Uma vez que as pessoas se deslocam ao centro mais próximo, os fornecedores localizam-se o mais longe possível uns dos outros, maximizando as suas áreas de mercado. Em relação a esse ponto, as particularidades das cidades médias brasileiras também levariam à contestaçáo desse primado, visto que, em grande parte, sendo marcadas por clara separação espacial entre ricos e pobres, as empresas comerciais voltadas a segmentos socioeconômicos médios e altos tendem a se localizar no mesmo setor da cidade, impondo aos que ganham menos a necessidade de se deslocarem por distâncias maiores entre suas residências e áreas de comércio e serviços, ${ }^{4}$ na mesma cidade ou em cidades diferentes, se quiserem ter acesso a certos produtos (bens ou serviços) e a espaços de consumo de mais prestígio social.

4 Para esse debate é importante a reflexão sobre a ideia de distância econômica que será abordada logo adiante. 
De acordo com a teoria, grandes, médias, pequenas cidades e até mesmo vilas rurais são consideradas como localidades centrais, dotadas de funçóes centrais, ou seja, bens e serviços destinados à população tanto da cidade como de seu entorno (área de influência ou regiáo complementar). A centralidade de cada localidade seria determinada pelo grau de importância de suas funçóes centrais, e para cada produto ou serviço haveria, em princípio, um alcance espacial específico, ou seja, a distância que as pessoas estariam dispostas a percorrer para adquirir algo. Assim, estabelece-se uma hierarquização dos centros no que diz respeito à oferta de bens e serviços.

O alcance espacial depende de certas variáveis, como distribuiçáo da população, distâncias econômicas a serem percorridas, tipos de bens ${ }^{6}$ etc., e cada bem tem um alcance específico, que pode variar em certos casos. $\mathrm{O}$ alcance de um bem central se constitui em um anel cujo limite superior é a distância mais afastada da localidade central em que ele pode ser adquirido e cujo limite inferior é a distância em que ocorre o montante mínimo de vendas para que sua produçáo e oferta seja compensadora.

O limite superior e limite inferior juntos determinam se um bem central pode ser oferecido em qualquer lugar central da regiáo com alguma chance de sucesso. O limite inferior circunscreve a região com o menor número de vendas que deve existir para se oferecer o bem central num lugar central dessa regiáo, enquanto o limite superior circunscreve aquela região em que a venda do bem central pode ser possível de qualquer modo. Isso significa que ambos os limites determinam a menor área e a maior região complementar de um lugar central com relação a um certo bem central. Esses limites se desenvol-

5 Christaller (1966) atribui mais importância ao que denomina de "distância econômica", ou seja, a distância relativa a tempo e custo, do que à distância em quilômetros. Inclusive afirma que a distância econômica possui elementos objetivos como, por exemplo, custos de frete, perdas de peso, danos eventuais causados por uma viagem mais demorada etc., e subjetivos, tais como, comodidade e conveniência.

6 Em relação aos tipos de bens, Christaller (1966) destaca a existência de quatro tipos: produtos com quantidade limitada e preço fixo; produtos com quantidade limitada e preço variável; produtos com quantidade ilimitada e preço fixo e, por último, produtos com quantidade ilimitada e preço variável. $\mathrm{O}$ autor descreve de que forma o preço e o alcance do produto afetam o desenvolvimento do "lugar" central, isto é, os bens com alcances semelhantes são oferecidos pelos mesmos "lugares" centrais. Quanto menor o alcance, maior será o número de "lugares centrais" que vendem esse bem e o inverso também é verdadeiro. 
vem em curvas fechadas, que se aproximam mais ou menos do círculo, e que se constituem em isolinhas (Christaller, 1966, pp. 109-10).

De acordo com Camagni (2005), a hipótese de Christaller era a de que a rede urbana se constituía a partir das zonas de influência econômica das localidades, cuja centralidade seria determinada pelo nível de complexidade dos produtos e serviços ali ofertados e, também, a partir do alcance desses mercados. Estes produtos e serviços, por sua vez, estariam classificados como de ordem superior ou de ordem inferior, indo dos mais aos menos especializados, e essa classificação também definiria os aglomerados. Em geral, "lugares centrais" de ordem superior abarcam outros, de ordem inferior, configurando relaçóes espaciais de interdependência assimétrica, ou seja, haveria uma forma de organização hierárquica em que as cidades pequenas se subordinam às cidades médias e estas às grandes, tal como mostra a Figura 4. Tais relaçóes permitem vislumbrar o estabelecimento de uma hierarquia de "lugares centrais", na qual os "lugares" de ordem mais elevada são mais populosos, porém menos numerosos, enquanto os "lugares" de ordem mais baixa são menores demograficamente e mais numerosos (Valbuena, 2013).

A abordagem teórica de Christaller realça a formaçáo de uma rede de centros urbanos com diferentes tamanhos e importâncias, do ponto de vista funcional. Cada localidade central tem a sua região complementar ou área de influência, que tem sempre o formato hexagonal, porque

se o território deve ser servido por uma rede perfeitamente uniforme de lugares centrais, então não haverá nem demasiado muitos nem demasiado poucos lugares deste tipo, e também não haverá nenhuma parte não suprida, entáo os lugares centrais contíguos devem estar equidistantes uns dos outros. (Christaller, 1966, p.115, grifo nosso). 
Figura 4 - Sistema de "lugares centrais" com diferentes níveis hierárquicos

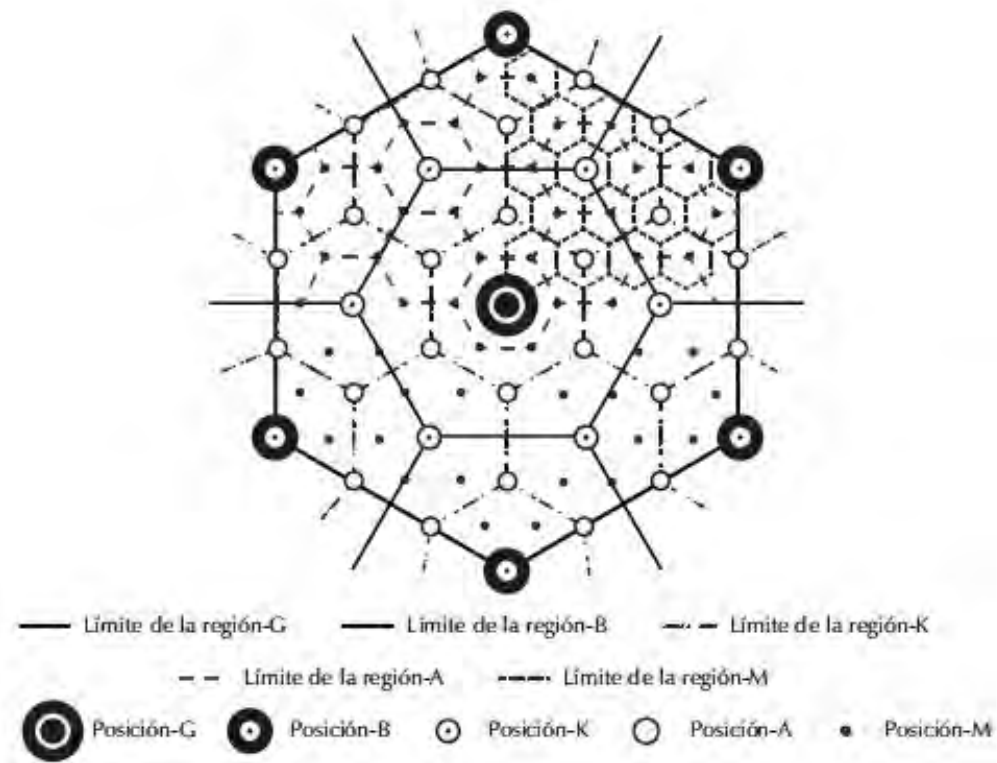

Fonte: Valbuena (2013, p. 86)

Sobre essa questáo, Bradford e Kent (1987) afirmam que, para assegurar que todos os consumidores sejam servidos, os fornecedores aproximam-se uns dos outros e, com isso, as áreas circulares de mercado interceptam-se. Considerando o pressuposto já explicado de que os consumidores das áreas sobrepostas preferem deslocar-se para o centro mais próximo, as áreas de mercado resultantes serão, então, hexagonais. Christaller (1981 [1933]) admite a possibilidade de haver o que ele chama de desvios do normal e afirma que esses desvios são sempre decorrentes de causas definidas que podem ser justificadas. Portanto, de acordo com a teoria, esse padrão hexagonal é o modo mais eficiente de organizaçáo das áreas de mercado de forma que sejam servidos todos os possíveis clientes. 
Para Christaller (1981 [1933]), as localidades centrais são organizadas de acordo com três princípios: ${ }^{7}$ o de mercado, que abarca as relaçóes existentes entre as localidades centrais de diferentes níveis hierárquicos; o de tráfego ou circulação, que prevê que as localidades centrais estejam alinhadas sobre rotas diretas de circulaçáo que se abrem em leque a partir do ponto central; e o administrativo, que considera os limites territoriais dos centros e determina a influência das localidades de ordem superior sobre aqueles de ordem inferior. A seguir, apresentamos as figuras 5, 6 e 7 que mostram o sistema de localidades centrais baseado nos três princípios supracitados.

Figura 5 - Princípios de mercado, de tráfego e administrativo

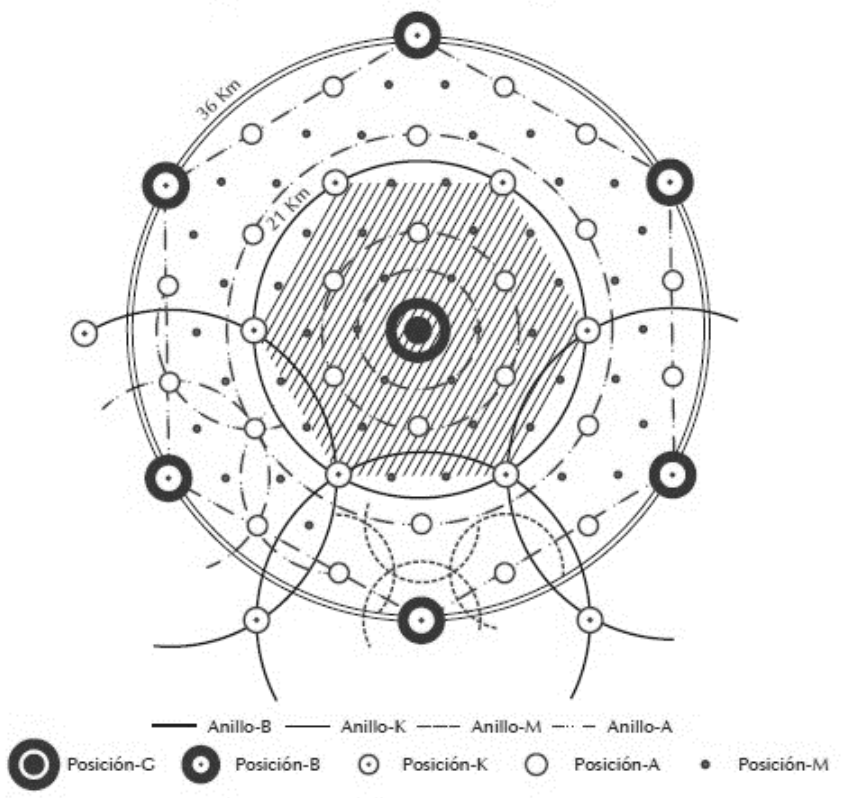

7 Para saber mais, consultar Bradford e Kent (1987) e Valbuena (2013). 
Figura 6 - Princípios de mercado, de tráfego e administrativo

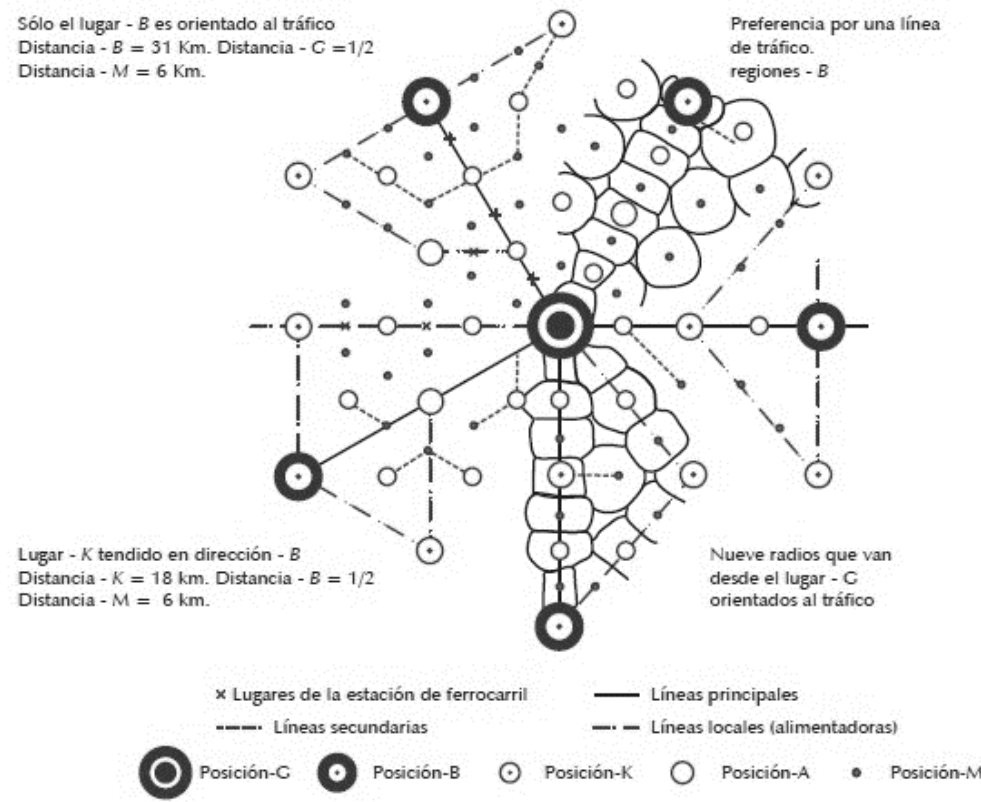

Figura 7 - Princípios de mercado, de tráfego e administrativo

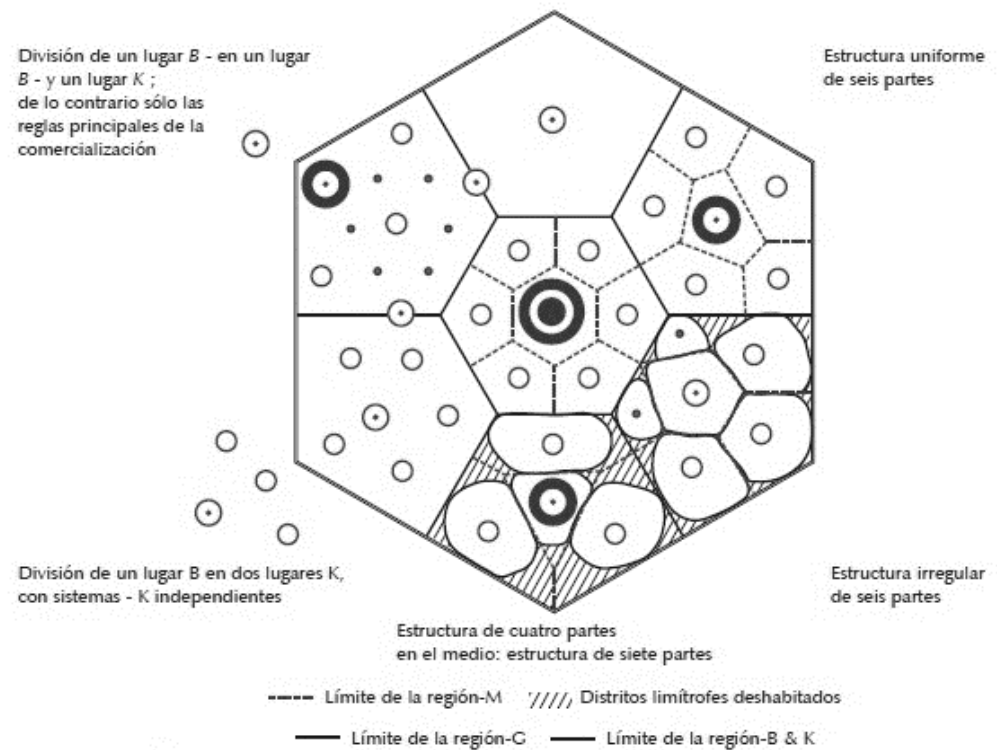
(O)
Posición-C
(-) Posición-B
$\odot$ Posición-K
Posición-A
Posición-M

Fonte: Valbuena (2013, pp. 89, 91 e 93) 
Dependendo das características da região, tais como nível de desenvolvimento, densidade e renda da população, entre outros aspectos, o princípio de tráfego pode ter um peso maior que supera o princípio de mercado ou vice-versa. Sobre essa questão Christaller afirma que:

Somente um território densamente povoado, com bom nível de vida, com população gozando de um alto nível de cultura e que seja principalmente industrial, pode suportar muitos lugares centrais; aqui, consequentemente, o princípio de circulação [tráfego] pode levar vantagem. Regiôes agrícolas densamente povoadas e mais pobres, de outro lado, consomem menos bens centrais e podem suportar poucos lugares centrais. Uma racionalidade mais alta é mais provável de ser obtida com um número mínimo de lugares centrais; portanto, o princípio de abastecimento [mercado] prevalece (Christaller, 1966, p. 138).

Segundo Christaller (1981 [1933]), a diferença fundamental entre o princípio de circulação e o princípio de mercado é que o primeiro é linear e o último atua de modo bidimensional. Em relação ao princípio administrativo, o autor afirma que este tem natureza completamente diferente dos anteriores, em razão da ordem centralista que lhe é característica, ou seja, ao redor do núcleo principal de ordem mais elevada, haveria uma coroa de localidades de menor importância e, em direção à periferia da região, uma densidade de população que vai diminuindo. Portanto, os três princípios determinam, cada um de acordo com suas próprias leis, os sistemas de localidades centrais. Os dois primeiros são econômicos e o terceiro é político. No que concerne ao princípio administrativo, mais uma vez, por meio desse livro, é possível questionar sua aplicabilidade às nossas cidades, nas quais, via de regra, sobretudo nas área de programas habitacionais com finalidade social, como o MCMV, a tendência é exatamente outra, pois a densidade de grandes conjuntos habitacionais é elevada e, paralelamente, as áreas centrais e pericentrais têm perdido prestígio e população nas últimas décadas.

Apesar de sua contribuição, diante de uma realidade mais complexa do que os pressupostos admitidos por Christaller, algumas de suas ideias já não se confirmavam nem sequer na realidade do século XX. Conforme apontam Bradford e Kent (1987), algumas das inconsistências lógicas de sua formulação teórica dizem respeito à distribuição uniforme da população e igualdade 
na capacidade de consumo; facilidade de transporte em todas as direções; a existência de áreas de mercado de dimensóes semelhantes no padrão de hexágonos perfeitos; relação perfeita entre o número e a dimensão dos centros; comportamento não realista dos consumidores (racionalidade econômica), presumindo que eles se deslocavam somente para os locais mais próximos, e também dos fornecedores, como se eles fossem incapazes de criar monopólios espaciais e que devido à concorrência as áreas de mercado se sobrepusessem.

Em relação aos diferentes níveis hierárquicos das cidades, Christaller (1981 [1933]) não incluiu algumas funçôes que também geravam emprego e população, como, por exemplo, a indústria. Uma possível justificativa para isso é a industrialização incipiente na porção sul da Alemanha (região analisada pelo autor), pois embora o país tenha começado a se industrializar no final do século XIX, esse processo foi bastante concentrado no Vale Ruhr (porção oeste), devido à sua posição estratégica do ponto de vista do escoamento da produção, à presença significativa de hulha (um tipo de carvão mineral) e à condição favorável dos nobres da região (Braga, 1999).

Entretanto, é importante ressaltar que não considerar a indústria não significa que ela tenha sido completamente ignorada pelo autor. Apesar do que muitos afirmam, Christaller náo ignorou nem os recursos naturais ${ }^{8} \mathrm{e}$ nem o papel da indústria como uma das maiores influências no sistema de localidades centrais, ele destacou, inclusive, que a localização industrial é responsável, juntamente com outros fatores, pelo direcionamento da expansão e desenvolvimento ou contração da regiáo complementar.

A opção por não incluir as indústrias em seu modelo é decorrente da ideia de que, no que concerne à produção, Christaller (1981 [1933]) afirma que raramente ocorre em "lugares centrais", porque as desvantagens são maiores que as vantagens, ou seja, os fatores desaglomerativos superam os fatores de aglomeração. Isso acontece porque os custos de produção são maio-

8 Considerando que, historicamente, as cidades surgem ao longo dos rios, Christaller (1981 [1933]), utilizou o exemplo de uma cidade próxima de um rio e uma cidade distante, para afirmar que o alcance dos bens oferecidos na primeira cidade é maior assim como sua região complementar, em razáo do custo de transporte fluvial ser mais barato. No caso de um "lugar central" próximo de um rio e isolado, o alcance espacial (mínimo e máximo) tem o formato de anéis, porém, no caso de haver "lugares centrais" vizinhos do outro lado da margem do rio, a área de influência e o alcance espacial assume a forma elíptica. Portanto, Christaller não somente considera os recursos naturais, como também destaca que o custo é variável de acordo com o modal de transporte. 
res em consequência dos salários mais altos e do preço do solo/imóveis mais elevados nos "lugares centrais". Deste modo, o autor afirma que não é a produção de bens, mas a oferta deles e a prestação de serviços que são vinculadas aos "lugares centrais".

Nesse sentido, Sposito (2007 e 2018) afirma que associar a indústria e o crescimento do urbano não é tâo direta como alguns autores estabelecem, especialmente aqueles que associaram esses dois processos para teorizar sobre desenvolvimento econômico. Segundo a autora, na maior parte dos casos, o desenvolvimento urbano não ocorre necessariamente após a chegada das indústrias, mas após a chegada dos produtos industriais destinados ao consumo dos citadinos. Em outras palavras, sobretudo hoje, o consumo associado à distribuição de bens e serviços explica muito mais a centralidade urbana do que a indústria. Embora a chegada e presença de indústrias seja importante, é o comércio e os serviços que mais oferecem emprego e geração de renda, além de ser o setor que promove maior movimentação de pessoas no espaço urbano, tendo em vista sua relação mais próxima e direta com os consumidores. ${ }^{9}$

Para Christaller (1981 [1933]), em contraposição aos "lugares centrais" estão os lugares dispersos, ou seja, todos aqueles que não são pontos centrais. Eles podem ser: a) vinculados a áreas, como por exemplo aquelas localidades cujos habitantes vivem de suas atividades agrícolas; b) vinculados a pontos, tais como aquelas localidades cujos habitantes desenvolvem uma atividade a partir de condiçóes presentes em determinado local, como a mineração; ou c) localidades que são indiferentes à sua localização como, por exemplo, as grandes indústrias, cujas posiçóes são determinadas por certas vantagens econômicas (reservas de mão de obra, vias de transporte etc.). Assim, as indústrias estão situadas no que Christaller classificou como lugares dispersos, que não são o foco de sua obra.

Levando em conta que a distribuição das atividades industriais não era uniforme no espaço geográfico, mas sim, muitas vezes, concentrada em determinados localidades, sua localização não seguia o pressuposto de Christaller. Além disso, como se intensifica o processo de industrialização em período posterior, surgiram várias empresas prestadoras de serviços para a indústria, situadas nas mesmas localizaçóes (Bradford e Kent, 1987). Conforme vere-

9 Isso que explica, por exemplo, porque cidades bastante industriais no estado de Sáo Paulo, como Americana, Limeira ou São Carlos, são menos importantes, do ponto de vista da hierarquia urbana, do que Presidente Prudente. 
mos a seguir, a formulação elaborada por Losch mostra-se mais realista para o caso das indústrias.

É importante destacar que, na formulação de Christaller, não é considerado o papel dos agentes econômicos e públicos na influência da distribuição, dimensões e funções das localidades centrais, tendo em vista que são os responsáveis, entre outras coisas, por determinar a direção da expansão e do desenvolvimento da cidade, além de oferecer vantagens para instalação de empresas e indústrias. Isso é decorrente, como já ressaltamos, da concepção de espaço vigente e utilizada pelo autor, além da influência da corrente do pensamento geográfico no qual está, ainda que indiretamente, inserido. ${ }^{10}$ Portanto, apesar de sua importância para a Geografia Urbana e Regional, a Teoria das Localidades Centrais deve ser analisada criticamente e com cuidado, pois alguns de seus princípios e pressupostos não são mais válidos e outros, ainda, podem ser questionados, até mesmo tomando como referência o período de sua elaboração.

Seguindo a exposição dos autores que se preocuparam com a localização de atividades econômicas, temos o economista alemão August Losch, que publicou a obra intitulada "A economia de localização" (Die Wirtschaftlichkeit des Standortes, edição original em alemão de 1939 e a edição inglesa, The economics of location, de 1967), na qual elabora uma teoria geral do equilíbrio das localizaçóes em um sistema econômico, estudando as relaçóes de interdependência existentes entre as localizaçôes individuais e o equilíbrio espacial geral (Bailly, 1978). Sua teoria dedicou especial atenção à definição das áreas de mercado, tendo como fator determinante da escolha da localização a maximizaçáo do lucro dos produtores, divergindo neste ponto de Christaller, para quem o determinante é a minimização dos custos de deslocamento dos consumidores. É importante ressaltar que a Teoria do Equilíbrio Locacional de Losch possui algumas hipóteses e pressupostos semelhantes aos que já foram apresentados em relação à formulação teórica elaborada por Christaller. Segundo Ablas (1982), é incontestável que Losch tenha se baseado, ao menos nas ideias principais, no trabalho de Christaller.

Segundo Losch, "nem a minimização de custos, nem a maximização de receitas leva à localização ótima, o que é apenas possível pela consideração da

${ }^{10}$ Em Santos (2018), situamos os modelos locacionais no respectivo contexto histórico e geográfico em que foram pensados e elaborados, tendo em vista que suas influências sobre o raciocínio dos autores são, de certa forma, bastante significativas. 
maximização de lucros" (Azzoni, 1982, p. 21). Além disso, Losch concentra-se mais na análise a partir da demanda, relegando a segundo plano as variaçôes de custo e considerando a maximização dos lucros como fundamental para determinar a localização ótima. Em outras palavras, ao contrário de seus antecessores, Losch acreditava que a escolha locacional deveria ser pautada na busca pelo maior lucro possível e não no menor custo possível.

De acordo com Azzoni (1982), a explicação de Losch para o sistema de cidades baseia-se em um raciocínio puramente econômico, tendo como principais pressupostos a concepção de espaço como planície isotrópica, isto é, superfície plana e homogênea na qual as matérias-primas estão distribuídas uniformemente e as possibilidades de transporte são iguais em todas as direçôes, resultando na regularidade de custos. Além disso, considerou também que a população está distribuída igualmente pela superfície e que os gostos e preferências dos consumidores são idênticos (Richardson, 1975), não considerando, portanto, as desigualdades sociais que redundam em diferenciação na capacidade e oportunidades de consumo.

Partindo do pressuposto de que os custos são iguais em todas as direçôes, Losch preocupou-se em analisar a demanda. Essa é outra importante diferença em relação aos seus antecessores, que se preocupam com a oferta. Deste modo, ao introduzir a demanda nas teorias de localização, Losch admitiu que "a elasticidade da curva de demanda varia segundo as regióes, conforme a preferência dos consumidores e, principalmente, de acordo com o seu poder aquisitivo" (Donda Jr., 2002, p. 34).

Ao centrar a sua análise na disputa por mercados, Losch afirmou que as empresas têm a oportunidade de auferirem mais lucros se diversificarem seus produtos e conseguirem manter a exclusividade de mercados. De acordo com Ablas (1982), o raciocínio de Losch partiu das variáveis econômicas que determinam a área de abrangência do mercado para um determinado bem, da mesma forma como o fez Christaller. No entanto, ele a inicia por meio da caracterização da curva de demanda de um consumidor individual para, em seguida, transpor essa formulação para o espaço e introduzir o custo de transporte. Assim, Losch concebe uma planície de áreas hexagonais de mercado, na qual as empresas buscam explorar adequadamente o cone de demanda e cujo tamanho varia em função dos custos de transporte.

Ao comparar o raciocínio de Losch com as proposiçóes de Christaller, Ablas (1982) destaca que, na essência, todas as conclusôes tiradas pelo pri- 
meiro estavam presentes na análise do segundo, sobretudo se lembrarmos do exemplo dos serviços médicos que apresentamos anteriormente quando falamos das simplificações da realidade bastante questionáveis de Christaller. "A única diferença possível entre as duas abordagens diz respeito à forma de apresentação. Losch procura incorporar na sua análise os conceitos de teoria econômica até entáo desenvolvidos, tornando-a mais facilmente compreensível, ao menos para os economistas" (Ablas, 1982, p. 69).

De acordo com Bailly (1978), as principais diferenças em relação às duas formulações teóricas dizem respeito, primeiro, à definição da dimensão ideal do hexágono e das áreas de influência e, segundo, que enquanto Losch parte da menor área de mercado para elaborar seu esquema e introduzir áreas de influência cada vez mais amplas, Christaller parte do "lugar central" de maior ordem para, em seguida, alcançar os lugares de níveis inferiores na hierarquia. O percurso do pensamento é, portanto, inverso. Outra notável diferença é que, para Christaller, "lugares centrais" de uma dada ordem podem oferecer todos os bens de "lugares" de ordem inferior a essa, enquanto Losch entende que a especialização torna possível que lugares centrais de ordem inferior possam oferecer produtos e serviços para "lugares centrais" de ordem mais elevada. Essa distinção de Losch em relação a Christaller pode ser valiosa para tratarmos sobre a localizaçáo das unidades de ensino superior, pois, no Brasil, no período dos Governos Federais de Luís Inácio Lula da Silva e Dilma Rousseff, houve efetiva tendência de interiorização da oferta desse nível de formação e pesquisa, com força em áreas urbanas não metropolitanas. É necessário que haja um tempo maior para se ter mais condiçôes de avaliar em que medida lugares centrais de ordem inferior, no caso desse serviço, estarão atendendo demandas de lugares centrais de ordem mais elevada.

Independente desse aspecto, Bailly (1978) acrescenta que as duas obras apresentam também, basicamente, as mesmas lacunas ou fraquezas, tais como a não previsão dos deslocamentos da população e do consumo realizado fora da planície; a afirmaçáo de que todos os empregadores e compradores procedem da área de mercado; não consideram os custos do espaço, fator que modifica os custos de produçáo e de oferecimento de serviços e; suposiçáo de que o comportamento de consumidores e produtores é sempre racional.

Richardson (1975) reconhece que, apesar de suas limitaçóes, a teoria geral de Losch deve ser reconhecida por ter sido a primeira tentativa de descrever relaçóes espaciais por meio de equaçóes simples e por apresentar 
um modelo de economia espacial, operado em condiçóes de concorrência monopolista. Além disso, a formulação proposta por Losch é considerada por alguns autores como mais sistemática e precisa por incluir um raciocínio em termos de teoria econômica que conduz a análise de forma mais suave e rigorosa (Ablas, 1982).

A seguir, apresentamos o economista norte-americano Walter Isard, considerado como o último grande expoente da teoria clássica de localização. Em 1957, publicou a obra "Localização e espaço econômico: uma teoria geral relacionada com a localização industrial" (Location and Space-economy: a general theory relating to industrial location), na qual sintetiza as teorias anteriores e propóe um modelo mais geral e abrangente, analisando a localizaçáo das atividades industriais. Sua grande contribuição foi relacionar a questáo locacional ao desenvolvimento regional, trazendo à tona novos aportes teóricos e temáticos - tais como a questáo ambiental, os valores culturais e o contexto político - como importantes para a definição dos tipos de atividades e a localização delas no espaço (Alves, 2015).

A importância do estudo da economia de localização é decorrente da existência de regularidades nas variaçóes de custos e preços no espaço geográfico, que emergem fundamentalmente, porque o custo de transporte é proporcional à distância (Donda Jr., 2002). Em sua formulação, Isard considera os fatores locacionais apenas pelo lado dos custos, conferindo grande importância aos custos de transporte, de transmissão e de produção. Além disso, tal como os autores dos modelos anteriores (com exceção de Losch), baseia-se na minimização de custos para determinar uma localizaçáo ótima (Coutinho, 2009).

De acordo com Bailly (1978), Isard teve um papel importante no aperfeiçoamento das formulaçóes teóricas de Christaller e Losch ao afirmar que a área de mercado das localidades centrais não se dá somente em função da distância máxima a que os consumidores estão dispostos a percorrer, mas pela densidade de consumidores. Constatou também que a dimensão das áreas de mercado é menor nas zonas mais populosas e o custo de transporte não se limita às áreas de mercado, a não ser que a densidade seja muito baixa.

Contudo, Isard não conseguiu solucionar uma das principais contradições da formulação teórica de Christaller, que consiste na relação nem sempre clara entre a dimensão das localidades centrais e o tamanho de sua populaçáo (Bailly, 1978). Sobre essa questão, o geógrafo norte-americano Brian Berry 
(1971), a partir de um conjunto de verificaçóes empíricas, constatou que o aumento da mobilidade das pessoas fez com que algumas cidades tivessem excesso de funçóes em relação à sua população. Em outras palavras, algumas cidades norte-americanas apresentavam funçóes muito abaixo ou muito acima ao esperado, considerando o tamanho de sua população, o que acontecia por várias razóes. Entre elas, o autor destaca as cidades-dormitórios, os centros históricos ou turísticos, ou ainda as cidades recém-criadas (Bradford e Kent, 1987).

Brian Berry publicou, em 1967, a obra "Geography of Market Centers and Retail Distribution" (traduzida para o espanhol em 1971 com o título "Geografía de los centros de mercado y distribución al por menor") e, com isso, passou a ser considerado como o autor que deu a maior contribuição à Teoria das Localidades Centrais (TLC), tanto do ponto de vista teórico como por meio de estudos empíricos. Essa contribuição foi sistematizada por Ablas (1982) em três linhas diferentes.

A primeira diz respeito à contribuição teórica derivada do relaxamento de algumas hipóteses restritivas colocadas por Christaller e Losch como, por exemplo, o reconhecimento de que a distribuição da população não é homogênea e há possibilidade de haver lucro para aquelas empresas que estáo localizadas em posiçóes convenientes no espaço (vantagens locacionais), assim como há possibilidade de algumas localidades centrais especializarem-se na oferta de determinado produto. A segunda refere-se às tentativas de comparação entre as formulaçóes de Christaller e Losch e as teorias que procuram determinar hierarquia dos centros urbanos, pois Berry parte da ideia de que, de um lado, centros de determinada ordem não precisam ter, necessariamente, a mesma população, podendo existir pequenas variaçóes de tamanho e, de outro, que o desenvolvimento das localidades centrais não está diretamente relacionado ao tamanho de sua população. A terceira e última linha do raciocínio de Berry corresponde àquela que procura demostrar que o comércio varejista é o intermediário entre a produçáo e o consumo e, na medida em que se estuda a distribuição de bens, é possível definir algumas leis sobre a organização dos centros urbanos.

Encerrada a apresentação dos cinco principais autores e suas respectivas formulações e modelos teóricos a respeito da localização das atividades econômicas no espaço geográfico, bem como a contribuição de Berry, elabo- 
ramos um quadro-síntese (Quadro 1) para apresentar uma visão comparada entre as hipóteses, os fatores locacionais, princípios etc., de cada um deles.

Quadro 1 - Síntese dos expoentes das teorias de localização

\begin{tabular}{|c|c|c|c|c|c|}
\hline & Obra & \begin{tabular}{|c|}
$\begin{array}{c}\text { Atividade } \\
\text { econômica }\end{array}$ \\
\end{tabular} & Orientação & $\begin{array}{c}\text { Fatores } \\
\text { locacionais }\end{array}$ & Princípio \\
\hline $\begin{array}{l}\text { Johann Hen- } \\
\text { rich Von Thü- } \\
\text { nen }(1826)\end{array}$ & $\begin{array}{l}\text { O Estado } \\
\text { Isolado }\end{array}$ & Agricultura & $\begin{array}{l}\text { Minimi- } \\
\text { zaçáo de } \\
\text { custos } \\
\text { (Oferta) }\end{array}$ & $\begin{array}{l}\text { Custos de } \\
\text { transporte }\end{array}$ & $\begin{array}{l}\text { Determina a composiçáo de cul- } \\
\text { turas que maximizava a renda da } \\
\text { terra em funçáo da distância da } \\
\text { área de mercado }\end{array}$ \\
\hline $\begin{array}{l}\text { Alfred Weber } \\
(1909)\end{array}$ & $\begin{array}{l}\text { Teoria de } \\
\text { localizaçãoo } \\
\text { das indús- } \\
\text { trias }\end{array}$ & Indústria & $\begin{array}{l}\text { Minimi- } \\
\text { zação de } \\
\text { custos } \\
\text { (Oferta) }\end{array}$ & $\begin{array}{l}\text { Custos de } \\
\text { transpor- } \\
\text { tes; mão } \\
\text { de obra; e } \\
\text { fatores aglo- } \\
\text { merativos }\end{array}$ & $\begin{array}{l}\text { Determina a localizaçáo ótima } \\
\text { da indústria, que corresponde } \\
\text { àquela em que há menor custo } \\
\text { de transporte. }\end{array}$ \\
\hline $\begin{array}{l}\text { Walter } \\
\text { Christaller } \\
(1933)\end{array}$ & $\begin{array}{l}\text { Lugares } \\
\text { Centrais } \\
\text { no Sul da } \\
\text { Alemanha }\end{array}$ & $\begin{array}{l}\text { Comércio e } \\
\text { serviços }\end{array}$ & $\begin{array}{l}\text { Minimi- } \\
\text { zação de } \\
\text { custos de } \\
\text { desloca- } \\
\text { mento } \\
\text { (Oferta) } \\
\end{array}$ & $\begin{array}{l}\text { Custos de } \\
\text { transportes } \\
\text { e economias } \\
\text { de aglome- } \\
\text { raçáo }\end{array}$ & $\begin{array}{l}\text { Determina as leis gerais dos } \\
\text { padróes de povoamento, classi- } \\
\text { ficando as localidades de acor- } \\
\text { do com as suas funçóes e com } \\
\text { a complexidade dos bens que } \\
\text { oferecem. }\end{array}$ \\
\hline $\begin{array}{l}\text { August Losch } \\
\text { (1939) }\end{array}$ & $\begin{array}{l}\text { A economia } \\
\text { da localiza- } \\
\text { ção }\end{array}$ & Indústria & $\begin{array}{l}\text { Maximi- } \\
\text { zação de } \\
\text { lucros (De- } \\
\text { manda) }\end{array}$ & $\begin{array}{l}\text { Custos de } \\
\text { transportes } \\
\text { (tarifas } \\
\text { uniformes) }\end{array}$ & $\begin{array}{l}\text { Elabora uma teoria geral do equi- } \\
\text { líbrio das localizaçóes em um } \\
\text { sistema econômico, estudando } \\
\text { as relaçôes de interdependência } \\
\text { existentes entre as localizaçóes } \\
\text { individuais e o equilíbrio espacial } \\
\text { geral. }\end{array}$ \\
\hline $\begin{array}{l}\text { Walter Isard } \\
(1956)\end{array}$ & $\begin{array}{l}\text { Localização } \\
\text { e espaço } \\
\text { econômico }\end{array}$ & Indústria & $\begin{array}{l}\text { Minimi- } \\
\text { zação de } \\
\text { custos } \\
\text { (Oferta) }\end{array}$ & $\begin{array}{l}\text { Custos de } \\
\text { transporte, } \\
\text { de trans- } \\
\text { missão e de } \\
\text { produçáo }\end{array}$ & $\begin{array}{l}\text { Sintetiza as teorias anteriores e } \\
\text { propóe um modelo mais geral e } \\
\text { abrangente. }\end{array}$ \\
\hline
\end{tabular}

* Não incluímos Berry no quadro, porque ele não formulou uma teoria, somente aplicou na realidade. Fonte: Elaboração própria.

Feita a apresentação das principais teorias locacionais existentes de modo a indicar os fatores considerados como determinantes para a escolha da localização ótima, bem como os princípios e pressupostos dos autores que as elaboraram, temos base para introduzir a discussáo dos novos fatores loca- 
cionais, das novas tendências e perspectivas de análise da questão locacional no período atual.

\section{Do espaço absoluto e relativo ao relacional}

Muitas vezes, e a partir de agora cada vez mais, tem se feito necessária uma tentativa de explicação do real simultaneamente a uma revisão do arcabouço teórico que herdamos. Assim, empreendemos uma síntese da emergência da questáo locacional e das principais teorias locacionais, em que demonstramos que os modelos clássicos de localização atribuíam ao custo de transporte um papel fundamental para compreender a distribuiçáo espacial das atividades econômicas, além de ter como base o comportamento otimizador dos agentes econômicos, seja por meio da minimização dos custos ou pela maximizaçáo dos lucros.

Para compreender os processos urbanos sob a égide do modo de produção capitalista, Harvey (1980 [1973]) ressalta a importância de refletir sobre a natureza do espaço e, para tanto, identifica uma divisáo tripartite no modo como o espaço pode ser entendido:

Se considerarmos o espaço como absoluto ele se torna uma 'coisa em si mesma’, com uma existência independente da matéria. Ele possui entáo uma estrutura que podemos usar para classificar ou distinguir fenômenos. A concepçáo de espaço relativo propóe que ele seja compreendido como uma relação entre objetos que existe pelo próprio fato de os objetos existirem e se relacionarem. Existe outro sentido em que o espaço pode ser concebido como relativo e eu proponho chamá-lo espaço relacional - espaço considerado, à maneira de Leibniz, como estando contido em objetos, no sentido de que um objeto pode ser considerado como existindo somente na medida em que contém e representa em si mesmo as relaçôes com outros objetos (Harvey, 1980 [1973], p. 13, grifos nossos).

A partir da revisão das teorias clássicas sobre o tema da localização das atividades econômicas, realizada no tópico anterior, observamos de que maneira as concepçóes de espaço absoluto e relativo estiveram presentes, enquanto, no período contemporâneo, a perspectiva relacional se faz cada vez 
mais necessária para a compreensão de uma realidade cujas relações e interaçôes são cada vez mais complexas. O surgimento do pensamento relacional na Geografia Econômica se viu reforçado pelas mudanças na organização das empresas nas últimas décadas, e é resultado da maneira como, de modo geral, os geógrafos passaram a conceber o espaço (Parnreiter, 2018).

En la geografía económica relacional no se entiende en calidad de ciencia del espacio, sino como una ciencia de la acción que analiza de qué maneras, por qué y con qué resultados los actores producen su entorno: los espacios económicos (p.192).

Assim, compreender as transformações econômicas e as estratégias das empresas em sua complexidade e, não como fenômenos abstratos e despersonalizados, tal como nas formulaçôes teóricas clássicas, é necessário dar mais atenção aos agentes econômicos e ao papel que exercem no espaço geográfico, isto é, como, quando e onde atuam. Quando analisado sob a perspectiva relacional, o espaço náo é fixo, mas sim considerado em relação com os processos e as interaçóes econômicas e os seus agentes. Em outras palavras, tenta-se, desse modo, analisar e explicar como as relaçóes subjacentes aos processos econômicos geram certos padróes de localização.

Parnreiter (2018) ressalta que a perspectiva espacial para abordar os processos e as estruturas econômicas não se desenvolveu de maneira suficiente na história do pensamento econômico e, basicamente, se limitou a apenas um aspecto espacial: o custo de superar a distância entre produtores e consumidores. Dessa forma, a Geografia era somente um fator de custo e, portanto, um obstáculo. Essa maneira de conceber a Geografia remonta às teorias de localização elaboradas desde a primeira metade do século XIX na Alemanha.

El propósito de los modelos de localización es conocer la razón por la que surgen ciertos patrones de localización de actividades económicas, la forma de descubrirla se sustenta en relacionar la ubicación de las instalaciones de producción con la extensión de los mercados (o, en otras palabras, con la distancia entre productor y consumidor). Por ende, las teorías de localización tratan dos aspectos geográficos, a saber: la distancia y el área (Parnreiter, 2018, p. 109). 
Quando observamos o modelo de Christaller, por exemplo, percebemos as localizaçóes absolutas e relativas por meio de um pensamento de natureza hierárquica segundo as funçôes que as localidades centrais desempenham. A ideia de relacional não está presente, porque embora o modelo se baseie em fluxos e interaçôes, eles estão despersonalizados. Quando incluímos as pessoas, as relaçôes e interaçôes se tornam mais complexas por uma série de razóes. Entre elas, o fato de que, segundo essa teoria, quem mora na localidade $A$ vai até a localidade $B$ para adquirir produtos e serviços náo existentes em $\mathrm{A}$ e, se esses produtos e serviços existirem em $\mathrm{A}$, as pessoas vão se restringir a essa situação geográfica. Em síntese, essa teoria pauta-se na ideia de que todos estariam dispostos a fazer o menor percurso.

$\mathrm{Na}$ época de elaboração das formulaçôes e modelos teóricos locacionais, o custo de transporte exercia uma influência bastante significativa sobre a localização, especialmente quando a relação entre custos totais de produção e tarifa de transporte variava muito entre os diferentes pontos do espaço geográfico. Deste modo, a localizaçáo que possibilitava o lucro máximo para o empreendimento era aquela em que os custos de transporte eram minimizados, enquanto, do ponto de vista do consumidor, o esforço mínimo em relação ao deslocamento, baseando-se também no custo de transporte, era considerado. Em grande medida, essa perspectiva está fundada no pressuposto de que há boa oferta de transportes e, assim frisamos, mais uma vez, que a realidade socioespacial desigual de nossas cidades e entre as nossas regióes constitui fator adicional a ser ponderado na análise espacial.

À parte essa especificidade, diante de um contexto fortemente globalizado e com relaçóes e interaçóes cada vez mais complexas, as teorias locacionais elaboradas nos séculos XIX e XX não são suficientes para explicar a distribuição espacial das empresas e indústrias no período contemporâneo. Se considerarmos a forma original dessas teorias, estaremos nos distanciando muito da realidade que é diversa e mais complexa do que a superfície completamente homogênea que pressupóem os autores.

Sua adaptação às novas condiçôes resulta em uma tarefa bastante delicada. Contudo, quando devidamente situadas e relativizadas em seus respectivos contextos e analisadas de maneira crítica, sobretudo em relaçáo à concepção de espaço homogêneo, às áreas de mercado como hexagonais perfeitos e ao comportamento otimizador dos agentes econômicos e consumidores, essas teorias se têm valor para enriquecer o entendimento geográfico da so- 
ciedade, isto é, fortalecer nossa compreensão sobre as diferentes formas de espacialização da sociedade.

Além disso, considerar a perspectiva relacional no estudo sobre como as relaçôes socioespaciais dos agentes se entrelaçam com as estruturas da economia implica, primeiramente, em nunca considerar o objeto por si mesmo, isto é, de maneira individual, mas sim a partir das relaçóes que estabelecem. "Los actores económicos, sean personas o empresas, no son entidades atomísticas, sino sujetos interdependientes cuyos activos - que les permiten actuar - son constituidos por y en sus relaciones con otros actores" (Parnreiter, 2018, p. 195).

Segundo, a valorização do entendimento das relaçóes estabelecidas entre os diversos agentes que atuam na produção do espaço urbano e na determinação da localização que melhor atenda aos interesses relacionados ao desempenho econômico do capital, demanda uma análise multiescalar, ou seja consideração de várias escalas geográficas e, mais do que isso, interescalar, para avaliar como os movimentos entre empresas, agentes políticos e sujeitos sociais ocorrem entre as escalas geográficas estabelecidas até o âmbito global.

Por último, a perspectiva relacional implica também em uma mudança na metodologia de pesquisa; isto é, ao estudar as práticas (espaciais e econômicas) dos agentes, é necessário alterar as perguntas que se fazem: como e o por que se tornam mais importantes do que o quanto e o onde, sem, no entanto, desconsiderar a relevância da combinação de metodologias qualitativas e quantitativas para complementar e a aprofundar a análise do objeto de estudo.

\section{Consideraçóes finais}

As duas principais críticas que fazemos às teorias locacionais são, primeiro, a compreensáo limitada de espaço enquanto uma mera distância a ser superada entre produtores e consumidores, além da concepçáo predominante do espaço como sendo absoluto, e, em segundo lugar, a racionalidade dos agentes econômicos. A escolha da localização de uma empresa é decisão de um ou vários agentes e é determinada com base em mais motivos do que somente a busca pelo equilíbrio entre custos e gastos. Seus interesses são muito mais complexos e, às vezes, até mesmo contraditórios. Os agentes econômicos, sejam eles empresas, poder público ou citadinos/consumidores, 
são complexos em suas açôes. Eles atuam, pensam e sentem, ponderam e avaliam, tomam decisóes segundo critérios racionais e irracionais.

A preocupação com a escolha da localização que melhor atenda aos interesses das empresas e indústrias sempre foi latente, porém a diferença em relação às formulaçóes e aos modelos teóricos sobre a localização de atividades econômicas é que esses autores consideravam o custo dos transportes como fator fundamental para determinação da localização ótima, enquanto no período contemporâneo, por outro lado, podemos identificar outros fatores que se tornaram mais importantes na medida em que esse fator relativamente perde importância devido ao fenômeno da globalização e unicidade da técnica (Santos, 1996) no espaço geográfico.

O que temos de novo no período contemporâneo é que, em virtude do acirramento da concorrência, do aumento do poder de consumo e da mobilidade da população e, consequentemente, do poder de escolha, a preocupaçáo dos empresários deixou de ser somente com a localização ótima do ponto de vista da acessibilidade e do fluxo de pessoas.

Portanto, as mudanças que têm ocorrido nas últimas décadas, por meio da modernizaçáo no modo de produção e nas formas de comercialização e consumo, têm exposto as limitaçóes dos enfoques tradicionais sobre a localização das atividades econômicas e é crescente as dificuldades para explicar o comportamento locacional dos indivíduos e empresários diante de práticas espaciais cada vez mais complexas.

Resta como questão a orientar novas pesquisas em que medida as mudanças que marcam o período contemporâneo alteram a própria ideia de hierarquia urbana, centrada no primado da importância das localidades centrais, uma vez que, na pesquisa realizada, quando se toma como análise os investimentos feitos nem sempre dada ordem, da maior para a menor localidade, foi o fator principal a definir a escolha locacional.

Esperamos que os leitores desse livro, ao se debruçarem sobre os demais capítulos, possam avançar no debate que apresentamos neste texto.

\section{Referências}

ABLAS, Luiz Augusto Queiroz. A Teoria do Lugar Central: Bases teóricas e evidências empíricas. Estudo do caso de São Paulo. São Paulo: Instituto de Pesquisas Econômicas da Faculdade de Economia e Administração da Universidade de São Paulo (IPE-USP), 1982. 
ALVES, Flamarion Dutra. "Questôes teórico-metodológicas entre geografia econômica e desenvolvimento regional”. Caderno Prudentino de Geografia, v. 1, n. 37, pp. 5-21, 2015. AZZONI, Carlos Roberto. Teoria da localização. Uma análise crítica: a experiência de empresas instaladas no Estado de São Paulo. (Dissertação) São Paulo: Universidade de São Paulo, 1982.

BAILLY, Antoine. La organización urbana: Teorias y modelos. Madri: Nuevo Urbanismo, 1978. BERRY, Brian. Geografía de los centros de mercado y distribución al por menor. Barcelona: Vicens-Vives, 1971 [1967].

BRADFORD, M. G. e KENT, W. A. “Teoria dos lugares centrais: O modelo de Christaller”. Geografia Humana: Teorias e Aplicaçóes. Lisboa: Gradiva, 1987, pp. 17-45.

BRAGA, José Carlos de Souza. Alemanha: império, barbárie e capitalismo avançado. Sáo Paulo: Editora Vozes, 1999.

BRAGA, Rhalf Magalhães. "Tendências e perspectivas das teorias locacionais no período contemporâneo”. In: Geografares, n. 6, 2008, pp.167-179.

CAMAGNI, Roberto. Economía Urbana. Barcelona: Antônio Bosh, 2005.

CHRISTALLER, Walter. Central Places in Southern Germany. Londres: Prentice Hall, 1966. Tradução de Mario Antônio Eufrásio, 1981.

CORREAA, Roberto Lobato. "O enfoque locacional na Geografia”. Terra Livre, n. 1, 1986, pp. 62-66.

COUTINHO, Clarisse. "Escolha locacional das atividades financeiras: Uma análise das teorias de localização”. In: Seminário de Pós-Graduação em Geografia. 2009, Rio Claro. Anais [...]. Rio Claro: Universidade Estadual Paulista, 2009, pp. 307-318.

DOBB, Maurice Herbert. A evolução do capitalismo. Tradução de Manuel do Rêgo Braga. São Paulo: Abril Cultural, 1983.

DONDA Jr, Alberto. Fatores influentes no processo de escolha da localização agroindustrial no Paraná: Estudo de caso de uma agroindústria de aves. (Dissertação). Florianópolis: Universidade Federal de Santa Catarina, 2002.

EUFRÁSIO, Mario Antônio. A estrutura da Teoria dos Lugares Centrais de W. Christaller. (Dissertação). São Paulo: Universidade de São Paulo, 1981.

FAJARDO, Sérgio. "A questão locacional e a Nova Geografia”. Ambiência Guarapuava, v. 6, n. 1, 2010, pp. 161-68.

HAGGETT, Peter. Modelos de estructura locacional. In: Análisis locacional en la Geografía Humana. Tradução de J. Obiols. Barcelona: Gustavo Gili, 1976, pp. 41-3.

Métodos de análisis locacional. In: Análisis locacional en la Geografía Humana. Tradução de J. Obiols. Barcelona: Gustavo Gili, 1976, p.239-241.

. "Modelos en Geografía”. In: Geografía: Una síntesis moderna - Tradução de Maravillas Nájar e Graziana Ramazzini. Barcelona: Omega, 1994 [1983], p. 21.

HARVEY, David. A justiça social e a cidade. São Paulo: Hucitec, 1980 [1973].

MORAES, Antônio Carlos Robert de e COSTA, Wanderlei Messias da. Geografia Crítica: A valorização do espaço. São Paulo: Hucitec, 1987.

PARNREITER, Christof. "La geografía económica antes de la geografía económica: las teorías de localización”. In:___ Geografía económica: Una introducción contemporánea. México: Universidad Nacional Autónoma de México, 2018, pp. 108-23. 
"La geografía económica relacional". In: Geografía económica: Una introducción contemporánea. México: Universidad Nacional Autónoma de México, 2018, pp. 190-196.

RICHARDSON, Harry. Economia Regional. Teoria da localização, estrutura urbana e crescimento regional. Rio de Janeiro: Zahar, 1975.

SANTOS, Milton. A natureza do espaço: Técnica e tempo. Razão e emoção. São Paulo: Hucitec, 1996.

SANTOS, Flaviane Ramos dos. "Questão locacional e teorias de localização: contextualização e análise de sua validade no período contemporâneo". Caderno Prudentino de Geografia, Presidente Prudente, n. 40, v. 2, pp. 120-42, jul./dez. 2018.

SPOSITO, Maria Encarnação Beltrão. "Cidades médias: Reestruturação das cidades e reestruturação urbana”. In: (Org.). Cidades médias: Espaços em transição. São Paulo: Expressão Popular, 2007, pp. 233-53.

. "Reestruturação econômica, urbana e da cidade: Os papéis intermediários de cidades médias em múltiplas escalas”. In: LAN, Diana et al (Org.). Reestructuración productiva e industria en ciudades intermedias de Argentina y Brasil. Tandil: Universidad Nacional del Centro de la Provincia de Buenos Aires, 2018, pp. 189-207.

VALBUENA, Luís Guillermo Bezerra. "Aproximaciones microeconómicas en la Teoría de los Lugares Centrales de Christaller". Ensayos sobre política económica, v. 31, n. 70, pp. 67-120, 2013. 



\section{Metrópole em movimento: reflexóes sobre a produção do espaço na região metropolitana do Recife a partir da localização dos empreendimentos do PMCMV}

Luciana de Carvalho Gomes ${ }^{1}$

\section{Introdução}

O processo de urbanização no Brasil ocorreu de forma intensa e foi profundamente marcado pela desigualdade social. $\mathrm{O}$ rápido crescimento demográfico estabeleceu demandas cada vez mais urgentes por infraestrutura, serviços e moradia. $\mathrm{O}$ atendimento a estas necessidades foi pautado em um modelo de urbanização excludente e precário, especialmente nas capitais e regióes metropolitanas. Este desequilíbrio pode ser observado por índices econômicos e sociais, mas também pela forma diferenciada como o espaço urbano se apresenta. Conforme Santos et al (2014), tal distinção pode ser reconhecida visualmente, não somente pelo padrão edilício, mas pelas características de infraestrutura e serviços disponíveis em cada porção do território.

Historicamente, as áreas mais favoráveis da cidade foram ocupadas pelas classes abastadas, restando aos pobres os nichos centrais insalubres e de difícil ocupação, e as periferias. A história da ocupação das cidades é, portanto, a história da disputa por terra - quanto mais centrais e bem-servidas de in-

1 O presente trabalho foi realizado com apoio da Fundação de Apoio à Pesquisa do Estado da Paraíba- FAPESQ e da Coordenaçáo de Aperfeiçoamento de Pessoal de Nível Superior - Brasil (CAPES) - Código de Financiamento 001. 
fraestrutura, mais valorizadas e, por consequência, menos acessíveis aos mais pobres. De acordo com Villaça (2010), a terra urbana só interessa enquanto terra-localizaçáo, ou seja, enquanto meio de acesso a todo sistema urbano. A adequação da moradia passa, portanto, não apenas pelo local onde se encontra, mas pela sua relação socioespacial com o restante da cidade. Quanto mais frágeis as conexôes, maior a segregação.

No Brasil, a segregação socioespacial está intimamente vinculada à concentração de renda e de oportunidades. Por isso uma favela incrustada entre bairros valorizados náo deixa de ser uma área segregada, uma vez que os equipamentos e serviços do entorno podem não ser acessíveis econômica ou socialmente a seus moradores. Ao mesmo tempo, se esta área náo se encontra protegida por algum instrumento legal, como a ZEIS, por exemplo, a tendência é ela acabar absorvida pelo mercado especulativo e sua população original migrar para áreas mais afastadas. Por vezes, este deslocamento se dá por intervenção do poder público que por várias razóes (como risco geotécnico, alagamentos, reurbanização etc.) remove famílias para conjuntos habitacionais distantes do centro, onde a terra é mais barata. Estes movimentos geralmente forçosos alimentam o que muitos autores denominam periferização da pobreza.

A segregação também se evidencia em outro fenômeno urbano, intermediado pelo mercado imobiliário: os condomínios fechados. Apelando para o discurso do caos e da violência urbanos em contraponto à vida bucólica oferecida "fora" da cidade, o mercado sorveu parcela da população, cujo ideal de moradia se materializava nesses bairros elitizados e autossuficentes. Esses núcleos isolados conferiram um novo tipo de apropriação da terra, provocando uma descontinuidade urbana, em sua maioria não previstas pelos instrumentos de planejamento local. Isolados por muros e sistemas de segurança, esses espaços, ao mesmo tempo que afastam seus moradores da vida urbana, colaboram para a segregação socioespacial de seu entorno.

É importante, no entanto, distinguir tais fenômenos segregantes. Villaça (2010) aponta para dois tipos de segregação socioespacial. Uma delas é a voluntária, que se produz quando o indivíduo, por iniciativa própria, busca viver com outras pessoas de sua classe. A outra é a involuntária, quando pessoas se veem obrigadas, pelas mais variadas forças, a morar em um setor ou deixar de morar em um setor ou bairro da cidade. Embora Villaça, se refira à tendência das classes abastadas se concentrarem em uma única região urbana, o que ele chama de segregação voluntária ilustra a situação dos condomínios 
para onde a burguesia migra por vontade própria, ainda que impulsionada por uma efêmera sensação de proteção e convívio com a natureza, diferindo do caso dos mais pobres, que se veem coagidos pelo mercado imobiliário a viver ou deixar de viver em determinado local. Ou, nas palavras de Harvey (1976, apud Villaça, 2010), os ricos podem comandar o espaço, enquanto os pobres são prisioneiros dele.

A localizaçáo, portanto, pode incentivar ou privar as classes pobres na fruiçáo das oportunidades urbanas. O maior ou menor contato com essas oportunidades apontam para o nível de segregaçáo socioespacial de uma determinada população. Segundo Santos (1987),

[...] cada homem vale pelo lugar onde está, o seu valor como produtor, consumidor, cidadão depende de sua localização no território. [...] Pessoas com a mesmas virtualidades, a mesma formação, até o mesmo salário, tem valor diferente segundo o lugar onde vivem: as oportunidades não são as mesmas. Por isso a possibilidade de ser mais ou menos cidadãos depende, em larga produção, do ponto do território onde se está. (Santos, 1987)

Se a localização da moradia é um fator determinante para oportunizar a vida urbana, o deslocamento humano pode nos servir de indicador quanto ao nível de segregação (ou inserção) socioespacial de um determinado território. A extensão dos deslocamentos é consequência da distribuição, na malha urbana, da infraestrutura e dos serviços e atividades essenciais para a vida na cidade. Quanto mais equilibrada for a repartiçáo no espaço, menores seráo os deslocamentos e melhor será o acesso dessa população às amenidades urbanas. Ressalvamos que ter uma escola ao lado de casa, mas sem professores suficientes, terá pouco efeito no direito à educaçáo. Entendemos que a inclusão social tem múltiplas variantes, mas consideramos que ter acesso caminhando por cinco minutos, por exemplo, a um posto de saúde, é um bom indicativo de inserção socioespacial.

Nahas et al (2006), quando fala dos indicadores de qualidade de vida, afirma que para mensurar a equidade no acesso da populaçáo aos bens e recursos urbanos devem ser considerados tanto o aspecto espacial (acesso espacial) quanto o social (acesso social). $\mathrm{O}$ acesso social é fundamentalmente determinado pela condição social, como renda e escolaridade, entretanto, não se pode esquecer que este acesso depende também da distância existente entre o local de moradia e o local onde se dá a oferta dos bens e serviços. $\mathrm{Na}$ 
dimensão acesso espacial, a distribuição física da infraestrutura e dos serviços é, portanto, tão importante como a condiçáo do deslocamento (dificuldade ou facilidade) para alcançá-los.

Castells (2000) nos dá indicativos da importância dos deslocamentos humanos quando sustenta que a circulação, seja ela de mercadorias, informaçôes e, principalmente, de pessoas, é um dos fatores estruturais e estruturantes de uma região metropolitana, sendo o seu entendimento revelador das relaçóes entre os elementos da estrutura urbana, produção (trabalho), reprodução (moradia) e consumo. Villaça traz essa análise regional para os limites intraurbanos, afirmando que o espaço urbano é estruturado fundamentalmente pelas condiçóes de deslocamento do ser humano, seja enquanto portador da mercadoria força de trabalho (deslocamento casa-trabalho), seja enquanto consumidor (deslocamento casa-compras, casa- lazer, escola etc.). Acrescenta ainda que daí vem o poder estruturador intraurbano das áreas comerciais e de serviços do centro, por gerarem a maior quantidade de deslocamentos, pois acumulam os deslocamentos força de trabalho com consumidor.

Temos, então, a condiçáo do deslocamento enquanto elemento estruturador do espaço (intraurbano e metropolitano) e a condição de deslocamento como indicador de inserção socioespacial da moradia (local). Essas dimensóes se entrelaçam quando consideramos que o espaço urbano é produzido e consumido por um único processo (Villaça, 2010), o que Santos (2006) por sua vez, chama de totalidade. Em cidades desiguais como as nossas se torna mais evidente, pois a classe dominante comanda a apropriação das vantagens do espaço urbano, como a condição dos deslocamentos, piorando a dos demais.

A conquista de cidades menos segregadas requer, portanto, que a moradia ocupe o centro desta discussáo. A habitaçáo vista além da terra e de padróes construtivos mínimos, mas inserida em uma localização que ofereça acesso à infraestrutura, equipamentos, comércio e serviços urbanos. $\mathrm{O}$ estudo da adequação habitacional, portanto, implica o entendimento de seus componentes locacionais, enquanto protagonistas da inserção socioespacial urbana.

\section{A política habitacional no Brasil: da provisão de moradias ao direito à cidade}

O advento da indústria após a Segunda Guerra e a modernização das cidades, nos anos 1960, estimularam a migração campo-cidade. Até 1940, as ci- 
dades brasileiras continham apenas $32 \%$ da população (12,8 milhóes), 30 anos mais tarde, a população urbana superava a rural (52 milhōes). Atualmente nossas cidades abrigaram mais de 160 milhóes de habitantes (85\%). Em números absolutos, em menos de 50 anos, quase 110 milhōes de pessoas migraram para áreas urbanas. Este deslocamento humano massivo levou a uma alta demanda por terra urbana e consequentemente sua rápida valorização. $\mathrm{O}$ alto preço do solo acabou por conduzir os mais pobres a ocupar às áreas centrais renegadas pelo mercado imobiliário, como morros e alagados, e as periferias.

Algumas iniciativas governamentais tentaram amenizar esse quadro crítico. Sempre centralizadas pelo governo federal, as políticas de financiamento e produção de moradia surgem a partir dos anos 1940, com os Institutos de Aposentadoria e Pensão (IAP), mas ganham dimensão nacional apenas nos anos 1960, com a criação do Banco Nacional de Habitação (BNH). O BNH produziu 4 milhóes de unidades habitacionais em 22 anos de atuação. Conforme Cymbalista e Moreira (2006) apenas 33,6\% das unidades habitacionais do $\mathrm{BNH}$ foram destinadas aos setores populares, sendo que a populaçáo com rendimento entre um e três salários mínimos foi contemplada com menos de 6\% dos totais de unidades. Estes empreendimentos foram construídos geralmente em terrenos afastados do centro e desprovidos de serviços públicos. A contínua condição de exclusão da moradia (formal e informal) dará forma à pauta de reivindicaçóes dos movimentos sociais por reforma urbana e direito à cidade que vai alimentar as novas agendas públicas na redemocratizaçáo do país, como veremos a seguir.

Em 1986, o BNH é extinto e a Caixa Econômica Federal (CEF) passa a ser a operadora do FGTS. Segundo Cardoso e Aragão (2013), entre 1986 e 1994 vários órgãos se sucederam na gestão da política habitacional do governo federal, evidenciando uma forte instabilidade política e institucional que se estendeu até a criação do Ministério das Cidades, em 2003. Em paralelo, a luta das entidades civis e dos movimentos sociais em defesa do direito à terra urbana e à moradia se fortalecia culminando na inclusão dos artigos $182 \mathrm{e}$ 183, sobre política urbana na Constituição de 1988. Este foi um marco importantíssimo no reconhecimento da funçáo social da cidade e do direito à moradia. A regulamentação jurídica destes artigos, no entanto, veio apenas 13 anos mais tarde com a promulgação, em 2001, do Estatuto das Cidades (Lei 10257). O pleno desenvolvimento das funçóes sociais da cidade e da propriedade urbana passa a associar-se à garantia do direito à terra urbana, à 
moradia, ao saneamento ambiental, à infraestrutura urbana, ao transporte e aos serviços públicos, ao trabalho e ao lazer para todos.

Neste contexto, em 2003, foi criado o Ministério das Cidades com o objetivo de traçar uma política nacional de desenvolvimento urbano integrando a política habitacional com a de saneamento e transporte. Entre outras atribuiçóes, o MCidades tinha como objetivo a implantação do Sistema Nacional de Habitação de Interesse Social (SNHIS) e o Fundo Nacional de Habitação de Interesse Social (FNHIS). O Fundo era um pleito antigo do Movimento Popular por Moradia solicitado por meio de um projeto de lei apresentado à Câmara Federal em 1991, e que apenas foi atendido em 2005 com a Lei 11.124. Ela cria o SNHIS e o FNHIS com o objetivo de garantir acesso à terra urbanizada e habitação digna à população de menor renda e promover a articulação das instituiçôes e órgãos do setor habitacional nas diferentes esferas governamentais.

O SNHIS previa o compartilhamento da política nas três esferas de governo, fortalecendo o papel do município e da população local. Neste sentido, para aderir ao SNHIS e pleitear recursos do FNHIS foi exigido o desenvolvimento dos Planos Locais de Interesse Social (PLHIS) em consonância com o Plano Nacional de Habitação (PLANHAB), bem como a criação dos conselhos locais de gestores do fundo. $\mathrm{O}$ repasse dos recursos federais para a promoção da política habitacional em nível local (estados e municípios) passa então a ser realizado de maneira direta aos fundos locais, que por sua vez são geridos com a participação social, por meio do conselhos gestores. Os programas vinculados ao SNHIS foram o principal instrumento da política nacional de habitação até 2007.

Em 2008, o mundo entra numa crise iniciada pelo desequilíbrio do setor financeiro americano, a chamada crise dos subprime. Para minimizar os efeitos no Brasil, o governo federal adotou medidas de expansão do crédito pelos bancos públicos (Banco do Brasil, BNDES e Caixa Econômica), de forma a compensar a retração do setor privado, e medidas de caráter anticíclico, mantendo os investimentos em infraestrutura previstos no âmbito do PAC e mobilizando a Petrobrás no sentido de que também mantivesse os investimentos previstos (Adauto, 2013).

O Programa Minha Casa Minha Vida (PMCMV) surge em 2009, nesta conjuntura, como alternativa para incremento do mercado imobiliário para famílias com renda até 10 salários mínimos. Ao mesmo tempo que im- 
pulsionava a economia, atendia uma enorme demanda reprimida por habitação. O Programa acaba de completar dez anos e seus resultados são vultuosos. Com um orçamento superior a 430 bilhões de reais, contratou 5,3 milhóes de moradias, das quais já foram entregues 3,9 milhōes. ${ }^{2}$ Em 2015, com apenas seis anos de programa, já superava, em contrataçáo, as 4 milhôes de unidades habitacionais construídas pelo Banco Nacional de Habitaçáo (BNH), em 22 anos de atuação, e considerada até então, a política habitacional mais relevante do país.

O PMCMV trouxe o tema da moradia para o centro das discussóes sobre desenvolvimento urbano no país. Após 20 anos sem políticas nacionais de habitaçáo expressivas e uma longa luta dos movimentos sociais pelo direito à cidade e à moradia, o Estado se viu obrigado a (re)pensar a produçáo de seus territórios a partir da questão da moradia.

\section{O marco regulatório do PMCMV e a localizaçáo dos empreendimentos}

Segundo Lucena (2016), as diferenças de renda se traduzem no acesso desigual às infraestruturas e à terra urbana disponível e que esse tem sido um grande entrave para se garantir o direito à moradia no Brasil. Os programas habitacionais, por sua vez, historicamente estiveram dissociados de uma política fundiária e acabaram por reproduzir esse processo de exclusão pré-existente. Em uma lógica mercantil e imediatista, de uma maneira geral, os conjuntos habitacionais foram implantados em terrenos periféricos, não só por estes serem mais baratos, mas também para estabelecer novas áreas de valorização imobiliária. Nesta decisão desconsidera-se a falta de oportunidades urbanas destes locais e os custos posteriores a serem realizados (pelo poder público) para levar serviços e infraestrutura.

Como visto, houve um importante processo de estruturação da Política Urbana e Habitacional no país no primeiro mandato do Presidente Lula, com forte destaque à capacitação dos municípios e mensuração dos problemas habitacionais em nível local. No entanto, conforme Santos et al (2014), o uso de uma demanda social para atingir objetivos econômicos imediatos ocasionou uma pequena aderência entre o PMCMV e as açôes no setor habitacional implantadas. A maioria dos autores defende que este descolamento

2 Dados do sistema de monitoramento CAIXA MCMV, atualizado em agosto de 2018. 
ocorreu fundamentalmente devido o papel preponderante das construtoras na execução do programa e sua desarticulação com uma política fundiária (Araújo, 2013; Amore et al, 2015; Lucena, 2014; Cardoso e Aragão, 2013 e Rolnik, 2015).

As primeiras exigências referentes à localização dos empreendimentos foram estabelecidas pelo Decreto n. 7.499 de 2011, que regulamenta a Lei de criaçáo do PMCMV de 2009 (Lei n. ${ }^{0}$ 11.977/09). Neste documento, o PMCMV adota preceitos em consonância com o Planhab e o Estatuto da Cidade no que se refere a localização dos conjuntos. Estão entre os critérios de prioridade do PMCMV:

Art. $4^{\circ}$ Em áreas urbanas, deverão ser respeitados os seguintes critérios de prioridade para projetos do PMCMV, observada a regulamentação do Ministério das Cidades:

I- a doação pelos estados, pelo Distrito Federal e pelos municípios de terrenos localizados em área urbana consolidada para implantaçâo de empreendimentos vinculados ao programa;

II- a implementação pelos estados, pelo Distrito Federal e pelos municípios de medidas de desoneração tributária para as construçôes destinadas à habitação de interesse social; e

III- a implementação pelos municípios dos instrumentos da Lei no 10.257, de 10 de julho de 2001, que visam ao controle da retenção das áreas urbanas em ociosidade. (Grifo nosso)

O instrumento determinava ainda que os projetos contratados estivessem inseridos na malha urbana, em local dotado de infraestrutura básica e com condiçóes de acesso a serviços públicos essenciais, como transporte e coleta de lixo, e de equipamentos sociais, como escola, creches e postos de saúde.

A medida provisória 514 (posteriormente Lei n. ${ }^{\circ} 12.424 / 11$ ) estabeleceu que os empreendimentos deveriam ser implantados em terrenos localizados na malha urbana ou em áreas de expansão previstas nos planos diretores municipais; deveriam ainda dispor de infraestrutura básica, transporte público e contar com a existência de equipamentos e serviços de educação, saúde e lazer, ou com o compromisso do poder público de instalá-los ou ampliá-los quando inexistentes ou insuficientes. Permitiu-se também a inclusão de áreas destinadas a atividades comerciais nos projetos. 
Em 2013, torna-se obrigatório destinar áreas para implantação dos equipamentos públicos necessários ao atendimento da demanda gerada (Portaria n..$^{\circ}$ 518). O MCMV3 já traz alguns formulários quanto à localização do conjunto que, para pleitear a contratação, deverão estar explicitadas as distâncias para os equipamentos públicos mais próximos. Pouco a pouco, as regras do programa tentam restringir a implantação dos conjuntos a áreas menos periféricas.

Na prática, o que parece é que estes critérios não foram suficientes para coibir a lógica capitalista dos empreendedores privados. Diante do preço mais acessível da terra, o mercado imobiliário acabou optando por terrenos mais periféricos pela possibilidade de lucros maiores, mesmo nas cidades médias onde a especulação não é tão acirrada. Para as habitaçôes na faixa de interesse social (HIS), esta lógica se torna mais aguda, uma vez que o empreendimento é construído e vendido integralmente para a Caixa Econômica Federal, que o repassa aos beneficiários selecionados a partir de critérios pré-definidos pelo programa e pelas prefeituras. Desta forma, a incorporadora não precisa se preocupar em oferecer um local que atraia o "cliente".

Por outro lado, as normativas do Programa nos leva a crer que havia uma expectativa que os municípios protagonizassem o processo de definição da localizaçáo dos empreendimentos a partir dos instrumentos de planejamento desenvolvidos, tais como Plano Diretor e PLHIS, sem mencionar, por ora, os Planos locais de Saneamento, Resíduos Sólidos e Mobilidade que surgiram um pouco mais tarde, mas que igualmente deveriam subsidiar essas decisóes. Cardozo e Lago (2012) oferece uma explicação para isso, quando expóe que o desenho do Programa não articula efetivamente, de forma mandatória, esses procedimentos com a aprovação de projetos. A diretriz estabelecida na normativa toma a utilização dos instrumentos do Estatuto apenas como um critério de priorização.

A participaçáo dos municípios, de um modo geral, limitou-se a atender os parâmetros da lei de uso do solo local, muitas vezes flexibilizando-a para garantir a "viabilidade" do empreendimento, ainda que em detrimento de sua qualidade urbana. Para a faixa de interesse social, o município participou ainda com a indicação de demanda, e por vezes, com aporte em alguns empreendimentos, cujo valor da terra ou da moradia excedia o permitido pelo programa. A atuação do município priorizou a "desoneração" do setor privado, maximizando o lucro imobiliário da operação. Os efeitos territoriais deste 
processo têm sido alvo de vários estudos no Brasil, com os quais pretendemos colaborar aqui através de algumas reflexóes sobre seus impactos na Região Metropolitana do Recife (RMR).

\section{O PMCMV na Regiáo Metropolitana do Recife}

Segundo Souza et al (2015), a provisão de moradias na RMR ocorre historicamente por meio de três formas: da produção empresarial, da produção informal ou da promoção pública, onde a primeira define os padróes de organização social do território, estando, portanto, as demais subordinadas a ela. As tipologias resultantes deste processo, inseridos em um contexto de profundas desigualdades econômicas, evidenciam uma diferenciaçáo socioespacial que configura a RMR atual. Por meio de autoprodução ou dos conjuntos habitacionais produzidos pelo poder público a partir da década de 1960 , a periferização do Recife e a sua expansão para as cidades vizinhas se deram majoritariamente pela população de menor renda. Mais recentemente, o limitado território do Recife, no entanto, acabou por impulsionar também a metropolização da produção empresarial ávida pela valorização de novas áreas. É neste contexto metropolitano que surge o Programa Minha Casa Minha Vida (PMCMV), que além dos objetivos de superação da crise financeira já mencionados surgia como o principal programa de combate ao déficit habitacional.

De acordo com dados da Fundação João Pinheiro (2012), o Déficit Habitacional na Região Metropolitana do Recife (RMR), em 2009, quando foi lançado o PMCMV, era de 140.406 unidades habitacionais, correspondendo então a $5,5 \%$ do total de domicílios do estado e aproximadamente metade do déficit habitacional urbano de Pernambuco. Quase em sua totalidade encontrava-se em área urbana (99\%) e na faixa de renda de 0 a 3 salários (94\%). A coabitação e o ônus excessivo com aluguel constituíam a significativa maioria do déficit urbano, somando 87\%. Dos 14 municípios da RMR 3 , apenas quatro (Recife, Jaboatão dos Guararapes, Olinda e Paulista) atendem

\footnotetext{
3 Em janeiro de 2018, o município de Goiana passou a fazer parte da RMR, no entanto não seria possível sua comparação, pois náo foi considerada nas pesquisas referentes à RMR utilizada neste capítulo. Ressalvamos que a sua participaçáo no PMCMV Faixa 1 é de apenas 30 unidades e 117 unidades considerando todas as faixas, sendo, portanto, pouco influente nos resultados.
} 
por quase $80 \%$ do déficit, correspondendo a mais de 110 mil unidades em números absolutos. Ou seja, trata-se de um déficit associado à insuficiência de renda, majoritariamente urbano e concentrado nos municípios litorâneos do centro da RMR.

Mapa 1 - Localização dos municípios na RMR e no estado de Pernambuco

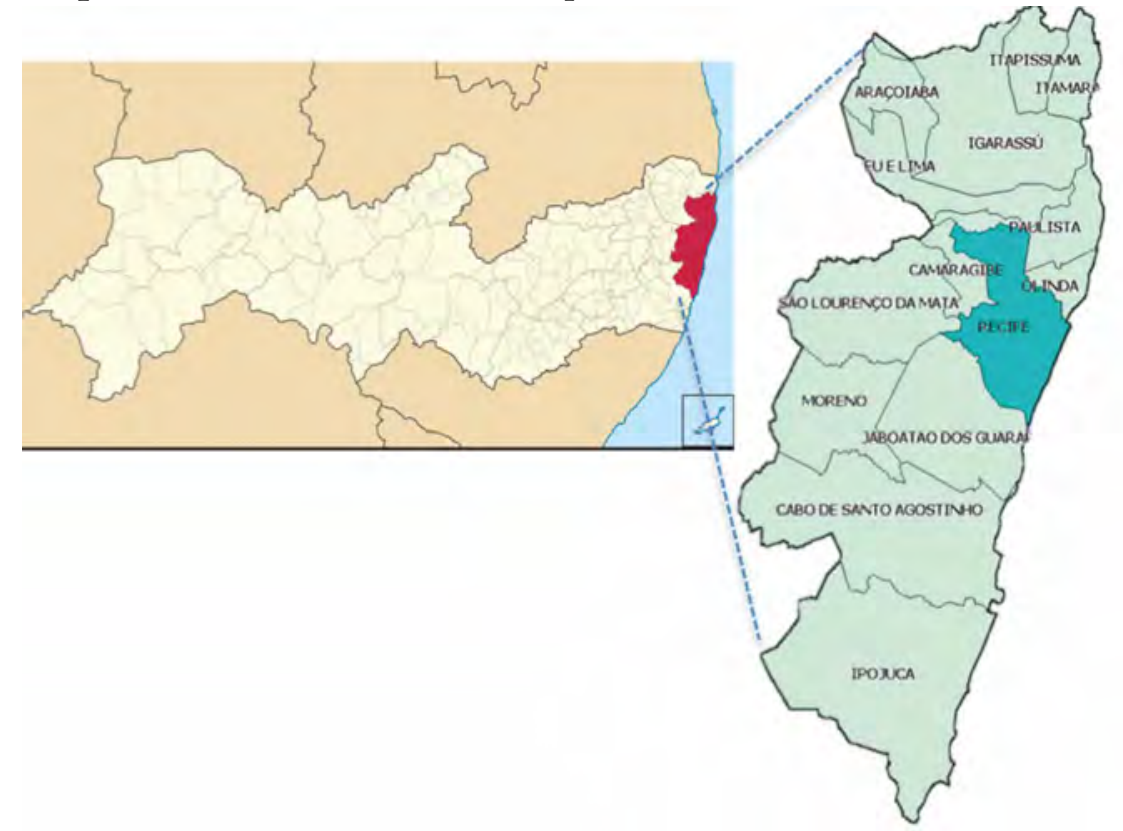

Fonte: https://pt.wikipedia.org/ e http://www.observatoriodasmetropoles.ufrj.br

Todos os municípios da RMR, com exceção de Araçoiaba, possuem empreendimentos do PMCMV (Tabela 1). No entanto, em todos eles, a maioria dos empreendimentos foram destinados às faixas de renda mais altas previstas no programa, famílias com rendimento até 9 mil reais. Apenas $24 \%$ das unidades habitacionais foram destinadas a famílias na faixa de renda mais baixa (Faixa 1), cujos rendimentos estão entre zero e 1,8 mil reais. Alguns municípios sequer possuem empreendimentos na Faixa 1, é o caso de Araçoiaba, Itapissuma e Camaragibe. Considerando todas as faixas de renda atendidas pelo programa, mais de 50 mil unidades habitacionais já foram entregues na RMR, e serão quase 84 mil considerando aquelas já contratadas. Ao observarmos os dados dos empreendimentos chamados Faixa 1, 
temos mais de 20 mil unidades contratadas, das quais cerca de 9 mil foram entregues.

Tabela 1 - Número de unidades habitacionais do PMCMV na RMR Todas as faixas

\begin{tabular}{|c|c|c|c|c|c|c|c|}
\hline $\begin{array}{c}\text { Setor da } \\
\text { RMR }\end{array}$ & Município & $\begin{array}{c}\text { Un. } \\
\text { Contratadas }\end{array}$ & $\begin{array}{c}\text { Un. } \\
\text { Entregues }\end{array}$ & $\begin{array}{l}\text { Un. Con- } \\
\text { tratadas } \\
\text { por Setor }\end{array}$ & $\begin{array}{c}\% \\
\text { Contrata- } \\
\text { das }\end{array}$ & $\begin{array}{l}\text { Un Entre- } \\
\text { gues por } \\
\text { Setor }\end{array}$ & $\begin{array}{c}\% \\
\text { Entregues }\end{array}$ \\
\hline \multirow{7}{*}{ NORTE } & $\begin{array}{l}\text { Abreu e } \\
\text { Lima }\end{array}$ & 2.875 & 2.861 & \multirow{7}{*}{38.949} & \multirow{7}{*}{$47 \%$} & \multirow{7}{*}{29.853} & \multirow{7}{*}{$59 \%$} \\
\hline & Araçoiaba & 0 & 0 & & & & \\
\hline & Itapissuma & 297 & 292 & & & & \\
\hline & Itamaracá & 1.144 & 1.058 & & & & \\
\hline & Olinda & 5.906 & 3.263 & & & & \\
\hline & Igarassu & 6.389 & 5.282 & & & & \\
\hline & Paulista & 22.338 & 17.097 & & & & \\
\hline \multirow{3}{*}{ OESTE } & Camaragibe & 5.168 & 2.727 & \multirow{3}{*}{13.321} & \multirow{3}{*}{$16 \%$} & \multirow{3}{*}{7.331} & \multirow{3}{*}{$15 \%$} \\
\hline & Moreno & 824 & 672 & & & & \\
\hline & $\begin{array}{l}\text { São Lou- } \\
\text { renço }\end{array}$ & 7.329 & 3.932 & & & & \\
\hline \multirow{3}{*}{ SUL } & Cabo & 3.447 & 465 & \multirow{3}{*}{25.685} & \multirow{3}{*}{$31 \%$} & \multirow{3}{*}{11.175} & \multirow{3}{*}{$22 \%$} \\
\hline & Ipojuca & 4.070 & 960 & & & & \\
\hline & Jaboatão & 18.168 & 9.750 & & & & \\
\hline CAPITAL & Recife & 5.746 & 2.035 & 5.746 & $7 \%$ & 2.035 & $4 \%$ \\
\hline \multirow{2}{*}{ TOTAL } & RMR & 83.701 & 50.394 & 83.701 & $100 \%$ & 50.394 & $100 \%$ \\
\hline & $\begin{array}{l}\text { Pernam- } \\
\text { buco }\end{array}$ & 200.683 & 136.204 & 200.683 & & 136.204 & \\
\hline
\end{tabular}

Fonte: Dados MCidades, abril/2019, elaborado pela autora 
Tabela 2 - Número de unidades habitacionais do PMCMV na RMR - Faixa 1

\begin{tabular}{|c|c|c|c|c|c|c|c|}
\hline $\begin{array}{c}\text { Setor da } \\
\text { RMR }\end{array}$ & Município & $\begin{array}{c}\text { Un. } \\
\text { Contrata- } \\
\text { das }\end{array}$ & $\begin{array}{c}\text { Un. } \\
\text { Entregues }\end{array}$ & $\begin{array}{l}\text { Un. Con- } \\
\text { tratadas } \\
\text { por Setor }\end{array}$ & $\begin{array}{c}\% \\
\text { Contrata- } \\
\text { das }\end{array}$ & $\begin{array}{l}\text { Un Entre- } \\
\text { gues por } \\
\text { Setor }\end{array}$ & $\begin{array}{c}\% \\
\text { Entregues }\end{array}$ \\
\hline \multirow{7}{*}{ NORTE } & \begin{tabular}{|l} 
Abreu e \\
Lima
\end{tabular} & 2.304 & 2.304 & \multirow{7}{*}{9.745} & & & \\
\hline & Araçoiaba & 0 & 0 & & & & \\
\hline & Itapissuma & 0 & 0 & & & & \\
\hline & Itamaracá & 553 & 500 & & $48 \%$ & 6.470 & $72 \%$ \\
\hline & Olinda & 3.000 & 1.551 & & & & \\
\hline & Igarassu & 1.504 & 1.267 & & & & \\
\hline & Paulista & 2.384 & 848 & & & & \\
\hline \multirow{3}{*}{ OESTE } & Camaragibe & 0 & 0 & \multirow{3}{*}{2.196} & & & \\
\hline & Moreno & 650 & 500 & & $11 \%$ & 570 & $6 \%$ \\
\hline & $\begin{array}{l}\text { Sao Lou- } \\
\text { renço }\end{array}$ & 1.546 & 70 & & & & \\
\hline \multirow{3}{*}{ SUL } & Cabo & 2.926 & 50 & \multirow{3}{*}{6.686} & & & \\
\hline & Ipojuca & 576 & 0 & & $33 \%$ & 1774 & $20 \%$ \\
\hline & Jaboatão & 3.184 & 1.724 & & & & \\
\hline CAPITAL & Recife & 1.608 & 192 & 1.608 & $8 \%$ & 192 & $2 \%$ \\
\hline \multirow[b]{2}{*}{ TOTAL } & RMR & 20.235 & 9.006 & 20.235 & $100 \%$ & 9.006 & $100 \%$ \\
\hline & $\begin{array}{l}\text { Pernam- } \\
\text { buco }\end{array}$ & 87.624 & 55.455 & 87.624 & & 55.455 & \\
\hline
\end{tabular}

Fonte: Dados MCidades, abril/2019, elaborado pela autora

Os empreendimentos da Faixa 1 de renda têm especial relevância no combate à pobreza na RMR, considerando que a população a que se destina compóe $94 \%$ do déficit habitacional, conforme já mencionado. A espacialização desses empreendimentos sobre o mapa de renda da RMR nos oferece os primeiros indícios de como está se dando a ocupação do território metropolitano. O Mapa 2 mostra que os empreendimentos da Faixa 1 estão localizados de maneira dispersa em todas as direçóes (norte, sul e oeste) da RMR, no entanto majoritariamente situados em áreas pobres e periféricas, 
em contraponto ao núcleo central historicamente com maior concentração de empregos e renda.

Mapas 2 - Renda por setor censitário e localização dos empreendimentos Faixa 1

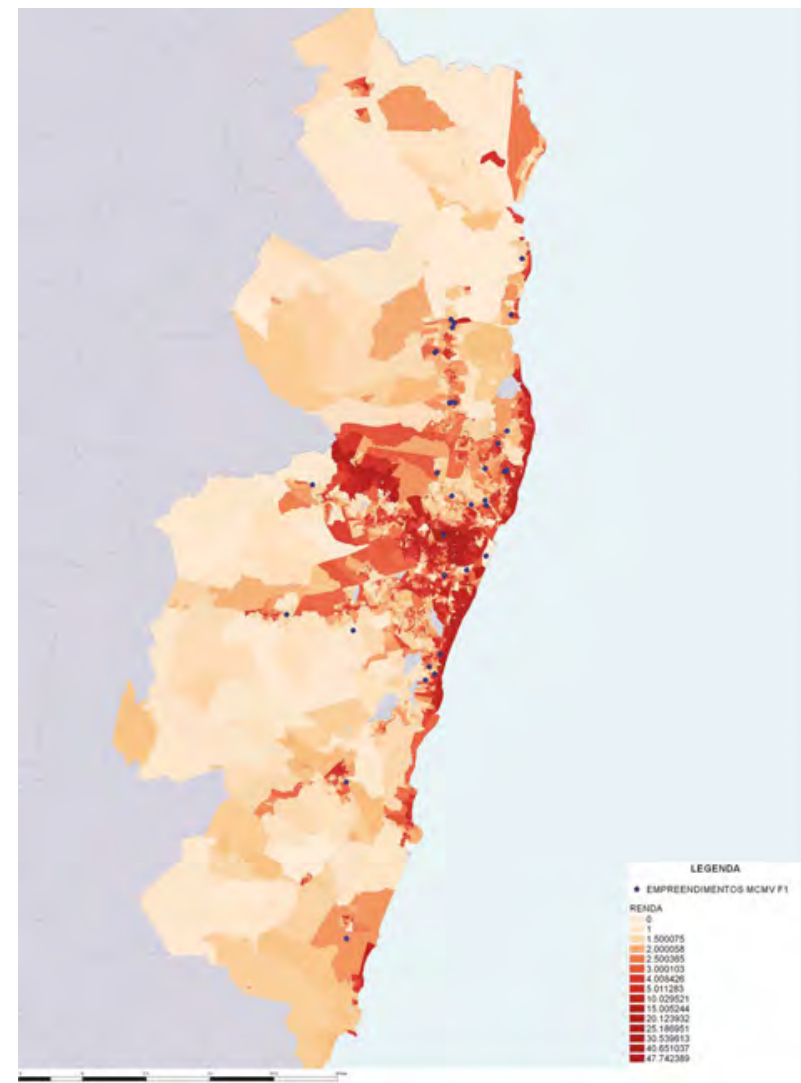

Fonte: Observatório das Metrópoles-Recife com base nos dados da CAIXA, 2019.

Elaboração: Luciana Gomes e André Lopes

O Mapa 3 nos traz a localização dos empreendimentos e os principais eixos viários da RMR, destacando, em branco, os núcleos urbanos. Podemos ver que a maioria dos terrenos escolhidos se encontram próximos a importantes eixos viários, como o formado pelas rodovias PE-15 e BR-101 norte, que atravessam vários municípios. Esta escolha não é aleatória, como explica Vilaça (2001), a via em si não provoca o crescimento urbano, ela oferece primeiro o aumento da acessibilidade, alterando, portanto, o valor da terra para além das estruturas construídas. 
A lógica de mercado da especulação de terrenos vazios ao longo de vetores de expansáo promissores antecede o PMCMV, no entanto, o que vemos é que o programa acaba por reforçá-la. Esta postura promove a maximizaçáo dos lucros do setor privado ao comprar terrenos mais baratos, ao mesmo tempo que estabelece novas áreas de valorizaçâo imobiliária. Em contraponto, desconsidera, nesta decisão, a falta de oportunidades urbanas destes locais, bem como os investimentos posteriores a serem realizados (pelo poder público) para levar serviços e infraestrutura. A expansão urbana neste contexto fortalece, portanto, o histórico processo de diferenciação do espaço urbano para ricos e pobres que caracteriza a RMR.

Mapa 3 - Localização dos empreendimentos Faixa 1 em relação aos núcleos urbanos e principais eixos de transporte

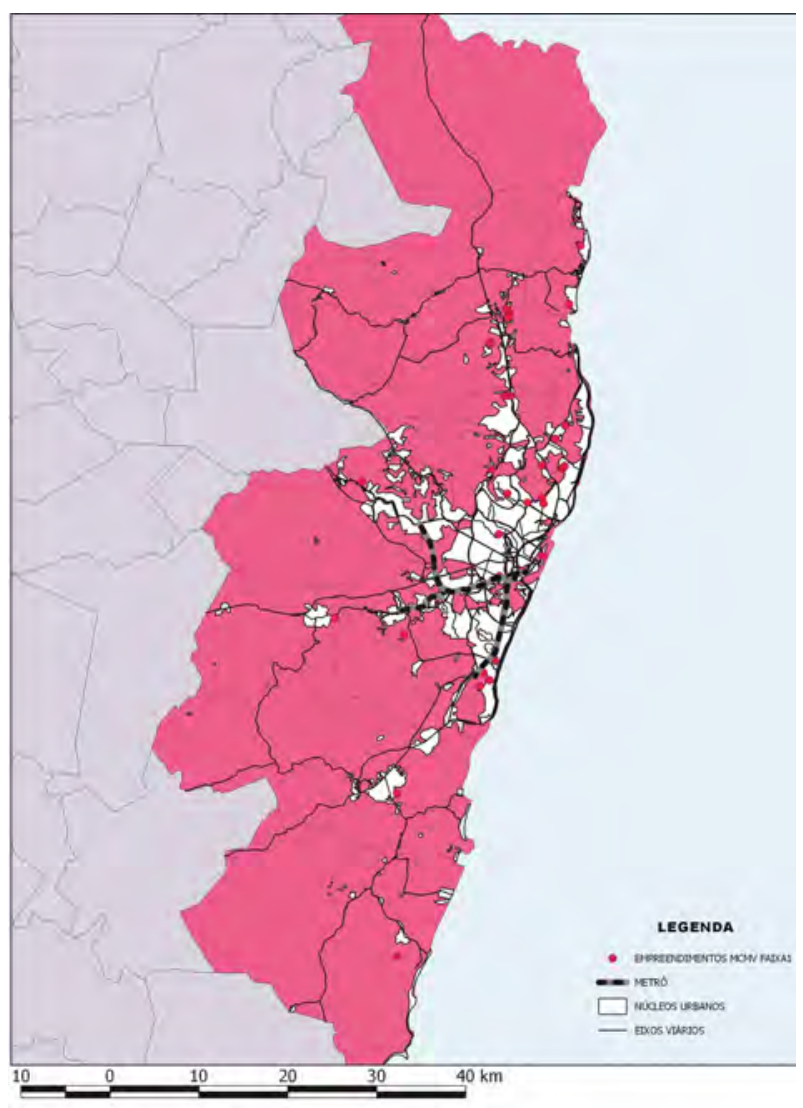

Fonte: Observatório das Metrópoles-Recife com base nos dados da CAIXA, 2019.

Elaboração: Luciana Gomes e André Lopes 
Retomando as Tabelas 1 e 2, podemos observar que a maioria das unidades da Faixa 1 entregues (72\%) encontram-se nos municípios ao norte da RMR. Este comportamento se repete para todas as faixas (com 59\%), indicando uma restruturação do território mais potente concentrada em um determinado setor. Além da questão associada ao preço da terra e ao lucro imobiliário, podemos afirmar que estes empreendimentos também foram impulsionados pela instalação de novas indústrias na região, como a fábrica de automóveis da Fiat e o Polo fármaco-químico.

De um modo geral, o setor sul apresenta, para todas as faixas, um desempenho mais lento nas entregas do que o setor norte. Ao sul da RMR predominam os residenciais voltados às faixas de renda maiores, provavelmente atraídos pela demanda criada com o surgimento de grandes empreendimentos, como o Complexo Portuário de SUAPE no Cabo de Santo Agostinho e o Estaleiro Atlântico Sul e a Refinaria Abreu e Lima, ambos em Ipojuca. Neste último município, as primeiras contrataçóes da Faixa 1 só ocorreram em 2018, ainda sem entrega. Jaboatáo do Guararapes, um dos municípios com alto déficit habitacional na RMR, se destaca como município do setor sul que mais atraiu empreendimentos do PMCMV em todas as faixas, no entanto executou apenas pouco mais da metade das unidades contratadas.

Entre os quatro municípios mencionados que mais contribuem com o déficit na RMR, Recife é o que apresenta pior desempenho. Na capital, cujo déficit supera 70 mil unidades, ${ }^{4}$ as primeiras 192 unidades da Faixa 1 foram entregues em 2018, bem como as demais contrataçôes, mencionadas na Tabela 2, foram efetivadas apenas em 2017. Isto evidencia, primeiro, que o programa não foi uma prioridade para a gestão local nos últimos anos, e segundo, indica uma postura do mercado da construçáo civil que, ao mesmo tempo que "desencoraja" a ocupação das áreas centrais pela populaçáo pobre, estimula a reorganização dos espaços metropolitanos prevendo os ganhos imobiliários atrelados a eles.

Embora uma relação direta exija estudos mais complexos, para efeito de escala observamos que o total de unidades construídas corresponde a cerca de $60 \%$ do déficit habitacional de 140.406 moradias apontado pela Fundação João Pinheiros para RMR em 2010 e quase 15\% deste universo, se con-

4 Déficit estimado pelo PLHIS de Recife, ainda em construção, é de 71.160 UH em 2017, disponível em https://habitatbrasil.org.br/wp-content/uploads/2018/10/Documento-S\%C3\%ADntese-LAB-Moradia-no-Centro-Recife.pdf 
siderarmos apenas a Faixa 1 de renda. Foram, portanto, avanços importantes, especialmente considerando as políticas habitacionais antecedentes. Porém, questiona-se: até que ponto este incremento de estoque impacta na redução das desigualdades de acesso às oportunidades urbanas enfrentadas pela populaçáo de baixa renda na metrópole?

No intuito de aproximar nossa discussão ao universo populacional, realizamos um comparativo demográfico simples. Utilizando a densidade populacional por domicílio média do estado, multiplicamos pelo número de moradias já entregues estimando a população beneficiada até o momento. Fizemos ainda cálculos relativos para entender o percentual de população já beneficiada, ou seja, que estâo residindo na moradia, e aquelas que virão a ser beneficiadas com a conclusão das unidades já contratadas (Tabelas 3 e 4).

Assim, estima-se mais de 173 mil pessoas ocupando novas localizações na RMR, impulsionadas por um único programa habitacional nos últimos 10 anos. Estes números devem chegar a cerca de 289 mil pessoas com a conclusão de todos os empreendimentos contratados. Milhares de novos trajetos desenhados para acessar ao trabalho, à escola, ao comércio e aos demais serviços. Os valores relativos são ainda mais impressionantes, uma vez que o número de beneficiários já atingiu o equivalente a mais de $10 \%$ da população total de alguns municípios. E logo serão mais de $20 \%$ desse universo, como nos casos de Igarassu, Paulista e São Lourenço.

Tabela 3 - Estimativa população beneficiada por município - Todas as faixas

\begin{tabular}{c|l|c|c|c|c|c|c|c}
\hline $\begin{array}{c}\text { Setor da } \\
\text { RMR }\end{array}$ & Município & $\begin{array}{c}\text { Populaçao } \\
\text { CENSO } \\
\mathbf{2 0 1 0}\end{array}$ & $\begin{array}{c}\text { Unids } \\
\text { Contrata- } \\
\text { das }\end{array}$ & $\begin{array}{c}\text { Unds. } \\
\text { Entregues }\end{array}$ & $\begin{array}{c}\text { Pop benefi- } \\
\text { ciada-con- } \\
\text { tratada* }\end{array}$ & $\begin{array}{c}\text { Pop con- } \\
\text { trat/ pop } \\
\text { total ** }\end{array}$ & $\begin{array}{c}\text { Pop. bene- } \\
\text { ficiada- en- } \\
\text { tregue* }\end{array}$ & $\begin{array}{c}\text { Pop } \\
\text { entreg/pop } \\
\text { total** }\end{array}$ \\
\hline & $\begin{array}{l}\text { Abreu e } \\
\text { Lima }\end{array}$ & 94.429 & 2.875 & 2.861 & 9.919 & $10,50 \%$ & 9.870 & $10,45 \%$ \\
\cline { 2 - 10 } & Araçoiaba & 18.156 & 0 & 0 & 0 & $0,00 \%$ & 0 & $0,00 \%$ \\
\cline { 2 - 10 } & $\begin{array}{l}\text { Itapissu- } \\
\text { ma }\end{array}$ & 23.769 & 297 & 292 & 1.025 & $4,31 \%$ & 1.007 & $4,24 \%$ \\
\hline & Itamaracá & 21.884 & 1.144 & 1.058 & 3.947 & $18,04 \%$ & 3.650 & $16,68 \%$ \\
\cline { 2 - 9 } & Olinda & 377.779 & 5.906 & 3.263 & 20.376 & $5,39 \%$ & 11.257 & $2,98 \%$ \\
\cline { 2 - 9 } & Igarassu & 102.021 & 6.389 & 5.282 & 22.042 & $21,61 \%$ & 18.223 & $17,86 \%$ \\
\cline { 2 - 9 } & Paulista & 300.466 & 22.338 & 17.097 & 77.066 & $25,65 \%$ & 58.985 & $19,63 \%$ \\
\hline
\end{tabular}




\begin{tabular}{l|l|c|c|c|c|c|c|c}
\hline \multirow{2}{*}{ OESTE } & $\begin{array}{l}\text { Camara- } \\
\text { gibe }\end{array}$ & 144.466 & 5.168 & 2.727 & 17.830 & $12,34 \%$ & 9.408 & $7 \%$ \\
\cline { 2 - 9 } & Moreno & 56.696 & 824 & 672 & 2.843 & $5,01 \%$ & 2.318 & $4 \%$ \\
\cline { 2 - 9 } & $\begin{array}{l}\text { Sao Lou- } \\
\text { renço }\end{array}$ & 102.895 & 7.329 & 3.932 & 25.285 & $24,57 \%$ & 13.565 & $13 \%$ \\
\hline \multirow{2}{*}{ SUL } & Cabo & 185.025 & 3.447 & 465 & 11.892 & $6,43 \%$ & 1.604 & $0,87 \%$ \\
\cline { 2 - 9 } & Ipojuca & 80.637 & 4.070 & 960 & 14.042 & $17,41 \%$ & 3.312 & $4,11 \%$ \\
\cline { 2 - 9 } & Jaboatáo & 644.620 & 18.168 & 9.750 & 62.680 & $9,72 \%$ & 33.638 & $5,22 \%$ \\
\hline \multirow{2}{*}{ CA P I - } & Recife & 1.537 .704 & 5.746 & 2.035 & 19.824 & $1,29 \%$ & 7.021 & $0,46 \%$ \\
\hline \multirow{2}{*}{ TOTAL } & \begin{tabular}{l} 
RMR \\
\cline { 2 - 9 } \\
\cline { 2 - 9 }
\end{tabular} & 3.690 .547 & 83.701 & 50.394 & 288.768 & $7,82 \%$ & 173.859 & $4,71 \%$ \\
\hline
\end{tabular}

Fonte: CENSO, 2010 e dados MCidades, abr. 2019, elaborado pela autora

* estimativa de beneficiados multiplicando o número de unidades pela média de moradores por domicílio em Pernambuco do CENSO 2010.

** percentual estimado dividindo o total de população beneficiada pelo PMCMV (considerando o total de unidades contratadas ou aquelas já entregues), pela população total do município conforme CENSO 2010.

Tabela 4 - Estimativa população beneficiada por município - Faixa 1

\begin{tabular}{|c|c|c|c|c|c|c|c|}
\hline $\begin{array}{c}\text { Setor da } \\
\text { RMR }\end{array}$ & Município & \begin{tabular}{|c} 
Unidades \\
Contratadas
\end{tabular} & $\begin{array}{l}\text { Unidades } \\
\text { Entregues }\end{array}$ & $\begin{array}{c}\text { Populaçáo } \\
\text { beneficiada- } \\
\text {-contratada* }\end{array}$ & $\begin{array}{l}\text { Pop contral } \\
\text { pop total }\end{array}$ & $\begin{array}{c}\text { Populacáo } \\
\text { beneficiada- } \\
\text { entregue* }\end{array}$ & $\begin{array}{l}\text { Pop entreg/ } \\
\text { pop total } * *\end{array}$ \\
\hline \multirow{7}{*}{ NORTE } & $\begin{array}{l}\text { Abreu e } \\
\text { Lima } \\
\end{array}$ & 2.304 & 2.304 & 7949 & $8,42 \%$ & 7949 & $8,42 \%$ \\
\hline & Araçoiaba & 0 & 0 & 0 & $0,00 \%$ & 0 & $0,00 \%$ \\
\hline & Itapissuma & 0 & 0 & 0 & $0,00 \%$ & 0 & $0,00 \%$ \\
\hline & Itamaracá & 553 & 500 & 1908 & $8,72 \%$ & 1725 & $7,88 \%$ \\
\hline & Olinda & 3.000 & 1.551 & 10350 & $2,74 \%$ & 5351 & $1,42 \%$ \\
\hline & Igarassu & 1.504 & 1.267 & 5189 & $5,09 \%$ & 4371 & $4,28 \%$ \\
\hline & Paulista & 2.384 & 848 & 8225 & $2,74 \%$ & 2926 & $0,97 \%$ \\
\hline \multirow{3}{*}{ OESTE } & \begin{tabular}{|l}
$\begin{array}{l}\text { Camara- } \\
\text { gibe }\end{array}$ \\
\end{tabular} & 0 & 0 & 0 & $0,00 \%$ & 0 & $0,00 \%$ \\
\hline & Moreno & 650 & 500 & 2.243 & $3,96 \%$ & 1.725 & $3,04 \%$ \\
\hline & $\begin{array}{l}\text { Sao Lou- } \\
\text { renco }\end{array}$ & 1.546 & 70 & 5.334 & $5,18 \%$ & 242 & $0,23 \%$ \\
\hline \multirow{3}{*}{ SUL } & Cabo & 2.926 & 50 & 10.095 & $5,46 \%$ & 173 & $0,09 \%$ \\
\hline & Ipojuca & 576 & 0 & 1.987 & $2,46 \%$ & 0 & $0,00 \%$ \\
\hline & Jaboatão & 3.184 & 1.724 & 10.985 & $1,70 \%$ & 5.948 & $0,92 \%$ \\
\hline
\end{tabular}




\begin{tabular}{l|l|c|c|c|c|c|c}
\hline CAPITAL & Recife & 1.608 & 192 & 5548 & $0,36 \%$ & 662 & $0,04 \%$ \\
\hline \multirow{2}{*}{ TOTAL } & RMR & 20.235 & 9.006 & 69.811 & $1,89 \%$ & 31.071 & $0,84 \%$ \\
\cline { 2 - 8 } & Pernambuco & 87.624 & 55.455 & 302.303 & $3,44 \%$ & 191.320 & $2,18 \%$ \\
\hline
\end{tabular}

Fonte: CENSO, 2010 e dados MCidades, abr. 2019, elaborado pela autora

* estimativa de beneficiados multiplicando o número de unidades pela média de moradores por domicílio em Pernambuco do CENSO 2010.

** percentual estimado dividindo o total de população beneficiada pelo PMCMV (considerando o total de unidades contratadas ou aquelas já entregues), pela população total do município conforme CENSO 2010.

Considerando apenas a Faixa 1, estima-se, em um futuro breve, quase 70 mil pessoas vivendo em novas localizaçóes. Apesar de resultados absolutos mais modestos, este universo tem especial impacto nas estruturas urbanas por sua maior dependência dos serviços públicos e, em especial, do transporte público. Neste sentido, observa-se uma quantidade relativa de população beneficiada bastante expressiva nos municípios de Abreu e Lima, Itamaracá, Igarassu e, futuramente, São Lourenço e Cabo, superando 5\% da população total destes municípios (Tabela 4).

O setor norte da RMR (Olinda, Paulista, Abreu e Lima, Igarassu e Itapissuma) foi o que apresentou maior número de famílias ocupando novas localizaçóes em seus territórios e nos traz algumas evidências sobre os impactos do programa na estrutura urbana. São municípios com baixo desenvolvimento econômico e social e um crescimento historicamente desarticulado do planejamento urbano. Alguns estáo ganhando certa dinâmica com o surgimento de novos equipamentos, como shoppings e faculdades particulares e algumas plantas industriais, mas todos ainda guardam grande dependência do Recife, tanto na produção quanto no consumo.

Os deslocamentos para satisfazer suas necessidades cotidianas no território metropolitano são, portanto, significativos. Conforme Andrade et al (2015), nos municípios de Abreu e Lima, Camaragibe, Olinda, Paulista e São Lourenço da Mata, em média 45\% dos trabalhadores necessitam se deslocar diariamente para outros municípios, pois residem em cidades-dormitórios. Não só a localização da população e seus destinos rotineiros configuram as crescentes demandas de transporte, mas também a renda destes grupos, uma vez que população de menor renda tende a usar mais o transporte público e fazer deslocamentos a pé.

O tempo médio nas viagens pendulares na RMR aumentou de $33 \mathrm{mi}$ nutos, em 1997, para 41 minutos, em 2010 e aumentou de 12,1\% para 
19,0\% o número de trabalhadores cujo tempo de viagem supera uma hora. Este fenômeno ocorreu em praticamente todos os municípios da RMR, mas com intensidade mais forte nos municípios periféricos, entre eles Abreu e Lima e Itapissuma. (Andrade et al, 2015). As longas distâncias casa-trabalho a serem percorridas por estas famílias, especialmente as da Faixa 1, nos indicam que o desequilíbrio na estrutura urbana metropolitana tende a ser reforçado pela expansão habitacional promovida pelo PMCMV. A distribuição periférica e dispersa da moradia associada à concentração de empregos em determinadas áreas onera o poder público que assume o ônus de expandir a oferta de infraestrutura e serviços urbanos (além de oportunidade de trabalho) a grandes extensóes territoriais. Bem como estabelece, na escala regional, uma urgência no que se refere à mobilidade, que extrapola o aspecto social e imprime entraves à própria economia da metrópole.

Apesar das melhorias da moradia em aspectos como pavimentação, drenagem, esgoto, luz e água, o fator localização amplia a vulnerabilidade dos moradores, quando eles passam a viver longe das oportunidades urbanas. Em que pese seu impacto na vida das pessoas (e de modo acumulativo, no espaço urbano), esse fator não é considerado nas estatísticas oficiais que subsidiam as políticas públicas voltadas para a habitaçáo. Os dados da Fundação João Pinheiro adotados, que servem de referência para vários programas de governo (como o PMCMV), por exemplo, não comportam esse tema. Sua metodologia visa principalmente mensurar a deficiência de estoque. Mesmo os indicadores de inadequação de domicílios se limitam a questôes de infraestrutura para servir à moradia e de titularidade do imóvel. Náo se trata de uma crítica à metodologia, mas apenas uma provocação sobre a construção de um discurso, cujas lacunas favorecem, antes de tudo, a produçáo empresarial. Precisamos de novos indicadores que o complementem ou até mesmo o contraponham. Considerar o fator localização no universo das necessidades habitacionais e o seu impacto na vida das pessoas é fundamental para romper o ciclo segregacionista de nossa urbanizaçáo, sobretudo pautando a revisáo das políticas públicas voltadas ao uso e ocupação do solo. 


\section{Consideraçóes finais}

A localização dos empreendimentos do PMCMV na RMR estão antes subordinadas aos interesses da produção empresarial da moradia do que à real demanda do déficit habitacional ou a capacidade de oferta de infraestrutura dos municípios. Alimentam, assim, uma lógica segregacionista, na qual o agente privado determina onde vivem ricos e pobres. As localizaçóes periféricas (definidas pela produção empresarial) das moradias acabam por transformar, em primeiro plano, o espaço urbano municipal (formal ou informalmente) diante das necessidades de produção, reprodução e consumo dos moradores. Não obstante, para além das questóes locais, a concentração de empregos e serviços nos municípios centrais, afastados dos conjuntos habitacionais, reforça a necessidade de tratamento do tema do transporte público em uma escala metropolitana.

Em um sentido mais amplo, observamos que a organização espacial desses empreendimentos implica em uma transformação na dinâmica espacial de milhares de famílias que passaram a residir em novas localizaçóes. Como vimos, a circulação de pessoas é um elemento estruturador e estruturante do espaço (intraurbano e metropolitano), o olhar, portanto, sobre o universo de moradores para além da moradia (inanimada) buscou aqui lançar alguns indícios sobre os impactos do PMCMV no território, considerando essa dimensão. A rápida transformação local com a chegada do empreendimento e, portanto, de milhares de famílias, quase sempre náo corresponde a respostas imediatas do poder público, que afinal não é o contratante e não tem assumido, neste caso, o protagonismo do uso e da ocupaçáo do solo em seus territórios.

Por fim, esclarecemos que as reflexóes aqui apresentadas impulsionaram uma pesquisa em andamento, de âmbito acadêmico. São fruto, sobretudo, de inquietaçóes diante da condição de isolamento destes conjuntos habitacionais periféricos, que apesar dos esforços financeiros, políticos e humanos vultuosos, mantêm a vulnerabilidade de seus moradores, ainda que sob um novo aspecto. Buscamos seguir refletindo sobre até que ponto estamos trocando um déficit habitacional por uma inadequação socioespacial que apenas vem alimentar as assimetrias de nossas cidades. 


\section{Referências}

ANDRADE, Mauricio et al. "Mobilidade urbana no contexto da organizaçáo social do território da Regiāo Metropolitana do Recife". In: Souza, M. Angela e Biton, Jan (orgs.) Recife: transformaçôes na ordem urbana. Rio de Janeiro: Letra Capital, 2015

AMORE, Caio Santo et al (orgs.) Minha Casa... E a Cidade? Rio de Janeiro: Letra Capital, 2015.

CYMBALISTA, Renato e MOREIRA, Tomás. "Política Habitacional no Brasil: a história e os atores de uma narrativa incompleta". In: Participação popular em políticas públicas: espaço de construção da democracia brasileira. - São Paulo: Instituto Pólis, 2006. 124p

CARDOSO, Adauto Lúcio e ARAGÃO, Thêmis Amorim. "Do fim do BNH ao Programa Minha Casa Minha: 25 anos da política habitacional no Brasil". In: CARDOSO, Adauto Lúcio (org.). O Programa Minha Casa Minha Vida e seus efeitos territoriais. Rio de Janeiro: Letra Capital, 2013.

CARDOSO, Adauto Lúcio e LAGO, Luciana Côrrea do. "O Programa Minha Casa Minha Vida e seus efeitos territoriais". In: CARDOSO, Adauto Lúcio (org.). O Programa Minha Casa Minha Vida e seus efeitos territoriais. Rio de Janeiro: Letra Capital, 2013.

CASTELLS, M. A questão urbana. Rio de Janeiro: Paz e Terra, 2000.

FJP - Fundação João Pinheiro, Centro de Estatística e Informaçôes. Déficit habitacional no Brasil 2009. Belo Horizonte, 2012. 200p.

LUCENA, Wilma Guedes de. A produção do espaço urbano da cidade de Patos - PB: do BNH ao Programa Minha Casa Minha Vida. (Dissertação). João Pessoa: Universidade Federal da Paraíba, 2014.

NAHAS, M.I.P. et al. "Metodologia de construção do Índice de Qualidade de Vida Urbana dos municípios brasileiros (IQVU-BR)". In: XV Encontro Nacional de Estudos Populacionais da Associação Brasileira de Estudos Populacionais, 2006, Caxambu, MG. Anais do XV Encontro Nacional de Estudos Populacionais da Associação Brasileira de Estudos Populacionais, 2006.

ROLNIK, Raquel et al. "O Programa Minha Casa Minha Vida nas regióes metropolitanas de São Paulo e Campinas: aspectos socioespaciais e segregação”. Cad. Metrop. São Paulo, v. 17, n. 33, pp. 127-54, maio 2015. Acesso em: mar. 2017. Disponível em: http://www. scielo.br/scielo.php?script=sci_arttext\&pid=S2236-99962015000100127\&lng=pt\&nr $\mathrm{m}=$ iso\&tlng=pt.

SANTOS, J.M et al. "Habitaçáo e Localização: Notas sobre padrōes de deslocamento em empreendimentos do PMCMV no Rio de Janeiro". Habitar 2014, nov. 2014.

SANTOS, Milton. O Espaço do Cidadão. São Paulo: Nobel, 1987.

SOUZA, M. Ângela et al. "As formas de provisão da moradia na configuração socioespacial da Regiáo Metropolitana do Recife". In: SOUZA, M. Angela e BITON, Jan (orgs.) Recife: transformaçôes na ordem urbana. Rio de Janeiro: Letra Capital, 2015

VILLAÇA, Flávio. Espaço intraurbano no Brasil. São Paulo: FAPESP, 2001. 


\section{O programa Minha Casa Minha Vida contribui para a construção do direito social à moradia? A experiência no Estado do Rio de Janeiro}

Angela Moulin Simóes Penalva Santos Pedro Henrique Ramos Prado Vasques

\section{Introdução}

O direito à moradia vem ganhando cada vez mais proteção no ordenamento jurídico nacional e internacional. O próprio conteúdo deste direito se transformou e passou a ser percebido como "moradia adequada", isto é, um abrigo conectado a uma rede de infraestrutura urbana. Apesar da crescente evoluçáo da proteçáo jurídica da moradia, ainda há uma grande demanda por habitação adequada para a população de baixa renda. Na Constituição Federal de 1988, a proteção do direito à moradia está estabelecida nas diretrizes da política urbana (função social da cidade, das terras públicas e proteção jurídica da posse); quando prevê expressamente o princípio da função social da propriedade elencado no art. $5^{\circ}$ (inciso XXIII); e, principalmente em seu art. $6^{\circ}$, após a entrada em vigor da Emenda Constitucional n. ${ }^{\circ} 26$, que incluiu a habitação no rol dos direitos sociais. Assim, o direito à moradia foi consagrado na Constituição de nossa República, sendo seu componente principal o princípio da dignidade da pessoa humana. $\mathrm{O}$ direito à moradia deve ser interpretado em suas duas dimensóes (Sarlet, 2002): i) na dimensão positiva, trata-se dever do poder público implementar uma política de habitação de interesse social; ii) na dimensão negativa, implica abster-se de promover deslocamentos involuntários de população carente que pode ser regularizada nos locais que ocupam. 
O Programa Minha Casa Minha Vida foi apresentado como inserido na dimensão positiva da construção do direito à moradia, ainda que o déficit habitacional tenha crescido ao longo de 2009-15 (último período publicado), segundo cálculo da Fundação João Pinheiro. Em face desta situação, o artigo discute em que medida o programa pode ser entendido como parte da construção do direito social à moradia, tomando por referência a experiência no Estado do Rio de Janeiro, destacando sua capital. Tal focalização no território fluminense apresenta peculiaridades que devem ser consideradas e relaciona-se à dimensão negativa do direito à moradia, desdobrando-se no princípio da não remoção, que pode ser excepcionado apenas quando as áreas ocupadas irregularmente por moradores pobres apresentarem risco às suas vidas. Este teria sido o caso, por exemplo, das fortes chuvas que castigaram vários municípios fluminenses em abril de 2010, deixando milhares de pessoas desabrigadas e outras centenas de famílias em situação de risco. Porém, muitas remoçôes ocorreram por causa dos projetos implementados pelas três esferas de governo para preparar a capital estadual para sediar os chamados "megaeventos" esportivos, como os Jogos Militares (2011), a Copa das Confederaçóes (2013), a Copa FIFA de Futebol (2014) e, principalmente, os Jogos Olímpicos (2016).

$\mathrm{O}$ artigo está organizado em três partes, além das conclusóes. A primeira é a introduçáo. Na segunda, apresenta-se o direito à moradia como uma construçáo social em curso, o que inclui a construção de novas moradias. A implantação da principal política pública no país, o Programa Minha Casa Minha Vida, ao enfocar na construção de novas unidades, suscitou uma série de críticas com base em estudos empíricos aqui sintetizadas. A terceira parte enfoca na análise da evolução do programa desde a sua criação, em 2009, até os últimos dados disponíveis, em 2018, nas unidades da federação mais beneficiadas pelo programa, de modo a servir de referência para o caso fluminense. Os municípios foram distribuídos entre capitais estaduais e municípios com população superior a 100 mil habitantes, sendo que estes foram divididos entre aqueles localizados dentro ou fora de regióes metropolitanas. $\mathrm{Na}$ quarta parte são apresentadas as conclusóes do estudo.

\section{O PMCMV em face do direito social à moradia}

O objetivo desta seção é fazer uma análise da construção normativa do direito social à moradia, bem como a elaboração de breve síntese da possível contribuição do PMCMV à efetividade daquele direito. 


\section{Direito à moradia: um direito social em construçãa ${ }^{1}$}

A moradia foi reconhecida como direito humano em 1948, com a Declaraçáo Universal dos Direitos Humanos, tornando-se um direito humano universal aceito como um dos direitos fundamentais. Posteriormente, o entendimento das Naçóes Unidas foi ampliado ao conceito de moradia adequada. Esta náo se resume a apenas um teto e quatro paredes, mas ao direito de toda pessoa ter acesso a um lar para se desenvolver e uma comunidade segura para viver em paz, com dignidade e saúde física e mental.

Afinal, sem uma casa não há como descansar, se alimentar, fazer a higiene pessoal, confraternizar, receber correspondência, conseguir um trabalho formal, enfim, satisfazer as necessidades mais básicas de forma digna. Segundo a Relatoria Especial da ONU pela Moradia Adequada, uma habitação adequada deve incluir segurança da posse; disponibilidade de serviços, infraestrutura e equipamentos públicos; custo acessível; habitabilidade; não discriminação e priorização de grupos vulneráveis; localização adequada, e adequaçáo cultural. Dessa forma, o ser humano pode se desenvolver por completo, provendo a si e à sua família a capacidade de viver de forma plena.

O Princípio da Não Remoção, compreendido como um desdobramento da dimensão negativa do direito à moradia (Sarlet, 2002), pode ser interpretado como uma construçáo normativa que é fruto de conquistas sociais e de uma crescente proteção e valorização dos direitos humanos fundamentais na ordem jurídica internacional. Portanto, seu conteúdo pode ser extraído de vasta legislaçâo protetiva, desde a esfera internacional, passando pela ordem jurídica nacional (Constituição da República e Leis Federais), Estadual (Constituição do Estado) e Municipal (Lei Orgânica do Município).

No âmbito do direito internacional, a moradia é considerada direito humano fundamental em diversos acordos e tratados dos quais o Brasil é signatário, tais como o Protocolo de San Salvador (Sistema Interamericano de Proteção Internacional dos Direitos Humanos) e o Pacto Internacional de Direitos Econômicos, Sociais e Culturais (ONU). Outras normas e convenções internacionais que cabe citar são: a Convenção Internacional sobre a Eliminação de todas as Formas de Discriminação Racial (1965), a Convenção

1 Esta seção se baseia no artigo de SANTOS, A. et al. "Direito à moradia: um direito social em construção no Brasil. A experiência do aluguel social no Rio de Janeiro". Planejamento e Politicas Públicas, v. jan./jun. 2016, pp. 217-42, 2016. 
Internacional sobre a Eliminação de todas as Formas de Discriminação da Mulher (1979), a Convenção sobre os Direitos da Criança (1989), Convenção dos Trabalhadores Migrantes (1990) e a Convenção 169 da Organização Internacional do Trabalho sobre Povos Indígenas e Tribais (1989).

Marco importante na disseminação internacional de uma nova e ampliada agenda de direitos dos residentes urbanos foi a criação da Agência ONU-Habitat, em decorrência da Conferência das Naçôes Unidas sobre Assentamentos Humanos (Habitat I), que aconteceu em Vancouver, Canadá, em 1976. A assembleia Habitat II, em Istambul, Turquia, em 1996, consagrou uma definição mais abrangente da moradia social (Antonucci et al, 2010). A partir de entáo, consolidou-se um novo sentido ao direito à moradia, o já mencionado "moradia adequada".

Este avanço normativo evoluiu para a construção do princípio da não remoção, como parte da dimensão negativa do direito à moradia. Tal princípio emana dos Comentários n. ${ }^{\circ} 4$ e n. 7 sobre os Direitos Econômicos, Sociais e Culturais, que conferiram conteúdo hermenêutico ao Pacto Internacional dos Direitos Econômicos, Sociais e Culturais. Eles foram editados porque um procedimento adequado aos litígios relativos à moradia, mesmo quando legítimo, não pode deixar os desalojados na condição de sem-teto ou em situação de vulnerabilidade com relação aos direitos humanos. Caso isso ocorra, os Estados signatários devem providenciar todas as medidas necessárias para ofertar uma moradia alternativa, o reassentamento ou o acesso à terra produtiva. Além disso, enfatiza-se a importância do devido processo legal em casos de despejo, principalmente pelo número de direitos fundamentais envolvidos, recomendando expressamente que todo despejo seja levado a cabo como última alternativa, apenas quando não houver condiçóes para a permanência. Mesmo assim, a remoção só pode ser efetivada depois do cumprimento de uma série de requisitos que incluem a participação da população na construção de uma alternativa e a realocação em local próximo.

No Brasil, especialmente desde a década de 1970, movimentos sociais urbanos, associados ao Fórum Nacional de Reforma Urbana, mantêm em sua plataforma de reivindicaçóes a defesa do direito à cidade e à moradia dos habitantes de assentamentos precários como forma de promover um meio ambiente urbano saudável para todos os moradores da cidade (Fernandes, 2006). Sendo assim, em âmbito nacional as conquistas legislativas no que tange ao direito social à moradia estão associadas à luta desses movimentos, 
uma vez que contribuíram significativamente pela inclusão do Capítulo da Política Urbana na Constituição Federativa de 1988 e pela elaboração do conteúdo de Leis Federais relacionadas ao tema.

Atualmente, o conteúdo e a proteção do direito à moradia na ordem jurídica interna decorrem de um novo paradigma jurídico-urbanístico (Fernandes, 2006). Seu principal balizador é a função socioambiental da propriedade, decorrente de avanços na defesa dos direitos humanos fundamentais concebidos de forma coletiva, inter-relacionados ${ }^{2}$ e presentes em normas definidas em todas as esferas federativas. Na Constituição Federal de 1988, a proteção do direito social à moradia está expressa quando estabelece as diretrizes da política urbana (função social da cidade, das terras públicas e proteção jurídica da posse) e também quando prevê o princípio da função social da propriedade elencado no art. $5^{\circ}$, XXIII. Mas o principal avanço normativo ocorreu no ano 2000, quando a Emenda Constitucional n. 26 incluiu a habitação rol dos direitos sociais definidos no art. $6^{\circ}$, sendo seu componente principal o princípio da dignidade da pessoa humana, disciplinado no art. $1^{\circ}$, III.

Os direitos sociais estão inseridos no Título II da Carta Magna e, portanto, são também direitos fundamentais. Dessa forma, podem ser objeto de aplicação imediata e direta, nos termos do art. $5^{\circ}, \$ 1^{\circ}$ da Constituição Federal. Além disso, seu art. 23, IX atribui competência comum à Uniáo, Estados, Distrito Federal e Municípios para "promover programas de construção de moradias e a melhoria das condiçóes habitacionais e de saneamento básico”, bem como, no inciso seguinte, para "combater as causas da pobreza e os fatores de marginalização, promovendo a integração social dos setores desfavorecidos". Portanto, é dever prestacional de todos os entes federativos garantir moradias para a população de baixa renda, contribuindo para a redução das desigualdades sociais, a erradicação da pobreza (art. $3^{\circ}$, III) e a preservação da dignidade da pessoa humana, fundamentos elementares da República e marcadamente importantes para que se alcance a plenitude do Estado Democrático de Direito no país.

2 A classificação dos direitos fundamentais em geraçóes (modernamente chamadas de dimensões) é utilizada de forma didática, no entanto não existe hierarquia entre as dimensóes de direitos humanos fundamentais, todos tem o mesmo grau de importância, deve-se sempre ter em vista o caráter inter-relacional e indivisível de todos os direitos conquistados (Cançado Trindade, 1992). 
$\mathrm{Na}$ esfera infraconstitucional, a promulgação do Estatuto da Cidade (Lei Federal n. ${ }^{\circ}$ 10.257/2001) foi de grande importância na defesa dos direitos na cidade. Cabe também destacar as Leis n. ${ }^{\circ} 11.124 / 2005$ e n. ${ }^{\circ}$ 11.481/2007, que dispóem respectivamente sobre a criação do Fundo de Habitaçáo de Interesse Social (FNHIS) e sobre a utilização prioritária de terrenos de propriedade da Uniáo Federal para a implantação de projetos habitacionais de interesse social, como principal desdobramento do princípio da função socioambiental da propriedade pública.

A proteçáo do direito à moradia é tratada ainda em várias constituiçôes estaduais e em leis orgânicas municipais, como no caso do Estado e do Município do Rio de Janeiro. Na Constituição do Estado, este direito está consagrado em seu art. $8^{\circ}$, com a seguinte redação: "Todos têm o direito de viver com dignidade. Parágrafo único - É dever do Estado garantir a todos uma qualidade de vida compatível com a dignidade da pessoa humana, assegurando a educação, os serviços de saúde, a alimentação, a habitação [...]”. Também está presente em seu art. 229, que assegura o dever do estado em prover acesso à moradia adequada por meio de uma política de desenvolvimento urbano que garanta o direito à cidade. E, no art. 239, define expressamente que "incumbe ao Estado e aos Municípios promover e executar programas de construção de moradias populares e garantir condiçóes habitacionais e infraestrutura urbana, em especial as de saneamento básico, escola pública, posto de saúde e transporte".

No âmbito da Lei Orgânica Municipal do Rio de Janeiro, o direito à moradia está elencado em vários de seus artigos, como no art. 12 e no art. 30. O inciso XXIX do art. 30 dispõe ser competência do Município: "promover, com recursos próprios ou com a cooperação da União e do Estado, programas de construção de moradias, de melhoramento das condiçôes habitacionais e de saneamento básico". Ainda no art. 422, quando dá conteúdo ao direito à cidade com o direito à moradia como um de seus componentes:

A política urbana, formulada e administrada no âmbito do processo de planejamento e em consonância com as demais políticas municipais, implementará o pleno atendimento das funçóes sociais da Cidade. $\$ 1^{\circ}$ - As funçóes sociais da Cidade compreendem o direito da população a moradia, transporte público, saneamento básico, água potável, serviços de limpeza urbana, drenagem das vias de circulação, energia elétrica, gás canalizado, abastecimento, iluminação 
pública, saúde, educação, cultura, creche, lazer, contenção de encostas, segurança e preservação, proteção e recuperação do patrimônio ambiental e cultural.

É também de crucial importância o art. 429 da Lei Orgânica Municipal, pois dele emana a proteção do direito à moradia em sua dimensão negativa. Ou seja, no dever do poder público não promover a remoção de moradores que habitam áreas informais da cidade, a não ser que estejam estabelecidos em locais que imponham risco às suas vidas. Dessa forma, expressa claramente o Princípio da Não Remoção. Mesmo assim, para estas hipóteses, há a previsão de medidas/procedimentos que devem ser prévia e obrigatoriamente adotadas:

Art. 429 - A política de desenvolvimento urbano respeitará os seguintes preceitos: [...] VI - urbanização, regularização fundiária e titulação das áreas faveladas e de baixa renda, sem remoção dos moradores, salvo quando as condiçôes físicas da área ocupada imponham risco de vida aos seus habitantes, hipótese em que serão seguidas as seguintes regras: a) laudo técnico do órgão responsável; b) participação da comunidade interessada e das entidades representativas na análise e definição das soluçôes; c) assentamento em localidades próximas dos locais da moradia ou do trabalho, se necessário o remanejamento.

Ao discorrer sobre o sentido do novo paradigma jurídico-urbanístico que se exprime em todas as leis acima elencadas, Jacques Távora Alfonsin aponta que a função social da cidade e a referência constitucional ao "bem-estar" dos habitantes impedem que "os conflitos em torno da propriedade na cidade sejam considerados de forma individual, não podendo ser julgados ou solucionados apenas pelo direito civil privado" (Alfonsin, 2004, p. 65). Vale dizer que deve-se considerar toda a legislaçáo interna e internacional protetora do direito à moradia, já que seu exercício é forma de atribuição de uma função social à propriedade inserida no contexto urbano. Assim, no caso concreto, longe de uma soluçáo individual para o conflito entre o proprietário e o possuidor, os Poderes Executivo e Judiciário devem "publicizar" a questáo, atribuindo eficácia ao direito social à moradia, reconhecendo suas dimensóes positiva e negativa. 
É possível também afirmar que essas dimensōes do direito à moradia estáo inter-relacionadas, de forma que a jurisprudência do Supremo Tribunal Federal e dos diversos tribunais estaduais vêm paulatinamente afastando a tese de que os direitos sociais constitucionais se traduzem apenas em normas programáticas, determinando em diversos casos a entrega de prestaçóes materiais aos jurisdicionados. ${ }^{3} \mathrm{O}$ Poder Judiciário, como parte da estrutura do Estado brasileiro, deve estar atento aos compromissos assumidos pelo país no cenário internacional, bem como aos direitos e garantias fundamentais consolidados em nossa Constituiçấo, em especial ao dever de respeitar o direito à moradia, principalmente da população mais vulnerável.

A legislação protetiva à moradia experimentou, assim, um grande avanço, demandando soluçóes que desafiam o poder público a priorizá-la na alocaçáo de seu orçamento. O programa MCMV constitui na mais onerosa política pública de moradia social implantada no país, ainda que sujeita a críticas que estáo sintetizadas na seção a seguir.

\section{MCMV: uma breve sintese da critica ao programa}

Por se tratar de uma importante política pública, que nos governos Dilma (2011-16) e Temer (2016-18) correspondeu à grande parte dos investimentos públicos realizados na economia brasileira, o Programa Minha Casa Minha Vida (MCMV), instituído pelo governo federal a partir de 2009, vem suscitando observaçóes, análises e críticas por parte da literatura especializada desde a sua formulaçáo. Nesse contexto, uma densa produção acadêmica vem se formando sobre o assunto, sendo possível observar inúmeras abordagens que envolvem aspectos econômicos, políticos e sociais. Dentre essas diversas aproximaçóes, destacamos dois objetos analíticos que, a despeito de sua aparente distância material e conceitual, podem ser percebidos como complementares para uma análise crítica do MCMV, quais sejam, a dimensão social do direito à moradia e a dinâmica das relaçôes interfederativas na implementação da política pública.

No que diz respeito ao MCMV como uma política social, tema amplamente trabalhado pela literatura, a hipótese principal é a de que o funcio-

3 Como exemplos os julgamentos: ADPF 45/DF, Rel. Min. Celso De Mello; AI 455.802/SP, Rel. Min. Marco Aurélio; AI 475.571/SP, Rel. Min. Marco Aurélio; dentre outros. 
namento do programa se encontra mais identificado com investimentos para sustentar a dinâmica econômica do que com a dimensão da política social. Como sustentam Loureiro et al.(2013), é possível identificar no primeiro governo Lula a emergência dos fundamentos de uma política habitacional nacional com a aprovação da Lei n. ${ }^{\circ} 11.124 / 2005$, que instituiu o Sistema Nacional de Habitação de Interesse Social (SNHIS) e criou o Fundo Nacional de Habitação de Interesse Social (FNHIS), bem como seu respectivo conselho gestor. No curso dessa trajetória, desenvolvida a partir do Ministério das Cidades, sob a gestão de Olívio Dutra, foi também elaborado - após cerca de dois anos de consultas públicas - o Plano Nacional de Habitação (PlanHab), lançado em dezembro de 2009, pouco depois do PMCMV. Ainda que o PlanHab tenha sido publicado já no segundo governo Lula, a influência da burocracia, assim como da composição do Ministério das Cidades até aquele momento responderam pelas características, abordagens e conteúdo do documento.

De todo modo, tanto o cenário econômico (significativamente influenciado pela crise de 2008) quanto a reestruturação dos principais cargos de alto escalão do governo - nesse sentido, a nomeação de Dilma Rousseff para a Casa Civil e Márcio Fortes para o Ministério das Cidades - provocaram um significativo descolamento entre as propostas habitacionais até então desenvolvidas - explicitadas no PlanHab - e o que passou a ser efetivamente implementado com o lançamento do Programa Minha Casa Minha Vida. Loureiro et al. (2013) destacam que a caracterização do MCMV como mecanismo de resposta à crise econômica, estimulando o mercado da construção civil, passou a se sobrepor aos objetivos iniciais de redução do déficit habitacional para famílias de baixa renda, assemelhando-se ao que ocorrera com o programa do Banco Nacional de Habitação (BNH). Os autores complementam que, se por um lado essa mudança de orientaçáo representou uma subordinação da perspectiva social da política pública às demandas do empresariado, por outro colocou o tema na agenda prioritária do governo federal. Importante destacar que o MCMV não está incluso no SNHIS e, portanto, está desvinculado dos mecanismos de financiamento e das respectivas obrigaçóes que, em linhas gerais, incluem instrumentos de controle e participação social, bem como reforçam a necessidade de articulações interdeferativas (Balbim et al., 2015). Dessa forma, ainda que tenha se limitado a um percentual ínfimo no universo do programa, o MCMV Entidades, fruto 
de pressóes de movimentos sociais junto ao governo federal, representou um dos poucos mecanismos de controle e participação direta da sociedade em dissociação ao modelo predominante, isto é, de produção massificada de habitaçôes (vide Tatagiba et al., 2013).

Mesmo antes da eclosão de uma nova crise em 2014, que implicou em uma drástica redução dos subsídios à faixa 1 do MCMV - oriundos do orçamento da Uniáo -, a literatura especializada já vinha alertando para o descolamento mencionado anteriormente. Nesse sentido, Krause et al. (2013) afirmam que, se comparado com o PlanHab, o MCMV não possuía as mesmas preocupaçóes de estruturaçáo de uma política habitacional com planejamento participativo e controle social. Para exemplificar a afirmação, os autores contrapóem o sistema de metas do MCMV, baseado apenas no déficit habitacional, com o do PlanHab que, ao olhar para o referido indicador, os organizava a partir de uma tipologia municipal que levava em conta o tamanho da populaçáo, sua inserção metropolitana, polarização regional e níveis de pobreza. Em termos operacionais, no atendimento à faixa de renda mais baixa, o MCMV privilegiaria áreas de maior interesse e facilidade para a produção habitacional em detrimento de uma avaliação pormenorizada das diferentes realidades propondo distintas soluçóes de habitaçóes. Dessa forma, para os autores, o programa náo se apresentaria como um instrumento de mudança da trajetória do processo de urbanização brasileiro, pois estimula o assentamento dos mais pobres nas periferias, impondo-lhes os ônus relacionados à habitação em áreas mais precárias e com menos oportunidades.

Apesar de o MCMV considerar o déficit habitacional para fixação de metas e alocação de recursos entre os Estados, as avaliaçóes sobre programa colocam em xeque seus resultados. Dessa forma, tanto Balbim et al. (2015) como Neto et al. (2015) concluem pela baixa aderência (ou, desvinculaçáo parcial) entre a produção habitação do MCMV e o déficit habitacional. Moreira et al. (2015) descrevem ainda que a carência de habitaçóes sociais em meio urbano não foi atendida proporcionalmente com maior número de moradias, que a opção de concentrar a política pública na produção de novas unidades acabou por inibir outras soluçóes previstas no PlanHab, e, finalmente, uma maior recorrência nas contrataçóes de empreendimentos urbanos para famílias alocadas nas faixas 2 e 3 (i.e., com renda entre três a dez salários mínimos). Tal como destacado, explicita-se a insuficiência dos critérios empregados para justificar os subsídios de localização do empreendimento 
que, na visão dos autores deveria levar em conta outros fatores, para além da sua condiçấo metropolitana. Os trabalhos também destacam que o próprio Ministério das Cidades e o Conselho Nacional das Cidades já vinham sugerindo a necessidade de implementação de alternativas. Uma política habitacional robusta não deveria tratar o déficit como seu único objetivo, tampouco adotar uma única solução. Nesse cenário, as sugestôes incluíam tanto um fortalecimento da produçáo social de moradia (vide MCMV Entidades), como o serviço de locaçáo social - devendo este ser compreendido como um serviço público, integrante da política habitacional e não apenas uma medida de assistência social. Mais recentemente, consultorias técnicas da Câmara dos Deputados (2017), amparadas por dados da Fundação Joáo Pinheiro, reforçaram a necessidade de integrar outras medidas à construçáo de novas habitaçóes, bem como a importância de que estas estejam conjugadas com políticas urbanas (e.g., mobilidade, energia elétrica, saneamento etc.).

Em outras palavras, ao manter-se limitado ao modelo de produção massificada de moradias, o MCMV perdeu a oportunidade de se distanciar das demais políticas formuladas para combate do déficit habitacional que, desde os anos 1960, adotaram a propriedade privada como paradigma (Santos et al., 2016). Ao tratar do aluguel social como uma importante ferramenta para materialização do direito social à moradia e náo como um mecanismo temporário (até a construção de novas moradias), as autoras destacam que a concretização desse direito constitucionalmente previsto não implicaria, necessariamente, no reconhecimento de direitos individuais sobre uma determinada propriedade - inclusive e, especialmente, em áreas públicas. Dessa forma, defendem que tanto o aluguel social como a titulação via concessão de uso poderiam ser mais eficazes na proteçáo da vinculaçáo da terra para moradia do que a transferência de propriedade. Isso porque não é incomum observar processos de gentrificação decorrentes da valorização imobiliária excessiva e do encarecimento do custo de vida em áreas regularizadas pelo poder público.

No tocante à dimensão interfederativa na implementação da política pública, tema menos abordado pela literatura que vem estudando o MCMV, é possível identificar alguns posicionamentos críticos importantes, como aquele introduzido por Balbim et al. (2015). A referida pesquisa aponta para o fato de que a não inserção do programa no âmbito da política habitacional que vinha sendo construída a partir do SNHIS e, em seguida, do PlanHab, configurou 
um marco nesse assunto. Isso porque, alijado dessa estrutura normativa e institucional, o MCMV ganhou uma configuração própria, autônoma, que se destacava das propostas que vinham sendo construídas durante o primeiro governo Lula. Especificamente sobre a possibilidade de articulaçóes interfederativas, estas aparecem de forma rarefeita nos mecanismos normativos introduzidos pelo MCMV. Por exemplo, na Lei n. ${ }^{\circ} 11.977 / 09$, aparecem no âmbito da formulação de critério de prioridade para o atendimento às famílias, sem, contudo, operar qualquer mecanismo indutor sólido capaz de estimular a atuação integrada dos entes de federativos. Por outro lado, a estrutura institucional que havia sido criada pelo SNHIS previa participação de estados, distrito federal e municípios na forma de conselhos, cabendo aos governos estaduais a tarefa de articular a integração dos planos municipais habitacionais com os planos de desenvolvimento regional, coordenando açóes intermunicipais, dando apoio operacional e também na forma de subsídios. No PlanHab, dentre as várias medidas propostas havia a necessidade de que os entes federativos interessados em participar do programa colaborassem com uma contrapartida que seria calculada de modo individualizado, considerando as disparidades regionais e da desigual distribuição das receitas tributárias.

Fica evidente que o conteúdo e estrutura do SNHIS e do PlanHab se aproximam muito mais do padrão planificador que vinha sendo desenvolvido em outras políticas públicas (e.g., as diretrizes nacionais para o saneamento básico, a política nacional sobre mudança do clima, a política nacional de resíduos sólidos, a política nacional de mobilidade urbana etc.), apelidado em outra pesquisa de nova Era dos Planos (Santos e Vasques, 2016). Uma importante diferença no caso do SNHIS é que - diferentemente das demais políticas citadas, em que a relação para obtençáo de recursos se dava majoritariamente entre Uniáo e Municípios - a previsão de participação estadual na gestáo da política habitacional era mais robusta e, em certa medida, indispensável para garantir que os objetivos propostos seriam atingidos. Quando se observa o programa MCMV a partir tanto das estruturas que vinham sendo desenvolvidas no Ministério das Cidades, como em outras políticas públicas, reitera-se o mencionado distanciamento. Há uma rarefeita preocupação entre a implementação da produção massificada de habitaçóes e o cumprimento dos planos locais e regionais de desenvolvimento urbano. Ao contrário, o que parece ter havido é uma simplificação dos critérios anteriormente adotados que, em última análise, aceleraram a transferência de recursos e conduçáo das obras. 
Para além das dinâmicas mais gerais explicitadas pelas análises já destacadas, estudos enfocados em determinadas regiốes contribuem para ressaltar que a diversidade e desigualdade político-institucional experimentada pelos municípios brasileiros conferiu contornos próprios ao MCMV. Ainda que determinadas peculiaridades possam, em alguma medida, reforçar as conclusôes de avaliações mais amplas sobre a política pública, a observação desses vários comportamentos evidencia a necessidade de estudos individualizados, que náo reproduzam analiticamente a predominante perspectiva unidirecional e massificadora adotada pelo programa. Dessa maneira, apresentamos sucintas observaçóes sobre avaliações envolvendo municípios com mais de 100 mil habitantes, trabalhadas pela bibliografia.

No caso da cidade de Uberaba, um dos dez municípios mais populosos do Estado de Minas Gerais e significativamente distante da capital, o estudo de Soares et al. (2013) reforça a ideia que, mesmo sendo um município bem estruturado, detentor de robustas capacidades administrativa e institucional, os gestores locais cederam às propostas do setor privado no âmbito do MCMV, a despeito da sua legislação local. Em termos práticos, isso implicou na desconsideraçáo de seu Plano Diretor, bem como de suas Zonas Especiais de Interesse Social (ZEIS), que delimitavam as áreas vazias mais adequadas sob o ponto de vista técnico para a construção de moradias sociais. Dessa forma, em vez de aplicar a legislaçáo urbanística municipal, os autores afirmam que foi a atuação de construtoras e de proprietários de terras que determinou a localizaçáo dos empreendimentos do MCMV, dispondo as ZEIS de limitada capacidade de influência para determinaçáo das moradias de interesse social. Assim, para os autores, a opção do governo federal de realizar o programa em conjunto com a inciativa privada teria enfraquecido a autonomia municipal da condução da política habitacional.

Observaçóes similares são introduzidas por Pequeno e Rosa (2016) a respeito da implementaçáo do MCMV em Fortaleza e sua respectiva regiáo metropolitana. Isto é, para além de questóes relativas à especulação imobiliária, as avaliaçóes sustentam que o programa, ao disponibilizar larga quantidade de recursos para a construção de habitaçóes pela iniciativa privada nas mais diversas faixas de renda, colocou em xeque os instrumentos de política urbana formulados nos últimos anos. No caso dos municípios cearenses estudados, percebeu-se uma progressiva concentração da produção habitacional nas mãos de poucos atores da construção civil - afastando as pequenas e mé- 
dias empresas que vinham atuando em outros programas desenvolvidos no Estado. Diante das dificuldades relativas ao preço e disponibilidade da terra, a pesquisa indica que o MCMV teria tido mais sucesso nos municípios do entorno da capital, por exemplo, em Caucaia e Maracanaú, onde teria sido possível viabilizar lucros a curto prazo.

Por outro lado, avaliação sobre a implementação do MCMV na região metropolitana de Natal (Moura, 2014) reforça conclusóes mais gerais que defendem que o programa contribuiu para o espraiamento da malha urbana. Neste caso, a pesquisa náo só reforça a afirmaçáo anterior, mas explicita que os espaços em que foram construídos os empreendimentos da faixa 1, em regra, encontram-se completamente carentes de equipamentos e serviços urbanos, dificultando não só o acesso dessas populaçôes às áreas centrais, mas limitando significativamente suas interações comunitárias. Ou seja, a estruturação desses espaços a partir da produção habitacional guiada pela iniciativa privada teria incentivado uma dinâmica de crescimento periférico, no qual os grupos sociais mais vulneráveis do MCMV são alocados em locais desequipados e sem infraestrutura. $\mathrm{O}$ trabalho defende que as unidades habitacionais construídas não garantiriam os direitos sociais da população instalada, pelo contrário. Apesar do acesso à moradia, potencializariam problemas urbanos que perpassam desde a luta pela habitação de qualidade até o acesso amplo a serviços públicos.

A avaliação realizada sobre o MCMV na grande Florianópolis (Biguaçu, Florianópolis, Palhoça e São José) segue uma direção similar, pois também defende que o programa constituiu em fator de indução e incentivo para a periferização urbana. No caso da regiáo estudada, o MCMV teria intensificado o espraiamento dos municípios localizados na área continental, transformando algumas das franjas urbanas em periferias monofuncionais, ou seja, com um grande número de novas habitaçóes, sem, contudo, dispor de equipamentos e serviços públicos e privados. $\mathrm{O}$ texto ressalta ainda que, apesar do crescimento incentivado pelo programa, essas zonas periféricas não estão recebendo investimentos públicos proporcionais. Entretanto, ainda que o MCMV tenha priorizado interesses imobiliários, asseverando problemas urbanos já presentes em diversas cidades, os autores apontam que o programa também trouxe benefícios na medida em que as novas moradias deram mais dignidade a comunidades que se encontram em condições habitacionais precárias. 
Finalmente, ao observar a implementação do MCMV no município de São Paulo, Marques e Rodrigues (2013) - em certa medida em linha com a parte do trabalho de Rolnik et al. (2015) que trata sobre a referida cidade ${ }^{4}-$ também relativizam observações mais gerais da literatura sobre o programa. Isso porque, diferentemente de outras regiões do país, na capital paulista, houve o atendimento de uma parcela pequena da faixa $1 \mathrm{e} \mathrm{um}$ alto quantitativo relativo às faixas de maior renda ${ }^{5}$. Até a data de publicação do trabalho, os autores identificavam que a proporção de atendimento à faixa 1 foi aproximadamente $35 \%$ (contra cerca de $60 \%$ na média nacional), o que teria representado uma baixa proporção do déficit - i.e., por volta de $7 \%$. Já para a faixa 2, pouco menos da metade teria sido atendido, enquanto na 3 teria sido integralmente atingido (sendo inclusive ultrapassado). Em termos de localização dos empreendimentos, mesmo que o padrão periférico reiteradamente destacado pelos estudos anteriores também se repita em São Paulo - i.e., habitações longe das centralidades e dos grandes equipamentos de transportes -, o trabalho destaca que as habitaçôes do MCMV não se distinguem das demais moradias produzidas pelo poder público na região. Dessa forma, os empreendimentos da faixa 1 estariam instalados em regióes similares aos conjuntos produzidos pelas Companhia Metropolitana de Habitação (COHAB) e de Desenvolvimento Habitacional e Urbano do Estado de São Paulo (CDHU), sendo alguns deles inclusive construídos em reservas de terras remanescentes dos conjuntos habitacionais produzidos nas décadas anteriores (Rolnik et al., 2015). As faixas $2 \mathrm{e}$ 3 possuiriam uma maior acessibilidade e centralidade, assim, para os autores, além de os empreendimentos do MCMV em São Paulo estarem seguindo a lógica geral dos padrões da metrópole, mas sem intensificá-los - tal como sugere parte substancial da bibliografia que conduz abordagens mais amplas sobre o programa -, entende-se que se perdeu uma oportunidade de contribuir para reduzir a segregação social na região.

4 O trabalho de Rolnik et al. (2015), além de tratar da capital paulista, também aborda a implementação do MCMV no município de Campinas. Neste caso, a pesquisa identificou elevadas semelhanças entre o que se verificou na referida cidade e o que foi realizado em Sáo Paulo entre os anos 1970 e 1980, ou seja, quando imensos aglomerados de conjuntos habitacionais da CO$\mathrm{HAB}$ foram construídos fora da malha urbana, em áreas sem infraestrutura e serviços urbanos adequados.

5 Considerando que o estudo é de 2013 e que, a partir de 2014, o número de unidades na faixa 1 reduziu ainda mais, é possível que esses números tenham mudado expressivamente. 
A partir dos estudos apresentados, acredita-se que a operacionalização do MCMV no Estado do Rio de Janeiro também vem sendo caracterizada por uma série de peculiaridades que a distingue de análises mais gerais, ainda que - certamente - seja possível identificar uma pluralidade de elementos comuns. Desse modo, indo além das abordagens extremadas que ora percebem o MCMV exclusivamente como instrumento econômico, ora somente como política social, entendemos que avaliações regionais específicas tendem a explicitar melhor as nuances que permitiriam uma avaliação crítica mais precisa sobre diversos aspectos, dentre eles, envolvendo as dimensóes social e de organização federativa desenvolvidas neste trabalho. Assim, as análises apresentadas no próximo capítulo visam, primeiramente, contextualizar os municípios fluminenses - fornecendo mais elementos para compreensão da dinâmica regional - e, em seguida, iluminar criticamente a trajetória de implementação do MCMV no Rio de Janeiro, considerando as particulares condições político-econômicas experimentadas no período.

\section{PMCMV: a experiência no Estado do Rio de Janeiro}

A crítica ao programa tem sido feita de forma generalizada, mas seu desenho institucional, ao envolver os municípios como responsáveis por sua execução, deve ser avaliado de forma singular. Neste capítulo, o objetivo é enfocar nos municípios fluminenses. A primeira subseção traz uma síntese de indicadores dos municípios considerados, enquanto a segunda apresenta dados do programa nestes municípios, situando-os em perspectiva com a média dos municípios brasileiros.

\section{Perfil dos municipios fluminenses}

Nesta seção elaboramos um breve perfil dos municípios fluminenses com população superior a 100 mil habitantes, que são aqueles onde um programa de acesso à moradia é mais impactante. Tratam-se de municípios que vêm experimentando maior dinamismo demográfico e, por isso, justifica-se a metodologia que usa o corte de 100 mil habitantes para a análise do impacto do MCMV.

O Estado do Rio de Janeiro conta com 92 municípios, mas sua população e sua atividade econômica está fortemente concentrada em sua região 
metropolitana, destacando-se a capital. Quando fazemos um corte de 100 mil habitantes, verificamos que existem 25 municípios, além da capital, dos quais 14 estão situados na Região Metropolitana e 11 localizados nas demais regiōes. A tabela 1 apresenta dados para a elaboração de um breve perfil socioeconômico destes municípios.

Tabela 1 - Perfil socioeconômico dos municípios fluminenses com população superior a 100 mil habitantes distribuídos entre capital, metropolitanos e não-metropolitanos

\begin{tabular}{|c|c|c|c|c|c|}
\hline Município & $\begin{array}{c}\text { População } \\
2010\end{array}$ & $\begin{array}{c}\text { PIB per } \\
\text { capita } \\
2016 \\
(\mathrm{R} \$)\end{array}$ & $\begin{array}{l}\text { Salário médio } \\
\text { mensal dos } \\
\text { trabalhadores } \\
\text { formais } 2016 \\
(\mathrm{em} \mathrm{SM})\end{array}$ & $\begin{array}{c}\% \text { da popu- } \\
\text { laçáo com } \\
\text { menos de } 1 / 2 \\
\text { SM per capita }\end{array}$ & $\begin{array}{c}\text { Taxa de } \\
\text { crescimento } \\
\text { demográfico } \\
2010 / 2000 \\
(\%)\end{array}$ \\
\hline \multicolumn{6}{|l|}{ Capital } \\
\hline Rio de Janeiro & 6.320 .446 & $50.690,82$ & 4,1 & 31,4 & 0,77 \\
\hline \multicolumn{6}{|l|}{ CMMetrop. } \\
\hline Belford Roxo & 469.261 & $16.764,54$ & 2,3 & 39,3 & 0,77 \\
\hline $\begin{array}{l}\text { Duque de } \\
\text { Caxias }\end{array}$ & 855.048 & $44.939,65$ & 2,7 & 37,8 & 0,98 \\
\hline Itaboraí & 218.008 & $18.864,13$ & 2,2 & 37,7 & 1,52 \\
\hline Itaguaí & 109.091 & $65.107,78$ & 3,3 & 37,1 & 2,90 \\
\hline Magé & 227.322 & $15.607,47$ & 1,8 & 38,2 & 1,03 \\
\hline Maricá & 127.461 & $39.078,14$ & 2,0 & 33,8 & 5,21 \\
\hline Mesquita & 168.376 & $13.396,88$ & 2,1 & 36,5 & 0,14 \\
\hline Nilópolis & 157.425 & $16.045,55$ & 1,8 & 33,8 & 0,24 \\
\hline Niterói & 487.562 & $46.202,31$ & 3,0 & 29,5 & 0,59 \\
\hline Nova Iguaçu & 796.257 & $20.625,93$ & 2,0 & 38,7 & $-1,45\left(^{*}\right)$ \\
\hline Petrópolis & 295.917 & $42.564,57$ & 2,4 & 30,6 & 0,33 \\
\hline Queimados & 137.962 & $32.314,25$ & 2,3 & 39,1 & 1,24 \\
\hline Sáo Gonçalo & 999.728 & $16.216,45$ & 2,1 & 34,5 & 1,16 \\
\hline $\begin{array}{l}\text { São João de } \\
\text { Meriti }\end{array}$ & 458.673 & $20.434,26$ & 1,9 & 35,4 & 0,22 \\
\hline C Não-Met & & & & & \\
\hline
\end{tabular}




\begin{tabular}{l|c|c|c|c|c}
\hline $\begin{array}{l}\text { Angra dos } \\
\text { Reis }\end{array}$ & 169.511 & $47.636,40$ & 3,5 & 34,9 & 3,57 \\
\hline Araruama & 112.008 & $19.748,08$ & 1,7 & 36,1 & 1,44 \\
\hline Barra Mansa & 177.813 & $26.346,46$ & 2,2 & 34,5 & 0,41 \\
\hline Cabo Frio & 186.227 & $33.969,57$ & 1,8 & 34,5 & 3,92 \\
\hline Campos & 463.731 & $35.475,94$ & 2,5 & 37,7 & 1,31 \\
\hline Macaé & 206.728 & $73.412,55$ & 6,6 & 31,5 & 4,55 \\
\hline Nova Friburgo & 182.082 & $25.979,30$ & 1,8 & 25,8 & 0,49 \\
\hline Resende & 119.769 & $50.234,49$ & 3,0 & 32,4 & 1,37 \\
\hline Rio das & 105.676 & 35.788 & 3,6 & 32,5 & 11,25 \\
Ostras & 163.746 & $29.997,09$ & 2,1 & 32,3 & 1,72 \\
\hline Teresópolis & 257.803 & $39.679,43$ & 2,4 & 32,7 & 0,64 \\
\hline Volta Redonda & & & & \\
\hline
\end{tabular}

Fonte: Cidades: IBGE, 2017

${ }^{*}$ ) (Nova Iguaçu sofreu desmembramento com a emancipação de três distritos à condição de municípios, sem o ajuste territorial para comparar os dois anos censitários, o resultado é de aparente perda de população.)

A Região Metropolitana do Rio de Janeiro (RMRJ) é a segunda maior aglomeração urbana brasileira em termos demográficos e econômicos, perdendo apenas para São Paulo. Constituída por 21 municípios, forma um território contínuo nucleado pela capital estadual, o Município do Rio de Janeiro. A RMRJ participa com $74 \%$ da população estadual (de 16,72 milhóes de habitantes) e seu peso no PIB estadual (de R \$ 659,136 bilhóes) é de $71,6 \%$. O Município do Rio de Janeiro tem $51 \%$ da população da RMRJ e 68\% do PIB da metrópole fluminense, todos dados relativos a 2015 (CEPERJ, 2017).

Na Região Metropolitana, os municípios de Niterói e a capital estadual apresentam indicadores socioeconômicos melhores do que os demais, sendo que sua população cresce abaixo da média dos municípios selecionados. Estes dois formam um subgrupo da RMRJ que poderia ser denominado "duas capitais", uma vez que Niterói foi a capital do antigo Estado do Rio de Janeiro até a fusão com a Guanabara, em 1975, quando a Cidade-Estado da Guanabara tornar-se-ia a nova capital do novo Estado do Rio de Janeiro. Pela condiçáo de capitais estaduais, ambas se beneficiaram de investimentos em infraestrutura produtiva e social, refletindo-se nas melhores condiçóes de vida de sua população frente aos demais municípios da RMRJ. 
Outros municípios poderiam ser incluídos num patamar acima da média da RMRJ, ainda que abaixo daquele das "duas capitais". Em termos de PIB per capita, destacam-se Maricá, Itaguaí, Duque de Caxias e Queimados, mas apenas em Itaguaí e Duque de Caxias, o salário médio mensal dos trabalhadores formais foi superior à média regional. Em ambos os casos, são municípios que se beneficiam pela presença de indústria e logística, não obstante o percentual de sua população com menos de $1 / 2$ salários mínimos per capita tenha sido superior a $37 \%$.

Nos demais municípios da RMRJ, prevalece um pior quadro socioeconômico, predominando baixos PIB per capita, bem como baixo nível salarial e forte incidência de pobreza, dentre os quais destacam-se, por seu pior desempenho, os municípios de Japeri, Queimados, Nova Iguaçu e Tanguá.

Este quadro mostra uma forte heterogeneidade vigente entre os municípios da região metropolitana, mas é também a situação entre os demais municípios com mais de 100 mil habitantes.

A população agregada desses 11 municípios, de 2,1 milhóes de habitantes, não atinge nem a metade da população dos 14 municípios da RMRJ, que é de 5,5 milhóes. Em ambos os grupos, o crescimento demográfico foi mais intenso nas cidades afetadas pela economia do petróleo. Esta é a atividade a responsável pelo grande destaque de Macaé em termos de PIB e salário médio dos seus trabalhadores.

Angra dos Reis, Resende e Volta Redonda também se destacaram por seu PIB elevado, mas esses dois últimos são municípios não dependentes do petróleo, mas sim de atividades industriais, experimentando estabilidade em sua população. Nestas localidades, as condiçôes de vida são também mais estáveis e o acesso à moradia traz menos desafios à política habitacional.

Rio das Ostras se destacou pelo forte crescimento demográfico, tendo sido o município campeáo brasileiro de crescimento populacional na primeira década do século XXI em razão de sua localização próxima à Macaé. O grande dinamismo da economia do petróleo em Macaé atraiu um grande fluxo migratório, parte do qual fixou-se em Rio das Ostras (Santos, 2010). A forte pressão demográfica gerou um impacto negativo em face do aumento do custo da terra conjugado à maior vulnerabilidade da populaçáo migrante que se fixou no município. 
A Tabela 2, a seguir, apresenta a evolução do número de unidades habitacionais contratadas ao longo do período 2009-18 (até outubro) nos municípios fluminenses com mais de 100 mil habitantes.

Tabela 2 - Unidades habitacionais contratadas por ano nos municípios fluminenses com população superior a 100 mil habitantes distribuídos entre capital, metropolitanos e não-metropolitanos

\begin{tabular}{|c|c|c|c|c|c|c|c|c|c|c|}
\hline & 2009 & 2010 & 2011 & 2012 & 2013 & 2014 & 2015 & 2016 & 2017 & 2018 \\
\hline \multicolumn{11}{|l|}{ Capital } \\
\hline $\begin{array}{l}\text { Rio de } \\
\text { Janeiro }\end{array}$ & 12837 & 19820 & 13710 & 13257 & 10255 & 7945 & 4485 & 3964 & 12425 & 6470 \\
\hline $\begin{array}{l}\text { CMMe- } \\
\text { trop }\end{array}$ & 6363 & 8434 & 16326 & 17925 & 30370 & 10536 & 5864 & 5156 & 8597 & 8687 \\
\hline $\begin{array}{l}\text { Belford } \\
\text { Roxo }\end{array}$ & 1455 & 664 & 4264 & 2295 & 3226 & 330 & 451 & 299 & 547 & 1036 \\
\hline $\begin{array}{l}\text { Duque de } \\
\text { Caxias }\end{array}$ & 1189 & 876 & 2707 & 1635 & 3263 & 1136 & 454 & 77 & 94 & 250 \\
\hline Itaboraí & 66 & 403 & 882 & 274 & 6406 & 187 & 513 & 723 & 823 & 1572 \\
\hline Itaguaí & 6 & 60 & 51 & 1148 & 422 & 59 & 62 & 50 & 58 & 500 \\
\hline Magé & 3 & 26 & 2035 & 863 & 125 & 138 & 145 & 114 & 69 & 58 \\
\hline Maricá & 143 & 816 & 791 & 2693 & 1350 & 129 & 179 & 259 & 246 & 324 \\
\hline Mesquita & 51 & 87 & 43 & 199 & 14 & 14 & 47 & 55 & 319 & 609 \\
\hline Nilópolis & 226 & 50 & 88 & 245 & 105 & 41 & 53 & 46 & 16 & 26 \\
\hline Niterói & 9 & 708 & 616 & 192 & 1671 & 1516 & 8 & 9 & 18 & 2 \\
\hline $\begin{array}{l}\text { Nova } \\
\text { Iguaçu }\end{array}$ & 440 & 2177 & 485 & 3626 & 8759 & 2821 & 1445 & 844 & 1968 & 948 \\
\hline Petrópolis & 0 & 1 & 1 & 58 & 962 & 1 & 288 & 505 & 303 & 227 \\
\hline $\begin{array}{l}\text { Queima- } \\
\text { dos }\end{array}$ & 1737 & 450 & 88 & 1817 & 1099 & 1258 & 117 & 346 & 335 & 75 \\
\hline $\begin{array}{l}\text { São Gon- } \\
\text { çalo }\end{array}$ & 1030 & 1297 & 4260 & 1897 & 2923 & 2860 & 2088 & 1801 & 3788 & 3021 \\
\hline $\begin{array}{l}\text { São João } \\
\text { de Meriti }\end{array}$ & 8 & 819 & 15 & 983 & 45 & 46 & 14 & 28 & 13 & 39 \\
\hline $\begin{array}{l}\text { C Não- } \\
\text {-Met } \\
\end{array}$ & 972 & 2547 & 4005 & 8979 & 9050 & 3702 & 1159 & 1729 & 6613 & 3249 \\
\hline $\begin{array}{l}\text { Angra dos } \\
\text { Reis }\end{array}$ & 0 & 0 & 6 & 1 & 1265 & 240 & 0 & 1 & 3 & 8 \\
\hline Araruama & 2 & 70 & 68 & 560 & 66 & 50 & 35 & 36 & 57 & 61 \\
\hline
\end{tabular}




\begin{tabular}{|c|c|c|c|c|c|c|c|c|c|c|}
\hline $\begin{array}{l}\text { Barra } \\
\text { Mansa }\end{array}$ & 66 & 163 & 14 & 313 & 132 & 145 & 26 & 170 & 216 & 710 \\
\hline Cabo Frio & 0 & 9 & 27 & 31 & 37 & 1827 & 0 & 4 & 7 & 173 \\
\hline $\begin{array}{l}\text { Campos } \\
\text { dos Goyta- } \\
\text { cazes }\end{array}$ & 750 & 581 & 848 & 2121 & 2460 & 455 & 499 & 962 & 3955 & 1019 \\
\hline Macaé & 3 & 409 & 2150 & 2586 & 1241 & 308 & 0 & 98 & 729 & 283 \\
\hline $\begin{array}{l}\text { Nova } \\
\text { Friburgo }\end{array}$ & 73 & 253 & 236 & 1023 & 1448 & 68 & 57 & 44 & 62 & 58 \\
\hline Resende & 63 & 222 & 287 & 1647 & 311 & 80 & 128 & 88 & 857 & 278 \\
\hline $\begin{array}{l}\text { Rio das } \\
\text { Ostras }\end{array}$ & 7 & 466 & 65 & 443 & 109 & 521 & 17 & 76 & 210 & 191 \\
\hline $\begin{array}{l}\text { Teresó- } \\
\text { polis }\end{array}$ & 8 & 374 & 304 & 254 & 1981 & 8 & 397 & 250 & 517 & 468 \\
\hline
\end{tabular}

Fonte: Elaboração própria a partir dos dados obtidos junto ao Ministério das Cidades

Como indicado pela Tabela 2, o ano de 2013 foi o auge de unidades contratadas, principalmente entre as cidades da regiáo metropolitana. Nos dois primeiros anos, a capital contratou o maior número de unidades, mas a partir de 2011 foram as cidades metropolitanas. Entre elas, destacam-se as mais populosas (Duque de Caxias, Nova Iguaçu e São Gonçalo), aquelas onde a incidência de pobreza é elevada. Cabe, ainda, destacar Itaboraí, que em 2013 contratou 6,4 mil unidades. Este resultado deve estar associado ao grande investimento no Complexo Petroquímico do Rio de Janeiro, o COMPERJ, paralisado em seguida devido à crise atravessada pela Petrobrás, responsável pelas obras.

Chama a atenção para o fraco desempenho relativo das cidades não metropolitanas. Entre elas, o município com mais contrataçóes foi Campos dos Goytacazes, cuja população cresce num ritmo fraco em comparação à média deste grupo de cidades. Macaé e Rio das Ostras, com muito maior dinamismo demográfico, apresentaram um desempenho inferior, ainda que melhor do que as demais cidades.

$\mathrm{Na}$ tabela 3, as unidades habitacionais contratadas estão divididas entre as faixas de renda do programa MCMV, o que permite avaliar o desempenho da faixa 1, aquela destinada aos adquirentes com rendimento inferior a 3 salários mínimos. 
Tabela 3 - Unidades habitacionais contratadas por faixa nos municípios fluminenses com população superior a 100 mil habitantes distribuídos entre capital, metropolitanos e não-metropolitanos

\begin{tabular}{|c|c|c|c|c|}
\hline & Faixa 1 & Faixa 1,5 & Faixa 2 & Faixa 3 \\
\hline \multicolumn{5}{|l|}{ Capital } \\
\hline Rio de Janeiro & 35454 & 6777 & 32883 & 30054 \\
\hline CMMetrop & 58939 & 8992 & 33163 & 16434 \\
\hline Belford Roxo & 8881 & 720 & 3817 & 1149 \\
\hline Duque de Caxias & 7372 & 0 & 1934 & 2375 \\
\hline Itaboraí & 3000 & 4272 & 3488 & 1089 \\
\hline Itaguaí & 1011 & 448 & 669 & 288 \\
\hline Magé & 2420 & 0 & 740 & 416 \\
\hline Maricá & 2932 & 0 & 2797 & 1201 \\
\hline Mesquita & 0 & 380 & 702 & 356 \\
\hline Nilópolis & 0 & 0 & 361 & 535 \\
\hline Niterói & 3007 & 0 & 750 & 992 \\
\hline Nova Iguaçu & 12740 & 424 & 7550 & 2799 \\
\hline Petrópolis & 846 & 0 & 816 & 684 \\
\hline Queimados & 6112 & 240 & 798 & 172 \\
\hline São Gonçalo & 8850 & 2508 & 9288 & 4319 \\
\hline $\begin{array}{l}\text { São João de } \\
\text { Meriti }\end{array}$ & 1768 & 0 & 183 & 59 \\
\hline C Não-Met & 14278 & 2910 & 20384 & 4433 \\
\hline Angra dos Reis & 1500 & 0 & 16 & 8 \\
\hline Araruama & 480 & 0 & 403 & 122 \\
\hline Barra Mansa & 680 & 128 & 990 & 157 \\
\hline Cabo Frio & 1800 & 80 & 208 & 27 \\
\hline $\begin{array}{l}\text { Campos dos } \\
\text { Goytacazes } \\
\end{array}$ & 2268 & 2176 & 7106 & 2100 \\
\hline Macaé & 2338 & 434 & 4731 & 304 \\
\hline Nova Friburgo & 2276 & 0 & 831 & 215 \\
\hline Resende & 856 & 0 & 2849 & 256 \\
\hline
\end{tabular}




\begin{tabular}{l|c|c|c|c}
\hline Rio das Ostras & 480 & 0 & 1310 & 315 \\
\hline Teresópolis & 1600 & 92 & 1940 & 929 \\
\hline
\end{tabular}

Fonte: Elaboração própria a partir dos dados obtidos junto ao Ministério das Cidades

$\mathrm{Na}$ capital estadual há equilíbrio entre as unidades contratadas das faixas 1, 2 e 3, mas entre as cidades metropolitanas a faixa 1 prevalece, o que está em linha com o perfil mais vulnerável da população que habita esses municípios, destacando-se, também aqui, os municípios mais populosos. Entre as cidades náo metropolitanas, contudo, a faixa 2 foi a mais frequente, destacando-se os municípios de Campos dos Goytacazes e Macaé. Esses dois municípios também se destacaram, junto com Resende, no número de unidades contratadas na faixa 1, sendo que Macaé e Resende apresentam um percentual de pobres menor do que na média deste grupo de cidades.

Cabe avaliar, na próxima seção, se esse desempenho entre os três grupos de cidades compara-se com a média brasileira dos mesmos grupos de cidades.

\section{Analisando o MCMV com enfoque no Rio de Janeiro}

Ainda que a pesquisa tenha sido conduzida a partir do estudo de diversos parâmetros e indicadores, para fins do presente artigo foram selecionados apenas os dados que mais diretamente contribuem para o desenvolvimento dos objetivos propostos (entre 2009 e outubro de 2018). Sáo apresentados a seguir seis gráficos que, em ordem, caminham de uma avaliação geral, a partir dos Estados mais representativos em quantidade de unidades habitacionais contratadas e recursos previstos, passando pela análise das capitais e dos municípios com mais de 100 mil habitantes - localizados dentro e fora das regióes metropolitanas brasileiras -, até chegar na performance do programa a nível municipal, neste caso, na cidade do Rio de Janeiro. Sempre que possível, houve o cuidado de destacar os dados referentes aos territórios fluminense e carioca quando esta opção favorecesse a interpretação das informaçôes reunidas. A via analítica adotada reitera determinados pontos destacados pelas análises produzidas pela literatura. Isto é, por um lado, uma elevada limitação dos efeitos do programa sobre o déficit habitacional e, por outro, uma pluralidade de dinâmicas locais que caracterizam a implementação do MCMV, haja vista a elevada diversidade e desigualdade dos municípios brasileiros. 
Gráfico 1 - Número de unidades habitacionais contratadas por ano nos 10 Estados mais representativos

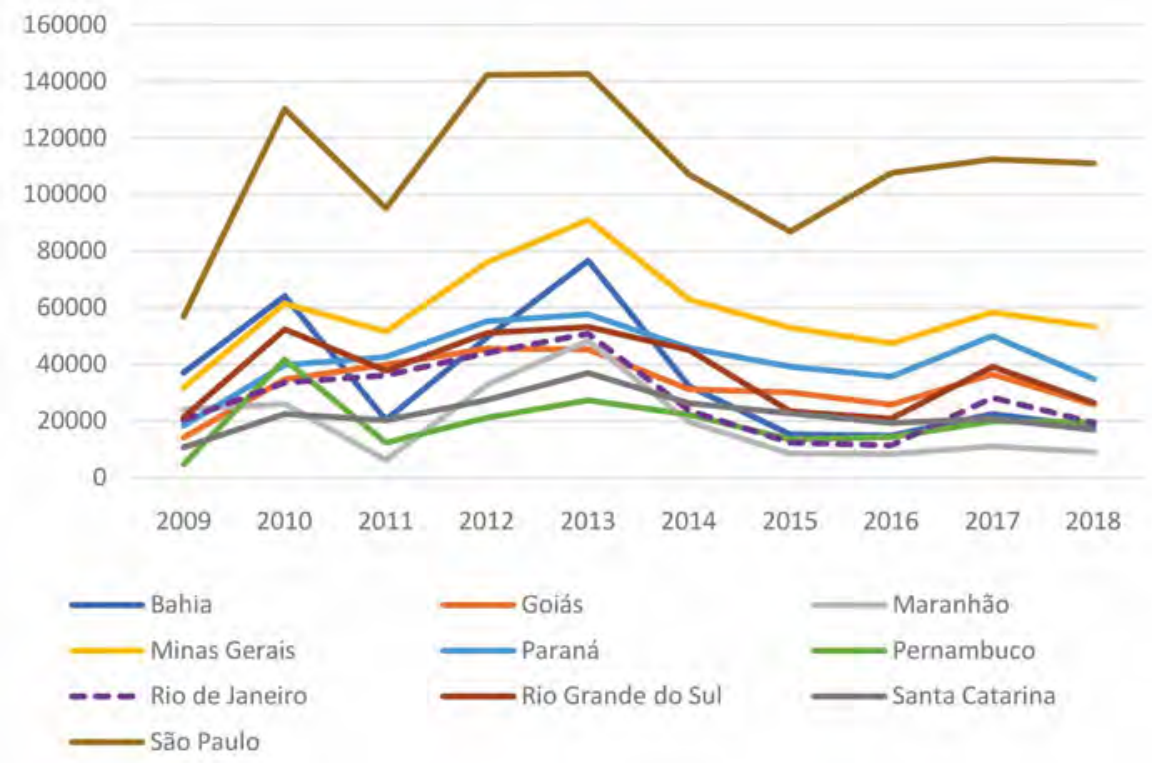

Fonte: Elaboração própria a partir dos dados obtidos junto ao Ministério das Cidades

No caso do Gráfico 1, foram destacados os dez Estados com maior participação no MCMV considerando o número de unidades habitacionais previstas para seus territórios por ano de implementação do programa. São Paulo é, de longe, o Estado que apresentou o maior número de unidades contratadas, seguido por Minas Gerais e Paraná. O Rio de Janeiro ocupa apenas a sétima posição. Interessante notar que os números identificados na série temporal (2007-15) sobre déficit habitacional produzida pela Fundação João Pinheiro ${ }^{6}$ colocam diversos outros Estados na frente do Paraná em termos de precariedade habitacional, restando compreender os fundamentos que justificaram tal previsão de recursos. Ademais, nota-se em 2011 uma queda da projeçáo de unidades em quase todos os estados exceto no Rio de Janeiro, priorizado pelo governo federal sob o argumento da necessidade de apoio para o cumprimento dos compromissos internacionais assumidos. Importante ressaltar que, mesmo estando contido no Programa de Aceleração

${ }^{6}$ Disponível em: http://fjp.mg.gov.br/index.php/produtos-e-servicos1/2742-deficit-habitacional-no-brasil-3. Último acesso em 12 fev. 2019 
do Crescimento, o MCMV passou a ser computado pelo Tesouro Nacional como investimento apenas a partir de 2012 - antes calculado como despesa de custeio.

A despeito do crescimento e estabilidade entre 2012 e 2013, para a maior parte dos Estados, os três anos seguintes apresentaram fortes quedas. Estas, por sua vez, estão associadas em larga medida à crise político-financeira que se torna aguda a partir de 2014 . No que diz respeito ao programa, esse cenário representou uma expressiva redução - chegando a zero em alguns momentos - dos subsídios oriundos do orçamento da União, ainda que mantidos os recursos advindos do FGTS. Em outras palavras, apesar da manutenção do MCMV, nesse período verifica-se uma queda significativa na previsão e construção de habitaçóes de interesse social (faixa 1). A recuperação observada em 2017, contudo, é seguida por uma oscilação aparentemente negativa para a maioria dos estados no ano seguinte (cujos dados analisados vão apenas até outubro de 2018), explicitando as incertezas associadas tanto ao cenário político quanto aos rumos da economia nacional, em especial, ante o início de um novo governo gestado sob um clima de elevada polarização. Sobre o Rio de Janeiro, a abordagem geral privilegiada pelo Gráfico 1 indica que a dinâmica de implementação do programa se aproxima do que foi verificado em grande parte dos demais Estados - exceto por 2011, como já destacado.

Gráfico 2 - Valor total (em milhóes de $\mathrm{R} \$$ ) por ano nos dez Estados mais representativos

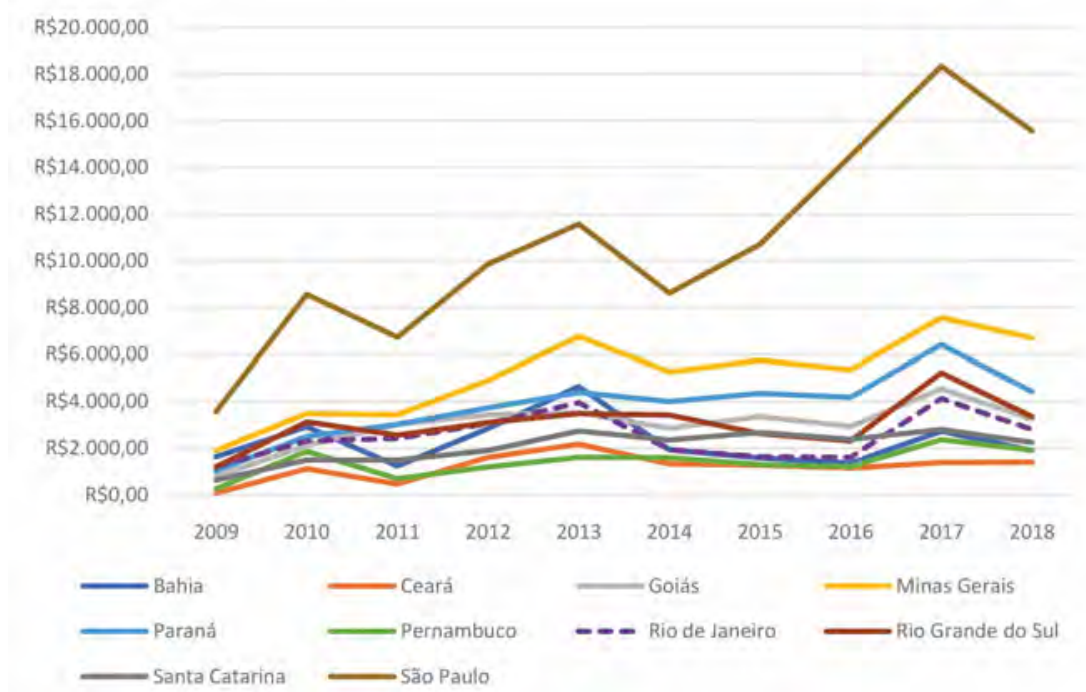

Fonte: Elaboração própria a partir dos dados obtidos junto ao Ministério das Cidades 
Complementando a análise anterior, o Gráfico 2 também lista os dez Estados mais representativos, mas, desta vez, apresenta as informações relativas aos valores totais previstos para cada uma das unidades da federaçáo destacadas por ano. Neste caso, São Paulo destaca-se ainda mais, porém continua seguido pelos mesmos estados de Minas Gerais e Paraná. O Rio de Janeiro vem em sexto lugar, sendo os valores contratados em 2009 e 2018 (até outubro) equivalentes a $\mathrm{R} \$ 1,2$ bilhóes e $\mathrm{R} \$ 2,8$ bilhóes, respectivamente, em termos nominais. Em São Paulo os montantes foram, respectivamente, de $\mathrm{R}$ \$ 3,6 bilhões e $\mathrm{R}$ \$ 15,6 bilhôes, também em valores nominais. Adicionalmente, é possível verificar também no Gráfico 2 as instabilidades experimentadas tanto em 2011 como em 2014, momento marcado por uma redução expressiva dos subsídios provenientes da União e que explicita, por contraste, os limites da participação estatal direta na disponibilização de recursos para construção de moradias. Neste último caso, o recuo dos valores totais observado é menos acentuado do que em relação à queda na produção habitacional, tal como descrito no Gráfico 1. Finalmente, o crescimento dos valores em 2017, seguido por um aparente declínio no ano seguinte, limita afirmaçóes no sentido de uma retomada sólida do MCMV, em especial, em virtude das incertezas postas pela nova administração federal.

Ao restringir a análise apenas à média de unidades habitacionais contratadas por ano e por faixa nas capitais brasileiras - com destaque para a cidade do Rio de Janeiro -, o Gráfico 3 apresenta uma dinâmica muito diferente do panorama geral evidenciado pelos dados anteriores e ainda mais complexo sob o ponto de vista de implementação da política pública. No caso da faixa 1, o movimento observado entre 2009 e 2012 para a média das capitais e para o Rio de Janeiro é praticamente oposto. Ou seja, enquanto a produção de habitaçóes de interesse social tem seu auge no território carioca em 2009, declinando nos anos seguintes, nas demais cidades destacadas há um suave crescimento que se acentua apenas em 2013, a partir de quando há uma aproximaçáo de ambas as dinâmicas. Elas voltam a se destacar apenas a partir de 2016, novamente produzindo movimentos opostos. Os dados referentes à faixa 1 náo só reforçam o fato de que a retirada dos subsídios do orçamento da União enfraqueceu significativamente a dimensão social do MCMV, mas também reafirmam a hipótese de que, na cidade do Rio de Janeiro, a implementação dessa parte do programa esteve atrelada às remoçóes realizadas e discursivamente justificadas como necessárias para 
o cumprimento dos compromissos internacionais assumidos para realização dos megaeventos na cidade.

Gráfico 3 - Média do número de unidades habitacionais contratadas nas capitais brasileiras e no Município do Rio de Janeiro por ano e por faixa de renda

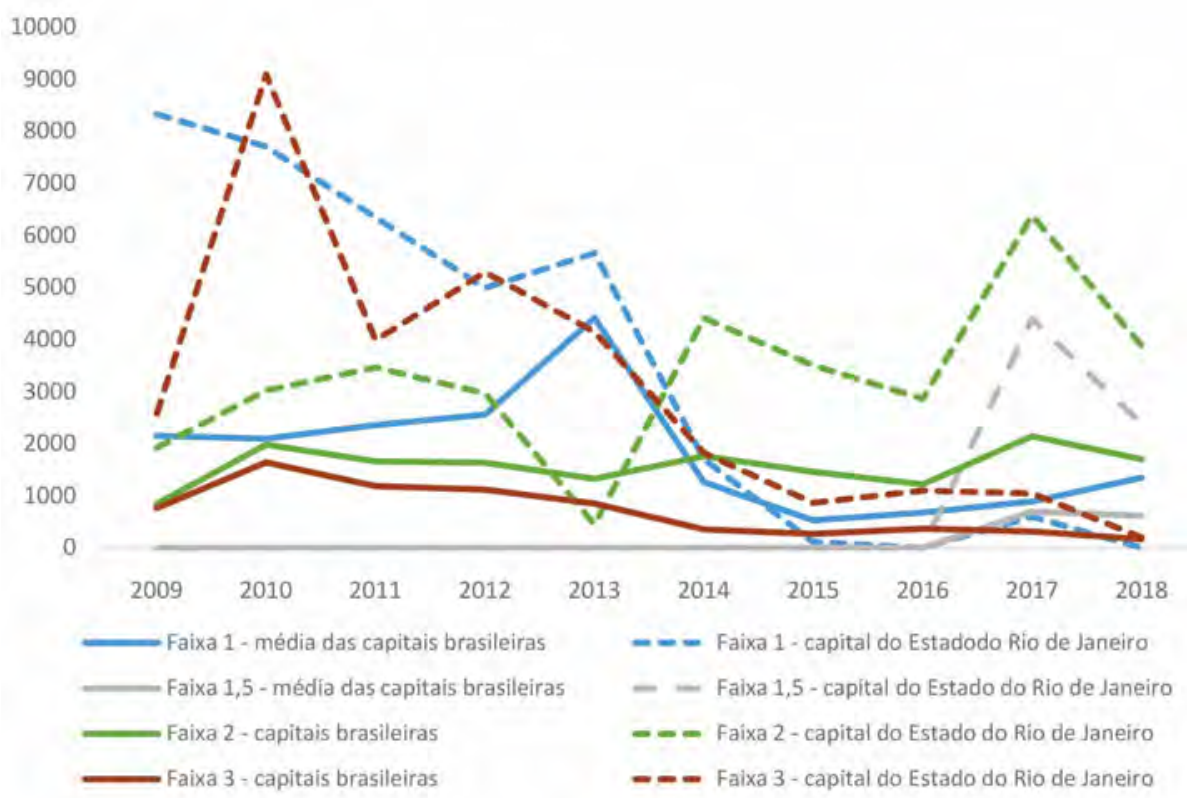

Fonte: Elaboração própria a partir dos dados obtidos junto ao Ministério das Cidades

Ainda sobre o Gráfico 3, os dados para a faixa 2 indicam que, de modo geral, os resultados para a capital fluminense estão bem acima da média observada nas demais capitais (exceto em 2013), apresentando amplas variaçóes no período estudado. Importante ressaltar que, em grande parte da sua trajetória, o movimento verificado para a faixa 2 no Rio de Janeiro se opóe àquele observado para as moradias de interesse social, necessitando uma avaliação mais detalhada para compreensão dessa dinâmica. No caso da faixa 1,5 - implementada a partir de 2016 -, seu montante no Rio de Janeiro é igualmente muito superior à média das capitais nacionais, seguindo um fluxo similar ao identificado para a faixa 2. Por último, no que tange à faixa 3, é interessante observar que, ainda que a capital fluminense também se destaque pelo alto volume de unidades habitacionais contratadas em relação à média as demais capitais - com ênfase para o ano de 2010, que chega a ultrapassar inclusive 
as contratações na faixa 1 -, seu movimento se assemelha em larga medida àquele verificado nas capitais brasileiras. Isto é, o declínio em 2011 e a aparente recuperação em 2012 são sucedidos por sequências de quedas que se interrompem em 2016 e 2017 e retomam no ano seguinte.

Gráfico 4 - Média do número de unidades habitacionais contratadas nas cidades metropolitanas brasileiras e fluminenses com mais de 100 mil habitantes por ano e faixa de renda

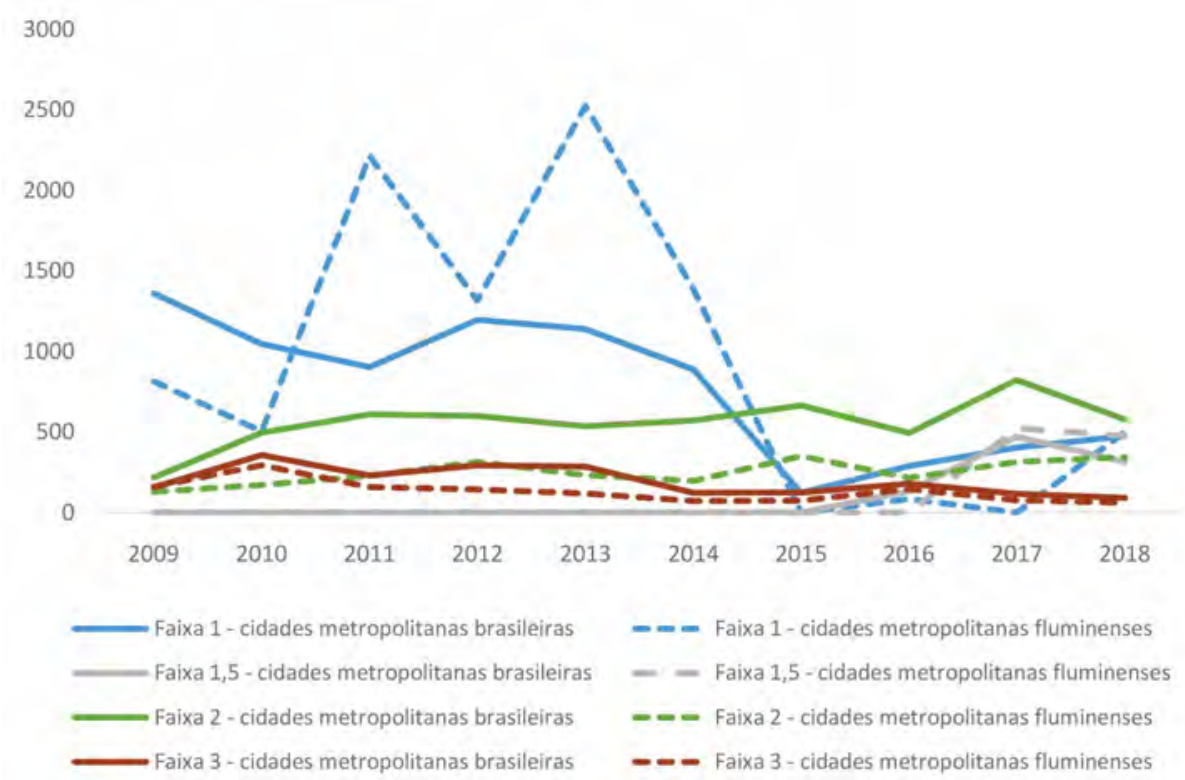

Fonte: Elaboração própria a partir dos dados obtidos junto ao Ministério das Cidades

Para o Gráfico 4, calculou-se a média do número de unidades habitacionais contratadas nas cidades metropolitanas brasileiras e fluminenses (listadas na Tabela 1 da seção anterior) com mais de 100 mil habitantes (a partir dos dados do Censo IBGE de 2010) por ano e faixa. Novamente, observa-se uma dinâmica diferenciada tanto em relação aos dois primeiros gráficos, mais gerais, como se comparado com o anterior, que tratou apenas das capitais. Analisando a média de contratação da faixa 1 para as cidades metropolitanas, nota-se certa semelhança com o Gráfico 1, na medida em que também há um declínio em 2011, e, ao menos até 2014, certo distanciamento em relação ao Gráfico 3. O auge dessa faixa se dá no início do programa (2009) e não em 
2013, apesar dos bons números naquele ano. Quando se observa especificamente a faixa 1 apenas para os municípios metropolitanos fluminenses, seu movimento acompanha tanto o pico em 2013 quanto o declínio a partir de 2014, entretanto seus resultados em 2011 se opóem aquilo que vinha sendo registrado nas demais análises. Estima-se que tais resultados positivos e acima da média nacional, entre 2010 e 2014, estejam relacionados em larga medida ao aumento do preço da terra na cidade do Rio de Janeiro, que experimentava significativo influxo de recursos privados no setor imobiliário. Ainda que não tenha sido decisiva para o resultado observado, é possível sustentar que a regulação municipal que restringiu as áreas possíveis para construção de habitaçóes beneficiadas pelos subsídios do MCMV na Zona Oeste da capital aos espaços que já possuíam infraestrutura urbana também teria contribuído para esse movimento. Tal observação encontraria particular relevância para os municípios fluminenses localizados a oeste e norte da capital, deixando o leste metropolitano - i.e., aqueles localizados do outro lado da Baía de Guanabara - a uma dinâmica distinta.

No caso da faixa 2, a média nacional experimenta alguma estabilidade - em semelhança ao movimento observado para as capitais brasileiras - destacando-se pela ocorrência de aumentos (em 2011 e 2015) com um ano de atraso em relação às capitais que, nos referidos anos, já decaíam. Na situação fluminense, há também uma dinâmica de relativa estabilidade que se assemelha a média nacional. No entanto, pela primeira vez sua média é inferior àquela verificada nos demais municípios brasileiros - em larga medida, é também o mesmo resultado percebido para a faixa 3. Mesmo no caso da faixa 1,5, que se destaca levemente entre 2017 e 2018, ainda há uma expressiva aproximação com a média nacional. Esses resultados, em especial os das faixas 2 e 3, sugerem que - a despeito da elevada demanda habitacional - houve baixo interesse do setor imobiliário privado de investir em habitaçóes no modelo proposto pelo MCMV fora da capital do Rio de Janeiro e sem subsídios diretos do governo federal.

A média do número de unidades habitacionais contratadas nas cidades não metropolitanas brasileiras e fluminenses com mais de 100 mil habitantes (IBGE, 2010) por ano e faixa e renda é trabalhada no Gráfico 5. Nesta etapa da análise é possível perceber, uma vez mais, que, exceto por momentos específicos nas faixas 1, em 2013, e 1,5, em 2017 - seguido por expressivo declínio em 2018 -, as cidades distantes do centro metropolitano no Estado do Rio 
de Janeiro encontram-se abaixo da média nacional, reforçando o desinteresse da iniciativa privada em investir nesses territórios. Analisando apenas a faixa 1 , há poucas divergências dos dados fluminenses em relação ao movimento nacional - ainda que se encontre abaixo da média -, demonstrando um evidente descolamento em relação ao que vinha ocorrendo na capital e na região metropolitana. No caso da faixa 2, os resultados observados no Estado do Rio de Janeiro acompanham em certa medida a dinâmica nacional, menos entre 2014 e 2016, momento no qual há um evidente recuo dos investimentos imobiliários, ampliando a distância em relação à média brasileira. Por fim, a faixa 3 no território fluminense apresenta trajetória similar à nacional, com pequenas divergências (e.g., 2010 e 2016).

Gráfico 5 - Média do número de unidades habitacionais contratadas nas cidades não metropolitanas brasileiras e fluminenses com mais de $100 \mathrm{mil}$ habitantes por ano e faixa de renda

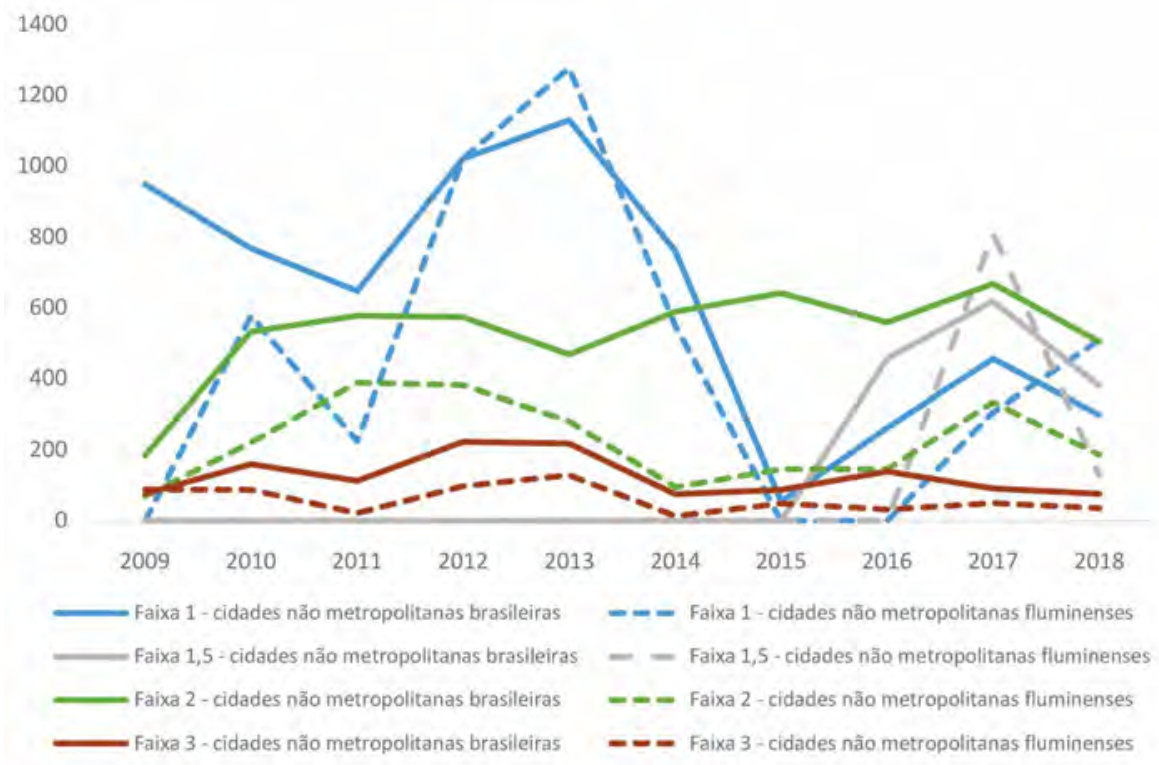

Fonte: Elaboração própria a partir dos dados obtidos junto ao Ministério das Cidades

O último conjunto de dados trabalhado, introduzido pelo Gráfico 6, ilustra o total de unidades residenciais implementadas no Município do Rio 
de Janeiro por ano e área de planejamento. ${ }^{77}$ Logo de início é possível notar a predominância do MCMV na AP5 - território localizado na Zona Oeste da cidade que vai desde Guaratiba, passando por Santa Cruz e Campo Grande, até Deodoro -, especialmente nos dois primeiros anos de implementação do programa. Após declínio em 2012, apresenta uma sequência de oscilaçóes, mas mantém-se hegemônico sobre as demais regiôes nos anos seguintes, exceto em 2014. Esses resultados reforçam a hipótese de que parte expressiva das habitaçóes sociais previstas para o município foram construídas a partir da demanda gerada com as remoçóes conduzidas pelo executivo local (Azevedo e Faulhaber, 2015), principalmente sob a justificativa de que se encontravam em áreas de risco ou que eram necessárias à realização dos megaeventos. Há, nesse sentido, um movimento em direçáo à Zona Oeste estimulado pela prefeitura que, em certa medida, acompanha os investimentos municipais em infraestrutura urbana, ainda que claramente insuficientes.

Gráfico 6 - Total de unidades residenciais implementadas no Município do Rio de Janeiro por ano e Área de Planejamento

25000

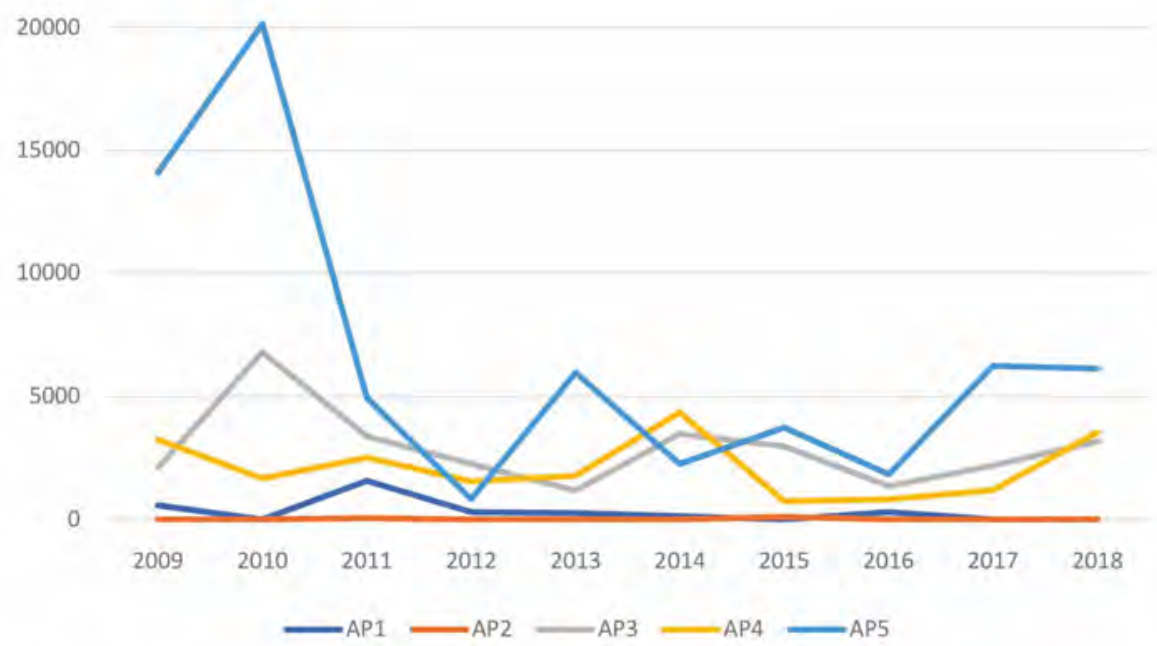

Fonte: Elaboração própria a partir dos dados obtidos junto à Prefeitura da cidade do Rio de Janeiro

7 Para lista de bairros e mapa descrevendo as áreas de planejamento da cidade do Rio de Janeiro veja o link: http://www.rio.rj.gov.br/dlstatic/10112/5148142/4145881/ListadeBairroseAPs_ Mapa (último acesso em 12.02.2019) 
Por outro lado, é possível sustentar que o aumento do valor da terra, estimulado pelo boom imobiliário experimentado nos primeiros anos da segunda década do século XXI, bem como pela regulação municipal na Zona Oeste - que circunscreveu e direcionou as construçôes do MCMV às áreas com infraestrutura urbana - tenha contribuído para a migração dos projetos para fora da cidade do Rio de Janeiro.

A análise conjunta dos Gráficos 3, 4 e 6 permite defender a hipótese de que esse extravasamento teria ocorrido junto aos municípios metropolitanos vizinhos à capital. Tal afirmativa torna-se ainda mais relevante quando a dinâmica se acentua tanto a partir do afluxo de recursos privados no setor imobiliário carioca e com a implementação das novas diretrizes normativas pela prefeitura (Santos e Cruz, 2018). Ou seja, considerando o cenário em que o preço da terra na capital encontrava-se em expressiva elevação, a regulação estatal - aparentemente positiva e adequada às boas práticas de planejamento urbano, pois direcionava os projetos para espaços que já possuíam infraestrutura de saneamento e mobilidade - também contribuiu para estimular o movimento de periferização, ainda que não tenha sido decisiva para tanto. Neste caso, a despeito de uma análise sobre os benefícios ou prejuízos desta dinâmica para os municípios vizinhos, sob a perspectiva regulatória, o que se observou foi uma decisão individualizada da capital que, ao menos aparentemente, não considerou seus impactos tendo em vista a dinâmica do setor imobiliário, tampouco esteve articulada com municípios vizinhos que pudessem ser impactados pelas novas restriçóes. A capacidade de garantir o cumprimento desse regramento no âmbito do MCMV é um desdobramento que se distingue significativamente do que foi verificado tanto por Soares et al. (2013) ao estudar a implementação da política pública na cidade de Uberaba, como por Duarte (2011) que a analisou no município de Petrópolis. Esses desdobramentos reforçam a necessidade de articulaçóes interfederativas como uma possível estratégia de implementação de políticas públicas que produzam efeitos para além dos territórios municipais.

As duas outras áreas de planejamento que apresentaram relevante número de unidades residenciais implementadas no município são a AP4 também localizada a oeste do centro da cidade, vai desde Grumari e Vargem Grande, incluindo Jacarepaguá e a Barra da Tijuca - e a AP3 - correspondente a boa parte da Zona Norte da cidade. Essas áreas apresentam alguma flutuação durante os anos, destacando diferentes momentos de crescimento 
não necessariamente refletindo a dinâmica geral do MCMV no Brasil ou no Estado. De todo modo, os últimos dois anos registram uma tendência de crescimento - inclusive para a AP5 -, ainda que não seja possível afirmar que vai ultrapassar a média que vinha vendo observada nos anos anteriores. Por último, tanto a AP2 - Zona Sul - como a AP1 - região central da capital apresentam valores residuais, representados por projetos pequenos e pontuais, em regra, realizados pelo poder público. Esse resultado é justificado em virtude tanto da limitada disponibilidade de áreas livres - veja, no entanto, as diversas críticas a respeito dos imóveis públicos vazios e daqueles privados não cumpridores da funçáo social da propriedade - quanto em relação ao elevado valor da terra nesses espaços.

\section{Consideraçóes finais}

A concepção e implementação do programa Minha Casa Minha Vida vem se dando em um contexto institucional marcado pela Constituição Federal de 1988, no qual os municípios foram elevados à categoria de ente federativo, concentrando um montante significativo de competências. Entretanto, a ampliação do rol de responsabilidades para os gestores locais não veio acompanhada de ampla distribuição de recursos que se encontram altamente concentrados na União. Ademais, o atual cenário político-econômico se distingue sobremaneira daquele experimentado no curso da implementação das políticas habitacionais pelo BNH. Nossos estudos anteriores (Santos e Vasques, 2016) sustentam que, durante principalmente os governos do Partido dos Trabalhadores, parte da estratégia adotada pela União para a redistribuição dos recursos federais residia no estabelecimento de canais de diálogo diretamente com os municípios - colocando em segundo plano a participação dos governos estaduais. A implementação desse modelo de articulação interfederativa dava-se, em regra, mediante o emprego de mecanismos normativos indutores que condicionavam o acesso a recursos federais à execução de determinadas açôes, dentre elas, a elaboração de planos (e.g., saneamento, resíduos sólidos, mudanças climáticas, mobilidade etc.).

No PMCMV é possível observar uma ruptura nesse modelo de atuação. Nesse sentido, ao mesmo tempo em que elege o setor privado como seu interlocutor privilegiado para a organização de um cenário regulatório-institucional favorável à captação de investimentos imobiliários, relega os es- 
tados e municípios (e a sociedade) a um papel secundário, imiscui-se em larga medida da sua condição político-econômica privilegiada e limita significativamente suas intervençôes no curso da implementação da política pública. Em linhas gerais, a União abre mão do papel quase tutelar observado no modelo descrito no parágrafo anterior, deixando para os municípios grande parte da responsabilidade de administrar a incidência do setor privado - via PMCMV - em seus territórios. Nesse contexto, tampouco oferece mecanismos robustos que estimulassem a atuação dos Estados nesse processo de ocupação do solo. Tal movimento náo é feito por descuido, mas constitui-se como parte da estratégia do governo federal na medida em que sua concepçáo e execução desloca-se da política habitacional que vinha sendo construída pelos técnicos, mas que teve sua implementação antecipada em face da eclosão da crise financeira nos Estados Unidos em 2007, assumindo mais uma dimensão de política anticíclica (no primeiro governo Lula). Ao deixar de incidir indiretamente sobre os municípios a partir dos referidos mecanismos indutores, diminuiu também uma série de potenciais obstáculos institucionais. Essa decisão contribuiu para viabilizar de forma acelerada a distribuição dos recursos federais - opção essa defendida como medida anticíclica, adotada em resposta à crise 2008 -, mas também conferiu ampla liberdade de atuação para o setor privado - o que colaborou para produção dos inúmeros desdobramentos explicitados pela literatura apresentada. Outra implicação importante dessa opção foi a limitação significativa da dimensão social da política pública habitacional implementada.

A afirmação anterior ganha ainda mais destaque quando se observa uma nova mudança no comportamento da Uniáo a partir de 2014, momento no qual a crise político-econômica nacional se torna aguda. Ou seja, até o referido ano, ao menos as para capitais e municípios com mais de $100 \mathrm{mil}$ habitantes - que representam parte substantiva de incidência do programa ${ }^{8}$ -, o governo federal vinha se destacando como o principal fomentador das moradias de interesses social. Depois desse período, verifica-se uma drástica redução dos recursos oriundos do Orçamento Geral da União, limitando

\footnotetext{
8 Ainda que não tenha sido objeto dessa análise, importante destacar que a partir de estudo técnico, a Confederação Nacional de Municípios (2018) sustenta que os atrativos federais empregados em municípios com população abaixo de 100 mil habitantes foram insuficientes para estimular o setor privado e, ao mesmo tempo, lidar com as expectativas dos gestores locais. Situação essa intensificada após 2014, com a redução dos recursos destinados pela União ao programa.
} 
sensivelmente a continuidade na produção de habitações inseridas na faixa 1 - de 0 a 3 salários mínimos. Sem os subsídios federais, a possibilidade de conferir uma dimensão social ao cenário regulatório-institucional construído tornou-se rarefeita. Nas demais faixas, as oscilaçôes não parecem estar associadas à redução de participação financeira da União, assemelhando-se à dinâmica de mercado.

No caso fluminense, a pactuação estabelecida a partir de 2008 entre o PT e o PMDB, viabilizando um inédito e sólido alinhamento entre governos federal, estadual e municipal, foi fundamental para a implementação do MCMV - em especial, na capital e sua respectiva região metropolitana. Um dos principais aspectos que explicitam essa convergência política é o emprego do programa habitacional (durante seus primeiros anos de existência) como mecanismo de suporte ao grande número de remoçóes promovido pela prefeitura carioca, sob administraçáo de Eduardo Paes, tendo como principal fundamento discursivo a realização dos megaeventos na cidade - também uma agenda integrada entre os três níveis de governo. Essa dinâmica fundamentaria o elevado número de contrataçóes do PMCMV no Estado do Rio de Janeiro até 2011 - em especial, na faixa 1 -, que ocorre em dissonância com o auge de contrataçóes no plano nacional - observado apenas em 2013, quando no Rio já é possível observar um declínio. De modo geral, o movimento verificado em território fluminense para a faixa 1 parece operar quase que de forma contrária, se comparado com o cenário nacional. A intensificação da crise financeira no Estado do Rio e a rearticulação do papel da União tanto no cenário nacional (a partir de 2014) quanto no território estadual (após a intervenção federal na segurança pública e o empréstimo realizado como resposta à decretaçáo do estado de calamidade financeira) dificultaram ainda mais a emergência de qualquer dimensão social para a política pública. A faixa 1 parece haver encontrado pouco espaço a partir de 2015, esboçando alguma recuperação apenas a partir de 2017.

O estudo da capital carioca ofereceu ainda outros elementos analíticos para analisar os municípios metropolitanos. Os resultados encontrados sugerem que, mesmo no caso de cidades médias, com populaçáo acima de 100 mil habitantes, sob o ponto de vista financeiro-institucional, a produção de soluçóes isoladas contribuiu pouquíssimo para o fortalecimento da dimensão social do MCMV. Pelo contrário, o espraiamento das construçóes, notadamente, aquelas inseridas na faixa 1, para os municípios metropolita- 
nos vizinhos à capital reforça a necessidade de que o tema - ao menos em territórios metropolitanos ou altamente conurbados - fosse tratado de maneira integrada entre os entes federativos potencialmente impactados. Nesse contexto, vislumbra-se que, para além de estimular o mercado imobiliário a produzir habitaçóes em massa, a política do MCMV operou de forma marginal na elaboração de estratégias institucionais voltadas para o fortalecimento e integração interfederativa. Pelo contrário, ao invés de induzir os municípios a atuarem cooperativamente, acabou por coloca-los em situação de disputa, na qual - submetidos as regras de mercado -os gestores deveriam atuar como empreendedores. Nessas condiçóes, aqueles que estivessem melhor preparados se destacariam na obtenção de recursos e de atenção da iniciativa privada, dispondo os demais elementos (e.g., indicadores, déficit habitacional) de uma participação secundária na definição dos resultados dessas disputas.

No caso dos municípios com mais de 100 mil habitantes localizados fora da regiáo metropolitana, ainda que o volume de resultados seja menor, o movimento evidenciado se assemelha à média nacional dessa categoria de municípios. Esse resultado reforça a limitação do modelo do MCMV para estimular a atuação da iniciativa privada nesses territórios. Ademais, explicita que tais regióes não fluminenses não acompanharam a dinâmica especulativa experimentada na capital e adjacências, que elevou o preço da terra e influenciou a localização e volume dos empreendimentos. Por outro lado, ao identificar um montante abaixo da média, é possível vislumbrar também que, no âmbito desse cenário de competição federativa, os municípios fluminenses demonstraram uma menor capacidade político-institucional para pleitear, disputar e mobilizar recursos e benefícios associados ao programa MCMV.

Por último, para além das críticas gerais sobre o MCMV envolvendo a necessidade de diversificação dos instrumentos (e.g., aluguel social, controle do preço da terra etc.), bem como sua limitada dimensão social, a análise empreendida visou reforçar a importância de outros aspectos institucionais para a produçáo dos resultados do programa. Adicionalmente, buscou-se reiterar a necessidade de produzir avaliaçóes mais restritas, que foquem nos desdobramentos locais e regionais como estratégia para melhor compreender os impactos da política habitacional. Isso porque, as conclusóes extraídas de estudos mais gerais sobre o tema vêm-se demonstrando demasiadamente limitadas, evidenciando uma série de contradiçôes quando comparadas com análises regionalizadas. 


\section{Referências}

AZEVEDO, Nena e FAULHABER, Lucas. SMH 2016: remoçóes no RJ Olímpico. Rio de Janeiro: Mórula, 2015.

BALBIM, Renato et al. "Para além do Minha Casa Minha Vida: uma política de habitação de interesse social?” In: IPEA, Instituto de Pesquisa Econômica Aplicada. Texto para discussão. n. 2116. Rio de Janeiro: Ipea, 2015.

CONFEDERAÇÃO NACIONAL DE MUNICÍPIOS. "Diagnóstico do Programa Minha Casa, Minha Vida (PMCMV).” Estudo Técnico. 2018. Disponível em: https://www.cnm. org.br/biblioteca/exibe/3695

DUARTE, Sandro Marino. Direito à moradia, políticas públicas em habitação e o enfrentamento do déficit habitacional: os desafios do programa Minha Casa Minha Vida. (Dissertação). Rio de Janeiro: UERJ, 2011. p. 233.

KRAUSE, Cleandro et al. "Minha Casa Minha Vida, nosso crescimento: onde fica a política habitacional?” In: IPEA, Instituto de Pesquisa Econômica Aplicada. Texto para discussáo. n. 1853. Rio de Janeiro: Ipea, 2013.

LINK, Clarisse et al. "Inserção urbana de habitação de interesse social: um olhar sobre mobilidade cotidiana e uso do solo". In: IPEA, Instituto de Pesquisa Econômica Aplicada. Texto para discussão. n. 2176. Rio de Janeiro: Ipea, 2016.

LOUREIRO, Maria Rita et al. "Democracia, arenas decisórias e políticas públicas: o programa minha casa minha vida”. In: IPEA, Instituto de Pesquisa Econômica Aplicada. Texto para discussâo. n. 1886. Rio de Janeiro: Ipea, 2013.

MARQUES, Eduardo e RODRIGUES, Leandro. "O Programa Minha Casa Minha Vida na metrópole paulistana: atendimento habitacional e padróes de segregaçáo". In Revista Brasileira de Estudos Urbanos e Regionais, v. 15, n. 2, nov. 2013. p. 159-77.

MOREIRA, Vinicius de Souza et al. "Minha Casa, Minha Vida' em números: quais conclusóes podemos extrair?” In IV Encontro Brasileiro de Administraçáo Pública. João Pessoa, 2017. Disponível em: http://www.ufpb.br/ebap/contents/documentos/0594-613-minha-casa. pdf. Acesso em 2 fev. 2019.

MOURA, Jéssica Morais de. "O Programa Minha Casa, Minha Vida na Região Metropolitana de Natal: uma análise espacial dos padróes de segregação e desterritorialização". In Revista Brasileira de Gestão Urbana (Brazilian Journal of Urban Management), v. 6, n. 3, set./dez. 2014. p. 339-59.

NETO, Vicente Correia Lima et al. "O déficit habitacional intrametropolitano e a localização de empreendimentos do programa minha casa, minha vida: mensurando possibilidades de atendimento". In: IPEA, Instituto de Pesquisa Econômica Aplicada. Texto para discussáo. n. 2044. Rio de Janeiro: Ipea, 2015.

PEQUENO, Renato e ROSA, Sara Vieira. "O Programa Minha Casa Minha Vida na Regiáo Metropolitana de Fortaleza-CE”. In Cadernos Metrópole, v. 18, n. 35, abr. 2016. pp. 191-215.

ROLNIK, Raquel et al. "O Programa Minha Casa Minha Vida nas regióes metropolitanas de São Paulo e Campinas: aspectos socioespaciais e segregaçáa”. In Cadernos Metrópole, v. 17 , n. 33, maio 2015. p. 127-54. 
SANTOS, Angela Moulin Simóes Penalva et al. "Direito à moradia: um direito social em construção no Brasil. A experiência do aluguel social no Rio de Janeiro". Planejamento e Políticas Públicas, p. 217-242, jan./jun. 2016.

e VASQUES, Pedro Henrique Ramos Prado. "Diálogo interfederativo na política de saneamento básico e resíduos sólidos". In: GERSHMAN, Silvia e SANTOS, Angela Moulin S. Penalva. (Org.). Saúde e politicas sociais no Rio de Janeiro. Rio de Janeiro: Editora Fiocruz, 2016, v. 1, pp. 229-60.

e CRUZ, Carlos Eduardo de Souza. "Regularizaçáo Fundiária: de seu avanço institucional à reprodução crescente do problema que a originou". In CORREIA, Arícia Fernandes. (org.). Direito da Regularização Fundiária Sustentável: pesquisa, teoria e prática sobre a Lei Federal n. 13.465/2017. Juiz de Fora: Editora Editar, 2018. pp. 35-51.

SOARES, Isabelle Oliveira et al. "Interesses especulativos, atuaçáo do Estado e direito à cidade: o caso do programa 'Minha Casa Minha Vida' em Uberaba (MG)". In Revista Brasileira de Gestão Urbana (Brazilian Journal of Urban Management), v. 5, n. 1, jan./dez. 2013. pp. 119-31.

SOUZA, Eduardo Leite e SUGAI, Maria Inês. "Minha Casa Minha Vida: periferização, segregação e mobilidade intraurbana na área conurbada de Florianópolis". In Cadernos Metrópole, v. 20, n. 41, jan./abr, 2018. Pp . 75-98.

TATAGIBA, Luciana F. et al. "Inovações participativas nas políticas habitacionais para população de baixa renda. Um estudo de caso sobre o Programa Minha Casa, Minha Vida - Entidades". Crítica Y Emancipación, v. VI, 2014, pp. 215-88. 


\section{Espacialização do programa Minha Casa Minha Vida no estado e na capital do Rio de Janeiro}

Gustavo Bezerra de Brito ${ }^{1}$

José Silvan Borborema Araújo ${ }^{2}$

Glaucio José Marafon ${ }^{3}$

\section{Introdução}

Há muitas pesquisas no país que se dedicam a analisar a problemática habitacional brasileira. A falta de moradias e suas qualidades são pontos centrais para compreender a realidade contemporânea da urbanização no país. De um ponto de vista geral, é consenso que o Estado e o mercado náo foram capazes de resolver essa questáo, de maneira que a parcela da população mais atingida pelos problemas urbanos é a de baixa renda. As pessoas que compóe esta faixa de renda, segundo especialistas, são a classe social que possui mais alto déficit habitacional.

Entretanto, a partir de 2009 que um novo ponto de inflexão se faz presente. No bojo de novas regulamentaçóes no setor imobiliário, no estabelecimento de grandes metas e com o recém-criado Ministério das Cidades, ocorre o lançamento do "Programa Minha Casa Minha Vida” (PMCMV).

1 Membro do Núcleo de Estudos de Geografia Fluminense (NEGEF/UERJ). Mestrando em Geografia pela Universidade Federal do Rio de Janeiro (PPGG/UFRJ).

2 Membro do Núcleo de Estudos de Geografia Fluminense (NEGEF/UERJ). Doutor em Geografia pela Universidade do Estado do Rio de Janeiro (PPGEO/UERJ).

3 Professor Associado IGEOG/UERJ Pesquisador CNPq/CNE

4 Atualmente o Programa está na sua terceira fase (PMCMV 3). Este artigo concentra sua análise em dados do Programa até 31 de dezembro de 2018, fim do Governo de Michel Temer. 
O Programa foi criado no segundo mandato do Governo Lula e aprofundado durante o Governo Dilma e contribuiu para dar subsídios para uma nova leva de estudos no campo das políticas públicas de habitação e nos estudos de organização das cidades.

Neste sentido, podemos compreender sua relevância e representatividade a partir de dois fatores. O primeiro é a incorporação de grandes subsídios, especialmente os aportes de recursos do próprio Orçamento Geral da União (OGU) e o volume das construçóes - só na primeira fase, foram planejadas um milhão de novas moradias. $\mathrm{O}$ segundo diz respeito aos avanços em sua perspectiva social. Seu objetivo era atender especialmente às demandas das populaçóes urbanas mais pobres.

Segundo Romagnoli (2015), o contexto de seu lançamento é tempestivo na história econômica brasileira. O programa foi tomado com uma política "anticíclica" pelo Governo Federal, como meio de enfrentar a crise financeira internacional que teve início no ano de 2008. Ele foi concebido no sentido de dinamizar a construçáo civil, criar empregos e aquecer o mercado interno.

Entretanto, é notável que há fortes problemáticas identificadas no programa. Estas giram em torno da contrariedade da construção de novas habitaçóes como um modelo satisfatório de combate à falta de moradia, embora tenha havido falta de menção ao planejamento urbano, além de falta de regularização fundiária. Outras críticas são direcionadas especialmente aos padróes de inserçáo urbana dos empreendimentos - que supostamente reafirmam um modelo de urbanização excludente e precário na maior parte das cidades do país, notadamente nas regióes metropolitanas (Rolnik et al., 2015, p. 127).

No caso do Estado do Rio de Janeiro (ERJ) e da capital fluminense, esses contornos se tornam mais palpáveis. É a partir de dados do Ministério do Desenvolvimento Regional (MDR) coletados até o fim de 2018 que podemos ilustrar a seguinte hipótese: embora inovador na concessão de subsídios para habitação de setores de renda baixa, além de ampliador de crédito para imóveis de camadas intermediárias da população, o programa não tomou o território como o aspecto central da política de moradia direcionada a sanar os problemas adequados nessa questão.

Sendo assim, neste trabalho nos preocupamos em verificar, por meio da análise dos dados quantitativos e cartográficos do ERJ e da capital Rio de Janeiro, um possível aumento da segregação socioespacial no estado em 
função da renda, além da concentração de unidades habitacionais nas faixas intermediárias com maior poder aquisitivo - notadamente as faixas 2 e 3 .

$\mathrm{O}$ artigo estrutura-se em três partes interligadas. Começamos discutindo brevemente aspectos gerais sobre o funcionamento e execução do PMCMV, tendo em vista que ao longo dos dez anos desde o seu lançamento, o Programa é alvo de inúmeras pesquisas e levantamentos sobre habitação do país. Na primeira parte, suas principais características são então explicitadas. No segundo momento, o Estado do Rio de Janeiro é o enfoque: a partir da análise do material cartográfico, expandimos os dados para apresentar as particularidades do ERJ. Por fim, tecemos consideraçôes sobre a associação dessa política pública e os padrôes identificados pela análise realizada.

\section{Aspectos gerais do Programa Minha Casa Minha Vida}

É notável que o Programa, uma política pública de habitação do Governo Federal brasileiro, possui um significado forte no discorrer das políticas de habitaçáo nos últimos anos. Seja por seus impactos econômicos, territoriais ou sociais, é considerado ponto central na história da moradia no país. Em termos práticos, foi responsável por reposicionar a questáo da habitaçáo na agenda governamental. Segundo Hervé $(2017$, p. 2), "este é o programa mais significativo no campo da habitação no país nos últimos trinta anos".

Após um hiato de mais de duas décadas de descaso com a questão habitacional a nível federal, com exceção de açôes singulares que não chegaram a provocar mudanças estruturais (Bonduki, 2008), o Programa Minha Casa Minha Vida foi regulamentado pela Lei n. ${ }^{\circ} 11.977$, de 7 de julho de 2009, que o estrutura a partir do Programa Nacional de Habitação Urbana (PNHU) e Programa Nacional de Habitaçáo Rural (PNHR).

No que tange aos objetivos e investimentos, a expectativa era alta. Em sua primeira fase, foram programadas a construção de 1 milhão de moradias num prazo relativamente curto, dois anos. Foram utilizados 34 bilhóes no total de investimentos, divididos em $\mathrm{R} \$ 25,5$ bilhōes no Orçamento Geral da União e R \$ 7,5 bilhôes do Fundo de Garantia por Tempo de Serviço (FGTS). Além disso, ficou previsto ainda um investimento de R\$ 1 bilhão para a infraestrutura urbana, distribuído pelo Banco Nacional de Desenvolvimento Econômico e Social (BNDES). 
Para as famílias com renda de até três salários mínimos, a meta era construir 400 mil unidades do PMCMV com um pagamento mensal, considerado simbólico, de R \$50,00. Para famílias com renda de 3 a 6 salários mínimos também se tinha como objetivo construir 400 mil unidades pelo PNHU. Para as famílias com renda de 6 a 10 salários mínimos, o objetivo era construir 200 mil unidades com o financiamento do FGTS. O produtor rural, por sua vez, solicitaria o financiamento de acordo com a sua renda (Cardoso e Aragão, 2013 apud Andrade, 2012).

Ainda nesta trilha de investigação, é interessante a análise do Gráfico 1, onde é possível identificar a maior incidência do déficit habitacional no país. Sendo este o somatório entre os componentes habitação precárias, coabitação familiar, ônus excessivo em aluguel e adensamento excessivo (FGV, 2018). A compreensão do problema é maior quando atrelada a problemáticas urbanas como violência, desigualdade, transporte deficitário, falta de infraestrutura de luz, saneamento etc.

Gráfico 1 - Distribuição relativa do Déficit Habitacional por Faixa de Renda Familiar - 2017

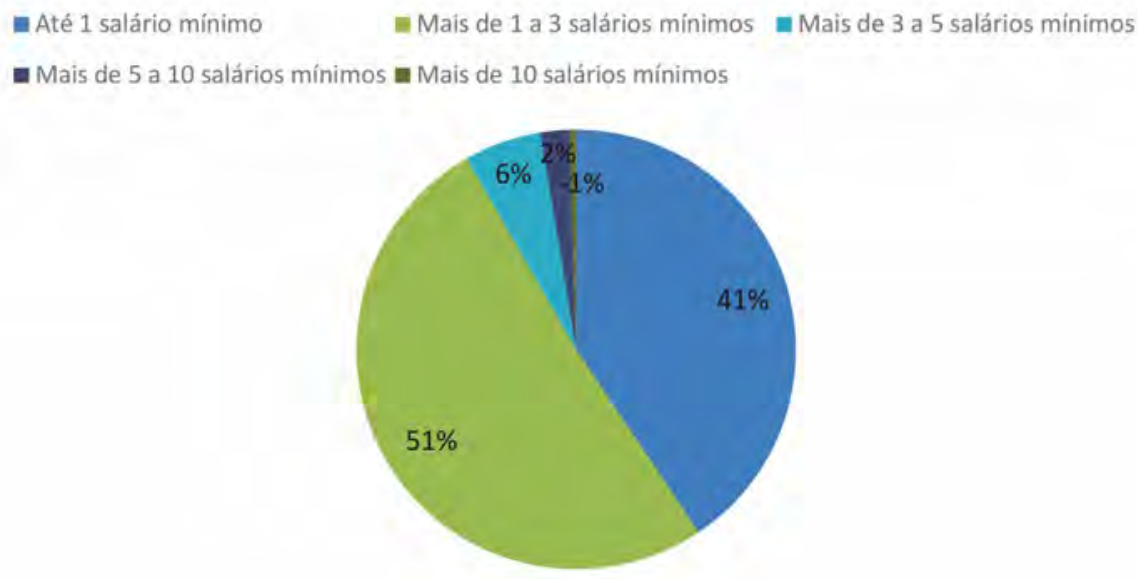

Fonte: Fundação Getúlio Vargas, 2018.

Logo, em termos da distribuição do déficit total por faixas de renda, nota-se a forte concentração nos estratos até três salários mínimos. Somadas, as faixas de renda até 1 salário mínimo e de 1 a 3 salários mínimos corresponderam por $91,7 \%$ do déficit total, o equivalente a 7,1 milhóes de unidades. 
Desta maneira, o Programa adequou os seus objetivos ao concentrar a maior parte da construção de unidades para a população que mais contribui nesta problemática.

Nesse contexto, onde o déficit habitacional brasileiro se concentra majoritariamente na população de baixa renda, as principais orientaçôes restavam em reduzir em $14 \%$ o déficit de moradias no Brasil, especialmente em municípios com mais de 100 mil habitantes, além de dinamizar o setor de construção civil, responsável por 5,7\% do PIB nacional (Romagnoli, 2012).

Já nas fases 2 e 3, iniciadas no governo de Dilma Rousseff, o prazo de duração previsto foi maior, de três anos, e com a meta de construção de 2 milhóes de unidades habitacionais. Para estas etapas, 60\% das unidades seriam destinadas às famílias com menor faixa de renda, até $\mathrm{R} \$ 1.600,00 ; 30 \%$ para a segunda faixa, entre $\mathrm{R} \$ 1.600,00$ e $\mathrm{R} \$ 3.100,00$; e $10 \%$ para a última faixa, $R \$ 3.100,00$ a $R \$ 5.000,00$ (Quadro 1). O Programa passa a ser operacionalizado, portanto, com três faixas de renda e náo quantidade de salários mínimos, como ocorreu em sua primeira edição (Ramos e Noia, 2014).

Quadro 1 - Metas de contratação do MCMV II

\begin{tabular}{l|c|c}
\hline Renda & Unidades & $\%$ \\
\hline Até R\$ 1.600 & 1.200 .000 & $60 \%$ \\
\hline 1.600 a 3.100 & 600.000 & $30 \%$ \\
\hline 3.1000 a 5.000 & 200.000 & $10 \%$ \\
\hline Total & 2.000 .000 & $100 \%$ \\
\hline
\end{tabular}

Fonte: Brasil, 20195. Elaboração própria.

Foi na fase 2 que seus recursos foram ampliados, com previsão de aporte da ordem de " 125 bilhôes de reais, sendo 72,6 bilhóes de reais orientados aos subsídios e 53,1 bilhôes de reais para os financiamentos" (Andrade, 2012, p. 53). Houve ainda mudanças operacionais: a agregação do Banco do Brasil ao Programa, visando propiciar mais agilidade nos processos de contratação, acompanhamento das obras, financiamento e repasse de recursos.

5 Dados da Secretaria de Governo do Brasil. Disponível em http://www.secretariadegoverno.gov.br/iniciativas/internacional/fsm/eixos/inclusao-social/minha-casa-minha-vida.Acesso em 2019. 
Além dessas mudanças, especificações técnicas dos apartamentos foram alteradas para incluir a obrigatoriedade da utilização de cerâmica no piso de todos os cômodos e a destinação de 3\% das unidades de cada empreendimento para pessoas com deficiências físicas (estas moradias são adaptadas com portas e banheiros maiores).

Apesar do montante de investimentos alocados e contornos de assistencialismo e redistribuição de renda, o programa é alvo de críticas diversas por parte de diferentes setores da sociedade. Boa parte da argumentaçáo gira em torno do grande atraso no cronograma de obras e da qualidade dos imóveis entregues.

Há exemplos notáveis de unidades que são contratadas e não foram entregues. Além disso, muitas são tidas como concluídas embora apresentem condiçôes como paredes desalinhadas, buracos na alvenaria, pintura malfeita, louças fora do padrão, goteiras e infiltraçóes (Andrade, 2012, p. 56)

Ademais, há críticas que afirmam que, apesar do Programa apresentar metas que tocam a questão urbana do país, são superficiais. Arantes e Fix (2009) argumentam que o PMCMV não possui nenhum dispositivo que estimule a reutilização de imóveis antigos não ocupados, que delimitariam a funçáo social da propriedade. Em sua maioria, as unidades habitacionais contratadas são construídas do zero.

Segundo os autores, esta última alternativa não é necessariamente a melhor maneira de enfrentar os problemas de habitação. As alternativas que dão conta de repetir e adaptar políticas públicas que transcorrem em outros países, notadamente a criação de fundos públicos para aquisição, desapropriação e aluguel subsidiado de unidades habitacionais, com a intenção de diminuir o déficit, além de enfrentar a especulação imobiliária e o crescimento da malha urbana seriam mais adequadas.

Ademais, não há diretrizes que incentivem as construtoras a promoverem a construção de imóveis em áreas centrais, já densamente urbanizadas e com infraestrutura, em lotes menores ou para requalificação de edifícios, práticas mais coerentes na proposta do PMCMV.

Borges (2013), por sua vez, indica que $97 \%$ do subsídio público no programa é destinado à oferta e produçáo direta por construtoras privadas, deixando de lado a regulamentação de planos diretores. Esta seria uma dificuldade por parte dos municípios para a efetiva aplicaçáo dos instrumentos previstos no Estatuto da Cidade, tornando a iniciativa privada protagonista. 
Rolnik et al (2015, p. 148) também destacam que existem outras formas de prover moradia, além da produção de novas unidades. Motivadas pela desarticulação entre as diretrizes da política e pelo Plano Nacional de Habitacão (PNH), ocorre a inibição de outras soluçôes habitacionais previstas, como a urbanização de assentamentos precários e construção em parceria com entidades organizadoras.

Este quadro contribuiria com o fenômeno da segregação socioespacial nas cidades - novamente, uma tendência de utilização de terrenos mais baratos, consequentemente, afastados da malha urbana. ${ }^{6} \mathrm{O}$ PMCMV seria omisso na questáo urbana, mesmo prevendo as condiçóes mencionadas acima.

Emínia Maricato, em entrevista concedida em 2010, afirma que um Programa de tamanha relevância para o setor deveria apresentar formas de tocar no estatuto da propriedade fundiária, buscando regular ganhos especulativos e garantir a função social da propriedade. O PMCMV, em sua visão, caracteriza um retrocesso diante da evolução conquistada e já devidamente consolidada na legislação urbanística do país.

No Estado do Rio de Janeiro, sobremaneira, este fenômeno tem contornos mais significativos. Com boa parte da sua população vivendo na Região Metropolitana (RMRJ), o estado apresenta uma forte tendência à concentração metropolitana. Náo nos surpreende, ao analisarmos o Quadro 2, que a RMRJ contribui em cerca de 66\% no déficit habitacional do Estado. No interior fluminense, esta taxa é de $34 \%$.

Quadro 2 - Déficit Habitacional no Estado do Rio de Janeiro - 2015

\begin{tabular}{|c|c|c|}
\hline \multirow[t]{2}{*}{ Especificação } & \multicolumn{2}{|c|}{ Déficit Habitacional no Estado do Rio de Janeiro - 2015} \\
\hline & Total & $\%$ no Estado \\
\hline RMRJ & 304.083 & $66 \%$ \\
\hline Interior Fluminense $^{7}$ & 155.977 & $34 \%$ \\
\hline Total ERJ & 460.785 & $100 \%$ \\
\hline
\end{tabular}

Fonte: Dados básicos do Instituto Brasileiro de Geografia e Estatística (IBGE), Pesquisa Nacional por Amostra de Domicílios (PNAD). Elaboração própria, 2019.

${ }^{6}$ Edificadas nas periferias, contribuindo para a formaçáo de cidades fragmentadas e custosas, haja visto que será necessário a instalação de novos equipamentos públicos nessas áreas.

7 Municípios fora da RMRJ. 
Neste sentido, o estado possui chances significativas de apresentar os problemas anteriormente citados. Cabe a nós, então, avaliarmos a situação das unidades habitacionais no estado, a fim de verificar os resultados de uma política pública que, supostamente, tenta sanar a questão da habitação, mas que por inabilidade dos instrumentos de organização das cidades, pode contribuir com a segregaçáo e a desigualdade social.

Ressaltamos também que, para a efetiva compreensão dos mapas que serão apresentados, é importante conhecer algumas das características do ERJ, notadamente sua divisão política administrativa e os elementos norteadores da organização especial fluminense. Neste sentido, sugerimos a leitura de Marafon et al (2011) a fim de contribuir com análises dos aspectos sociopolíticos antigos e atuais que configuram as regióes do estado.

\section{Espacialização do Programa Minha Casa Minha Vida no Estado do Rio de Janeiro}

Levando em consideração a ampla dimensão do Programa Minha Casa Minha Vida, que envolve variados aspectos de caráter socioeconômico, político e cultural, devemos atentar para a questão da sua espacialização e efetivação na entrega das unidades habitacionais no território do estado do Rio de Janeiro.

Localizado na região Sudeste do país (mapa 1), com uma população estimada para 2019 de aproximadamente 17.264.943 habitantes (IBGE, 2019), o déficit habitacional é expressivo, principalmente na Região Metropolitana, embora não isente outras regióes administrativas do estado. 
Mapa 1 - Regióes de Governo e Municípios - Estado do Rio de Janeiro

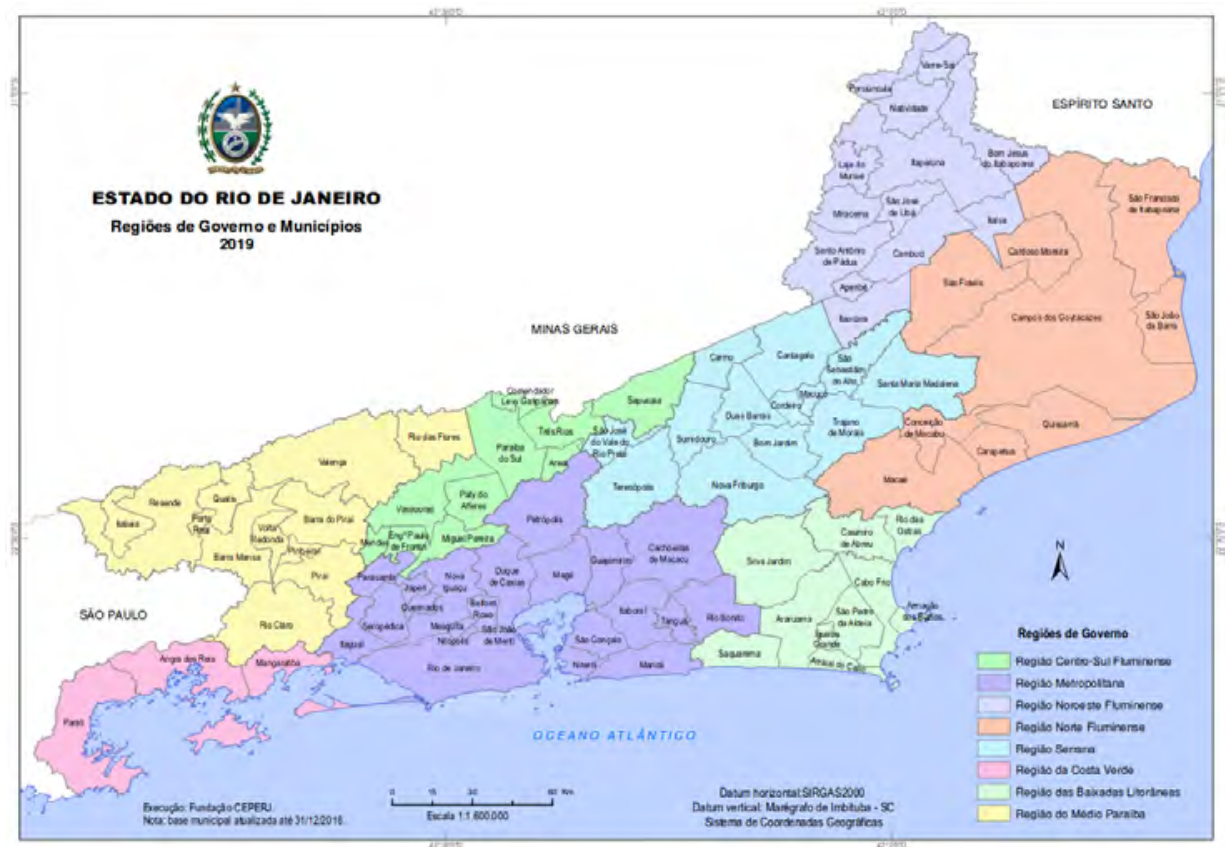

Fonte: CEPERJ, 2019.

Nesse cenário, o programa se espacializou em todas as regióes do estado, distribuído nas três faixas de renda, ${ }^{8}$ embora, dentre as unidades contratadas, a entrega tenha ocorrido com maior destaque na faixa 3 , destinada à classe social com maior poder aquisitivo.

No entanto, a faixa 1, destinada às famílias de baixa renda, de até três salários mínimos, foi a que apresentou os menores números de unidades (mapa 2) se comparado às outras faixas de renda.

${ }_{8}$ Salientamos que, além das faixas 1, 2 e 3, o Programa também atendeu a uma faixa intermediária para quem recebe até 1,5 salário mínimo. Não contemplamos esta faixa na nossa análise, uma vez que não resultou em quantidades expressivas de unidades contratadas, concluídas e entregues e que não interfere na análise do Programa no estado do Rio de Janeiro. 
Mapa 2 - Unidades contratadas para a faixa 1 do PMCMV

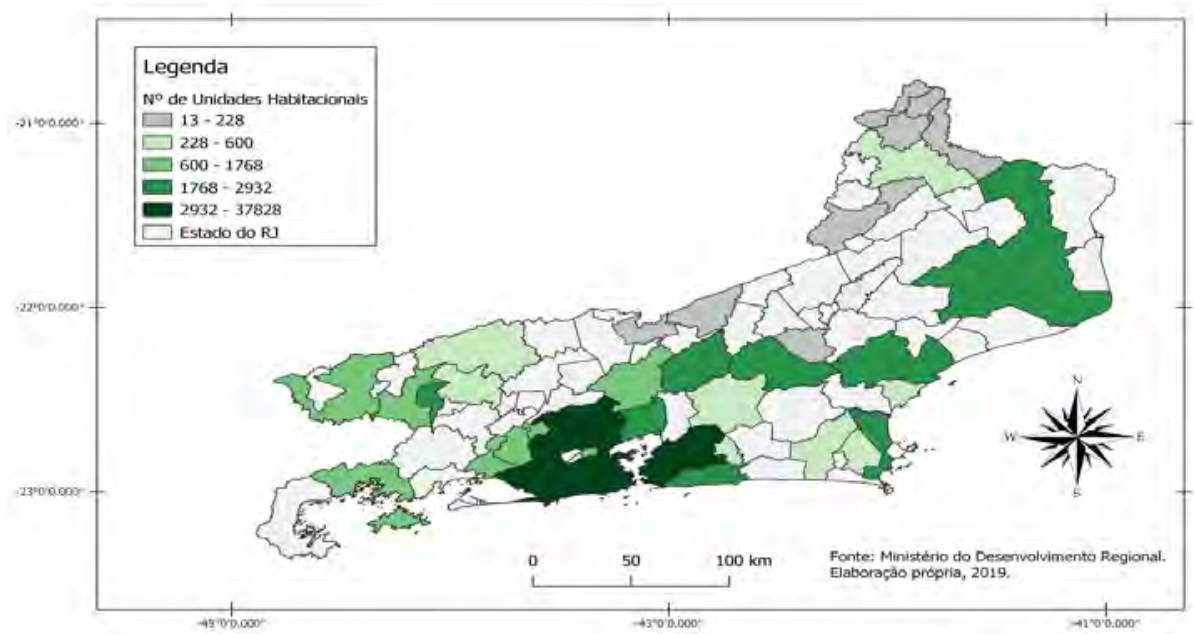

Fonte: Ministério do Desenvolvimento Regional. Elaboração própria, 2019.

Diante do exposto, podemos perceber que esta etapa do Programa esteve espacializada em todas as regiốes do estado, embora não tenha contemplado muitos municípios interioranos. Notamos que teve maior concentração na Região Metropolitana, com o número de unidades expressivo, variando entre 2.932 a 37.828 unidades contratadas, abrangendo a capital Rio de Janeiro e os municípios de Duque de Caxias, Belford Roxo, Nova Iguaçu, Queimados, Niterói, São Gonçalo e Itaboraí. Além disso, alguns municípios que polarizam outras regiôes administrativas do estado também receberam unidades contratadas da faixa 1. Municípios como Campos dos Goytacazes, Teresópolis, Nova Friburgo, Macaé, Cabo Frio, Maricá, Magé e Volta Redonda apresentaram números de unidades contratadas variando entre 1.768 a 2.932. As demais regióes do estado não foram contempladas com um número expressivo de unidades contratadas para esta faixa. Sendo assim, o maior número dessa faixa ficou concentrado nos municípios supramencionados, deixando de contemplar grande parte do território estadual.

Importante destacar que a tendência de espacialização das unidades para a faixa 1 segue a tendência também nas outras etapas do programa, embora apresente déficit na etapa de conclusão e na entrega das unidades (mapas 3 e 4): 
Mapa 3 - Unidades concluídas para a faixa 1 do PMCMV

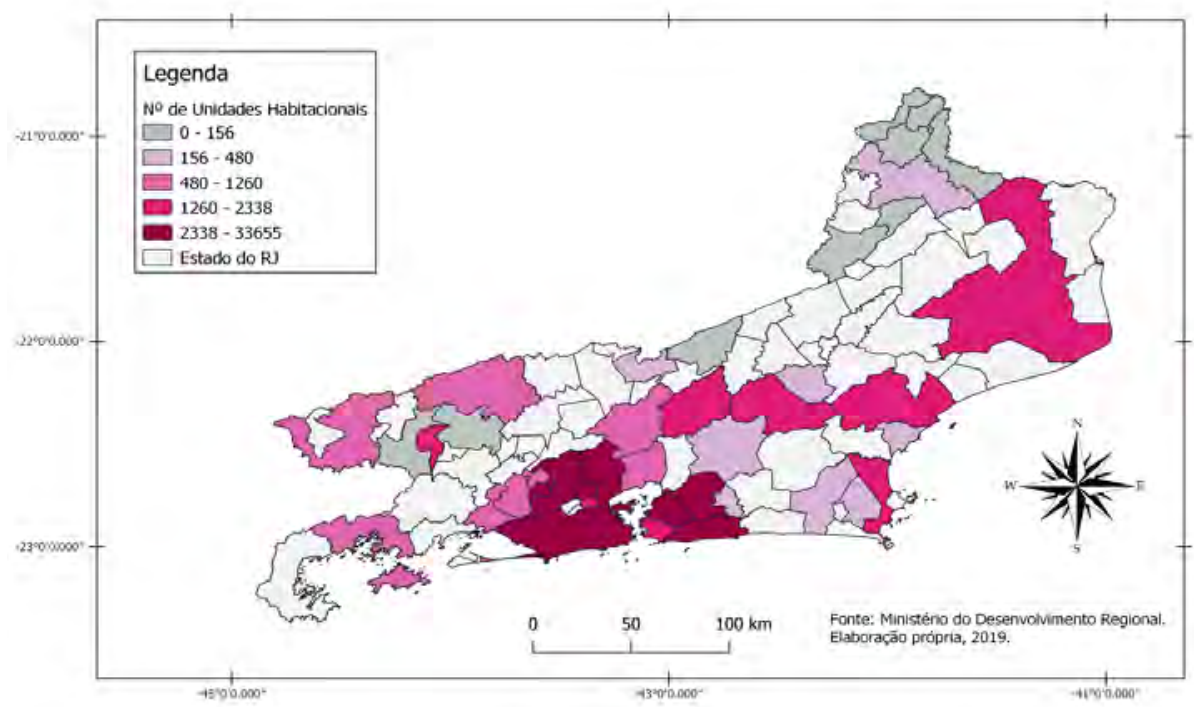

Fonte: Ministério do Desenvolvimento Regional. Elaboração própria, 2019.

As unidades concluídas, logicamente, concentram-se nas áreas onde houve mais unidades contratadas. No entanto, percebemos que, nessa etapa do programa, municípios como Nova Friburgo, na Região Serrana, conseguiram entregar uma quantidade de unidades bem acima da média, considerando que o município possuía entre 1.260 a 2.338 unidades concluídas e, desse total, configura-se na classe entre 2.128 a 32.702 unidades entregues (mapa 4). Ou seja, Nova Friburgo pode ter entregue todas as unidades contratadas. Isso se deve ao fato do município ter sido atingido por uma tragédia climática em 2011, em que grande parte da população perdeu os seus imóveis nas enchentes. 
Mapa 4 - Unidades Entregues para a faixa 1 do PMCMV

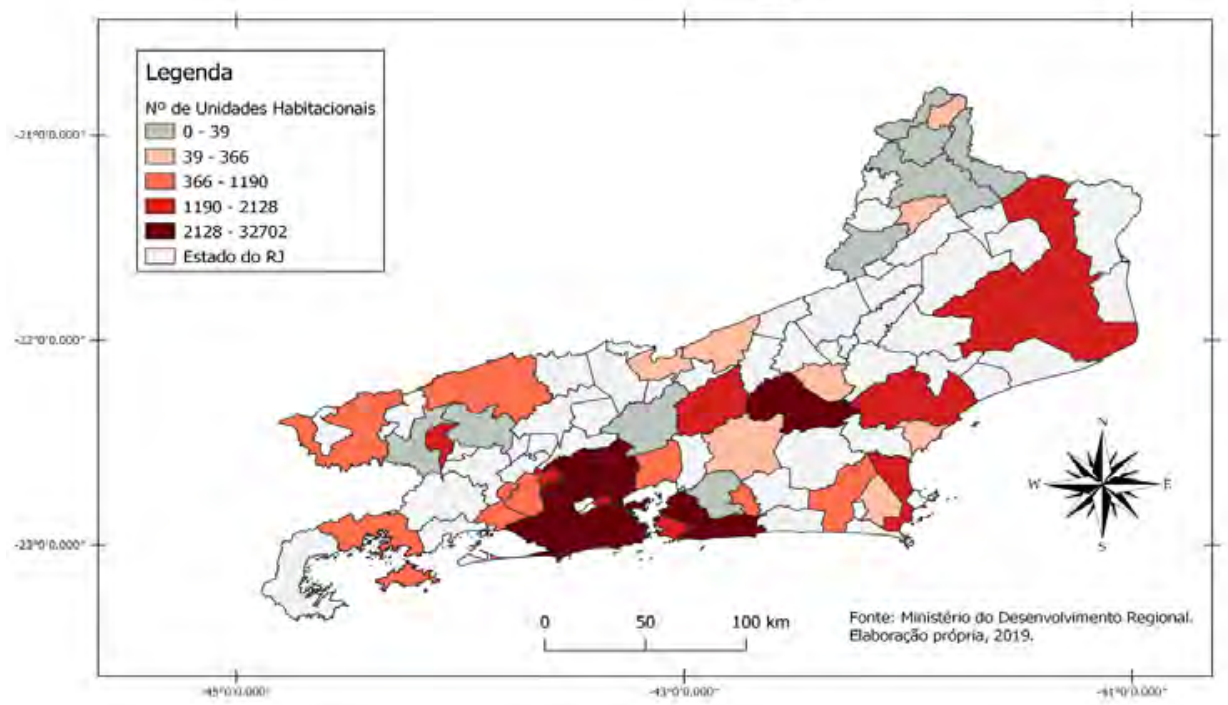

Fonte: Ministério do Desenvolvimento Regional. Elaboração própria, 2019.

Sendo assim, analisando a espacialização das unidades entregues para a faixa 1 do Programa, confirmamos a espacialização seletiva do processo. De fato, a região metropolitana, por concentrar maior contingente populacional, possui um déficit maior na questão de habitação, o que justifica a maior concentração de unidades na área, contudo, municípios que apareciam com unidades contratadas foram perdendo a sua participação na medida em que o programa avançava, não conseguindo entregar as unidades.

Percebemos que as unidades para a faixa 1 do Programa foram concentradas espacialmente, com menor número de unidades tanto contratadas, quanto concluídas e entregues, apesar deste grupo ser o mais vulnerável no que diz respeito ao déficit habitacional e enfoque do programa.

Levando em consideração as unidades destinadas à faixa 2 , que atendeu famílias com renda de 3 a 6 salários mínimos, apresenta maior espacialização, aparecendo com mais expressividade em todas as regióes do estado e em todas as modalidades (contratadas, concluídas e entregues) (mapa 5). 
Mapa 5 - Unidades contratadas para a faixa 2 do PMCMV

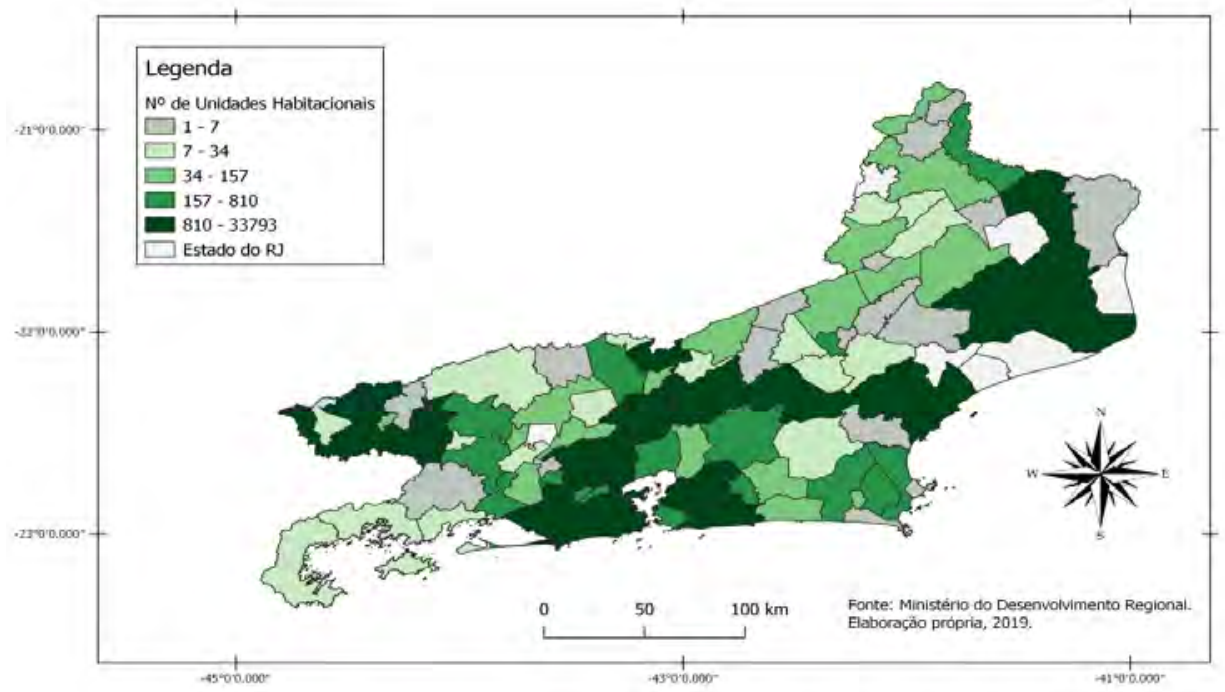

Fonte: Ministério do Desenvolvimento Regional. Elaboração própria, 2019.

Além dos municípios já citados na faixa 1 , aparecem com mais unidades os municípios de Petrópolis, Rio das Ostras, Três Rios, Barra Mansa e Resende. Estes municípios participam presenciando os maiores números de unidades contratadas, variando de 810 a 33.793 unidades.

$\mathrm{Na}$ faixa 2, apesar das outras etapas terem apresentado uma leve diminuição de unidades, não representam grandes variaçóes se comparado com as diferenças verificadas na faixa 1 (mapa 6). 
Mapa 6 - Unidades concluídas para a faixa 2 do PMCMV

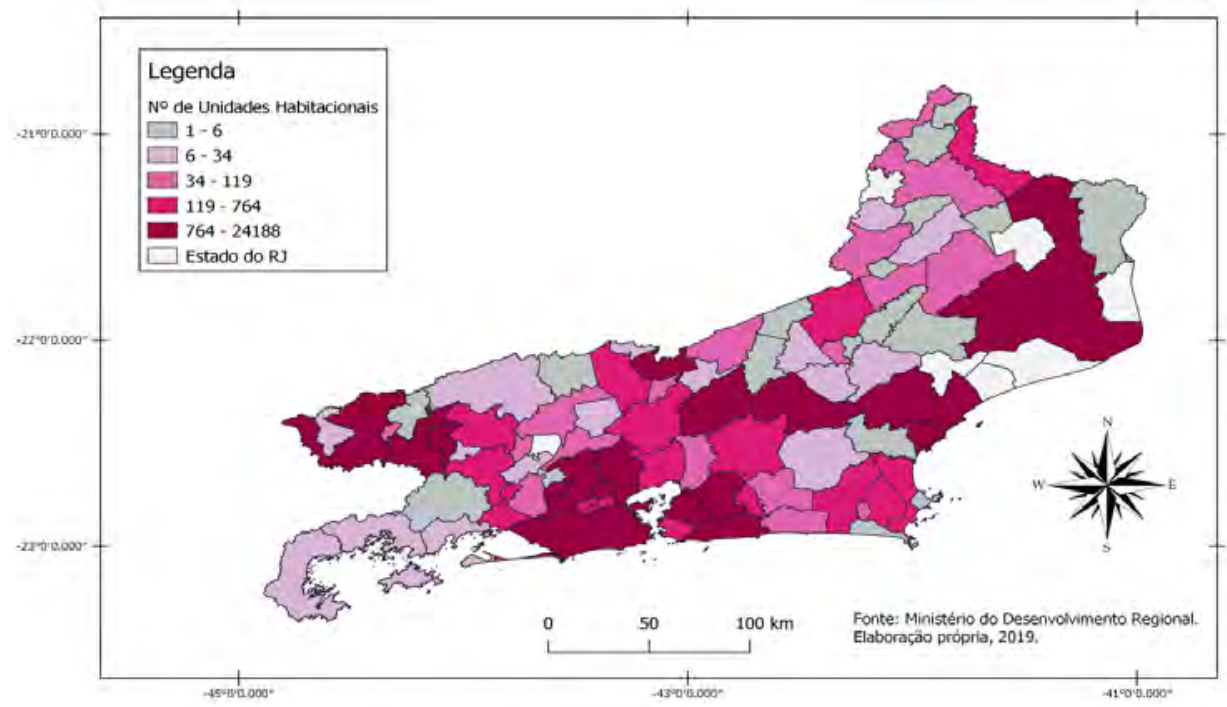

Fonte: Ministério do Desenvolvimento Regional. Elaboração própria, 2019.

De modo geral, não houve interrupção entre as etapas de contratação e conclusão das unidades habitacionais para a faixa 2. É possível perceber que os mesmos municípios que apresentaram unidades contratadas tiveram as unidades concluídas, não gerando perdas significativas para esta faixa.

A mesma tendência foi seguida para a etapa final do programa, com a entrega das unidades (mapa 7), onde todos os municípios que possuíam unidades contratadas conseguiram entregá-las, sem interrupção das etapas. 
Mapa 7 - Unidades entregues para a faixa 2 do PMCMV

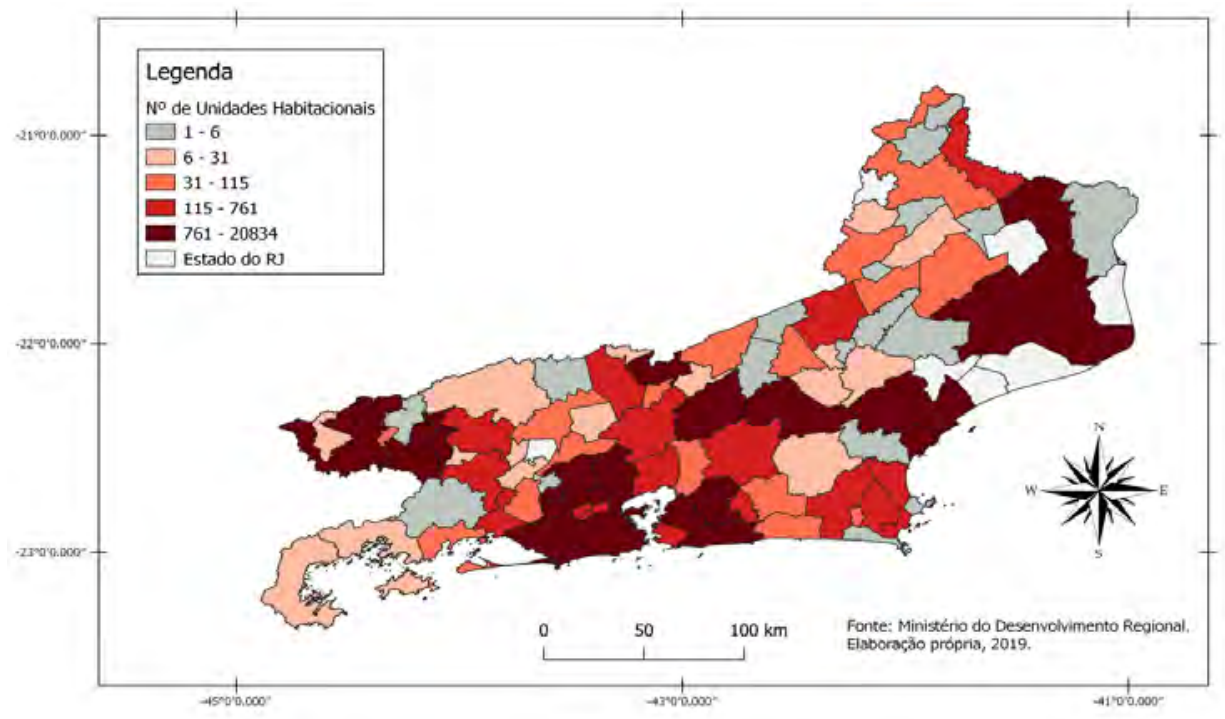

Fonte: Ministério do Desenvolvimento Regional. Elaboração própria, 2019.

Sendo assim, podemos observar que, para esta faixa de renda, o Programa conseguiu cumprir significativamente com as etapas, entregando mais de $50 \%$ das unidades contratadas em cada área do estado. Vale ainda ressaltar que, de maneira geral, a faixa 2 apresenta maior número de unidades em relação à faixa 1 .

No que diz respeito à faixa 3 do programa, destinada às famílias com renda entre 6 e 10 salários mínimos, verificamos uma menor espacialização em relação às faixas 1 e 2, embora ainda maior que a primeira faixa (mapa 8). 
Mapa 8 - Unidades contratadas para a faixa 3 do PMCMV

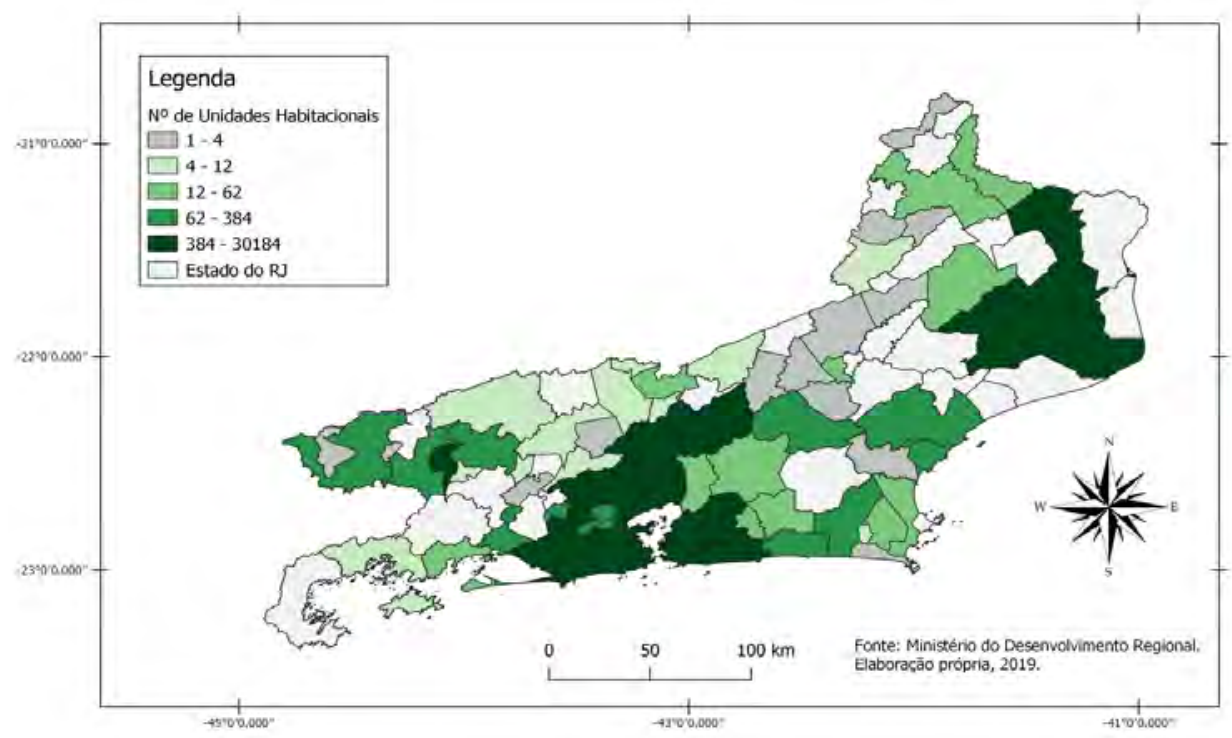

Fonte: Ministério do Desenvolvimento Regional. Elaboração própria, 2019.

Como tendência de espacialização para todas as faixas, a área da RMRJ concentra as maiores unidades, em todas as etapas, ficando menos denso no interior do estado, embora esteja presente em todas as regiōes.

Essa espacialização mais uniforme pelo território estadual vai se repetir nas outras etapas do programa, a exemplo das unidades concluídas (mapa 9), não apresentando perdas significativas dessas unidades em relação às unidades contratadas. 
Mapa 9 - Unidades concluídas para a faixa 3 do PMCMV

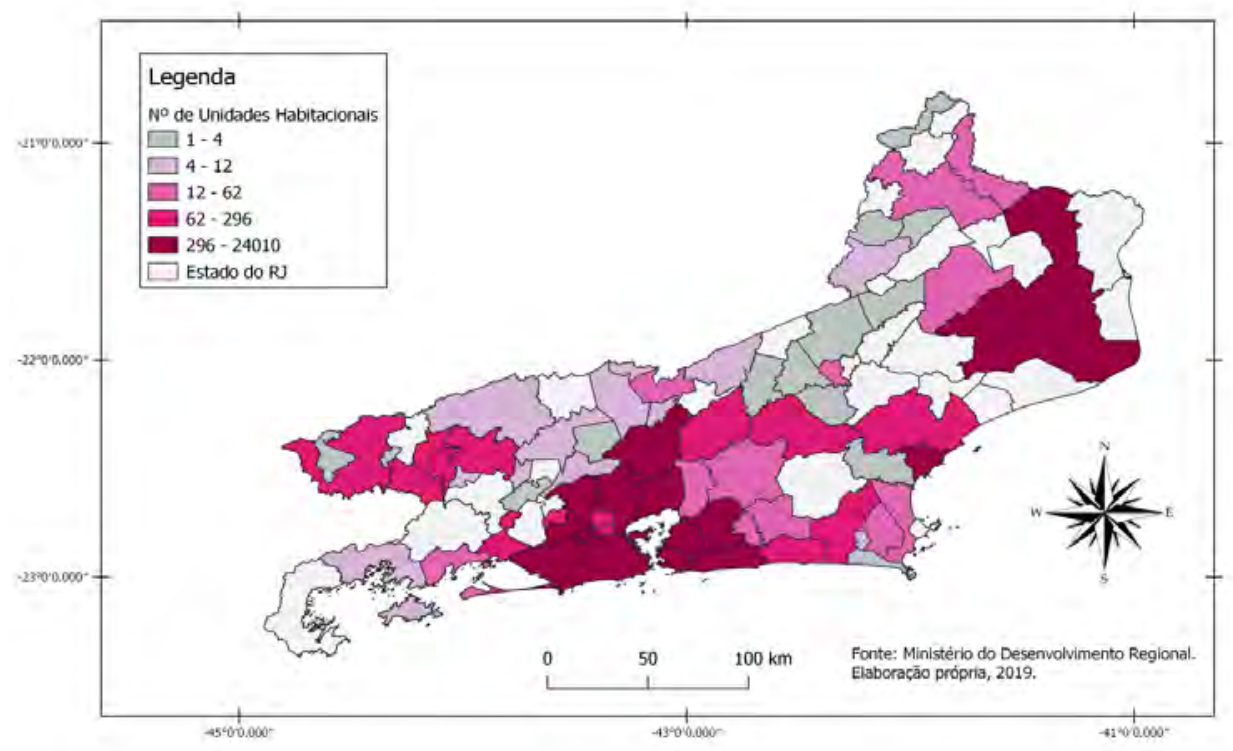

Fonte: Ministério do Desenvolvimento Regional. Elaboração própria, 2019.

Como dito, nesta etapa a espacialização do programa pelos municípios do estado permaneceu a mesma, não havendo perdas significativas de unidades concluídas. Embora nesta faixa o programa tenha conseguido manter o maior número unidades, de maneira geral, referente às contratadas e concluídas, na etapa de unidades entregues houve pequena, mas significativa perda, como percebido no mapa 10. 
Mapa 10 - Unidades entregues para a faixa 3 do PMCMV

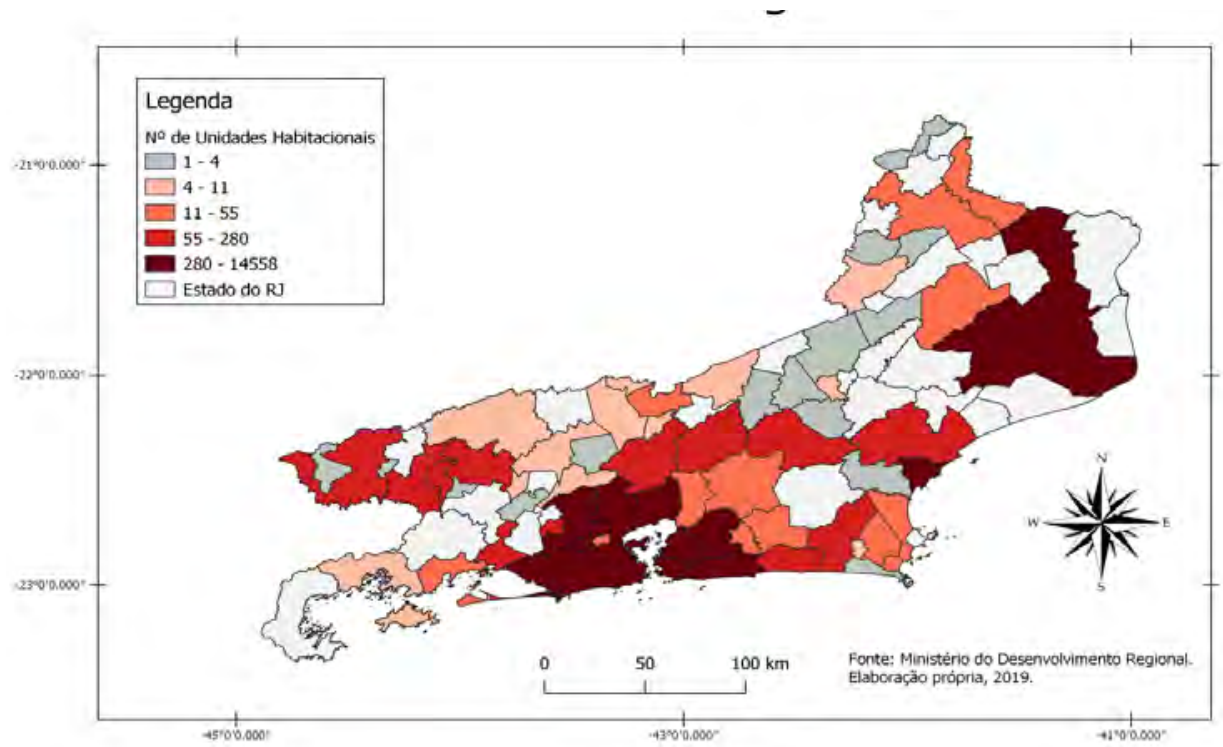

Fonte: Ministério do Desenvolvimento Regional. Elaboração própria, 2019.

Diante disso, podemos reafirmar que esta faixa apresenta melhor continuidade das unidades que foram contratadas, concluídas e entregues. Estando concentradas na maioria dos municípios da RMRJ, nos municípios de Campos dos Goytacazes e Rio das Ostras, com unidades entregues variando entre 280 a 14.558. Resende, Barra Mansa, Volta Redonda, Barra do Piraí, Itaguaí, Queimados, Petrópolis, Teresópolis, Nova Friburgo, Macaé, Maricá e Araruama participam com unidades entregues variando entre 55 a 280.

Nesse contexto, percebemos o caráter seletivo e até excludente do programa, no qual as faixas 2 e 3 , foram mais privilegiadas que a faixa 1 . Isso envolve a escolha de melhores locais dentro das cidades, que não apresentem sérios riscos, infraestrutura, formato das unidades (que não são necessariamente apartamentos, mas também casas), entre outros aspectos.

Para a faixa 1, que o subsídio do governo era maior e contemplava a maioria da população com déficit habitacional, os interesses do setor imobiliário parecem ter prevalecido, não havendo um estudo prévio sobre as condiçóes de risco, além de desrespeitar a origem das pessoas que seriam contempladas com o programa, como foi o caso do Terra Nova, em Nova Friburgo, onde famílias de variadas origens, ao terem seus imóveis perdidos 
pela tragédia, foram realocadas para uma área mais distante de seu local de origem e sem a garantia de uma qualidade de vida, porque lhes faltava uma série de serviços básicos.

Todavia, esta realidade não se apresenta apenas no interior do estado, mas também na capital, como será possível perceber na próxima seção.

\section{Espacializaçáo do Programa Minha Casa Minha Vida no município do Rio de Janeiro}

A grande demanda por habitação encontrada no estado do Rio de Janeiro também foi sentida pelo Programa Minha Casa Minha Vida na capital, principalmente para o segmento da faixa 1 do programa.

No entanto, seguindo a mesma lógica do que ocorreu no estado, esta faixa de renda náo se especializou por todas as áreas do território municipal, concentrando-se mais na regiáo oeste (mapa 11).

Mapa 11 - Unidades Contratadas para a faixa 1 do PMCMV na capital do Rio de Janeiro

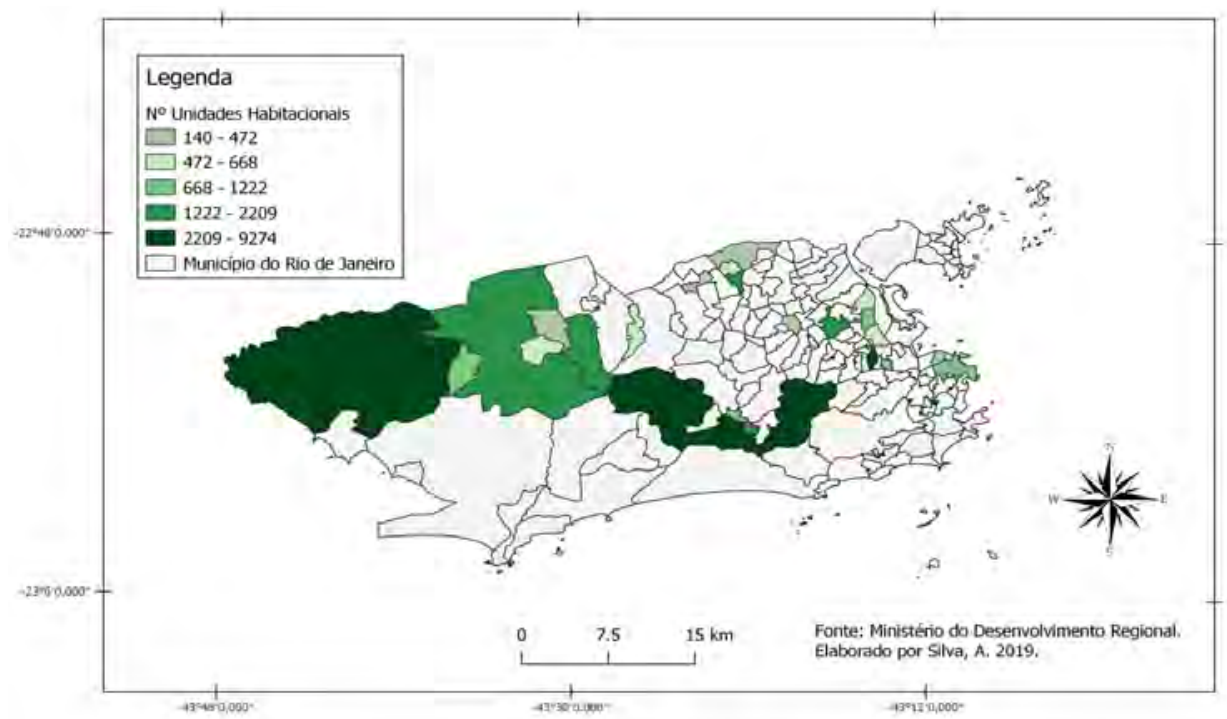

Fonte: Ministério do Desenvolvimento. Elaboração: Silva, 2019. 
Nesse sentido, bairros como Santa Cruz, no extremo oeste, além de Paciência e Jacarepaguá presenciaram uma quantidade maior de unidades contratadas para esta faixa, variando entre 2.209 a 9.274 unidades.

A mesma lógica de espacialização seguiu com a faixa 2 (mapa 12), em que a maioria dos bairros da zona oeste foram contemplados com unidades contratadas, embora para esta faixa apareçam bairros que não estavam na faixa anterior.

Mapa 12 - Unidades contratadas para a faixa 2 do PMCMV na capital do Rio de Janeiro

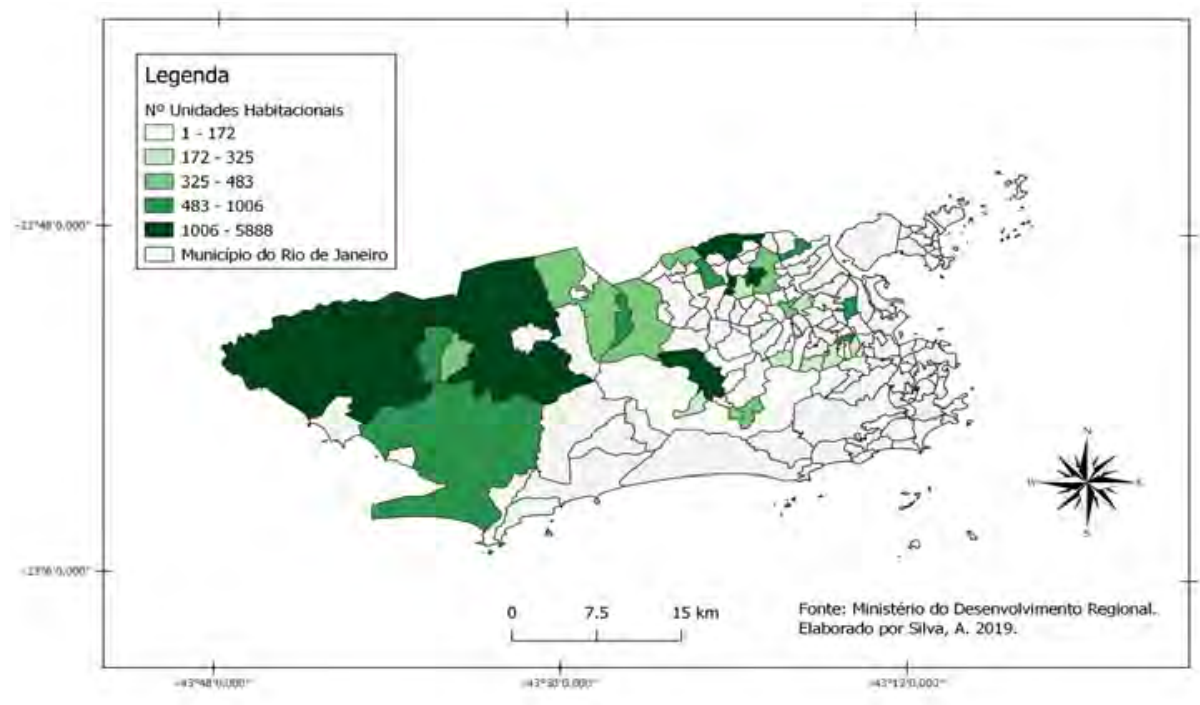

Fonte: Ministério do Desenvolvimento. Elaboração: Silva, 2019.

No entanto, percebemos que, das unidades contratadas para a faixa 3, o programa se espacializou com mais intensidade também pela zona norte da capital fluminense (mapa 13): 
Mapa 13 - Unidades contratadas para a faixa 3 do PMCMV na capital do Rio de Janeiro

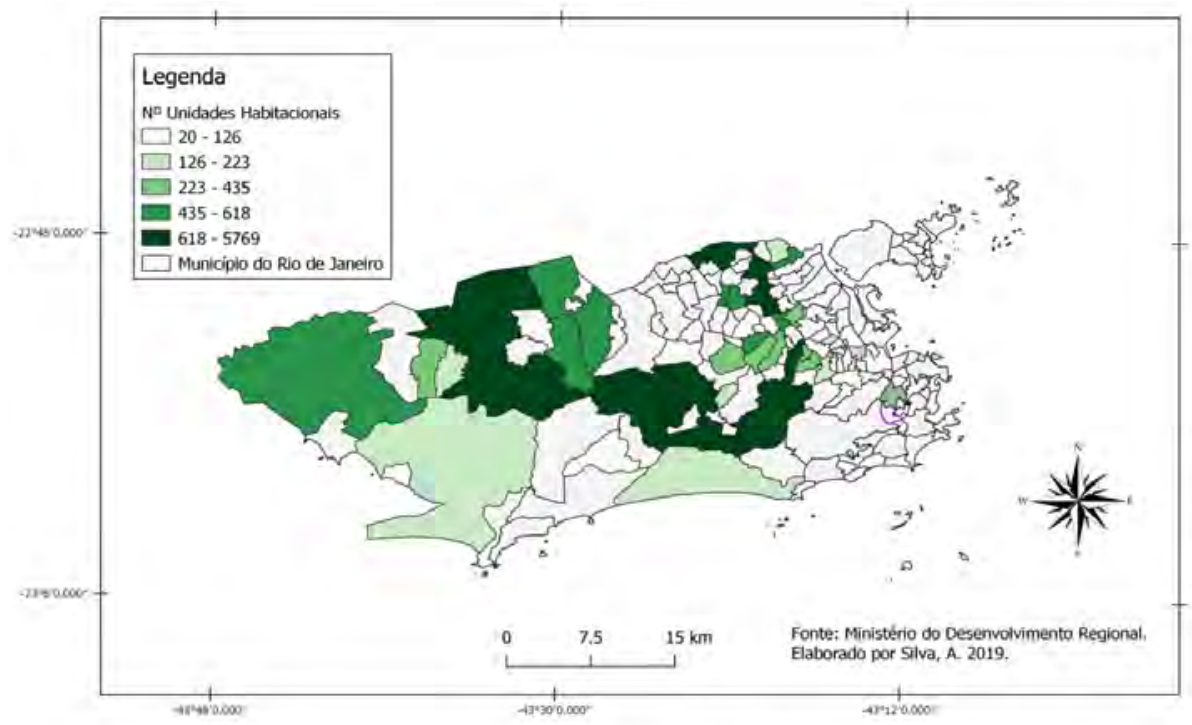

Fonte: Ministério do Desenvolvimento. Elaboração: Silva, 2019.

Nesse cenário, quando observamos as unidades que foram concluídas, notamos que houve um decréscimo do quantitativo em todas as faixas, embora mantendo certa estabilidade nos bairros em que estão espacializados. Ou seja, os bairros que apresentaram mais unidades contratadas conseguiram manter a quantidade de mais unidades concluídas (mapas 14, 15 e 16): 
Mapa 14 - Unidades concluídas para a faixa 1 do PMCMV na capital do Rio de Janeiro

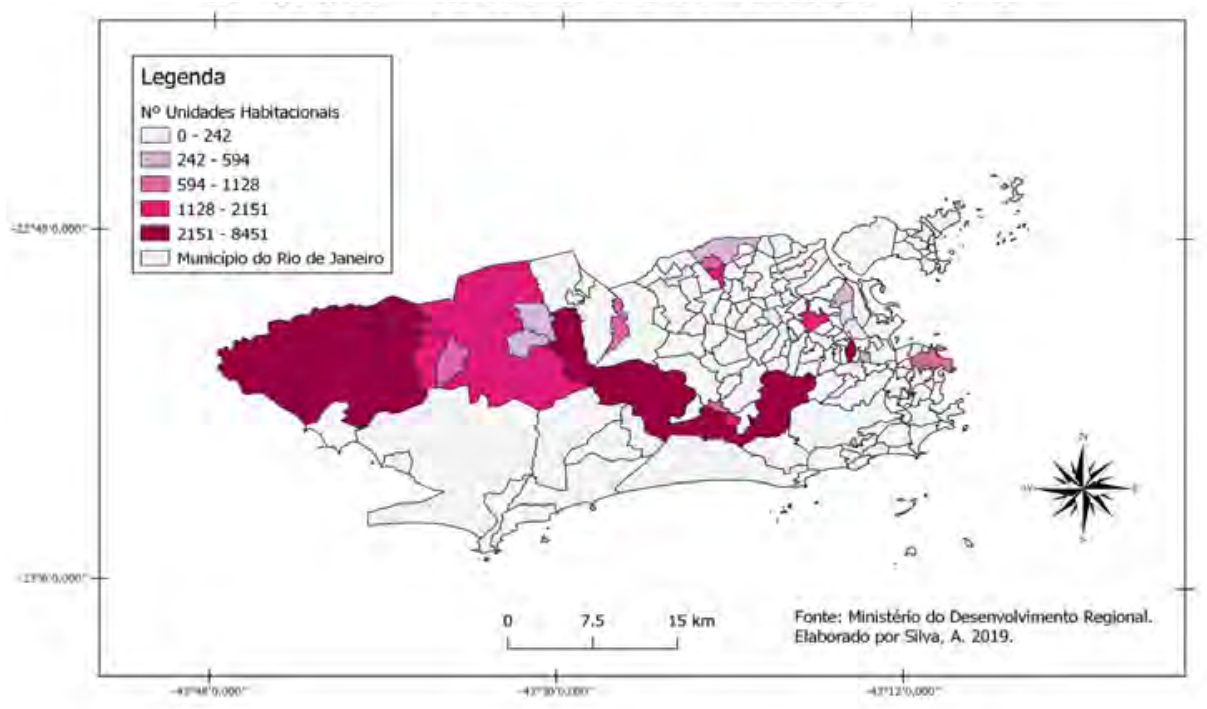

Fonte: Ministério do Desenvolvimento. Elaboração: Silva, 2019.

Mapa 15 - Unidades concluídas para a faixa 2 do PMCMV na capital do Rio de Janeiro

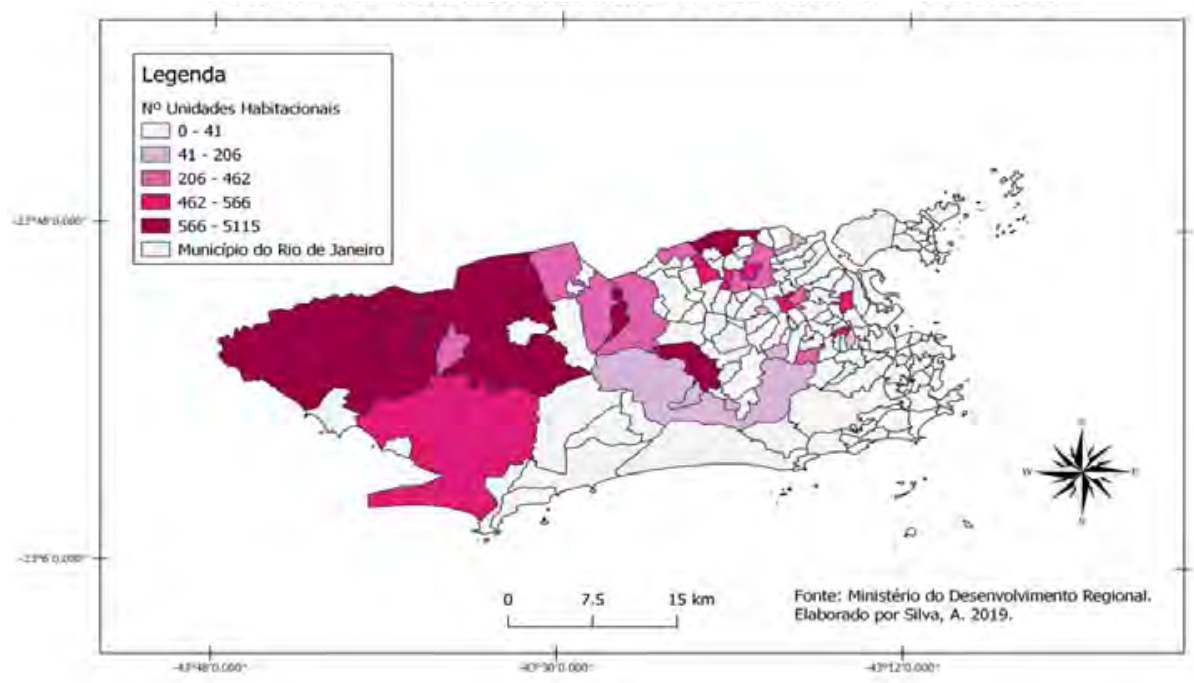

Fonte: Ministério do Desenvolvimento. Elaboração: Silva, 2019. 
Mapa 16 - Unidades concluídas para a faixa 3 do PMCMV na capital do Rio de Janeiro

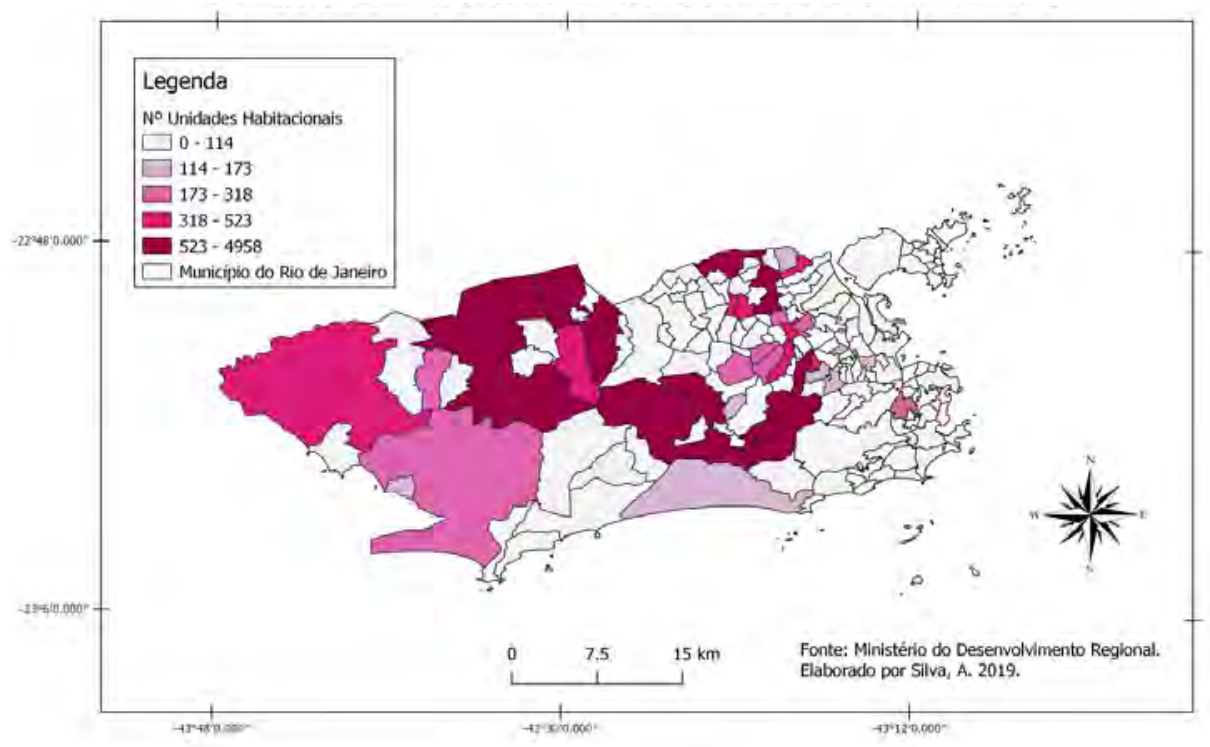

Fonte: Ministério do Desenvolvimento. Elaboração: Silva, 2019.

Diante desse contexto, reforçamos a lógica do programa para todas as faixas. Para as duas primeiras (faixa 1 e 2), as unidades tiveram maior concentração na zona oeste, enquanto que para a faixa 3 o programa se espacializou também pela zona norte.

Sendo assim, a mesma lógica seguiu também para as unidades entregues, tendo uma perda leve para a faixa 1 e um pouco mais significativa para as faixas 2 e 3 (mapas 17, 18 e 19) 
Mapa 17 - Unidades entregues para a faixa 1 do PMCMV na capital do Rio de Janeiro

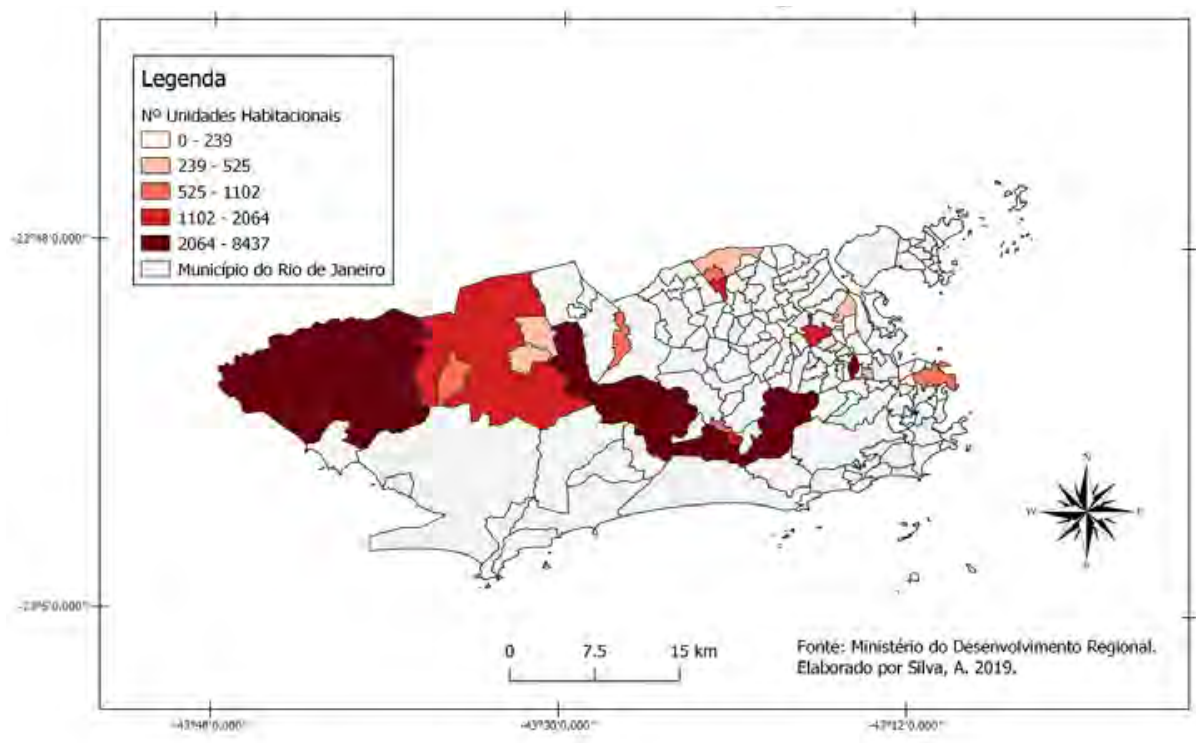

Fonte: Ministério do Desenvolvimento. Elaboração: Silva, 2019.

Mapa 18 - Unidades entregues para a faixa 2 do PMCMV na capital do Rio de Janeiro

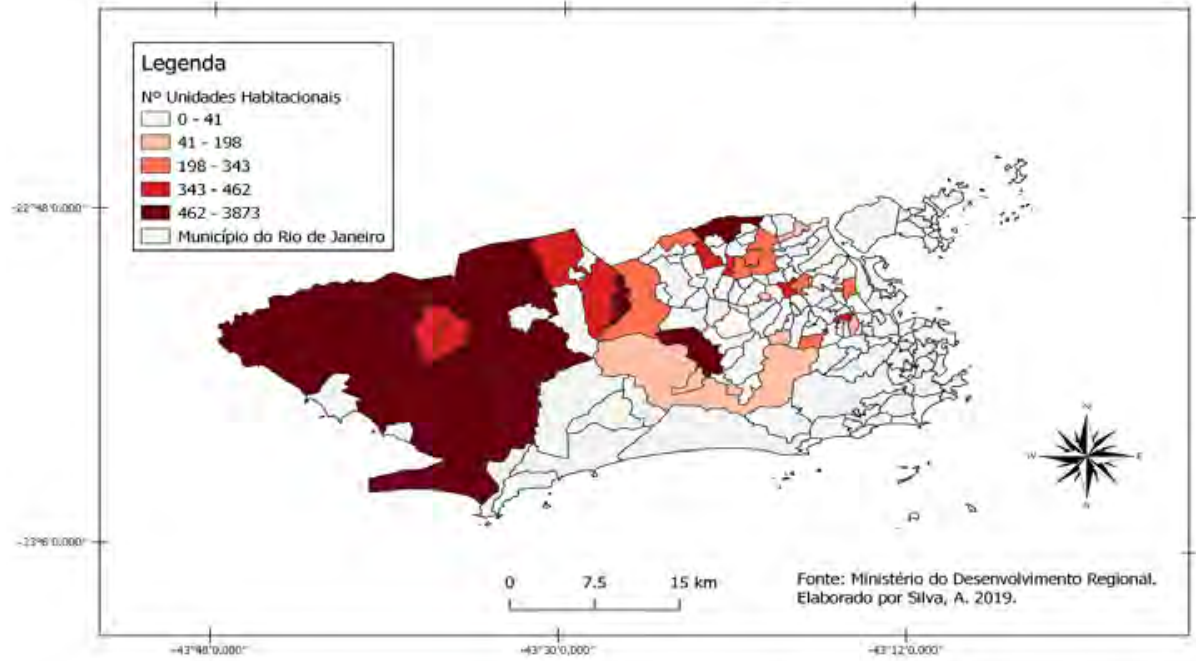

Fonte: Ministério do Desenvolvimento. Elaboração: Silva, 2019. 
Mapa 19 - Unidades entregues para a faixa 3 do PMCMV na capital do Rio de Janeiro

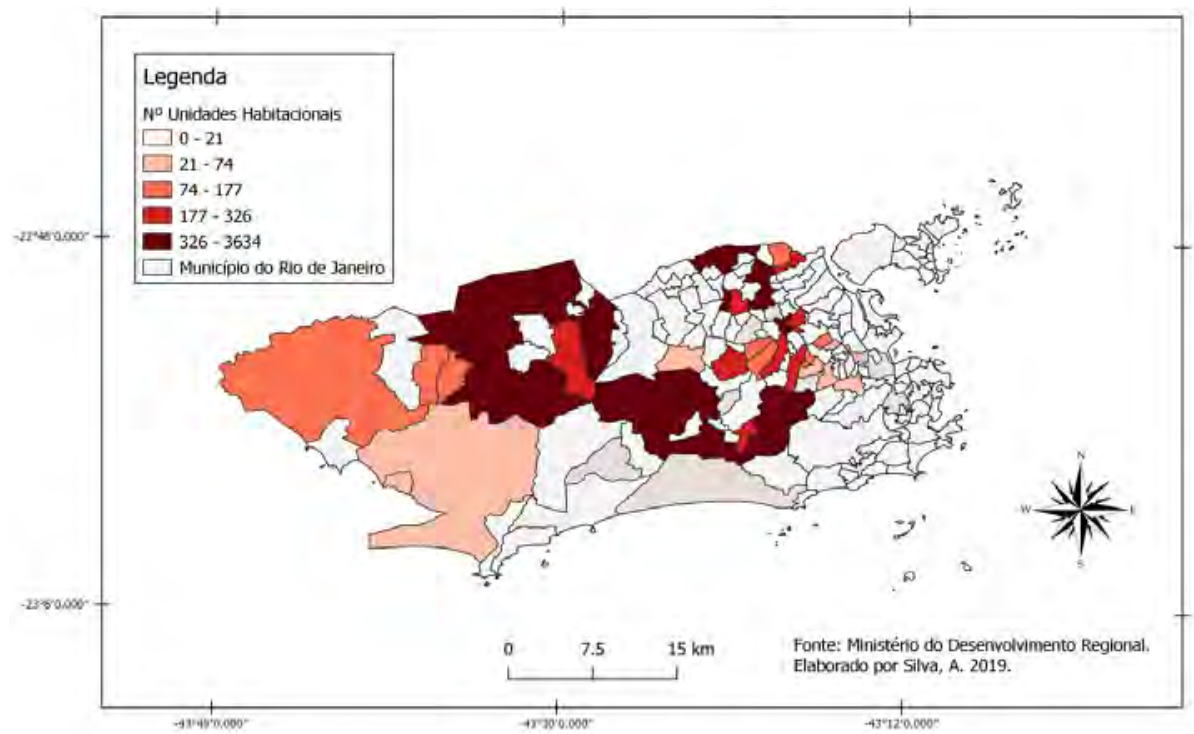

Fonte: Ministério do Desenvolvimento. Elaboração: Silva, 2019.

No geral, é possível identificar, com base na leitura dos mapas, uma concentração bastante significativa do PMCMV nas zonas oeste e norte da capital fluminense, inexistindo para todas as faixas na zona sul e muito pouco na área central.

De todo modo, o programa que deveria privilegiar a faixa social que mais necessita e sofre com o problema de habitação no estado e na capital do Rio de Janeiro deixou algumas lacunas. Isso fica mais visível quando analisamos os mapas para a faixa 1 nas três modalidades, sobretudo em relaçáo à localização das unidades, infraestrutura de toda a área do entorno dos condomínios, além da completa entrega das unidades. É preciso políticas públicas de qualidade e que levem em conta a diversidade de áreas e interesses presentes no nosso território para que, assim, sejam efetivadas.

\section{Consideraçóes finais}

Pensando as políticas públicas para habitação no país nas últimas décadas, pudemos perceber ao longo do capítulo que o Programa Minha Casa 
Minha Vida desempenhou papel de importante relevância para esta pasta do governo federal, uma vez que reposicionou a questão da habitação no país, além de ter impulsionado a economia, retardando o enfrentamento da crise que já vinha sendo enfrentada por outros países.

Considerando que as estimativas de construção de moradias nas três etapas analisadas do Programa - iniciado no governo Lula, em 2011, continuado até o governo Temer, em 2018 - chegaria a 3 milhóes de unidades, a maioria dessas unidades deveria privilegiar o grupo da populaçáo que recebia até 1 salário mínimo, haja vista o grande número de pessoas no país e, consequentemente, no estado do Rio de Janeiro, que sofrem com essa questão.

No entanto, as ações para minimização do problema do déficit habitacional no país pelo PMCMV ainda deixaram algumas lacunas que não foram preenchidas, principalmente no que diz respeito à faixa 1 , classe de rendimento que mais sofre com a questão de falta de moradia.

No estado do Rio de Janeiro, bem como na capital, esta faixa foi a que mais apresentou problemas nas três etapas de execuçáo do programa (contratação, conclusão e entrega), além de problemas relacionados à localização dos loteamentos, que de modo geral, ficavam muito distantes dos centros das cidades e das áreas onde as pessoas desenvolviam as suas vidas. Também apresentou problemas referentes à falta de serviços no entorno dos empreendimentos, o que força essa população a buscá-los em outras áreas da cidade. Enfim, a faixa social que mais necessitava das açôes do programa não teve suas aspiraçóes alcançadas em um sentido mais amplo para o estabelecimento de uma vida mais confortável.

Por outro lado, as faixas 2 e 3 do programa viram-se mais contempladas em vários aspectos, variando de localizaçáo à modalidade de moradia (casa ou apartamento). Pode-se dizer que as unidades contratadas, concluídas e entregues para essas faixas foram muito consideráveis se comparadas à faixa 1, enfoque do programa.

Para a capital fluminense, percebemos que o programa se concentrou na zona oeste do município, apresentando também unidades na zona norte, principalmente quando destinada para as faixas 2 e 3 .

Nesse sentido, embora o PMCMV tenha tido alguns pontos falhos na sua execução, não podemos deixar de salientar seu aspecto positivo ao garantir a habitação para milhóes de brasileiros e, em especial, para a população do 
estado e da capital do Rio de Janeiro. Um contingente considerável do estado conseguiu garantir a casa própria a partir deste programa.

\section{Referências}

ANDRADE, Gabriel Vieira Marx. Políticas Habitacionais Brasileiras: Uma Avaliaçáo do Programa Minha Casa, Minha Vida em suas duas ediçôes (Dissertação). Rio de Janeiro, 2012. ARANTES, Pedro Fiori e FIX, Mariana. "Como o governo Lula pretende resolver o problema da habitação". Caros Amigos, pp. 1-25, 2009. Disponível em: https://xa.yimg.com/kq/ groups/14917735/451095191/name/Pacote_Pedro_Mariana_Final_COMPLETO.pdf. Acesso em 2019.

BONDUKI, N. "Política habitacional e inclusão social no Brasil: revisão história e evolução no Governo Lula. Revista Eletrônica de Arquitetura e Urbanismo, São Paulo, n. 1, pp. 70-104, 2008.

BORGES, Raphael Melo. Análise de desempenho térmico e acústico de unidades habitacionais construidas no conjunto habitacional Benjamin José Cardoso em Viçosa-MG. (Dissertação). Viçosa: Universidade Federal de Viçosa, 2013.

Fundação CEPERJ - Centro Estadual de Estatísticas, Pesquisas e Formação de Servidores Públicos do Rio de Janeiro. Cartografia fluminense, 2019. Disponível em: <http://www. ceperj.rj.gov.br/>. Acesso em 2019.

Fundação Getúlio Vargas. Análise das necessidades habitacionais e suas tendências para os próximos 10 anos. Rio de Janeiro, 2018.

HERVÉ, Thery. "Novas Paisagens Urbanas do Programa Minha Casa, Minha Vida”. Mercator - Revista de Geografia da UFC., Fortaleza, v. 16, n. 1, 2017.

IBGE - Instituto Brasileiro de Geografia e Estatística. População do estado do Rio de Janeiro. Disponível em: https://cidades.ibge.gov.br/brasil/rj/panorama Acesso em: 24 set. 2019.

MARAFON, G. J. (orgs.). Geografia do Estado do Rio de Janeiro: Da compreensão do passado aos desafios do presente. Rio de Janeiro: Gramma, 2011. $161 \mathrm{p}$.

MARICATO, Erminia. "O 'Minha Casa' é um avanço, mas segregação urbana fica intocada". Carta Maior, maio 2009. Disponivel em http://cartamaior.com.br. Acesso em: mar. 2010.

Portal Brasileiro de Dados Abertos. Indicadores sobre o Programa Minha Casa, Minha Vida. 2016.

RAMOS, J. da S. e NÓIA, A. C. "Análise da execução do Programa Minha Casa Minha Vida nos municípios de Ilhéus e Itabuna, Bahia". Semana do Economista, 4., Encontro de Egressos, 4., Ilhéus, 2014. pp. 1-20.

ROMAGNOLI, Alexandre J. "O programa 'minha casa, minha vida': continuidades, inovaçôes e retrocessos”. In: Temas de Administração Pública - TEMAP., São Paulo, v. 4, n. 7, pp. 1-29, 2012.

ROLNIK, Raquel et al. "O Programa Minha Casa Minha Vida nas regiôes metropolitanas de São Paulo e Campinas: aspectos socioespaciais e segregação”. In: Cad. Metrop., São Paulo, v. 17, n. 33, pp. 127-54, 2015. 



\title{
A inserção urbana de empreendimentos do Programa Minha Casa Minha Vida em João Pessoa, Campina Grande e Patos, na Paraíba
}

\author{
Livia Miranda \\ Demóstenes Moraes \\ Juliana Peixoto de Araújo
}

\section{Consideraçóes iniciais}

Os avanços institucionais nas últimas duas décadas em relação à questão habitacional no Brasil foram significativos. Foram elaborados a Política Nacional de Habitação (PNH), em 2004, e o Plano Nacional de Habitação (PlanHab), em 2008. Também foram instituídos em 2005, pela Lei Federal n..$^{\circ} 11.124$, o Sistema Nacional de Habitaçáo de Interesse Social (SNHIS) e o Fundo Nacional de Habitação de Interesse Social (FNHIS). Além destes instrumentos, dois programas federais, o Programa de Aceleração do Crescimento (PAC), lançado em 2007, e o Programa Minha Casa Minha Vida (PMCMV), criado em 2009, foram responsáveis pela provisão de soluçóes habitacionais em escala inédita.

O PMCMV, concebido pelos Ministérios da Casa Civil e da Fazenda em parceria com grandes construtoras, instituído pela Lei Federal n. ${ }^{\circ}$ 11.977/2009, tinha como objetivo fundamental enfrentar as repercussóes no País da crise econômica global de 2008, servindo como medida anticíclica a partir do investimento na construçáo civil para a ampliaçáo da oferta de habitaçôes, com repercussóes, ainda, na geração de empregos e nas dinâmicas imobiliárias. O programa foi implementado contando com a combinação de 
subsídios e financiamentos e em parceria com estados, municípios, empresas e entidades sem fins lucrativos.

O PMCMV, em função do volume de recursos e abrangência de intervenção e, também, em decorrência dos subsídios para alcançar a população de baixa renda, teve repercussóes econômicas e sociais expressivas, com mais de 5 milhóes de contratos assinados em 9 anos (2009-18), número acima dos 4,8 milhóes de contratos realizados pelo Banco Nacional de Habitação (BNH) em 22 anos. O programa possibilitou, ainda, o estímulo ao mercado privado para o atendimento da populaçáo de baixa renda e a criação de um marco regulatório para a regularização fundiária de áreas ocupadas. Mesmo com estes avanços, diversas avaliaçóes do PMCMV têm apontado para problemas em relação aos empreendimentos, principalmente os da Faixa 1, voltados à população de baixa renda.

Vários estudos para a avaliação do PMCMV foram realizados, entre eles é importante destacar o conjunto de pesquisas decorrentes do edital lançado pelo Conselho Nacional de Desenvolvimento Científico e Tecnológico (CNPq) e Ministério das Cidades em 2012, resultando na avaliação de empreendimentos do programa em 22 municípios de 6 estados. As instituiçóes envolvidas na pesquisa constituíram a Rede Cidade e Moradia e, a partir dos estudos e avaliaçóes, apontaram questóes importantes em relação aos empreendimentos voltados à população de baixa renda, na Faixa 1 do programa, entre as quais destacam-se: (i) a prevalência de um padrão de produção de soluçóes homogêneas, nos âmbitos arquitetônico, urbanístico e construtivos, em decorrência de obstáculos normativos e dos interesses das construtoras; (ii) a periferização dos empreendimentos, em áreas com insuficiência de serviços, equipamentos e oportunidades socioeconômicas; (iii) a flexibilização das legislaçóes locais para a aprovação dos projetos, incluindo a ampliaçáo dos perímetros urbanos; (iv) a predominância do condomínio para a gestão dos empreendimentos pelos moradores, que tem acarretado dificuldades na manutenção de espaços coletivos, conflitos de vizinhança e vulnerabilidade para atuação de facçóes do narcotráfico e de milícias (Santo Amore et al., 2015).

Em relação à inserção urbana, os empreendimentos do PMCMV da Faixa 1 foram executados, em sua maioria, sem atentar às especificidades dos municípios, com insuficiente integração ao tecido urbano local. Estão localizados predominantemente em áreas menos valorizadas das cida- 
des, marcadas por alguma forma de precariedade e pela insuficiência de infraestrutura, serviços urbanos e de oportunidades socioeconômicas. Vale ressaltar as grandes dimensóes dos empreendimentos para viabilizar a reprodução de muitas unidades. A omissão dos governos locais no tocante ao estabelecimento de regras e controle do uso e ocupação do solo contribuiu à ampliação do processo de periferização e espraiamento da área urbana, quando muitas vezes há diversos vazios na malha urbana consolidada, com maior oferta de serviços.

As crises econômicas e políticas que se sucederam entre 2015 e 2016 resultaram na diminuiçáo drástica dos investimentos em políticas sociais (Cardoso e Denaldi, 2018, p. 12). É muito provável que náo haja programas federais habitacionais que alcancem de modo significativo a população de baixa renda nos próximos anos, em um contexto de predominância de políticas pró-mercado.

Todas as questóes levantadas sobre o PMCMV serviram de estímulo para a proposiçấo da Pesquisa: "Empreendimentos Habitacionais em Espaços Periféricos: Desafios para o Planejamento Territorial Integrado" (Miranda, 2018). Buscou-se por meio dessa pesquisa desenvolver análises sobre a inserçáo urbana e a qualidade arquitetônica e urbanística dos empreendimentos produzidos pelo PMCMV em alguns municípios paraibanos.

Alguns resultados da pesquisa serão apresentados nesse artigo que está estruturado em três partes, além dessas consideraçóes iniciais: na primeira, apresenta-se algumas consideraçóes metodológicas e os parâmetros de avaliaçâo utilizados; na segunda discute-se os principais impactos da inserçáo de cinco empreendimentos os casos de João Pessoa, Campina Grande e Patos, de forma associada com entrevistas que coletaram a impressão dos moradores. Por fim, são apresentadas algumas consideraçôes finais.

\section{Algumas consideraçôes metodológicas}

A pesquisa tomou como referências o "Estudo sobre a formas de provisão da moradia e seus impactos na reconfiguração espacial das metrópoles", desenvolvido no âmbito da rede INCT Observatório das Metrópoles e a pesquisa da Rede Cidade e Moradia (Santo Amore et al., 2015). Para complementar as análises das características arquitetônicas e urbanísticas dos empreendimentos, novos indicadores foram acrescentados. Além dos obje- 
tivos propostos inicialmente, foi possível, ainda, construir uma adaptação metodológica para adequar a aplicaçáo de instrumentos, indicadores e parâmetros para os casos de cidades intermediárias e para avaliar os impactos nas periferias das cidades paraibanas, caracterizadas por fragilidades ambientais e pela precariedade das condiçóes socioespaciais.

A análise da provisão de empreendimentos habitacionais do PMCMV no estado da Paraíba estruturou-se em três escalas: (i) na escala do estado, foram observadas as estratégias de promoção do programa, as modalidades e a sua distribuição territorial; (ii) na escala dos municípios foram analisados três estudos de caso: João Pessoa, Campina Grande e Patos - municípios que concentravam $70 \%$ dos empreendimentos promovidos para a população mais vulnerável do Estado; (iii) na escala do empreendimento foram analisados cinco casos assim distribuídos - dois em João Pessoa (Solar das Mangueiras e Morada dos Hibiscos); dois em Campina Grande, com quatro condomínios cada (Residenciais Major Veneziano I, II, III, IV e Residenciais Dona Lindu I, II, III, IV) e um em Patos, com dois empreendimentos (Residenciais Vista da Serra I, II).

O porte das cidades estudadas implicou na necessidade de adequaçóes metodológicas, em funçáo do diâmetro da mancha urbana (menores do que nos casos de estudo paulistas e cariocas) e das modalidades de deslocamento, que tinham implicação direta sobre o tempo de deslocamento, distâncias a equipamentos, entre outros parâmetros.

Após a seleção dos municípios, foram definidos os empreendimentos do PMCMV que seriam analisados. Para o desenvolvimento do estudo, foram utilizados o conjunto de variáveis da pesquisa nacional (Rede Cidade e Moradia), observando: (i) a diversidade no porte dos empreendimentos; (ii) o tempo de ocupação, dando preferência aos que tivessem no mínimo 1 ano de ocupação; (iii) as faixas de renda a que se destinavam, priorizando aqueles da Faixa 1; (iv) observação da produção a partir de modalidades diferentes do programa; (v) a inserção na cidade, considerando a localização e conexóes com a malha urbana e o acesso dos moradores a equipamentos e serviços urbanos.

Foram selecionados empreendimentos com características, padróes de inserção e portes distintos, listados no Quadro 1, discriminados por faixa, número de unidades, tipologias, fase, ano de entrega e modalidade. 
Quadro 1 - Características dos empreendimentos selecionados por município.

\begin{tabular}{|c|c|c|c|c|c|c|c|}
\hline$\underset{\mathrm{U}}{\stackrel{\mathrm{U}}{\mathrm{O}}}$ & 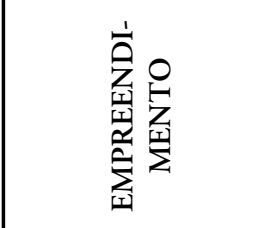 & 发 & 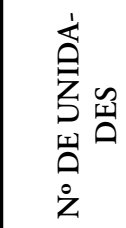 & \begin{tabular}{l}
$j$ \\
\multirow{3}{5}{} \\
0 \\
0 \\
0 \\
$\vdots$
\end{tabular} & 占 & 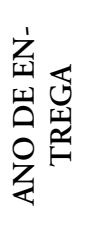 & 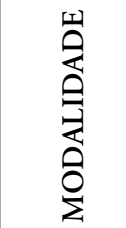 \\
\hline \multirow{2}{*}{$\begin{array}{l}\text { João } \\
\text { Pessoa }\end{array}$} & Morada dos Hibiscos & 1 & 224 & Apartamento & 1 & 2015 & Entidades \\
\hline & Solar das Mangueiras & 1 & 165 & Casa & 1 & 2010 & Entidades \\
\hline \multirow{8}{*}{$\begin{array}{l}\text { Campina } \\
\text { Grande }\end{array}$} & Major Veneziano I & 1 & 496 & Apartamento & 2 & 2013 & Urbano \\
\hline & Major Veneziano II & 1 & 496 & Apartamento & 2 & 2013 & Urbano \\
\hline & Major Veneziano III & 1 & 496 & Apartamento & 2 & 2013 & Urbano \\
\hline & Major Veneziano IV & 1 & 496 & Apartamento & 2 & 2014 & Urbano \\
\hline & Dona Lindú I & 2 & 240 & Apartamento & 1 & 2011 & Urbano \\
\hline & Dona Lindú II & 2 & 240 & Apartamento & 1 & 2011 & Urbano \\
\hline & Dona Lindú III & 2 & 256 & Apartamento & 1 & 2011 & Urbano \\
\hline & Dona Lindú IV & 2 & 208 & Apartamento & 1 & 2011 & Urbano \\
\hline \multirow{2}{*}{ Patos } & Vista da Serra I & 1 & 136 & Casa & 1 & 2011 & Urbano \\
\hline & Vista da Serra II & 1 & 109 & Casa & 2 & 2014 & Urbano \\
\hline
\end{tabular}

Fonte: Ministério das Cidades (Brasil, 2015 e Miranda, 2018).

No Quadro 2, estão relacionados os instrumentos de análise, com as dimensôes e indicadores trabalhados na pesquisa.

1 Os empreendimentos de João Pessoa e Campina Grande se configuram em condomínios fechados (cercado por muros com guarita e porta única de entrada) e os de Patos, condomínios abertos. 
Quadro 2 - Instrumentos de análise - Dimensóes e Indicadores

\begin{tabular}{l|l}
\hline DIMENSÓES & INDICADORES \\
\hline Condiçóes Socioeconômicas e Inserçáo no & Perfil Socioeconômico da Família \\
\cline { 2 - 2 } Mundo do Trabalho & Situação de Trabalho \\
\hline \multirow{2}{*}{ Direito à Cidade e Inserçáo Urbana } & Condiçôes de Moradia \\
\cline { 2 - 2 } & Mobilidade Urbana \\
\cline { 2 - 2 } Trabalho Social, Participação e & Acesso à Cidade e a Serviços \\
\hline Sociabilidade & Sociabilidade \\
\cline { 2 - 2 } & Participação \\
\cline { 2 - 2 } & Avaliação sobre o Trabalho Social \\
\hline \multirow{2}{*}{ Satisfação e Necessidades do Morador } & $\begin{array}{l}\text { Avaliação do Morador sobre Necessidades, Condiçóes } \\
\text { de Moradia e Relaçóes Sociais }\end{array}$ \\
\hline
\end{tabular}

Fonte: Miranda, 2018.

No Quadro 3 estão as quantidades de questionários calculados e aplicados em cada um dos empreendimentos. Aplicou-se, na maioria dos casos, um número maior de questionários, ultrapassando a amostra calculada e, assim, conferindo mais segurança na obtenção de dados. A exceçáo foi o caso do Condomínio Residencial Dona Lindú em Campina Grande, em decorrência de dificuldades de acesso aos condomínios.

Quadro 3 - Características dos Empreendimentos estudados

\begin{tabular}{l|c|c|c}
\hline $\begin{array}{l}\text { EMPREENDIMEN- } \\
\text { TOS ESTUDADOS }\end{array}$ & $\begin{array}{c}\text { No TOTAL DE UNI- } \\
\text { DADES }\end{array}$ & $\begin{array}{c}\text { QUESTIONÁRIOS } \\
\text { CALCULADOS }\end{array}$ & $\begin{array}{c}\text { QUESTIONÁRIOS } \\
\text { APLICADOS }\end{array}$ \\
\hline Morada dos Hibiscos & 224 & 54 & 58 \\
\hline Solar das Mangueiras & 165 & 50 & 68 \\
\hline $\begin{array}{l}\text { Major Veneziano I, II, } \\
\text { III e IV }\end{array}$ & 1984 & 69 & 80 \\
\hline $\begin{array}{l}\text { Dona Lindú I, II, III } \\
\text { e IV }\end{array}$ & 944 & 66 & 60 \\
\hline Vista da Serra I e II & 245 & 55 & 63 \\
\hline
\end{tabular}

Fonte: Miranda, 2018.

\section{O universo de estudo: Joáo Pessoa, Campina Grande e Patos}

No município de João Pessoa, foram estudados empreendimentos do PMCMV na Modalidade Entidades. O objetivo foi confrontar com os 
demais casos estudados e averiguar se o modelo de empreendimento nessa modalidade, produzido por associaçóes, cooperativas etc., apresentaria diferenças quanto à inserção e às condições urbanísticas, arquitetônicas e construtivas. Os empreendimentos selecionados foram os condomínios Morada dos Hibiscos e Solar das Mangueiras, realizados por uma cooperativa, com tipos habitacionais diferentes; o primeiro, integrado por edifícios multifamiliares e o segundo, contando com unidades térreas unifamiliares. No Caso de Campina Grande foram analisados os conjuntos residenciais Dona Lindú I, II, III e IV e o Major Veneziano I, II, III e IV, ambos compostos por condomínios integrados por edifícios multifamiliares verticalizados. Eram os maiores empreendimentos habitacionais entregues até o momento de seleção dos casos para a pesquisa. No município de Patos foram analisados os Residenciais Vista da Serra I e II, compostos por edificaçóes unifamiliares térreas independentes.

Cartograma 1 - Regióes Metropolitanas de João Pessoa, Campina Grande e Patos no Estado da Paraíba

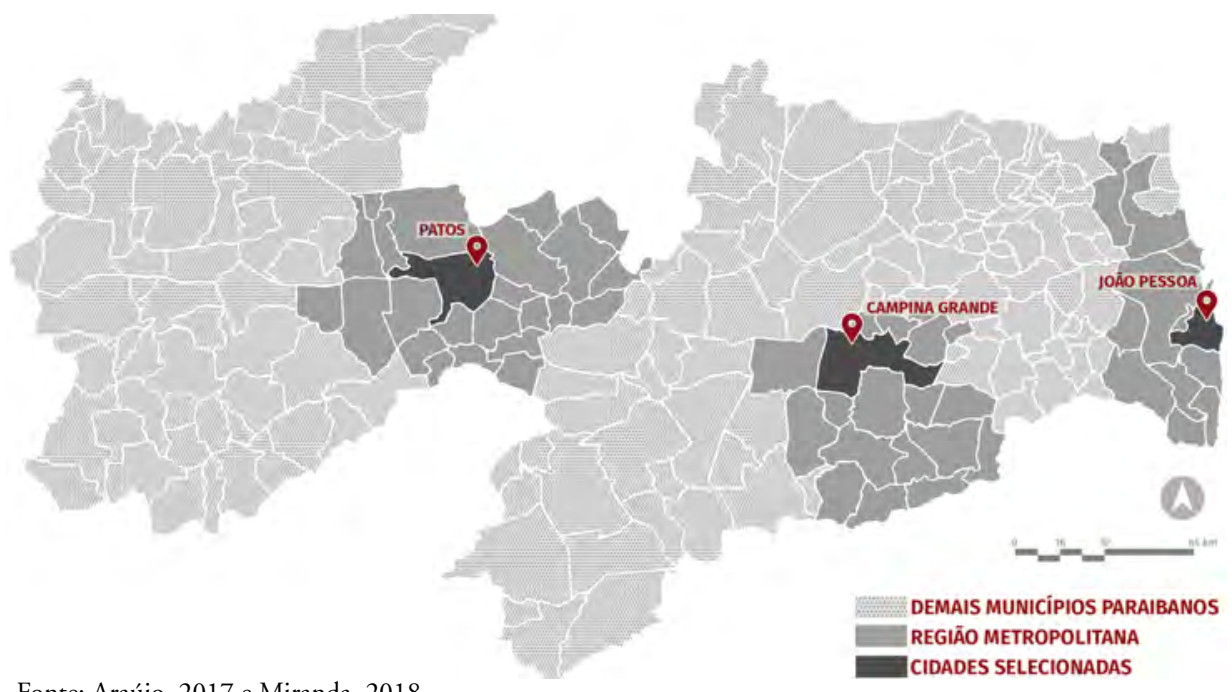

Fonte: Araújo, 2017 e Miranda, 2018. 
Cartograma 2 - Morada dos Hibiscos e Solar das Mangueiras em João Pessoa-PB

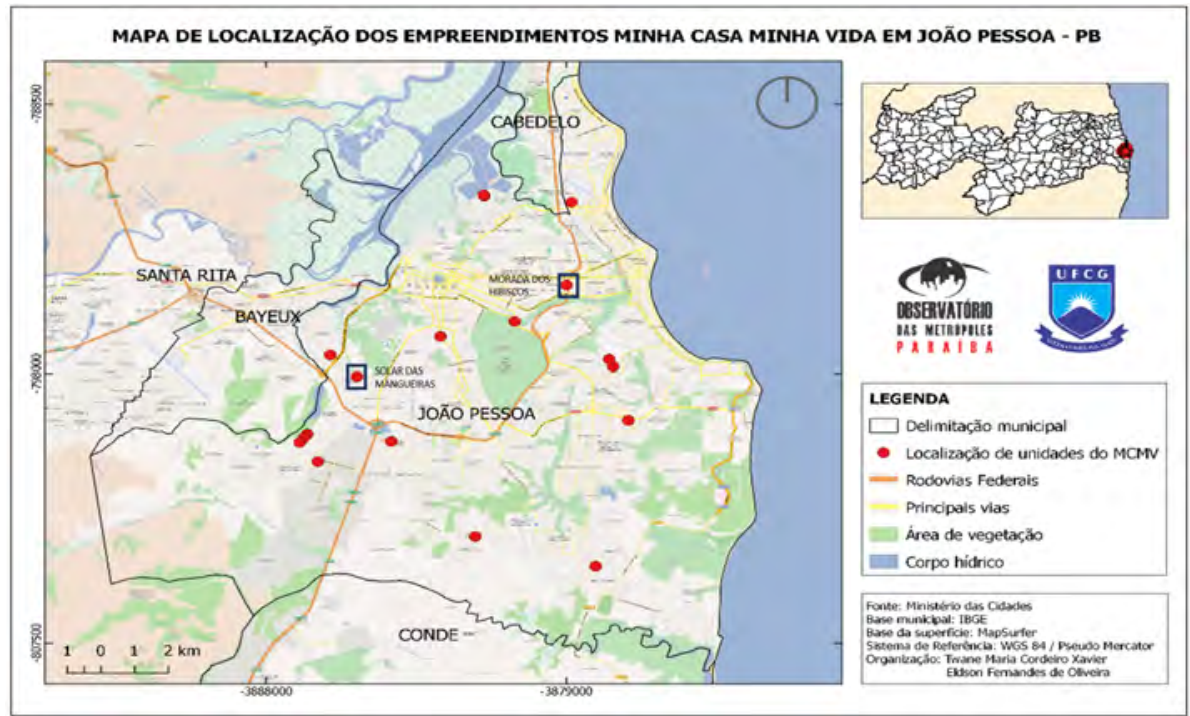

Fonte: Araújo, 2017 e Miranda, 2018.

Cartograma 3 - Residenciais Dona Lindú I, II, III e IV e Major Veneziano I, II, III e IV em Campina Grande-PB

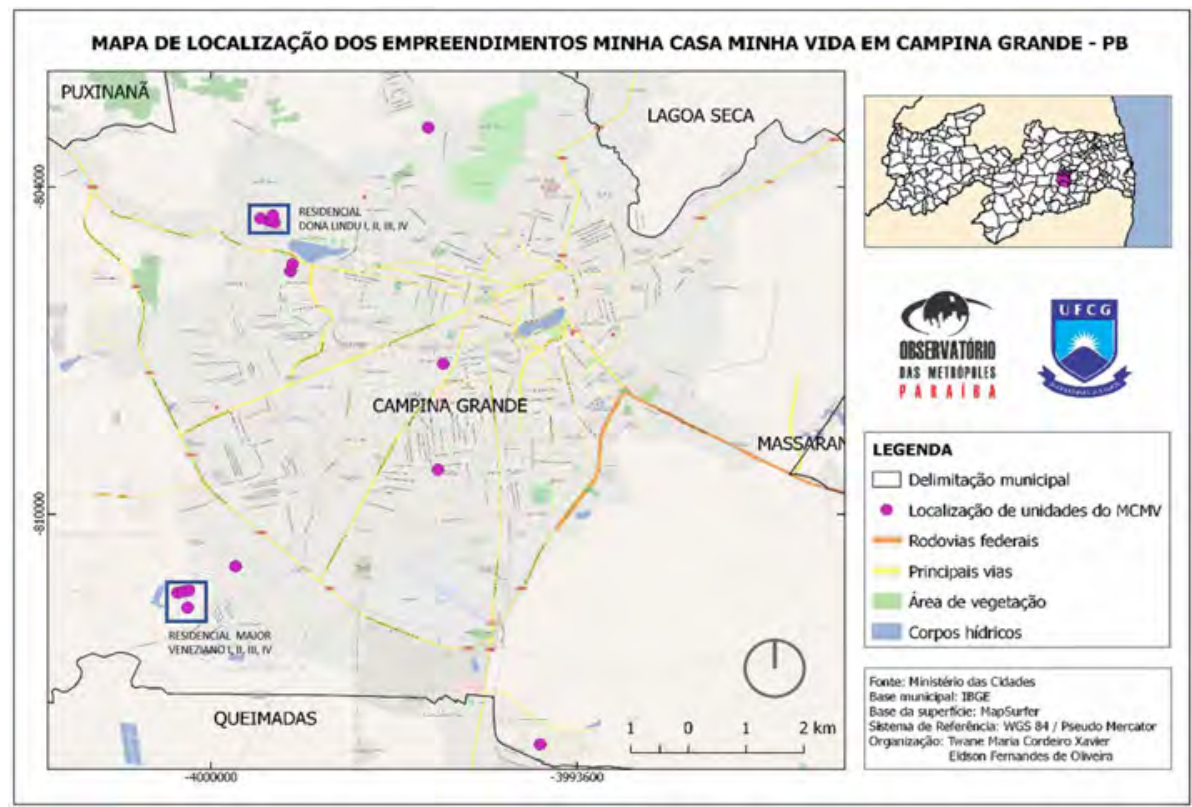

Fonte: Araújo, 2017 e Miranda, 2018. 
Cartograma 4 - Residenciais Vista da Serra I e II em Patos-PB

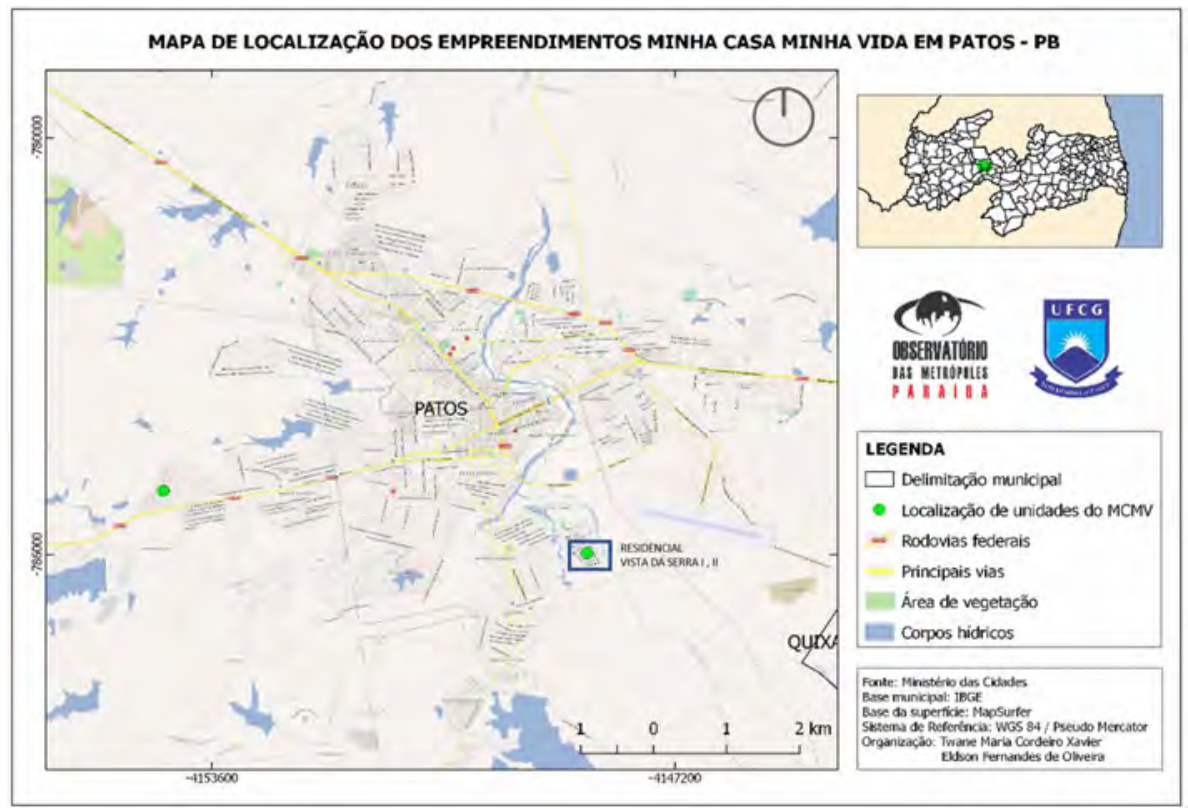

Fonte: Araújo, 2017 e Miranda, 2018.

Ferramenta de avaliação de inserção urbana: temas, indicadores parâmetros e qualificação

A Ferramenta é fruto de uma parceria entre o LabCidade (Laboratório Espaço Público e Cidade da Faculdade de Arquitetura e Urbanismo da USP) e o ITDP Brasil (Instituto de Políticas de Transporte e Desenvolvimento). ${ }^{22}$ No Quadro 4 constam os temas, indicadores, parâmetros e qualificação que foram utilizados na pesquisa, referenciados na Ferramenta, com parâmetros adaptados considerando as condições dos Municípios estudados.

2 A ferramenta foi desenvolvida como produto da pesquisa "Ferramentas para avaliação da inserção urbana dos empreendimentos do MCMV", coordenada por Raquel Rolnik e realizada com recursos do CNPq (com recursos da Chamada MCTI/CNPq/ MCIDADES no 11/2012) e da Ford Foundation. 
Quadro 4 - Ferramenta de Avaliação de Inserção Urbana

TEMA 01: TRANSPORTE

\begin{tabular}{|c|c|c|}
\hline Indicadores & Parâmetros & Qualificação \\
\hline $\begin{array}{l}\text { 1. OPÇÓES DE } \\
\text { TRANSPORTE }\end{array}$ & \multirow{3}{*}{$\begin{array}{l}\text { Quantidade de itinerários di- } \\
\text { ferentes realizados por uma ou } \\
\text { mais linhas de transporte públi- } \\
\text { co, que podem ser acessadas em } \\
\text { pontos de ônibus localizados no } \\
\text { entorno do empreendimento. }\end{array}$} & $\begin{array}{l}\text { Boa - } 4 \text { ou mais itinerários dife- } \\
\text { rentes }\end{array}$ \\
\hline \multirow{2}{*}{$\begin{array}{l}\text { Avaliar se o local onde será } \\
\text { construído o empreendimento } \\
\text { é bem servido de opçóes de } \\
\text { transporte público e diversidade } \\
\text { de itinerários. }\end{array}$} & & $\begin{array}{l}\text { Aceitável - Pelo menos } 3 \text { itinerá- } \\
\text { rios diferentes }\end{array}$ \\
\hline & & $\begin{array}{l}\text { Insuficiente - } 2 \text { ou menos itinerá- } \\
\text { rios diferentes }\end{array}$ \\
\hline $\begin{array}{l}\text { 2. FREQUENCIA DO } \\
\text { TRANSPORTE }\end{array}$ & \multirow{3}{*}{$\begin{array}{l}\text { Frequência e período de opera- } \\
\text { ção das linhas de transporte pú- } \\
\text { blico identificadas no Indicador } \\
1 \text { - Opçóes de Transporte duran- } \\
\text { te os dias úteis. }\end{array}$} & $\begin{array}{l}\text { Boa - Até } 10 \text { min., com período } \\
\text { de operaçáo } 24 \text { horas }\end{array}$ \\
\hline \multirow{2}{*}{$\begin{array}{l}\text { Avaliar o serviço das opçóes de } \\
\text { transporte público existentes, } \\
\text { observando a presença de frequ- } \\
\text { ência regular e tempos de espera } \\
\text { aceitáveis. }\end{array}$} & & $\begin{array}{l}\text { Aceitável - } 11 \text { a } 20 \text { min., com pe- } \\
\text { ríodo de operaçáo } 17 \text { horas }\end{array}$ \\
\hline & & $\begin{array}{l}\text { Insuficiente - Acima de } 20 \text { min., } \\
\text { com período de operaçáo inferior } \\
\text { a } 17 \text { horas }\end{array}$ \\
\hline
\end{tabular}

TEMA 02: OFERTA DE EQUIPAMENTOS, COMÉRCIO E SERVIÇOS

\begin{tabular}{|c|c|c|}
\hline Indicadores & Parâmetros & Qualificação \\
\hline 3. USOS COTIDIANOS ${ }^{33}$ & \multirow{3}{*}{$\begin{array}{l}\text { Existência de todos os Usos Obri- } \\
\text { gatórios e uma porcentagem dos } \\
\text { Usos Complementares, acessíveis } \\
\text { em } 15 \text { minutos }(1000 \mathrm{~m}) \text { a pé; }\end{array}$} & $\begin{array}{l}\text { Boa - Todos os usos obrigató- } \\
\text { rios e complementares }\end{array}$ \\
\hline \multirow{2}{*}{$\begin{array}{l}\text { Avaliar a diversidade de equi- } \\
\text { pamentos, comércio e serviços } \\
\text { próximos que impliquem } \\
\text { deslocamentos diários com } \\
\text { crianças ou pequenas compras. }\end{array}$} & & $\begin{array}{l}\text { Aceitável - Todos os usos obri- } \\
\text { gatórios e pelo menos } 4 \text { com- } \\
\text { plementares }\end{array}$ \\
\hline & & $\begin{array}{l}\text { Insuficiente - Não há todos os } \\
\text { usos obrigatório e/ou menos de } \\
4 \text { complementares }\end{array}$ \\
\hline 4. USOS EVENTUAIS ${ }^{44}$ & \multirow{3}{*}{$\begin{array}{l}\text { Existência de todos os Usos } \\
\text { Obrigatórios e uma porcentagem } \\
\text { dos Usos Complementares, aces- } \\
\text { síveis em } 20 \text { minutos (1400m) a } \\
\text { pé ou } 30 \text { minutos com transporte } \\
\text { público. }\end{array}$} & $\begin{array}{l}\text { Boa - Todos os usos obrigatórios } \\
\text { e complementares }\end{array}$ \\
\hline \multirow{2}{*}{$\begin{array}{l}\text { Avaliar a oferta de equipamen- } \\
\text { tos, comércios e serviços de usos } \\
\text { eventuais ou que possam ser } \\
\text { mais demorados para usuários } \\
\text { adultos. }\end{array}$} & & $\begin{array}{l}\text { Aceitável - Todos os usos obri- } \\
\text { gatórios e pelo menos } 7 \text { com- } \\
\text { plementares }\end{array}$ \\
\hline & & $\begin{array}{l}\text { Insuficiente - Não há todos os } \\
\text { usos obrigatório e/ou menos de } \\
7 \text { complementares }\end{array}$ \\
\hline
\end{tabular}

${ }^{3}$ Usos Obrigatórios: Creche pública, escola pública de ensino infantil, área de lazer e mercadinho. Usos Complementares: açougue, padaria, farmácia, restaurantes, salão de beleza, academia, lotérica, assistência técnica e loja de materiais de construção.

${ }^{4}$ Usos Obrigatórios: Escola pública de ensino fundamental, médio e/ou técnico, UBS, farmácia, área para práticas esportivas, supermercado, lotérica. Usos Complementares: 


\begin{tabular}{|c|c|c|}
\hline 5. USOS ESPORÁDICOS 5 & \multirow{3}{*}{$\begin{array}{l}\text { Existência de todos os Usos } \\
\text { Obrigatórios e uma porcentagem } \\
\text { dos Usos Complementares, aces- } \\
\text { síveis em } 1 \text { hora com transporte } \\
\text { público. }\end{array}$} & $\begin{array}{l}\text { Boa - Todos os usos obrigatórios } \\
\text { e complementares }\end{array}$ \\
\hline \multirow{2}{*}{$\begin{array}{l}\text { Avaliar a oferta de equipamen- } \\
\text { tos, comércios e serviços não } \\
\text { essenciais, mas que garantam } \\
\text { boa inserção urbana do empre- } \\
\text { endimento. }\end{array}$} & & $\begin{array}{l}\text { Aceitável - Todos os usos obri- } \\
\text { gatórios e pelo menos } 3 \text { comple- } \\
\text { mentares }\end{array}$ \\
\hline & & $\begin{array}{l}\text { Insuficiente - Não há todos os } \\
\text { usos obrigatórios e/ou menos de } \\
3 \text { complementares }\end{array}$ \\
\hline
\end{tabular}

TEMA 03: DESENHO E INTEGRAÇÃO URBANA

\begin{tabular}{|c|c|c|}
\hline Indicadores & Parâmetros & Qualificação \\
\hline $\begin{array}{l}\text { 6. RELAÇÃO COM } \\
\text { ENTORNO }\end{array}$ & \multirow{3}{*}{$\begin{array}{l}\text { Porcentagem do perímetro, ou dos } \\
\text { empreendimentos contíguos, que } \\
\text { é adjacente ao entorno urbano. }\end{array}$} & Boa - 100\% \\
\hline \multirow{2}{*}{$\begin{array}{l}\text { Avaliar a relaçáo do empreendi- } \\
\text { mento com o entorno imediato. }\end{array}$} & & Aceitável $-40 \%$ ou mais \\
\hline & & Insuficiente - Menos de 40\% \\
\hline $\begin{array}{l}\text { 7. TAMANHO DAS } \\
\text { QUADRAS }\end{array}$ & \multirow{3}{*}{$\begin{array}{l}\text { Média do perímetro das qua- } \\
\text { dras do empreendimento, ou } \\
\text { conjunto de empreendimentos } \\
\text { contíguos, e de todas as quadras } \\
\text { imediatamente adjacentes a eles. }\end{array}$} & Boa - Até 500 metros \\
\hline \multirow{2}{*}{$\begin{array}{l}\text { Avaliar o padrão do desenho } \\
\text { urbano, observando forma e } \\
\text { dimensóes das quadras dentro e } \\
\text { adjacentes aos empreendimentos } \\
\text { produzem caminhos variados, } \\
\text { curtos e diretos. }\end{array}$} & & Aceitável - De 500 a 800 metros \\
\hline & & $\begin{array}{l}\text { Insuficiente - Acima de } 800 \text { me- } \\
\text { tros }\end{array}$ \\
\hline $\begin{array}{l}\text { 8. ABERTURAS PARA O } \\
\text { ESPAÇO PÚBLICO }\end{array}$ & \multirow{3}{*}{$\begin{array}{l}\text { Número de acessos de pedestres } \\
\text { para cada } 100 \text { metros de divisas } \\
\text { entre as áreas privadas do empre- } \\
\text { endimento e as vias públicas de } \\
\text { circulação de pedestres. }\end{array}$} & Boa - 4 ou mais \\
\hline \multirow{2}{*}{$\begin{array}{l}\text { Avaliar a interface com o espaço } \\
\text { público, ou seja, as relaçóes entre } \\
\text { espaço público e espaços privados } \\
\text { produzidos pelo empreendimento. }\end{array}$} & & Aceitável - 2 ou mais \\
\hline & & Insuficiente - Menos de 2 \\
\hline $\begin{array}{l}\text { 9. REDE DE CIRCULAÇÃO } \\
\text { DE PEDESTRES }^{6}\end{array}$ & \multirow{3}{*}{$\begin{array}{l}\text { Caminhos até pontos de ônibus, } \\
\text { sistema de transporte e usos coti- } \\
\text { dianos sejam completos. }\end{array}$} & $\begin{array}{l}\text { Boa - Todos os elementos com- } \\
\text { pletos ao transporte e usos coti- } \\
\text { dianos }\end{array}$ \\
\hline \multirow{2}{*}{$\begin{array}{l}\text { Avaliar se os caminhos de } \\
\text { pedestres obedecem a padróes } \\
\text { mínimos de acessibilidade e } \\
\text { qualidade. }\end{array}$} & & $\begin{array}{l}\text { Aceitável - Todos os elementos } \\
\text { completos ao transporte }\end{array}$ \\
\hline & & $\begin{array}{l}\text { Insuficiente - Trechos não com- } \\
\text { pletos }\end{array}$ \\
\hline
\end{tabular}

Fonte: Miranda (2018) a partir da Ferramenta de Avaliação de Inserção Urbana (Rolnik, 2014).

Instituição de ensino superior, CRAS, biblioteca pública, delegacia, centro médico, correios, lojas, restaurantes, banco, escritórios, livraria, assistência técnica, escolas de formação complementar.

5 Usos Obrigatórios: Hospital público, centro administrativo, instituição de ensino superior, banco. Usos Complementares: Cinemas, parques, teatro, museu, hipermercado, cartório.

6 A rede de circulação pedestres é composta e completa quando (i) Todo o espaço de circulação de pedestres (calçadas, calçadóes, travessias) e pontos de acesso ao transpor- 
No caso do Município de João Pessoa, há particularidades nas bases de dados sobre a disponibilidade e oferta de serviço de transporte. Foram usadas as informações do site "Ônibus JP” (João Pessoa, 2017). Nele é possível localizar os pontos de ônibus e os itinerários da cidade. Também é possível selecionar os lugares de partida e chegada e é disponibilizado o percurso tanto a pé, até a parada do transporte público mais próximo, quanto as rotas que se deve pegar para chegar ao destino. Entretanto, não é possível verificar o tempo do trajeto, por isso, para a aferiçáo do tempo do percurso até os usos considerados, recorreu-se ao Google Maps. Para a capital, não existe o recurso de transporte público, estando disponível apenas outros modais. Então, marcou-se o trajeto da rota do ônibus no mapa da segunda base, com o tempo de duração até os usos com o carro, mesmo tomando em conta que os tempos não são exatos em função das paradas durante o caminho, não consideradas na marcação do tempo com o carro. Foi considerado o tempo encontrado, mas sabendo que pode haver variação.

A partir da ferramenta para avaliação da inserção urbana, adaptada aos municípios da Paraíba, foram avaliadas as condiçôes de inserção urbana dos empreendimentos selecionados para o estudo. Em função do grande número de variáveis contidas na ferramenta e da limitação da quantidade de páginas disponíveis para apresentação do trabalho, foram selecionadas apenas algumas variáveis para apresentação no corpo do artigo. A análise completa se encontra disponível no relatório Empreendimentos Habitacionais em Espaços Periféricos: Desafios para o Planejamento Territorial Integrado (Miranda, 2018).

\section{A inserção Urbana de empreendimentos do Programa Minha Casa Minha Vida em João Pessoa, Campina Grande e Patos na Paraíba}

Até o ano de 2015, o Programa Minha Casa Minha Vida destinou 1/3 da sua produçáo nas duas primeiras fases para o Nordeste, mas o estado da Paraíba foi um dos que menos contrataram pelo PMCMV. Dos 223 municípios que compóem o estado, 219 receberam empreendimentos do PMCMV. Segundo os dados do Ministério das Cidades (2015), foram os Municípios de João Pessoa e Campina Grande que concentraram o maior número de

te são dedicados aos pedestres, desobstruídos, seguros e contenham abrigo; (ii) Rede de iluminação cobrem toda a extensão da circulação à noite e; (iii) a arborização e o sombreamento nos caminhos não obstruem a circulação do pedestre. 
empreendimentos e de unidades habitacionais promovidos pelo PMCMV na Faixa 1, com quase $80 \%$ dos empreendimentos executados no estado.

Em Campina Grande, foram construídos os maiores empreendimento executados na Paraíba. Os condomínios se avizinham sucessivamente, conformando conjuntos de três ou mais empreendimentos, a exemplo do Dona Lindú (I, II, III, IV), Major Veneziano (I, II, III, IV) e Aluízio Campos. Esse perfil deve-se à maior disponibilidade de terrenos nas bordas urbanas. Patos e Maranguape se destacam com dois empreendimentos realizados no período.

\section{João Pessoa: a inserção urbana dos residenciais Solar das Mangueiras e Morada dos Hibiscos}

Os empreendimentos selecionados em João Pessoa escolhidos para a análise - Solar das Mangueiras e Morada dos Hibiscos - foram promovidos com recursos do PMCMV na modalidade Entidades. Embora estejam localizados em áreas periféricas, esses empreendimentos diferenciam-se dos demais estudados na Paraíba por suas condiçóes de inserção urbana e portes menores.

Para o Tema 1, que se refere ao transporte, foram levantados os pontos de transporte público acessíveis em $1 \mathrm{~km}$ de distância do centro geométrico, levando em conta que este é considerado a partir da intersecção das poligonais traçadas pelas extremidades de cada empreendimento (Cartogramas 5 e 6). Ambos os residenciais são atendidos por apenas uma linha de ônibus (indicador 1). Portanto, os moradores desses conjuntos têm que buscar alternativas em integraçóes ou outros pontos de ônibus para poderem acessar outros itinerários e destinos. Os moradores relataram que os tempos de espera dos ônibus são longos, variando de $30 \mathrm{~min}$ a 1 hora, apesar das partidas dos ônibus estarem previstas para ocorrer de 30 em 30 minutos (indicador 2). Essas condiçóes conferem aos empreendimentos estudados a qualificação de insuficiente considerando os dois indicadores, opçóes (1) e frequência (2) do transporte.

Nos dois casos de João Pessoa, o transporte público não era o meio de deslocamento mais utilizado. No residencial Morada dos Hibiscos, das 58 famílias entrevistadas, 45 utilizavam veículos individuais próprios, moto e/ou carro. No Condomínio Residencial Solar das Mangueiras, 53 das 68 famílias que responderam aos questionários também utilizavam veículos individuais próprios, prioritariamente, para os deslocamentos diários. 
Cartograma 5 - Unidade central e pontos de ônibus - Morada dos Hibiscos, João Pessoa

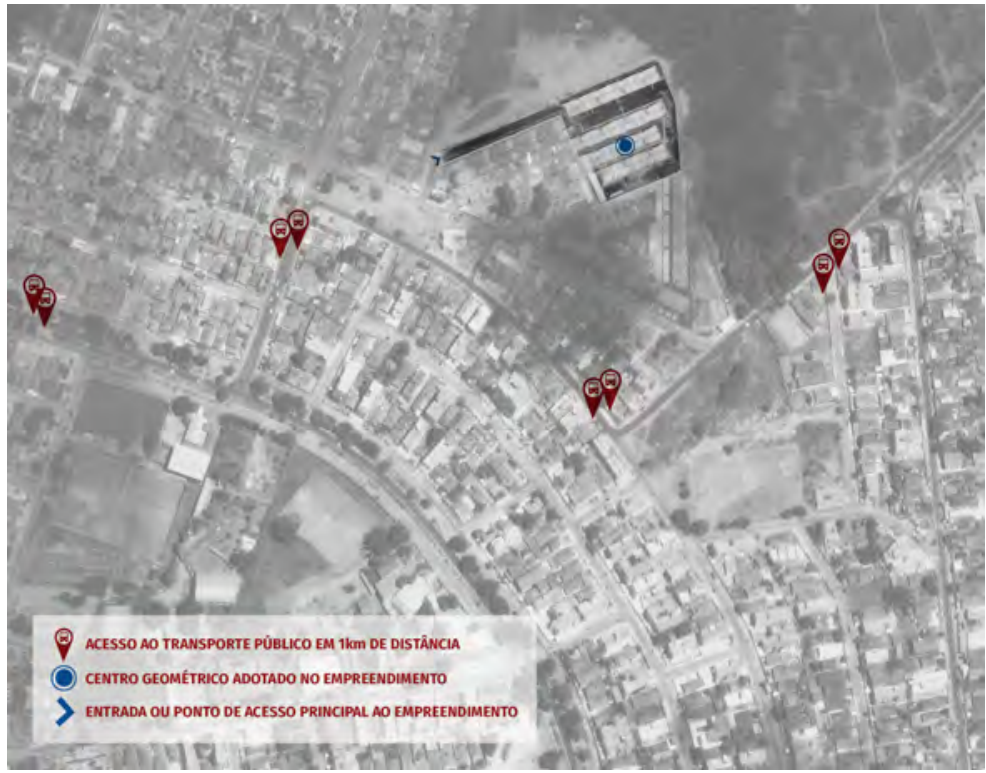

Fonte: Base Google Earth, Base Google Earth, Araújo, 2017 e Miranda, 2018.

Cartograma 6 - Unidade central e pontos de ônibus - Solar das Mangueiras, João Pessoa

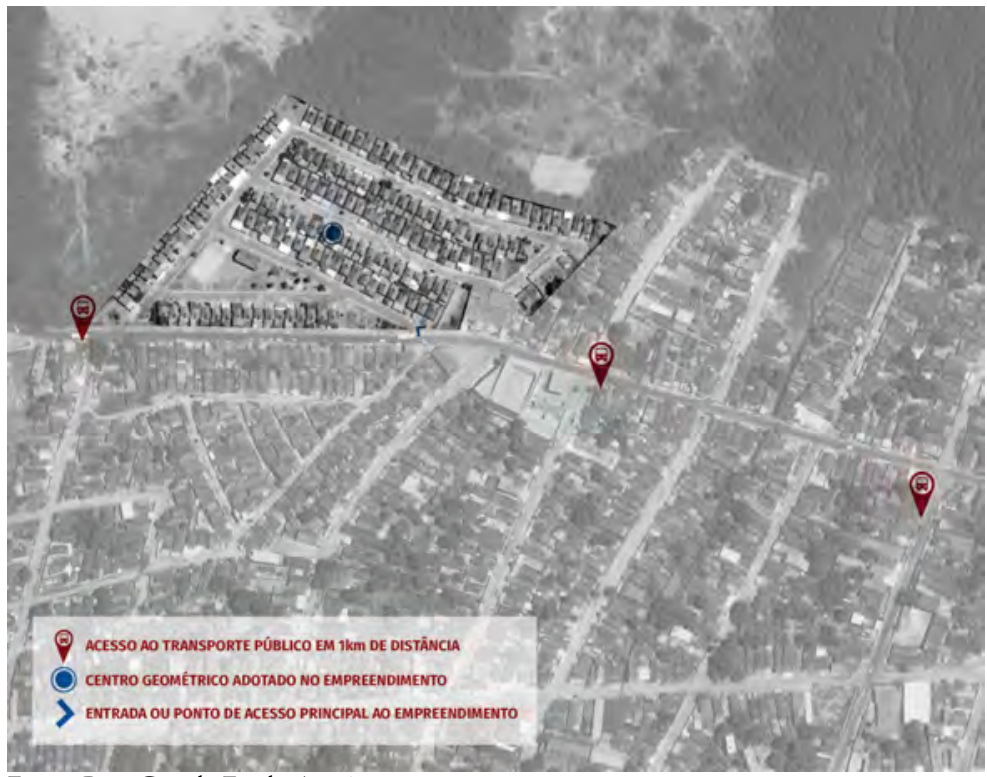

Fonte: Base Google Earth, Araújo, 2017. 
O Tema 2, relativo à oferta de equipamentos no entorno dos conjuntos, para os indicadores que avaliam o entorno de $1 \mathrm{~km}$ a $1,4 \mathrm{~km}$, os empreendimentos obtiveram a pior qualificação, Insuficiente, apesar de ser observado que a maioria dos usos está no raio de $1,4 \mathrm{~km}$ ou bem próximos dele. Os empreendimentos de João Pessoa, mesmo com insuficiências, apresentaram a maior diversidade de usos e equipamentos em seus entornos em comparação aos empreendimentos estudados nas demais cidades. O Solar das Mangueiras conta, em seu entorno, com 26 de 34 equipamentos essenciais e o Morada dos Hibiscos, com 25.

Para o indicador relativo a usos esporádicos, foram destacados apenas três usos obrigatórios e de mais facilidade de identificação na cidade: Hospitais Públicos, Centro Administrativo Público (Prefeitura) e Instituiçóes de Ensino Superior Públicas. A qualificação foi Aceitável, considerando que estes equipamentos estão acessíveis em 1 hora com transporte público.

No Tema 3, referente aos aspectos de desenho urbano, configurações métricas, qualitativas, físicas e formais dos empreendimentos, foram analisados: a relação com entorno (indicador 6); tamanho das quadras (7); Abertura para espaços públicos (8); e a Rede de circulação de pedestres. $\mathrm{O}$ indicador 6 é relativo à porcentagem de áreas limítrofes do conjunto habitacional que estão adjacentes a um entorno qualificado como efetivamente urbano. Os empreendimentos apresentam cerca de $47 \%$ do seu entorno conectado ao tecido urbano (Cartogramas 7 e 8), com o restante margeando Zonas de Preservação Ambiental.

Cartograma 7 - Relação com entorno 46.6\% - Morada dos Hibiscos, Joáo Pessoa

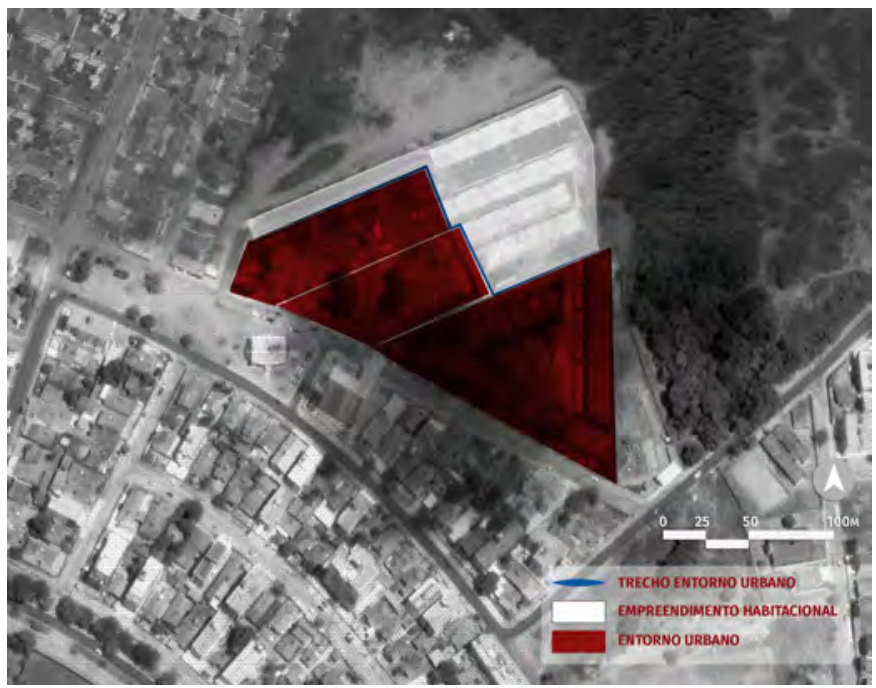

Fonte: Base Google Earth, Base Google Earth, Araújo, 2017. 
Cartograma 8 - Relação com entorno 47,13\% - Solar das Mangueiras, João Pessoa

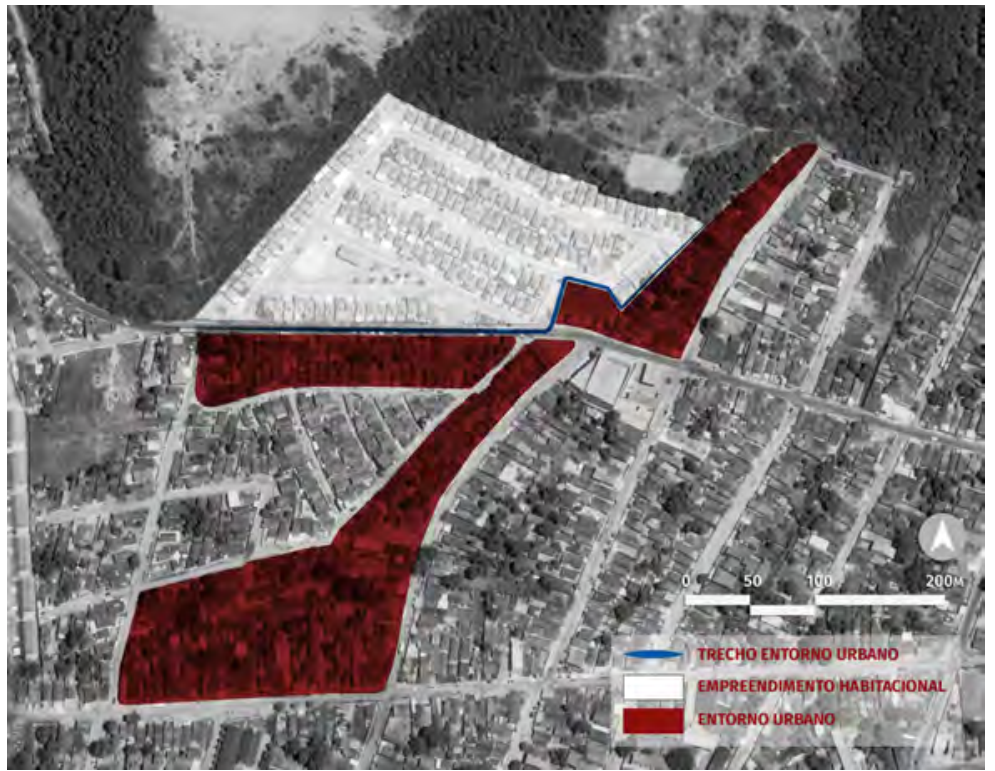

Fonte: Base Google Earth, Araújo, 2017.

Os tamanhos das quadras são avaliados buscando observar se as suas configuraçôes produzem caminhos variados que se integram facilmente à cidade. Em relação ao empreendimento Morada dos Hibiscos, que faz parte de uma quadra (Cartograma 9), foi considerada a quadra inteira para os parâmetros da Ferramenta e o resultado da qualificação foi Bom. O Solar das Mangueiras apresentou a qualificação Aceitável (Cartograma 10). 
Cartograma 9 - Tamanho das quadras 775m - Morada dos Hibiscos, Joáo Pessoa

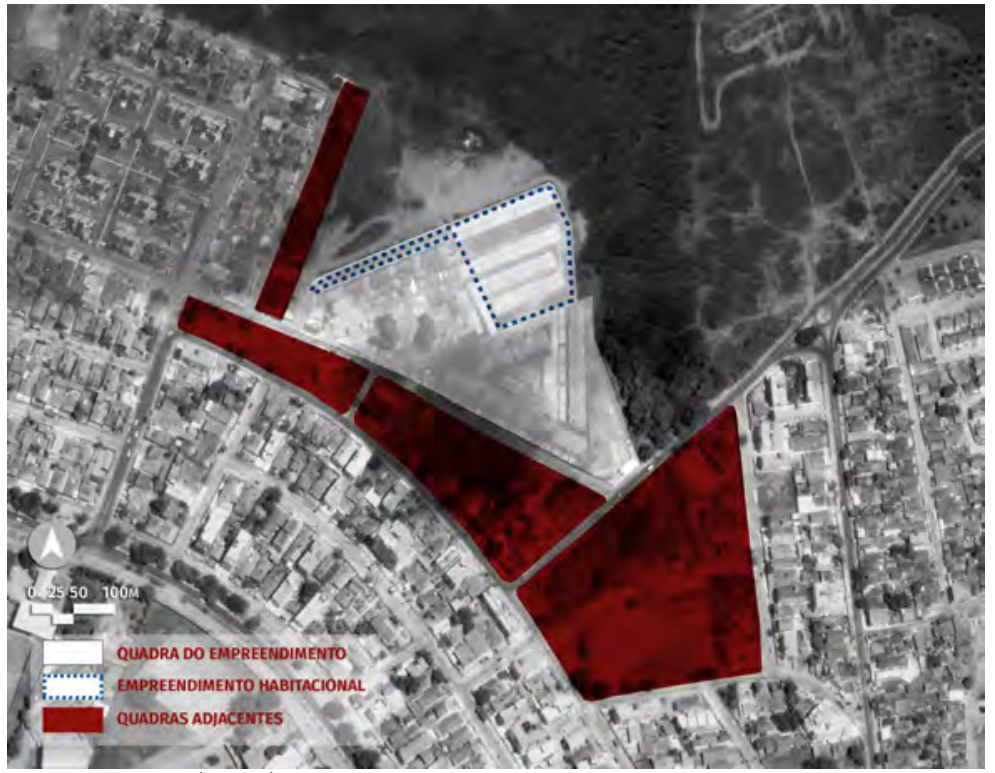

Fonte: Base Google Earth, Araújo, 2017.

Cartograma 10 - Tamanho das quadras 775m - Solar das Mangueiras, Joáo Pessoa.

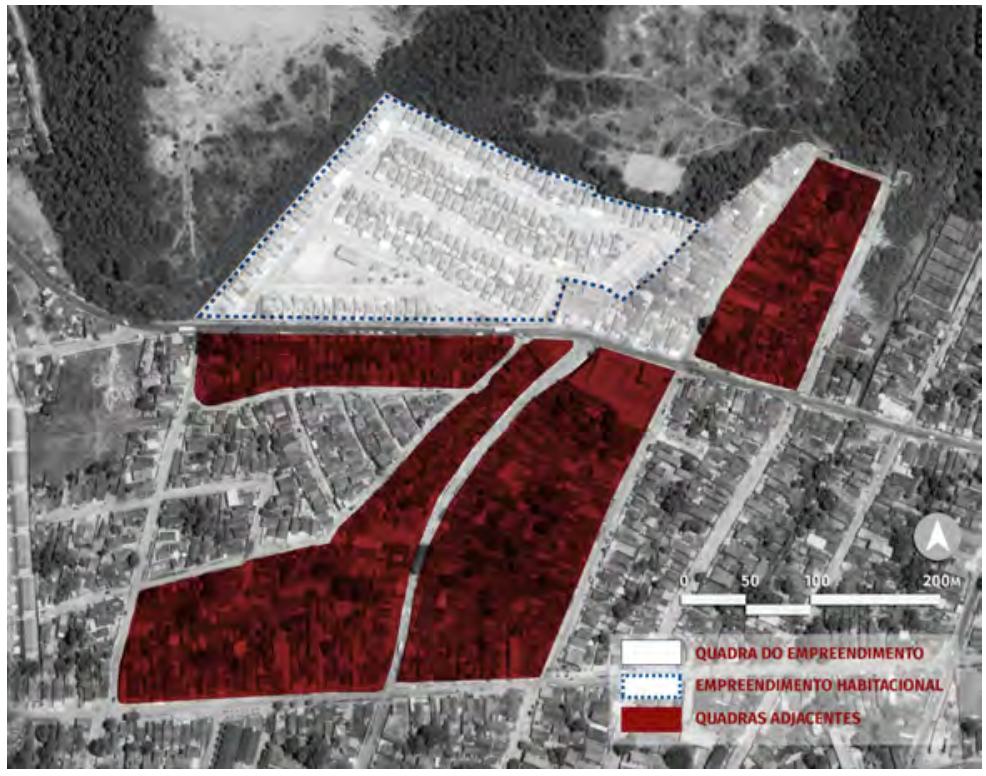

Fonte: Base Google Earth, Araújo, 2017. 
As aberturas para o espaço público (indicador 8) são aferidas a partir da verificação da quantidade de relaçôes ou divisas público/privado, a cada 100 metros, entre o conjunto habitacional e vias de circulação de pedestres pelos parâmetros da Ferramenta. Como o Solar das Mangueiras e o Morada dos Hibiscos são empreendimentos com uma única entrada, ambos tiveram a qualificação de Insuficiente.

O último indicador (9) da Ferramenta trabalhado avalia a qualidade e a acessibilidade dos caminhos internos e externos, das portas das unidades habitacionais em direção aos equipamentos e serviços do entorno. Foi possível perceber nos empreendimentos estudados, que a acessibilidade foi priorizada apenas para as entradas das unidades acessíveis. No Morada dos Hibiscos, as unidades acessíveis estão no início do conjunto. No Solar das Mangueiras, quando não há desnível, existe um degrau para a entrada da casa, interferindo na mobilidade para o acesso à casa. A qualificação para a rede de circulação de pedestres, a partir dos parâmetros da Ferramenta, foi Insuficiente.

\section{A inserção urbana dos Residenciais Dona Lindú I, II, III E IV e Major Veneziano I, II, III E IV em Campina Grande}

Na cidade de Campina Grande, oito conjuntos foram estudados no âmbito da pesquisa, integrantes dos Residenciais Dona Lindú I, II, III, IV, organizados como quatro condomínios, voltados à Faixa 2 do PMCMV, situados no Bairro Novo Bodocongó, a noroeste da cidade; e dos Residenciais Major Veneziano I, II III e IV, também como quatro condomínios para a Faixa 1, situados no Bairro Três Irmãs, localizado na Área de Expansão Urbana.

Para o Tema 1, foram analisadas a oferta e frequência do transporte disponíveis e acessíveis aos moradores dos residenciais em Campina Grande (indicadores 1 e 2). Os pontos de parada de ônibus ofertados pelo município que estão a $1 \mathrm{~km}$ da unidade central de cada conjunto. Foram verificados, também, quais os percursos podiam ser efetuados a partir dessas paradas e se as linhas de ônibus faziam trajetos diferentes (Cartogramas 11 e 12). 
Cartograma 11 - Unidade central e pontos de ônibus - Dona Lindú, Campina Grande

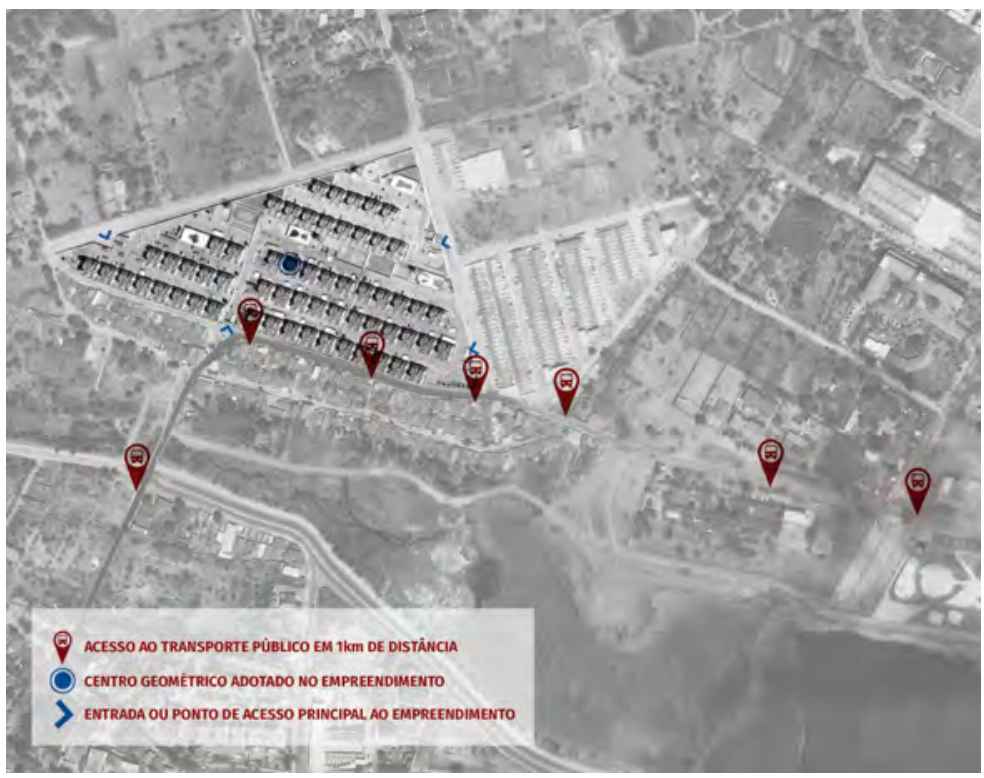

Fonte: Base Google Earth, Araújo, 2017.

Cartograma 12 - Unidade central e pontos de ônibus - Major Veneziano, Campina Grande

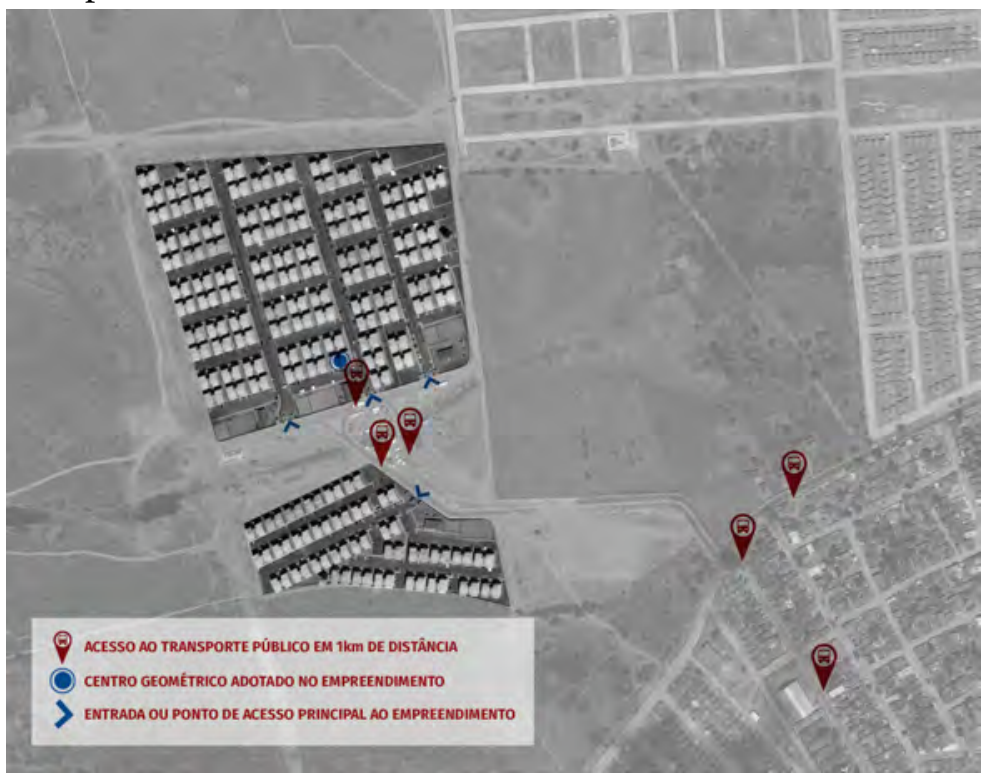

Fonte: Base Google Earth, Araújo, 2017. 
Para os Residenciais Dona Lindú, os percursos das 4 linhas acessadas pelos moradores ao percurso de $1 \mathrm{~km}$ têm distâncias inferiores a $2 \mathrm{~km}$ entre si quanto a seus itinerários, o que, pela Ferramenta, expressa uma única opção de rota, resultando em uma qualificação Insuficiente. Em relação aos Residenciais Major Veneziano I, II, III e IV, foram identificadas 2 linhas de ônibus como acessíveis ao percurso de $1 \mathrm{~km}$, com itinerários que distam apenas 900 metros. O resultado é qualificado, também, como Insuficiente.

Dos casos estudados, os moradores dos conjuntos de Campina Grande eram os que mais utilizavam o transporte público, por essa razão também havia mais reclamaçóes relacionadas aos tempos de espera e à quantidade de ônibus insuficiente para as linhas que vão até as áreas periféricas. Estes ônibus acabam percorrendo percursos mais longos até o destino ou ao terminal de integração para a conexão com outras linhas.

Em relação ao Tema 2, referente a equipamentos, para os indicadores 3 e 4, considerando as distâncias ou tempos estabelecidos como parâmetros, a qualificação para os dois conjuntos de Residenciais de Campina Grande foi considerada Insuficiente. Para o indicador 5, referente aos usos esporádicos, foram selecionados os três primeiros obrigatórios, Hospitais Públicos, Centro Administrativo Público (Prefeitura) e Instituiçóes de Ensino Superior Públicas. A partir dos tempos dos deslocamentos, foi constatado as qualificaçóes de Aceitável para o Dona Lindú, com deslocamentos em torno de 45 minutos para diferentes destinos e o Major Veneziano como Insuficiente, pois apresentou três deslocamentos com tempo superior a 1 hora.

A análise do Tema 3 foi realizada considerando os indicadores de 6 a 9 , estudando as métricas e configuraçóes urbanas dos conjuntos selecionados na cidade. As porcentagens de conexão com o entorno urbanizado (indicador 6) encontradas foram de 75\% e 0\%, para o Dona Lindú e o Major Veneziano, respectivamente (Cartogramas 13 e 14). A localização do Major Veneziano é periférica, em área que representa uma nova frente de expansão, com terrenos não ocupados na vizinhança. 
Cartograma 13: Relação com entorno 75\% - Dona Lindú, Campina Grande

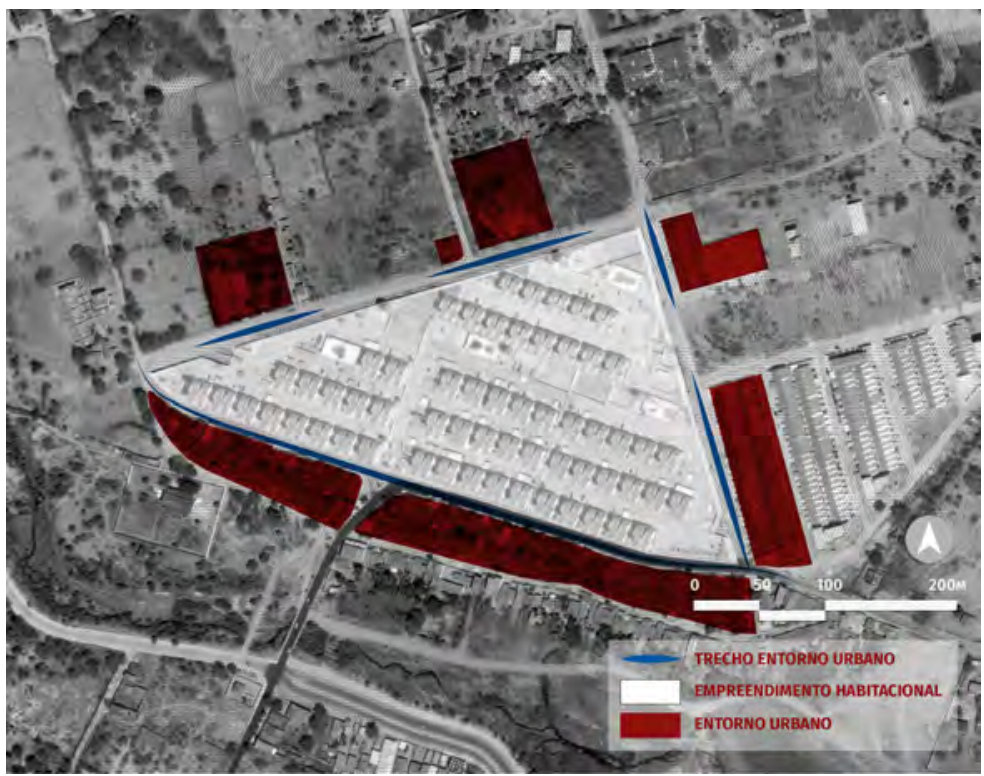

Fonte: Base Google Earth, Araújo, 2017.

Cartograma 14: Relação com entorno 0\% - Major Veneziano, Campina Grande

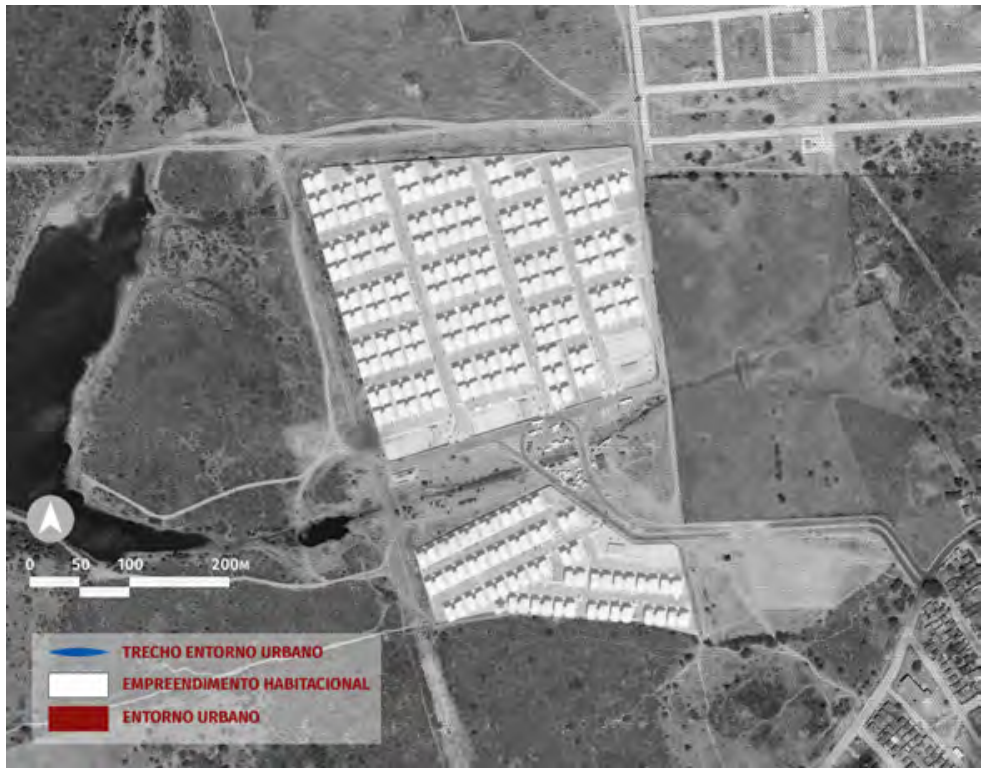

Fonte: Base Google Earth, Araújo, 2017. 
Os empreendimentos de Campina Grande são condomínios murados, com entradas e saídas únicas para conjunto. Devido ao grande porte e em decorrência da configuração urbanística, há caminhos mais longos para os moradores dos edifícios (indicador 7). Por essas razóes, considerando os parâmetros adotados na Ferramenta, suas qualificaçóes para o tamanho das quadras foram Insuficientes, em função de percursos superiores a 800 metros.

$\mathrm{Na}$ aferição das aberturas das divisas entre os espaços públicos (indicador 8), os empreendimentos de Campina Grande, a partir da Ferramenta, foram qualificados como Insuficientes, pois em cada residencial-condomínio há apenas uma abertura que dá acesso às vias públicas de circulação de pedestres.

A rede de circulação de pedestres (indicador 9) no interior no empreendimento e nos caminhos do entorno que levam aos equipamentos essenciais foram considerados como Insuficientes em função dos desníveis internos e problemas quanto à acessibilidade a espaços comuns, como a falta de rampa apesar da variação das dimensóes das calçadas, chegando a 20 centímetros de largura. Em relação ao transporte e ao caminho até ele, pôde ser observado que as condiçóes de acessibilidade são adequadas apenas em alguns trechos.

Os Residenciais Major Veneziano obtiveram a pior qualificação em todos os indicadores e os Residenciais Dona Lindú tiveram, em função da localização, resultados melhores, mas com apenas dois dos nove indicadores com qualificaçóes Aceitáveis, e nenhuma como Boa.

\section{A inserção urbana dos Residenciais Vista da Serra I E II em Patos}

A produção do espaço urbano em Patos vem se caracterizando, nessa última década, por uma diversidade de investimentos imobiliários que vêm gerando a expansão da malha urbana da cidade. Nessa área de transição rural-urbana, vem sendo realizados os empreendimentos habitacionais pelo PMCMV. Importante ressaltar que Campina Grande e Patos tiveram Leis Municipais que ampliaram os limites dos perímetros urbanos das cidades (Maia e Lucena, 2015). Os Residenciais Vista da Serra I e II em Patos, foram implantados de modo desarticulado da malha urbana, entre o Rio Espinharas e um braço desse rio. Outra especificidade desses empreendimentos é que são abertos, não se constituindo em condomínios murados, diferentes dos demais estudados no âmbito desta pesquisa. 
Em relação aos dois primeiros indicadores relativos (1 e 2) ao Tema Transporte, foram observadas questóes específicas relacionadas aos serviços urbanos. No período da pesquisa de campo na cidade, não havia transporte público. As linhas de coletivos na cidade pararam de funcionar em 2014 até o final de 2016, quando o serviço foi retomado. Eram somente quatro linhas que ligavam alguns bairros da cidade, com poucos ônibus circulando. Apenas uma linha atendia ao bairro (Araújo, 2017). Os moradores foram questionados sobre os deslocamentos ao trabalho e ao estudo e os três meios mais utilizados foram a motocicleta, a pé e a bicicleta.

A partir dos levantamentos para o Tema 2, foram identificados equipamentos, serviços e pontos de comércio, e detectados 18 dos 34 usos relacionados pela Ferramenta de Inserção urbana, sendo a qualificação considerada como Insuficiente. Em Patos, as percepçôes dos moradores em relação às distâncias não corresponderam às reais extensões. Estas percepçóes podem estar associadas às dificuldades para deslocamento em decorrência da precariedade das vias que dáo acesso aos equipamentos e aos empreendimentos de serviços e comerciais, com ruas sem calçamento ou deterioradas por falta de manutenção.

As análises dos usos esporádicos foram realizadas a partir da identificação dos três primeiros usos obrigatórios do indicador. Para os Residenciais Vista da Serra I e II, quando as visitas de campo foram feitas, não havia transporte público disponível e os deslocamentos eram realizados a partir de outros modais, como a bicicleta, o carro, a motocicleta e a pé, todos como modos individuais. Os resultados quanto ao tempo de deslocamento foram, então, aferidos da mesma forma dos casos estudados nas outras cidades e a qualificação foi Insuficiente.

Para os últimos indicadores, do Tema 3, relativo ao desenho e integração urbana, os casos de Patos foram os que obtiveram melhor qualificação em dois dos quatro indicadores, apesar de ter obtido um dos piores resultados para o indicador 6 , a relaçáo com o entorno. $\mathrm{Na}$ Cartograma 15, está demarcada linha que representa a porcentagem do perímetro dos empreendimentos selecionados na cidade que são adjacentes ao entorno urbanizado. Os residenciais tiveram o segundo pior resultado, com apenas $24,05 \%$ conectado aos espaços parcelados e efetivamente urbanos, por se localizarem em novas frentes de expansão. 
Cartograma 15 - Relação com entorno 24.05\% - Vista da Serra, Patos

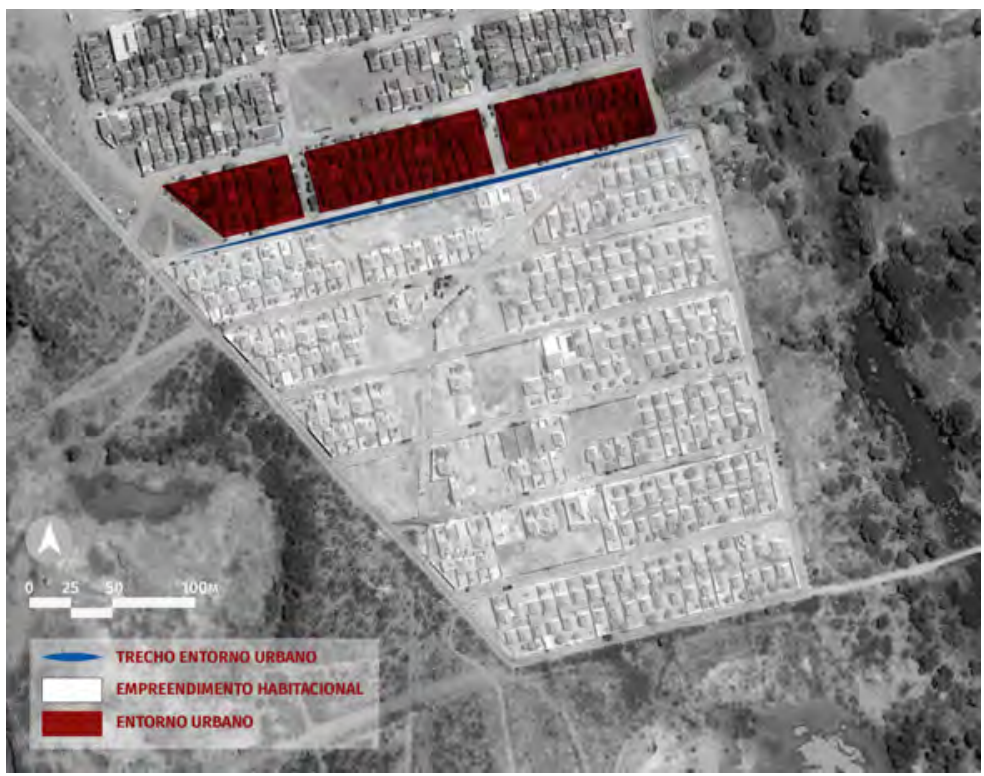

Fonte: Base Google Earth, Araújo, 2017.

Nos dois indicadores, Tamanho da Quadra (7) e Aberturas para o Espaço Público (8), os Residenciais Vista da Serra I e II receberam, a partir das suas características, as melhores qualificaçóes dos empreendimentos estudados. Os Residenciais Vista da Serra I e II obtiveram a média de 368,20 metros por quadra, sendo a melhor dos empreendimentos do PMCMV estudados na Paraíba.

Para o indicador 8, as aberturas das unidades habitacionais foram aferidas em sua totalidade, visto que os empreendimentos são abertos e cada conexão público/privado é considerada pela ferramenta. Assim, eles foram os únicos dos estudados na Paraíba que receberam a qualificação Boa. Esses indicadores podem ser identificados nas Cartogramas 16 e 17.

Sobre a rede de circulação dos pedestres, indicador 9, foi possível observar que as empresas e projetistas desses empreendimentos não priorizaram a acessibilidade nos casos dos Residenciais Vista da Serra I e II, em Patos. Apesar de ser apontado que, no projeto original, as calçadas, por exemplo, seriam desobstruídas, houve alteraçóes dos níveis das calçadas promovidas pelos moradores, conferindo obstáculos na acessibilidade e nos deslocamentos dos pedestres. Além disso, problemas de deterioração dos pavimentos das calçadas, dificuldades de acesso a unidade (desníveis) 
e a falta de pavimentação nas ruas de acesso ao residencial, resultaram na qualificação Insuficiente.

Cartograma 16 -Tamanho das quadras 368.20m - Vista da Serra, Patos

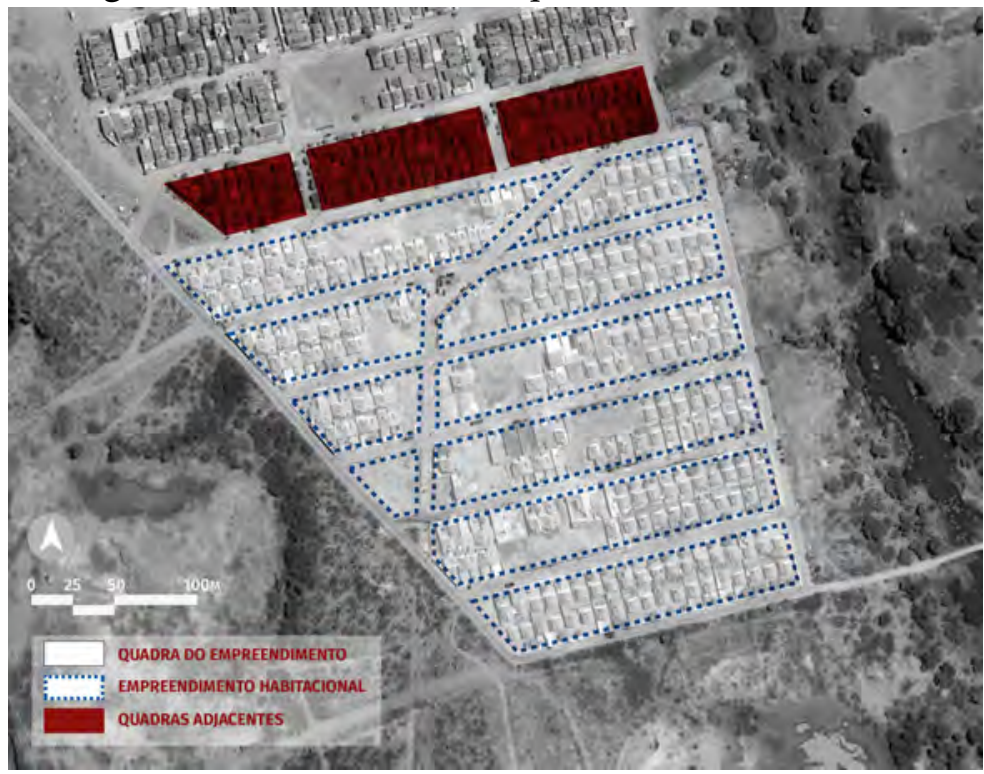

Fonte: Base Google Earth, Araújo, 2017.

Cartograma 17: Aberturas para o espaço público 6.65 - Vista da Serra, Patos

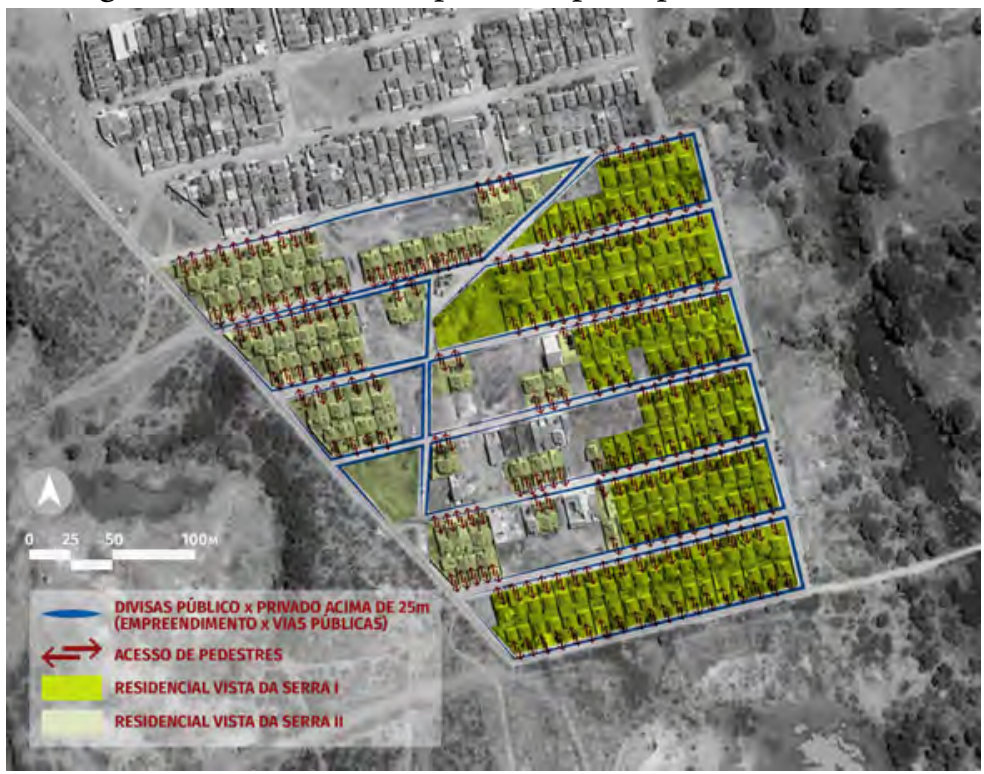

Fonte: Base Google Earth, Araújo, 2017. 


\section{Consideraçóes finais}

A pesquisa possibilitou a sistematização e análise de informações e observaçóes sobre os empreendimentos habitacionais promovidos no âmbito do PMCMV para o estado da Paraíba. Embora existam inúmeros estudos sobre o programa, poucos enfocaram as características dos espaços intermediários nordestinos. No caso paraibano, foi necessário propor adaptaçóes para diminuir constrangimentos metodológicos decorrentes das cidades estudadas, considerando a relação entre as dinâmicas e as dimensóes da mancha urbana, diferentes das encontradas na maioria das cidades que tiveram empreendimentos do PMCMV estudados. A partir de uma abordagem interdisciplinar, a pesquisa demonstra que há grande necessidade de articulaçáo, entre as várias dimensóes espaciais das políticas urbanas e dessas com os respectivos instrumentos de planejamento e gestão. Dessa forma, o estudo poderá contribuir para orientar a elaboração de planos, programas e políticas públicas que influenciem e regulem a produção do espaço para promover maior urbanidade e garantir uma inserção mais adequada e justa das habitaçóes de interesse social na cidade.

São diversas as dificuldades para a implementação de políticas públicas federais, geralmente pouco flexíveis à diversidade e às especificidades dos municípios brasileiros. Mais especificamente, no caso do PMCMV, importante para atender as famílias com baixíssima renda, não se pode deixar de reconhecer que o programa fomentou, em muitas cidades, uma urbanizaçáo periférica, pouco diversificada e pouco inclusiva. Em relação aos empreendimentos estudados na Paraíba nesta pesquisa, não foi diferente.

A pesquisa contribuiu, também, para evidenciar que houve pouca articulação entre os instrumentos de planejamento, como os Planos Diretores, os Planos de Habitação, Saneamento e a alocação dos empreendimentos. Ficou claro que a regulaçáo dos processos de ocupação do solo está principalmente pavimentada em estratégias para viabilizar as principais dinâmicas promovidas pelo capital. Nessa perspectiva, a pesquisa serve como referência aos processos de planejamento territorial, principalmente para a implantação adequada de conjuntos habitacionais de interesse social, seja no âmbito governamental ou não governamental, permitindo definir estratégias para alcançar um desenvolvimento socioespacial mais equilibrado e inclusivo. 


\section{Referências}

ABNT ASSOCIAÇÃO BRASILEIRA DE NORMAS TÉCNICAS. NBR 9050: Acessibilidade a edificaçóes, mobiliário espaços e equipamentos urbanos. Rio de Janeiro. 2004.

ARAUJO, J. P. Inserção Urbana Habitacional: Possibilidades e Limites na Avaliação do Programa Minha Casa Minha Vida (PMCMV) em Cidades Médias da Paraíba. (Trabalho de Conclusão de Curso). Campina Grande: Universidade Federal de Campina Grande, 2017.

BRASIL. "Lei no 12.424, de 16 de junho de 2011". Presidência da República - Casa Civil. Disponível em: http:/www.planalto.gov.br/ccivil_03/_ato2011-2014/2011/lei/11242 4.htm. Acesso em: 20 ago. 2016.

CAMPINA GRANDE. Gerência de Operação e Fiscalização de Transportes, Central Integrada de Operação e Monitoramento de Ônibus, 2017. Disponível em: http://www.ciomcg.com. br/linhas-e-rotas.html. Acesso em: 25 jul. 2017.

CARDOSO, A. L. e DENALDI, R. Urbanização de Favelas no Brasil. Um balanço do PAC. Rio de Janeiro: Letra Capital, 2018.

et al. 22 anos de politica habitacional no Brasil: da euforia à crise. Rio de Janeiro: Letra Capital Editora, 2016.

JOÃO PESSOA. Onibus de João Pessoa, Pontos e Rotas, 2017. Disponível em: http://www. onibusjp.com. Acesso em: 1 ago. 2017.

MAIA, D. S. e DE LUCENA, W. G. "A expansão periférica e a habitação popular nas cidades do interior do território brasileiro: o processo de urbanização recente em cidades de distintas escalas geográficas - Campina Grande e Patos na Paraíba”. In: BELLET, Carmen et al. (Org.) Urbanización, producción y consumo en ciudades medias/intermedias Urbanização, produção e consumo em cidades médias/intermediárias. pp. 339-71, 2015.

MIRANDA, L. I. B. Empreendimentos Habitacionais em Espaços Periféricos: desafios para $o$ planejamento territorial integrado, Pesquisa Universal 2014/2017, (Relatório de Pesquisa, Edital MCTI/CNPq/UNIVERSAL No 11/2014 - Processo 461933/2014-4), 2018.

OBSERVATÓRIO DAS METRÓPOLES. Desafios para a politica habitacional: $2^{a}$ etapa do programa Minha Casa, Minha Vida. Disponível em: http://observatoriodasmetropoles. net/. Acesso em: 20 Dez. 2017.

ROLNIK, R. (Coord.). Ferramentas para avaliação da inserção urbana dos empreendimentos do MCMV. (Relatório de Pesquisa). São Paulo: Universidade de São Paulo; Laboratório Espaço Público e Direito à Cidade, 2014.

SANTO AMORE, C. S. et al (Org.). Minha Casa...e a Cidade? Avaliação do Programa Minha Casa Minha Vida em Seis Estados Brasileiros. Rio de Janeiro: Letra Capital, 2015. 



\section{Periferização da produção imobiliária no século XXI: a produção do Programa Minha Casa Minha Vida em Joáo Pessoa - PB}

Eliane Campos dos Santos Paula Dieb Martins

\section{Introdução}

A cidade de João Pessoa, localizada no Nordeste brasileiro, tem apresentado intensas transformaçóes em seu espaço urbano no início do século XXI, tanto em decorrência da execuçáo de projetos urbanos realizados pelo poder público, quanto pela grande quantidade de lançamentos imobiliários empreendidos pelos agentes privados, predominantemente, de origem e atuação local.

De acordo com o estudo das Regióes de Influência das Cidades (REGIC) (IBGE, 2007), que definiu configuraçóes da rede urbana brasileira, João Pessoa é classificada como uma Capital Regional A, isto é, um centro urbano com capacidade de gestáo inferior à metrópole, com uma área de influência regional. A capital do estado da Paraíba apresenta uma população estimada de aproximadamente 811.000 habitantes (IBGE, 2017), ocupando uma área de $211,5 \mathrm{~km}^{2}$.

A partir de meados do século XX, a cidade sofreu um acelerado processo de expansão urbana, relacionado, sobretudo, à política de atuação do Sistema Financeiro de Habitação (SFH) por meio do Banco Nacional de Habitação (BNH) que, com o lançamento de conjuntos habitacionais, criou e consolidou a tendência de crescimento da cidade voltada para as direçóes Sul e Sudeste (Lavieri e Lavieri, 1999). Essa, por sua vez, resultou na produção 
da cidade espraiada (Santos, 2008), assim como no aumento das distâncias sociais no espaço intraurbano e no fenômeno de segregação - residencial (Villaça, 2001 e Corrêa, 2003) e/ou espacial imposta (Souza, 2003) -, cuja configuração persiste no espaço intraurbano de João Pessoa até os dias atuais.

O setor imobiliário de João Pessoa tem apresentado altos percentuais de crescimento, que por vezes superam aqueles referentes a outras cidades brasileiras. Tal foi o caso do aumento do número de estabelecimentos de atividades imobiliárias e de construção nela atuantes entre 2006 e 2015. Além disso, destacou-se também o crescimento do valor total gasto em construção e incorporação no Estado da Paraíba que, de acordo com dados da Câmara Brasileira da Indústria da Construção, entre 2005 e 2015, apresentou crescimento duas vezes maior que a média nacional.

Essas mudanças estão diretamente relacionadas a um contexto mais amplo provocado pela maior articulação do capital financeiro com o imobiliário e pela expansão do capital imobiliário que, no Brasil, ocorreu sobretudo a partir da década de 2000 , com a criação de uma conjuntura internacional e nacional (Melazzo, 2013).

Dentre as açóes que compóem tal conjuntura, destacam-se a mudança da lei de alienaçóes fiduciárias, o aumento dos subsídios pelos Fundo de Garantia por Tempo de Serviço (FGTS), a ampliação dos recursos do Orçamento Geral da União (OGU), a ampliação de crédito para a produção imobiliária, a abertura do capital imobiliário na Bolsa de Valores, a entrada de capitais internacionais no mercado imobiliário nacional e a criaçáo do Programa Minha Casa Minha Vida (PMCMV).

Nesse amplo contexto, como afirmou Melazzo (2013), “[...] o mercado imobiliário é considerado, portanto, como o lugar econômico da valorização de capitais que agem sobre a cidade e seus objetos na busca permanente e crescente de sua valorização" (p. 34). Sendo assim, para se compreender a produção do espaço urbano no Brasil contemporâneo, se faz necessária a articulação de escalas e processos, investigando os agentes, estratégias e projetos relacionados ao setor imobiliário.

Deste modo, diante das recentes e intensas mudanças no espaço urbano de Joáo Pessoa e do relevante aumento da produçáo imobiliária na cidade, o presente artigo tem como objetivo analisar a produçáo do seu espaço intraurbano a partir do PMCMV, no período compreendido entre os anos 2009 e 2018. Para tanto, foi realizada a caracterização da produção habita- 
cional do mencionado programa na cidade estudada e a identificação de suas repercussões no tecido urbano do município.

A pesquisa foi realizada em três etapas. A primeira, compreendeu o levantamento e a leitura de produção bibliográfica acerca dos assuntos ora abordados - tais como Rolnik (2015), Shimbo (2010), Maricato (2014), Rufino (2016), entre outros -, assim como do objeto empírico de estudo Lavieri e Lavieri (1999), Maia (2000 e 2014) e Martins (2019).

Em seguida, foi feito o levantamento em base de dados disponibilizada pelo extinto Ministério das Cidades, cujas informaçóes abrangem as unidades habitacionais contratadas, concluídas e entregues pelo PMCMV entre os anos de 2009 e 2018. Nela, foram coletados os quantitativos relativos às unidades habitacionais entregues e seus respectivos endereços. Com isso, foi possível quantificar a produçáo imobiliária do referido programa de acordo com cada faixa de renda, assim como visualizar sua localização no tecido urbano de Joáo Pessoa. Tais dados obtidos foram sistematizados e representados por meio de tabelas e mapas.

Por fim, a partir dos dados obtidos e sistematizados nas pesquisas bibliográficas e documental, foi desenvolvida uma análise geral sobre a produção do PMCMV em João Pessoa e a sua relaçáo como o processo de expansáo urbana da cidade. Como resultado, pode-se afirmar que, em João Pessoa, o PMCMV possibilitou a extensão do imobiliário e do urbano ao mesmo tempo que reforçou a segregação socioespacial ao implantar os empreendimentos de faixa mais baixa em áreas periféricas, nas bordas da cidade.

A análise é apresentada, a seguir, em duas partes: na primeira, são realizadas breves notas acerca da estruturação do espaço intraurbano de João Pessoa para fundamentar a análise mais específica da produção habitacional vinculada ao PMCMV na cidade entre 2009 e 2018, a qual é realizada em seguida, na segunda parte do capítulo. Por fim, são expostas as principais constataçóes e reflexóes da pesquisa.

\section{A estruturação da cidade no século XX: espraiamento e periferização em João Pessoa-PB}

De uma maneira geral, a estrutura urbana é uma realidade do espaço em um momento no tempo, que mostra como o espaço da cidade está organizado. Como bem descreveu Sposito (2004, p. 311), "a expressão 'estrutura 
urbana' é, a nosso ver, apropriada para se fazer referência à forma como se encontram dispostos e se articulam os usos de solo, num dado momento do contínuo processo de estruturaçáo dos espaços da cidade”.

De acordo com Villaça (2001), o espaço intraurbano estrutura-se de acordo com as condiçóes de deslocamento dos seus habitantes - tanto como força de trabalho quanto como consumidores -, os quais definem percursos marcados por práticas sociais e cotidianas que seguem tendências, indicaçóes e resultados. Desta maneira, essa estruturação passa a adquirir uma forma e uma lógica evolutiva específicas, a partir da luta de classes na produção de localizaçóes estratégicas nesse espaço. Afirma-se assim que a estruturação da cidade é orientada pela divisão técnica e social do trabalho.

A cidade de João Pessoa, fundada no século XVI, teve seu tecido urbano pouco alterado ao longo dos seus primeiros séculos de existência. Até o final do século XIX, permaneceu concentrada no entorno das suas unidades morfológicas originais, apresentando uma malha contínua, expandindo-se lentamente. Contudo, a partir de meados do século XX, tal processo tem sua intensidade e configuração modificada por meio, sobretudo, da atuação do Estado, tanto pela realização de obras e programas, quanto pela elaboração de leis de zoneamento, uso e ocupação do solo urbano.

Assim como ocorreu em outras cidades brasileiras, o tecido urbano de João Pessoa expandiu-se de forma mais latente e descontínua a partir da segunda metade do século XX, devido, principalmente, à atuaçáo da política habitacional com a construção de conjuntos habitacionais pelo Banco Nacional de Habitação (BNH) (Maia, 2000). Em tal período, diversos acontecimentos - como o aumento do uso do automóvel, as melhorias nos sistemas de transporte, o acelerado crescimento da populaçáo urbana -, bem como a intervenção do Estado no planejamento urbano desencadeou a expansão da malha urbana, fomentando agentes privados e intensificando as lógicas especulativas - fundiária e imobiliária - e a segregação socioespacial.

A habitação de interesse social no Brasil está associada à produção desigual do espaço urbano, sendo os déficits relativos à moradia um problema latente em nossa sociedade. Podemos observar ao longo da história da política habitacional diferentes formas de acesso à moradia, as quais se desenvolveram sob a lógica capitalista de produção.

O período anterior aos anos 1930 aponta inexpressiva presença do Estado no que diz respeito à produção da habitação. O princípio da intervenção 
estatal na questão da habitação de interesse social no Brasil teve início com destaque para o período Vargas (1930-54) com a criação dos Institutos de Aposentadoria e Pensão (IAPs) e da Fundação Casa Popular. Porém, a grande intervenção estatal na história da política habitacional brasileira no século XX foi, sem dúvida, a criação do Banco Nacional de Habitação (BNH) pela Lei n. ${ }^{\circ}$ 4.380, de 21 de agosto de 1964, que durou até 1986.

De acordo com Rufino (2016), durante o período, a produção imobiliária de mercado deu-se nas áreas centrais e privilegiadas da cidade e construiu edificaçóes voltadas para um público consumidor de alta renda. Deste modo, houve a valorização daquelas áreas, o que provocou a intensificação dos contrastes entre o centro e a periferia urbana.

Diante do acelerado aumento populacional, restou aos grupos com menores rendimentos, a ocupação de áreas menos valorizadas da cidade e distantes do centro, produzindo assim a "periferia dos pobres" por meio da espoliação urbana (Kowarick, 1979). Como descreveu Maia (2014),

Na história da urbanização brasileira, a expansão das cidades é marcada pelos grandes loteamentos oficiais destinados às camadas da populaçáo de maiores rendimentos e, também, pelos loteamentos irregulares ou clandestinos. Além disso, há a periferização da cidade produzida pelo Estado, com a construção de conjuntos habitacionais, destacadamente no período 1960-1980, financiados pelo Banco Nacional de Habitação (BNH) (p. 92).

O processo de periferização brasileira e as suas respectivas especificidades foi estudado e caracterizado por diversos autores das ciências sociais nas últimas décadas do século XX, tais como Francisco de Oliveira (1979), Lúcio Kowarick (1979), Bolaffi (1979) e Santos (2008). Sua origem está relacionada profundamente à atuação do Estado para promover um pacto político desenvolvimentista, com base na acumulação marcada por um padrão expansionista do urbano e da produção industrial.

Nesse momento de mudanças na base econômica com a ascensão e domínio da indústria, a população de João Pessoa apresentou inédito crescimento populacional decorrente, entre outros fatores, da migração da população que vivia da produçáo agrícola oriunda de regióes interioranas do estado em busca de melhores condiçóes de vida na capital. De acordo com os dados quantitativos referentes à população residente em João Pessoa de 1950 
a 2010 (tabela 1), observa-se que, além do relevante aumento apresentado, na década de 1950, a população de João Pessoa já se caracterizava como predominantemente urbana.

Tabela 1 - População residente no município de João Pessoa (1950-2010)

\begin{tabular}{l|l|l|l|l|l|l}
\hline \multirow{2}{*}{ ANO } & \multicolumn{3}{|l}{ URBANA } & \multicolumn{2}{l}{ RURAL } & \multicolumn{3}{l}{ TOTAL } \\
\cline { 2 - 7 } & TOTAL & $\%$ & TOTAL & $\%$ & TOTAL & $\%$ \\
\hline $\mathbf{1 9 5 0}$ & 89.517 & 93,29 & 6.436 & 6,71 & 95.953 & 100 \\
\hline $\mathbf{1 9 6 0}$ & 135.820 & 95,03 & 7.096 & 4,97 & 142.916 & 100 \\
\hline $\mathbf{1 9 7 0}$ & 213.569 & 96,40 & 7.977 & 3,60 & 221.546 & 100 \\
\hline $\mathbf{1 9 8 0}$ & 326.582 & 98,98 & 3.360 & 1,02 & 329.942 & 100 \\
\hline $\mathbf{1 9 9 1}$ & 497.600 & 100 & -- & -- & 497.600 & 100 \\
\hline $\mathbf{2 0 0 0}$ & 597.934 & 100 & -- & -- & 597.934 & 100 \\
\hline $\mathbf{2 0 1 0}$ & 720.785 & 99,5 & 2.730 & 0,5 & 723.515 & 100 \\
\hline
\end{tabular}

Fonte: IBGE - Censos 1970, 1980, 1991, 2000 e 2010; Plano de Desenvolvimento Urbano e Comunitário de João Pessoa - 1983-86 (PMJP, 1983). Elaboração da autora (2018).

Entre as décadas de 1960 e 1980, a produção dos conjuntos habitacionais do BNH em João Pessoa provocou uma expansão urbana em escala expressiva, numa área que era, até então, ocupada por estabelecimentos agropecuários, correspondendo assim à materialização da expressão já conhecida de que "a cidade vai engolindo o campo". Ao analisar a localização dos conjuntos habitacionais no território de João Pessoa, produzidos em período anterior e durante a atuação do $\mathrm{BNH}$, é possível constatar o que foi afirmado acima no tocante ao início do processo de periferização da cidade. ${ }^{11}$

Durante a atuação do BNH, de 1964 a 1986, foram construídas cerca de 29.000 unidades habitacionais em João Pessoa, distribuídas em 42 conjuntos habitacionais. Isso representou uma relevante produção imobiliária na cidade, tendo em vista que, de acordo com o Censo Demográfico do IBGE de 1970, havia apenas 38.663 domicílios permanentes em João Pessoa.

${ }^{1}$ Embora a maioria dos conjuntos do $\mathrm{BNH}$ tenha sido instalada em áreas periféricas, alguns deles foram implantados em áreas desocupadas contíguas ao tecido urbano existente de João Pessoa. Tais conjuntos foram aqueles implantados nos primeiros anos de atuação da instituição. 
Por se caracterizarem, predominantemente, como conjuntos habitacionais de grande porte - com centenas de habitaçôes -, foram, portanto, implantados em grandes lotes ou glebas disponíveis em áreas menos valorizadas, com solo mais barato, isto é, em áreas de expansão e/ou antigas propriedades rurais.

Essa ampla escala de produção, que se caracterizou por conjuntos habitacionais compostos por residências unifamiliares ocupando grandes extensôes de terra, contribuíram para a alteração das áreas limítrofes do perímetro urbano incorporando inclusive grandes glebas rurais, de modo que, entre os anos de 1972 e 1983, de acordo com Oliveira (2006), a área da cidade dobrou de tamanho. As terras rurais foram transformadas em urbanas, pois passaram a ser providas com os serviços e equipamentos de uso coletivo.

Vale ressaltar ainda que, nas décadas de 1960 e 1970, por meio de açóes do programa nacional de desenvolvimento e crescimento urbano, outras relevantes alteraçōes no entorno da malha urbana de João Pessoa influíram diretamente em sua estruturação. Foram elas: a implantação do Campus da Universidade Federal da Paraíba e do Distrito Industrial, na Zona Sul de seu território; e a criação de um anel rodoviário (BR-101/ BR-230) que corta o espaço intraurbano da cidade, ligando-o aos municípios vizinhos (Bayeux, Santa Rita e Cabedelo).

Deste modo, é possível afirmar que o programa nacional de desenvolvimento e dinamizaçáo da economia atuou diretamente na produçáo do espaço urbano local e, de fato, transformou a cidade "tradicional" de outrora, em cidade "modernizada", caracterizada pela expansão territorial e desconcentraçáo do seu centro tradicional, pelo surgimento de novas centralidades e pela diversificação de atividades e interesses sociais (Maia, 2000).

Nesse momento, novas tendências de crescimento de seu território foram estabelecidas, apresentando visivelmente a estratificaçáo do uso do espaço da cidade, marcado pelo aumento das distâncias sociais: na direção leste e norte se concentraram a populaçáo de alta renda e, para a direçáo sul e sudeste, foram conduzidas as de baixa renda (Lavieri e Lavieri, 1999).

Segundo Martins (2019), tal quadro de segregaçáo socioespacial e periferização urbana, conformado desde a década de 1960, se intensificou ao longo dos anos não apenas pela continuidade das dinâmicas que lhes deram origem, mas também em decorrência da criaçáo de marcos legais que os institucionalizaram e os nortearam, tais como o Código de Obras, o Código de Urbanismo e o Plano Diretor de João Pessoa. Deste modo, 
verifica-se assim que, ao longo do tempo, no tocante à legislação vinculada ao planejamento e controle do uso e ocupação do solo da cidade, foi realizada uma definição cada vez mais precisa das zonas destinadas à preservação ambiental e patrimonial, no entanto, constatou-se ao mesmo tempo a ampliação e a intensificação da ocupação da área urbana de modo descontínuo, assim como o seu avanço sobre a Área Rural (Martins, 2019, p. 102).

Assim, o espaço foi preparado para o mercado imobiliário pelo planejamento urbano, que estimulou o processo especulativo na cidade ao expandir o perímetro urbano e instalar infraestrutura urbana de forma desigual nas áreas da cidade (Santos, 2008).

De acordo com Santos (2015), na década de 1990, mudanças na política, no modo de organização e nos parâmetros de acumulação do capital acarretaram a centralização da dinâmica geográfica do capital e a sua concentração no espaço, de modo que houve a valorização das áreas centrais das grandes cidades em detrimento das suas zonas periféricas. Dessa forma, o padrão de ampliação do capital vinculado à expansão geográfica da cidade foi modificado a partir da década de 1980, com a crise do pacto desenvolvimentista do governo.

Nesse processo, o mercado imobiliário se destacou ainda mais como local de absorção dos excedentes com geração de lucro, substituindo as estratégias anteriores voltadas para o desenvolvimento econômico extensivo. No Brasil, as décadas de 1980 e 1990 foram marcadas, sobretudo, pela diminuição dos financiamentos habitacionais e pelo aumento dos índices de desemprego e do empobrecimento da população (Santos, 2015).

Nesse período, a política de habitação nacional sofreu intensa modificação: no lugar de uma "Política de Estado", na qual se insere a atuação do BNH, deu-se início uma "Política de Governo", que se caracterizou pela ausência de uma política definida e objetiva e pela presença de programas diversos e específicos, desenvolvidos segundo cada mandato presidencial, descentralizadas e distribuídas entre instituiçôes diversas, como a Caixa Econômica Federal (CEF) e o Banco Central (Bonates, 2007).

De acordo com Bonates (2007), nas últimas décadas do século XX e na primeira do século XXI, a produção estatal da habitação social em João Pessoa sofreu um arrefecimento em relação ao período de atuação do BNH. Entre 
1987 e 2006, foram financiadas pelo poder público cerca de 17.500 unidades habitacionais, implantadas predominantemente em bairros da Zona Sul da cidade. Os empreendimentos englobaram tanto habitações unifamiliares como multifamiliares (edifícios com quatro pavimentos, em média). A verticalização das construções deu-se devido às dimensões mais reduzidas e aos altos preços dos terrenos, e foi utilizada, também, como solução para melhor aproveitamento da área passível de construção do lote, para racionamento dos materiais, da mão de obra e dos custos.

Ademais, destacou-se também, em tal período, a produção habitacional realizada por empresas privadas - como cooperativas habitacionais e incorporadoras - por meio de financiamento pela CEF com recursos de programas habitacionais do governo. Tal produção, diferentemente daquela realizada pelo poder público, voltou-se para um público diversificado, geralmente com rendimento médio, e compreendeu um total de 4.536 unidades habitacionais localizadas, predominantemente, em áreas centrais e valorizadas da cidade (Bonates, 2007) (mapa 1). Assim, como constatou Martins (2019),

a produção de habitaçáo social em Joáo Pessoa, em tal momento, ocupou espaços já urbanizados da cidade e, portanto, não induziu dinâmicas de expansão e dispersáo urbana. Ademais, a implantação dos empreendimentos em bairros urbanizados não alterou a estruturação da cidade, formada no período de atuação do BNH. Pode-se então inferir que a construção dos conjuntos habitacionais no período em questão apenas intensificou a ocupação de bairros iniciada décadas antes, ao implantá-los em terrenos vazios remanescentes (p. 104-105). 
Mapa 1 - Localização dos conjuntos habitacionais produzidos no século XX em João Pessoa

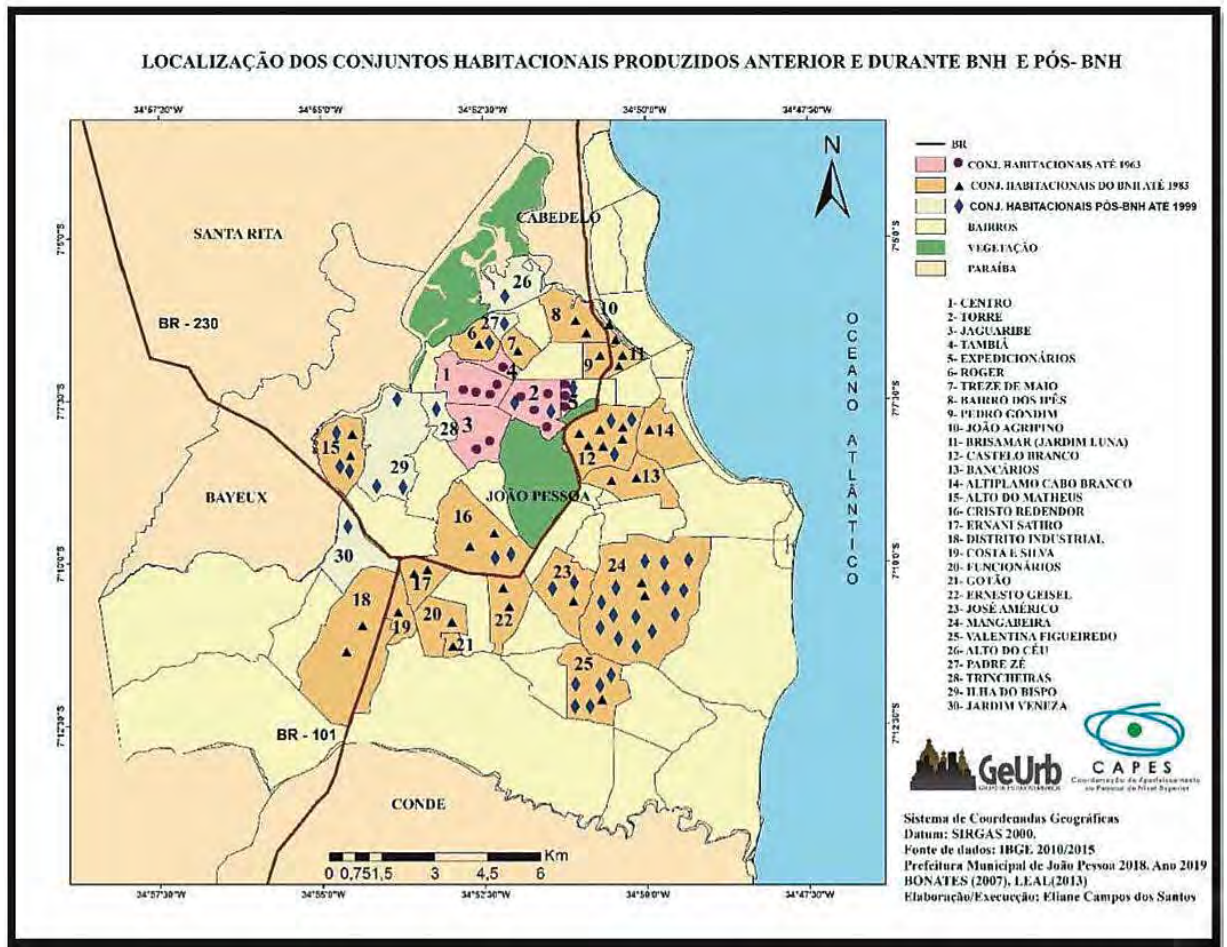

Elaboração: Eliane Campos dos Santos, 2019.

Conclui-se, portanto, que o Estado desempenhou papel preponderante na estruturação do território de João Pessoa, sobretudo ao longo do século XX e início do século XXI, tanto por meio das políticas públicas de desenvolvimento - entendido como crescimento -, quanto pela regulação do uso e ocupaçáo do solo, produzindo um tecido urbano expandido de forma espraiada e descontínua a partir do processo de periferização (Martins, 2019). Processo que, de acordo com Sierra (2004), assume no século XXI uma complexidade inédita, marcada por porosidades e ausência de limites precisos. 


\section{A periferia no centro da produção imobiliária: O PMCMV em João Pessoa-PB}

Após um período de ausência de políticas habitacionais no século XXI, deu-se início a um novo momento de estímulo à produção imobiliária no país, resultante do processo de neoliberalização da política e de recentes mudanças econômicas que - como mencionado na introduçáo - aproximaram cada vez mais o capital financeiro do setor imobiliário. Tais mudanças imprimiram novas dinâmicas urbanas no tecido da cidade, alterando profundamente a sua estruturação, sobretudo por meio da formação de novos conteúdos socioespaciais na periferia urbana.

Dentre as açôes do Estado que repercutiram na produção habitacional das periferias e na estrutura de muitas cidades brasileiras, destacam-se a implantação do Sistema Nacional de Habitação de Interesse Social (SNHIS) e do Fundo Nacional de Habitação de Interesse Social (FNHIS), a regulamentação do Estatuto da Cidade, a criação do Ministério das Cidades em 2003 e o início do Programa de Aceleração do Crescimento (PAC) em 2007.

Na primeira década do século XXI, houve a elaboração de uma agenda marcada pela construçáo de um Estado de direitos e, ao mesmo tempo, por pautas e práticas neoliberais. Foram realizadas açóes a fim de expandir o mercado interno, com a inclusão de estratos de renda mais baixa ao circuito de consumo. Os bancos e fundos públicos também retomaram seu papel a partir de programas como o PAC e o PMCMV, por meio da provisão de créditos e do estímulo aos investimentos tanto por parte do setor público como do privado (Rolnik, 2015).

No PMCMV, os preços dos imóveis são pré-determinados de acordo com cada faixa de renda contemplada, o que fez com que as empresas que produziam imóveis voltados para a comercialização através do programa utilizassem estratégias para minimizar os custos dos empreendimentos imobiliários e, assim, otimizar seus ganhos.

Dentre as estratégias, Rufino (2016) destacou a padronização, a ampliação da escala da produção e a escolha por terrenos mais baratos, geralmente localizados em áreas mais distantes dos centros das cidades. A ocupação das áreas mais afastadas se tornou ainda mais latente devido ao fato do PMCMV ter permitido o lançamento de empreendimentos nos municípios menores inseridos em regióes metropolitanas o que, por sua vez, "legitimou 
a metropolização do déficit” (p. 227). A ampliação das possibilidades e distâncias de localização dos empreendimentos fez com que, até 2011, a maioria das unidades contratadas pelo programa fossem inseridas em municípios localizados na periferia metropolitana (Rufino, 2016).

Contudo, na Regiāo Metropolitana de João Pessoa (RMJP), como constatou Martins (2019), a produçáo do PMCMV se localizou e se concentrou de modo diferente da realidade retratada por Rufino (2016). Ao analisar a quantidade de empreendimentos entregues pelo programa nas cidades que compóem a RMJP (tabela 2), foi possível constatar que as unidades habitacionais construídas no âmbito do mencionado programa se concentraram no espaço intraurbano de João Pessoa, principalmente aquelas inseridas na Faixa 1 que, segundo Rufino (2016), são as que geralmente estão localizadas nas áreas mais distantes dos centros urbanos.

Tabela 2 - Unidades entregues pelo PMCMV nas cidades que compóe a RMJP

\begin{tabular}{l|c|c|c}
\hline \multirow{2}{*}{ Cidades da RMJP } & \multicolumn{3}{|c}{ Unidades Habitacionais Entregues do PMCMV } \\
\cline { 2 - 4 } & Faixa 1 & Faixa 2 & Faixa 3 \\
\hline Alhandra & -- & 489 & 3 \\
\hline Bayeux & -- & 1.091 & 25 \\
\hline Caaporá & 30 & 15 & 2 \\
\hline Cabedelo & -- & 417 & 99 \\
\hline Conde & 219 & 398 & 23 \\
\hline Cruz do Espírito & -- & 1 & -- \\
\hline Santo & 6.622 & 34.633 & 1.935 \\
\hline Joáo Pessoa & -- & 102 & 6 \\
\hline Lucena & 123 & 471 & 21 \\
\hline Pedras de Fogo & 70 & 9 & -- \\
\hline Pitimbu & 43 & 85 & 5 \\
\hline Rio Tinto & 1.051 & 9.338 & 61 \\
\hline Santa Rita & & & \\
\hline
\end{tabular}

Fonte: Banco de Dados do Ministério das Cidades. Edição nossa (2018) 
Entretanto, não se pode afirmar que os mencionados empreendimentos foram implantados em áreas privilegiadas do ponto de vista da localização intraurbana. Ao identificar a localização da implantação de cada empreendimento do Faixa 1, observou-se que concentraram-se, sobretudo, em bairros periféricos da cidade, distantes do seu centro principal, aqui entendido como a área da cidade que ainda concentra os principais serviços, comércios e instituiçóes da cidade, apesar da coexistência de subcentros ou novas centralidades em seu espaço intraurbano (mapa 2).

Mapa 2 - Mapa de localização dos conjuntos habitacionais do PMCMV no município de João Pessoa - PB

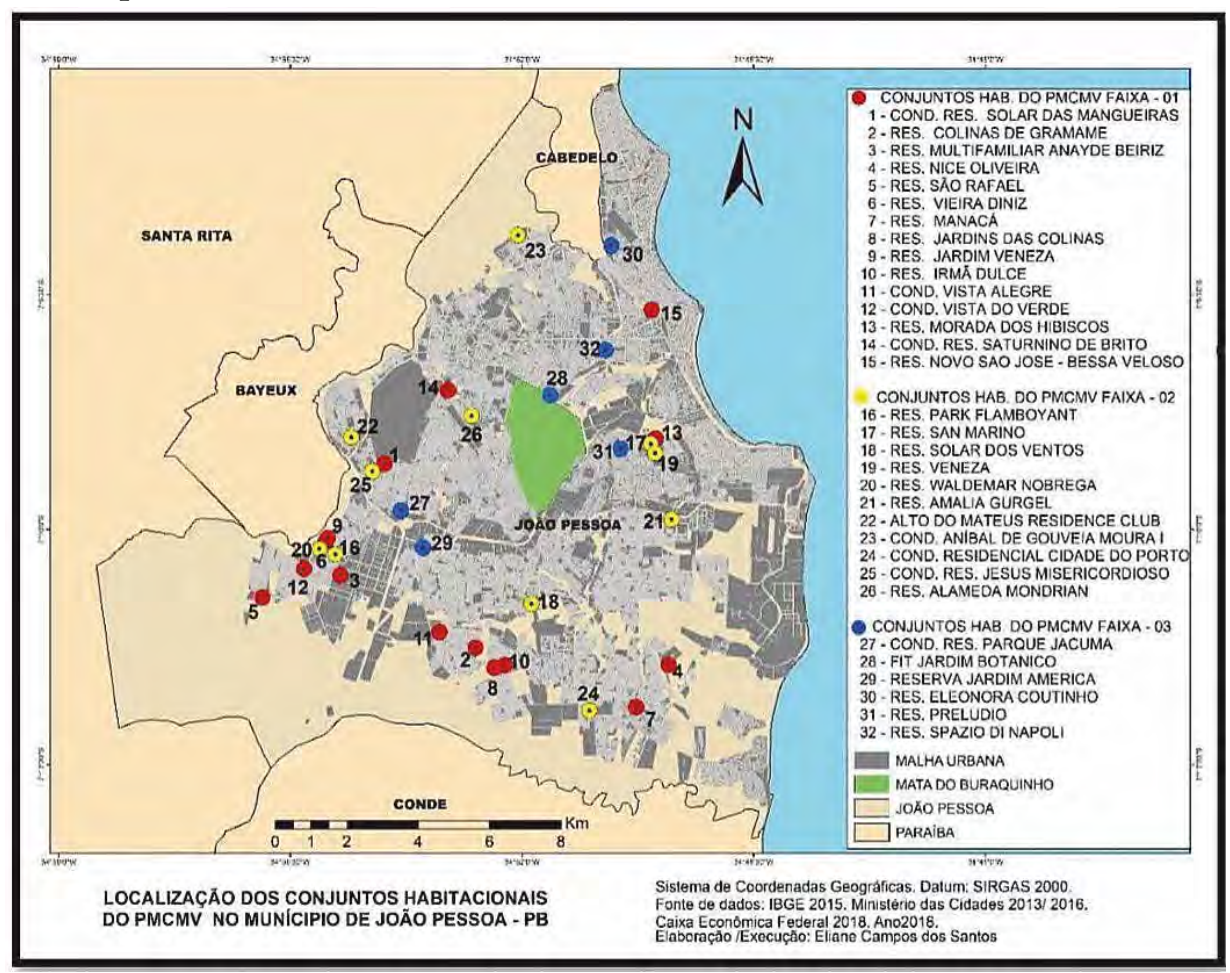

Elaboração: Eliane Campos dos Santos, 2018.

Apesar disso, não se pode afirmar que os empreendimentos do PMCMV estimularam um processo de dispersão urbana em Joáo Pessoa, tendo em vista que os eles ocuparam alguns vazios urbanos remanescentes, mas há continuidade no espraiamento, pois as construçóes se deram sobretu- 
do em áreas contínuas ao tecido urbano existente inseridas em zonas ou em bairros de ocupação recente, com relevante quantidade de lotes desocupados a serem comercializados.

Deste modo, com a ocupação desses novos espaços, houve acelerado processo de expansão urbana sobre áreas rurais remanescentes nas bordas do município e de sua valorizaçáo, pois, ao receberem infraestruturas e serem ocupadas, se transformaram em áreas urbanas.

As açóes das empresas construtoras e incorporadoras refletem nas transformaçóes do espaço e, principalmente, no espaço intraurbano, como está ocorrendo na periferia da cidade de João Pessoa, mas essas mudanças também ocorrem em outros setores, em áreas residenciais de grande valor especulativo. Contudo, na maioria dos casos, tais localizaçóes se devem a obras atreladas a projetos mais amplos de infraestruturação de comunidades/favelas ou à produção de mercado do PMCMV, voltada para as faixas 2 e 3 .

Os empreendimentos referentes às Faixas 2 e, principalmente, 3 do PMCMV foram implantados em áreas menos periféricas, com infraestrutura urbana mais completa e ocupação urbana consolidada. É possível identificar no Mapa 2, a localização de empreendimentos do PMCMV Faixa 3 em bairros como Torre, Tambauzinho, Aeroclube e Jardim Cidade Universitária.

Além da localização, os empreendimentos das três faixas diferiram também em relação às suas características estéticas, estruturais e funcionais. Aqueles vinculados à Faixa 1 apresentaram, geralmente, uma estrutura mais simples, com alvenaria estrutural, unidades com área privativa mínima exigida pelo programa e pela legislaçáo municipal, assim como reduzidas áreas de uso comum (foto 1). 
Foto 1 - Empreendimento PMCMV Faixa 1 (Res. Vieira Diniz), localizado no bairro Jardim Veneza, em João Pessoa - PB

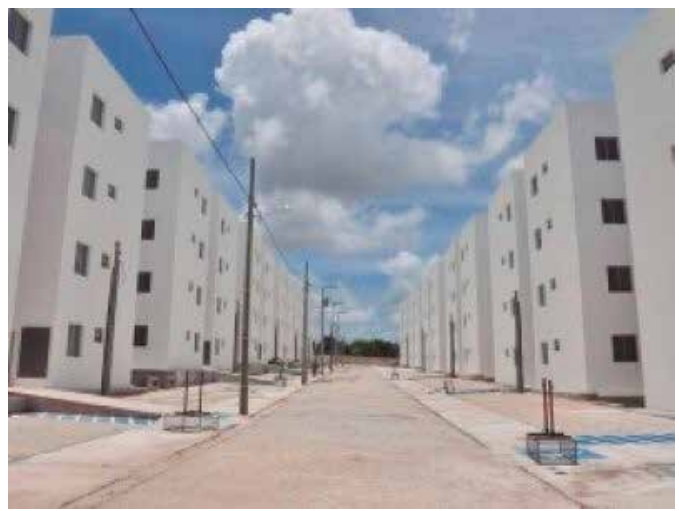

Disponível em: https:/www.pbagora.com.br/noticia/policial/moradores-do-vieira-diniz-denunciam-falta-de-seguranca/. Acesso em: 10 jun. 2019.

Os empreendimentos da Faixa 2 apresentaram qualidade construtiva e de acabamento superior, com unidades habitacionais com áreas um pouco maiores e áreas de uso comum mais completas (foto 2). Aqueles referentes à Faixa 3, por sua vez, diferenciam-se das demais faixas por apresentar, geralmente, edificaçóes verticalizadas com áreas de lazer e de uso comum com equipamentos mais diversificados como piscinas, quadras poliesportivas, garagens cobertas, entre outros (foto 3).

Foto 2 - Empreendimento PMCMV Faixa 2 (Res. Amália Gurgel), localizado no bairro Mangabeira, em João Pessoa - PB

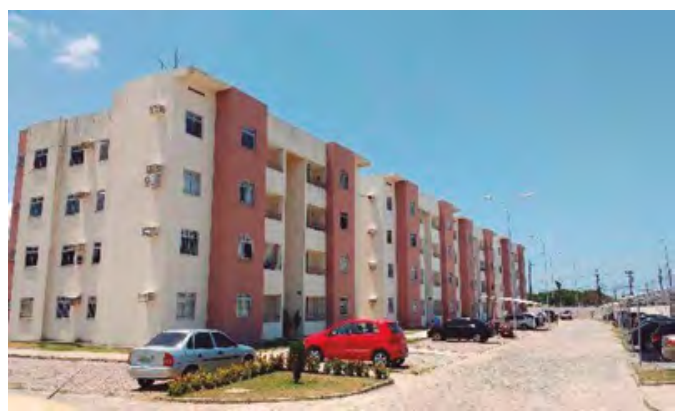

Disponível em: https://pb.mgfimoveis.com.br/aluguel-pb-joao-pessoa-apartamento-em-mangabeira-joao-pessoa-pb-perto-do-1120228. Acesso em: 10 jun. 2019. 
Foto 3 - Empreendimento PMCMV Faixa 3 (Res. Spazio di Napoli), localizado no bairro Tambauzinho, em João Pessoa - PB

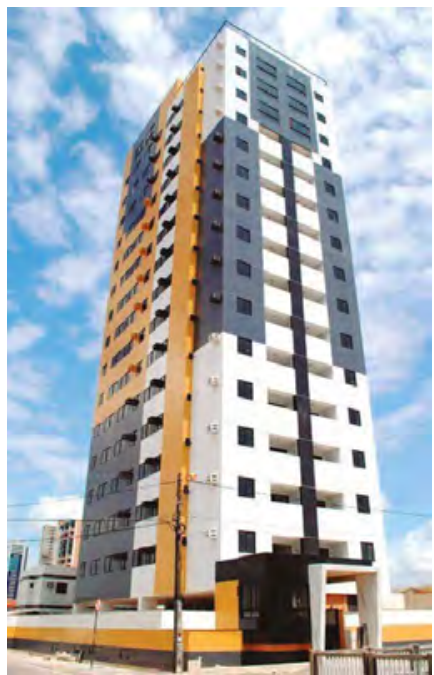

Disponível em: http://www.massai.com.br/novo/empreendimento/spazio-di-napoli-joao-pessoa/\#fotos. Acesso em: 10 jun. 2019.

Contudo, ressalta-se aqui que, em ambos os casos, as plantas dos apartamentos apresentaram, em sua maioria, ambientes com áreas mínimas permitidas, o que significa dizer que, apesar do preço do imóvel ser mais alto e da estrutura do empreendimento ser mais completa na Faixa 3, as unidades habitacionais foram projetadas seguindo um padrão de racionalização de espaços dos ambientes em detrimento do conforto e das necessidades reais dos seus futuros moradores.

O avanço da produção imobiliária sobre a periferia da cidade tem ocasionado a diversificação e complexificação desse espaço: antes lugar da autoconstrução e do loteamento irregular, ela agora é um espaço disputado e produzido pelos agentes imobiliários, pelos proprietários de terra e pelo Estado; não são construídos nela apenas edificações unifamiliares com estruturas precárias e sem infraestrutura; muitas vezes são instaladas infraestruturas básicas e são construídas outras tipologias, como casas geminadas, edifícios multifamiliares e condomínios horizontais com área de lazer, além de ser ainda comum encontrar terrenos ou glebas de grandes extensóes desocupados ou de uso agrícola ou pecuário (Martins, 2019). 
Assim, a periferia que, de acordo com Santos (1981), possuía conteúdo social específico e menor grau de participação na estruturação da cidade e um conteúdo social específico, passou a concentrar o capital no espaço ao atrair capital público e privado e reproduzi-lo com a intensificação da sua ocupação e a reprodução do espaço urbano.

Contudo, como afirmou Sposito (2004), as periferias urbanas nas cidades contemporâneas possuem novos conteúdos que não abrangem a superação da pobreza, da falta de integração e das más condiçóes de vida, mas a diversificação dos modos que esses espaços sáo produzidos e apropriados pela sociedade.

\section{Consideraçóes finais}

Apesar de proporcionar a regularização fundiária e a melhoria das condiçóes habitacionais de parte da população, os recentes programas do governo relacionados à produção do espaço urbano, de modo geral, reiteram a lógica da especulação fundiária e imobiliária, o que favorece financeiramente os proprietários de terra e promotores imobiliários e, também, ocasionam perdas para aqueles que involuntariamente passaram a habitar em áreas cada vez mais distantes dos locais de trabalho e de comércio e serviços.

De uma maneira geral, a ocupação intensa da periferia urbana de João Pessoa por meio da produção habitacional desencadeada pelo PMCMV expõe os avanços da produção imobiliária e da valorização fundiária e imobiliária sobre as áreas periféricas no início do século XXI.

Nesse processo emergem novas relaçóes socioespaciais e alteraçóes no processo de urbanização: a periferização não decorre mais do desenvolvimento e crescimento da indústria, mas da dinâmica econômica atual, que tem a reprodução do espaço urbano como elemento central para sua dinamização junto ao capital financeiro, reproduzindo e intensificando a segregação e a desigualdade na cidade. Como explicou Rufino (2016),

Os impactos da disseminação dessa lógica de produção sobre as periferias não se restringem aos proprietários, tende ainda a promover novas formas de desigualdades, à medida que dificulta a produção de habitação mais acessível e entrava o seu acesso por outros meios de produção, que permanecem a acontecer com maior precariedade. Essa contradição, levada à periferia, tende a extinguir as condiçóes de acesso à moradia dos mais empobrecidos na 
cidade. Nesse sentido, as desigualdades se impóem com maior força entre os mais empobrecidos e não beneficiados por essa lógica de disseminação da propriedade imobiliária (p. 231).

Ao verificar a disposição locacional das construções dos empreendimentos do PMCMV Faixa 1, percebe-se que as áreas dos conjuntos estáo predominantemente na zona sul da cidade e, em sua maioria, com distância entre 7,5 e $10 \mathrm{~km}$ do Centro principal da cidade. Implementados sob o discurso da moradia digna e da casa própria para a população de baixa renda, eles impóem a este grupo uma moradia com localização que não lhe garante o direito à cidade. Náo se trata apenas de garantir a habitação, mas também condições dignas de acesso a serviços - educação, saúde e lazer - e infraestrutura.

Diante do que foi colocado acima, o setor imobiliário brasileiro de fato passou a intensificar e a expandir territorialmente sua produçáo, interferindo diretamente nas realidades urbanas das cidades brasileiras. Entretanto, tais mudanças não foram capazes de solucionar os problemas urbanos existentes, inclusive em relação ao déficit habitacional existente.

Como ressaltou Maricato (2015), apesar dos investimentos do governo voltados para a habitação e para as infraestruturas urbanas nos últimos 30 anos, não foram alterados o controle sobre a ocupação e uso do solo nem os grupos sociais que os dominam e, deste modo, a situação de desigualdade nas cidades se intensificou, piorando a cada dia, desencadeando um momento denominado pela autora de "crise urbana".

\section{Referências}

BOLAFFI, Gabriel. "Habitação e urbanismo: o problema e o falso problema". In: MARI-

CATO, Ermínia (Org.). A produção capitalista da casa (e da cidade) no Brasil Industrial. 1. ed. São Paulo: Alfa-omega, 1979. pp. 37-70.

BONATES, Mariana Fialho. Ideologia da casa própria... sem casa própria: O programa de Arrendamento Residencial na cidade de João Pessoa-PB. (Dissertação). Natal: Universidade Federal do Rio Grande do Norte, 2007.

CORRÊA, Roberto Lobato. O Espaço Urbano. 4. ed. São Paulo: Ática, 2003. 96p.

IBGE. Regiôes de influência das cidades 2007. Disponível em: https://biblioteca.ibge.gov.br/ visualizacao/livros/liv40677.pdf. Acesso em: 05 dez. 2017.

KOWARICK, Lúcio. A Espoliação Urbana. 1. ed. Rio de Janeiro: Paz e Terra, 1979. 202p. 
LAVIERI, João Roberto e LAVIERI, Maria Beatriz Ferreira. Evolução urbana de João Pessoa - pós 60 . In: GONÇALVES, R. C. et al (Org.). A questão urbana na Paraíba. 1. ed. João Pessoa: Ed. Universitária/UFPB, 1999. 74p. pp. 39-66.

MAIA, Doralice Sátyro. Tempos lentos na cidade: Permanências e Transformaçóes dos costumes rurais em João Pessoa - PB. (Tese). São Paulo: Universidade de São Paulo, 2000.

. "A habitação popular e o processo de periferização e fragmentação urbana: uma análise sobre as cidades de João Pessoa-PB e Campina Grande-PB”. Geosul, Florianópolis, v. 29, n. 58, pp. 89-113, jul./dez. 2014.

MARICATO, Ermínia. O impasse da política urbana no Brasil. 3. ed. Petrópolis: Vozes, 2014. $186 \mathrm{p}$.

. Para entender a crise urbana. 1. ed. São Paulo: Expressão Popular, 2015. 112p.

MARTINS, Paula Dieb. O imobiliário e a reestruturaçáo urbana: a cidade de João Pessoa/PB no século XXI. (Tese). João Pessoa: Universidade Federal da Paraíba, 2019.

MELAZZO, Everaldo Santos. "Estratégias fundiárias e dinâmicas Imobiliárias do capital financeirizado no Brasil”. Mercator, Fortaleza, v. 12, n. especial 2, pp. 29-40, set. 2013.

OLIVEIRA, Luciano Agra de Oliveira. Uma contribuição aos estudos sobre a relação de transportes e crescimento urbano: $O$ caso de João Pessoa - PB. (Dissertação). João Pessoa: Universidade Federal da Paraíba, 2006.

REIS, Nestor Goulart. Notas sobre Urbanização Dispersa e Novas Formas de Tecido Urbano. 1. ed. São Paulo: Via das Artes, 2006. 201p.

ROLNIK, Raquel. Guerra dos lugares: a colonização da terra e da moradia na era das finanças. 1. ed. São Paulo: Boitempo, 2015. 423p.

RUFINO, Beatriz. "Transformação da periferia e novas formas de desigualdade nas metrópoles brasileiras: um olhar sobre as mudanças na produção habitacional”. Cadernos Metrópole, São Paulo, v. 18, n. 35, pp. 217-36, abr. 2016.

SANTOS, Milton. Manual de Geografia Urbana. 1. ed. São Paulo: Hucitec, 1981. 226p.

. Urbanizaçâo Brasileira. 5. ed. São Paulo: Editora da Universidade de São Paulo, 2008. 176p.

SANTOS, César Simoni. A Fronteira Urbana: Urbanização, industrialização e mercado imobiliário no Brasil. 1. ed. São Paulo: PPGH-USP/FAPESP/Annablume, 2015. 366p.

SHIMBO, Lúcia Zanin. Habitação social, Habitação de mercado: a confluência entre Estado, empresas construtoras e capital financeiro. 2010. 361f. (Tese). São Carlos: Universidade de São Paulo, 2010.

SIERRA, Pablo Arias. Periferias y nuevas ciudades: el problema del paisaje em los procesos de dispersión urbana. 1. ed. Sevilla: Universidad de Sevilla, 2004. 552p.

SOUZA, Marcelo Lopes de. ABC do Desenvolvimento Urbano. 5. ed. Rio de Janeiro: Bertrand Brasil, 2003. 192p.

SPÓSITO, Maria Encarnação Beltrão. O chão em pedaços: Urbanização, economia e cidades no Estado de São Paulo. (Tese). Presidente Prudente: Universidade Estadual Paulista, 2004. VILLAÇA, Flávio. Espaço intra-urbano no Brasil. 2. ed. São Paulo: Studio Nobel, 2001. 392p. 



\section{PMCMV e produçáo imobiliária nas cidades de Patos e Cajazeiras/PB}

Luciana Medeiros de Araújo

O presente capítulo apresenta alguns resultados da pesquisa doutoral sobre a produçáo imobiliária e a expansão urbana das cidades de Patos e de Cajazeiras, situadas na mesorregião do Sertão Paraibano, às margens da BR230. Conforme a recente Divisão Urbano Regional (IBGE, 2013), cada uma dessas cidades compóe Regiôes Intermediárias de Articulação Urbana, cujas áreas de influência territorial extrapolam os limites definidos por suas microrregiôes geográficas e os limites estaduais.

A delimitação territorial das duas regióes intermediárias abrange 56 municípios, o que equivale a $25 \%$ do total existente no estado, chegando a mais de 60\% dos municípios do Sertáo Paraibano. Entre os anos de 2009 e 2015, Patos e Cajazeiras se destacaram entre as cidades interioranas pela grande abertura de loteamentos residenciais e pela produção habitacional financiada pelo Programa Minha Casa Minha Vida (PMCMV), instituído em 2009 pelo governo federal, no governo do presidente Luiz Inácio Lula da Silva (2003-11).

Em âmbito nacional, esse programa reafirmou o imprescindível lugar do Estado como propulsor da promoção imobiliária voltada à habitação de interesse social, bem como à de mercado. Igualmente redefiniu as diretrizes de subvenção de crédito habitacional para famílias de baixa renda e garantiu o crédito imobiliário a empresas de construção para a promoção privada de habitação de mercado, com abrangência de segmentos da população de médio e alto rendimento. Assim, as açóes do Estado propiciaram grande impulso à economia urbana, à mobilidade do capital e, por conseguinte, à convergência de agentes imobiliários privados locais e não locais, em especial 
incorporadores e construtoras, com capacidade de investir, intervir e transformar o setor imobiliário e o espaço urbano.

O presente texto aporta-se em referenciais teórico-metodológicos relativos à produção capitalista do espaço urbano, com ênfase na produção da habitação de interesse social pelo PMCMV. A coleta de dados primários e secundários, bem como os trabalhos de campo foram realizados no decorrer da pesquisa doutoral (2013-16). Os dados primários foram arrolados a partir da análise dos processos de incorporaçóes dos empreendimentos imobiliários, disponibilizados para consulta nos cartórios de registros de imóveis das cidades investigadas; e os secundários obtivemos por meio do acesso a sites oficiais e a demandas enviadas às instituiçóes nacionais, estaduais e municipais pelo Serviço Eletrônico de Informação ao Cidadão (e-SIC) e Formulário de Acesso à Informação, disponíveis na internet. Dentre essas instituiçôes, estáo a Secretaria Nacional de Habitação, o Ministério das Cidades, o Instituto Brasileiro de Geografia e Estatística (IBGE), a Fundação João Pinheiro, o Conselho Regional de Engenharia e Agronomia (CREA/PB) e as prefeituras municipais. Nos trabalhos de campo, realizamos registros fotográficos, entrevistas semiestruturadas e conversas informais. Os dados sistematizados estão representados em gráficos, tabelas e imagens do Google Earth.

\section{Notas introdutórias sobre o PMCMV}

Desde a sua instituição, o PMCMV objetiva criar mecanismos de incentivo à construção e à aquisição de novas habitaçôes por famílias com rendimento bruto de até dez salários mínimos, discriminadas por diferentes faixas de renda familiar - Faixa 1 (até 3 salários mínimos), Faixa 2 (de 3 a 6 salários mínimos) e Faixa 3 (até 10 salários mínimos ). ${ }^{11}$ A meta inicial do programa estabeleceu a produção de um milhão de moradias para todo o território nacional, sendo $40 \%$ desse total para as famílias com renda de até três salários, portanto, inseridas na Faixa 1. Para esta faixa, os beneficiários devem

1 No final de 2016, o governo Temer inverteu as metas de produção por faixa, favorecendo a produçáo da habitaçáo de mercado. Foi aumentado o limite de renda em todas as faixas, principalmente, na Faixa 3, que passou de 6,5 para 9 mil reais. Ampliou-se o limite do uso do FGTS, bem como o teto dos preços dos imóveis. Nesse contexto, das 610 mil unidades previstas para contratação, apenas 27,8\% (170 mil) foram destinadas para a Faixa 1; 6,5\% (40 mil), para a Faixa 1,5 (nova faixa criada); e 65,5\% (400 mil) para as Faixas 2 e 3, cujo rendimento pode variar de 4 a 9 nove mil reais 
ser cadastrados pelas prefeituras, na Secretaria de Desenvolvimento Humano, e a habitação é subsidiada, quase totalmente, pelo governo federal, com um comprometimento de, no máximo, $5 \%$ da renda familiar, ${ }^{22}$ ou seja, a aquisição é feita fora do crédito hipotecário (Shimbo, 2010 e Rolnik, 2015).

No contexto de sua implantação, o PMCMV foi revestido como a "mais importante ação no campo econômico-social, articulando a oferta de moradia, demanda histórica e ativo eleitoral tradicionalmente forte, com uma estratégia keynesiana de crescimento econômico e geração de empregos”, segundo Rolnik (2015, p. 301). Nesse sentido, ante esse apelo e essas expectativas, o programa foi articulado como base em três campos de ação: o social, o econômico e o político.

Em linhas gerais, o PMCMV teria que, socialmente, garantir o acesso à casa própria para um crescente número de famílias de diferentes segmentos de renda; isto é, reduzir o déficit habitacional dos segmentos mais pobres, bem como atender à grande demanda social por habitação das famílias de médio rendimento, retida desde os anos 1990. Para isso, o governo federal ampliou as estratégias de aquisição de moradia, por meio da liberação de subsídio, associado ou não à concessão de crédito.

Economicamente, foi necessário impulsionar o crescimento da economia e a geração de emprego e aquecer o setor imobiliário, notadamente a construção civil e a comercialização de habitação de mercado. Segundo o Balanço do PAC (2015), entre 2009 e 2013 foi criada, por ano, uma média de 921 mil empregos diretos e indiretos na construção civil. Como especificado em relatório, "calcula-se, ainda, que, para cada $\mathrm{R} \$ 1$ milhão desembolsado pelo programa, outros $\mathrm{R} \$ 744$ mil são gerados em renda, com impacto direto no consumo e repercussão em diversas outras cadeias produtivas da economia" (PAC, 2015, p. 45).

Do ponto de vista político, para garantir mais apoio da base dos movimentos sociais de luta pela moradia, o governo definiu linhas de crédito associativo vinculado às entidades, bem como para as famílias do campo, além de estender o programa aos municípios com população inferior a 50

2 Conforme o site do Portal Minha Casa Minha Vida, as recentes mudanças nos limites de renda familiar para efeito de financiamento, em 2016, não alteram a Faixa 1. Contudo, as prestaçóes passaram a ser pagas em até 120 meses, sem juros, com comprometimento máximo de $28 \%$ da renda familiar. Os subsídios podem chegar até $90 \%$ do valor do imóvel. 
mil habitantes. Porém, é no âmbito econômico que o PMCMV está efetivamente assentado. Como admite Rolnik (2015), desde a criação do programa, o PMCMV-Empresas passou a constituir o "núcleo duro" da atual PNH.

Nessa modalidade, a empresa de construção civil apresenta o projeto do empreendimento à instituição financeira - CEF ou Banco do Brasil - que, depois de analisar a viabilidade, contrata a operação e acompanha a execução da obra. Concluída a obra, a instituição financeira gestora responsabiliza-se pela alienação das unidades para as famílias selecionadas. Nesse caso, o PMCMV prevê o limite de trezentas unidades habitacionais por projeto. Entretanto, é frequente a inobservância dessa norma, a exemplo da contratação do Residencial Itatiunga, em Patos, feita com 770 unidades edificadas na Faixa 1, operacionalizadas pelo Banco do Brasil, em parceria com os governos municipal e estadual.

No âmbito do Brasil, ao tomarmos como referência o recorte temporal 2009-15, a análise dos relatórios de produção habitacional do PMCMV (SNH/MCIDADES, 2016) revelou que, na primeira etapa, o PMCMV 1 atingiu a meta, consolidando-se para a implementação da segunda etapa. Nesta, o total de unidades contratadas em todo o país chegou a mais de 2,7 milhóes de unidades, sendo mais de $40 \%$ desse total destinado a famílias de baixa renda.

Nas duas primeiras etapas, somente na Faixa 1, foram edificadas mais de 1,7 milhão de habitaçóes, importando uma contratação média superior a trezentas mil unidades por ano. Um volume que foi bastante desacelerado na terceira etapa do programa, a partir de 2015. Todavia, certificamos que a produçáo habitacional dentro da linha de financiamento da Faixa 2 teve contrataçóes sempre crescentes, superando o total de unidades contratadas naquela faixa. Vejamos os dados sistematizados na tabela 1 : 
Tabela 1 -. Brasil: Unidades habitacionais contratadas por faixa e por etapa do PMCMV - 2009 a 2015

\begin{tabular}{|c|c|c|c|c|c|c|c|c|}
\hline \multirow[b]{2}{*}{ FAIXAS } & \multicolumn{6}{|c|}{ ETAPAS DO PMCMV } & \multicolumn{2}{|c|}{ Total por faixa } \\
\hline & $\begin{array}{c}\text { PMCMV } 1 \\
(2009-10)\end{array}$ & $(\%)$ & $\begin{array}{c}\text { PMCMV } 2 \\
(2011-14)\end{array}$ & $(\%)$ & $\begin{array}{c}\text { PMCMV } 3 \\
(2015) \\
\end{array}$ & $(\%)$ & Absoluto & $(\%)$ \\
\hline Faixa 1 & 482.741 & 48,0 & 1.226 .605 & 44,6 & 16.890 & 4,1 & 1.726 .236 & 41,4 \\
\hline Faixa 2 & 375.764 & 37,3 & 1.216 .341 & 44,2 & 349.604 & 85,8 & 1.941 .709 & 46,6 \\
\hline Faixa 3 & 146.623 & 14,5 & 307.054 & 11,1 & 40.557 & 9,9 & 464.234 & 11,2 \\
\hline Total/Etapa & 1.005 .128 & 100 & 2.750 .000 & 100 & 407.051 & 100 & 4.162 .179 & 100 \\
\hline
\end{tabular}

Fonte: Elaborada por Luciana M. de Araújo (2017), a partir de relatórios da SNH/MCIDADES (2016).

Como já observado, para as Faixas 2 e 3, os limites de rendimento familiar para o financiamento variam de três a dez salários mínimos. Essas faixas concentram as contrataçóes financiadas com recursos do FGTS, contraídas diretamente pelo comprador nas instituiçóes financeiras autorizadas pelo Banco Central. Em ambas, os financiamentos incluem as taxas de juros, que podem chegar a $8 \%$ ao ano, segundo informativos da CEF. Porém, como demonstrado no overview do PMCMV, o funcionamento operacional é diferenciado.

Para a Faixa 2, o governo garante dois tipos de subsísdios. Um é complementar, com aporte financeiro direto, variando em função da renda, da modalidade e da unidade federativa; o outro é definido como de equilíbrio, pois visa reduzir a taxa de juros do financiamento. Além destes, é disponibilizado o acesso ao Fundo Garantidor da Habitaçáo (FGHab), usado para reduzir custos de seguro e refinanciar parte das prestaçóes em caso de perda da renda ou de desemprego. Esse fundo é destinado também para financiamentos na Faixa 3.

Conforme o Ministério das Cidades (2012), para assegurar a compatibilização do pagamento das prestaçóes com a renda familiar, o PMCMV estabeleceu diretrizes, tais como: o pagamento da primeira prestação a partir da entrega do imóvel; nos casos de financiamento, pagamento opcional de entrada; a redução do risco do financiamento com o Fundo Garantidor; ${ }^{3}$

3 Segundo o Ministério das Cidades, o Fundo Garantidor tem aporte em recursos da União para garantir o refinanciamento de parte das prestaçóes em caso de perda da renda, estabelecendo a cobertura para o período de vigência do contrato. 
o barateamento do seguro; e a desoneração fiscal e de custos cartoriais. Essas diretrizes tornaram o PMCMV uma política pública que toma o Estado como agente impulsionador da expansão da produção imobiliária no país (Maricato, 2015).

Para as Faixas 2 e 3, tanto a construção quanto a comercialização da habitação são feitas de modo direto via construtora ou construtor, na forma de pessoa jurídica e/ou física. Como Rolnik (2015, p. 304) reforça, “a Caixa [CEF] financia a produção e fornece subsídios para quem quiser comprar as unidades, mas os riscos e as responsabilidades são assumidos pela empresa”. Para controlar as construtoras, as instituiçóes financeiras e garantir os subsídios, é o programa que define o preço máximo da habitação a ser adquirida, segundo a unidade federativa e a localidade para a execução das obras.

Em um ano, correspondente à terceira etapa do programa - o PMCMV 3 -, a produção habitacional pela Faixa 2 atingiu um percentual que superou $80 \%$ do total das novas unidades contratadas. Uma quantidade de contratos efetivados díspar do verificado na Faixa 1, inferior a 5\%. Segundo Rolnik (2015), houve um deslocamento das empresas incorporadoras que atuaram na Faixa 1, na primeira etapa do programa, e quando conseguiram grandes lucros, voltaram para seus antigos nichos de mercado, ou seja, para as faixas de mais capacidade de solvência.

Ao nosso ver, essa é uma tendência ratificadora do viés empresarial do programa, distanciando-o de suas diretrizes iniciais de priorizar a política habitacional de interesse social. Náo resta dúvida de que com o PMCMV o setor imobiliário foi extremamente contemplado pela interposição do Estado. Nas palavras de Fix (2011, p. 26), a atual PNH, alargou o espaço do circuito imobiliário em vários sentidos, aumentando a capacidade de circulação e de acumulação de capital, por meio da produção habitacional.

De modo efetivo, as novas diretrizes da Política Nacional de Habitação (BNH) impulsionaram a mobilidade do capital imobiliário também para as cidades de porte médio, sobretudo para as que exercem mais centralidade socioeconômica em suas regióes de influência urbana, imediata e intermediária (IBGE, 2013). É nesse contexto que a produção imobiliária em Patos e em Cajazeiras assume dimensão considerável na dinâmica de expansão territorial e de circulação de capitais.

Segundo registrado no próximo gráfico (n. ${ }^{\circ}$ 1), nos seis anos de intervalo investigados pela pesquisa (2009-15), as novas unidades habitacionais 
contratadas pelo PMCMV totalizaram 1.635 em Cajazeiras e 2.772 em Patos (SHN/MCIDADES, 2016). Nessas cidades, os financiamentos habitacionais instrumentalizados pelo Sistema Nacional Habitação de Interesse Social (SNHIS) somaram um número maior nas faixas contratadas com recursos do Fundo de Garantia por Tempo de Serviço (FGTS). A considerar as dimensões populacionais nessas localidades, houve um equilíbrio no número de contrataçóes realizadas por meio desses recursos, o que evidencia a existência de uma demanda retida por parte das famílias com rendimento acima de três salários mínimos.

Gráfico 1 - Total de unidades habitacionais contratadas pelo PMCMV, por origem de recursos, em Patos e Cajazeiras/PB - 2009 a 2015

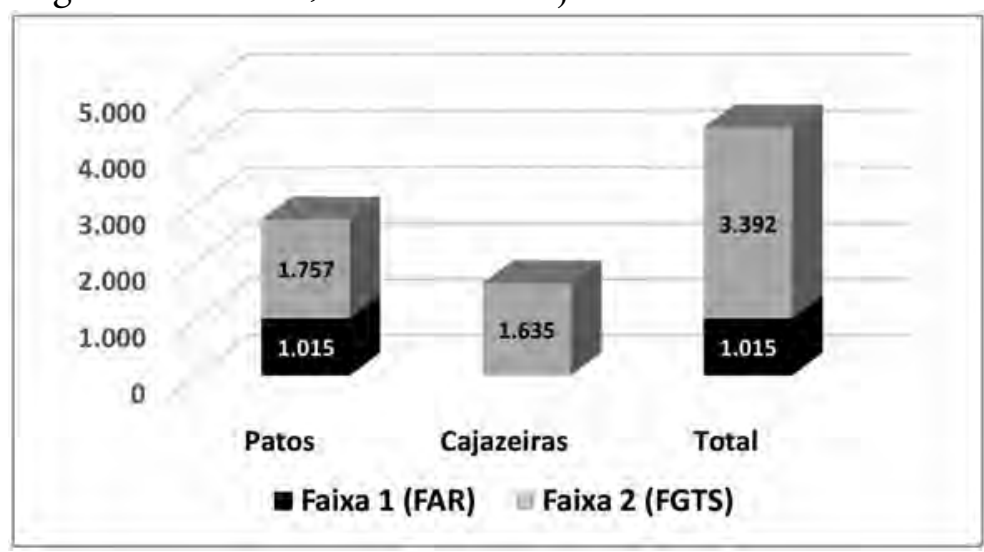

Fonte: Elaborado por Luciana M. de Araújo (2017), a partir de relatórios da SNH/MCIDADES (2016).

O gráfico evidencia também que apenas em Patos foram produzidas habitaçóes na Faixa 1, com subvenção do Fundo de Arrendamento Residencial (FAR). O percentual de unidades habitacionais produzidas nessa faixa de rendimento, entre 2009 e 2015 , correspondeu a 23\% do total de unidades. Em Cajazeiras, como a produção atendeu somente ao segmento de renda enquadrado nas Faixas 2 e 3, os financiamentos realizados via FGTS constituíram a totalidade da produção habitacional contratada pelo PMCMV.

Salientamos que, nesta breve análise, os dados consultados referentes ao PMCMV não incluem a contratação de financiamento habitacional pelo Sistema Brasileiro de Poupança e Empréstimo (SBPE), vinculada ou não ao 
Sistema Financeiro de Habitação. ${ }^{4}$ Esses financiamentos são realizados diretamente com o construtor, contratados por famílias com rendimento acima de dez salários mínimos, portanto, fora das linhas de rendimento previstas pelo programa e sem limites máximos prefixados.

A par dos dados relativos à recente produção habitacional vinculada apenas ao PMCMV, depreendemos que esses percentuais devem ser melhor avaliados pela gestão local para fins de elaboração de políticas urbanas. Com efeito, a manutenção do ritmo acelerado dessa produção tem exercido mais pressão sobre o Estado, em diferentes esferas públicas, no que diz respeito à necessidade de implantar e/ou ampliar equipamentos de infraestrutura básica, bem como as de uso coletivo, como escolas, creches e postos de saúde.

Igualmente, reafirmamos o lugar de destaque dos construtores e dos promotores imobiliários de capital não local como agentes propulsores do processo de expansão territorial das cidades de Patos e de Cajazeiras. Os memoriais de incorporação dos empreendimentos contratados pelo FAR, em Patos, registram que foram incorporados por empresas com sede em João Pessoa: o Residencial Itatiunga, incorporado pela BW Construção e Imobiliária Ltda., com execução das obras pela CRE Engenharia Ltda. O Vista da Serra I e II foram incorporados e construídos pela JGA Engenharia Ltda. em parceria com a CEHAP-PB.

Independente da origem do capital investido na promoção imobiliária e do empreendimento ser destinado à construção de habitação popular, o processo de promoção imobiliária, atinente à realizaçáo de suas etapas, não se diferencia. Comumente, o rito desse processo se assemelha e se reproduz como uma prática da produção da habitação em diferentes escalas territoriais e para distintas finalidades de consumo da mercadoria produzida: a habitação.

De modo sucinto, o passo inicial para transcorrer a incorporação é a aquisição da gleba rural, que, em geral, é desmembrada de uma propriedade rural periurbana. Como sequenciado por Topalov (1979b, s/p.), adquirida a terra, o promotor "acude a un arquitecto o va a una oficina de estudios para

${ }_{4}^{4}$ Apesar de o governo federal não subvencionar créditos imobiliários diretos para os financiamentos realizados pelo SFH, com recursos do SBPE, os contratos firmados apresentam condições diferenciadas em relação às contraçóes instrumentalizadas pelo SFI, a exemplo do uso do FGTS. Quando os financiamentos são requeridos nesse último sistema, os recursos são oriundos do mercado de capitais, tais como: fundos de pensóes, fundos de renda fixa e bancos de investimentos (Fix, 2011), cujas taxas de juros são reguladas pelo Banco Central. 
transformar esse programa en proyecto, y acude a empresas para construir los edifícios”. Portanto, além da aquisição da terra, em geral o construtor terá que recorrer à busca de capital para a execução do seu projeto.

No âmbito do ciclo de reprodução do capital investido na produção e na circulação de habitações, essa busca é indispensável à execução do projeto e à realizaçáo do lucro. Como assinala aquele mesmo autor (1979), o período de rotaçáo do capital é longo, principalmente no que refere ao período de produção, o qual corresponde ao processo de trabalho necessário para se executar a obra até a entrega da unidade habitacional produzida.

De modo particular, esse é um processo lento, cuja duração depende da existência da concentração anterior de capital da empresa, em especial, "de um capital de giro que garanta o retorno à forma de dinheiro do capital produtivo antes do final do período de produção, isto é, uma rotação normal do capital industrial [partes de capital investido nas construtoras, por exemplo, o capital produtivo]" (Topalov, 1979, pp. 54-5). Significa, assim, a existência de condiçôes financeiras para o pré-financiamento da obra.

No caso das construtoras selecionadas, aptas a executarem obras operacionalizadas pelo PMCMV, no "pacote" contratual inclui-se o capital de promoção, viabilizado pela instituição financeira pública gestora e fiscalizadora do projeto. Ou seja, isenta a empresa de disponibilizar imediatamente seu capital de giro, que é pré-condição para a realização da obra. Esse capital vai intervir no curso e no tempo do período de produçáo, reduzindo-o, por exemplo. Portanto, inserida nos termos contratuais de adesão ao programa, a construtora garante, com antecipação, o capital necessário para se construir habitação e prevê seus lucros, a considerar que o valor da unidade habitacional é previamente contratado, definido por normativas elaboradas pelo Ministério das Cidades por meio de portaria. ${ }^{5}$

Feitas essas breves consideraçóes sobre o PMCMV, a seguir apresentaremos os dois empreendimentos contratados pelo FAR em Patos.

\footnotetext{
5 Segundo a Portaria no 168/2013, do Ministério das Cidades, "os valores máximos de aquisição estabelecidos [...] poderão compreender os custos de aquisição do terreno, edificação, equipamentos de uso comum, tributos, despesas de legalização, trabalho social e execução de infraestrutura interna, excetuada a de responsabilidade da distribuidora de energia elétrica”.
} 


\section{Caracterização dos empreendimentos imobiliários contratados com recursos do FAR na cidade de Patos/PB}

O Residencial Itatiunga, contratado em 2012 por meio de parceria entre os governos federal, estadual e municipal, é o conjunto com o maior número de unidades habitacionais construído pelo PMCMV no sertáo paraibano. ${ }^{6}$ Esse empreendimento começou com a formação da Empresa BW Construção e Imobiliária $\mathrm{Ltda}^{7}$, seguido do processo de incorporação do loteamento, com a compra do terreno.

Em consulta ao site consultasocio.com, ${ }^{8}$ sobre sociedades empresariais no Brasil, apuramos que os sócios administradores daquela empresa estão vinculados a outras atividades econômicas distintas das que compóem o setor imobiliário (compra, venda e construçâo de imóveis). Conforme consta nesse site e no da Receita Federal, um dos sócios incorporadores do Loteamento Itatiunga possui empresas de comércio varejista de alimentos associado à rede de Supermercados Bemais, localizada em João Pessoa, e de produção de eventos de vaquejadas e rodeios em Sáo Miguel de Taipu (PB). O outro sócio tem atividades relacionadas à comunicação e à radiofonia, com sede em Catolé do Rocha $(\mathrm{PB})$.

Isso ratifica a mobilidade social e espacial de distintas fraçóes do capital para o setor imobiliário e reafirma as reflexóes de Cano (2010) sobre a particularidade especulativa e rentista de fraçôes de capital mercantil investido nesse setor, especialmente nas atividades de incorporação e de construção civil. Esse capital, ao convergir para a produção imobiliária, tende a dominar o processo de expansão territorial da cidade, bem como a "administração privada de negócios públicos” (Cano, 2010), a exemplo da incorporação de conjuntos habitacionais a serem operacionalizados pelo PMCMV.

6 Em Sousa, no Sertão Paraibano, o PMCMV operacionalizou a construção de 726 unidades habitacionais, financiadas com recursos do FAR e já entregues: o Residencial Lagoa dos Patos, com 274 unidades, contratado em 2010, com valor de 10 milhóes de reais; e o Residencial de Sousa, com 452 unidades, contratado pelo valor de 21,6 milhóes de reais, em 2012.

7 A empresa está inscrita no CNAE e sua atividade principal é a corretagem para compra, venda e avaliação de imóveis. Porém, o quadro de atividades secundárias é bastante diversificado e inclui a construção de edifícios e de obras de urbanização, terraplanagens e de incorporaçóes etc.

8 Site de cadastro de empresas e sócios de empresas brasileiras, com busca a partir do nome. Disponível em: https://www.consultasocio.com/. 
O Residencial Itatiunga faz parte do loteamento de mesmo nome, localizado no Bairro Morada do Sol, às margens da BR-361, Km 7, saída para Piancó, no setor oeste da cidade de Patos. A certidão vintenária presente no memorial de incorporação atesta que as terras rurais que abrigam o loteamento pertenciam à Fazenda Várzea da Jurema, cuja área total era de 745,3ha.

Essa propriedade foi por várias vezes desmembrada em glebas para o parcelamento em lotes urbanizados, cujos loteamentos originaram os conjuntos habitacionais Bivar Olyntho (1982), com 30ha, e o Pró-Moradia (2008), com 5,6ha, construídos pela CEHAP-PB. Em 2011 e 2012 foram implantados dois loteamentos: o Antônio David Lima I e o II, que somam uma dimensão de 6,8ha, além do Itatiunga, já referido, com 61,4ha. Ou seja, 103,8 ha, cerca de $14 \%$ das terras daquela propriedade, foram transformados em lotes urbanizados, agregados à malha urbana consolidada. Em termos de lotes, foram abertos 2.699 lotes, dos quais 770 , inseridos nesse último loteamento, voltados à construçóes do PMCMV.

A incorporação do Residencial Itatiunga compreende uma área de $614.992,00 \mathrm{~m}^{2}(61,4 \mathrm{ha})$, e a área dos lotes mede $343.528,19 \mathrm{~m}^{2}$, ou seja, cerca de 55\% do total loteado. Respaldado pela Portaria n. ${ }^{\circ}$ 168/2013 do Ministério das Cidades, o projeto arquitetônico foi executado em duas etapas: uma relativa à implantação do Residencial Itatiunga, outra, ao Loteamento Parque Itatiunga, compreendendo 954 lotes comercializáveis.

Consoante à referida portaria, quando o projeto do empreendimento é apresentado para que se executem as obras em mais de uma etapa, este é identificado como único. Entretanto, é necessário que seja "considerado contíguo a outro quando a menor distância, em linha reta, do ponto do perímetro da sua poligonal mais próximo ao perímetro da poligonal do outro empreendimento for igual ou inferior a 1.000 (um mil) metros" (MCidades, 2013).

No que concerne à contiguidade, o projeto daquele residencial encontra-se adequado à portaria. Contudo, há inadequação quanto à feitura em duas etapas no que diz respeito ao número mínimo de mil unidades habitacionais por etapa. Igualmente, a portaria estabelece o máximo de doze meses entre cada etapa, porém, apenas uma foi entregue, e com dois anos de atraso.

Apesar do loteamento ter sido incorporado como um projeto único, no decorrer de sua implantação ele assumiu duas finalidades distintas: a construção de HIS, vinculada ao PMCMV, e a comercialização privada dos lotes. A 
parte comercializada terminou por corresponder à segunda etapa do Projeto Residencial Itatiunga, como pode ser observado nas figuras 1 e 2 .

Figura 1 - Outdoor do Residencial Itatiunga, financiado com recursos do FAR, PMCMV, pelo Faixa 1 - Patos/PB

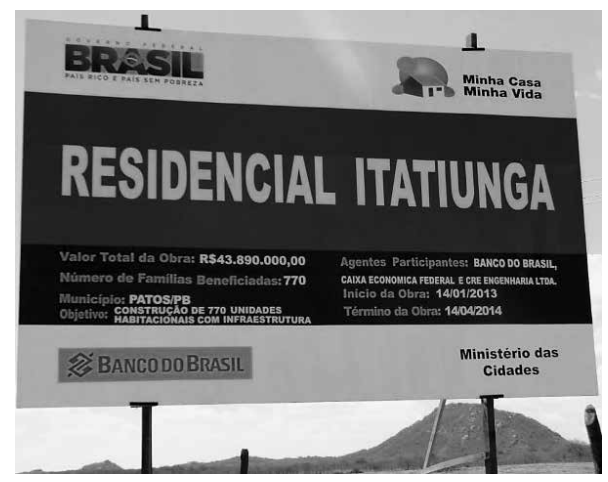

Figura 2 - Panfleto de lançamento do Loteamento Parque Itatiunga, março de 2014 - Patos/PB

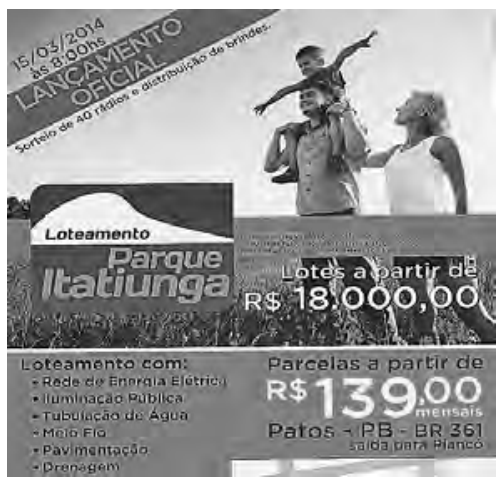

A partir das reflexóes de Smolka (1987), entendemos que essa é uma prática especulativa, comum na movimentação do capital incorporador que visa valorizar a terra. A valorização ocorre, inicialmente, com a transformação do uso da propriedade fundiária, do rural para o urbano. À medida que o empreendimento - no caso, o loteamento - é beneficiado com a adição dos equipamentos de infraestrutura básica, a tendência é agregar mais valor venal aos lotes.

Em relação aos conjuntos habitacionais operacionalizados pelo PMCMV, o "pacote" contratado pelo governo federal, em parceria com outros níveis de governo, inclui as obras de terraplenagem, a abertura das vias de circulação e de escoamento das águas pluviais, entre outras, bem com a implantação da infraestrutura básica (saneamento, abastecimento de água, eletrificação etc.) e de serviços comunitários (postos de saúde, escolas, segurança pública etc.).A implantação e/ou extensão desses equipamentos, obrigatórios para a habitabilidade do conjunto, torna-se atributo valorativo, utilizado pelo marketing de vendas de empreendimentos privados, tal como no panfleto recuperado pela figura 2. Nesse caso, o Estado contribui com a produção de externalidades que favoreceram o empreendedor, desonerando-o, por exemplo, do uso de parte de seu capital de incorporação, reservado à adequação 
de tais equipamentos em seu empreendimento. ${ }^{9}$ Essa é uma das formas dos incorporadores controlarem a valorização dos lotes para obter mais renda fundiária e mais ganhos imobiliários.

$\mathrm{Na}$ primeira etapa, o projeto Residencial Itatiunga submetido ao PMCMV compreendia uma área total de 204.642,60 $\mathrm{m}^{2}$, da qual $61,1 \%$ era destinada a lotes habitáveis, com apenas $4,8 \%$ de área verde. De acordo com o seu memorial descritivo, nessa etapa estava prevista a implantação de cinco equipamentos públicos, distribuídos em pouco mais de cinco mil metros quadrados, dentre eles: uma escola, com seis salas de aula; uma unidade básica de saúde; e uma estação de tratamento de esgoto pré-fabricada. Os dois primeiros foram implantados com recursos do Fundo de Amparo ao Trabalhador (FAT) sob a gestão do Banco Nacional do Desenvolvimento (BNDES) e do Ministério Desenvolvimento, Indústria e Comercio Exterior.

Segundo informação do representante da CRE Engenharia Ltda., construtora responsável pelas obras desse residencial, o projeto foi executado de acordo com o padrão normativo de especificação mínima exigido pelo Ministério das Cidades e fiscalizado pelo Banco do Brasil, instituição financeira gestora dos recursos. Porém, a despeito da rigidez dessa instituição sobre o cumprimento das normas técnicas e do prazo para a entrega, prevista para 2014, a entrega das casas aconteceu somente em 2016, depois de forte pressão das famílias beneficiadas.

Conforme o secretário de habitação da Prefeitura de Patos, o atraso da entrega do conjunto decorreu por alguns equipamentos previstos na Portaria n. ${ }^{\circ}$ 168/2013 não terem sido concluídos. Pela normativa, "as redes de energia elétrica e iluminação pública, o abastecimento de água potável e as soluçóes para o esgotamento sanitário deverão estar operantes até a data de entrega do empreendimento ou da respectiva etapa" (MCidades, 2013). Isso não ocorreu. As obras dos demais equipamentos básicos, como a escola e o posto de saúde, foram oficialmente anunciados em 2016, após a entrega das casas aos beneficiários.

Outro equipamento de infraestrutura básica reivindicado pelos moradores foi a conclusão da via de acesso que interliga o conjunto à BR-361, cujo trecho era carroçável e considerado por um entrevistado como "muito

${ }^{9}$ Cf. Lei n.o 9.785/99, a qual dispõe sobre alteraçóes na Lei n.o 6.766/79 de Parcelamento do Solo Urbano. 
ruim, cheio de buraco e sem iluminação pública" $\cdot{ }^{10}$ Segundo manifestou um morador, o conjunto ficou muito distante do centro da cidade, fato agravado pela falta de transporte público, o que dificultava o deslocamento das pessoas para terem acesso aos mais diferentes serviços. Assim relatou:

Aqui não é ruim, porque a casa é da gente, né? Mas está todo mundo abandonado, sabe? Até agora, não apareceu ninguém da prefeitura [...] tem lixo por todo canto e falta muita coisa ainda para a gente. [...] está difícil demais, para sair daqui para o centro [...] é tudo muito longe [...]. Quem tem moto, carro está bom, mas ficou longe de tudo mesmo. Tem gente que deixou ir para a escola porque não tem como ir, não tem como pagar o mototáxi. Eles também não querem fazer viagem de noite para cá. É muito perigoso [...] tem outro problema, falta a gente receber os contratos [...]. Sim, tem mais, o papel da luz está vindo alto demais, a gente não sabe por que a luz é cara aqui. Eles não tão respeitando ninguém aqui. [...] o povo tá se organizando se vem alguma coisa pra gente. ${ }^{11}$

Esse depoimento é emblemático porque ratifica o quanto persistem historicamente as velhas práticas que revelam a reprodução do negligenciamento por parte do poder público com as condiçóes de infraestrutura da habitação de interesse social, em diferentes esferas territoriais do nosso país. Reativa também os velhos dilemas e as contradiçôes que assinalam o descompasso entre a política habitacional e a política de urbanização.

Conforme o croqui de localização geográfica do residencial, presente o projeto arquitetônico, as distâncias em relação a importantes equipamentos de serviços e espaços públicos e de consumo, como a prefeitura, os correios, o hospital regional, o mercado público ou a catedral, situados na área mais central da cidade, são realmente consideráveis. No cotidiano dos moradores, o deslocamento onera o orçamento familiar e estabelece um custo relativo ao tempo-espaço necessário para que seja exercido, especialmente pela inexistência de transporte público regular.

No que respeita às distâncias, fica o destaque em relação ao centro da cidade. Quando o Estado aprova projetos de grandes conjuntos habitacionais

\footnotetext{
${ }^{10}$ Informação direta obtida por meio de conversa informal com os moradores durante trabalho de campo realizado em julho de 2016.

${ }^{11}$ Cf. nota anterior.
} 
voltados a interesse social, sendo necessária a obtenção de maiores porções de glebas rurais, a terra disponibilizada, em geral, encontra-se bem afastada da área central da cidade, fora dos limites do perímetro urbano, comumente desprovida de qualquer infraestrutura básica.

Além das distâncias dificultarem o acesso de grande parte dos moradores do conjunto a esses serviços, a inexistência de linhas de transporte público, interligando o conjunto ao centro, onde estáo localizados a maioria dos equipamentos básicos, constitui-se em um outro problema. O deslocamento dos moradores é feito essencialmente por serviços de moto-táxi, ofertados sobretudo no turno diurno.

Assim, entendemos que, para que os moradores de conjuntos habitacionais obtenham o mínimo possível para torná-las urbanizadas e habitáveis, é necessário formar organizaçôes sociais e de mobilização, cuja pauta reivindicatória exerça forte pressão sobre o poder público. Com efeito, a mobilidade da sociedade, em diferentes áreas da cidade, ao reivindicar o atendimento de suas demandas específicas, tensiona um movimento de forças entre os moradores organizados e o poder público, bem como entre os distintos movimentos, diferentemente espacializados na cidade.

Registramos situação semelhante no Vista da Serra I e II, embora os problemas quanto ao acesso ao centro tenham sido pouco referidos. Esses conjuntos fazem parte da incorporação do Loteamento Empresarial Hardman Cavalcante, no Bairro Monte Castelo, localizado na zona sul da cidade, às margens do Rio da Farinha, em terras desmembradas do antigo Sítio Mutuca/Frei Manoel. A incorporação do loteamento também foi feita por uma construtora com sede em João Pessoa, a JGA Engenharia Ltda. No total, foram abertos 286 lotes, com uma área média de $200 \mathrm{~m}^{2}$, abrangendo 10 , 5 ha.

Após a incorporação, em 2012, foram contratadas 136 unidades habitacionais pelo PMCMV para edificar o Residencial Vista da Serra I, e em 2013, o Residencial Vista da Serra II, com 106. Portanto, 245 habitaçóes, ambos em parceria com o governo do Estado, por meio da Companhia Estadual de Habitação Popular (CEHAP-PB), com recursos do FAR sob a gestão da CEF como instituição financeira. As duas etapas somaram um investimento de 6,3 milhóes de reais.

Para descrever o processo de incorporação daquele loteamento, reiteramos os escritos de Lucena (2014), ao esclarecer que 
o proprietário da construtora já possuía o terreno, que foi adquirido em um momento anterior. Segundo o engenheiro responsável pela obra, o processo de loteamento ocorreu da seguinte forma: foi realizado um primeiro loteamento, no qual o proprietário desmembrou alguns lotes e os deixou como suas propriedades; em seguida, juntou os demais terrenos novamente e loteou pela segunda vez, agora com as características mínimas exigidas pela CEF para aprovar o projeto através do PMCMV. Quando as unidades do RSV I estavam praticamente prontas, foi promovida a venda dos lotes desmembrados daquele primeiro loteamento, cujos preços dos terrenos foram estabelecidos em torno de R\$18.000,00. (Lucena, 2014, p. 156).

Com base na autora, confirmamos a construção do conjunto habitacional em duas etapas, sob a mesma lógica especulativa descrita para o Itatiunga. No intervalo entre a conclusão da primeira etapa e o início das obras da segunda, quando foram enunciados e/ou instalados os equipamentos básicos pelo Estado, o incorporador lançou no mercado imobiliário os lotes de sua propriedade, valorizados pela infraestrutura pública. Desse modo, o capital do incorporador tende a se expandir com a ampliação da base de incidência das rendas, metamorfoseando o ganho imobiliário do proprietário do loteamento e dos adquirentes futuros.

Assim, à maneira da explicação de Smolka (1987, p. 53), "trata-se aqui de criação de vantagens locacionais, pertinentes não propriamente a diferenças de produtividade na produção de moradia, mas sim às condiçóes de criação do solo de características dadas, como a acessibilidade”. Da mesma forma, os equipamentos básicos implantados geram externalidades internalizáveis apropriadas pelo incorporador para a criação de rendas diferenciais.

No caso desse loteamento e, por conseguinte, dos conjuntos habitacionais Vista da Serra I e II, outra particularidade que merece menção são as condiçôes ambientais. Como representado na planta arquitetônica, do total loteado, 1,7ha corresponde a três áreas de preservação ambiental, sendo uma delas relativa ao remanescente das margens rio da Farinha, afluente do rio Espinharas, que dista uma média de 40 metros dos quarteiróes situados a leste do conjunto. Conforme vemos nas imagens do Google Earth, os lotes destinados ao conjunto estão situados muito próximos ao curso hídrico, o que torna a área propícia a alagamentos em períodos de chuvas (figura 3). 
A despeito da existência de problemas ambientais, de infraestrutura e de serviços existentes no Conjunto Vista da Serra e nas imediaçôes, na época do lançamento do Loteamento Hardman Cavalcante, em 2010, depois de concluída a primeira etapa do conjunto, o marketing de venda anunciava, antecipadamente, a implantação de equipamentos básicos, de áreas para comércio e uma rede hoteleira não especificada no projeto arquitetônico. Entretanto, como vimos in loco, e pelo que foi noticiado em mídias digitais, ${ }^{12}$ as condiçóes de habitabilidade do Conjunto Vista da Serra não estão em consonância com o que foi propalado no processo de vendas dos lotes.

Figura 03 - Usos e apropriaçôes no Loteamento Hardman Cavalcante, Bairro Monte Castelo - Patos/PB

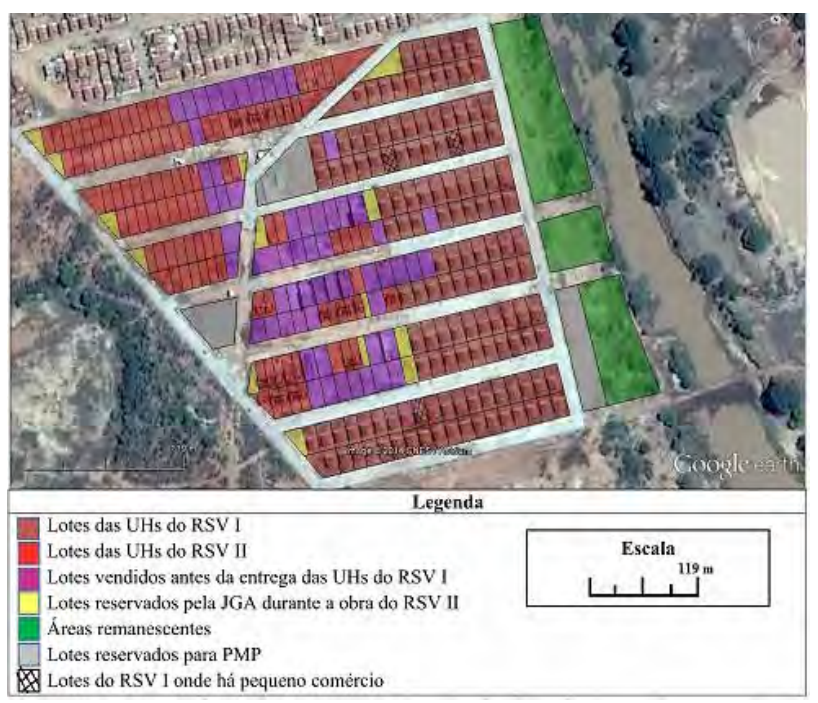

Fonte: Lucena, 2014, p.179.

Pelo exposto, o problema da habitação popular assume similaridade em diferentes escalas de tempo e de espaço, cujas condiçóes de habitabilidade são negligenciadas pelo poder público, em especial quando se trata da Habitação de Interesse Social (HIS). Contudo, ao que parece, sem a intervenção do Estado, nada de efetivo se realiza para saná-lo. As famílias de baixa renda se submetem a viver em meio à precariedade dos conjuntos habitacionais por

${ }^{12}$ Cf. vídeo: "Morador do conjunto vista serra, Monte Castelo, Patos, fala dos problemas". Disponível em: https:/www.youtube.com/watch?v=26hoZqIl3-I. Acesso em: mar. 2017. 
suas condiçôes de renda, ante a impossibilidade de escolher onde morar ou como morar. Ou seja, historicamente, como enfatiza Hall (2002, p. 25), as famílias pobres estão sujeitas a "um sistema de governo local incompetente e amiúde corrupto, inepto no manejo dos pobres".

$\mathrm{Na}$ seção seguinte, analisaremos a produção habitacional das cidades de Patos e de Cajazeiras voltadas para as modalidades de financiamento nas faixas II e III, contratadas pelo FGTS.

\section{Produçáo habitacional do PMCMV financiada pelo FGTS em Patos e em Cajazeiras}

No âmbito do SNH, as contrataçóes para a produção de novas unidades habitacionais nas faixas 2 e 3 são subvencionadas por meio de créditos habitacionais, especialmente oriundos do FGTS. Essas modalidades atendem às famílias inseridas nas linhas de rendimento que variam de mais de três a dez salários mínimos que, grosso modo, constituem a segunda grande base da demanda habitacional. Lembramos ao leitor que, no caso dos financiamentos com recursos do FGTS, dentro dessas duas faixas, o governo federal criou o PMCMV-Habitacional, que funciona a partir de duas linhas de financiamento para o comprador da habitação - pessoa física -, como ocorre na Faixa 1, na qual as contrataçóes são realizadas por meio do PMCMV-Empresa.

Como vimos na seção anterior, no que concerne à Faixa 1, a cidade de Patos foi beneficiada com 1.015 unidades financiadas pelo FAR. Se somarmos todos os financiamentos, temos 2.772 contrataçóes operacionalizadas pelo PMCMV, com mais de $63 \%$ do total da produção habitacional voltados a famílias com rendimento acima de três salários mínimos. A questão é que esse segmento apresentou uma demanda habitacional menor (cerca de $20 \%$, relativos a 876 novas moradias). Já o déficit habitacional correspondente àquela faixa, também para o ano de 2010, equivalia a 80\% (3.521 novas moradias), segundo a Fundação João Pinheiro (FJP).

O gráfico 2 foi elaborado com base na planilha de produção habitacional fornecida pelo Ministério das Cidades, entre o ano de 2009 até o mês de outubro de 2015. Nele, vemos que, nas cidades de Patos e Cajazeiras, o PMCMV contratou 3.392 unidades habitacionais financiadas pelo FGTS. Dessas contrataçóes, quase $52 \%$ foram efetuadas em Patos, sendo as demais em Cajazeiras. 
Isso significa que não houve equidade na distribuição dos recursos públicos subvencionados pelo PMCMV. Essa problemática agrava-se ainda mais em Cajazeiras, como sabemos, pois as famílias mais pobres sequer foram comtempladas na cidade, em que o déficit habitacional urbano apontava uma carência de 1.850 novas moradias, das quais 1.442 envolvia esse segmento (similarmente, quase $80 \%$ ).

Gráfico 2 - Número de unidades habitacionais contratadas pelo PMCMV, nas modalidades das Faixas 2 e 3, em Patos e Cajazeiras/PB - 2009 a 2015

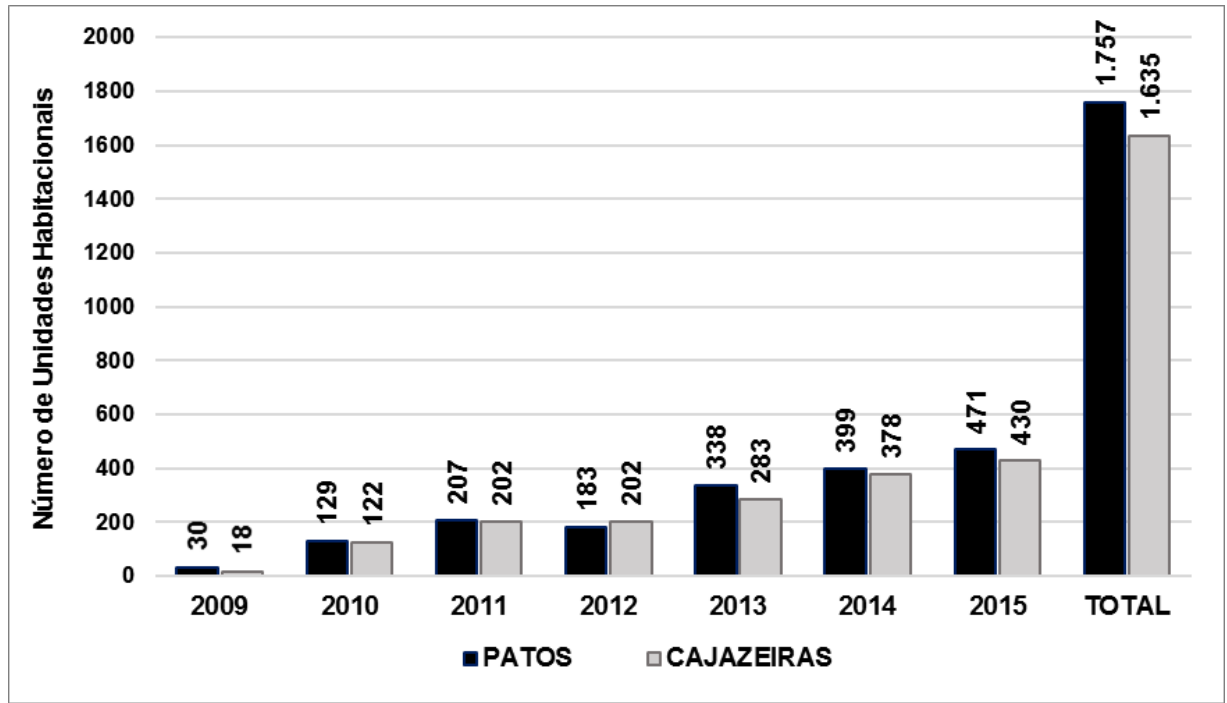

Fonte: Elaborado por Luciana M. de Araújo (2017), a partir de relatórios da SNH/MCidades (2016)

Os valores investidos nas duas cidades, vistos por faixa, são outra maneira de apontar o descompasso no curso dos financiamentos viabilizados pelo PMCMV. Em Patos, não obstante a construção das 1.015 novas moradias em três conjuntos habitacionais pelo PMCMV, a Faixa 1 absorveu apenas $20 \%$ do total de créditos, um dado que é sequer existente no que diz respeito à cidade de Cajazeiras.

Diferentemente da modalidade Faixa 1, o exame das planilhas do PMCMV, fornecidas pela Secretaria Nacional da Habitação do Ministério das Cidades, revelou que o valor das contrataçóes para a produção de habitação pela Faixa 2 na cidade de Patos e de Cajazeiras, absorveu o correspondente a $77 \%$ e $98 \%$, respectivamente, relativas ao total do valor contratado entre 
os anos de 2009 e 2015. Quanto ao valor da contratação por unidade habitacional, ainda relativo à Faixa 2, constatamos uma pequena diferença para menos na cidade de Cajazeiras (média de $\mathrm{R} \$ 97 \mathrm{mil} / \mathrm{unid}$.), comparado ao valor da unidade contratada em Patos (média R\$101 mil/unid.) (Gráfico 3).

No cálculo geral, a proporção dos investimentos em relação ao número de unidades habitacionais construídas chega à média de $\mathrm{R} \$ 110$ mil, abaixo do limite normatizado pelo Ministério das Cidades, fixado em até $150 \mathrm{mil}$ reais para grande parte do país, inclusive para o Nordeste. ${ }^{13}$

Gráfico 3 - Valores contratados pelo PMCMV, por modalidade de faixa, entre 2009 e 2015 - Cajazeiras e Patos/PB

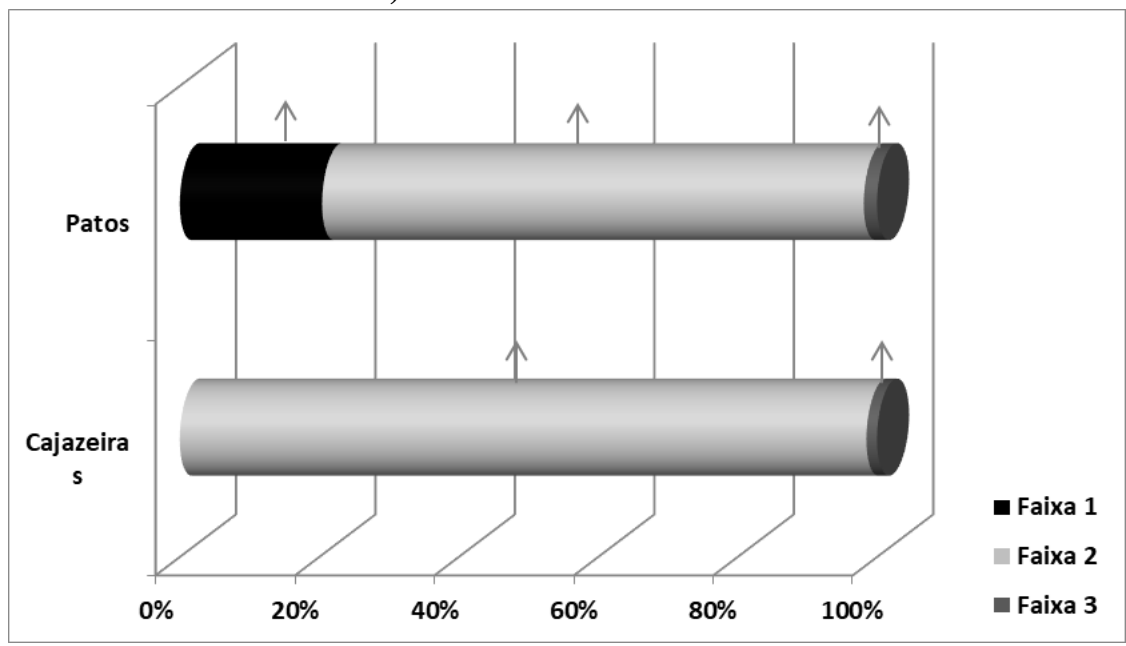

Fonte: Elaborado por Luciana M. de Araújo (2017), a partir de relatórios da SNH/MCidades (2016).

No tocante ao total de habitaçóes produzidas pelo PMCMV, a Faixa 2 é responsável pela contratação de 76,9\% dessa produção. Isso reforça a compreensão de que a expansão desse sistema de financiamento tem como característica o modelo de subsídios para a demanda, que direciona a disponibilização direta de recursos públicos aos compradores de imóveis. Como admite Rolnik: "o raciocínio por trás dos programas de subsídios para a demanda é o de que mesmo famílias de menor renda poderão mobilizar suas poupanças para financiar suas moradias no livre mercado" (Rolnik, 2015, p. 111).

${ }^{13}$ Esses valores são diferenciados para as regiōes metropolitanas de São Paulo, Rio de Janeiro e Distrito Federal, fixado em até 170 mil reais. 
Para corroborar o impacto do PMCMV sobre o setor imobiliário, sobretudo no que concerne à construção civil exclusivamente dirigida à produção residencial, elaboramos a tabela 2. Nela, temos a indicação entre todas as Anotaçóes de Responsabilidade Técnica (ART) emitidas pelo Conselho Regional de Engenharia e Agronomia (CREA/PB) nas duas cidades e os dados relativos aos imóveis produzidos pelo programa, sendo eles correlacionados. Isso nos remete ao incremento verificável nessa produção a partir de 2010, logo depois da implementação dessa política habitacional.

Tabela 2 - Total de emissão de anotaçóes de responsabilidade técnica (ART) e total de unidades habitacionais contratadas pelo PMCMV nas Faixas 2 e 3, em Cajazeiras e Patos/PB - 2009 a 2015.

\begin{tabular}{l|c|c|c|c|c|c}
\hline \multirow{2}{*}{ Ano } & \multicolumn{3}{|c|}{ Cajazeiras } & \multicolumn{3}{c}{ Patos } \\
\cline { 2 - 7 } & $\begin{array}{c}\text { ART } \\
\text { Emitidas }\end{array}$ & $\begin{array}{c}\text { Unidades } \\
\text { Produzidas } \\
(\text { PMCMV) }\end{array}$ & $\begin{array}{c}\text { Produçáo } \\
\text { PMCMV/ } \\
\text { ART } \\
(\%)\end{array}$ & $\begin{array}{c}\text { ART } \\
\text { Emitidas }\end{array}$ & $\begin{array}{c}\text { Unidades } \\
\text { Produzidas } \\
(\text { PMCMV) }\end{array}$ & $\begin{array}{c}\text { Produçáo } \\
\text { PMCMV/ } \\
\text { ART } \\
(\%)\end{array}$ \\
\hline $\mathbf{2 0 0 9}$ & 177 & 18 & 10.1 & 107 & 30 & 28,0 \\
\hline $\mathbf{2 0 1 0}$ & 282 & 122 & 43,2 & 187 & 129 & 68,9 \\
\hline $\mathbf{2 0 1 1}$ & 379 & 202 & 53,2 & 202 & 207 & 102,4 \\
\hline $\mathbf{2 0 1 2}$ & 326 & 202 & 61,9 & 398 & 183 & 45,9 \\
\hline $\mathbf{2 0 1 3}$ & 370 & 283 & 76,4 & 460 & 338 & 73,4 \\
\hline $\mathbf{2 0 1 4}$ & 599 & 378 & 63,1 & 366 & 399 & 109,0 \\
\hline $\mathbf{2 0 1 5}$ & 575 & 430 & 74,7 & 390 & 471 & 120,7 \\
\hline Total & 2.708 & 1.635 & 60,3 & 2.110 & 1.757 & 83,2 \\
\hline
\end{tabular}

Fonte: Elaborada por Luciana M. Araújo (2017), com base em dados do CREA/PB e da SNH/MCidades (2016)

Ainda sobre a tabela 2, destacamos que nos anos de 2011, 2014 e 2015, o número de unidades habitacionais contratadas pelo PMCMV superou o de ART. Isso justifica-se pela compra de imóveis produzidos anteriormente, pois havia um grande estoque de imóveis para comercialização em seu mercado imobiliário, conforme informado pelo presidente do Conselho Regional de Corretores de Imóveis (CRECI). Os indicadores consolidam o lugar determinante do Estado naquele incremento da produção habitacional. 
Desse modo, no contexto da atual PNH, o PMCMV foi fundamental para a garantia do acesso ao crédito habitacional, subvencionando a aquisição da casa própria realizada por milhares de famílias com rendimento baixo e médio. Todavia, no tocante às condiçóes de habitabilidade do entorno e das edificaçôes em si, muito há para se analisar e discutir. Afinal, como sentenciam Rolnik e Nakano (2009), a despeito dos instrumentos normativos de controle sobre a produção de habitação de interesse social ou de mercado, ambas continuam sendo realizadas em áreas de expansão urbana sem adequaçôes satisfatórias de habitabilidade, marcadas por infraestruturas e acessibilidades precárias e/ou inexistentes.

\section{Consideraçóes finais}

Como constatamos, a partir da instituição do PMCMV, houve um incremento da produção da habitação de interesse social, porém, sobremaneira, grande parte dessa produção foi destinada à habitação social de mercado, o que favoreceu os promotores privados da produção imobiliária. Os dados apresentados atestam a viabilidade econômica dessa produção e reforçam o viés empresarial que o PMCMV assumiu desde a sua implantação, em 2009, ao atender muito mais à demanda habitacional de mercado do que a carência de moradias para as famílias mais pobres, carência essa trazida nos relatórios do déficit habitacional.

Portanto, entendemos que a PNH segue um curso de práticas que deixam lacunas na qualidade da política pública voltada à habitação. Essas práticas são remissivas a um modelo de fragmentação da cidade, repartida em espaços desiguais, em que a precariedade urbana e ambiental é reproduzida, tensionadas por conflitos de interesses entre os distintos agentes imobiliários e os moradores de conjuntos habitacionais.

De modo recorrente, percebemos o discurso reducionista e até mesmo demagógico de representantes do poder público quanto à realizaçáo do "sonho da casa própria” por famílias de baixa renda. Um discurso em que impossibilidade socioeconômica dessas famílias quanto à escolha e à qualidade de onde morar na cidade é encoberta pelo "sonho" realizado. À maneira de Bonduki (1998), mitifica-se essa realização, diluindo-se as precariedades que a perpassam. 
Assim, o Estado, como agente imobiliário ou como gestão pública, não tem desempenhado efetivamente o seu papel de fiscalizador dos processos de apropriaçáo e de uso do solo urbano pelos agentes privados, nem de produzir habitação de interesse social para a população com menos poder aquisitivo, diretamente excluída dos processos decisórios sobre essa produçáo. Devido à falta de um planejamento comprometido com o desenvolvimento urbano, o poder público não se interpôs à celeridade da expansão urbana, que aconteceu independentemente da capacidade da gestão e da disponibilidade das receitas orçamentárias das prefeituras municipais destinadas aos programas urbanos.

Como admite Melazzo (2013) ao discutir a produção habitacional pelo PMCMV, é inquestionável que a nova PNH repercutiu em mudanças substanciais na forma de produção e de apropriação da cidade. Porém, tais mudanças acentuaram as desigualdades inerentes à expansão urbana, bem como os conflitos entre os diferentes agentes produtores do espaço urbano.

Por fim, à cidade imprime-se uma celeridade na sua expansão territorial, com repercussóes diferenciadas sobre a sociedade local, com evidente favorecimento do setor imobiliário como um todo e do mercado de terras, potencializando a renda delas advinda, a partir do expressivo aumento de lotes urbanizados disponibilizados para o mercado.

\section{Referências}

BONDUKI, Nabil. As origens da habitação social no Brasil: arquitetura moderna, Lei do Inquilinato e difusão da casa própria. São Paulo: Estação Liberdade, FAPESP, 1998. 343 p. BRASIL. "Política Nacional de Habitação". In: Cadernos Mcidades Habitação. Ministério das Cidades, 2004. Disponível em: http://www.cidades.gov.br/images/stories/ArquivosSNH/ ArquivosPDF/4PoliticaNacionalHabitacao.pdf. Acesso em: dez. 2009.

. Presidência da República. "Decreto n. ${ }^{\circ}$ 025/2007 de 22 de janeiro de 2007. Institui o Programa de Aceleração do Crescimento - PAC, o seu Comitê Gestor e dá outras providências". Diário Oficial [da] República Federativa do Brasil, Brasília, DF. Disponível em: http://www.planalto.gov.br/ccivil_03/_Ato2007-2010/2007/Decreto/D6025compilado. htm. Acesso em: set. de 2010.

. Presidência da República. Lei n. ${ }^{\circ} 11.977$, de 7 de julho de 2009. Dispóe sobre o Programa Minha Casa, Minha Vida - PMCMV e a regularizaçấo fundiária de assentamentos localizados em áreas urbanas; altera o Decreto-Lei $n^{\circ} 3.365$, de 21 de junho de 1941, as Leis $n^{o s} 4.380$, de 21 de agosto de 1964, 6.015, de 31 de dezembro de 1973, 8.036, de 11 de maio de 1990, e 10.257, de 10 de julho de 2001, e a Medida Provisória no 2.197-43, de 24 
de agosto de 2001; e dá outras providências. Disponível em: https://www.planalto.gov.br/ ccivil_03/_ato2007-2010/2009/lei/111977.htm. Acesso em: jan. 2013.

. Portal Minha Casa, Minha Vida. Disponível em: http://www.minhacasaminhavida. gov.br/. Acesso em: jun., 2014

PAC. Programa de Aceleração do Crescimento. $1^{\circ}$ Balanço, 2015. Disponível em: http://www.pac.gov.br/pub/up/relatorio/ccedac8ebd8bfe1 fefc25c0e4e4e8c0c.pdf Acesso em: maio 2015.

CANO, W. Reflexöes sobre o papel do capital mercantil na questäo regional e urbana do Brasil. v. 177. Campinas: IE/Unicamp, 2010.

CAIXA ECONÔMICA FEDERAL. Circular Caixa no 681 de 10 de junho de 2015. Define critérios e procedimentos operacionais para aplicação das diretrizes da Politica Socioambiental do Fundo de Garantia do Tempo de Serviço - FGTS, nas áreas de habitação, saneamento e infraestrutura. Disponível em: http://www.caixa.gov.br/Downloads/FGTS-circulares-caixa-fgts2015/CircularCAIXA_2015_681.pdf

FIX, Mariana. Financeirização e Transformaçōes Recentes no Circuito Imobiliário no Brasil. (Tese). Campinas: UNICAMP, 2011.

FJP. Fundação João Pinheiro. Déficit Habitacional no Brasil, 2000. . Déficit Habitacional no Brasil, 2010.

HALL, Peter. "A Cidade da Noite Apavorante. Reaçôes à cidade encortiçada do século XIX: Londres, Paris, Berlim e Nova York (1880 a 1900)”. In: Cidades do Amanhã. São Paulo: Perspectiva, 2002. pp. 19-53.

IBGE. Divisão do Brasil em Mesorregiōes e Microrregiōes geográficas, 1990. Disponível em: http://www.biblioteca.ibge.gov.br/visualizacao/monografias/GEBIS\%20-\%20RJ/DRB/ Divisao\%20regional_v01.pdf. Acesso em: abr. 2013.

. Divisão Urbano Regional, 2013. Disponível em: ftp://geoftp.ibge.gov.br/organizacao_do_territorio/divisao_regional/divisao_urbano_regional/documentacao/divisao_urbano_regional_apresentacao_do_trabalho.pdf. Acesso em: mar. 2015.

LUCENA, Wilma G. A produção do espaço urbano da cidade de Patos/PB: do BNH ao Programa Minha Casa, Minha Vida. (Dissertação). João Pessoa: UFPB, 2014.

MARICATO, Ermínia. Para entender a crise urbana. São Paulo: Expressão Popular, 2015.

MELAZZO, Everaldo S. "Dinâmica Imobiliária e Processos de Estruturação Intra-Urbana em Cidades de Porte Médio: hipóteses e propostas de Trabalho". In: Encontro Nacional de Geógrafos, n. 16, 2010, Porto Alegre. Anais Eletrônico. Disponível em: file:///D:/ Downloads/T0026\%20-\%20EVERALDO\%20MELAZZO.pdf. Acesso em: mai. 2013. ROLNIK, Raquel. Guerra dos Lugares. A Colonização da Terra e da Moradia na Era das Finanças. $1^{\text {a }}$ ed. São Paulo: Boitempo, 2015.

e NAKANO, Kazuo. "As armadilhas do pacote habitacional". Le monde diplomatique Brasil, 2009, 5 mar. 2009.

SHIMBO, Lúcia Z. Habitação Social, Habitação de Mercado: a Confluência entre Estado, Empresas Construtoras e Capital Financeiro. (Tese). São Carlos (SP): USP, 2010.

SMOLKA, Martin O. "O capital incorporador e seus movimentos de valorizaçáo". In: Cadernos IPPUR/UFRJ, ano II, n. 1, jan./abr. Rio de Janeiro: UFRJ, 1987. pp. 41-78. 
TOPALOV, C. "Análise do ciclo de reprodução do capital investido na produção da indústria da construçáo civil. Capital e propriedade fundiária”. In: FORTI, R. (org.) Marxismo e Urbanismo Capitalista: textos críticos. São Paulo: LECH, 1979a.

C. La Urbanización Capitalista. Algunos Elementos para su Análisis. México: Edicol, 1979b. Disponível em: http://institutodeestudiosurbanos.info/dmdocuments/cendocieu/ Especializacion_Mercados/Documentos_Cursos/Urbanizacion_Capitalista-Topalov_ Christian-1979.pdf. Acesso em: jan. 2016. 



\title{
A produção imobiliária do PMCMV no bairro de Santa Cruz - Rio de Janeiro/RJ: Análises e contextos no período de 2005 e $2010^{1}$
}

\author{
Vania Regina Jorge da Silva \\ UERJ (FEBF) - Professora Adjunta \\ Miguel Angelo Ribeiro \\ UERJ - IGEOG - PPGEO - Professor Associado
}

[...] Podemos afirmar que habitar uma cidade não se resume apenas a morar em uma casa ou apartamento, por mais confortável e adequado que este provavelmente seja ou deveria ser. Habitar não é apenas possuir uma residência física [...]. O habitar e o construir, embora sejam experiências distintas, configuram o movimento de instauração do ser-no-mundo (Barbosa, p. 426, 2017).

\section{Introdução}

O presente artigo sobre a produção imobiliária do Programa Minha Casa Minha Vida (PMCMV) no bairro² de Santa Cruz, localizado na Zona

${ }^{1}$ O presente artigo faz parte da tese de Vânia Regina Jorge da Silva, defendida em janeiro de 2016 no Programa de Pós-Graduação em Geografia (PPGEO) do Instituto de Geografia (IGEOG) da Universidade do Estado do Rio de Janeiro (UERJ), intitulada O bairro de Santa Cruz-RJ no contexto da metropolização: escalas, dinâmicas e processos socioespaciais - 2005-15, sob orientação do professor Miguel Angelo Ribeiro. $\mathrm{O}$ artigo que apresentamos trata-se de uma versão para o presente livro.

2 Na nossa pesquisa, nos referimos ao bairro como sendo a menor porçáo delimitada e reconhecida pela divisão político-administrativa do município do Rio de Janeiro. 
Oeste da urbe carioca, tem por preocupação observar as mudanças espaciais no referido bairro, relacionadas a uma gama de investimentos. ${ }^{3}$

Em um contexto geral, o número de domicílios urbanos cresceu de 2 milhóes para aproximadamente 40 milhóes em meio século de urbanização acelerada. Tal fato, como apontou Barbosa (2017, p. 429), acompanhou o crescimento da população em geral e da urbana em particular.

Entretanto, apenas 20,0\% dessas moradias fizeram parte direta da construção e do financiamento por parte dos governos (federal, estaduais e municipais) e de suas agências de fomento. Grande parte da populaçáo urbana construiu suas residências com seus próprios recursos e esforços, diante da insuficiência das políticas estatais de habitação e do desinteresse do mercado formal pelas demandas das "populaçóes de baixa renda".

Desta feita, relacionamos essas mudanças a processos tanto de metropolização como o de expansão urbana no período que se estende dos anos de 2005 até 2015. Este recorte temporal justifica-se em decorrência dos incrementos em investimentos imobiliários terem a sua projeção e implementaçáo nessa faixa de tempo, ocasionando mudanças no bairro, entre outras, a produção intensificada no setor imobiliário.

Nesse contexto, houve uma promoção não só uma quantidade expressiva de empreendimentos no bairro de Santa Cruz, com destaque para o PMCMV. ${ }^{4}$ Como aponta Barbosa (2017), o Programa Minha Casa Minha

3 Sobre empreendimentos mencionados, bem como a relação estabelecida entre eles e o processo de metropolização, consultar: O bairro de Santa Cruz-RJ no contexto da metropolização: escalas, dinâmicas e processos socioespaciais - 2005-15. Disponível em: http://catalogo-redesirius.uerj.br/sophia_web/.

4 Com o objetivo de diminuir o déficit habitacional, estimular o crescimento da economia brasileira, manter o desenvolvimento dos setores imobiliários e da construçáo civil, o Governo Federal criou, em julho de 2009, o Programa Minha Casa /Minha Vida (PMCMV). Esse está vinculado ao Programa de Aceleração do Crescimento (PAC). Incentiva a produção e aquisição de novas unidades habitacionais para as famílias com renda na faixa de 0 a 10 salários mínimos com a captação de recursos do Fundo de Garantia por Tempo de Serviço (FGTS) e do Sistema Brasileiro de Poupanças e Empréstimos (SBPE). No Programa Minha Casa Minha Vida, o Governo Federal, em conjunto com a Caixa Econômica Federal, estabeleceu três faixas de financiamento dos imóveis a serem construídos, contemplando as famílias que possuem renda entre 0 e 10 salários mínimos. A primeira faixa atenderia às famílias com renda de 0 a 3 salários mínimos, a segunda, contemplaria as que possuem renda de 3 a 6 salários 
Vida vem no contexto da criação do Ministério das Cidades, no governo do presidente Luiz Inácio Lula da Silva, no qual "a moradia de baixa renda" na agenda das políticas governamentais de habitação obteve destaque, com políticas anteriormente abandonadas, exemplificadas com a extinção por decreto do banco Nacional de Habitação em 1986 e a crise do sistema financeiro de habitação.

Para Barbosa (2017, pp. 431-32),

o Programa Minha Casa Minha Vida (PMCMV) é o exemplo maior da retomada do enfrentamento do déficit de moradia para a 'populaçáo de baixa renda', incluindo a substituição de 'assentamentos precários ou de risco' (favelas, cortiços, loteamentos clandestinos) por 'moradias adequadas', por parte do estado.

Reconhecemos que tal Programa significou a possibilidade que a camada da população de menor renda pudesse se inserir no mercado formal com o tipo de moradia em condomínios fechados acompanhados de área de lazer. Para tal, articulando com o que Silva (1996) observou sobre a construçáo de elementos simbólicos na inovação do tipo de moradia em condomínios fechados, um novo conceito de morar, temos de perceber o que ocorre no bairro de Santa Cruz para além do pensamento reducionista de que o propósito era tão somente o deslocamento da população mais pobre para áreas mais distantes do centro metropolitano do Rio de Janeiro.

O recorte espacial escolhido, o bairro de Santa Cruz (figura 1), se deve a vários motivos, entre eles o interesse dos autores em analisar processos espaciais na parte Oeste do município do Rio de Janeiro, localizada ao norte do Maciço da Pedra Branca, área contemplada pelo Programa, influenciando na expansão da Metrópole a partir do capital imobiliário e do mercado de terras, sob a influência do Estado.

Nesse contexto, esse artigo tem como objetivos apreender e analisar o processo de expansão do setor imobiliário ao compararmos o bairro de Santa Cruz com outros na cidade do Rio de Janeiro durante o período que compre-

mínimos e, por último, as de 6 a 10 salários mínimos. As famílias com renda de 0 a 3 salários mínimos que seráo contempladas pelo Programa são indicadas e selecionadas pela administraçáo municipal ou pelo Governo do Estado e, no caso de Brasília, pelo Governo do Distrito Federal. 
ende os anos de 2005 e 2015. Entre as questóes norteadoras temos, no que diz respeito à construção de moradias, por exemplo: como Santa Cruz se destaca no contexto da urbe carioca? Ainda a respeito da promoção de unidades imobiliárias do PMCMV em Santa Cruz, estamos observando tão somente a ratificação do bairro como lócus para a reprodução da classe menos abastada?

Nas palavras do senso comum, é a repetição de uma noção em que o pobre deve ser levado a morar longe dos centros principais e, portanto, em áreas com menor quantidade de equipamentos urbanos de uso coletivo ratificando a cidade dual centro-periferia?

Para alcançarmos os objetivos e respondermos aos questionamentos propostos, buscamos dados disponíveis em relatórios da Secretaria Municipal de Urbanismo do Rio de Janeiro (SMU) para compreender as diferenças e similaridades da produção imobiliária no bairro de Santa Cruz em comparaçáo a outros na cidade carioca. Ainda, cabe ressaltar que esse tipo de empreendimento, embora seja intitulado como produçáo social de moradia, opera de acordo com a lógica de produção para o mercado. Essa discussão está de acordo com Pereira (2005), Lencioni (2008), Brenner (2014), entre outros autores citados no decorrer do texto. 
Figura 1 - O bairro de Santa Cruz-RJ em contextos escalares

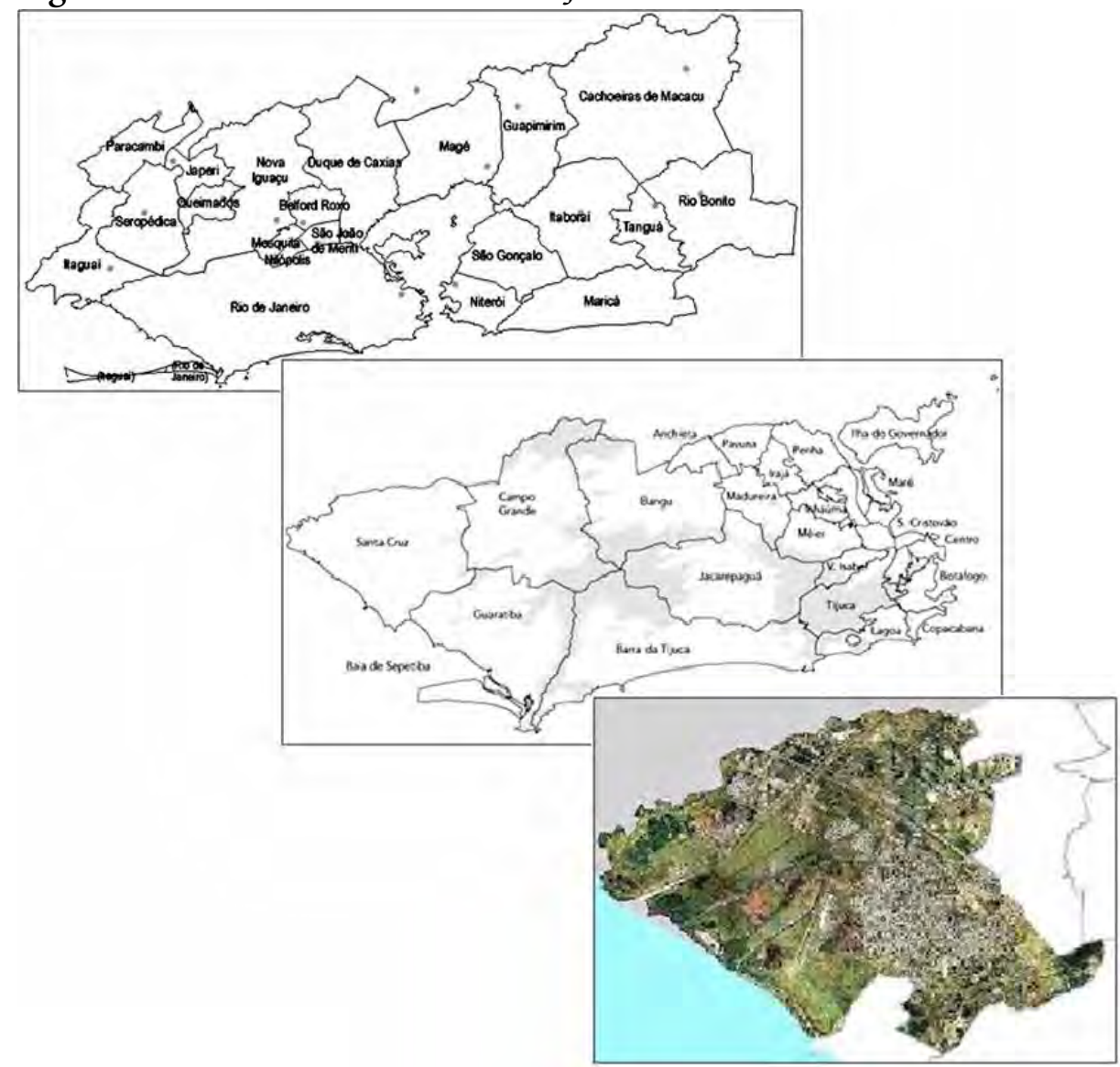

Fonte: Armazém de dados da Prefeitura do Rio de Janeiro. Elaborado por Vânia Silva (2015).

O artigo está dividido em duas seçôes: a primeira relaciona a produção imobiliária na urbe carioca, inclusive no recorte espacial de análise, em sua conjuntura político-econômica nacional e global para que possamos compreender o expressivo quantitativo de construçóes do PMCMV no referido bairro. A segunda parte apresenta, com base em relatórios da Secretaria $\mathrm{Mu}$ nicipal de Urbanismo do Rio de Janeiro (SMU), os números relativos à gama de licenciamentos imobiliários no referido recorte temporal selecionado, suscitando novos questionamentos. 


\section{A produção imobiliária no bairro de Santa Cruz- Rio de Janeiro/RJ: PMCMV, reproduçáo da pobreza?}

Segundo os relatórios da SMU do Rio de Janeiro, a partir de 2005 até 2015 percebemos uma intensificação da produção imobiliária em todo o município. Porém, com o objetivo de perceber o que isso significou para o bairro de Santa Cruz em relaçáo ao processo de produção desse setor da economia, cabe observarmos em que aquele momento se diferenciou de momentos anteriores. Primeiramente, no que diz respeito à dinâmica imobiliária apresentada no referido período, Brenner (2014) ressalta a iniciativa de governos em criar condiçóes propícias para o investimento de capitais transnacionais se refletindo no ambiente urbano com estratégias que visam tanto o núcleo metropolitano como as estruturas organizacionais que promovem a expansão com uma urbanização estendida em formas variadas. Então, podemos entender o que vinha acontecendo no município do Rio de Janeiro com investimentos em infraestrutura de transporte público, ${ }^{5}$ o Projeto Porto Maravilha e os investimentos imobiliários, tendo o urbano como meio para a ampliação da acumulação.

Nessa mesma direção, Lencioni (2008) nos aponta que um dos fatores que contribuem para a dispersão da metrópole como uma mancha urbana é o mercado de terras que incorpora áreas menos valorizadas em relação às tradicionais. O que podemos observar em relação ao bairro de Santa Cruz é que, mesmo sendo uma área interna do núcleo metropolitano, há a disponibilidade de terrenos amplos e acessíveis que apresentam esse recorte como área propícia para a expansão urbana. Então, entendemos a produção imobiliária atual no referido bairro com ênfase nos empreendimentos do PMCMV como uma forma de reprodução do capital via urbano que ocorre na direção oeste da urbe carioca, configurando-se como uma expansão urbana via setor imobiliário.

Dessa forma, Sánchez (1998) apresenta o espaço funcional metropolitano relacionado ao assentamento produtivo de indústrias, de serviços e

\footnotetext{
5 Esses empreendimentos de transporte público se referem às instalaçóes de vias expressas com BRS (Bus Rapid System), bem como as linhas de BRTs (Bus Rapid Transit) e o Veículo Leve sobre Trilhos (VLT). Todos estavam relacionados a uma agenda na qual o governo local promovia tais empreendimentos para a locação de capitais transnacionais disponíveis para investimentos deste tipo.
} 
residencial articulado por redes de transporte. Silva (2016) atenta para o fato de que não se pode desperceber que a "divisão e a hierarquização estão na essência do sistema capitalista” (p. 74) em congruência com a especulação imobiliária diferenciando parcelas do solo urbano como meio para auferir maiores lucros. Relacionando Sánchez (1998) e Lencioni (2008), podemos acrescentar que essa dinâmica ocorre tanto na expansão da metrópole como para além dela, a exemplo do espaço intrametropolitano, com uma expansão do adensamento nas áreas internas da cidade.

Nessa direção, temos as observaçôes de Ferreira (2014) que, para entender a produção do espaço em sua materialização dentro da lógica metropolitana, nos valemos do trinômio da homogeneização, fragmentação, hierarquização como um método de análise em que o primeiro termo viabiliza a conformação da cotidianidade do espaço à própria intercambialidade dos lugares. O segundo termo, a fragmentação, viabiliza a intensa mercadificação do solo em que a especulação é utilizada de acordo com os fragmentos diferenciados, promovendo a ampliação dos rendimentos. Essa fragmentação é feita de maneira atrelada ao terceiro termo, o da hierarquização, que promove os diferentes valores de troca em decorrência dos investimentos particularizados, colaborando para reproduzir e ratificar antigas hierarquizaçóes.

No nosso entendimento, essa é uma lógica que alcança lucros em todos os contextos, valendo-se, inclusive, da diferenciação existente, porque as empresas se aproveitam delas e adotam estratégias também distintas de acordo com essas diferenças. Por exemplo, o uso de terrenos amplos, mais acessíveis e afastados dos centros principais da cidade, é oportuno e questionado para a produção, visando camadas da população com menor renda, aproveitando investimentos de recursos públicos, produzindo em grande escala para minimizar os custos e ampliar os lucros.

Para entendermos a lógica do mercado imobiliário para os extratos de renda mais baixos, tivemos de comparar o momento anterior ao recorte temporal selecionado. No período entre 1960-80, na área que compreende desde Deodoro até Sepetiba e Guaratiba, incluindo Santa Cruz, observamos a produção imobiliária para a reprodução prioritária da força de trabalho no contexto urbano-industrial, com os loteamentos irregulares e clandestinos. Nesse contento, a construção de habitação era feita pelos próprios moradores nos finais de semana e com a ajuda da família e dos amigos. Esse padrão tradicional de urbanização, com expansão horizontal pela produção de moradia 
na periferia, predominou até por volta da década de 1980. Desse modo, essa urbanização tradicional apesar de precária e pobre, servia ao capital, mas, sobretudo, ao trabalhador, visto que a "cidade crescia para servir de lócus privilegiado da reprodução do trabalho" (Pereira, 2005, p.160). Em contrapartida, principalmente de 2009 até julho de 2015, tivemos um total de empreendimentos do PMCMV para a cidade do Rio de Janeiro na ordem 35.121 unidades. Sendo que cerca de 50,0\% estáo localizados em Santa Cruz e a ênfase na produção para a faixa de renda mais baixa. Podemos pensar que essa é uma estratégia para direcionar os mais pobres para bem longe das áreas mais seletivas da cidade carioca, porém, afirmamos que esse é um modo de pensar reducionista que não considera diversos elementos que estão envolvidos, para dar sentido a esta realidade.

Como nos indica Pereira (2005), observamos uma dinâmica imobiliária na qual há a emergência de produtos imobiliários condominiais somados à produção pública de habitação social para o mercado. Desse modo, "a cidade muda para servir prioritariamente ao capital” (Pereira, 2005, p. 160). Essas mudanças, inclusive na produçáo imobiliária visando as camadas de menor renda, são denotadas nos grupos envolvidos, nos investimentos e na maneira de se construir e comercializar os produtos imobiliários.

Observamos, no nosso recorte de estudo, pequenas e grandes empresas imobiliárias recorrendo aos fundos disponíveis pelo PMCMV com diversas estratégias, de acordo com a sua capacidade de produção. $\mathrm{O}$ que podemos depreender é que, para os empreendimentos destinados a famílias que ganham entre 0 e 3 SM, a Prefeitura do Rio de Janeiro é o principal agente, junto à Caixa Econômica Federal (CEF), para a venda das unidades às famílias que serão contempladas com subsídio do Governo Federal. Considerando as famílias da faixa 2, que ganham entre 3 e 6 SM, ou da faixa 3, entre 6 e 10 SM, a Prefeitura do Rio de Janeiro age como fiscalizadora diante da legislação de urbanismo, deixando as empresas privadas livres para agirem junto à Caixa Econômica Federal na venda das unidades de habitação para o mercado. $\mathrm{Ou}$ seja, os recursos são do PMCMV e o empreendimento é escolhido pela CEF, só que, as unidades são vendidas pelo e para o mercado imobiliário.

Não podemos deixar de perceber e ignorar como o setor financeiro está envolvido na produção imobiliária em geral e na habitação social em particular. Como destaca Lencioni (2014), a lógica do capital financeiro acompanhada da metropolização é hegemônica, mas possui ritmos e intensidades 
diferentes, por isso, o espaço assim produzido é homogêneo e fragmentado. Segundo a autora, as mudanças na produção do espaço coincidem com o avanço das políticas neoliberais, com as inovaçôes no planejamento, na gestão e na implementação de políticas urbanas imobiliárias e habitacionais em que o neoliberalismo, apesar do discurso contra o Estado, se impóe com a sua proteção, uma urbanização neoliberal que afirma o poder da finança. $\mathrm{O}$ conteúdo expresso é a produção do valor, a apropriação do valor na forma de patrimônio com a generalizaçáo da propriedade condominial. Essa última característica sendo representativa também na produção imobiliária para a população de menor renda.

Nessa mesma direçáo, Pereira (2014) ressalta a ideia de que a construção civil é um setor estratégico, tendo nas relaçóes de trabalho uma das estratégias que lhe permite a produção de excesso de valor e a possibilidade de ampliação do excedente. Outra estratégia é a especulação que aumenta a apropriação da renda da terra. Ambas são importantes para os intentos de sobrevida do sistema capitalista.

Se apropriando do pensamento de Smith (2007) quanto ao conceito de fronteira do capital, Pereira (2014) entende a ideia de fronteira urbana como o fenômeno da urbanizaçáo capitalista na qual observamos novas necessidades e carências da ordem próxima com o emprego de demandas globais para o investimento de capital disponível tendo como essência, o imobiliário e o financeiro. Como novas necessidades da ordem próxima, observamos a produção dos empreendimentos do PMCMV como uma apropriação da ideia de condomínios fechados no qual há a proposta de isolamento em relação ao entorno por muros e guarita, visando uma suposta segurança. Destacamos, novamente, os condomínios, principalmente verticais, que "[...] multiplica e eleva a parte da renda no valor imobiliário e, assim, aumenta a capitalizaçáo da propriedade da terra" (Pereira, 2005, p. 162). São novos conteúdos que se revelam pelas mudanças nas condiçóes de geração de valor, repartição na produção, comercializaçáo e financiamento dos produtos imobiliários. Novas formas de acesso e conceito de propriedade por meio do qual se exacerba os rendimentos do valor, visto que a verticalizaçáo promove a possibilidade de multiplicação da extração da renda da terra.

Nesse contexto, devemos nos remeter a Silva (1996) quando observa a construção de elementos simbólicos para atrair consumidores para o Recreio e para a Barra da Tijuca, locais que na época eram balneários distantes das 
áreas mais proeminentes da cidade. Lançava-se um novo conceito de morar que, embora longe da área central e com difícil acesso, o comprador estaria adquirindo um modo de viver longe dos congestionamentos adensados, com todas as benesses de lazer incluídas. Era a introdução da ênfase na construção de condomínios exclusivos que recebem hoje uma nova onda de produção, visando também classes média-baixa e baixa. Ou seja, é o envolvimento do simbólico para a produção de habitação, mas que, na verdade, promove a possibilidade de grandes ganhos.

A construção de conjuntos habitacionais MCMV tem como particularidade, em relação aos conjuntos de habitação social construídos em períodos anteriores - como os do BNH (Banco Nacional de Habitação) e da antiga COHAB (Companhia de Habitaçáo Popular do Estado do Guanabara), hoje denominada CEHAB (Companhia Estadual de Habitação do Rio de Janeiro) -, o fato de apresentarem a forma de condomínio murado, fechado, com segurança e acesso a equipamentos de lazer exclusivos para os condôminos, caracterizando um tipo particular de segregaçáo, pois isola esse tipo de moradia do restante do bairro pelos extensos muros, como pode ser visto nas fotos 1 e 2 .

$\mathrm{Na}$ primeira foto temos o empreendimento Village Ventura na Av. Padre Guilherme de Decaminada, perto da Av. Brasil. Esse empreendimento na verdade não é um só, são vários, um ao lado do outro. Possui um total de 1500 unidades destinadas a pessoas com renda entre 3 e 6 SM, oferecendo áreas de lazer com piscina, murado e com guarita. Na segunda foto é possível perceber o entorno do empreendimento, caracterizado por uma ocupação anterior sem muito ordenamento, ilegal ou irregular. 


\section{Foto 1 - Empreendimento Village Ventura - Santa Cruz-RJ}

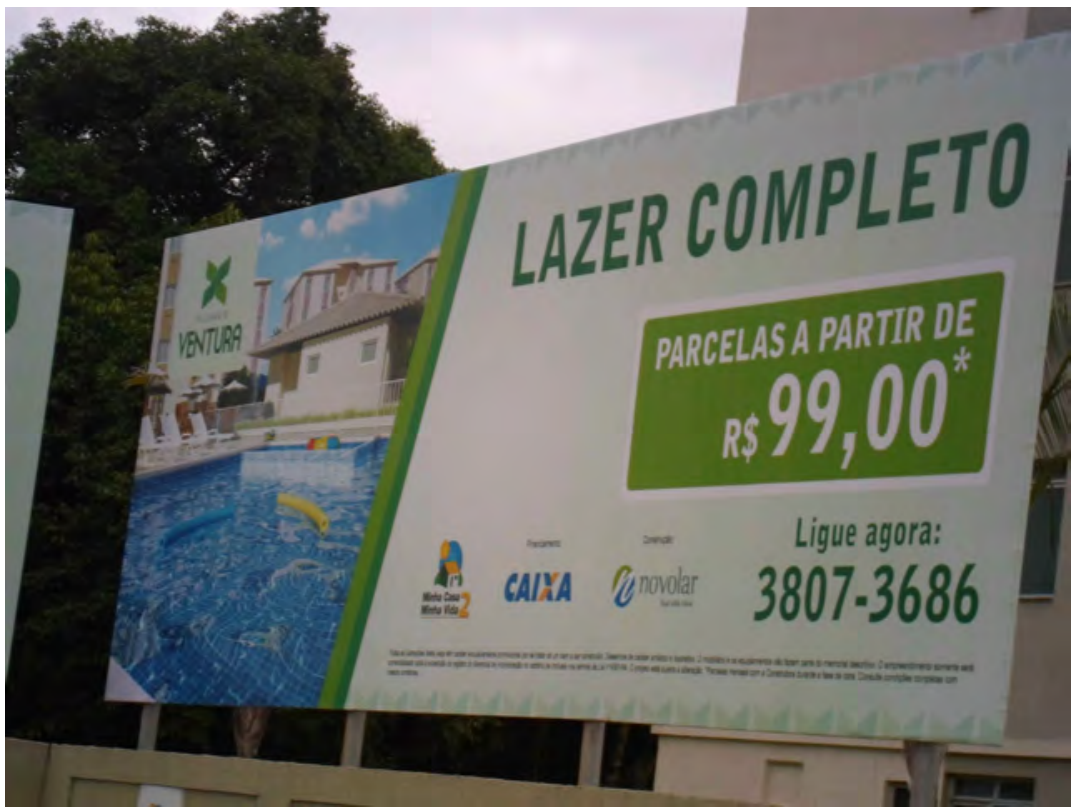

Autoria: Vânia Silva, 2015. Empreendimento com recurso do PMCMV para famílias que ganham entre 3 e 6SM. Uma apreensão do conceito de moradia condominial com lazer e privacidade

\section{Foto 2 - O entorno do empreendimento Village Ventura - Santa Cruz-RJ}

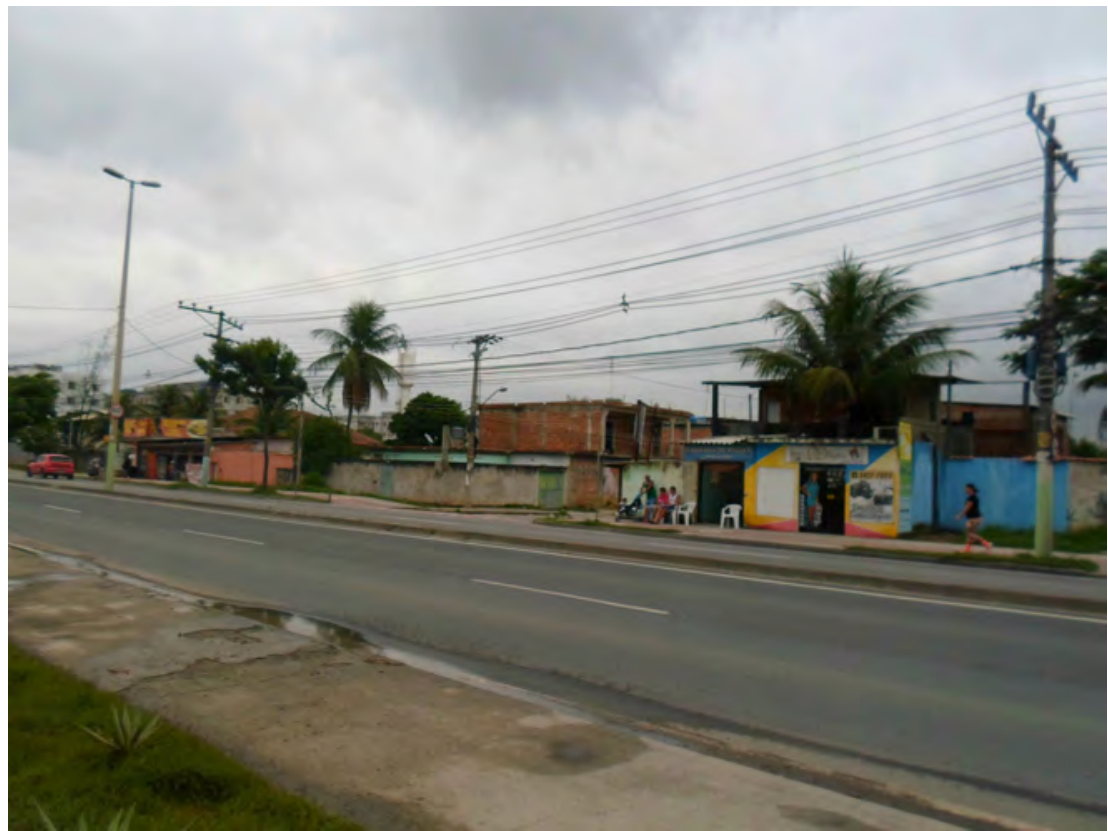


Antes de prosseguirmos, reafirmamos que, no recorte temporal selecionado para análise, no contexto nacional e, particularmente, na cidade do Rio de Janeiro, percebemos que o principal intento da produção imobiliária era a ampliação do excedente frente à crise de acumulação capitalista expressa a partir de 2008. Como conteúdo, temos a maior inserção do capital em diversos tipos de empreendimentos imobiliários diferenciados nas parcelas do espaço urbano, todos com estratégias que visam a possibilidade de expansão dos ganhos, como, por exemplo, o uso intensivo do solo em condomínios verticais. Esses aspectos são trabalhados na próxima seção.

\section{Os novos contextos de produçáo imobiliária na cidade do Rio de Janeiro: a participação do bairro de Santa Cruz}

Como ponto de partida, tomamos a noção de reestruturação imobiliária desenvolvida por Pereira (2014), considerando a distribuição desigual do valor e dos grupos sociais no território sob a ação do capital, percebendo a influência do Estado, das empresas e do capital financeiro como agentes nos negócios imobiliários, de acordo com uma política de habitação que vem em resposta às necessidades do mercado e do capital disponível para investimento, não em resposta à demanda por moradias. Observamos, assim, os empreendimentos imobiliários tanto nas antigas periferias distantes como nas áreas urbanas centrais com conteúdos sociais que denotam uma fragmentação urbana por serem diferenciados, e uma segregação diante da ênfase em condomínios com a promessa de segurança que, na verdade, cria separaçóes intraurbanas.

O que foi observado durante o período de dez anos (2005-15) pode ser caracterizado como urbanismo empresarial, porque são os agentes privados dos negócios que indicam a direçáo do crescimento da cidade tendo o patrimônio urbano e imobiliário como fonte de rendimento. Os espaços da cidade são instrumentalizados via empreendimentos imobiliários, inclusive do PMCMV, que direcionam estímulos e investimentos para a produção condominial que serve, sobretudo, ao interesse do capital. Sendo assim, a política urbana, mesmo aquela que tem um cunho de política habitacional social, é desfavorável aos que realmente necessitam, pois suas intençôes não são na direção da justiça social. Desfavorável porque concentram-se, na maior parte, em áreas distantes dos principais centros comerciais e de serviços, de locais 
de emprego e trabalho, onerando o deslocamento do morador e implicando no seu desgaste físico.

A partir do que discutimos a respeito da produçáo imobiliária de Santa Cruz, cumpre apresentar a quantidade de empreendimentos em comparação à urbe carioca. Nos relatórios disponibilizados pela SMU de 2005 até agosto de 2015 sobre quantitativos de licenciamentos por áreas e por unidades na cidade do Rio de Janeiro, obtivemos dados por bairros na medida em que houve disponibilidade de acesso. Quando não foi possível, apresentamos por Área de Planejamento (AP). Em todo o município, o ano de 2005 foi marcante com um aumento de 32,0\% de licenças novas em relaçáo a 2004. Entre os fatores apontados para esse expressivo crescimento, temos a conjuntura macroeconômica nacional no período caracterizada pelo aumento médio da renda da população, melhores condiçôes de financiamento e queda das taxas de juros.

$\mathrm{Na}$ verdade, a referida conjuntura foi engendrada pelo Governo Federal garantindo fundos de financiamento tanto para os empreendimentos que seguissem suas diretrizes como para os compradores, fossem de imóveis, móveis, eletrodoméstico etc., uma condição promovida para manter e aumentar a circulação da economia. Houve ainda políticas de isenção fiscal para determinados produtos relacionados com o setor imobiliário, como máquinas e equipamentos, e a garantia de juros baixos para o financiamento para a compra da casa própria associado ao aumento do número de prestaçóes.

As medidas tomadas promoveram a expansão do emprego e a possibilidade de aquisição do imóvel próprio. Além do exposto, os relatórios citam outros fatores que estimularam o setor imobiliário, como, por exemplo, os investimentos públicos e privados para tornar a cidade do Rio de Janeiro atraente para sediar megaeventos; os programas habitacionais sociais - como o Programa de Assentamento Residencial (PAR) que foi substituído em 2009 pelo PMCMV.

A atuaçáo do Governo Federal nesse contexto tem sido por meio de legislaçóes e instituições de pacotes econômicos como o PAC (Programa de Aceleraçáo do Crescimento). Com a primeira versão lançada em 2007, tendo como enfoque investimentos em infraestrutura de habitação, saneamento e transporte. A intenção dessa iniciativa pública foi atrair investimentos privados nacionais e internacionais. $\mathrm{O}$ primeiro $\mathrm{PAC}$ orçou suas bases na ordem de 503 bilhôes de reais, enquanto o segundo PAC, que começou em 2010, previu um montante de 1,59 trilhôes de reais para investir em transporte, 
energia, saúde, áreas sociais e habitação. A origem dessas verbas é de empresas estatais e de economia mista, do orçamento da União, da seguridade social e da iniciativa privada.

Devemos entender esse contexto como estratégias político-econômicas com a finalidade de fazer frente à conjuntura que se esboçava na escala global. O problema de insustentabilidade do setor imobiliário estadunidense reverberou sobre o modelo de acumulação de capital pautado na especulação financeira, desencadeando o que ficou conhecido como crise de 2008. Diante disso, o governo brasileiro adotou medidas para ampliar o crédito, inclusive, o destinado à construção civil e para a compra de imóveis.

Nesse cenário, houve uma ampliação da financeirização da produção imobiliária via Sistema Financeiro de Habitação (SFH), institucionalizado desde a Lei n. ${ }^{\circ}$ 9514/97, que permite a possibilidade de associação entre o capital financeiro e o setor imobiliário. Com o objetivo de ampliar a formaçáo de excedentes, as estratégias das empresas do setor imobiliário que atuam na cidade do Rio de Janeiro têm sido a de buscar terrenos amplos com metragem igual ou maior que $10.000 \mathrm{~m}$. Em determinados casos, esses terrenos têm como atrativo estarem localizados próximos a grandes eixos de transporte e com ligaçáo à região oceânica. Também há busca por terrenos grandes e a baixo custo em áreas deprimidas economicamente e pouco valorizadas, como é o caso do bairro de Santa Cruz, na Zona Oeste Carioca, que tem se tornado atrativo diante de investimentos de infraestrutura, como o Arco Metropolitano do Rio de Janeiro. Além desse, a retórica é de que, agora, aquela área está a dez minutos da Barra da Tijuca pelo Túnel da Grota Funda.

A partir de dados disponíveis quanto a licenças concedidas, somando-se as destinadas a usos residenciais, as não residenciais e as de usos mistos pela Secretaria Municipal de Urbanismo do Rio de Janeiro, tentamos realizar algumas análises para perceber o bairro de Santa Cruz no que diz respeito ao setor imobiliário com destaque para as novas construçóes. Fizemos algumas análises por ano, de acordo com a disponibilidade de informaçóes organizadas por Área de Planejamento (AP), Região Administrativa (RA) e bairros. O intento é de perceber como ocorreu a dinâmica de construçóes imobiliária na cidade do Rio de Janeiro procurando alguns dos aspectos mais relevantes e detalhados a respeito da AP5 por RAs e bairros, por conter o nosso recorte espacial de análise. 
O quadro 1, construído a partir da nossas análises dos relatórios, apresenta primeiramente as APs da cidade do Rio de Janeiro. A AP 5 é composta pelas RAs de Bangu, Campo Grande, Santa Cruz, Guaratiba e Realengo, com um total de 21 bairros $^{66}$ sendo que três deles, Campo Grande, Santa Cruz e Guaratiba, são os maiores em extensão. Como podemos observar, há aumentos de licenças nos anos de 2007, 2010 e 2014, de modo que apresenta-se como área de expansão do setor imobiliário propiciado, principalmente, pelos recentes investimentos em infraestrutura de transporte, como o BRT TransOeste e o Túnel da Grota Funda.

Quadro 1 - Número de licenças concedidas de 2005 - 2015 (até setembro) por AP na cidade do Rio de Janeiro

\begin{tabular}{c|c|c|c|c|c|c|c|c|c|c|c}
\hline AP & 2005 & 2006 & 2007 & 2008 & 2009 & 2010 & 2011 & 2012 & 2013 & 2014 & 2015 \\
\hline Total & 3680 & 3875 & 8760 & 3850 & 4209 & 3326 & 3200 & 3201 & 2854 & 2677 & 1436 \\
\hline AP 1 & 125 & 120 & 132 & 128 & 33 & 32 & 100 & 80 & 82 & 39 & 33 \\
\hline AP 2 & 451 & 555 & 783 & 400 & 75 & 108 & 148 & 84 & 93 & 106 & 62 \\
\hline AP 3 & 1379 & 1352 & 737 & 1384 & 726 & 705 & 616 & 661 & 564 & 626 & 347 \\
\hline AP 4 & 1071 & 1145 & 5378 & 1168 & 1003 & 923 & 1475 & 1534 & 1229 & 1018 & 435 \\
\hline AP 5 & 654 & 703 & 1024 & 770 & 2350 & 1557 & 861 & 842 & 886 & 1324 & 561 \\
\hline
\end{tabular}

Fonte: Secretaria Municipal de Urbanismo do Rio de Janeiro.

A título de comparaçáo, destacamos os bairros da AP5 que têm apresentado crescentes números de licenciamentos. Se tomarmos aleatoriamente o número acima de 100 licenças perceberemos alguns destaques nessa AP (quadro 2). Primeiramente, o bairro de Campo Grande desponta com número de licenças acima de 100 em todos os anos de 2005 até 2015, com notoriedade especial para o ano de 2009 com 1.089 licenças.

Logo a seguir, temos Santa Cruz que nos anos de 2007, 2009, 2010 e 2013 apresenta quantitativos de licenças superiores a 200 (respectivamente, 498, 402, 324, 202). Devemos compreender essa situação, dentro do

${ }^{6}$ Composição da AP 5 - RA XVII Bangu - Bangu, Gericinó, Padre Miguel, Senador Camará; RA XVIII Campo Grande - Campo Grande, Cosmos, Inhoaíba, Senador Vasconcelos; RA XIX Santa Cruz - Paciência, Santa Cruz, Sepetiba; RA XXVI Guaratiba - Barra de Guaratiba, Guaratiba, Pedra de Guaratiba; RA XXXIII Realengo - Campo dos Afonsos, Deodoro, Jardim Sulacap, Magalhães Bastos, Realengo, Vila Militar. 
PMCMV. Em seguida, percebemos o auge de licenças no ano de 2009 no bairro de Jardim Sulacap, que deve ser entendido no bojo de um evento internacional, os Jogos Mundiais Militares que aconteceu na cidade do Rio de Janeiro no mês de julho de 2011. E por fim, o aumento de licenciamentos no bairro de Guaratiba também no ano de 2009.

Quadro 2 - Licenças na AP 5 por RA e bairros nos anos de 2005 - 2015 (até o mês de setembro)

\begin{tabular}{|c|c|c|c|c|c|c|c|c|c|c|c|}
\hline RA e bairros & 2005 & 2006 & 2007 & 2008 & 2009 & 2010 & 2011 & 2012 & 2013 & 2014 & 2015 \\
\hline XVII Bangu & 145 & 162 & 29 & 183 & 260 & 97 & 90 & 73 & 106 & 205 & 58 \\
\hline Bangu & 105 & 104 & 23 & 30 & 90 & 82 & 66 & 48 & 74 & 152 & 41 \\
\hline \multicolumn{12}{|l|}{ Gericinó } \\
\hline Padre Miguel & 29 & 35 & 6 & 36 & 20 & 10 & 15 & 14 & 25 & 40 & 12 \\
\hline Senador Camará & 11 & 23 & & 17 & 150 & 5 & 9 & 11 & 7 & 13 & 5 \\
\hline $\begin{array}{l}\text { XVIII Campo } \\
\text { Grande }\end{array}$ & 344 & 319 & 489 & 373 & 1175 & 935 & 528 & 566 & 401 & 986 & 334 \\
\hline Campo Grande & 307 & 276 & 112 & 327 & 1089 & 728 & 469 & 522 & 331 & 785 & 250 \\
\hline Cosmos & 17 & 20 & 376 & 10 & 61 & 181 & 47 & 26 & 39 & 76 & 42 \\
\hline Inhoaíba & 6 & 10 & & 4 & 11 & 7 & 4 & 2 & 18 & 21 & \\
\hline Santíssimo & 9 & 5 & 1 & 14 & 9 & 16 & 6 & 7 & 7 & 94 & 35 \\
\hline $\begin{array}{l}\text { Senador Vascon- } \\
\text { celos }\end{array}$ & 5 & 8 & & 18 & 5 & 3 & 2 & 9 & 6 & 10 & 7 \\
\hline XIX Santa Cruz & 37 & 35 & 498 & 33 & 656 & 415 & 90 & 54 & 230 & 138 & 64 \\
\hline Paciência & 10 & 9 & & 10 & 254 & 91 & 17 & 16 & 26 & 39 & 11 \\
\hline Santa Cruz & 27 & 26 & 498 & 21 & 402 & 324 & 72 & 38 & 202 & 97 & 50 \\
\hline Sepetiba & & & & 2 & & & 1 & & 2 & 2 & 3 \\
\hline XXVI Guaratiba & 29 & 63 & & 47 & 147 & 52 & 77 & 80 & 65 & 2 & 36 \\
\hline $\begin{array}{l}\text { Barra de Gua- } \\
\text { ratiba }\end{array}$ & & & & 1 & & & 1 & & & & \\
\hline Guaratiba & 21 & 54 & & 42 & 124 & 43 & 59 & 67 & 60 & 2 & 29 \\
\hline $\begin{array}{l}\text { Pedra de Gua- } \\
\text { ratiba }\end{array}$ & 8 & 9 & & 4 & 23 & 9 & 17 & 13 & 5 & & 7 \\
\hline XXXIII Realengo & 99 & 124 & 8 & 134 & 112 & 58 & 76 & 69 & 84 & 201 & 69 \\
\hline $\begin{array}{l}\text { Campo dos } \\
\text { Afonsos }\end{array}$ & 1 & 2 & & & & 3 & & & & 6 & \\
\hline
\end{tabular}




\begin{tabular}{l|c|c|c|c|c|c|c|c|c|c|c}
\hline Deodoro & & 1 & & 2 & 1 & & 18 & & 13 & 8 & \\
\hline Jardim Sulacap & 27 & 28 & 3 & 36 & 405 & 9 & 8 & 17 & 10 & 19 & 13 \\
\hline $\begin{array}{l}\text { Magalhães } \\
\text { Bastos }\end{array}$ & 12 & 14 & & 12 & 26 & 6 & 50 & 4 & 60 & 19 & 8 \\
\hline Realengo & 57 & 75 & 5 & 84 & 73 & 39 & & 45 & 313 & 130 & 48 \\
\hline Vila Militar & 2 & 4 & & & 17 & 1 & & 3 & 1 & 19 & \\
\hline Total & 654 & 703 & 1024 & 770 & 2350 & 1557 & 861 & 842 & 886 & 1324 & 561 \\
\hline
\end{tabular}

Fonte: Secretaria Municipal de Urbanismo do Rio de Janeiro.

Para ressaltar o nosso período de análise (2005-15) que tem como contexto particular a reprodução do capital no urbano via setor imobiliário em conjunção com o financeiro em volume inédito, cabe tomarmos algumas das informaçôes do relatório da SMU para 2009 no qual realiza comparação com anos anteriores. Mencionando a década de 1980, podemos destacar que houve uma redução abrupta na área licenciada em 1984, com 2,3 milhôes de licenciamentos, em comparação com 1983 que teve 5,4 milhôes de $\mathrm{m}^{2}$. Essa situação é explicada pela extinção do BNH no contexto do esgotamento do modelo de desenvolvimento econômico adotado no Brasil entre os anos de 1960-80. A partir de 2005, a situação se reverte e o licenciamento passa a atingir um patamar de 3 milhóes $\mathrm{de}^{2}$ de forma consistente e com forte tendência de elevação. Como especificidade desse momento, podemos salientar a abertura de um novo mercado constituído pelos segmentos sociais de famílias que ganham até 10 salários mínimos, beneficiadas diretamente por políticas habitacionais do PMCMV, possibilitando a essa camada da populaçáo acesso ao mercado habitacional formal. Assim, em 2009 temos um volume de licenças no mesmo patamar do início dos anos 1980, com mais de 5 milhóes de $\mathrm{m}^{2}$ licenciados. Segundo o referido relatório, sete bairros concentraram $51,0 \%$ do total da área total licenciada, sendo que, cinco deles são da Zona Oeste carioca e três da AP 5, Campo Grande, Santa Cruz e Senador Camará, como pode ser visto no gráfico 1. Destaque para o bairro de Santa Cruz na quarta posição desse ranqueamento no gráfico 1 .

Em seguida, é possível perceber, a partir do gráfico 2, o total de unidades residenciais licenciadas em 2009. Campo Grande e Santa Cruz se destacam, representando cerca de 35,0\% do total dessas unidades. Destaque para Santa Cruz em segundo lugar na lista de participaçôes. As análises da 
SMU para 2010 continuam acusando o aumento da produção imobiliária na cidade do Rio de Janeiro, com um total de 7,0\% em relação ao ano anterior, com destaque para as APs 3, 4, 5 em números absolutos e aumento da participação relativa das AP3 e 5 em comparação às demais.

Para os gráficos do ano de 2010 referentes a áreas e a unidades licenciadas, podemos observar que o quadro de 2009 se repete. Observamos no gráfico 3, referente a unidades licenciadas, o bairro de Santa Cruz mais uma vez em segundo lugar no que diz respeito à área total licenciada e em segundo quanto a unidades totais licenciadas.

Em 2011, os relatórios apontam para um aumento de 8,2\% nos licenciamentos para a cidade do Rio de Janeiro. O bairro de Santa Cruz perde sua posição em 2010, caindo da segunda para a sexta no que diz respeito ao número de unidades licenciadas, como pode ser visto no gráfico 4 .

Gráfico 1 - Área total licenciada nos bairros com as maiores participações

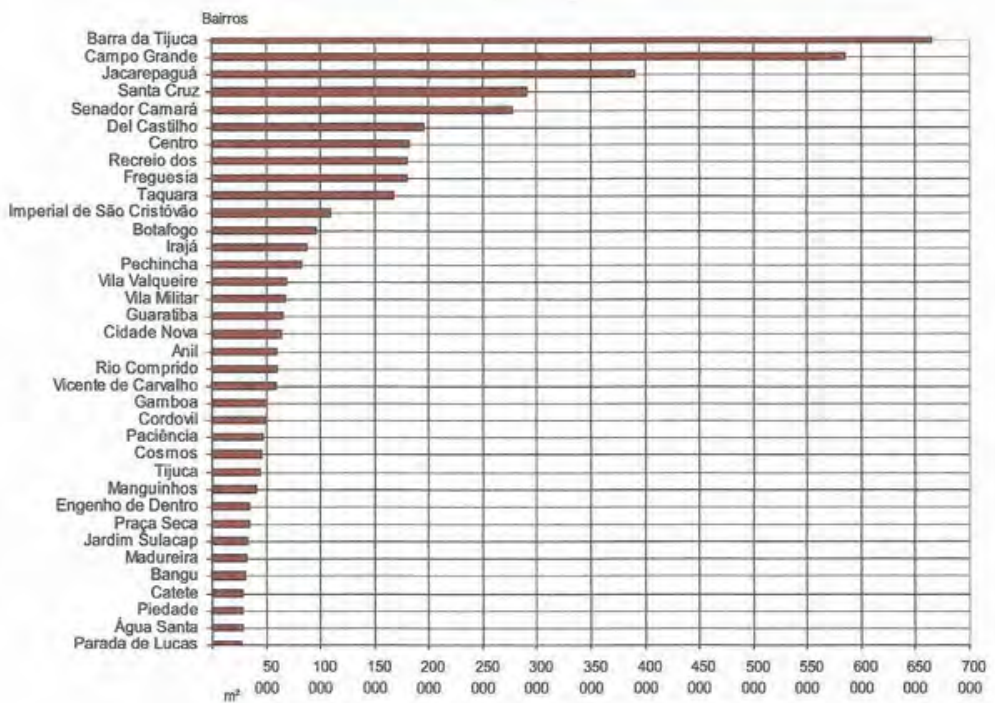

Fonte: Secretaria Municipal de Urbanismo do Rio de Janeiro. 
Gráfico 2 - No de unidades residenciais licenciadas nos bairros com as maiores

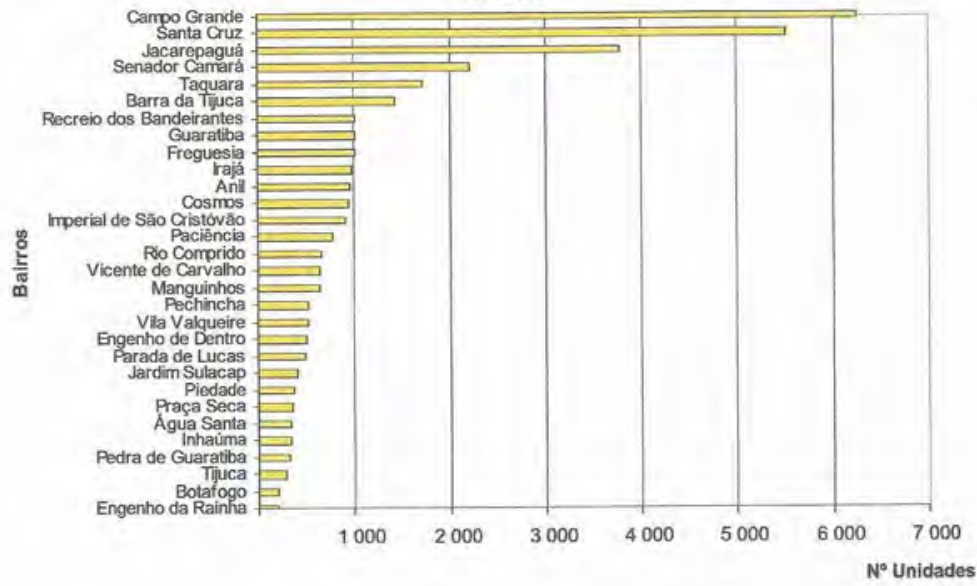

Fonte: Secretaria Municipal de Urbanismo do Rio de Janeiro.

Gráfico 3 - Total de unidades licenciada nos bairros com as maiores participaçóes - 2010

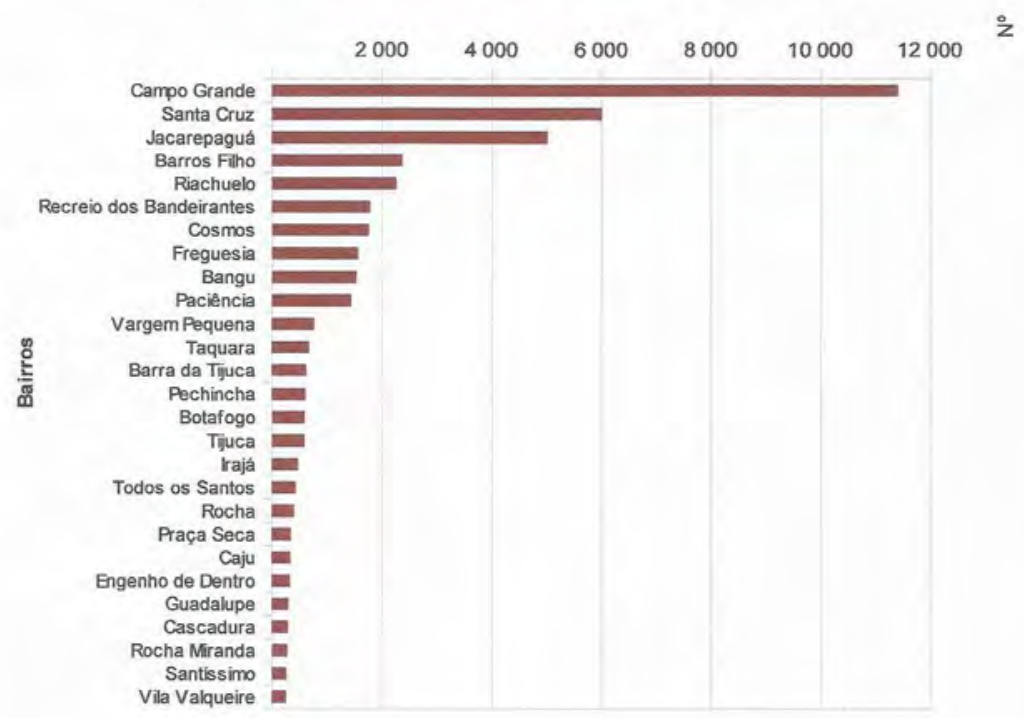

Fonte: Secretaria Municipal de Urbanismo do Rio de Janeiro. 
Gráfico 4 - No de unidades licenciadas - total, residencial, não-residencial, por bairro, com no igual ou acima de 150 unidades licenciadas - 2011

Número de Unidades Licenciadas Total, Residenclal e Năo Residencial, por Bairro, com número de unidades licenciadas igual ou maior que $150-2011$

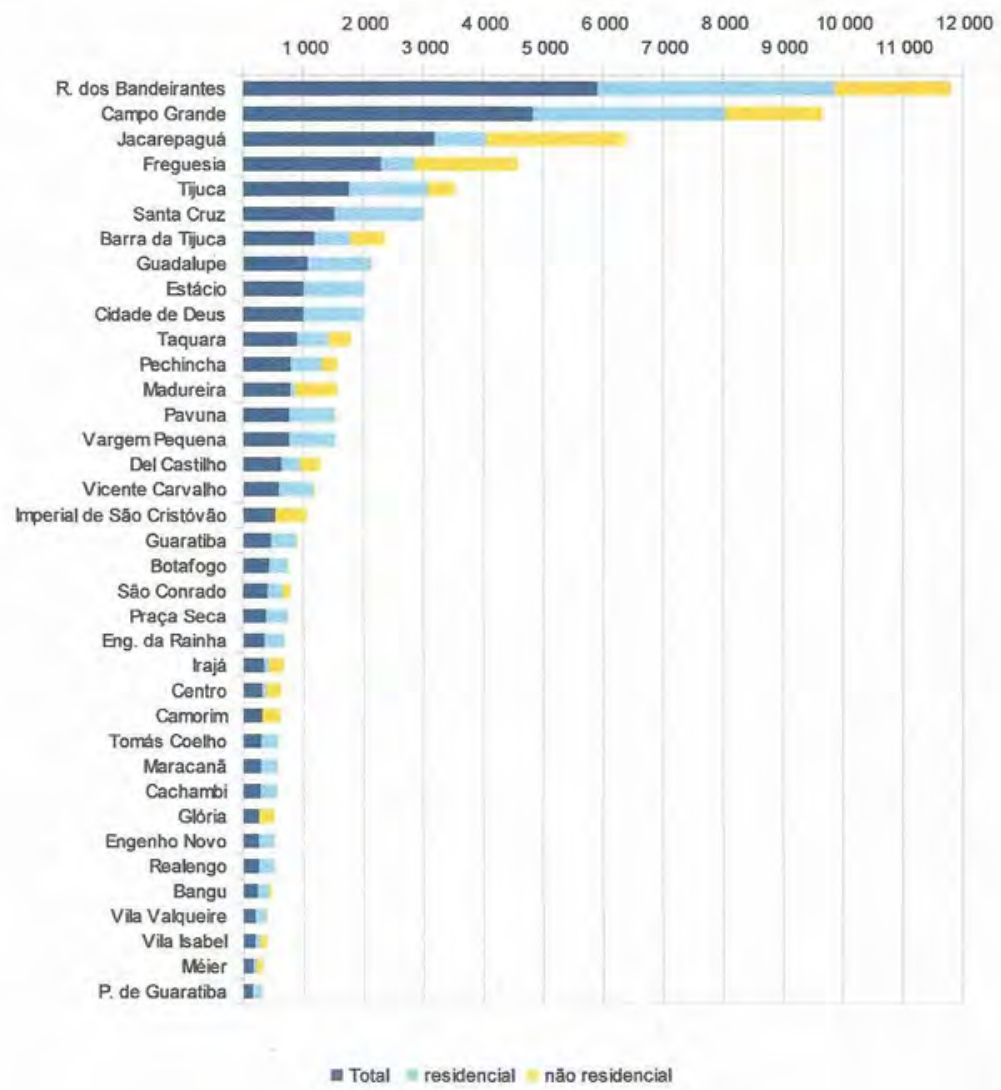

Fonte: Secretaria Municipal de Urbanismo do Rio de Janeiro.

Para 2012, temos uma queda de $-2,0 \%$ no total da área licenciada em relação a 2011, apontando para uma estabilidade no setor ou esgotamento do modelo de produção imobiliária adotado. Mesmo assim, as cifras totais continuam altas, visto que em 2012 foram licenciados um total aproximado de 5,2 milhóes de $\mathrm{m}^{2}$ contra 5,3 milhóes em 2011. O gráfico 5 registra uma queda vertiginosa no licenciamento da AP5. Essa situaçáo nos acusa que o setor começa a dar sinais de esgotamento no que diz respeito à produção 
visando a camada da população menos abastada, considerando que o grande volume apresentado nos bairros da AP5, principalmente em Campo Grande e em Santa Cruz, estão relacionados ao PMCMV.

Gráfico 5 - Área total licenciada, conforme uso, por Área de Planejamento - 2012

Área Total Licenciada, conforme o Uso, por Área de Planejamento - 2012

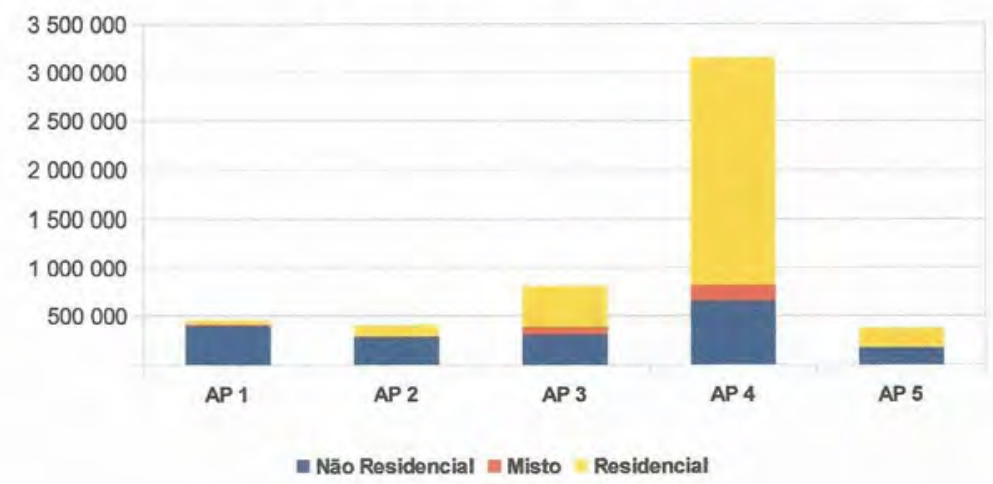

Fonte: Secretaria Municipal de Urbanismo.

Embora apresente, no geral, um quadro ainda positivo, o resultado do licenciamento no ano de 2013, segundo os relatórios da SMU, também registra sinais de desaquecimento e retraçáo em todo o setor imobiliário segundo a Câmara brasileira da indústria da Construção Civil. Só na AP5, a queda foi de 19,3\% nas edificaçóes no primeiro trimestre em relação ao mesmo período do ano anterior. $\mathrm{O}$ ano de 2015 continua o quadro apresentado no ano anterior com um aumento de 4,0\% no mês de agosto em relação ao mesmo mês em 2014. No entanto, os números acumulados até agosto de 2015 de áreas licenciadas no período caíram em 24,9\%.

Em síntese, o que queremos destacar é que a área que compreende a AP5 vem se caracterizando como sendo de interesse para a expansão imobiliária. De 2005 até 2015 a AP5 se apresentou como mais uma área de vultosos números de empreendimentos. Isso ocorreu diante dos investimentos estatais em infraestrutura viária e de transporte, evidenciando essa área para o interesse do capital. 
Os dados informados acima apresentam o bairro de Santa Cruz estando sucessivamente entre os bairros que mais lograram licenciamento nos anos analisados. Porém, temos que perceber qual é o conteúdo social dessa produção capitalista de moradias no referido bairro.

Em conformidade com toda essa discussão, passamos a analisar de maneira mais acurada a produção imobiliária para a população de menor renda, que no nível municipal está sob a Lei n. ${ }^{\circ}$ 40/1999 relativa a empreendimentos de interesse social de baixa renda incluído em programas de política social habitacional de outras esferas do governo. O que temos observado na cidade do Rio de Janeiro é a alocação de tais empreendimentos em áreas que não atendem todas as especificaçóes normatizadas pela lei, principalmente no que diz respeito ao transporte público e aos equipamentos de saúde e de educação. Além disso, essa legislação prevê a construção de, no máximo, 500 unidades por empreendimentos de quatro andares. Mas, para que as empresas possam ampliar seus excedentes, muitas têm burlado a legislação, construindo mais de 1000 unidades divididas em empreendimentos diferentes para o mesmo terreno.

Segundo Cardoso (2011), há duas possibilidades de formação de excedentes pelas empresas que não são excludentes. Uma delas é a redução do custo de construção, a outra é a redução do preço da terra, ou seja, dois tipos de lucratividade de naturezas diferentes. A redução do preço da terra se refere ao lucro imobiliário que é maximizado com a capacidade das empresas desenvolverem estratégias de redução do valor pago ao proprietário. Nesse sentido, a ampliação da escala dos empreendimentos implica na busca por glebas mais amplas, reforçando a tendência de expansão para a Zona Oeste, local com maior disponibilidade desses terrenos.

Observamos que o PMCMV transcende a dimensão social da questão habitacional e se insere na dimensão político-econômica, tornando-se elemento chave para a dinamizaçáo da economia. $\mathrm{O}$ modelo adotado coloca a iniciativa privada como principal agente promotor da política que decide onde o empreendimento será construído, a faixa de renda beneficiada e as características dos imóveis, cabendo à administração municipal realizar levantamento da demanda e sortear os contemplados para adesão ao programa para as unidades que realmente têm a função de habitação social, são destinadas para famílias que recebem até 3 SM.

Exemplificando com a adesão dos consumidores, não se pode negar que o programa tem permitido que famílias que ganham menos de três salários mí- 
nimos possam obter seus imóveis. Ou seja, é uma parcela da população que alcançou a possibilidade da propriedade privada por meio do mercado formal. Embora saibamos que alguns dos proprietários de unidades MCMV podem ter sido forçados a aderir ao empreendimento em virtude de remoçóes de áreas da cidade que estão passando por processo de requalificação, como é o exemplo da área portuária do Rio de Janeiro, muitos aderem voluntariamente para escapar das áreas de risco ou com alto índice de violência, além daquelas que estão "interessadas em obter garantia legal definitiva da posse do imóvel, ou [...] seduzidas pelo desejo de consumir um 'produto' imobiliário diferenciado, materializado pela tipologia condomínio-fechado amplamente adotada pelas incorporadoras que produzem para o programa" (Cardoso e Jaenisch, 2014, s/n).

Como já afirmamos, o aumento da escala de construção significa realizar vários empreendimentos com licenças diferentes no mesmo terreno. $\mathrm{Na}$ foto 3 , temos três licenciamentos em um só terreno, o Parque Recanto Verde, o Recanto da Serra e o Recanto da Colina, todos construídos pela MRV Engenharia com cerca de 500 unidades cada, dotados de áreas de lazer e segurança.

Foto 3 - Três empreendimentos MCMV pela MRV na Estrada Padre Guilherme de Decaminada - Santa Cruz-RJ

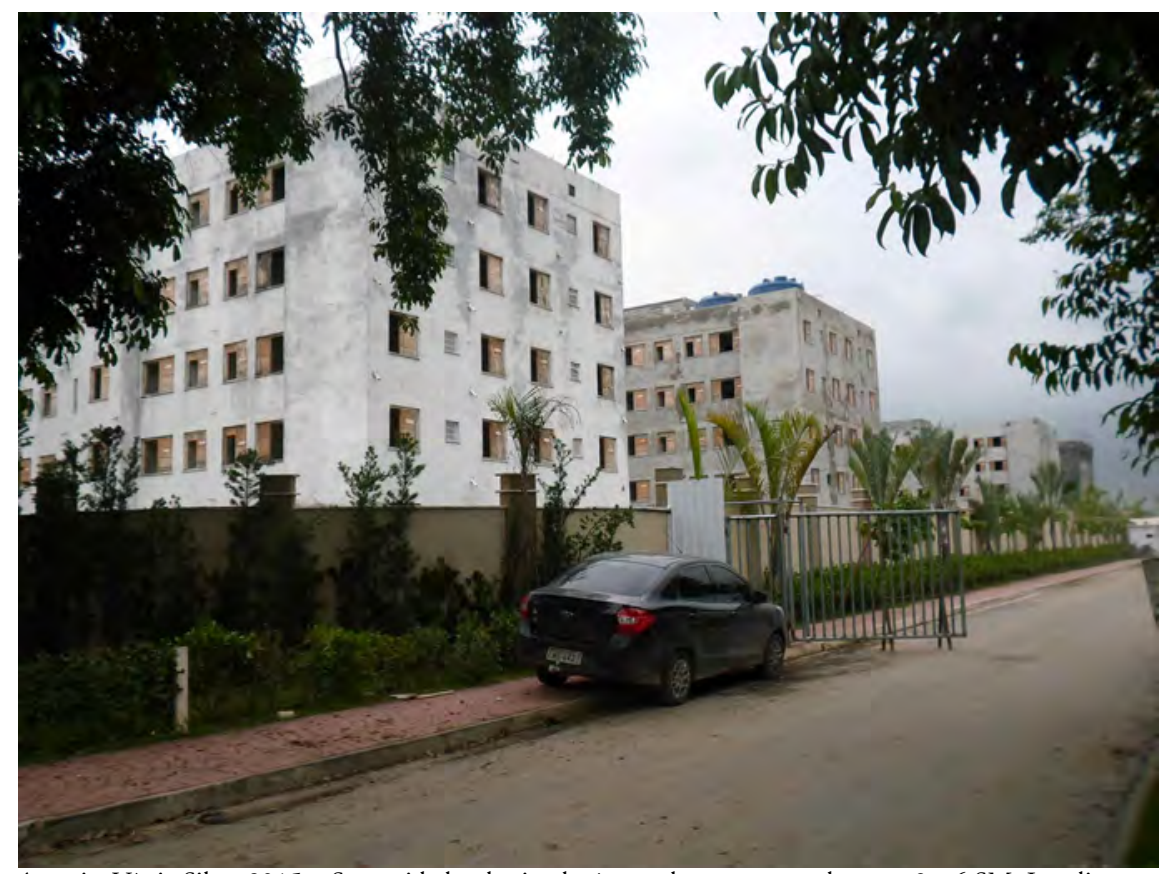

Autoria: Vânia Silva, 2015 - São unidades destinadas à população com renda entre 3 e 6 SM. Localiza-se perto da Av. Brasil e oferece total infraestrutura de lazer e segurança. 
Posto isto, podemos destacar a configuração das construçóes do PMCMV por faixa de rendimento. Do total de unidades contratadas pelo município do Rio de Janeiro, 48,2\% são para a faixa 1 (0 a 3 salários mínimos), $16,3 \%$ para a faixa 2 (3 a 6 salários mínimos) e $35,4 \%$ para a faixa 3 (6 a 10 salários mínimos). Deste total, 48,3\% estáo localizadas na Zona Oeste Carioca, nos bairros de Campo Grande, Santa Cruz, Cosmos, Paciência, Senador Camará, Guaratiba, Inhoaíba, Santíssimo, Realengo, Bangu, Pedra de Guaratiba, Jardim Sulacap e Senador Vasconcelos.

É possível ressaltar que $58,5 \%$ das unidades dessa área foram destinadas a população que se enquadra na faixa 1 e $41,5 \%$ para as faixas 2 e 3 . Cabe ressaltar, ainda, que segundo o relatório da SMU em abril de 2010, cerca de 93,3\% do total das unidades habitacionais em análise ou licenciadas para o PMCMV em 2010 estão Na AP5 (figura 2).

Figura 2 - Unidades de habitação do PMCMV por bairro no município do Rio de Janeiro

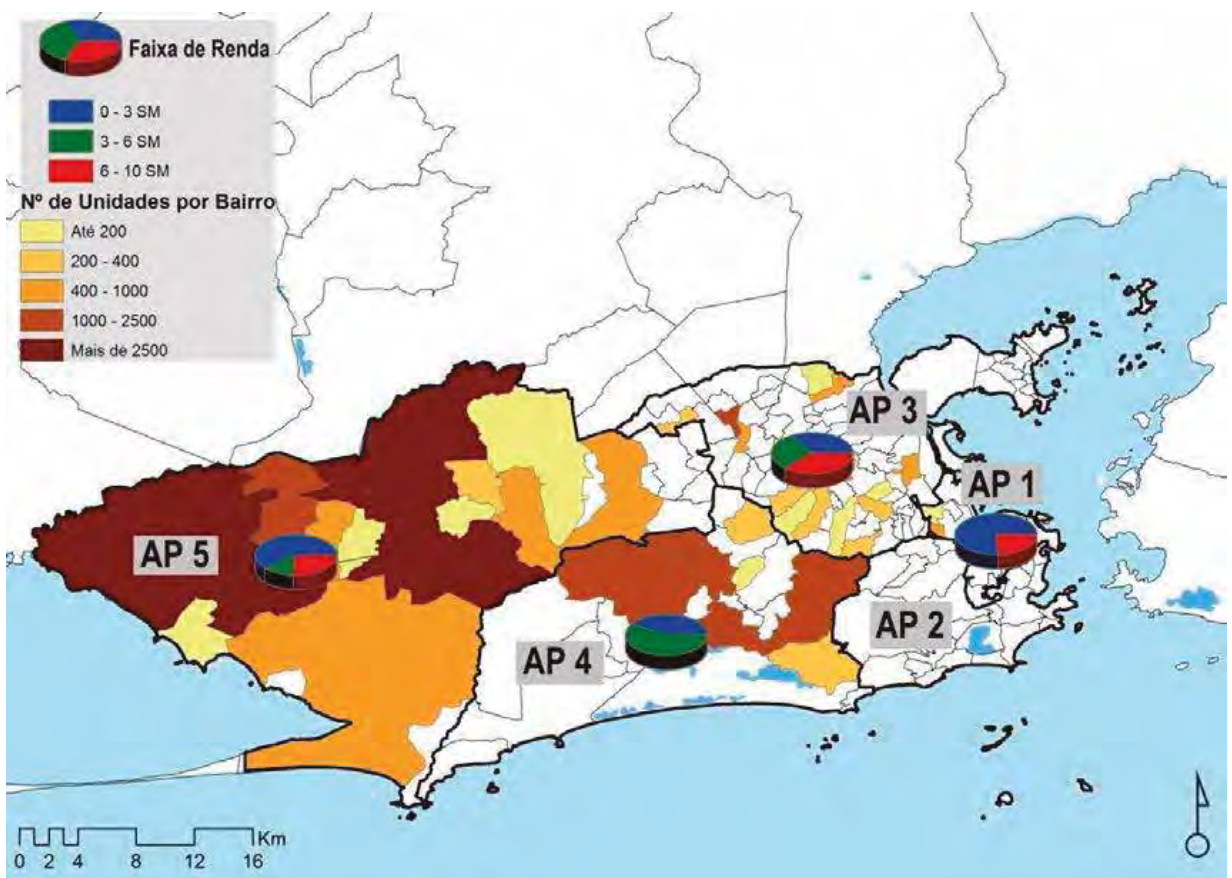

Fonte: Cardoso et al., 2013. 
Esses empreendimentos da MRV têm como atrativo o fato de propor apartamentos de dois quartos em Santa Cruz, com ou sem suíte, em condomínio fechado, com área de lazer completa, Saláo de Festas, Playground, Espaço Fitness, Quadra Gramada, Espaço Gourmet, Piscinas Adulto e Infantil, Próximo ao Supermercado Extra, Shopping Pátio Mix Itaguaí, Hospital Pedro II, Estação BRT Santa Cruz e Estação de Trem Santa Cruz, tendo como vias de acesso a Av. Brasil, a BR-101, a Av. Joáo XXIII e a rodovia Rio-Santos.

Cabe ainda registrar que, do total de construçôes do PMCMV para os anos de 2009 até 2015, 54.976 unidades foram para o Rio de Janeiro. Destas, $42.980(78,2 \%)$ foram para a AP5. É importante enfatizar que, desses totais, o bairro de Santa Cruz participa com 16.064, representando 29,2\% em relação à cidade do Rio de Janeiro e 37,4\% em relaçáo à AP5. No bairro, 12.697 unidades são destinadas à faixa de renda mais baixa. Isso significa $23,0 \%$ do total da cidade, $29,5 \%$ em relação ao total de AP5, 36,1\% em relação ao total de construçôes para a faixa 1 na cidade do Rio de Janeiro que é de 35.121 unidades.

Nota-se, portanto, a preponderância do bairro de Santa Cruz no que diz respeito à construção de unidades MCMV, sobretudo, na faixa de renda de 0 a 3 salários mínimos. Como já abordamos anteriormente, isso não significa apenas essa é uma estratégia para deslocar a populaçáo menos abastada para longe das áreas mais dinâmicas economicamente do Rio de Janeiro. Antes disso, diante da política implementada na qual o empresariado se serve de condiçóes propícias para auferir grandes ganhos em todos os nichos de mercado, a populaçáo de menor renda tornou-se mais um desses nichos. A estratégia que explica a maior concentração dos empreendimentos MCMV em Santa Cruz e em outros bairros de AP5 diz respeito ao valor máximo da unidade habitacional pré-determinado pela Caixa Econômica Federal, que era de $\mathrm{R} \$ 190.000,00$ para a Regiáo Metropolitana do Rio de Janeiro. Assim, as incorporadoras apostam no volume produzido para aumentar os ganhos em terrenos mais amplos. Sabemos que os terrenos que comportam essa prática não estáo disponíveis em todo o tecido urbano carioca. Devido à extensão de Santa Cruz e de seu histórico de ocupação, o bairro apresenta terrenos de acordo com essas especificaçóes tornando-se área propícia para esse tipo de construção em larga escala, fazendo com que o capital incorporador extraia lucros excedentes. 


\section{Consideraçóes finais}

$\mathrm{Na}$ escala intraurbana carioca, autores como Silva (1996) e Abreu (2006) analisaram o prolongamento do núcleo metropolitano pelos bairros da Barra da Tijuca e, mais tarde, do Recreio, denotando processos desencadeados nas décadas de 1980 e 1990 . A esse respeito, observamos o capital imobiliário buscando ampliar seus lucros com o empreendimento carregado de simbolismo para as classes média-alta e alta representado por condomínios fechados, afastados da Área Central adensada e com infraestrutura de lazer e segurança.

Na pesquisa, destacamos os empreendimentos imobiliários, principalmente os voltados para habitaçáo social do PMCMV no bairro de Santa Cruz. Assim, observamos em Silva (1996) o novo conceito de morar que foi lançado na década de 1980 para as camadas da população de classe média e média alta na direção da Zona Norte carioca e, principalmente para a Barra da Tijuca, com habitação em condomínios fechados com estruturas de lazer, segurança e áreas exclusivas. Trata-se da construção de um simbolismo que também passou a ser utilizado para a produção de habitação social. Entendemos assim, que o volume de empreendimentos em condomínios fechados do PMCMV promove a possibilidade de grandes ganhos pelo capital imobiliário formal por meio da produção intensiva por terreno para driblar a imposição do preço máximo do imóvel nesse tipo de produção imobiliária.

A partir do momento em que entendemos o espaço produzido de Santa Cruz, fizemos uma análise do referido recorte no contexto da cidade do Rio de Janeiro. Buscando analisar em quais aspectos o período mais recente se diferenciou dos anteriores no sentido político e econômico, de acordo com os dados disponíveis quanto a licenças concedidas, percebemos o bairro de Santa Cruz se destacando para as novas construçóes imobiliárias em relação ao restante da cidade do Rio de Janeiro. Compreendemos que os empreendimentos sociais de grande porte significam um artifício para reduzir os custos e ampliar os lucros, não simplesmente a alocação prioritária de pobres na periferia.

Como observamos, há a prática da empresa incorporadora procurar terrenos amplos e acessíveis que são mais comuns nas áreas afastadas e fracionar os lotes de terras em vários empreendimentos criando conjuntos contíguos.

Diante desse contexto, o que podemos observar em relação ao bairro de Santa Cruz é que, mesmo estando nos limites do núcleo metropolitano, devido à disponibilidade de terrenos amplos e acessíveis se apresenta como 
uma área propícia para a expansão urbana e frente de interesse para o capital imobiliário em determinado nicho, para a população de menor renda. Então, entendemos essa produçáo imobiliária no referido bairro com ênfase nos empreendimentos do PMCMV, antes de tudo, como uma forma de reprodução do capital via urbano que ocorre na direção oeste da urbe carioca se configurando como uma expansão urbana via setor imobiliário.

Devido aos conteúdos supracitados, a dinâmica imobiliária nesse recorte é diferente da expansão do período urbano-industrial e se insere no processo de metropolização porque é possível atrelá-lo à gama de empreendimentos e instalaçóes do setor produtivo e de infraestrutura, e ainda porque essa dinâmica se expressa na junção ente o setor financeiro e o imobiliário.

Devemos acrescentar que, na época do Programa, foi prevista a terceira fase do PMCMV com a meta de construir mais de três milhóes de unidades até 2018, tendo como mudanças para os novos contratos quatro faixas de renda, com a criação de mais uma para quem recebe entre $\mathrm{R} \$ 1.800,00$ e $\mathrm{R} \$$ $2.350,00$. As famílias que se encaixam nessa faixa contaráo com um subsídio de até R \$ 45 mil do Governo Federal e pagarão juros de 5,0\% ao mês. Ainda, as que ganham até $\mathrm{R} \$ 1.800,00$ terão isenção de $100,0 \%$ dos juros. E, as famílias com renda a partir de $\mathrm{R} \$ 2.350,00$ até $\mathrm{R} \$ 6.000,00$ terão aumento dos juros cobrados e pagarão percentuais entre 6,0\% e 8,0\% (Laporta, 2015).

Essa informação nos aponta a necessidade de continuar pesquisando a produção imobiliária em Santa Cruz, bem como nos demais que bairros que compóem a Zona Oeste Carioca ao norte do Maciço da Pedra Branca.

Como agenda para futuras pesquisas, podemos apontar nosso interesse pela AP5 e pelos bairros de Campo Grande e Santa Cruz. Tal fato se reafirma porque reconhecemos diferenças entre os mesmos. Nosso interesse é perceber o que os diferencia para o setor imobiliário.

A justificativa dessa indagação ocorre pela expansão imobiliária em Campo Grande para residentes de classe média destacado por Macedo (2002); Lago e Mammarella (2009); Miranda e Miller (2010); Cardoso e Lago (2015); Ribeiro e Ribeiro (2015).

Além disso, na presente pesquisa podemos observar, a partir dos dados e gráficos apresentados, a proeminência da produção imobiliária em Campo Grande se comparado aos demais bairros da AP 5. Se tomarmos a ideia de que a construção do túnel da Grota Funda e do BRT TransOeste abriu uma fronteira para a expansão imobiliária, como podemos entender a produção 
ainda tímida nos bairros de Guaratiba, Pedra de Guaratiba, Barra de Guaratiba e Sepetiba?

Podemos afirmar, segundo as ideias expressas por Barbosa (2017, pp. 432 e 434) que,

a política de produção de novas residências não foi e jamais será suficiente para resolver a questáo da moradia urbana sem a devida incorporaçáo do controle público da propriedade privada. [...] O construir e o habitar significam inventar possibilidades de existência diante da ordem urbana perversamente desigual.

Por outro lado, passados mais de quatro anos, o referido Programa encontra-se em atraso em suas operaçóes (O Globo, 2019), comprometendo os sujeitos sociais de classes de menor poder aquisitivo nas quais a moradia popular é um dos elementos mais significativos da luta social pelo espaço urbano, no qual o direito a moradia é uma das condiçóes de cidadania.

\section{Referências}

BARBOSA, Jorge Luiz. "O direito à morada". In: FERREIRA, Alvaro et al. O espaço e a metropolização: cotidiano e ação. Rio de Janeiro: Consequência Editora, 2017. pp.425-40. BRENNER, Neil. "Teses sobre a urbanização". In: emetropolis. n. 19, ano 5, dez. 2014. pp. 6-25.

CARDOSO, Adalto Lúcio. "Habitação de interesse social: política ou mercado? Reflexos sobre a construção do espaço metropolitano". XIV Encontro Nacional da Anpur. Rio de Janeiro, 2011.

e JAENISCH, Samuel Thomas. "Nova política, velhos desafios: problematizaçōes sobre a implementação do programa minha casa minha vida na Região Metropolitana do Rio de Janeiro". In: emetropolis. n. 18, ano 5, set. 2014. pp. 6-19.

e LAGO, Luciana Correa do. "Dinâmica Imobiliária: Estado e capital imobiliário". In: RIBEIRO, Luiz Cesar de Queiroz (Org.). Rio de Janeiro: transformaçôes na ordem urbana. 1. ed. Rio de Janeiro: Letra Capital; Observatório das metrópoles, 2015. pp. 320-53.

et al. Morando no limite: sobre padröes de localização e acessibilidade do Programa Minha Casa Minha Vida na Região Metropolitana do Rio de Janeiro. XV Encontro Nacional d Anpur. Rio de Janeiro, 2013.

FERREIRA, Álvaro. "Metropolização do Espaço, cotidiano e ação: uma contribuição teórico-

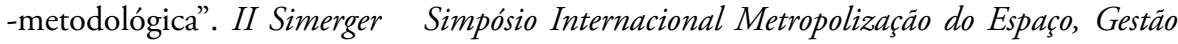
Territorial e Relaçōes Urbano-Rurais, 2014. Disponível em: http://simegerpucrio.wix.com/ simeger. Acesso em 12 mar. 2015. 
LAGO, Luciana Corrêa do e MAMARELLA, Rosetta. "Da hierarquia de classes à organização social do espaço intra-urbano: um olhar comparativo sobre grandes metrópoles brasileiras". In: $33^{\circ}$ Encontro Anual da Anpocs, Caxambu, 2009.

LAPORTA, Tais. "Entenda as novas regras do Programa Minha Casa Minha Vida”. G1 - Economia. Disponível em: http:/g1.globo.com/economia/noticia/2015/09/entenda-novas-regras-do-programa-minha-casa-minha-vida.html. Acesso em 20 nov. 2015.

LENCIONI, Sandra. "Concentração e centralização das atividades urbanas: uma perspectiva multiescalar. Reflexóes a partir do caso de São Paulo”. In: Revista de Geografía Norte Grande, n. 39. Santiago: Pontificia Universidad Católica de Chile, 2008. pp. 7-20.

. "Metropolização e a constituição da mega-região". In: II Simeger - Simpósio Internacional de Metropolização do Espaço, Gestão territorial e Relaçóes urbano-rurais. Metropolização do espaço: processos e dinâmicas. Disponível em: http://simegerpucrio.wix.com/simeger. http://simegerpucrio.wix.com/simeger. Acesso em 10 abr. 2015.

MACEDO, Andréia Pereira de. Produção Imobiliária e segregação na periferia do Rio de Janeiro: o bairro de Campo Grande. (Dissertação). Rio de Janeiro: UFRJ, 2002. 156p.

MIRANDA, Gisele dos Santos de e MÜLLER, Clarisse da Cunha. "As transformaçôes locais no "bairro" Rio da Prata, em Campo Grande , a partir da expansão de condomínios fechados: uma perspectiva multiescalar da dinâmica espacial da cidade do Rio de Janeiro - RJ". XVI Encontro Nacional de Geógrafos. Porto Alegre: Universidade Federal do Rio Grande do Sul, 2010. Disponível em file://C:/Users/Ruiz/Downloads /download(924).PDF.

PEREIRA, Paulo Cesar Xavier. "Dinâmica imobiliária e metropolização: a nova lógica do crescimento urbano em Sáo Paulo”. Scripta Nova-Revista electrónica de geografia y ciências sociales. v. IX, n. 194, ano 10, 1 ago. 2005.

. Reestruturação imobiliária e produção do espaço metropolitano. II Simerger - Simpósio Internacional Metropolização do Espaço, Gestão Territorial e Relaçôes Urbano-Rurais, 2014. Disponível em: http://simegerpucrio.wix.com/simeger. Consultado em: 12/03/2015.

O GLOBO. FGTS vai arcar com todo subsídio no Minha Casa. Economia, 12 mpv; 2019, p. 19.

RIBEIRO, Luiz Cesar Queiroz e RIBEIRO, Marcelo Gomes. "Segregação residencial: padróes e evolução”. In: RIBEIRO, Luiz Cesar de Queiroz (Org.). Rio de Janeiro: transformaçóes na ordem urbana. 1. ed. Rio de Janeiro: Letra Capital; Observatório das metrópoles, 2015. pp. 163-92.

SÁNCHEZ, Joan-Eugeni. "Barcelona: transformaciones em los sistemas productivos y expansión metropolitana”. In: MONCLÚS, Francisco Javier. La ciudad dispersa. Suburbanización y nuevas periferias. Barcelona: Centro de Cultura Contemporània de Barcelona. 1998. pp. 59-81.

SILVA, Carlos Alberto F. da. "A promoção imobiliária recente no município do Rio de Janeiro". Revista Território, n. 1, v. 1, 1996. pp. 43-57.

SMITH, Neil. "Gentrificação, a fronteira e a reestruturação do espaço urbano”. GEOUSP _ Espaço e Tempo, n. 21. São Paulo, 2007, pp. 15-31.

SILVA, Vânia Regina Jorge. O bairro de Santa Cruz-RJ no contexto da metropolização: escalas, dinâmicas e processos socioespaciais - 2005-2015. (Tese). Rio de Janeiro: UERJ. 2016. 



\section{A produção do espaço urbano e o Programa Minha Casa Minha Vida em Russas - Ceará}

Jéssica Liana de Sousal

\section{Introdução}

A pesquisa dissertativa, ${ }^{2}$ da qual deriva este artigo, teve por objeto espacial a cidade de Russas, localizada no baixo Jaguaribe, Ceará, no Nordeste brasileiro. Este núcleo urbano possui 76.884 habitantes (IBGE, 2018), podendo ser considerada uma pequena cidade. Desta forma, aqui há que se considerar a dinâmica socioespacial de um núcleo urbano no interior do território do Nordeste brasileiro com as suas particularidades e singularidades, náo se esquecendo do contexto global.

${ }^{1}$ Graduada em Licenciatura em Geografia pela Faculdade de Filosofia Dom Aureliano Matos (UECE/FAFIDAM) e mestre em Geografia pela Universidade Federal da Paraíba.

2 Este texto provém da pesquisa desenvolvida em nível de mestrado no Programa de Pós-Graduação em Geografia da Universidade Federal da Paraíba (UFPB), no período de março de 2016 a agosto de 2018, sob a orientaçáo da Profa. Dra ${ }^{a}$. Doralice Sátyro Maia e financiada pela Coordenação de Aperfeiçoamento de Pessoal de Nível Superior (CAPES). 
Mapa 1 - Localização do município de Russas - Ceará
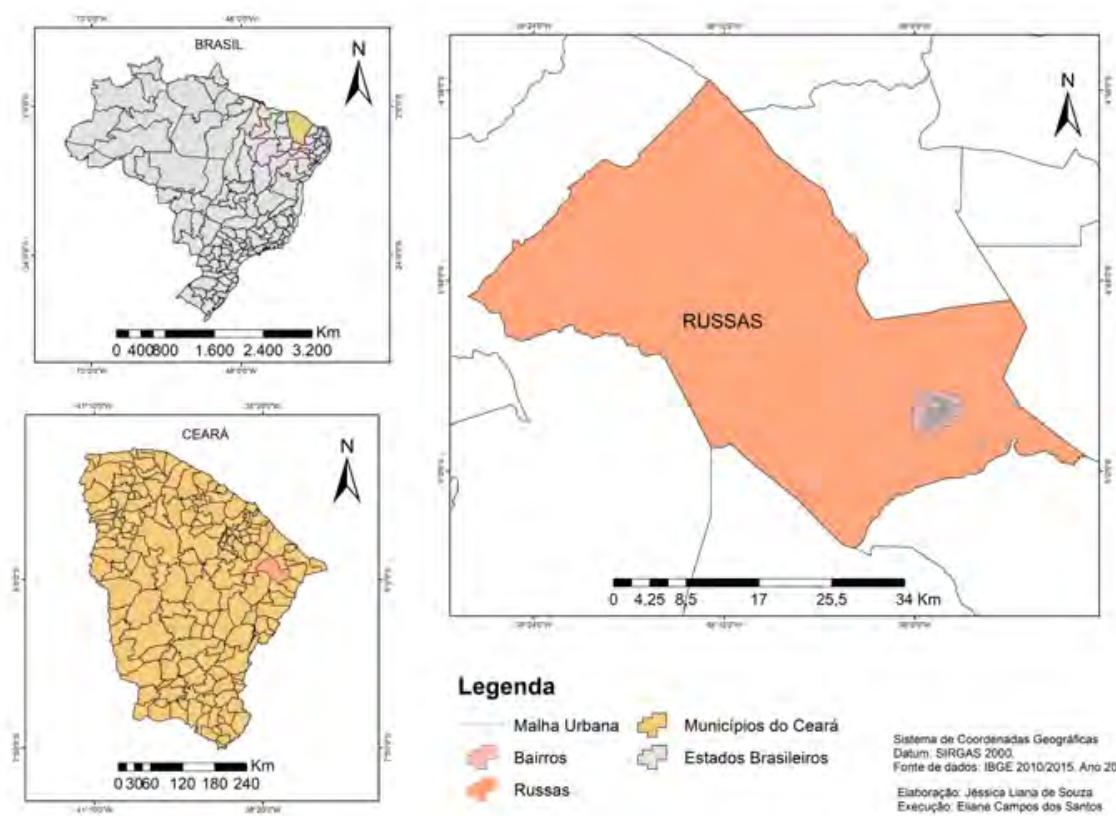

Sistema de Coordenadas Geogratcas
Datum. SRRGAS 2000 . Forte de dados: IBGE 20102015. Ano 2016

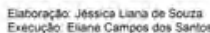

Fonte: IBGE 2010/2015. Ano 2018.

A institucionalização do Programa Minha Casa Minha Vida no Brasil no ano de 2009 dá-se como medida econômica anticíclica, ${ }^{3}$ visando também promover a produçáo de habitaçóes para a população de faixas de renda média à baixa, tem-se a expansão dos investimentos imobiliários em todo o país com associação entre capital imobiliário e capital financeiro. Observamos, neste momento, que náo somente os espaços metropolitanos, mas as cidades de menor porte, passam a atrair cada vez mais investimentos do tipo. Em 2009, a cidade de Russas passa a aderir ao PMCMV, ação motivada pelo interesse das construtoras que procuraram a Caixa Econômica Federal (CEF) para realizar os financiamentos dos primeiros empreendimentos construídos na faixa $2 \mathrm{e}$, posteriormente, na faixa 3 do respectivo programa. ${ }^{4}$

${ }^{3}$ Em decorrência da crise do capital, cujo ápice é demarcado no ano de 2008.

${ }^{4}$ Como mencionado em outros capítulos deste livro, o PMCMV nas suas três versóes sofreu alteraçóes. No início, eram três faixas; na última versão, a de 2017, foi criada uma faixa intermediária, a Faixa 1,5 . Nesta faixa, o limite de renda mensal era até $\mathrm{R} \$$ 2,6 mil; na Faixa 2, limite de renda mensal até R $\$ 4$ mil; e, na Faixa 3, limite de renda 
Tal política habitacional apresenta expressivos desdobramentos na produção e reproduçáo do espaço urbano da cidade estudada, alterando significativamente sua estrutura e dinâmica urbana. Esse processo foi constatado em várias realidades brasileiras - a exemplo de estudos como Araújo (2017) em Cajazeiras - PB ; Valença (2018) em Caruaru - PE; Volochko (2007) em Sáo Paulo - SP; e Pequeno (2013) em Fortaleza - CE, dentre outros realizados em várias cidades brasileiras. Em Russas a implantação desse programa em território nacional incrementou o mercado imobiliário que, por sua vez, promoveu diversas transformaçóes socioespaciais. Assim, pensar e compreender a atuaçáo do PMCMV em uma cidade do interior do Nordeste contribui para uma avaliaçáo mais precisa e ampliada das repercussóes desta política governamental, e melhor entendimento do processo de (re)produção e o de expansão urbana.

O principal objetivo aqui é apresentar a cidade de Russas com a finalidade de mostrar quais foram as repercussóes do Programa Minha Casa minha Vida (PMCMV) na (re)produçáo do espaço da referida cidade e os empreendimentos construídos, especialmente os inseridos na faixa 2, visto que é a faixa predominante na cidade.

Como caminho metodológico, utilizamo-nos de pesquisa bibliográfica, de pesquisa documental com a obtenção de dados estatísticos e de informaçôes e de material cartográfico. As informaçôes e os dados foram obtidos em órgãos públicos como a Prefeitura Municipal de Russas e a Secretaria de Desenvolvimento Econômico e Tributos, além dos sites de instituiçóes - Instituto Brasileiro de Geografia e Estatística (IBGE), Instituto de Pesquisa e Estratégia Econômica do Ceará (IPECE) e a Fundação João Pinheiro (FJP) - e das construtoras e incorporadoras imobiliárias. Acrescenta-se como procedimento metodológico a realização do trabalho de campo quando se concretizou o exercício da observação para melhor caracterizaçáo dos empreendimentos.

O texto está estruturado com essa introdução e dois subtítulos: "A produção do espaço em Russas e a política habitacional com o PMCMV" e "A produção da habitação pelo PMCMV". Para encerrar, teceremos algumas consideraçóes finais.

mensal até R\$ 9 mil. Nas primeiras versóes do Programa, as rendas familiares correspondentes a cada faixa era definida pelo número de salários mínimos. 


\section{A produção do espaço em Russas e a política habitacional com o PMCMV}

Segundo o último estudo elaborado pelo IBGE (2017) sobre a classificação e caracterização dos espaços rurais e urbanos do Brasil, o Município de Russas se classifica como predominantemente urbano, ${ }^{5}$ ou seja, apresenta maior concentração da população em área urbana, embora, de acordo com Elias (2013), a sua economia seja dinamizada pelo agronegócio e atividades tipicamente rurais. Além disso, a cidade de Russas apresenta uma centralidade na região na qual se insere - principalmente pelos serviços de educação e atividades comerciais -, apesar do seu relativo baixo contingente populacional, considerando o quadro demográfico urbano brasileiro.

Como se pode observar no quadro 1 , foi justamente a partir da década de 1990 que a população urbana do Município de Russas ultrapassou sua população rural. A migração campo-cidade nesse período foi estimulada pela decadência das atividades no campo, destacadamente o algodáo e a cera da carnaúba.

\begin{tabular}{l|l|l|l|l|l|l}
\multicolumn{6}{c}{ Quadro $1-$ Evolução da população Urbana e Rural em Russas até o ano de 2016} \\
\hline & 1970 & 1980 & 1991 & 2000 & 2010 & 2016 \\
\hline Total & 34.239 & 38.513 & 46.566 & 57.320 & 69.833 & 75.762 \\
\hline Urbana & 11.374 & 18.558 & 27.055 & 35.323 & 44.952 & 48.768 \\
\hline Rural & 22.865 & 19.955 & 19.511 & 21.997 & 24.881 & 26.994 \\
\hline
\end{tabular}

Fonte: Dados retirados do IPECE/2017. Elaborado pela autora.

Destarte, com base nas informaçóes disponibilizadas, podemos verificar que, no período de 1990 a 2016, houve um crescimento exponencial da população total e urbana do município. Como justificativa para tal elevação, destacamos a implantação da indústria calçadista Dakota no final dos anos 1990 e do campus da Universidade Federal do Ceará (UFC) em 2014, em função da política de interiorização e expansão das instituiçôes de ensino superior (IES). Também deve-se ressaltar os investimentos feitos e produzidos por setores e agentes do mercado imobiliário e da construçáo civil na produção habitacional a partir do PMCMV e, por fim, a presença do agronegócio

5 Contudo, de acordo com Elias (2013), trata-se de uma cidade com economia dinamizada pelo agronegócio e com atividades tipicamente rurais em partes do seu território. 
como a principal atividade econômica na região. Ou seja, esses fatores foram e são determinantes para impulsionar o crescimento demográfico e a expansão do tecido urbano de Russas.

Da década de 1990 em diante, a população rural também apresentou significativo crescimento, muito embora seja bastante inferior se comparado ao da população urbana. Certamente um dos fatores que justificaram esse aspecto foram as políticas de modernização das atividades agrícolas (agronegócio) presentes na Região do Baixo Jaguaribe. Em Russas, tais políticas se materializam por meio do Perímetro Irrigado Tabuleiro de Russas (PITR). ${ }^{6}$

Como já se sabe, o crescimento populacional é um dos fatores que condicionam o processo de urbanização. Em Russas, a partir do final dos anos de 1990, tal incremento tem se dado pela dinâmica comercial, dos serviços e das atividades agroindustriais.

As primeiras fábricas instaladas no munícipio localizaram-se no centro da cidade e foram fundamentais para a instalação de alguns serviços, como a energia elétrica e a iluminação pública. Na segunda metade do século XX, duas novas indústrias se instalaram na cidade: a RICASA (Russas Indústria Comércio e Agricultura S/A), em 1966, localizada na Avenida Dom Lino, principal via de circulação da cidade; e a RICOL (Russas Indústria e Comércio de Óleos Ltda), em 1973, que teve sua planta instalada na Rua João Marcial Pereira, atualmente bairro Nossa Senhora de Fátima.

Em 1998, como já mencionado, foi implantada a fábrica de calçados Dakota Nordeste S/A. O bairro Tabuleiro do Catavento foi escolhido pela Prefeitura Municipal como lugar para a sua localização. Inicialmente em um galpão situado no Bairro Alto São João, dois anos depois passou para seu atual endereço, na Avenida Coronel Antônio Cordeiro, às margens da BR116, no bairro Tabuleiro do Catavento. O terreno foi cedido pela Prefeitura Municipal para a relocação da Dakota-Russas e é conexo aos terrenos doados para a construção dos Conjuntos Habitacionais Padre Abdon Valério e Dr.

${ }^{6}$ Localiza-se nos municípios de Russas, Limoeiro do Norte e Morada Nova, mais precisamente no baixo Vale do Jaguaribe, na chamada zona de Transição Norte dos Tabuleiros de Russas. A área é constituída por uma faixa contínua de terras agricultáveis ao longo da margem esquerda do Rio Jaguaribe, entre a cidade de Russas e a confluência do rio Banabuiú, região nordeste do Estado do Ceará. É administrado pelo Departamento Nacional de Obras contra a Seca (DNOCS). 
José Martins Santiago. O Cartograma 1 foi construído em 2002 e o segundo, em 2003 , logo após a instalação da fábrica de calçados no seu novo endereço.

Cartograma 1 - Localização dos conjuntos Padre Abdon Valério e Dr. José Martins Santiago

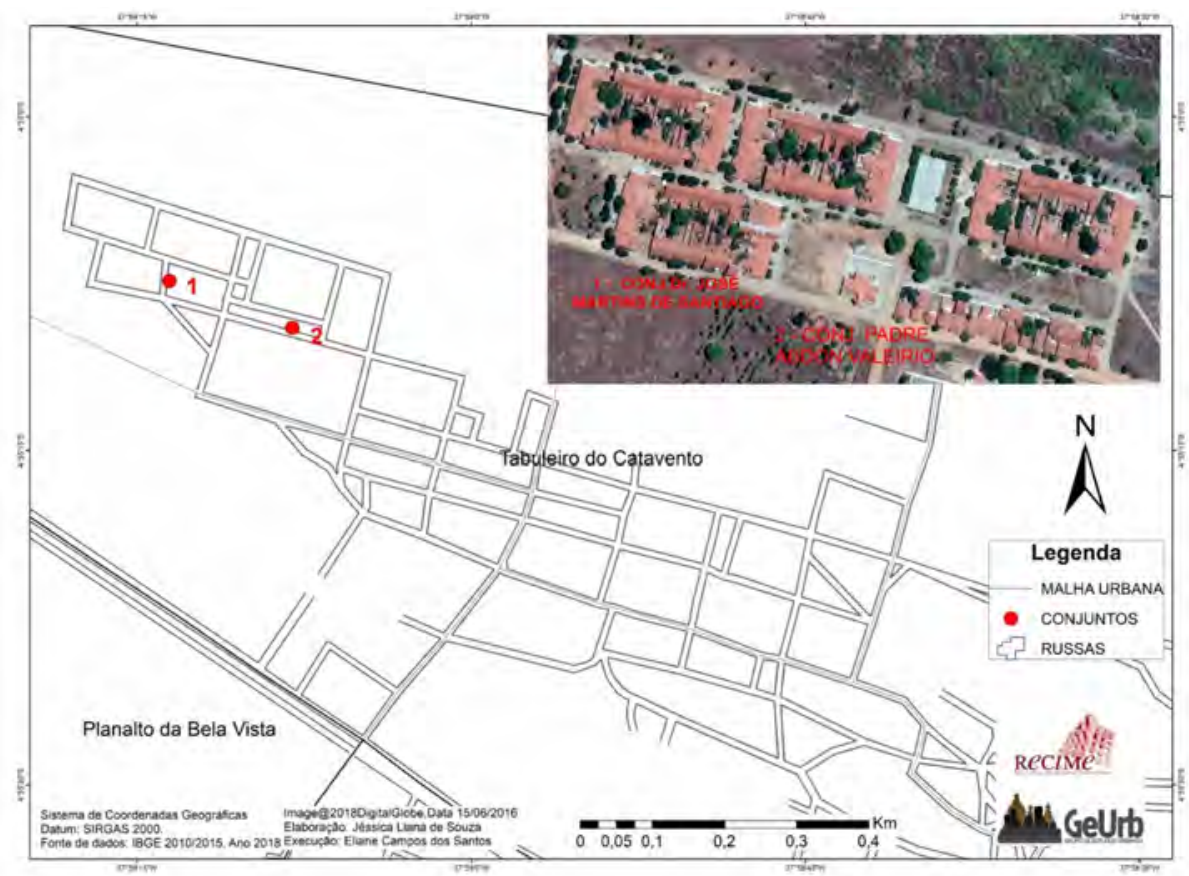

Fonte: IBGE 2010/2015. Ano 2018.

A instalação do Campus Avançado da UFC (figura 1) em Russas expressa o entendimento de como essas instituiçóes públicas repercutem na dinâmica das cidades, na ação dos agentes produtores do espaço e na reconfiguração do espaço intraurbano. Embora suas atividades só tenham iniciado em 2014, desde que a instalação do campus foi confirmada, passou-se a noticiar grandes expectativas quanto a uma nova dinâmica que ele provocaria na cidade. Para o setor imobiliário, significou um fator essencial na ampliação e reprodução habitacional na cidade, tomando-o como símbolo de futuro promissor da cidade e utilizando como marketing em seus negócios, além de gerar aumento exponencial nos preços dos terrenos e dos aluguéis, principalmente nas proximidades do campus. 
Figura 1 - Obras de expansão no campus universitário - UFC/Russas

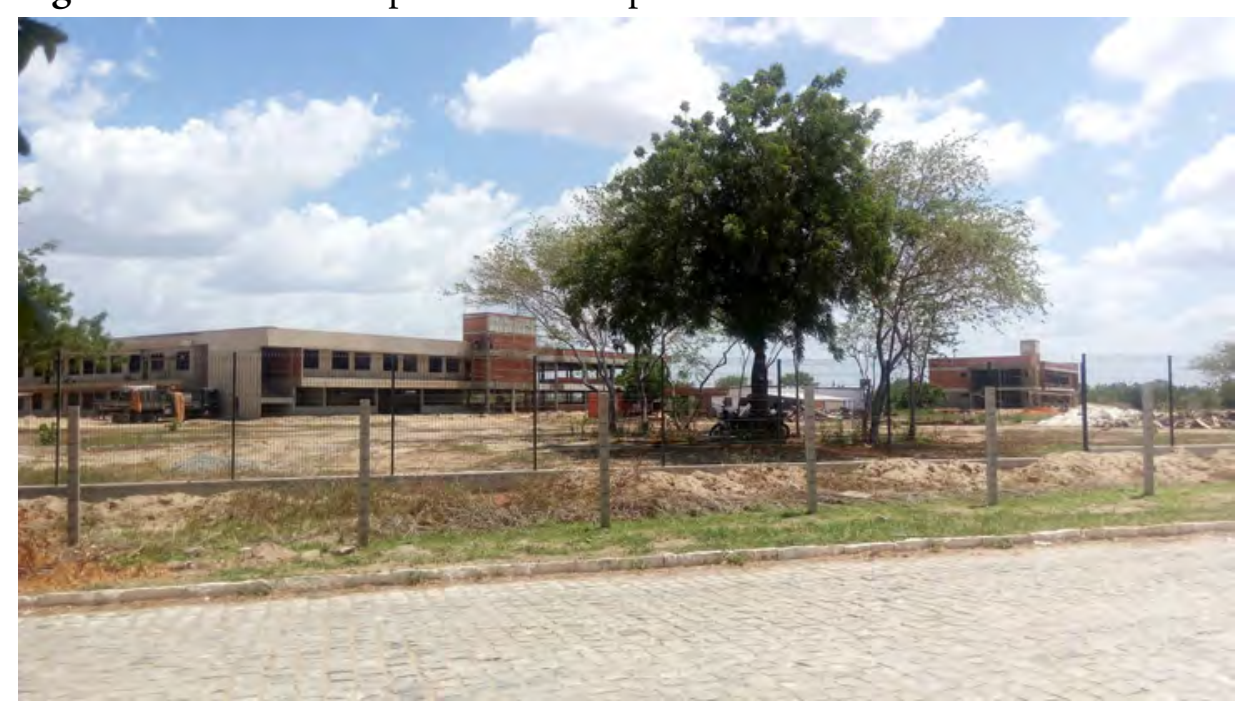

Fonte: Acervo próprio (Sousa, 2018. Trabalho de Campo - mar. 2018.

No que se refere à legislação e à política urbana, o município de Russas teve seu primeiro Plano Diretor elaborado em 1981 pelo Governo do Estado do Ceará, por meio do Departamento de Desenvolvimento Microregional. Em 2017, tiveram início as primeiras discussóes e audiências públicas para a revisão do Plano Diretor Participativo que teve vigência nos anos de 200708. Dentre as diretrizes e as estratégias delineadas na revisão do Plano Diretor Municipal, destaca-se a ampliação e melhoria do atendimento de saneamento básico, especialmente do esgotamento sanitário e a integração da política habitacional às demais políticas públicas, priorizando o atendimento das necessidades habitacionais de interesse social.

Além dessas diretrizes gerais, o plano especifica a criação de um sistema municipal de habitação de interesse social, a atualização do Plano Local de Habitação e Interesse Social (PLHIS), a elaboração de normas e instrumentos legais que favoreçam a habitação de interesse social e o apoio às açóes do PMCMV para atender as famílias de baixa renda. No entanto, é importante afirmar que, apesar do PLHIS ter realizado o levantamento das demandas habitacionais, sobretudo para habitação de interesse social (com o PMCMV em vigor), até o ano de 2017 ainda não tinha sido efetuada nenhuma ação no município referente à habitação social desde sua criação. Essa realidade só 
começou a se modificar recentemente, em 2018, com a construção (ainda em andamento) do primeiro projeto do PMCMV faixa 1.

Dessa forma, afirma-se que as primeiras práticas de intervenção estatal na produção habitacional de Russas se deram a partir da década de 1980 no contexto de criação da principal política habitacional no Brasil durante o período do Banco Nacional de Habitaçáo (BNH). Posteriormente, como exposto, a implantaçáo da indústria Dakota no final dos anos de 1990 provocou inicialmente um atrativo para a produção de habitaçóes no seu entorno, mas de forma inexpressiva.

Observamos que foi a partir do PMCMV que efetivamente a produção habitacional em Russas se consolidou e o mercado imobiliário local se expandiu. Ademais, foi mediante o PMCMV, em 2009, que o Estado passou a atuar de forma incisiva nesta cidade, onde se percebe facilmente a elevada produção de empreendimentos em comparação aos anos anteriores.

Pelo exposto, podemos perceber uma íntima relação entre as açóes do Estado e as estratégias do setor imobiliário, principalmente para fins especulativos e com elevada extração de renda. $\mathrm{O}$ empreendimento mais representativo dessa expansão do mercado imobiliário sob a instalação do Campus Universitário na cidade é o Condomínio Residencial Santiago I e II, construídos pelo PMCMV (faixa 3) localizados na maior área de crescimento e valorização imobiliária da cidade. Entendemos que se confirma, de fato, a tese de que cada vez mais a expansão e interiorizaçáo das IES repercutem concretamente na produção de novas relaçóes e dinâmicas nos espaços urbanos, dado o papel desempenhado pelas universidades como agentes da reestruturação urbana. Tal afirmativa corrobora o que escreve Henrique (2015):

A compreensão do papel das universidades como agentes da (re)estruturação urbana e das cidades torna-se importante, tanto em razão do volume de recursos financeiros movimentados quanto pela modificação de dinâmicas intraurbanas (moradia, circulaçáo, usos, etc.) e do cotidiano dos moradores. (p. 1).

Reafirma-se que, nos últimos dez anos, o setor imobiliário se expandiu de maneira significativa em Russas, inicialmente por meio de loteamentos regularizados e pelo crescimento do mercado de venda e locaçáo de prédios comerciais e residenciais, principalmente no centro da cidade. No entanto, de forma mais expressiva, há pelo menos cinco anos esse setor passa por uma 
reestruturação mais significativa e dinâmica que a demonstrada anteriormente. Compreendemos que esse novo "período" do mercado imobiliário em Russas pode ser caracterizado pelos seguintes elementos: lançamentos de loteamentos planejados e fechados, dotados de infraestruturas, como pavimentação, água e energia elétrica; abertura de novos escritórios imobiliários; surgimento de empresas especializadas na construção civil; crescimento da comercialização de novas residências e apartamentos; e construção de condomínios verticais e horizontais fechados. Destaca-se que os três últimos elementos demonstram ser dinamizados pelo crescimento e maior acesso aos financiamentos e subsídios habitacionais ofertados pelo PMCMV.

Dessa forma, podemos afirmar que a expansão urbana se dá reproduzindo o "formato" centro - periferia decorrente da conjunção de processos: do contínuo crescimento populacional, modernização das indústrias ceramistas, ações do Estado por meio de obras de infraestrutura, construçáo de conjuntos habitacionais e instalação de órgãos públicos e, mais recentemente, da chegada da indústria calçadista e, ainda, a atuação dos proprietários fundiários e dos promotores imobiliários a partir do PMCMV.

Contudo, para além desses processos que induzem a expansáo urbana, vale destacar a ausência de uma política urbana municipal eficaz, inclusive no que diz respeito à atualização da legislação urbana como também a demanda por habitaçôes pela população de baixa renda. Esta última é uma das problemáticas que vem se agravando ao longo do tempo, recebendo intervençóes pontuais em alguns períodos, contudo, permanecendo sem a resolução definitiva. Assim, indica-se uma suposta contradição: o crescimento da indústria da construção civil, a edificação de um número expressivo de habitações no âmbito da Política Nacional do Programa Minha Casa Minha Vida e o crescimento da demanda habitacional. Tal incoerência já foi constatada por vários pesquisadores que vêm se dedicando à análise do PMCMV, cujas críticas são expressas especialmente no que se refere à linha de atendimento ao mercado imobiliário, mas que também se revelam na cidade de Russas, mesmo esta náo se configurando um centro urbano de maior centralidade na rede urbana ou de uma dinâmica urbana táo expressiva como as cidades que se situam em níveis superiores da hierarquia urbana. Tal fato reforça a importância da análise realizada e ora apresentada.

Torna-se perceptível um crescimento da malha urbana e a formação de uma periferia na cidade de Russas são processos decorrentes do contínuo 
crescimento populacional, da modernização das indústrias ceramistas, das ações do Estado por meio de obras de infraestrutura, construção de conjuntos habitacionais e instalação de órgãos públicos, e, mais recentemente, da chegada da indústria calçadista e da atuação dos proprietários fundiários e dos promotores imobiliários a partir do PMCMV.

\section{O Programa Minha Casa Minha Vida em Russas}

Para melhor entendermos as repercussóes do PMCMV em Russas vale trazer algumas informaçóes sobre o déficit habitacional. Segundo os dados elaborados pela Fundação João Pinheiro a partir do Censo Demográfico de 2010, o DH total de Russas era de 1.834 unidades habitacionais. A tabela 1 mostra os dados referentes ao $\mathrm{DH}$ em Russas decomposto em variáveis pelo tipo de habitação.

Tabela 1 - Déficit habitacional total e relativo, por componente, no Estado do Ceará e no Município de Russas - 2010

\begin{tabular}{c|c|c|c|c|c|c|c|c|c|c}
\hline & \multicolumn{2}{|c|}{$\begin{array}{c}\text { Déficit Habita- } \\
\text { cional }\end{array}$} & \multicolumn{2}{c|}{$\begin{array}{c}\text { Domicílios } \\
\text { precários }\end{array}$} & \multicolumn{2}{c|}{$\begin{array}{c}\text { Coabitaçáo } \\
\text { familiar }\end{array}$} & \multicolumn{2}{c|}{$\begin{array}{c}\text { Ônus excessivo } \\
\text { com aluguel }\end{array}$} & \multicolumn{2}{c}{$\begin{array}{c}\text { Adensamento } \\
\text { em domicílio } \\
\text { alugado }\end{array}$} \\
\cline { 2 - 11 } & Total & Relativo & Total & Relativo & Total & Relativo & Total & Relativo & Total & Relativo \\
\hline Ceará & 276.284 & 11,66 & 46.028 & 1.94 & 125.745 & 5.31 & 79.478 & 3.35 & 25.033 & 1.06 \\
\hline Russas & 1.834 & 8,99 & 269 & 1,32 & 1007 & 5,94 & 471 & 2.30 & 87 & 0,43 \\
\hline
\end{tabular}

Fonte: Fundação João Pinheiro (2010). Elaboração própria.

Pelos números apresentados na tabela 1 , verifica-se que no estado do Ceará e no município de Russas o maior responsável pelo déficit habitacional é a população em condição de coabitação familiar, e a segunda condição é o número de habitantes que apresentam ônus excessivo com aluguel. Importante mencionar que o número total de domicílios particulares permanentes em Russas é de 20.411. A Fundação João Pinheiro (2010) mostra que "embora o ônus com aluguel seja um componente mais expressivo nas áreas metropolitanas (35,8\% do déficit), é forte também nas áreas não metropolitanas $(25,6 \%)$ ". No caso de Russas, percebemos que isso ocorre porque o aluguel tem sido a solução mais frequente para aqueles que não possuem casa própria. A grande parte do déficit urbano se concentra na população cuja renda 
é de até três salários mínimos e que, portanto, tem dificuldades em arcar com o pagamento de aluguéis. Assim, o incremento de unidades habitacionais financiadas pelo PMCMV - como são todos até o ano de 2017 - nas faixas 2 e 3 não atende ao déficit habitacional.

Tal fato merece ainda ser melhor analisado, uma vez que, no ano de 2019, o PMCMV sofreu cortes de orçamento e os ajustes feitos dirimem mais o fomento e os subsídios para os financiamentos para a população mais pobre, a saber, a faixa 1 em que o déficit habitacional é preponderante. Ou seja, a redução de investimentos nesta faixa impacta severamente a aquisição de moradias para a classe trabalhadora. Reafirma-se que até 2017 não existiam empreendimentos direcionados à faixa 1 em Russas. Concomitantemente, os recursos aplicados nas faixas correspondentes a atuação do mercado imobiliário (faixas 2 e 3) foram mantidas e até expandidas. Tal acréscimo deve-se ao expressivo aumento de investimentos para o setor privado na produção habitacional e às alteraçóes nos valores das faixas de renda e do teto dos preços de imóveis requeridas por setores do mercado imobiliário. No quadro 2 temos a distribuição e a quantidade de empreendimentos produzidos em Russas no período de 2009 a 2018.

Quadro 2 - Empreendimentos do PMCMV em Russas no período de 2009 a 2018

\begin{tabular}{l|l|l|l|c|c|c}
\hline Faixa & Modalidade & $\begin{array}{l}\text { Empreendi- } \\
\text { mento }\end{array}$ & Construtora & $\begin{array}{c}\text { No UH } \\
\text { Contratadas }\end{array}$ & $\begin{array}{c}\text { No UH } \\
\text { Concluídas }\end{array}$ & $\begin{array}{c}\text { No UH } \\
\text { Entregues }\end{array}$ \\
\hline $\mathbf{1}$ & Empresas & $\begin{array}{l}\text { Residencial } \\
\text { Tabuleiro do } \\
\text { Catavento }\end{array}$ & $\begin{array}{l}\text { CR DUAR- } \\
\text { TE ENGEN }\end{array}$ & 117 & - & - \\
\hline $\mathbf{2}$ & CCFGTS & & & 1.060 & 1.060 & 910 \\
\hline $\mathbf{3}$ & CCFGTS & & & 56 & 56 & 46 \\
\hline Total & & & & 1.233 & 1.116 & 956 \\
\hline
\end{tabular}

Fonte: Dados coletados no Ministério das Cidades (2018). Posição: 30 jun. 2018. Elaboração própria.

Sabe-se que os empreendimentos comercializados pelo programa podem ser unifamiliares e multifamiliares, estando ou não inseridos em condomínios ou organizados em agrupamentos de casas. Para cada uma dessas tipologias existem requisitos que devem ser cumpridos para que o projeto seja aprovado pela CEF para assim poder ser comercializado por meio do programa. 
Em Russas, ocorre a comercialização das duas tipologias: unifamiliares e multifamiliares. No entanto, há a predominância dos conjuntos de casas construídas de forma geminada e de arquitetura semelhante. Essa forma de construção é um mecanismo utilizado pelas empresas a fim de economizarem espaço, materiais, tempo de construção e trabalho, garantindo maior rentabilidade na produção desses empreendimentos.

Os primeiros contratos realizados pelo PMCMV em Russas foram efetivados ainda em 2009, construídos pela empresa ESBRA Construçáo Civil Ltda., que possui sede em Fortaleza. (quadro 2). O empreendimento não possui nome e constitui-se de blocos de dois pavimentos de apartamentos, computando um total de oito unidades domiciliares. Os apartamentos são organizados por blocos, cada um composto por oito apartamentos. Cada apartamento possui dois quartos, um banheiro, sala e cozinha americana. Eles são distribuídos em quatro tipos de plantas, com área total variando entre 47,69 $\mathrm{m}^{2}$ e 49,73 $\mathrm{m}^{2}$. (Figuras 2 e 3).

A partir de 2010, ou seja, após a institucionalização do PMCV, iniciou-se a construção de unidades familiares agrupadas, formando os primeiros conjuntos de casas construídas na cidade através do referido programa. Estas foram edificadas nos bairros Tabuleiro do Catavento, Vila Ramalho e Vila Matoso. Segundo as definiçóes do IBGE, a localização desse empreendimento se encontra fora dos limites desse bairro e até mesmo do perímetro urbano. (Figura 4). 
Figuras 2 e 3 - Primeiro empreendimento do PMCMV em Russas - Faixa 2
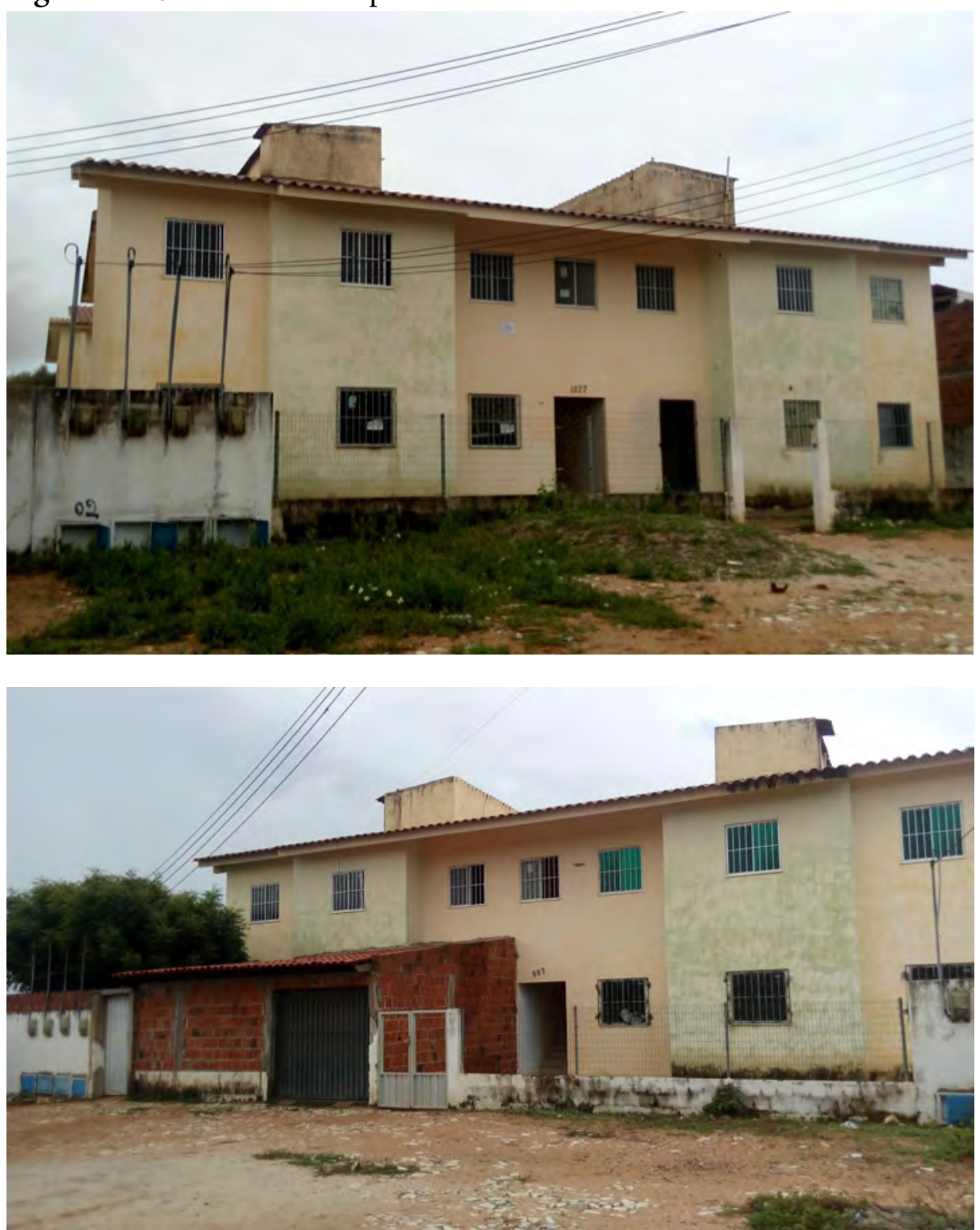

Foto: Sousa, 2018. Trabalho de Campo - mar. 2018.

Acrescenta-se que as primeiras empresas de construção civil surgem na cidade após 2009. Estas empresas são de capital local. Elas se consolidaram no mercado local e podem ser vistas como "especializadas" na construçáo de 
casas para serem vendidas por meio do PMCMV. Em entrevista com o proprietário da MS Construções e Incorporações, ele afirma que, “esse programa tem fortificado o mercado imobiliário local, mesmo nesse período de crise política e econômica e os investimentos para as faixas 2 e 3 foram mantidas, eles só reduziram a faixa 1". Aqui é possível observar os interesses reais do setor imobiliário e que foram os mais beneficiados por esse programa: as faixas de renda intermediária e elevada mantiveram os investimentos, enquanto a faixa destinada para habitação social (faixa 1), em que os subsídios são fundamentais para a compra e acesso à moradia, teve cortes significativos no orçamento. Tal fato revela o perfil mercadológico do programa, já que Russas, até meados de 2017, não possuía empreendimentos destinados à faixa 1 .

Em 2009 começaram a surgir as primeiras empresas locais do ramo da construção civil se tornando, "especializadas" na construção de empreendimentos com as características determinadas pelo PMCMV. Entre elas se destacam a MS Construçóes e incorporaçóes Ltda. e a S. Gurgel Empreendimentos Imobiliários Ltda. Atualmente essas duas empresas praticamente dominam o mercado de construção desses empreendimentos e administram também as vendas desses imóveis. Sendo que a MS Construçóes e Incorporaçóes é a que possui maior capital da cidade.

Figura 4 - Casas na Vila Ramalho - Faixa 2

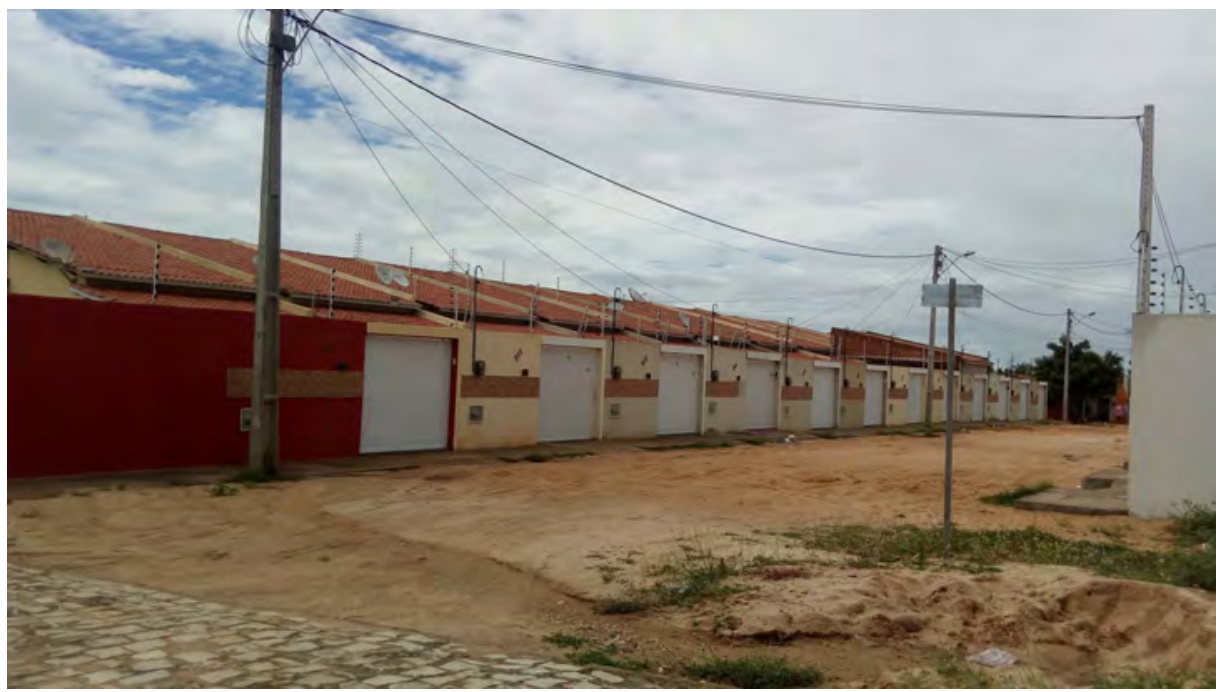

Foto: Sousa, 2018. Trabalho de Campo. 
Um dos exemplos de empreendimentos de domicílios unifamiliares da faixa 2 é o Loteamento Boa Vista, inaugurado em 2012 e construído pela empresa Tec Urbanismo. Ele teve início com a venda de lotes e, mais recentemente, em sua segunda etapa de expansão, a comercialização foi de casas já construídas. Este empreendimento localiza-se em área mais próxima ao centro da cidade e com a infraestrutura e vias de acesso. Além disso, a sua localização em frente à Lagoa da Caiçara é considerada pelo mercado imobiliário como a melhor área de localizaçáo e a de maior expansáo, juntamente com o bairro da Cidade Universitária. Por conseguinte, os preços dos imóveis são superiores a outros com tipologia similar, mas com localização menos atrativa. Os lotes residenciais possuem área média de $150 \mathrm{~m}^{2}$ e os comerciais de $300 \mathrm{~m}^{2}$. As casas são compostas por sala, dois quartos, dois banheiros, cozinha americana, garagem, quintal e churrasqueira e possuem $70 \mathrm{~m}^{2}$ de área construída . Os valores dessas casas são de $\mathrm{R} \$ 130.000 .00$, o valor máximo de acordo com o teto estabelecido pelo PMCMV em Russas com as modificações em 2017 (figura 5):

Figura 5 - Casas para vendas no Loteamento Bela Vista

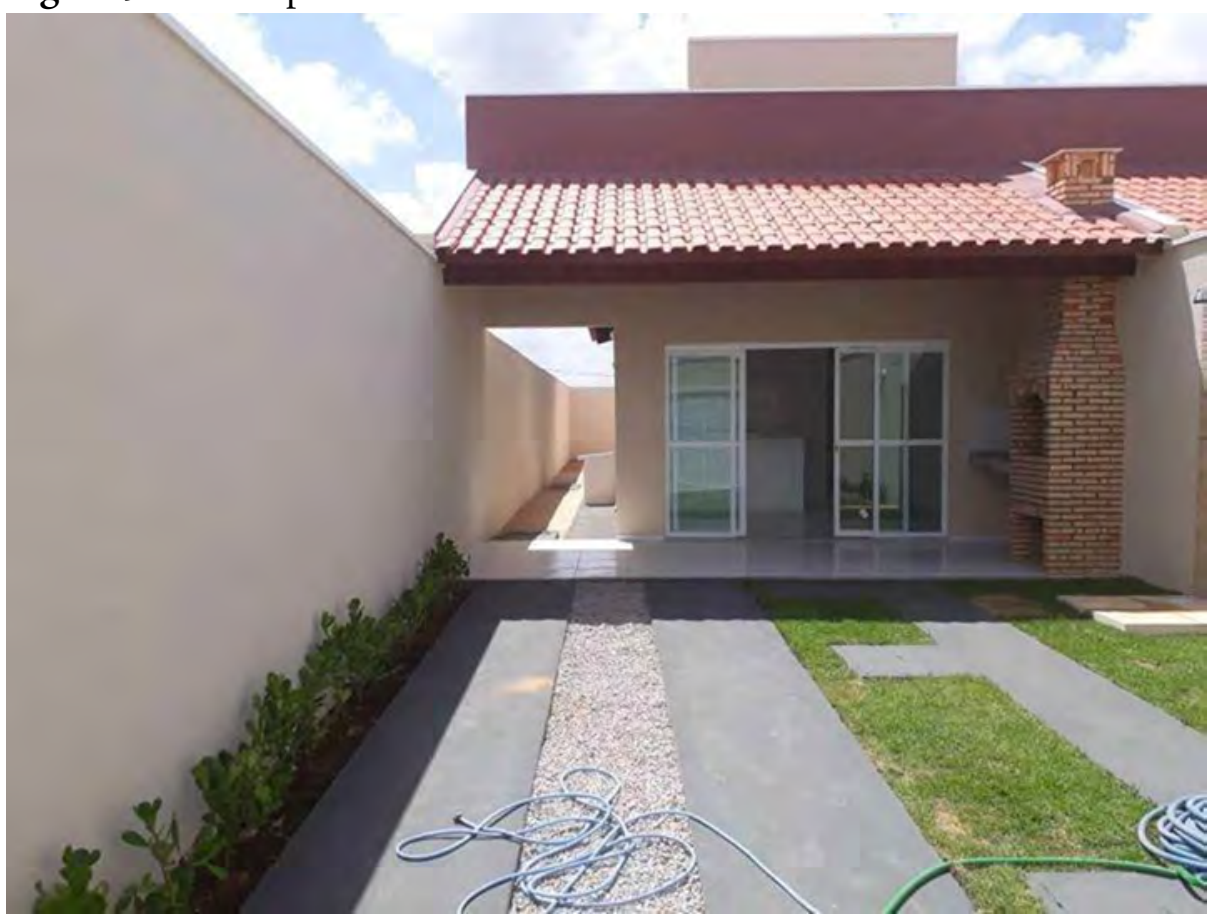

Foto: Sousa, 2018. Trabalho de Campo. 
As primeiras vendas das unidades do Condomínio Residencial Santiago I e II foram realizadas ainda na fase "da planta". Dentre os empreendimentos que a MS Construçôes e Incorporaçôes constrói na cidade tem-se o Residencial Unifamiliar. Este possui $83,89 \mathrm{~m}^{2}$ de área total construída em um terreno com área total de $180,55 \mathrm{~m}^{2}$. As casas possuem cozinha, varanda, sala de estar, dois quartos e uma suíte. Eles se inserem na faixa 2 do programa.

Dentre as empresas e escritórios de construção civil instaladas em Russas, os cita-se o escritório denominado Odilo Almeida Arquitetura e Urbanismo. É um escritório especializado na elaboração de projetos residenciais e de execução de obras, com sede em Fortaleza e foi fundado no ano de 1994. Os principais campos de atuação do escritório são: arquitetura residencial, comercial e de serviços; projetos urbanísticos; arquitetura de interiores; elaboração e revisão de planos diretores, arquitetura paisagística, incorporação e venda de imóveis e inspeção predial. Nos empreendimentos construídos em Russas, o arquiteto responsável é originário da cidade e possui vários projetos não apenas em Russas, mas em outras regiôes do estado. $\mathrm{O}$ empreendimento localiza-se no bairro Tabuleiro do Catavento e é composto por casas com sala, cozinha americana, quintal, dois quartos, banheiro, garagem e varanda (figuras 6 e 7 ).

Figuras 6 e 7 - Empreendimento no Bairro Tabuleiro do Catavento

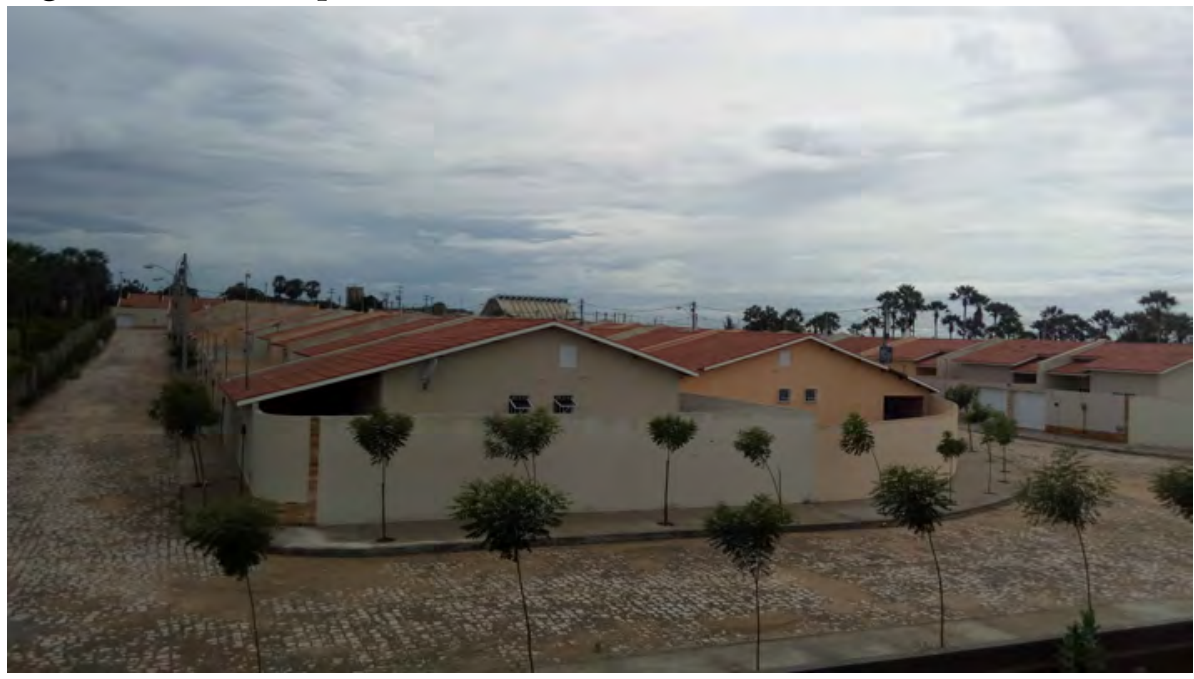




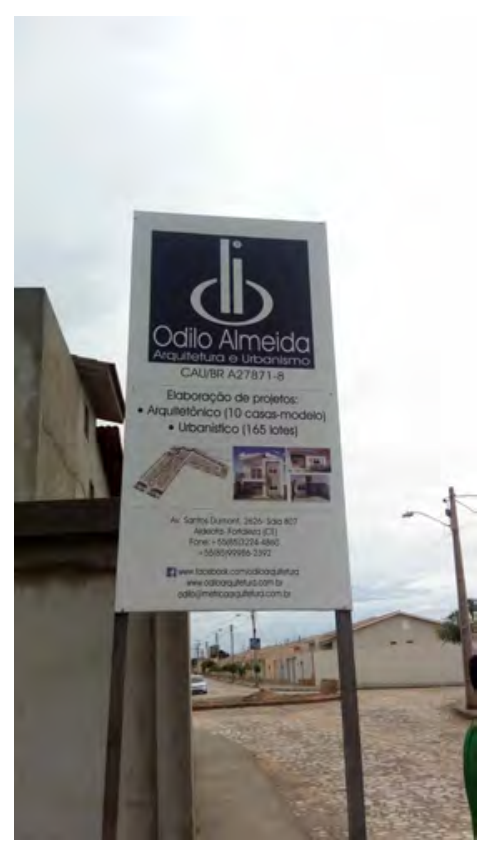

Foto: Sousa, 2018. Trabalho de Campo.

Ao compararmos as primeiras unidades construídas no âmbito do PMCMV com os empreendimentos mais recentes, observamos que houve uma mudança significativa na estrutura, no tamanho, na aparência, na localização e nos valores destes imóveis. Na observação in loco foi possível apreender que existem perceptíveis diferenciaçôes na estrutura dos imóveis do programa. Inicialmente, tais diferenças se dão pelas alteraçóes sofridas pelo programa nas suas diferentes versôes. Na versão de 2017, algumas normativas foram acrescidas, destacando-se a obrigatoriedade de todas as unidades terem aquecimento de água por energia solar e serem adequadas à acessibilidade (rampas, banheiros adaptados etc.). Além disso, vale acrescentar que muito embora se trate de um programa nacional e que as normativas sejam válidas para todo o território, o que implica em vários problemas pela diversidade - regional, climática, costumes etc. -, além das diferenças das faixas por renda familiar, constata-se diferenças nos padróes de estrutura construtiva. Em Russas, isso é evidente. Significa afirmar que os conjuntos nas faixas $2 \mathrm{e}$ 3 existentes na cidade apresentam diferenciaçôes nítidas comparadas com os 
empreendimentos das mesmas tipologias construídos nas cidades de Fortaleza ou São Paulo, por exemplo.

Apesar dessa diferença, alguns elementos vêm se mantendo ao longo dos anos e são comuns a outras cidades e regiōes. É o caso, por exemplo, dos empreendimentos construídos em áreas periféricas não dotadas de infraestrutura e de serviços públicos. Essas áreas são escolhidas pelos construtores por terem um menor preço no mercado imobiliário, potencializando as possibilidades de maior rentabilidade.

De maneira geral, observamos que a maioria dos empreendimentos está localizada em áreas e bairros periféricos e que nenhuma unidade foi construída nas áreas contíguas ao centro da cidade, já que se trata de um núcleo cuja dinâmica urbana é centralizada e a malha não é por demais extensa, além de apresentar terrenos ociosos. O mapa 2 mostra a espacialização dos empreendimentos existentes na cidade de Russas e as faixas de renda em que são classificadas. Com base neste mapa, verificamos que a maior parte dos empreendimentos se estende para as áreas periféricas da cidade. De acordo com a espacialização indicada, é possível observar que os empreendimentos estáo distribuídos entre seis dos 13 bairros que compóem o espaço urbano de Russas, e um localizado fora dos limites do perímetro urbano, o primeiro construído por meio do PMCMV na cidade, ainda em 2009. A maior concentração desses empreendimentos ocorre no bairro Tabuleiro do Catavento, onde há a predominância de conjuntos formados por dezenas de casas e que vêm modificando a paisagem e a dinâmica do referido bairro. 
Mapa 2 - Localização dos empreendimentos do PMCMV em Russas

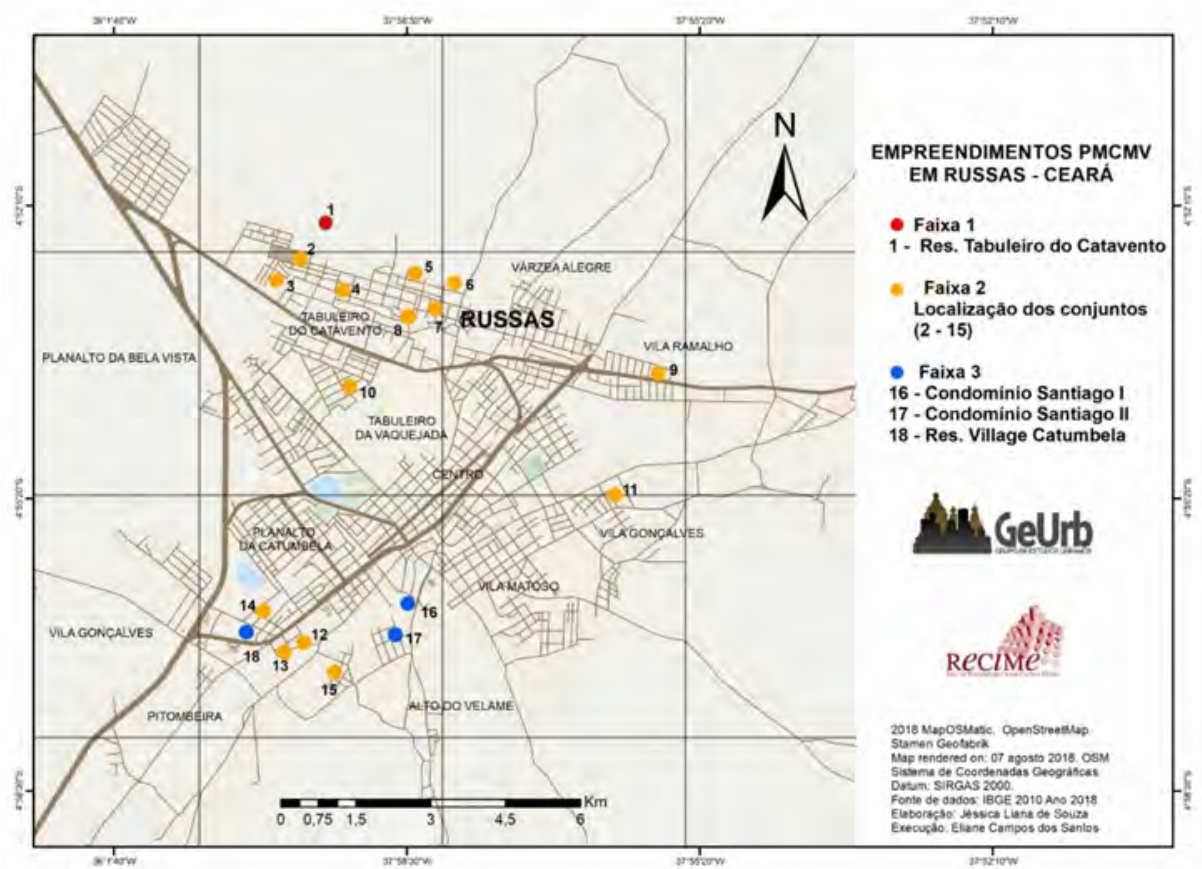

Fonte: IBGE 2010. Ano 2018.

Os bairros Nossa Senhora de Fátima e Planalto da Catumbela também apresentam quantidade significativa de empreendimentos. O bairro Nossa Senhora de Fátima, que desde 2010 vem recebendo a construção dessas unidades, possui uma quantidade de UHs bem superior ao bairro Planalto da Catumbela, onde a construção dessas unidades é mais recente.

Podemos observar que os empreendimentos estão, em sua maioria, localizados em áreas adjacentes ao centro da cidade, intermediadas por grandes vazios, e de menor ocupação. Dessa forma, o PMCMV, ao passo que potencializou e expandiu o mercado imobiliário na cidade, ativa o processo de segregação em Russas. Nesse sentido, essa distribuição locacional é uma estratégia do mercado imobiliário para garantir maior rentabilidade dos seus negócios.

Recentemente usando o PMCMV como objeto de análise, Cardoso e Aragão (2013) explicam essa estratégia afirmando que os lucros adquiridos pelas construtoras não se limitam aos conseguidos por meio do processo de construção, mas também inclui o lucro que pode ser retirado no processo de mercantilização das unidades. 
Essa estratégia de "maximização de lucros" está integralmente ligada à transformação do solo, uma vez que os preços são pensados pelas características definidas pelo setor imobiliário como atributos de valorização, que variam da localização dos empreendimentos até a estrutura oferecida em seu entorno. Tal prática é também observada em Russas. Os empreendimentos do PMCMV estão localizados em áreas periféricas e com distância considerável do centro da cidade, onde se concentra a grande maioria dos serviços públicos e privados como hospitais, escolas, e empreendimentos comerciais.

O bairro Tabuleiro do Catavento é o maior expoente dessa estratégia. Este bairro tem sido historicamente um dos vetores de direcionamento das famílias de baixo poder aquisitivo, inclusive por meio da construção de dois conjuntos habitacionais, e sempre apresentou uma carência de infraestrutura e de serviços urbanos, o que acarreta numa desvalorização dos terrenos localizados em seus limites.

Apesar de não ter sido contemplado por projetos de infraestrutura que atendam às demandas e que estimulem a sua ocupação, nesse bairro estão sendo construídos empreendimentos financiados pelo PMCMV desde 2010 e hoje é o que abraça a maior quantidade de unidades comercializadas pelo programa em Russas.

No bairro Nossa Senhora de Fátima também estão sendo construídas muitas unidades por meio do PMCMV, localizadas em terrenos não loteados, adquiridos exclusivamente para a construção dos empreendimentos e que também não oferecem pavimentação.

Já os empreendimentos situados no bairro Planalto da Catumbela encontram-se próximos a áreas já consolidadas, bastante habitadas e dotadas de infraestrutura como pavimentação e saneamento básico. A maioria das unidades construídas no bairro Ipiranga também possuem vias pavimentadas.

As mudanças na variedade, padrão e qualidade dos empreendimentos lançados recentemente em Russas resultam da modernização e especialização do setor imobiliário na cidade e que, no nosso entender, sofre influência dos incentivos oportunizados pelo PMCMV. Afirmamos tal compreensão com base nas mudanças que ocorreram neste setor a partir da intervençáo gerada pelo programa, principalmente depois de 2010, e que são perceptíveis na cidade.

Além disso, é possível dizer que foi a partir dos incentivos do PMCMV que a construção empresarial de moradias começou a ocorrer de 
forma expressiva na cidade. Ou seja, a institucionalização deste programa na cidade de Russas possibilitou o surgimento de empresas e construtoras vinculadas ao mercado imobiliário pelos próprios empresários que residem e moram em Russas, bem como de outras cidades, em sua maioria de Fortaleza e, como já foi mencionado, de Minas Gerais (LCM Construção), responsável pelos empreendimentos da faixa 1 que seráo construídos em etapas posteriores.

Pela espacialização dos empreendimentos mostrada anteriormente no mapa 2 e apresentada no próprio texto, podemos observar que bairros periféricos, antes habitados apenas por famílias de baixa renda estâo recebendo empreendimentos do PMCMV. Como vimos, essa localização faz parte da estratégia de maximização dos lucros das construtoras. No entanto, é preciso destacar que esses empreendimentos tendem a gerar mudanças nas dinâmicas socioespaciais dos bairros onde se localizam. As novas famílias que passam a residir nesses bairros geram de imediato um novo fluxo de pessoas e veículos por suas vias e tendem, com o passar dos anos, a atrair a instalaçáo de novos comércios e serviços, como mercadinhos e lanchonetes.

A construçáo de um conjunto residencial e a consecutiva dotaçáo de infraestrutura valorizam os terrenos no entorno, estimulando os proprietários a uma espera especulativa. Produzem-se novos vazios urbanos, ao passo que a população que precisa de habitação, mas não pode pagar pelo seu preço nas áreas mais equipadas, precisa deslocar-se para mais longe, ampliando o processo de periferização.

Neste sentido, podemos observar que o PMCMV tem impulsionado o surgimento e a atuação de novas empresas no ramo da construção civil em Russas e estas, por meio da compra de terras menos valorizadas, têm gerado a ocupação e a diversificação da habitação de áreas periféricas da cidade, principalmente nos bairros Tabuleiro do Catavento e Nossa Senhora de Fátima.

Além dessas consideraçóes, a oferta de outros serviços públicos como o saneamento básico, a iluminação pública e a coleta de lixo nessas unidades, ou seja, a dotaçáo dos equipamentos de consumo coletivo pelo Estado, bem como a localizaçáo dos empreendimentos em relaçáo aos espaços de lazer, entretenimento, alimentação e comércio, por exemplo, também precisam ser analisadas para termos uma melhor leitura sobre as condiçóes de inserção urbana desses empreendimentos. 


\section{Consideraçóes finais}

Discutimos alguns dos processos socioespaciais decorrentes da implementação do PMCMV na produção do espaço urbano e na expansão da cidade supracitada. Os números da produção habitacional por meio do PMCMV em Russas apresentados são significativos, principalmente por se tratar de uma pequena cidade que não apresentava um histórico de construção de moradias na forma empresarial. Este, certamente, foi o ponto de partida para encontrarmos os efeitos do programa em Russas. Compreendemos que a atuação do setor empresarial no ramo da construção civil em Russas se desenvolve a partir do crescimento do acesso ao crédito imobiliário oferecido pelo PMCMV. A atuação do Estado por meio deste programa tem fomentado o desenvolvimento do setor imobiliário.

Como se pôde observar por meio da espacialização e das demais características dos empreendimentos comercializados em Russas, o setor empresarial tem optado por construir a maioria dos empreendimentos em áreas mais afastadas do centro da cidade, onde as terras possuem preços mais baixos e garantem um lucro maior no final do processo construtivo. Dentro desta estratégia podemos destacar principalmente os Bairros Tabuleiro do Catavento e Nossa Senhora de Fátima.

Além disso, a demanda por moradia e a crescente procura pelas condições oferecidas pelo PMCMV (subsídios e financiamentos com baixos juros) têm gerado o surgimento de empresas especializadas na construção civil, especificamente para fins de financiamento mediante o programa. Tal realidade foi bem explorada e trabalhada por Araújo (2017) ao estudar as cidades de Patos e Cajazeiras na Paraíba. Em Russas, apesar de existir a atuação de empresas de outras cidades, como Fortaleza, Aracati e Mossoró, a predominância no setor é de empresas locais, algumas fundadas há menos de seis anos. Surgem novos agentes entre os produtores do espaço urbano. Novos construtores, novos corretores, novas terras a serem comercializadas, algumas agora valorizadas pela ótica imobiliária apenas pela sua aproximação com os empreendimentos do PMCMV. Com elas, surgem também novos proprietários fundiários do espaço urbano.

Nesse momento, a cidade de Russas vem passando por um rápido processo de expansão da malha urbana e por um forte incremento do mercado imobiliário local. Com mais possibilidades de acesso à casa própria também 
por parte das famílias de renda média e, mais recentemente, principalmente por esta faixa, ativa-se o setor construtivo e o mercado imobiliário. Assim, o espraiamento da cidade vai ocorrendo de forma acelerada e em descompasso com a oferta de infraestrutura.

A pesquisa mostra também que a localização dos empreendimentos construídos pode trazer ônus aos seus compradores dada à precária ou mesmo ausente inserção urbana e o distanciamento das áreas centrais. A predominância dos empreendimentos para as faixas 2 e 3 do programa reafirma o caráter econômico e empresarial da política pública de provisão habitacional para famílias de baixo poder aquisitivo. A não priorização ao acesso à moradia para a faixa da populaçáo que efetivamente carece em Russas foi constatada desde o início da pesquisa, ao se verificar a inexistência de habitaçóes da faixa 1 do PMCMV.

Portanto, constatamos que o PMCMV tem propiciado o surgimento de novas dinâmicas no setor imobiliário de Russas, com novos agentes, meios de construção e áreas de atuação, e com ela, a produção e expansão do espaço urbano tem adquirido novas formas, mantendo a segregação ao acesso à habitação e à cidade. Observa-se cada vez mais, a consolidação de duas periferias bem distintas: a dos conjuntos habitacionais, onde habita, predominantemente, a população de baixa renda, e a dos pequenos condomínios fechados e grandes loteamentos direcionados para a população de renda mais elevada. Esses espaços se diferenciam, principalmente, por sua morfologia e conteúdo social.

\section{Referências}

ARAÚJO, Luciana Medeiros. de. Produção Imobiliária e novas Dinâmicas de Expansão Urbana em Patos e Cajazeiras (PB). (Tese). João Pessoa - PB: Universidade Federal da Paraíba, 2017. CORRÊA, Roberto Lobato. O espaço urbano. 4. ed. São Paulo, Ática, 2002.

CARLOS, Ana Fani Alessandri et al. (org.). A produção do espaço urbano: agentes e processos, escalas e desafios. 1a. ed. São Paulo: Contexto, 2011.

HENRIQUE, Wendel. "Cidades universitárias, cidades médias, cidades pequenas: análises sobre o processo de instalação de novos Campi universitário". In: Revista Espaço Aberto, $P P G G$ - UFRJ, v. 5, n. 1, pp. 73-93, 2015.

LEFEBVRE, Henry. “O Espaço”. In: Espaço e política. Belo Horizonte: UFMG, 2008. 
PEQUENO, Renato e FREITAS, Clarissa. "Programa minha Casa minha Vida em Fortaleza: primeiros resultados". In: CARDOSO, Adauto Lucio. O programa Minha Casa Minha Vida e seus efeitos territoriais. Rio de Janeiro: Letra Capital, 2013.

SANTOS, Milton. A urbanização brasileira. São Paulo, Hucitec, 1993.

VALENÇA, Mariana Rabêlo. Ensino Superior e Empreendimentos Imobiliários do Programa Minha Casa Minha Vida: uma análise sobre as interaçôes espaciais de Caruaru - PE. (Tese). João Pessoa - PB: Universidade Federal da Paraíba, 2018.

VOLOCHKO, Danilo. A produção do espaço e as estratégias reprodutivas do capital: negócios imobiliários e financeiros em São Paulo. (Dissertação). São Paulo: Universidade de São Paulo, 2007. 


\section{Uma crítica ao processo de autossegregação através da análise de três condomínios Minha Casa Minha Vida}

Fábio Gustavo Pontes Martins ${ }^{l}$

Marcelo Werner da Silva ${ }^{2}$

Introdução

O presente artigo visa aprofundar o debate a respeito do processo de segregação urbana com uma visão crítica do conceito de autossegregaçáo. Este debate se dará por meio da análise de três condomínios situados na cidade de Campos dos Goytacazes, produzidos no âmbito do maior programa habitacional do país, o Minha Casa Minha Vida (PMCMV), na modalidade empresarial.

É preciso frisar que a crítica que iremos fazer se circunscreve à realidade brasileira, não sendo nossa intenção desconstruir o arcabouço conceitual vigente sobre a questão da autossegregação ou reelaborá-lo sob novas bases. Também não o consideramos ultrapassado, apenas que não se aplica a todos os contextos que envolvem o morar em condomínios, principalmente quando estes são produzidos para os segmentos de menor renda em nosso país, como verificado no PMCMV.

Para cumprir este objetivo, vamos elaborar uma breve exposição do PMCMV, situando a natureza do maior programa habitacional brasileiro, que em nossa opinião é muito mais do que uma simples política habitacional do governo federal.

1 Professor de Geografia das redes públicas estadual e municipal, licenciado em Geografia e pós-graduado em Ensino de Geografia pelo Instituto Federal Fluminense e mestre em Geografia pela Universidade Federal Fluminense. E-mail: fgustavopontes@ gmail.com

2 Pós-doutorado pela Universidad de Barcelona, professor do Departamento de Geografia de Campos e do Programa de Pós-Graduação em Geografia (PPG) da Universidade Federal Fluminense, Campos dos Goytacazes - RJ. E-mail: marcelows@id.uff.br 
O passo seguinte será discutir o conceito de autossegregação, normalmente associado à autossegregação residencial dos estratos de renda média alta e alta em nosso país (Corrêa, 2004 e Souza, 1996), elaborando algumas questôes sobre alguns pontos que envolvem a produção imobiliária no contexto do PMCMV.

Por fim, realizaremos o contraponto que almejamos produzir à literatura que versa sobre o processo de autossegregação. Nesta etapa do trabalho, vamos, sempre que necessário, revisitar os conceitos discutidos à luz de uma realidade concreta, os residenciais Vida Boa Condomínio Clube Campos, Vida Bela Condomínio Clube Campos e Viva Vida Condomínio Clube Campos, todos na cidade de Campos dos Goytacazes - RJ.

\section{O Programa Minha Casa Minha Vida}

O Minha Casa Minha Vida é um programa habitacional federal de produção de moradias criado em março de 2009, por meio da Medida Provisória (MP-459), no governo do presidente Luiz Inácio Lula da Silva, do Partido dos Trabalhadores (PT). Ele foi o resultado de uma demanda do setor da construção civil (Rolnik, 2015), que almejava produzir 200 mil residências em nosso país.

Entre os seus objetivos, também estava minimizar os efeitos da crise do subprime. ${ }^{33}$ Em síntese, o PMCMV, em seu âmago, buscava muito mais gerar estímulos econômicos (Amore, 2015, p. 15), do que ser uma solução a um problema estrutural brasileiro que é a falta de moradias para famílias de baixa renda.

Mesmo considerando estas colocações iniciais, deve-se destacar que, por iniciativa do presidente Lula, o número de residências a serem construídas por meio do programa passou para 1 milhão, com enfoque também nas camadas de baixa renda, que recebem até 3 salários mínimos, que correspondem a $90 \%$ do déficit habitacional brasileiro e que, com o programa, poderiam adquirir uma residência quase totalmente subsidiada (Romagnoli, s/d) com recursos do Orçamento Geral da União (O.G.U.).

3 O subprime é uma crise do setor financeiro, de julho de 2007, em função da queda de Dow Jones e tem na sua origem a concessão de empréstimos hipotecários de alto risco. 
O Minha Casa Minha Vida encontra-se atualmente na sua Fase 3. A Fase 1 foi de março de 2009 à junho de 2011; a Fase 2 foi de junho de 2011 até dezembro de 2014 e a fase 3 teve início em 2016 com previsão de duração até dezembro de 2018, segundo o Governo Federal. ${ }^{44}$

O programa apresenta três faixas de rendas distintas. As Faixas 1 e 1,5 são compostas por famílias com rendimentos de até três salários mínimos, com a diferença de que na Faixa 1,5 os subsídios são menores do que na Faixa 1.

Já para os indivíduos e famílias com rendimentos superiores a 3 salários mínimos, inseridos nas Faixas 2 e 3, o PMCMV oferece condições mais vantajosas, tais como juros mais reduzidos que os praticados pelos bancos privados no país, por exemplo.

A Faixa 2 do PMCMV é composta por famílias cujo rendimentos variam entre 3 a 6 salários-mínimos, para as quais há a concessão de algumas vantagens para o acesso à moradia. Nessa faixa de renda, na terceira Fase do programa, o governo produziu algumas alteraçóes quando comparado às Fases 1 e 2 . Antes, o pretendente ao imóvel pelo programa obtinha um financiamento com juros girando em torno de $5 \%$ a $7,5 \%$ ao ano, dependendo da renda bruta familiar. $\mathrm{Na}$ fase 3 , os juros praticados pelo programa serão de $6 \%$ ou $7 \%$, dependendo sempre do rendimento familiar. Os adquirentes dos imóveis nesta faixa, além do benefício do crédito mais barato que os praticados pelo mercado, contam também com a garantia do pagamento da prestação por parte do Fundo Garantidor da Habitação (FGHab), de natureza privada (Rolnik, 2015), bem como de estímulos para a aquisição da moradia, como custos de seguro do imóvel reduzidos (Romagnoli, s/d). Neste caso, a produção imobiliária e o processo de aquisição é realizado pela empresa construtora, o que denota a diversidade de modalidades existentes dentro do mesmo programa habitacional.

O programa Minha Casa Minha Vida, portanto, apresenta diversas modalidades. A principal delas é a "Empresarial”, que detém a maior parte dos recursos do programa. As outras modalidades são a "Entidades", que engloba entidades da sociedade civil sem fins lucrativos, cooperativas ou associaçóes.

O público-alvo do programa consiste em famílias que tenham suas casas localizadas em áreas de risco, insalubres ou que tenham sido desabrigadas

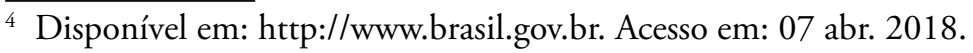


com a devida comprovação dos governos locais ou regionais. O MCMV-Entidades visa atender mulheres que sejam responsáveis pelos seus lares, desde que devidamente comprovado por autodeclaração; e de pessoas com deficiência física, devidamente atestada por um médico.

O Fundo de Arrendamento Residencial (FAR), é composto por recursos transferidos do Orçamento Geral da Uniáo (OGU) para viabilizar a construção de unidades habitacionais para famílias até $\mathrm{R} \$ 1.800,00$ e, diferentemente do Entidades, que visa uma produção imobiliária autogestionária, o FAR fundamenta-se na construçáo habitacional por meio de empresas do setor da construção civil e destina-se a famílias com renda mensal de até $\mathrm{R} \$ 1.800,00$ com as mesmas condiçóes verificadas no MCMV-Entidades.

O Programa Nacional de Habitação Rural (PNHR) visa atender famílias que tenham residências localizadas em áreas de risco, insalubre ou tenham sido desabrigadas, com a devida comprovação por agente público. Mulheres são uma prioridade do programa, desde que sejam responsáveis por seus lares, bem como de que façam parte da composição familiar indivíduos com deficiência. Entretanto, o Minha Casa Minha Vida Sub-50 criada para atender os menores municípios do país (Rolnik, 2015, p. 303).

\section{A autossegregação residencial}

A segregação urbana é o processo de marginalização ou de periferização de grupos ou indivíduos na sociedade, constituindo, segundo Alvarez (2013, p. 111), um dos fundamentos da produção do urbano capitalista.

Sua explicaçáo reside em fatores de ordem social, econômica, política, cultural, histórica e racial. Os exemplos mais evidentes deste processo no Brasil materializam-se em nossas favelas e nas periferias distantes dos principais núcleos urbanos, o que a literatura especializada classifica como segregaçáo imposta (Vasconcelos, 2013 e Corrêa, 2013). Esta segregação difere-se de maneira tênue da induzida, que é aquela em que existem algumas possibilidades de escolhas condicionadas ao preço das terras e dos imóveis (Corrêa, 2013, p. 43). A segregação induzida, ao contrário, não permite escolha alguma a não ser residir onde é possível.

É importante salientar que a segregação é um processo dialético (Villaça, 2001), na qual aqueles que se autossegregam - "os de cima” - em condomínios exclusivos, por exemplo, geram, por conseguinte, a segregação de 
outros - "os de baixo" - evidenciando a complexidade do processo que apresenta duas faces (Spósito, 2013, p. 69).

Os estudos mais recentes sobre a segregação se debruçam sobre o tema em trabalhos que têm como escopo os condomínios fechados (Rolnik, 1995; Villaça, 2011 e Souza, 2008). Várias pesquisas foram produzidas no campos da Antropologia (Caldeira, 2000), da Geografia (Corrêa, 2004) e da Sociologia (Villaça, 2001), entre outros, possibilitando aos pesquisadores do país um aprofundamento do processo, tendo por base a realidade nacional. Os exemplos mais eloquentes são os condomínios da Barra da Tijuca, na cidade no Rio de Janeiro, e Alphaville, em São Paulo (Souza, 1996).

Os trabalhos produzidos tornam evidente uma pluralidade de formas de segregação e seus autores cunharam diversas expressōes (Spóito, 2013, p. 69) para tratar deste processo, tais como espaços fechados e murados (Spósito e Góes, 2013), autossegregação (Corrêa, 2004), enclaves fortificados (Caldeira, 2000) ou autoenclausuramento (Souza, 2005). No entanto, da mesma forma que Spósito (2013), daremos preferência ao termo autossegregação.

Apesar desta profusão de trabalhos, isto não significa dizer que já tenhamos desnudado todos os aspectos que estáo envolvidos na questão, como aponta Villaça (2011), pois as abordagens recentes a respeito da segregaçáo em condomínios apresentam limitaçôes que necessitam de mais aprofundamento, posto que tocam, fundamentalmente, em temas como a insegurança (Spósito e Góes, 2013), a qualidade de vida e a dinâmica do mercado imobiliário (Pádua, 2015).

Este fato exemplifica a grande complexidade da autossegregação urbana, que outrora era apanágio das camadas de status social elevado de nossa sociedade, para as quais morar em condomínios cada vez mais afastados dos núcleos principais de nossas metrópoles e cidades médias não era um grande problema, uma vez que eram dotadas de grande mobilidade espacial e, sendo assim, a distância a se percorrer cotidianamente de suas casas para os locais de trabalho e lazer não era um complicador.

O que nos interessa é atestar que este novo padrão de produçáo de condomínios, como os do PMCMV, difere daquele destinados às elites, porque para elas, ao longo do século $\mathrm{XX}$, a busca pelo isolamento teve, como um de seus fundamentos, a separaçáo dos indivíduos de menor poder e prestígio social. 
Vemos que agora a autossegregação apresenta um novo conteúdo, avançando sobre os segmentos de renda média e baixa, somos levados a concordar com Spósito (2013), pois estamos assistindo a novas formas de segregação socioespacial com modificação no rumo que imperou na maior parte do século XX em relação ao conceito de segregação.

Esse novo conteúdo se relaciona à elevação do poder de compra, do consumo e ampliação do crédito aos indivíduos de renda média e baixa, propiciando que possam se inserir, mais satisfatoriamente, neste mercado de consumo. Tal fato foi potencializado pela política de juros mais baixos e crédito subsidiado pelo governo, como é o caso do PMCMV, possibilitando a elevação no padrão da habitação dos indivíduos de menor poder aquisitivo, cuja autossegregação popular sempre tendeu à "periferização" de suas casas (Spósito, 2013).

Mas aí reside um novo fato. Ele se exprime, ao nosso ver, no fato que a autossegregação em condomínio não é mais uma exclusividade das elites. Entretanto, questionamo-nos até que ponto o conceito pode ser aplicado à realidade dos imóveis destinados às famílias de menor poder aquisitivo.

Os residentes do Vida Boa Condomínio Clube Campos, Vida Bela Condomínio Clube Campos e Viva Vida Condomínio Clube Campos, construídos no âmbito do PMCMV, são exemplos de autossegregação semelhantes aos condomínios da Barra da Tijuca, no Rio de Janeiro, ou Alphaville, em São Paulo?

Teriam eles as mesmas possibilidades de acesso a bens e serviços, empregos, mobilidade no espaço urbano, ou mesmo status, condiçóes de aquisição dos imóveis e o prestígio no morar que desfrutam os condomínios de luxo? Se a resposta é negativa, também é inegável que em ambos os casos verifica-se a autossegregação, aproximando os dois casos.

Sendo assim, nos perguntamos: os condomínios produzidos no âmbito do PMCMV são uma evidência irrefutável da autossegregação? Os condomínios produzidos pelo PMCMV se enquadram nesta definiçáo? São eles mais um exemplo deste processo ou seriam uma expressão da segregação induzida? Os seus residentes dispóem dos mesmos recursos financeiros e de mobilidade que as classes médias e as elites nacionais que perfazem o público-alvo deste modelo de moradia? Ou estaríamos diante de um processo de exclusão socioespacial e não o contrário como a literatura nos leva a crer? Tais questóes se somam as indagaçóes suscitadas por Villaça (2011): 
Em que os condomínios fechados se distinguem das tradicionais formas de segregação, por classe e por bairro, que existem há mais de um século em nossas cidades? Em que se distinguem do Jardim América, Pacaembu ou Alto de Pinheiros? Só no tocante à proteção contra violência? Aos controles de portaria? À produção imobiliária? No tocante à novidade imobiliária, eles em nada se distinguem desses bairros há 50 ou 80 anos atrás. [...] Em que e por que esses aspectos são algo novo? Claro que são novos. A questão é, insistimos, se são significativamente novos. Em que e por quê são relevante e irrelevantes? Como integrar sua análise a processos socioespaciais mais amplos? Como interpretar os condomínios fechados superando a denúncia e os interesses dos moradores? (p. 39).

Para determinar todas essas questóes é indispensável o aprofundamento in locu com os residentes dos condomínios, na medida que a discussão teórica aqui encontra seu limite, que será sanada pelo recurso da análise empírica.

\section{O Vida Boa, Vida Bela e o Viva Vida Condomínio Clube Campos: uma possibilidade de crítica ao conceito de autossegregaçáo residencial}

A questão que formulou o presente artigo pauta-se numa visão formulada a partir de três condomínios produzidos pela construtora PDG (vide figuras 1, 2 e 3), no âmbito do Programa Minha Casa Minha Vida, no bairro do Jockey Club, cidade de Campos dos Goytacazes - RJ, que nos permitem elaborar uma crítica ao processo de autossegregação.

Tal análise fundamenta-se, num primeiro momento, no tipo de imóvel construído, sua localização periférica na cidade, perfil dos moradores detectado através de entrevistas ${ }^{55}$ e observaçóes in loco e o próprio fato de estarem inseridos em um programa habitacional do Governo Federal, no âmbito do Minha Casa Minha Vida.

5 Foram realizadas 15 entrevistas entre moradores dos condomínios e os residentes da rua João Manoel de Faria. O número se apoia na metodologia elaborada por Bauer e Gaskel (2008), que enfatizam que, para um pesquisador individual, a quantidade deve girar entre 15 a 20 entrevistas em função do número de versóes da realidade e do tamanho do corpus a ser analisado. 
Figuras 1, 2 e 3 - Vida Boa Condomínio Clube Campos, Vida Bela Condomínio Clube Campos e Viva Vida Condomínio Clube Campos
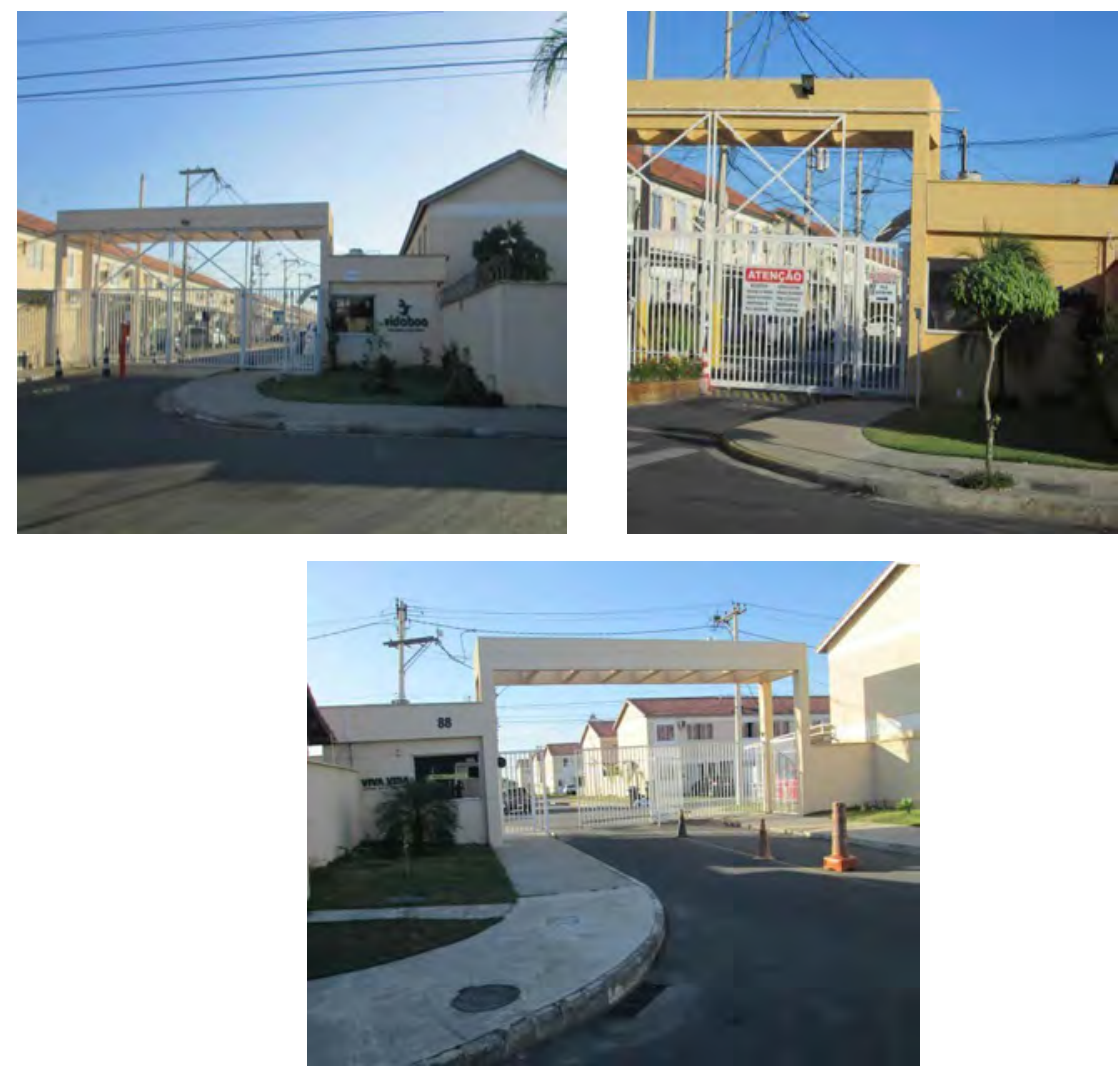

Fonte: Fábio Gustavo Pontes Martins.

Porém, antes de tudo, retomemos a literatura a respeito do processo de segregação para que nossa exposição fique mais evidente. A segregação manifesta-se no espaço urbano por meio da formação de espaços distintos na cidade (Rolnik, 1998), sendo uns mais associados às elites e outros à classe trabalhadora, por exemplo.

No primeiro caso, temos como maior forma de manifestação no presente momento os condomínios exclusivos (Villaça, 2011), ao passo que, para o segundo, observamos as periferias autoconstruídas, favelas, cortiços (Kowarick, 1979) que abrigam uma porção numerosa da população pobre deste país, as quais experimentam, mais do que ninguém, os efeitos da exclusão social. 
$\mathrm{Na}$ cidade capitalista a segregação está relacionada às diferenças de classes e a localização destas no espaço urbano. É neste espaço que se verifica como as classes utilizam e se apropriam de espaços localmente diferenciados. Quem pode pagar mais escolhe onde e como morar. Aqui surge também uma dura realidade das cidades brasileiras que é a questão da habitação (Filho et al, 2009, pp. 2-3).

O conceito de segregação, destaca Spósito (2013, p. 64) é multidimensional. A autora pauta cinco pontos na caracterização da segregação: a) Nem todas as formas de diferenciação e desigualdades são necessariamente formas de segregação; b) há múltiplas formas de adjetivá-la; c) a segregação é sempre de natureza espacial; d) a segregação é um processo; f) a segregação estabelece uma mescla de condicionantes e expressóes objetivas e subjetivas.

Spósito (2013, p. 66) advoga que prefere o termo segregação socioespacial e informa que tal escolha relaciona-se ao fato do conceito congregar as duas dimensóes, as quais estáo em consonância com o terceiro item. A segregação é sempre de natureza espacial "e, por esta razão, ela se distingue da discriminação, da estigmatização, da marginalização, da exclusão, da espoliação ou da pobreza, que podem ter expressão espacial, mas se constituem, estruturalmente, em outros planos: o social, o econômico, o político, o cultural, etc." (Spósito, 2013, p. 66).

A questão se torna mais complexa quando percebemos que fatores como os subsídios para a aquisição de imóveis, os juros mais baratos no PMCMV do que os oferecidos pelos bancos privados, a ampliação do crédito ao longo do governo do Partido dos Trabalhadores (PT) etc., possibilitaram que segmentos da sociedade, outrora negligenciados pelo mercado formal de moradias, adquirissem residências na modalidade condominial, que a princípio configurava-se como um típico processo de autossegregação.

A autossegregação é resultado de uma decisão voluntária de reunir grupos socialmente homogêneos, cujo melhor exemplo é o loteamentos e condomínios fechados, com suas entradas restritas, muros e sistemas de segurança. É uma forma radical de agrupamento residencial defensivo que procura juntar os semelhantes e excluir os diferentes e impedir o acesso dos indesejáveis (Vasconcelos, 2013, p. 27). 
A despeito das políticas públicas habitacionais, historicamente, elas reproduzem e referendam o processo de segregação socioespacial, pois as moradias populares, regra geral, são produzidas muito distantes da área central da cidade e, consequentemente, dos serviços urbanos que a sociedade necessita (Filho et al., 2009, pp. 2-3).

Os imóveis do programa Minha Casa Minha Vida em Campos dos Goytacazes evidenciam o fato de que a produção imobiliária ensejada por políticas públicas tem como tônica uma localização afastada das áreas centrais das cidades, em bairros de periferia. São imóveis com dimensóes reduzidas e que em muitos casos impedem a realização de alteraçóes.

No condomínio Viva Vida, para enfocar em um único exemplo, é vedada qualquer alteração na planta da casa, que detém dimensóes reduzidas, com cerca de $60 \mathrm{~m}^{2}$ de área construída, sendo apenas dois quartos e cerca de $80 \mathrm{~m}^{2}$ de área utilizável. Assim sendo, uma família que tenha o segundo ou terceiro filho ficará em imóvel incompatível com a sua configuração.

A segregação assim redimensionada aparece com um duplo papel, o de ser um meio de manutençáo dos privilégios por parte da classe dominante e o de um meio de controle social por esta mesma classe sobre os outros grupos sociais, especialmente a classe operária e o exército industrial de reserva (Corrêa, 2004, p. 64).

Ao nosso ver os condomínios Vida Boa, Vida Bela e Viva Vida não são uma expressão cabal de um processo de autossegregaçáo como explicado pela literatura especializada sobre o tema e como pode sugerir um primeiro vislumbre desses condomínios. Se eles não são uma evidência do processo, que tipo de segregação podemos constatar em sua observação?

Vejamos, mais uma vez, o que diz a literatura sobre tema. A autossegregação "caracteriza-se como uma política de classe e liga-se diretamente aos estratos superiores classe média [...] e implica, ao menos por parte de membros do grupo de alto status, controle, em maior ou menor grau, do aparelho de Estado, das principais atividades econômicas, melhores terras urbanizáveis e da empresas imobiliárias (Corrêa, 2013, p. 43, grifo nosso).

Spósito e Góes (2013, p. 281) indicam que autossegregação está atrelada aos estratos sociais com melhores condições financeiras, que escolhem se isolar do conjunto da cidade que, na visão deles, "é o espaço dos outros e, portanto, náo mais de todos". 
De forma geral a tônica na fala de Corrêa (2013), Souza (2013) e Spósito e Góes (2013) indica que a autossegregação é um processo no qual seus principais atores são os indivíduos que estão inseridos nas camadas de alto status, o que é diametralmente oposto ao verificado no Vida Boa, Vida Bela e Viva Vida Condomínio Clube Campos.

Sendo assim, quando cotejamos a literatura com a realidade concreta, o que se percebe é que de um lado há os condomínios exclusivos onde a elite reside, já nos três condomínios estudados, temos indivíduos muito mais identificados com a Nova Classe Trabalhadora, uma vez que seus rendimentos, empregos e escolaridade, por exemplo, estáo aquém daqueles percebidos tradicionalmente pela classe média

Questionamos também se todos os condomínios produzidos no âmbito do programa Minha Casa Minha Vida se enquadram no referido processo de autossegregação, mas quanto a isso devemos enfatizar que toda forma de generalização é sempre temerária, seja em função da grande diversidade de imóveis produzidos e por não dispormos de dados relativos à todos os empreendimentos Minha Casa Minha Vida.

No caso específico que estudamos, somos levados a afirmar que náo é um típico processo de autossegregação residencial, portanto não se configura como um exemplo desse fenômeno. O leitor deve estar se perguntando que, se eles não são uma manifestação da autossegregação e se os condomínios PMCMV compóem um quadro de enorme diversidade, que processos evidenciam o Vida Boa, Vida Bela e o Viva Condomínio Clube Campos?

A segregação é um processo dialético (Villaça, 2001) e, como vimos em (Souza, 2008), o autoenclausuramento está associado aos segmentos de maior renda. No entanto, quando nos referimos aos segmentos de menor poder aquisitivo, a segregação resulta de uma política de classe, como aponta Corrêa (2013, p. 43), mas elaborada pelos indivíduos de maior poder na sociedade.

Revisitando mais uma vez a teoria, temos duas situaçôes: a segregação imposta e a induzida (Corrêa, 2013, p. 43). O primeiro caso tem sua expressão quando indivíduos e famílias vão morar onde lhes é imposto, uma vez que suas condiçóes financeiras não permitem escolhas e, na maioria das vezes, a alternativa é a favela ou as periferias distantes. Já no segundo, temos a segregação induzida. Neste caso, as famílias e os indivíduos têm opçôes de escolha até um certo limite circunscrito ao preço do imóvel e da terra. 
Nas entrevistas realizadas, constatamos a situação descrita anteriormente na forma de uma segregaçáo induzida, uma vez que nas respostas que obtivemos dos entrevistados sobre o porquê de terem escolhido aquela forma de moradia, a maioria concentrou-se no preço do imóvel e nas condiçóes de pagamento. Vejamos:

Entrevistada: Facilidade de pagamento da entrada; entrada facilitada dividida em 16 vezes. É [...] que a gente não tinha dinheiro para a entrada da compra do imóvel próprio. (Márcia, 39 anos, professora universitária e moradora do Viva Vida Condomínio Clube Campos, grifo nosso).

As três respostas a seguir sobre a mesma questão dão o tom do quão importante é a questão do preço do imóvel e como ele é o elemento central que levou os moradores a adquirirem uma residência naquele condomínio/bairro:

Entrevistado: Rapaz foi situação mais fácil de dar entrada foi na, na época, entendeu? Por causa da questão do dinheiro. (Paulo, 27 anos, Eletricista de Rede e Morador do Viva Vida Condomínio Clube Campos, grifo nosso).

Entrevistado: Foi o preço e o imóvel. Gostei muito da casa. (João, 54 anos, aposentado e morador do Vida Bela Condomínio Clube Campos).

Entrevistado: Preço e forma de pagamento. (Adilson, 41 anos, e morador do Vida Bela Condomínio Clube Campos, grifo nosso).

Só um dos entrevistados tocou na temática de segurança quando questionado do porquê da escolha daquela forma de moradia. Em nosso entendimento, isto deve-se ao fato de que a violência na cidade de Campos dos Goytacazes concentra-se em bairros do subdistrito de Guarus, que concentra a populaçáo de baixa renda, sendo que a maior parte dos entrevistados tem uma origem em bairros do subdistrito do centro, que náo registram os casos mais graves de crimes na cidade, como os assassinatos cotidianos.

Entrevistado: Tamanho do imóvel e o sossego. Atende melhor [...] e sistema de condomínio, segurança. (Arivaldo, 63 anos, Técnico Eletricista, Pintor, Pedreiro e morador do Vida Bela Condomínio Clube Campos, grifo nosso). 
No que tange ao status social que se tem ao residir em condomínio, as respostas foram esclarecedoras e os entrevistados foram unânimes em destacar que não percebem um status social elevado por terem como local de residência um condomínio.

Entrevistada: Sim e depende do condomínio também, né? Entrevistador: Por quê? Entrevistada: Eu acho que tem muito mais a ver com uma questáo estética do condomínio. Então, por exemplo, este condomínio (Viva Vida) esteticamente é desfavorecido. Ele está na margem da cidade, ele tem, ele não confere status. Eu acredito nisso, mas ele apresenta outros benefícios; Entrevistador: Como? Entrevistada: Segurança, o principal deles. (Márcia, 39 anos, professora universitária e moradora do Viva Vida Condomínio Clube Campos, grifo nosso).

No entanto, quando questionados se sentem-se privilegiados por morarem em condomínios, a maioria respondeu que sim. Nesta pergunta, o tema violência de certa forma se impôs e vários entrevistados destacaram este fato, apesar da violência não ter sido a razão que os levou a adquirir os imóveis como vimos acima.

Entrevistada: Sim. Por exemplo, eu estou procurando casa para comprar e eu quero continuar morando em condomínio. Por que? Porque a gente tem um problema crônico nessa cidade que se chama Terceiro Comando Puro (TCP), A.D.A. (Amigos dos Amigos). A cidade é dividida por muros invisíveis que aparecem pichados nas casas, ninguém faz nada, a polícia não funciona. (Márcia, 39 anos, professora universitária e moradora do Viva Vida Condomínio Clube Campos) ${ }^{66}$

Como vimos, apesar do tema violência ter sido considerado, as razóes que levaram os segmentos de maior renda a se autossegregarem não explicam a aquisiçáo do imóvel pelos residentes entrevistados. Temos, entáo, mais um elemento para embasar a nossa argumentação, de acordo com a qual os condomínios Vida Boa, Vida Bela e Viva Vida não se configuram como um processo

${ }^{6}$ Segundo Latuf $(2015$, p. 123), "Por facçôes criminosas deve-se entender, ao menos durante a leitura do presente artigo, que se trata de um grupo de pessoas que, por partilharem de uma mesma realidade (estarem encarcerados), organizou-se". 
de autoenclausuramento típico. Também não se trata de uma forma de exclusão socioespacial que a princípio tínhamos aventado, apesar da segregação e da exclusão serem processos que mantêm uma correlação entre si, como aponta Sposati (1998), o que não significa dizer que estamos diante dela.

A exclusão alcança valores culturais, discriminaçôes. Isto não significa que o pobre não possa ser discriminado por ser pobre, mas que a exclusão inclui até mesmo o abandono, a perda de vínculos, o esgarçamento das relaçóes de convívio, que necessariamente não passam pela pobreza (Sposati, 1998, pp. 3-4).

Nossa primeira formulação fundamentava-se em dois princípios. $\mathrm{O}$ primeiro referia-se à localização dos imóveis, situados no fim de uma antiga rua sem saída que tinha como limite um vazio urbano. $\mathrm{O}$ segundo associava-se à limitada disponibilidade de serviços e equipamentos urbanos nas proximidades dos condomínios, fato que obriga seus residentes a caminharem distâncias consideráveis para acessar o transporte público de modo que possam se dirigir ao centro da cidade e outros locais em que possam ter acesso a bancos, hospitais, universidades, cinemas, shopping, entre outros. Esta característica nos leva a concordar com Pontes (2018, p. 2) para quem

[...] a acessibilidade é condicionada pela interação entre o uso do solo e o transporte, e que se constitui num importante indicador de exclusão social ao lado da mobilidade, da habitação, da educação e da renda. A acessibilidade ou a falta dela, ao ser parte integrante e fundamental da dinâmica e do funcionamento das cidades, passa a ser um elemento que contribui para a condição de exclusão/inclusão socioespacial, na medida em que facilita o acesso da população aos serviços e equipamentos urbanos, além de viabilizar sua aproximação com as atividades econômicas (Pontes, 2018).

Todos os nossos entrevistados possuem automóveis e os utilizam como principal meio de locomoção na cidade. Eles podem usufruir dos serviços públicos que ela oferece sem maiores problemas, o que significa que para eles o local de residência não se configura como um fator de limitação para uso do espaço citadino, algo táo associado aos que detém parcos recursos e ficam presos ao lugar (Bourdieu, 2001). Porém, isto não significa que todos os residentes dos condomínios possuam automóveis, pois parcelas considerá- 
veis dos moradores têm como meio transporte bicicleta ou andam a pé até o ponto de ônibus.

Quando buscamos outros aspectos relacionados à exclusão, como a baixa escolaridade e o desemprego (Oliveira, 1997), por exemplo, vemos que nossos entrevistados apresentam uma situação diametralmente oposta, na qual há uma grande predominância de indivíduos com formação superior, bem como empregos no serviço público. Oliveira (1997, p. 3) destaca ainda que, no Brasil, os excluídos são "os moradores e meninos de rua, os desempregados das favelas e periferias, muitos convertidos em flanelinhas e mesmo delinquentes, os catadores de lixo, etc. Mais do que simplesmente pobres, eles estão mais próximos do que normalmente designamos miseráveis" (Grifo nosso).

Dos entrevistados, apenas três receberam o subsídio governamental. Mesmo assim, não estamos afirmando que eles tenham uma renda muito elevada, sendo, portanto, de uma classe social superior. Os próprios entrevistados atestaram que não e a maioria se via como parte integrante da classe trabalhadora. Porém, este fato é mais um elemento que se soma aos já destacados por nós, que tem como finalidade compor um panorama geral do que estamos investigando.

Após o exame das entrevistas, das análises de campo e da forma como os imóveis foram adquiridos pelos entrevistados fomos levados à seguinte conclusão: de que ali temos algo mais próximo de uma segregação induzida do que um processo de exclusão socioespacial que a princípio tínhamos sugerido ou propriamente uma autossegregação.

A afirmaçáo anterior tem como embasamento os pressupostos apresentados a seguir. Primeiro, não se observa no Vida Boa, Vida Bela e Viva Vida Condomínio Clube Campos um típico processo de autossegregação, uma vez que os residenciais não se caracterizam por elementos de exclusividade e não foram destinados aos privilegiados de nossa sociedade. Este aspecto é relevante, pois como atesta a literatura especializada em autossegregação, em condomínios é um processo ligado a setores da classe média e da elite, cujos grandes exemplos são os empreendimentos localizados na Barra da Tijuca, na cidade do Rio de Janeiro, e o complexo Alphaville, na regiáo metropolitana de São Paulo (Souza, 1996).

Segundo: os residentes dos condomínios não podem ser vistos como excluídos de maneira alguma, ainda que pese o fato de morarem em um bairro periférico com serviços públicos precários, como eles próprios atesta- 
ram. Temos que levar em consideração que eles fazem uso dos equipamentos públicos existentes em outras partes da cidade com auxílio de um meio de locomoção individual, pois dada as condiçôes de localização dos condomínios é um recurso de primeira ordem.

O automóvel conformou as cidades e definiu, ou pelo menos foi o mais forte elemento a influenciar, o modo de vida urbano na era da industrializaçáo. Aquilo que era inicialmente uma opção - para os ricos, evidentemente - o automóvel passou a ser uma necessidade de todos (Maricato, 2014, p. 171).

Recorrendo às entrevistas que realizamos nos condomínios citados, constatamos uma grande homogeneidade entre eles; porém, nas observaçóes de campo, verificamos inúmeros casos que expuseram uma grande diversidade no interior dos condomínios. A pesquisa de campo apontou uma série de indícios que sáo indicativos da variedade existente no interior dos condomínios, uma vez que constatamos a ocorrência de residentes saindo de suas casas para o trabalho a pé, de bicicleta e de carro. Percebemos que alguns residentes vão ao trabalho de uniforme, e ao mesmo tempo conversamos com uma professora da Universidade Estadual do Norte Fluminense (UENF), doutora em Antropologia, moradora do Viva Vida Condomínio Clube Campos e que reside no local com seu marido, também professor da referida instituição.

A necessidade do automóvel para os residentes dos condomínios é muito evidente em função da sua localização e da própria limitação do bairro do Jockey Club na oferta de bens e serviços. Para termos uma compreensão melhor, o ponto de ônibus mais próximo que se destina ao centro da cidade de Campos dos Goytacazes encontra-se a cerca de um quilômetro de distância, na BR-356, no trecho denominado de Avenida Presidente Kennedy.

Com tais condiçóes, o carro é um recurso de primeira ordem para os residentes dos condomínios. Esta constatação foi possível dada a grande quantidade de veículos estacionados nas garagens dos moradores: "sem o automóvel não há como abastecer uma casa na cidade marcada pela urbanização dispersa: ocupação de vastas áreas com baixa densidade de ocupação onde predomina, no uso do solo, frequentemente de forma absoluta e exclusiva, a moradia e a infraestrutura rodoviária" (Maricato, 2014, pg.172). 
Os entrevistados têm um perfil marcado por pessoas com formação superior, majoritariamente composto por funcionários públicos de carreira, sendo, portanto, com trabalhos estáveis.

O terceiro ponto é, ao nosso ver, o mais central de todos os elementos que destacamos para corroborar a afirmação segundo a qual os condomínios podem exprimir um processo de segregação induzida. Por quê? Porque o processo que estamos diante foi induzido pelo preço dos imóveis e pelas condiçóes de pagamento obtidas pelos nossos entrevistados e como aponta Corrêa (2013, p. 43), a segregação induzida é verificada naqueles que ainda têm escolhas possíveis, mas tais escolhas apresentam-se dentro de determinados limites com o preço do solo e dos imóveis.

Vejamos: O que levou o senhor (a) a escolher esta forma de moradia?

Entrevistado: Foi o preço e o imóvel. Gostei muito da casa. (João, 54 anos, aposentado e morador do Vida Bela Condomínio Clube Campos, grifo nosso).

Não pretendemos ser diversionistas com as entrevistas e, com isso, tentar manobrar e enquadrar um conceito a partir das respostas obtidas. As informaçôes se casaram de tal forma que não poderíamos negligenciar o fato segundo o qual temos uma ação - a compra do imóvel - por parte dos moradores, que teve como grande elemento condicionador o preço da casa e as condiçóes de pagamento e financiamento verificados.

Sendo assim, somos levados mais do que nunca a assumir uma posição em que estamos diante de um cenário muito mais próximo de uma segregação induzida do que, por exemplo, uma autossegregação ou exclusão socioespacial. Estamos convictos de todos os riscos que tal postura traz, uma vez que seria um tanto insólita a afirmação feita por nós, porque condomínios sempre são associados com autossegregação ou condomínio para classes de alto status social e econômico. Porém, a sociedade não é estática e as mudanças são verificadas exigindo uma reformulação dos conceitos produzidos para explicar uma dada situação, que atualmente encontra-se em franca transformação do seu conteúdo.

Não pretendemos aqui dizer que a teoria a respeito da autossegregação está incorreta, porém, dadas as atuais condiçóes de produção imobiliária, que vêm avançando por meio dos segmentos de menor renda pertencentes à 
Nova Classe Trabalhadora, estamos sendo levados a questioná-la, pois ela não seria capaz de explicar como condomínios como o Vida Boa, Vida Bela e o Viva Vida Condomínio Clube Campos configuram-se muito mais como um processo de segregação induzida do que propriamente uma autossegregação, como a teoria nos leva a crer.

Para nós, essa teoria é totalmente capaz de explicar o processo quando se parte da premissa básica que o objeto a ser estudado é especificamente os destinados ao segmento de alto status, o que evidentemente não é o nosso caso. $\mathrm{O}$ nosso objeto de estudo, produzido no âmbito do programa Minha Casa Minha Vida, maior programa habitacional do país, destina-se a um outro público composto por indivíduos das mais variadas origens que vão desde uma acadêmica, passando por um técnico especializado e culminando em um empregado de uma importante rede de supermercados da cidade.

Nosso objeto de estudo é a expressão de uma produção imobiliária caracterizada pela impessoalidade nas residências, com construção padronizada, estandardizada, em escala, com valores de venda reduzidos no mercado residencial - se compararmos aos condomínios exclusivos -, mas foram eles em última instância, o elemento definidor da aquisição da casa - por exemplo, o valor da prestaçáo, a forma de pagamento, se caberia ou não orçamento familiar. Em função deste fato, dissemos que o Vida Boa, Vida Bela e o Viva Vida Condomínio Clube Campos caracterizam um processo de segregaçáo induzida, ainda que a literatura especializada diga o contrário.

\section{Consideraçóes Finais}

O presente artigo buscou aprofundar a problemática envolvida no processo de autossegregação residencial e questionar, em certo grau, a aplicação do conceito, uma vez que cada vez mais assistimos um avanço do capital imobiliário em nossas cidades, onde, a cada dia que passa, novos produtos imobiliário são lançados com o intento de se alcançar todos os públicos possíveis.

Este fato, devemos frisar, se impóe aos que se dedicam à problemática em tela uma nova visão a respeito do processo de autossegregação, que é, ao nosso ver, um conceito passível de ressalvas, uma vez que sua aplicação a cada dia que passa sujeita a questionamento todos aqueles que se dedicam à tarefa de desnudar o urbano, com todas as suas especificidades encontradas em cidades de um país como o Brasil. 
Contudo, queremos deixar claro que não temos a pretensão de negar a aplicabilidade do conceito de autossegregação, mas achamos que sua eficácia como recurso analítico no cenário atual, em que há uma avanço quase que implacável do capital imobiliário no segmento de menor renda em nosso país, deve ser questionada. Advogamos a tese segundo a qual o conceito, para ser aplicado, sem prejuízo analítico, deve ficar mais condicionado aos imóveis que têm como alvo os segmentos de maior renda.

\section{Referências}

ALVAREZ, Isabel Pinto. "A segregação como conteúdo da produção do espaço urbano". In: BAUER, Martins W. e GASKEL, George. Pesquisa qualitativa com texto, imagem e som: um manual prático. Petrópolis, RJ: Vozes, 2008.

BOURDIEU, Pierre. "Efeitos do lugar". In: (coord.). A miséria do mundo. 4 ed. Petrópolis: Vozes, 2001.

CALDEIRA, Teresa Pires do Rio. Cidades de muros: crime, segregação e cidadania em São Paulo. São Paulo: Ed. 34/Edusp, 2000.

CASTELLS, Manuel. A questão urbana. Rio de janeiro: Paz e Terra, 1983.

CORRÊA, Roberto Lobato. O espaço urbano. São Paulo: Editora Ática. São Paulo, 2004. . "Segregação Residencial: classes e espaço urbano". In: VASCONCELOS, Pedro de Almeida et al. (orgs.). A cidade contemporânea: segregação espacial. São Paulo: Contexto, 2013. pp. 38-59.

KOWARICK, Lúcio. A espoliação urbana. Rio de Janeiro: Paz e Terra, 1979.

LATUF, Julia Rosa. "Garantismo e faç̧óes criminosas: correlação da teoria Garantista com o surgimento e existência do Primeiro Comando da Capital". Revista Liberdades, n. 20, pp. 107-33, set.-dez. 2015.

MARICATO, Ermínia. O impasse da politica urbana no Brasil. Petrópolis, RJ: Vozes, 2014. 3. ed.

OLIVEIRA, L. "Os excluídos existem?: notas sobre a elaboração de um novo conceito". Revista Brasileira de Ciências Sociais, São Paulo, v. 12, n. 33, pp. 49-61, 1997.

PÁDUA, Rafael Faleiros de. "Produção estratégica do espaço e os 'novos produtos imobiliários”. In: CARLOS, Ana Fani Alessandri et al. (orgs.). A cidade como negócio. São Paulo: Contexto, 2015.

PONTES, Eduardo. Exclusão socioespacial, acessibilidade e mobilidade: notas para uma análise da Regiāo Metropolitana do Rio de Janeiro pela ótica do sistema de transportes, no contexto dos grandes eventos esportivos. Disponível em: http://www.chaourbano.com.br/visualizarArtigo. php?id=68. Acesso em: 11 jan. 2018.

ROLNIK, Raquel. O que é cidade. São Paulo: Brasiliense, 1998.

. Guerra dos lugares: a colonização da terra e da moradia na era das finanças. Sáo Paulo: Boitempo, 2015. 
ROMAGNOLI, Alexandre J. O programa "minha casa, minha vida”: continuidades, inovações e retrocessos. Disponível em https://periodicos.fclar.unesp.br. Acesso em 12 jan. 2018.

SOUZA, Marcelo Lopes de. Urbanização e desenvolvimento no Brasil atual. Editora Ática. São Paulo, 1996.

. O desafio metropolitano: um estudo sobre a problemática sócio-espacial nas metrópoles brasileiras. Rio de Janeiro: Bertrand Brasil, 2005.

. Fobópole: o medo generalizado e a militarização da questão urbana. Rio de Janeiro: Bertrand Brasil, 2008.

SPOSATI, A. "Exclusão social abaixo da linha do Equador". Seminário sobre exclusão social - PUC/SP, abr. 1998. Disponível em: http://www.dpi.inpe.br/geopro/exclusao/exclusao. pdf. Acesso em 21 fev. 2018.

SPÓSITO, Maria Encarnação Beltrão. “Segregação socioespacial e centralidade urbana”. In: VASCONCELOS, Pedro de Almeida et al. (orgs.). A cidade Contemporânea: segregação espacial. São Paulo: Contexto, 2013. pp. 61-93.

e GÓES, Eda Maria. Espaços fechados e cidades: insegurança urbana e fragmentação socioespacial. Sáo Paulo: Editora Unesp, 2013.

VASCONCELOS, Pedro de Almeida. "A aplicação do conceito de segregação residencial ao contexto brasileiro na longa duração". Cidades, Presidente Prudente. v. 1, n. 2, pp. 259-74, 2004.

. "Contribuição para o debate sobre processos e formas espaciais nas cidades". In: VASCONCELOS, Pedro de Almeida et al. (orgs.). A cidade Contemporânea: segregação espacial. Sáo Paulo: Contexto, 2013, pp. 17-37.

VASCONCELOS FILHO, João Manoel et. al. "A segregação sócio-espacial e a luta pelo direito a moradia: em foco a ocupação do setor Monte Sinai em Araguaína - TO”. In: Jornada Internacional de Políticas Públicas, IV, São Luís-MA: UFMA, 2009.

VILLAÇA, Flávio. Espaço intra-urbano no Brasil. São Paulo: Studio Nobel; Fapesp; Lincoln Institute, 2001.

. "São Paulo: segregação urbana e desigualdade". Estudos Avançados, n. 25, v. 71, pp. 37-58, 2011. 


\section{A apropriaçáo dos espaços de lazer no conjunto habitacional Major Veneziano (I, II, III e IV) em Campina Grande, PB}

Sâmara Iris de Lima Santos

\section{Introdução}

A política habitacional empreendida a partir do Programa Minha Casa Minha Vida tornou-se importante no que concerne à produção de moradias no Brasil desde 2009. Apesar de ser instrumento para a promoção da política urbana no contexto brasileiro, alguns estudos demonstram a continuidade de problemas ligados, sobretudo, ao processo de segregação. Para Lucena e Maia (2016), o PMCMV, apesar de proporcionar a habitação para muitos que não possuíam, também "tem contribuído para intensificar processos como a acelerada expansão das cidades, estimulando dessa maneira o aprofundamento das desigualdades socioespaciais, especialmente no que diz respeito ao acesso a serviços e infraestruturas”.

A partir de estudos realizados junto à rede $\mathrm{ReCiMe}^{1}$ (Rede de Pesquisadores sobre Cidades Médias), constatou-se que as dinâmicas intraurbanas aparecem como um dos resultados mais sensíveis desse processo nas cidades médias, a exemplo da construção de grandes empreendimentos que têm impactado as relaçóes entre centro e periferia, favorecendo a ampliação dos processos voluntários e involuntários de segregação.

Compreender a questão habitacional é avaliar que ela vai além da estrutura física da "casa", pois diz respeito a todo o conjunto de fatores asso-

1 As pesquisas mencionadas fazem parte do projeto intitulado: Grandes Infraestruturas Urbanas, Ensino Superior e Desenvolvimento Regional: Reconfigurando as relaçóes entre as cidades médias, as cidades pequenas e o campo. 
ciados à urbanidade, os quais são propícios para o viver na cidade, como a infraestrutura urbana, a segurança, o lazer, os serviços etc.

Nesse sentido, entende-se que a moradia, a partir da atuação do capital no espaço urbano, passou a ser produto criado em escala mercadológica, o que evidencia um conflito com o que se assegura no Art. $6^{\circ}$ da Constituição Federal (1988), ${ }^{2}$ ou seja, a de constituir-se como um dos direitos sociais do cidadáo. No Art. 23 (1988), ${ }^{3}$ aparece como sendo de competência comum da União, dos Estados, do Distrito Federal e dos Municípios: promover programas para a construção de moradias e a melhoria das condiçóes habitacionais e de saneamento básico. Ao identificar as particularidades das políticas habitacionais brasileiras, nota-se um aumento dos programas destinados à construçáo e ao provimento da casa própria, muito embora o direito à moradia e aos demais aspectos da urbanidade ainda persistam como uma lacuna para o Estado.

De acordo com Maia (2013, p.31), Campina Grande possui importância regional e "forte concentraçáo de serviços e comércio e uma indústria que, embora pouco se destaque na realidade nacional, no Nordeste brasileiro se sobressai". Historicamente, a cidade tornou-se um "espaço socioeconômico significativo no conjunto do Estado da Paraíba entre o final do século XIX e o começo do século XX, a partir da redefiniçáo do eixo dos transportes e a consolidação da matriz comercial - algodoeira" (Oliveira, 2009, p. 12). Segundo o IBGE (2014), a cidade possui 402.912 habitantes, está localizada no agreste paraibano e apresenta-se como atrativo diário de pessoas advindas de outras regióes em decorrência da disponibilidade de serviços especializados nas áreas de saúde, educação e comércio.

A inserção de conjuntos habitacionais financiados pelo "Programa Minha Casa Minha Vida” em Campina Grande concretizou-se a partir de 2011. De acordo com as pesquisas da $\mathrm{ReCiMe}$, percebe-se que o avanço quantitativo de grandes empreendimentos náo converge para o direito à cidade, ${ }^{45}$ fato verificado também em outras cidades brasileiras.

2 Segundo a Constituição Federal da República Federativa do Brasil de 1988, são direitos sociais: a educação, a saúde, a alimentação, o trabalho, a moradia, o lazer, a segurança, a previdência social, a proteção à maternidade e à infância, a assistência aos desamparados.

3 Segundo a Constituição Federal da República Federativa do Brasil de 1988.

${ }_{4}^{4} \mathrm{O}$ direito à cidade vai além do direito individual (elites locais, poder público etc.), mas o direito da maioria dos habitantes nos espaços urbanos, conforme as análises de David Harvey e Ermínia Maricato. 
Ao analisar os espaços destinados ao lazer nos conjuntos habitacionais do PMCMV, percebe-se que a produçáo desses conjuntos tem desconsiderado, em sua maioria, as peculiaridades dos locais onde são construídos, ${ }^{56}$ tanto dentro dos conjuntos como nas áreas do entorno dos empreendimentos. Sobarzo (2006) explica que a realidade hoje é ainda mais complexa, pois a construção desses novos produtos urbanísticos tem acentuado a virtualidade das relaçôes, no sentido de produçáo e apropriação do espaço.

Portanto, para compreender alguns dos resultados da política habitacional do PMCMV em Campina Grande, optou-se por analisar o conjunto Major Veneziano, pois foi o primeiro conjunto entregue, no ano de 2011, destinado à população da faixa 1 do programa, ou seja, às famílias com renda até 3 salários mínimos, conforme regia o documento do programa na época. O referido conjunto está localizado na porção Sudoeste da cidade, uma das áreas de expansão urbana de Campina Grande, e que de acordo com o IBGE (2014) apresenta espaços vazios e carência de infraestrutura.

Como caminho para construção da pesquisa, optou-se pela aproximação com a abordagem qualitativa a fim de entender as contradiçóes presentes no processo de apropriação do conjunto Major Veneziano. Assim, como recurso metodológico foram realizadas entrevistas do tipo semiestruturada com os moradores e agentes locais. Contudo, não foi desconsiderada a importância das informaçóes quantitativas, especialmente os dados sobre renda, faixa etária e número de moradores.

O texto apresentado está estruturado, além desta introdução, em duas partes: a) a produçáo do conjunto Major Veneziano partindo da observaçáo do projeto do empreendimento e do cotidiano analisado por meio das entrevistas com os agentes e moradores e b) a análise da apropriaçáo dos espaços de lazer do conjunto habitacional Major Veneziano a partir dos resultados das entrevistas realizadas durante a pesquisa.

${ }_{5}^{5}$ De acordo com as análises de Amore, Shimbo e Rufino (2015). 


\section{A produção do conjunto habitacional Major Veneziano (I, II, III E IV) em Campina Grande - PB}

Criado no ano de 2009, o Programa Minha Casa Minha Vida PMCMV propóe atender à população com renda mensal de até 10 salários mínimos, sendo ampliado a partir do PMCMV-2 com moradias para a população rural e para reformas habitacionais. Assim, o programa, na sua fase 2, atende aos seguintes grupos: 1) Aqueles que possuem renda de até $\mathrm{R} \$$ 1.600,00 são beneficiados com auxílio substancial para habitações de interesse social, conforme consta na Cartilha do PMCMV. ${ }^{6}$ A faixa 2 compreende habitaçôes para famílias com nível de renda de até $\mathrm{R} \$ 3.275,00$. A faixa 3 integra as famílias com renda entre $\mathrm{R} \$ 3.275,01$ e $\mathrm{R} \$$ 5.000,00.

Em Campina Grande, a produção habitacional a partir da inserção da política empreendida pelo PMCMV foi iniciada em 2011 com a introduçáo de projetos voltados para as faixas 1 e 2 do programa. Para Maia e Lucena (2015, p. 351), Campina Grande tornou-se "atrativa para investimentos do excedente do capital imobiliário, portanto, como lugar atraente para empreendimentos do PMCMV".

O primeiro conjunto habitacional entregue à população da cidade e classificado como conjunto habitacional destinado à população com renda salarial de até 3 salários mínimos, foi o Major Veneziano (I, II, III e IV). O empreendimento está situado no Bairro Três Irmãs em Campina Grande. De acordo com o IBGE (2010), o bairro limita-se ao Norte, com o Serrotão; ao Sul, com o Bairro das Cidades; a Leste, com os bairros Santa Cruz, Presidente Médici e Acácio Figueiredo; e a Oeste, com a zona rural (mapa 1). O bairro apresenta carência de infraestrutura e grandes vazios, com áreas ambientalmente frágeis (riachos com águas poluídas). Entretanto, é um dos espaços da cidade onde o processo de ocupação tem se tornado intenso, com a implementaçáo dos conjuntos habitacionais destinados à faixa 1 do PMCMV como, por exemplo, os empreendimentos Acácio Figueiredo e Raimundo Suassuna.

O projeto do conjunto Major Veneziano I, II e III, foi aprovado em 2011 e entregue à população em dezembro de 2013. De acordo com o documento, são 496 apartamentos em cada unidade habitacional (4 unidades),

${ }^{6}$ Para aprofundar essa análise, consultar a Cartilha do PMCMV. Disponível em: http:// www.caixa.gov.br/voce/habitacao/minha-casa-minha-vida/Paginas/default.aspx. Acesso em: abr. de 2015. 
divididos em 31 blocos de apartamentos. Cada apartamento possui dois quartos, sala, cozinha, um banheiro social e um espaço de serviço, com uma área total de $50 \mathrm{~m}^{2}$.

A partir da aprovação do projeto, deu-se o processo de seleção das famílias por parte da Prefeitura Municipal, levando em consideração critérios socioeconômicos. No caso do referido conjunto, um dos objetivos mencionados pela gestão municipal foi o de retirar as famílias da Comunidade do Papeláo. De acordo com depoimentos dos moradores que viviam na comunidade, muitas foram as manifestaçóes por parte da população para obter uma moradia, além das reunióes com autoridades do município, até que a Secretaria de Planejamento da Prefeitura Municipal (SEPLAN) realizasse visitas para cadastrar os moradores nos sorteios.

Ao avaliar a localização do Conjunto Major Veneziano (mapa 01), percebe-se que ele segue a lógica segregacionista, comum ao PMCMV no território brasileiro. Maricato (2000, p. 4), analisa essa lógica e escreve:

Pelo fato de que os pobres não cabem nas cidades, que os conjuntos habitacionais têm sido construídos em terras baratas a longas distâncias. Levar a cidade até eles, resulta socialmente muito caro, mas essa lógica de extensão da cidade alimenta aquilo que ocupa o lugar central da desigualdade urbana: a valorização imobiliária e fundiária. 
Mapa 1 - Localização do conjunto habitacional Major Veneziano em Campina Grande, PB

\section{MAPA DE LOCALIZAÇÃO DO CONJUNTO HABITACIONAL MAJOR VENEZIANO - CAMPINA GRANDE - PB}
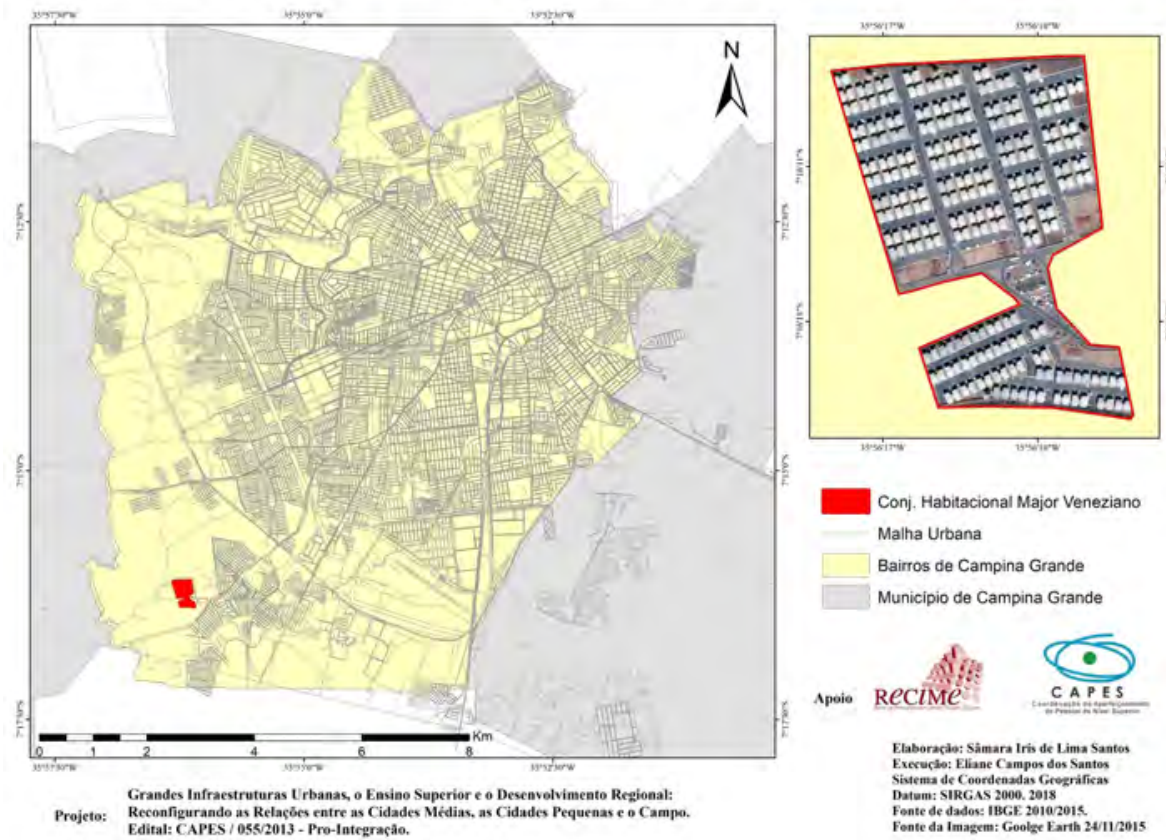

Fonte: elaboração própria com execução de Eliane Santos, a partir dos dados fornecidos pelo IBGE (2010-15)

A partir da análise do projeto e da sua edificação, bem como dos resultados das entrevistas junto aos moradores, afirma-se que o conjunto é afastado do centro da cidade. A localização é indicada pelos habitantes do conjunto como um fator negativo. Apesar de haver transporte coletivo, este é insuficiente, principalmente em finais de semana, quando o tempo de espera é de aproximadamente $1 \mathrm{~h}$ para chegar nas proximidades do conjunto, além de circular apenas uma linha. Além disso, o percurso mínimo de $11 \mathrm{~km}$ até o terminal de integraçáo localizado no Centro se dá com grande desconforto, dada a superlotação, visto que os ônibus transportam moradores dos conjuntos habitacionais vizinhos - Acácio Figueiredo e Raimundo Suassuna -, e pessoas de outros bairros durante o percurso até o Centro da cidade, tornando-o uma problemática para os que precisam utilizá-lo.

Em relação aos serviços de comércio nas proximidades dos conjuntos, a população confirma a existência apenas de pequenos estabelecimentos na 
área externa. Estes referem-se à área de um terreno em frente ao conjunto, que no projeto é onde deve ser construído equipamentos sociais e que é ocupado por barracas que comercializam produtos diversos, principalmente os para o consumo diário. Para os moradores, essas barracas são importantes no cotidiano, pois alguns comércios como farmácias, padarias etc., só são encontrados nos outros bairros, como Cidades, Três Irmãs, Presidente Médici e o Centro. Além disso, alguns serviços se tornam mais caros devido à localização do conjunto, a exemplo dos mototáxis ${ }^{7}$ que cobram desde o centro da cidade, taxas em torno de $\mathrm{R} \$ 12,00$, enquanto para outras áreas o preço cobrado, em média, é de R \$. 6,00. As farmácias da cidade apresentam dificuldades em relação à entrega de medicamentos devido à distância ou cobram taxas extras, de acordo com alguns moradores. A respeito da problemática da localização dos conjuntos habitacionais construídos pelo PMCMV, Maricato (2009, p. 6) afirma:

Há no Brasil conjuntos habitacionais com localização tâo distante e inadequada que não apenas colocaram os moradores em uma condição de sofrimento, como criaram uma série de deseconomias urbanas. Quando se instala um conjunto fora da cidade, é preciso levar a cidade até o conjunto. É uma condição de deseconomia e de insustentabilidade, que no mínimo gera muitas viagens. O contrário do que o urbanismo atualmente preconiza.

A partir de visitas in loco e de acordo com entrevistas realizadas, ${ }^{8}$ apesar da importância existente em relação à construção dos apartamentos, considerando que muitos não dispunham de um lugar "próprio" para moradia," alguns aspectos, sobretudo relacionados à ausência de infraestrutura (posto de saúde, espaços públicos insuficientes, mercado público, escolas etc.), dificultam o cotidiano dos moradores, pois não foram construídos na localidade,

${ }^{7}$ De acordo com a STTP (Superintendência de Trânsito e Transportes Públicos) em 2016, esse tipo de serviço não pode ultrapassar os $\mathrm{R} \$ 7,00$ (finais de semana e feriados).

${ }^{8}$ Comentários realizados por meio de questionários aplicados no conjunto Maj. Veneziano durante o primeiro semestre de 2015.

9 De acordo com Silva (2010), este conjunto foi destinado para abrigar famílias que vivem na comunidade do Papeláo, nas proximidades do Estádio "O Meninão". em campo (dezembro de 2014), constatou-se que nessa área ainda existem famílias que esperam ser beneficiadas com casas do PMCMV. 
embora, como anteriormente mencionado, existam terrenos no entorno destinados à construção dos equipamentos públicos. ${ }^{10}$

De acordo com os autores Pequeno e Rosa (2009, p. 150), o direito à cidade mostra-se "negado quando se analisa a localização dos empreendimentos com relação às centralidades, reconhecidas a partir da convergência de equipamentos de saúde, comércio mais diversificado e áreas que concentram empregos".

Portanto, ao analisar a produção do conjunto Major Veneziano (I, II, III e IV), percebe-se que os moradores estáo presenciando um processo segregacionista em decorrência da localização dos empreendimentos no tecido urbano, decorrente também da distância das áreas mais urbanizadas detentoras de serviços comerciais e infraestrutura suficientes para a população.

\section{Análise da apropriação dos espaços de lazer no conjunto Major Veneziano}

Os espaços de lazer e de uso comum destacam-se como importantes instrumentos para a prática cotidiana e vivência no urbano. É possível caracterizá-los como aqueles cuja necessidade básica seria a de proporcionar a ação da coletividade, mediante equipamentos para práticas esportivas, acesso e uso, ou que ajudem a manter o citadino em um momento de descanso. De acordo com Rolnik (2000, p. 2), os espaços de lazer podem ser observados de duas formas:

A primeira sugere a ideia de lazer como um privilégio de consumo real (ou mera possibilidade) de prazer, da cidade e do tempo. Nesta concepçáo o espaço fica reduzido a um simples local de acesso, tornando- se apenas o suporte para a conexáo de pontos, de endereços; rotas para se chegar aos locais onde existe o prazer; isso tanto dentro do espaço doméstico - televisáo, vídeo e vida familiar - como nos espaços do consumo cultural e esportivo. A segunda posição vê o lazer encarnado na cidade, estreitando a relação de uns cidadãos com os outros, ou seja, um lazer com funçôes pessoais e sociais, identificando com a dimensão pública da cidade. O lazer passa a ser primordial da denominada qualidade de vida. (Grifos nossos).

${ }^{10}$ Esta informação foi obtida por meio de uma conversa com o Secretário de Obras da cidade, em maio de 2015, após a observação em campo, e do projeto na Prefeitura. 
Entende-se que os espaços de lazer dos conjuntos habitacionais podem ser caracterizados como espaços privados por estarem fixados dentro dos conjuntos e condomínios residenciais verticais, e foram criados a partir de políticas públicas habitacionais de interesse social, mas desenhados e comercializados pelo mercado imobiliário. Portanto, faz-se necessário tratar os espaços de lazer dos conjuntos estudados em duas dimensóes: a da produçáo e a da apropriação.

$\mathrm{Na}$ produçáo desses conjuntos habitacionais, duas esferas de poder se destacam e são as mesmas que atuam nos espaços urbanos. Sobarzo (2004, p. 60) entende que a primeira esfera corresponde ao poder no espaço. Ou seja, sendo o exercício do poder no controle do espaço, esse poder tem o intuito de atuar a partir das normativas legais e da ocupação do uso com vistas à dominação política. Como exemplo, podemos citar a atuação do poder municipal a fim de promover a construçáo de empreendimentos destinados às faixas salariais (2 e 3) em locais com melhor localização ou com possibilidades futuras de valorização. A segunda perspectiva é o poder do espaço. Este, por sua vez, é caracterizado e produzido nas desigualdades e contradiçóes, dificultando o processo anterior de dominação política. Como exemplo, podemos citar as açóes dos moradores dos conjuntos habitacionais destinados à faixa salarial 1 que, na tentativa de dirimir a escassez de estabelecimentos comerciais e de serviços nas áreas do conjunto, construíram estabelecimentos comerciais na área externa de forma ilegal.

O cotidiano pode ser entendido a partir dos usos que se revelam nas práticas das apropriaçóes socioespaciais e socioterritoriais. Portanto, podemos conceber como práticas de "um mesmo sujeito coletivo ou grupo social que se organiza para desenvolver uma determinada ação em defesa de seus interesses, em possíveis enfrentamentos e conflitos, com objetivo de transformação da realidade" (Fernandes, 2005, p. 31). Para Sobarzo (2004, p. 146), "os usuários e as suas maneiras de se apropriar do espaço constituem uma superação da racionalidade planejada e dominante que tenta impor a cidade”. Assim, a contraposição construída por meio da prática cotidiana dos usuários revela o modo de apropriaçáo do espaço vivido. Enquanto um conjunto é planejado, seguindo normas do desenho arquitetônico e a rotina do cotidiano dos moradores, ou seja, os "modos de fazer" na concepçáo de Certeau (1998, p. 41), acabam por "revelar as mil práticas pelas quais os usuários se reapropriam do espaço organizado". 
A fim de entender a forma como os espaços de lazer são apropriados no conjunto Major Veneziano, pode-se observar a relação dos moradores com esses espaços e, em especial, as práticas exercidas pelas crianças por meio do ato de brincar nas áreas de uso comum (figura 1). No conjunto, além das ruas, existem também um playground (figura 2) e uma quadra poliesportiva. No entanto, conforme foi apontado pelos moradores, esses equipamentos se tornam insuficientes devido à quantidade de crianças. Além disso, alguns brinquedos apresentam danos em sua estrutura, porém, um outro fator que merece atenção é a insalubridade (figura 3) em relação aos ambientes nas proximidades desses espaços comuns.

Figura 1 - Crianças brincando nas áreas de uso comum do conjunto Major Veneziano

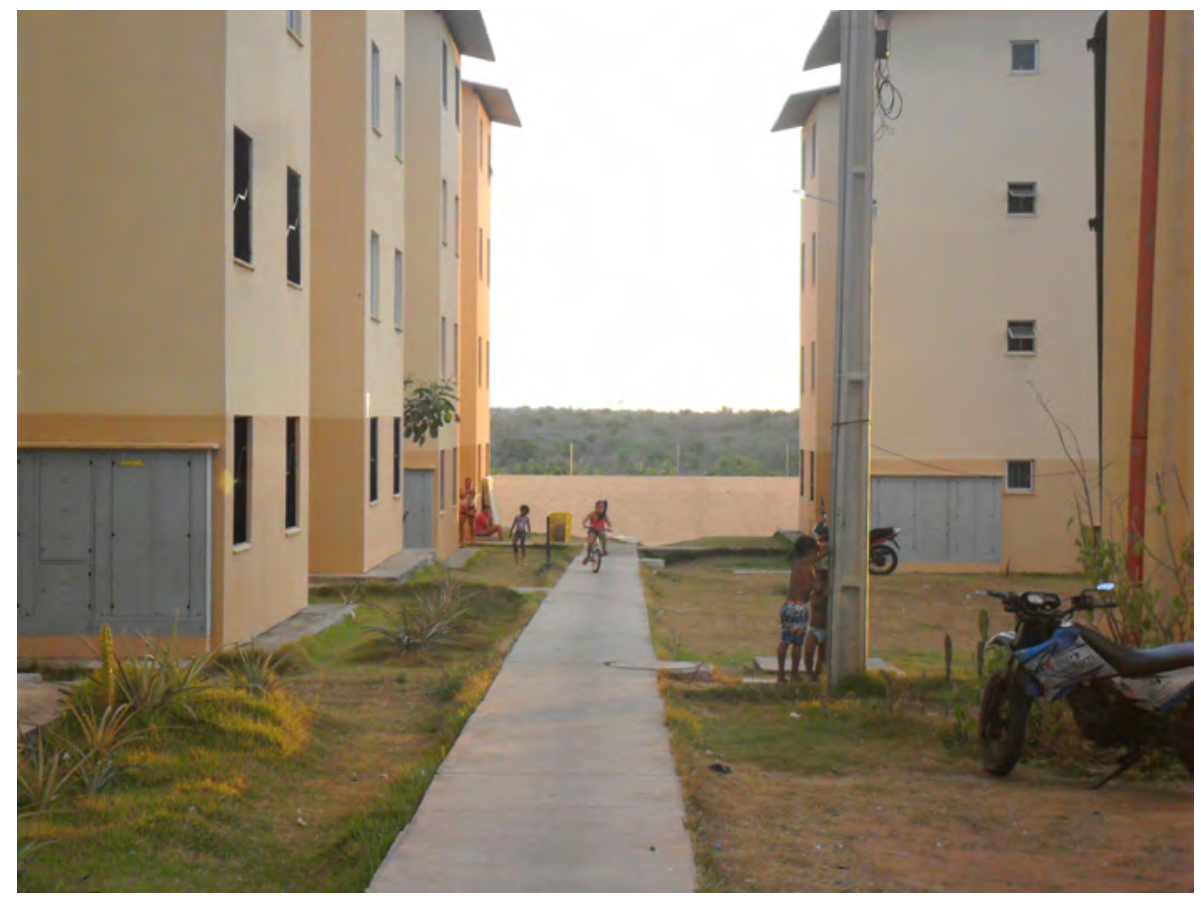

Fonte: Elaboração própria. Trabalho de campo, jan. 2016. 


\section{Figura 2 - Playground do conjunto Major Veneziano II}

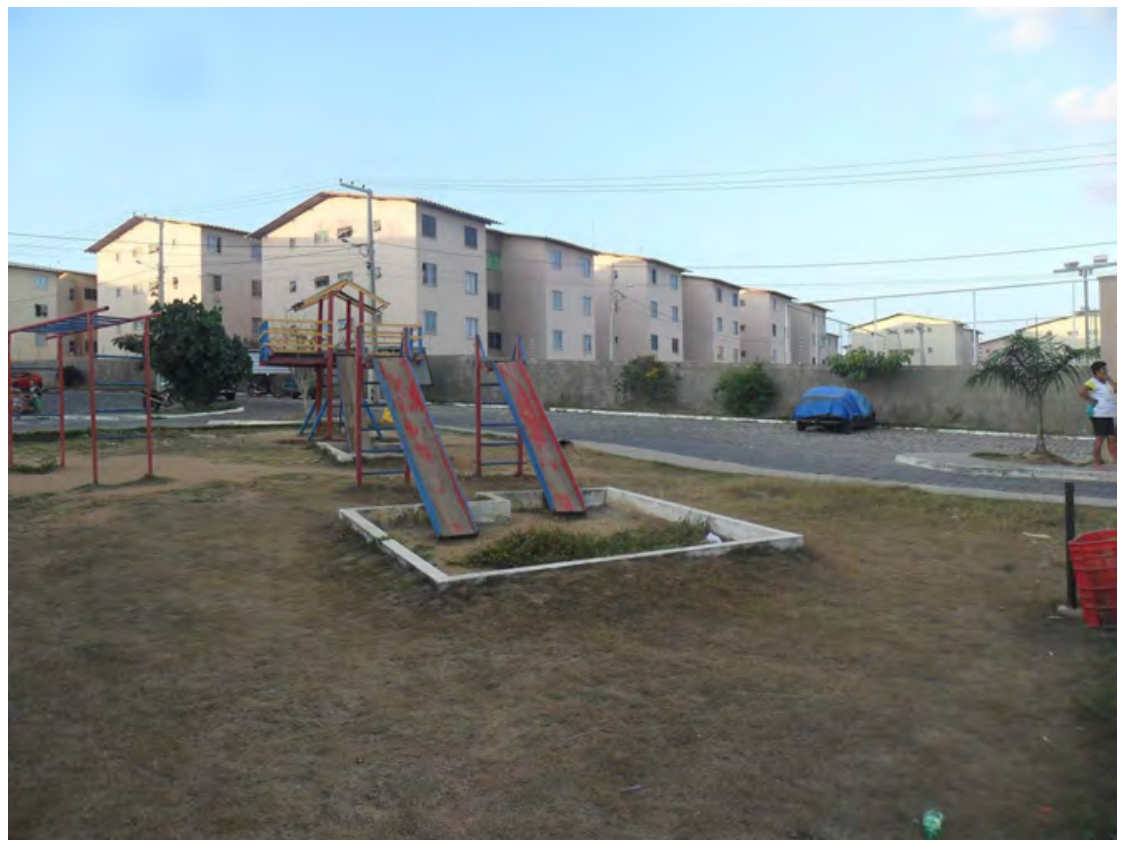

Fonte: Elaboração própria. Trabalho de campo, jan. 2016.

Figura 3 - Situação das caixas de esgoto nas proximidades das áreas de uso comum

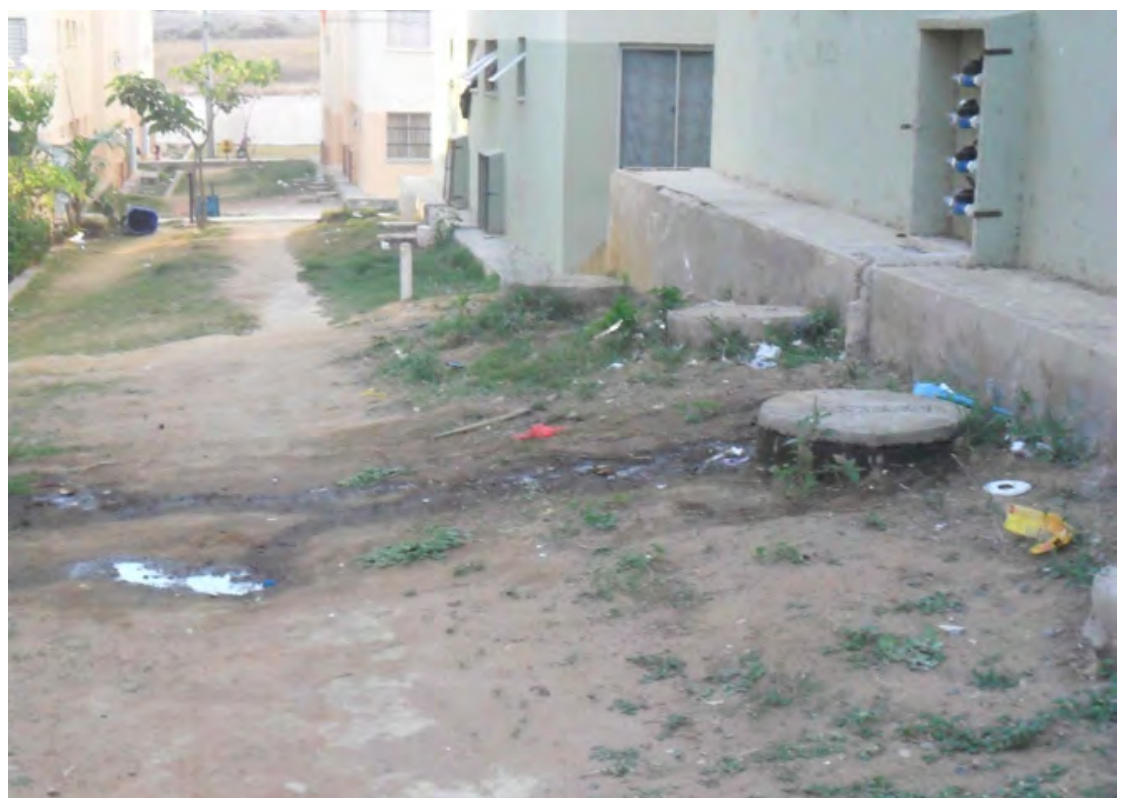

Fonte: elaboração própria. Trabalho de campo, jan. 2016. 
Percebe-se a existência de espaços destinados ao lazer dentro dos conjuntos habitacionais estudados. No entanto, no caso do Major Veneziano II, alguns fatores dificultam o pleno acesso e o uso por parte dos moradores. As crianças acabam realizando suas atividades lúdicas em espaços próximos às caixas de esgoto e lixo ou em estruturas que estão enferrujadas e danificadas (playground). Para Marcellino (2007), os espaços de lazer englobam vários lugares como o lar, a escola, os bares, até as ruas e praças. Logo, o autor enfatiza que

A precariedade na utilização dos equipamentos não específicos coloca-nos três questôes igualmente importantes: 1- a necessidade de desenvolvimento de uma política habitacional, que considere, entre outros aspectos, também o espaço para o lazer - o que não é fácil num País como o nosso, com alto déficit habitacional, e que deve estimular alternativas criativas em termos de áreas coletivas; 2- a consideração da necessidade da utilização dos equipamentos para o lazer, através de uma política de animação; 3- a preservação de espaços urbanizados "vazios" (Marcellino, 2007, p.10).

De acordo com os moradores, os espaços de lazer seriam as praças, as áreas de lazer, academias públicas, brinquedos etc. Logo, são os espaços destinados à circulação livre, aos usos, às trocas e à diversão. Todavia, esse perfil não é identificado nos conjuntos pelos moradores, apesar dos equipamentos distribuídos nos empreendimentos. Para uma das entrevistadas:

Os espaços de lazer geralmente são poucos, e os poucos que têm a população danifica, e é muito pequeno os espaços de lazer aqui, só tem dois balanços e quantas pessoas vivem num condomínio desse? Várias pessoas. Pequeno demais, e fez um espaço grande de jogos de futebol, com relaçáo a outras partes, ficou pequena (Entrevista concedida no conjunto Major Veneziano em janeiro de 2016).

Os espaços destinados ao lazer das crianças são restritos a um playground na entrada de cada conjunto. Esses equipamentos, em sua maioria, apresentam problemas de manutenção e acabam não atendendo à quantidade de crianças, segundo a administração e os próprios moradores. Como já mencionado, as crianças utilizam outras áreas do conjunto, próximas à caixas de esgoto danificadas, o que pode favorecer o acúmulo de lixo e doenças. Sobre esse problema, uma moradora expóe: 
Precisam fazer alguma coisa pelas crianças porque elas quando não estão nas escolas, estão dentro dos condomínios, e não tem nada para se fazer, então ficam ali (fazendo referência às crianças que estavam nas ruas do conjunto), então ali elas podem quebrar janelas, fazendo confusão. Então, se elas se ocupassem, se tivesse alguma atividade física para se manter ocupadas, porque aí, se incentivassem elas, ficariam focadas em alguma coisa (Entrevista concedida no Major Veneziano, em janeiro de 2016).

A falta de equipamentos de lazer para os adultos também foi mencionada no discurso dos entrevistados. Existe, em cada unidade do Conjunto Major Veneziano (I, II, III e IV), uma quadra de futebol, mas segundo os pesquisados, a sua utilização é condicionada ao pagamento de uma taxa à noite por causa do uso dos refletores. Em relação ao uso do salão de festas que fica ao lado do playground, no conjunto Major Veneziano II (figura 4), ele foi transformado em um Clube de Mães que atende a todas as unidades do Conjunto Major Veneziano (I, II, III e IV). Apesar de ser uma prática proibida pelo estatuto interno, passou a ser realizada pelos moradores, pois a área destinada pela Prefeitura para a construção de um espaço para as mães não foi entregue de acordo com os pesquisados.

Foto 04 - No segundo plano, o salão de festas do Conjunto Major Veneziano

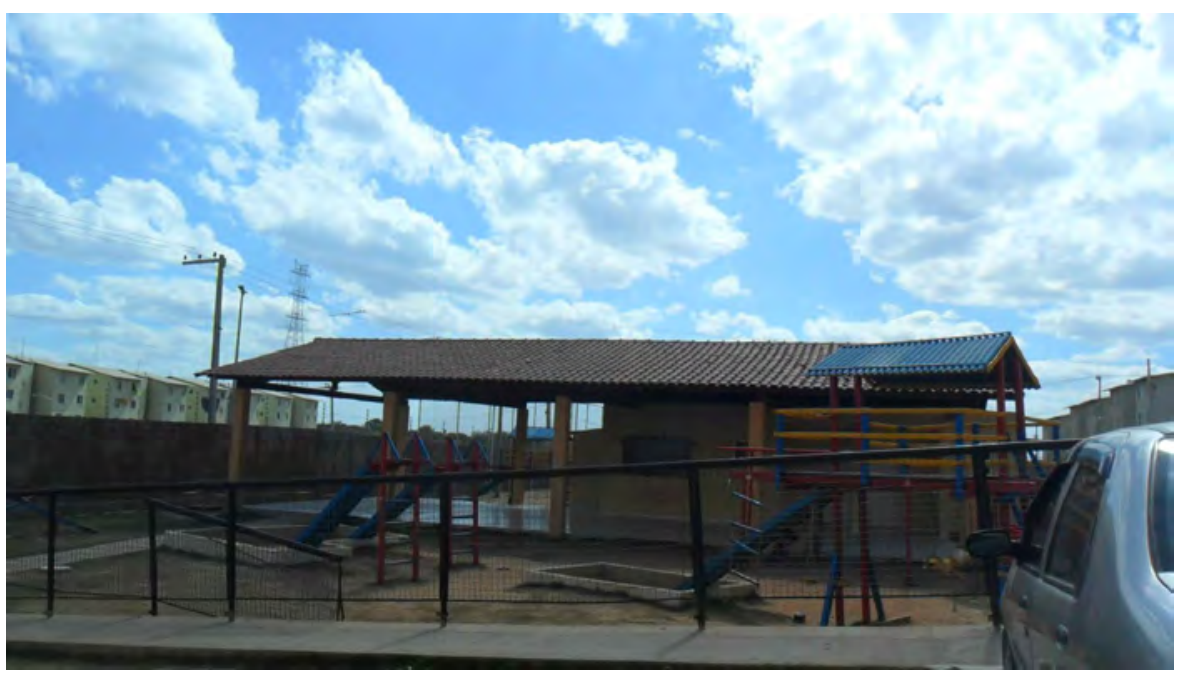

Fonte: Elaboração própria. Trabalho de campo, jun. 2014. 
A construção do espaço para as mulheres no conjunto foi uma tentativa da administração a fim de possibilitar a ocupação das moradoras que ficam ociosas em suas residências. No espaço do saláo são desenvolvidas atividades e minicursos ministrados pelas próprias moradoras para ensinar umas às outras atividades artesanais e os produtos são comercializados. A respeito disso, uma das moradoras nos disse:

No clube de máes tudo que é feito assim, tudo é vendido para ajudar a manter o clube de mães. Quase toda semana tem oficinas de sandálias, de adesivagem de sandálias, tem vários tipos de cursos, de rosas, EVA. E assim, cada curso que tem fica uma parte para ser arrecadado dinheiro para o clube de máes (Entrevista concedida no conjunto Major Veneziano em janeiro de 2016).

Logo, ao relacionar a produção dos espaços destinados ao lazer no conjunto Major Veneziano, identifica-se que a quantidade dos espaços construídos é insuficiente na compreensão dos moradores. A depreciação dessas áreas torna-se um fator negativo para a atração das pessoas quanto ao uso, pois as áreas são mínimas e não existem recursos financeiros para realizar a conservação dos locais. Apesar de existir um trabalho de conscientização quanto às regras de utilização e convívio no conjunto, que é realizado pela Caixa Econômica Federal e pela Prefeitura Municipal, observou-se, a partir das entrevistas, que alguns moradores não contribuem com o pagamento das taxas condominiais, acarretando a falta de recursos para a manutenção.

Marcellino (2006, p. 97) destaca que "para a realização do lazer, é necessário, antes de tudo, que o tempo disponível corresponda um espaço disponível". Segundo as autoras Nascimento e Tostes (2011), não existem diretrizes específicas empregadas pela Caixa Econômica Federal ${ }^{11}$ em relação ao projeto do espaço público (ou comum), tanto no que diz respeito ao uso coletivo quanto ao dimensionamento, com exceçáo do terreno, a localização e a segurança (iluminação de áreas comuns). Assim, ao construir uma análise sobre a estrutura dos espaços destinados ao lazer a partir da política do PMCMV, verifica-se que alguns problemas se tornam mais perceptíveis

${ }^{11}$ A Caixa é uma empresa $100 \%$ pública e atua como agente mediador dos financiamentos para as políticas urbanas como habitação, saneamento básico, infraestrutura e prestaçáo de serviços. Ela constitui o principal agente financiador do Programa Minha Casa Minha Vida. 
para aqueles que vivem cotidianamente nos empreendimentos. Tal fato proporciona a acentuaçáo das diferenças na produção dos espaços de lazer dos conjuntos para os segmentos (faixas salariais) aos quais são destinados.

Portanto, constata-se a relação conflituosa entre a produção dos espaços de lazer no conjunto e a apropriação por parte dos moradores. Alguns equipamentos, a exemplo dos playgrounds, entram quase em desuso por causa da estrutura física e a manutenção, dando lugar a outras áreas do conjunto que servem como um espaço de lazer, mas que originalmente foram pensados como espaço de passagem - como a rua. $\mathrm{O}$ salão de festas é utilizado como uma sala para as atividades do Clube de Máes, pois não existe um outro local de acordo com os pesquisados, inclusive fora dos conjuntos, para a reunião das mulheres que ficam em atividades ociosas. Além disso, há o comércio e alguns serviços realizados nos apartamentos, nas áreas de uso comum e fora do empreendimento, acarretando formas de uso "ilegal" dos espaços por não terem ambientes destinados aos serviços e ao comércio adequados. Dessa forma, "surgem conflitos decorrentes da superposição de interesses, quanto a um mesmo espaço, dada a escassez dos espaços disponíveis à livre apropriação" (Aranha, 2004, p. 11).

Diante da insuficiência dos equipamentos destinados ao lazer e a ausência da manutenção, observa-se que novas práticas socioespaciais são construídas nos espaços do referido conjunto. Assim, são estabelecidas resistências nos espaços a partir do que é produzido pela lógica do Programa Minha Casa Minha Vida.

\section{Consideraçóes finais}

Ao examinar a produção das moradias pelo PMCMV a partir do caso do conjunto Major Veneziano, percebe-se uma reprodução de problemas comuns em outras regióes do país, a exemplo da localizaçáo no tecido urbano, perpetuando processos segregacionistas, e a insuficiência dos equipamentos de infraestrutura e lazer, desconsiderando as particularidades dos espaços e dos seus habitantes.

Neste sentido, a partir da espacialização dos empreendimentos destinados ao PMCMV e os novos produtos urbanísticos da cidade, é possível conceber que a atuação do poder público contribui para a produção de uma cidade segregada. O Art. 21 do Plano Diretor (2006) permite a ampliação da área 
para a construção de conjuntos em áreas de zona de expansão (oeste, sudoeste e sul) que estão em processo de urbanização. Assim, uma grande parcela dos empreendimentos voltados ao segmento de baixa renda estáo se fixando na área Sudoeste da cidade, enquanto nas zonas leste e norte, especialmente nos bairros do Catolé, Alto Branco e Naçóes, existe um crescimento expressivo de condomínios residenciais fechados, destinados à população de alta renda.

A pesquisa a respeito das áreas de lazer e de uso comum em um conjunto habitacional do Programa Minha Casa Minha Vida da Faixa 1, ou seja, habitaçóes sociais, em Campina Grande possibilitou visualizar um outro aspecto no que diz respeito ao programa habitacional brasileiro.

Os espaços de lazer mostram-se insatisfatórios por causa do contingente de moradores nos conjuntos, que é superior aos espaços reservados para essa finalidade, o que reproduz movimentos contrários à lógica imposta pela produção. Além disso, um agravante é a ausência de espaços públicos como praças nas imediaçóes dos empreendimentos habitacionais. Assim, as pessoas se apropriam dos espaços que não são destinados ao lazer como alternativa à proposta do desenho do projeto. A construção do Clube de Mães no Conjunto Major Veneziano é um exemplo da criatividade e da resistência empregada por meio dos usos no cotidiano. Além disso, a disponibilidade de espaços de lazer para todas as faixas etárias é baixa e muitos moradores (adultos) ficam sem opçóes de lazer, mantendo-se dentro dos apartamentos. O descaso com os espaços de lazer e com as áreas comuns transformam-se em uma maneira de evidenciar as resistências por parte do que é imposto, indicando as necessidades dos moradores.

Ao confrontar as análises obtidas sobre os espaços de lazer nesses dois conjuntos habitacionais, é possível identificar a importância da sua existência para a sociabilidade e para o uso cotidiano pelos moradores. Porém, as condiçóes para a apropriação por meio dos usos no Major Veneziano são mínimas, condicionadas pela precarização dos equipamentos. A necessidade é perceptível quando as pessoas, ao serem entrevistadas sobre o que seriam esses espaços de lazer, relatam que "é um espaço que não existe aqui".

Portanto, ao observar a relaçáo entre o que foi produzido e entregue à população do conjunto Major Veneziano, nota-se a carência em relação à infraestrutura, o que favorece a ampliação dos embates entre a comunidade com o poder público local, uma vez que eles passam a criar de acordo com o cotidiano, espaços de lazer e uso que não estáo estabelecidos no projeto, o 
que acentua o embate entre a produção dos conjuntos habitacionais e a apropriação. Vale ainda acrescentar que um dos fatores que agravam a situação é por se tratar de um condomínio vertical fechado para uma população de baixa renda. Assim, os moradores ficam confinados neste espaço, sem espaço de lazer e/ou de uso comum, e tampouco encontram alternativas no espaço público, ou seja, nega-se à cidade o direito à cidade.

\section{Referências}

AMORE, Caio S. et al. (org.). Minha casa... e a cidade?: avaliação do programa Minha Casa Minha Vida em seis estados brasileiros .1. ed. Rio de Janeiro: Letra Capital, 2015. 428 p.

COSTA, Leonardo. Estruturação da cidade de Campina Grande: as estratégias e intencionalidades do mercado imobiliário. (Dissertação). João Pessoa: Universidade Federal da Paraíba.

DINIZ, Lincoln. Permanências e transformaçôes do pequeno comércio na cidade: as bodegas de e a sua dinâmica socioespacial em Campina Grande. Campina Grande: EDUFCG, 2009.120 p.

IBGE. Cidades. 2014. Disponível em: https://cidades.ibge.gov.br/brasil/pb/campina-grande/ panorama. Acesso em maio 2015.

LACERDA JÚNIOR, J. A. e LIRA, A. N. Retratos de Campina Grande: um século em imagens urbanas. Campina Grande: UFCG, 2012. 552 p.

. MAIA, D. S. "A periferizaçấo e a fragmentação da cidade: loteamentos fechados, conjuntos habitacionais populares e loteamentos irregulares na cidade de Campina Grande-PB, Brasil”. Revista Scripta Nova, Universidad de Barcelona, v. XIV, n. 331 (80), 2010. e LUCENA, W. "A expansão periférica e a habitação popular nas cidades do interior do território brasileiro: o processo de urbanizaçáo recente em cidades de distintas escalas geográficas - Campina Grande e Patos na Paraíba”. In: BELLET, Carmen. et al. (org.). [FALTA O TÍTULO DA OBRA]. Presidente Prudente: UNESP, Lleida: Edicions de la Universidade de Lleida. 2015, 514p.

e

. 'Habitaçáo e expansão urbana: análise do Programa Minha Casa Minha Vida nas cidades de Campina Grande, PB e Caruaru, PE". In: Encontro Nacional de Geógrafos, XVIII. A construção do Brasil: geografia, ação política e democracia. São Luís. Anais eletrônicos, 2016. Disponível em: http://www.eng2016.agb.org.br/site/capa. Acesso em: 02 jan. 2017.

et al. "Campina Grande: dinâmica econômica e reestruturação urbana. Permanências e transformaçōes". In: ELIAS, D. et al (Org). Agentes econômicos e reestruturação urbana e regional: Campina Grande e Londrina. 1. ed. São Paulo: Outras Expressôes, 2013. pp. 29-60. MARICATO, Ermínia. "Por um novo enfoque teórico na pesquisa sobre habitação". Cadernos metrópole. São Paulo. n. 21, 2009. MARICATO, Ermínia. O "Minha Casa” é um avanço, mas segregaçáo urbana fica intocada. Carta Maior, 27 de maio de 2009. Disponível em:< hZps://www.cartamaior.com.br/?/Editoria/Poli_ca/O-Minha-Casa-e-um-avanco-mas-segregacao-urbana-fica-intocada/4/15160 
. É preciso repensar o modelo. Arquitetura e Urbanismo, São Paulo, Editora Pini, set. 2009. Disponível em: < hZps://erminiamaricato.files.wordpress.com/2016/12/c3a9-preciso-repensar-o-modelo-_-au-arquitetura-e-urbanismo.pdf> Acesso em agosto de 2019. MARCELLINO, Nelson C. "As Cidades e o Acesso aos Espaços e Equipamentos de Lazer". Revista Impulso. Piracicaba, n. 17. 2006, pp. 55-66.

OLIVEIRA, Roberto Veras (org.). Campina Grande em debate: a condição urbana da periferia pela lente do trabalho e das politicas públicas. Campina Grande: EDUEP, 2009. 213p.

SILVA, Iranise. A crise da moradia: a politica habitacional para as classes de baixa renda de Campina Grande- PB. (Dissertação) João Pessoa: UFPB. 1987.

SILVA, Yure. A politica habitacional em Campina Grande -PB (1988 -2009). (Dissertação). João Pessoa: Universidade Federal da Paraíba.

SPÓSITO, M. E. B. Capitalismo e urbanização. 14.ed. São Paulo: Contexto, 1997.

. "Reestruturação urbana e segregação socioespacial no interior paulista". Revista Scripta Nova. Universidad de Barcelona, v. XI, n. 245 (11), 2007.

ROLNIK, R. et al. "O Programa Minha Casa Minha Vida nas regiōes metropolitanas de Sáo Paulo e Campinas: aspectos socioespaciais e segregaçáo". Cad. Metrópole, São Paulo, v. 17, n. $33,2015$. 


\section{Sobre os autores}

Angela Moulin S. Penalva Santos: Economista (UERJ), Mestre em Engenharia da Produção (COPPE/UFRJ), Doutora e Pós-Doutora em Planejamento Urbano (USP). Professora dos Programas de Pós-Graduação em Direito da Cidade e em Economia, ambos da Universidade do Estado do Rio de Janeiro. Autora de "Política Urbana no Contexto Federativo Brasileiro. Aspectos Institucionais e Financeiros”, EdUERJ, 2017.

Demóstenes Andrade de Moraes: Arquiteto e urbanista e mestre em Desenvolvimento Urbano pela Universidade Federal de Pernambuco. Doutor em Arquitetura e Urbanismo (UFPB). Professor do curso de Arquitetura e Urbanismo na UFCG. Pesquisador no Instituto Nacional de Ciência e Tecnologia Observatório das Metrópoles (INCT - IPPUR/UFRJ). Suas principais áreas de atuação são planejamento urbano e habitação de interesse social.

Doralice Sátyro Maia: Professora Titular da Universidade Federal da Paraíba, do Programa de Pós-Graduação em Geografia e do Programa de Pós-Graduaçáo em Arquitetura e Urbanismo e Colaboradora do Programa de Pós-Graduação em Geografia da Universidade Federal de Pernambuco. Pesquisadora CNPq (PQ) e da Fundação de Apoio à Pesquisa do Estado da Paraíba (FAPESQ-PB). Coordenadora do grupo de pesquisa Grupo de Estudos Urbanos (GeUrb/UFPB/CNPq) e Vice-Coordenadora da Rede de Pesquisadores sobre Cidades Médias (ReCiMe).

Eliane Campos dos Santos: Graduada em Geografia pela Universidade Federal da Paraíba e pela Universidade Estadual Vale do Acaraú. Mestranda em Geografia pela Universidade Federal da Paraíba (Bolsista CAPES). Pesquisadora do Grupo de Estudos Urbanos (GeUrb)/UFPB e da Rede de Pesquisadores sobre Cidades Médias (ReCiMe). 
Fábio Gustavo Pontes Martin: Graduado em Geografia e pós-graduado em Ensino de Geografia pelo Instituto Federal Fluminense (2007). Mestrando em Geografia pela Universidade Federal Fluminense.

Flaviane Ramos dos Santos: Licenciada (2013), Bacharel (2015) e Doutora em Geografia (2019) pela Faculdade de Ciências e Tecnologia da Universidade Estadual Paulista (FCT/UNESP) - Campus de Presidente Prudente. Participa do Grupo de Pesquisa Produção do Espaço e Redefiniçóes Regionais (GAsPERR) e da Rede de Pesquisadores sobre Cidades Médias (RECIME).

Glaucio José Marafon: Professor associado do Insituto de Geografia da Universidade do Estado do Rio de Janeiro. Pesquisador CNPq, CNE/ FAPERJ.

Gustavo Bezerra de Brito: Bacharel e Licenciado em Geografia pela Universidade do Estado do Rio de Janeiro (UERJ). Foi bolsista CNPq do Núcleo de Estudos de Geografia Fluminense (NEGEF/UERJ). Atualmente realiza mestrado no Programa de Pós-Graduação em Geografia da Universidade Federal do Rio de Janeiro (PPGG/UFRJ). Atua na área de Geografia Humana, com ênfase em conflitos socioambientais. Possui experiência em trabalhos de campo, organização de eventos acadêmicos e elaboração de atlas escolares municipais.

Jéssica Liana de Sousa: Graduada em Licenciatura em Geografia pela Faculdade de Filosofia Dom Aureliano Matos (UECE/FAFIDAM) e mestre em Geografia pela Universidade Federal da Paraíba (Bolsista Capes). Pesquisadora do Grupo de Estudos Urbanos (GeUrb)/UFPB e da Rede de Pesquisadores sobre Cidades Médias (ReCiMe).

José Silvan Borborema de Araújo: Graduado em Geografia pela Universidade Estadual da Paraíba (2009). Mestre em Geografia pela Universidade Federal de Pernambuco (2012). Doutor em Geografia pela Universidade do Estado do Rio de Janeiro, com período sanduiche na Università degli Studi di Roma “Tor Vergata”. Tem experiência na área de Geografia, atuando em pesquisas ligadas à Geografia Agrária, principalmente nos temas relacionados a espaços periurbanos, relação cidade/campo, rural/urbana e relações agrárias. 
Juliana Peixoto de Araújo: Arquiteta e urbanista (UFCG). Pesquisadora do Observatório das Metrópoles - núcleo Paraíba. Graduação-sanduíche em Arquitetura no Institut National des Sciences Appliquées de Strasbourg INSA Strasbourg, França (Programa BRAFITEC, com bolsa Capes). Possui experiência em pesquisa nas áreas do planejamento urbano e habitaçáo social.

Lívia Izabel Bezerra de Miranda: Arquiteta e urbanista, mestre em Geografia e Doutora em Desenvolvimento Urbano (UFPE). Professora do curso de Arquitetura e Urbanismo e do Programa de Pós-graduação em Engenharia Civil e Ambiental na UFCG e no Programa de Pós-graduação em Desenvolvimento Regional na UEPB. Pesquisadora no Instituto Nacional de Ciência e Tecnologia Observatório das Metrópoles (INCT - IPPUR/UFRJ).

Luciana Medeiros de Araújo: Graduada em Geografia (UFPB), mestre e doutora em Geografia Urbana pela Universidade Federal da Paraíba. Professora adjunta da Universidade Federal de Campina Grande, lotada na Unidade Acadêmica de Geografia, do Centro de Formação de Professores, campus de Cajazeiras/PB. Pesquisadora do Grupo de Estudos Urbanos (GeUrb)/UFPB e da Rede de Pesquisadores sobre Cidades Médias (ReCiMe).

Marcelo Werner da Silva: Geógrafo pela Universidade Federal do Paraná, especialização em Urbanismo, Ciudad, Historia pela Universidad Politecnica de Cataluńa, mestrado em Geografia pela Universidade Estadual Paulista Júlio de Mesquita Filho, campus de Rio Claro e doutorado em Geografia pela Universidade Federal do Rio de Janeiro.

Maria Encarnaçáo Beltrão Sposito: Licenciada (1977), Bacharel (1980) em Geografia pela Unesp - Campus de Presidente Prudente, Mestre em Geografia (1984), pela Unesp - Campus de Rio Claro, Doutora em Geografia (1991) pela Universidade de São Paulo, pós-doutorado em Geografia pela Université de Paris (1995), livre docente pela Unesp e atualmente professora titular do Departamento de Geografia, também da Unesp, Campus de Presidente Prudente. Participa do Grupo de Pesquisa Produção do Espaço e Redefiniçôes Regionais (GAsPERR) e da Rede de Pesquisadores sobre Cidades Médias (RECIME). Bolsista Produtividade (PQ) CNPq e Pesquisadora da FAPESP. 
Paula Dieb Martins: Professora do Ins_tuto Federal de Educação, Ciência e Tecnologia da Paraíba. Arquiteta e Urbanista (UFPB). Mestre e Doutora em Arquitetura e Urbanismo pela Universidade Federal da Paraíba (Bolsista CAPES). Graduada pela Universidade Federal da Paraíba. Membro do Grupo de Pesquisa Estudos Urbanos (GeUrb) e da Rede de Pesquisadores sobre Cidades Médias (ReCiMe).

Pedro Vasquez: Pós-doutorando em Ciência Política (UNICAMP), vinculado ao INCT-INEU. Doutor em Ciência Política (UNICAMP) e em Direito (UERJ). Mestre em Direito (UERJ). Especialista em Direito Ambiental Brasileiro (PUC-Rio). Bacharel em Direito (PUC-Rio).

Sâmara Iris de Lima Santos: Graduada em Geografia pela Universidade Federal de Campina Grande (Bolsista PIBIC/CNPq). Mestre em Geografia pela Universidade Federal da Paraíba (Bolsista Capes/Projeto Pró-Integração). Professora da Rede Estadual de Educação do Estado de Santa Catarina. 

Formato 16 × 23

Tipologia: Garamond (texto) Garamond (títulos)

Papel: Offset $90 \mathrm{~g} / \mathrm{m}^{2}$ (miolo)

Supremo $250 \mathrm{~g} / \mathrm{m}^{2}$ (capa)

CTP, impressão e acabamento: ? 